Univerza v Mariboru

Filozofska fakulteta

DOKTORSKA DISERTACIJA

\title{
Feminativi v slovenskem jeziku
}



Univerza v Mariboru

Filozofska fakulteta

DOKTORSKA DISERTACIJA

\section{Feminativi v slovenskem jeziku}

Mentorica: red. prof. dr. Irena Stramljič Breznik UDK: 811.163.6'373(043.3) 


\section{ZAHVALA}

„Če ti preostane samo še en dih, ga porabi za to, da rečeš hvala.« (Pam Brown)

Hvala, spoštovana mentorica, red. prof. dr. Irena Stramljič Breznik, za strokovno vodenje, za dragocene nasvete, spodbudne besede in večno pozitivno energijo. Hvala za vse ponujene priložnosti, skrb za mojo strokovno rast in predstavljen čar raziskovalnega dela. Hvala za razumevanje, prijaznost in potrpežljivost.

Hvala, cenjene profesorice in profesorji Oddelka za slovanske jezike in književnosti Filozofske fakultete Univerze v Mariboru, za vso posredovano strokovno znanje in spodbujanje pedagoškega erosa.

Hvala, mama in oče, za privzgojene marljivost, natančnost in odgovornost; za nenehno nesebično podporo in brezpogojno ljubezen; za vse, kar sta mi omogočila in z mano delila.

Hvala, B. in M., za najlepše prijateljstvo.

Hvala, Denis, za vse. 
Jezik ni univerzalen, niti nevtralen, in ni nedotakljiv.

(Luce Irigaray) 


\section{POVZETEK}

Stališče družbe do posameznega spola in do družbenih razlik med žensko in moškim se odraža na posameznih ravneh življenja, tudi v jeziku. Dejstvo, da se namesto ženskih poimenovanj za bitja uporabljajo moška, lahko razložimo s tem, da ima slovnični spol možnost posploševanja. V Sloveniji se je začelo o tem razmišljati v devetdesetih letih prejšnjega stoletja, v nekaterih drugih državah pa že prej; ena od rešitev za neseksistično rabo jezika so feminativi. Tvorjenje le-teh je tipična besedotvorna možnost slovenščine in tudi drugih (slovanskih) jezikov, pri čemer je mogoča tvorba iz občnoimenske in lastnoimenske podstave. Feminativi se v slovenščini po teoriji Jožeta Toporišiča tvorijo na dva načina: (a) z dodajanjem ženskospolskega obrazila tvorjenkam moškega spola; (b) $\mathrm{z}$ zamenjavo celotnega ali le izglasnega dela moškospolskega obrazila $\mathrm{Z}$ ženskospolskim ob isti podstavi. V pričujoči doktorski disertaciji nas zanima družbena prepoznavnost žensk, kot jo razberemo iz slovenskega jezikovnega sistema. Besedotvorje namreč omogoča prepoznavanje zakrite ali izražene družbene hierarhizacije. Namen je bil ugotoviti funkcijsko produktivnost feminativnih obrazil in njihovo pojavnost potrditi $s$ pomočjo jezikovnih priročnikov in korpusov. Feminativi se sicer po Toporišiču (2004) lahko tvorijo z naslednjimi priponskimi obrazili: -a/-á, -ica/-íca, -ja, -ulja, -inja/-inja, -ka, -ovka in -ićna. To velja za tvorbo iz občnoimenske in lastnoimenske podstave. Za raziskavo feminativne tvorbe $\mathrm{v}$ slovenščini smo uporabili različne jezikovne vire in ugotovili, da se $\mathrm{v}$ novejših virih pojavljajo še druga priponska obrazila, s katerimi tvorimo feminative, pri čemer nekatera nastopajo samo kot dodajalna, druga pa zgolj kot zamenjevalna. Raziskovali smo, kateri način tvorjenja feminativov $\mathrm{v}$ slovenščini prevladuje, $\mathrm{z}$ dodajanjem feminativnega priponskega obrazila samostalniku moškega spola ali z zamenjavo moškospolskega obrazila $\mathrm{z}$ ženskospolskim. Disertacija opozarja tudi na variantna feminativna obrazila (dve različni obrazili ali več ob enakem pomenu in podstavi). Pri analizi gradiva se je nabralo veliko število feminativov, kjer sta se ob isti podstavi pojavili dve ali več variantnih priponskih obrazil. Primerjava tovrstnih tvorjenk glede na kvalifikatorje $\mathrm{v}$ obeh izdajah Slovarja slovenskega knjižnega jezika in $\mathrm{v}$ 
Slovenskem pravopisu je pokazala njihovo slogovno zaznamovanost, večpomenskost in možnost zamenljivosti, korpusna analiza pa prikazuje njihovo pogostnost; glede na vse našteto bomo predlagali ustreznejši feminativ. Nadaljnja analiza dokazuje, da $\mathrm{k}$ večini moškospolskih poimenovanj bitij $\mathrm{v}$ sodobnem knjižnem jeziku feminativ že obstaja ali pa njegovo obliko lahko predvidimo. V posebnem poglavju smo obravnavali tvorbo feminativov iz lastnoimenske podstave. Proučevali smo ženskospolska poimenovanja za prebivalke, zbrana v slovarskem delu Slovenskega pravopisa kot podiztočnice pri zemljepisnih lastnih imenih, in priimkovne feminative, prav tako zbrane po Slovenskem pravopisu, analizo pa smo obogatili s korpusnimi podatki. Pri analizi prvih se kot najpogostejše ženskospolsko priponsko obrazilo še vedno kaže obrazilo $-k a$, pri priimkih pa opažamo zlasti, da je ženska kot družbeno bitje še vedno zapostavljena, priimkovni feminativi iz korpusa Gigafida pa izražajo izrazito negativno konotacijo.

$\mathrm{V}$ slovenskem besedotvorju so raziskave feminativov redke, celovite predstavitve in pregleda pa do zdaj sploh ni bilo. Gre za razvijanje novih besedotvornih spoznanj, ki so lahko povezana z družbeno realnostjo.

Ključne besede: jezikoslovje, besedotvorje, feminativ, priponsko obrazilo 


\section{ZUSAMMENFASSUNG}

Die Einstellung der Gesellschaft zu einzelnem Geschlecht und den sozialen Unterschieden zwischen Frauen und Männern spiegelt sich in den unterschiedlichen Lebensbereichen, auch in der Sprache, wider. Die Tatsache, dass männliche Formen für Bezeichnungen von Lebewesen anstelle von weiblichen Formen verwendet werden, kann durch die Tatsache erklärt werden, dass das grammatische Geschlecht die Möglichkeit der Verallgemeinerung aufweist. Darüber nachzudenken begann man in Slowenien in den 1990er Jahren, in einigen anderen Ländern jedoch schon früher. Eine mögliche Lösung für die nicht-sexistische Sprachverwendung ist der Gebrauch von weiblichen bzw. femininen Formen. Ihre Bildung ist eine typische Wortbildungsmöglichkeit für slowenische und auch für andere (slawische) Sprachen, wobei die Bildung sowohl aus Gattungsnamen- als auch aus Eigennamen-Derivationsbasis möglich ist. In der slowenischen Sprache gibt es nach der Theorie von Jože Toporišič zwei unterschiedliche Wortbildungsmöglichkeiten der weiblichen Formen: (a) den männlichen Wortbildungskonstruktionen wird das Suffix für weibliche Formen angefügt; (b) das Ersetzen des ganzen oder nur des auslautfähigen Teils des maskulinen Suffixes mit dem weiblichen Suffix bei der gleichen Derivationsbasis. Die vorliegende Dissertation thematisiert die gesellschaftliche Erkennbarkeit der Frauen, die aus dem slowenischen Sprachsystem zu erkennen ist. Die Wortbildung ermöglicht nämlich die Erkennung der verdeckten oder ausgedruckten gesellschaftlichen Hierarchie. Das Forschungsziel war, mit Hilfe von Sprachhandbüchern und Korpora die funktionelle Produktivität der weiblichen Suffixe festzustellen. Weibliche Formen können nach Toporišič (2004) mit folgenden Suffixen gebildet werden: -a/-á, -ica/-ica, -ja, -ulja, -inja/-ínja, -ka, -ovka und -ična. Das gilt sowohl für die Wortbildung von Gattungsnamen- als auch Eigennamen-Derivationsbasis. Für die Forschungsarbeit der weiblichen Wortbildungskonstruktionen im Slowenischen wurden unterschiedliche Sprachquellen verwendet. Man fand heraus, dass es in neueren Quellen noch weitere Suffixe gibt, die die Wortbildung von weiblichen Formen ermöglichen, wobei einige Suffixe beigefügt und die anderen ausgewechselt werden. Es wurde unter anderem untersucht, welche Wortbildungsmöglichkeit zur 
Bildung von weiblichen Formen im Slowenischen überwiegt: das Hinzufügen der femininen Suffixe den maskulinen Substantiven oder die Auswechslung der männlichen Suffixen mit weiblichen. Die Dissertation weist auf die parallelen weiblichen Suffixe hin (zwei oder mehr verschiedene Suffixe bei der gleichen Bedeutung und Basis). Die Materialanalyse weist darauf hin, dass bei einer großen Anzahl von weiblichen Formen mit der gleichen Basis zwei oder mehrere parallele Suffixe erscheinen können. Der Vergleich derartiger Wortbildungskonstruktionen in Bezug auf Qualifikatoren in beiden Ausgaben des Wörterbuches der slowenischen Standardsprache (Slovar slovenskega knjižnega jezika) und im Wörterbuch der slowenischen Rechtschreibung (Slovenski pravopis) weist auf ihre stilistische Markierung, Mehrdeutigkeit und die Möglichkeit der Substituierbarkeit hin, während die Korpusanalyse ihre Häufigkeit zeigt. In Anbetracht all dessen wird eine angemessenere weibliche Form vorgeschlagen. Eine weitere Analyse in dieser Dissertation beweist, dass die meisten Benennungen von maskulinen Lebewesen in der gegenwärtigen Standardsprache bereits eine weibliche Form vorweisen oder dass ihre Form vorausgesagt werden kann. Im Sonderkapitel wird die Bildung der weiblichen Formen aus Eigenamen thematisiert. Erforscht wurden weibliche Formen für Einwohnerinnen, gesammelt im Wörterbuch der slowenischen Rechtschreibung (Slovenski pravopis) als Sublemmata bei geographischen Eigennamen und weiblichen Formen für Familiennamen; die Analyse wurde anschließend mit Korpusdaten bereichert. Es stellt sich heraus, dass bei der weiblichen Benennungen für die Einwohnerinnen am häufigsten das weibliche Suffix -ka vorkommt, bei Familiennamen stellt man jedoch fest, dass Frauen als soziale Lebewesen noch immer benachteiligt sind, wobei die weiblichen Formen der Familiennamen aus dem Gigafida-Korpus extrem negativ konnotiert sind.

In der slowenischen Wortbildung sind die Studien der weiblichen Formen eine Seltenheit, eine umfassende Darstellung und Übersicht fehlt bis heute. Es geht darum, neue Wortbildungseinsichten zu entwickeln, die mit der Gesellschaftsrealität in Verbindung gebracht werden können.

Schlüsselwörter: die Sprachwissenschaft, die Wortbildung, weibliche Formen, das Suffix 
KAZALO VSEBINE

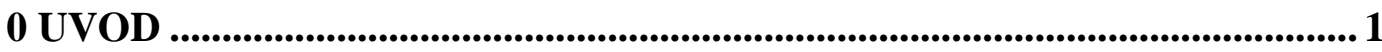

0.1 Opredelitev problema ............................................................................................... 1

0.2 Namen in cilji doktorske disertacije............................................................... 2

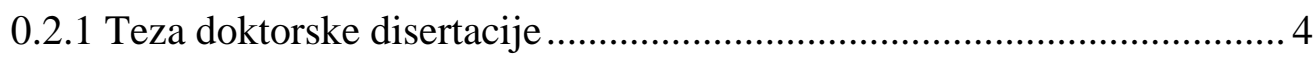

0.2.2 Pričakovani izvirni znanstveni prispevki ........................................... 6

0.3 Predpostavke in morebitne omejitve.............................................................. 7

0.4 Predvidene metode raziskovanja..................................................................8 8

1 SOCIOLOŠKI PRISTOP: DRUŽBENO VREDNOTENJE SPOLOV ..........9

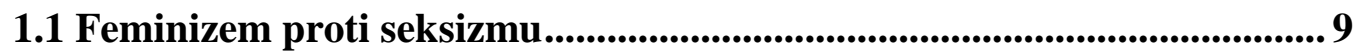

1.1.1 Zgodovina ženskega gibanja ........................................................ 11

1.1.2 Mednarodno povezovanje žensk .................................................... 14

1.1.3 Ženske v Evropski uniji................................................................... 16

1.2 Položaj žensk na Slovenskem............................................................... 18

1.2.1 Zgodovina ženskega gibanja na Slovenskem.................................... 18

1.2.2 Vloga Slovenk v javnem življenju .................................................... 20

1.2.3 Položaj žensk v znanosti na Slovenskem .......................................... 22

1.2.4 Slovenske feministične literarnovedne raziskave ............................... 23

2 LINGVOKULTUROLOŠKI PRISTOP ....................................................... 24

2.1 Zapostavljanje ženskega spola $v$ tujih jezikih ........................................ 25

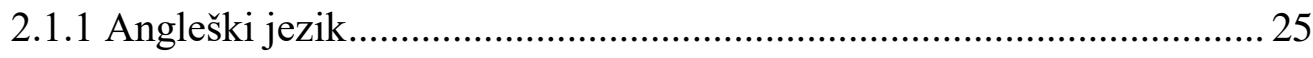

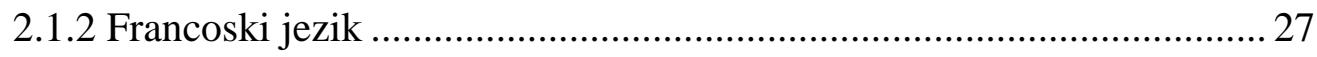

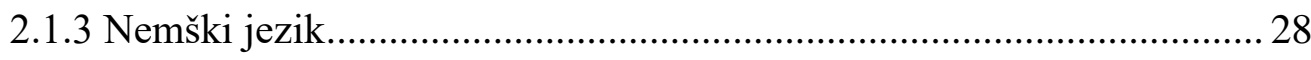

2.2 Spolno (ne)občutljiva raba v slovanskem jezikoslovju............................. 28

2.3 (Ne)seksistična raba v slovenskem jeziku ............................................. 31

2.3.1 Razprave o seksizmu v slovenskem jeziku ....................................... 31

2.3.2 Ženskospolska poimenovanja $v$ uradovalnih besedilih in pravnih aktih35

2.3.3 Ženskospolska poimenovanja za poklice ........................................... 40 
2.3.3.1 Klasifikacija poklicev po Kroupovi ..............................................40

2.3.3.2 Klasifikacija poklicev po Statističnem uradu $R S$...........................42

2.3.3.3 Ženskospolska poimenovanja za poklice v jezikovnih virih...........44

2.3.3.4 Ženskospolska poimenovanja za poklice v razpisih za delo..........65

2.3.4 Priporočila za neseksistično rabo jezika ......................................... 71

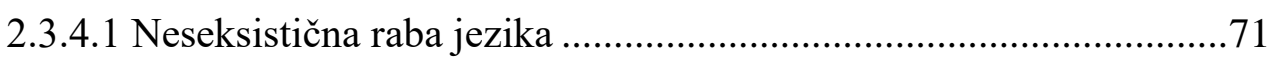

2.3.4.2 Interne smernice za splošno občutljivo rabo jezika ......................73

2.3.5 Pomanjkljivosti neseksistične rabe jezika.......................................75

3 LINGVISTIČNI PRISTOP ...........................................................................77

3.1 Besedotvorni pomeni samostalniških tvorjenk v slovenistiki...................77

3.1.1 Besedotvorni pomeni $\mathrm{v}$ starejših slovenskih slovnicah $\mathrm{s}$ posebnim poudarkom na pomenski skupini feminativi...............................................77

3.1.2 Pomenske skupine samostalniških izpeljank po Antonu Bajcu.............80

3.1.3 Model Jožeta Toporišiča .................................................................. 81

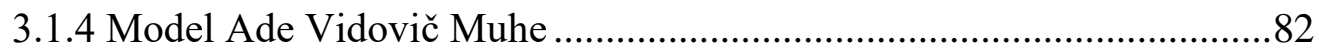

3.2 Funkcijska obremenitev feminativnih priponskih obrazil po pomenskih skupinah ........................................................................................................................................83

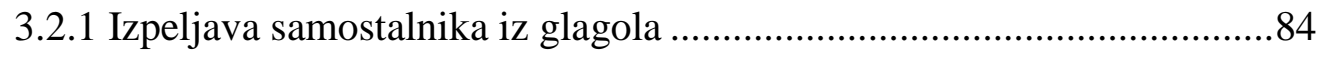

3.2.2 Izpeljava samostalnika iz pridevniške besede ....................................87

3.2.3 Izpeljava samostalnika iz samostalnika ...........................................90

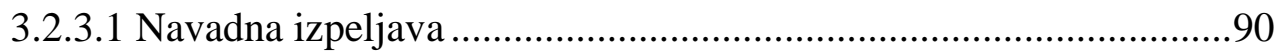

3.2.3.2 Inačenjska ali modifikacijska izpeljava .......................................93

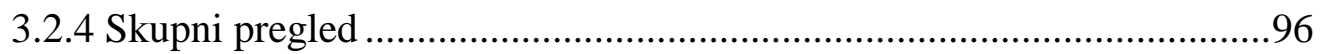

4 TVORBA FEMINATIVOV V SLOVANSKIH JEZIKIH ..........................97

4.1 Vzhodnoslovanski jeziki...................................................................................97

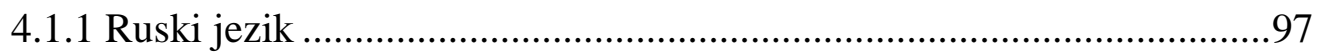

4.1.2 Beloruski jezik ............................................................................ 100

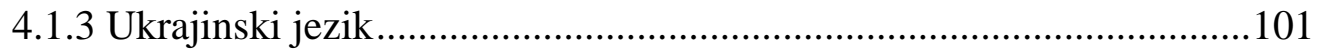

4.2 Zahodnoslovanski jeziki..................................................................102 


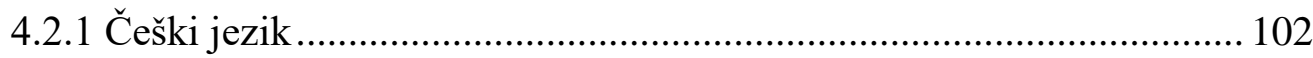

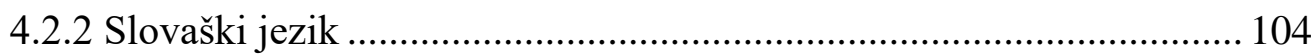

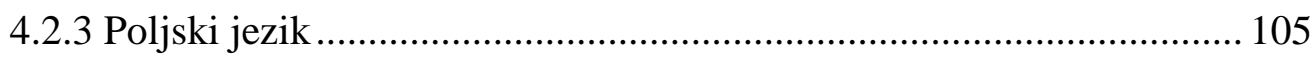

4.3 Južnoslovanski jeziki ....................................................................................... 107

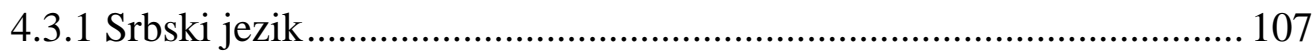

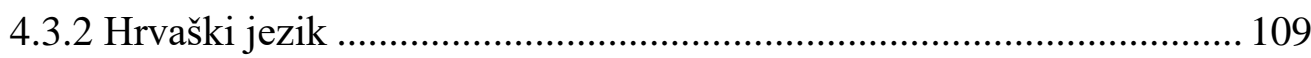

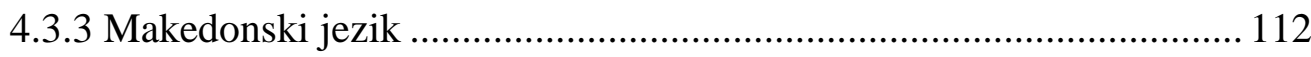

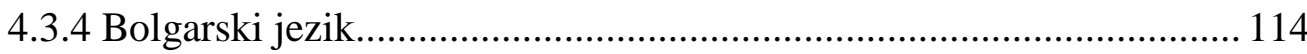

5 ZGODOVINSKI PREGLED DISTRIBUCIJE FEMINATIVNIH PRIPONSKIH OBRAZIL V SLOVENŠČINI ..................................................... 116

5.1 V slovnicah od Bohoričeve (1584) do Toporišičeve (2004) ..................... 116

5.2 V Bajčevem Besedotvorju slovenskega jezika ............................................ 141

5.3 Primerjalni pregled............................................................................................ 144

6 TEORETIČNA IZHODIŠČA OBRAVNAVE FEMINATIVOV ................ 149

6.1 Obravnava feminativov v sodobnem slovenskem knjižnem jeziku..... 149

6.1.1 Slovenska slovnica o feminativih (Toporišič 2004) ………………..... 149

6.1.2 Tvorba feminativov po Adi Vidovič Muhi ......................................... 149

6.1.3 Tvorba feminativov po Ireni Stramljič Breznik ................................... 151

6.1.4 Obravnave drugih jezikoslovcev ......................................................... 152

6.2 Pomenske tipologije feminativov $v$ slovenščini.......................................... 154

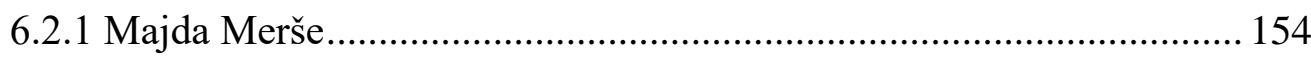

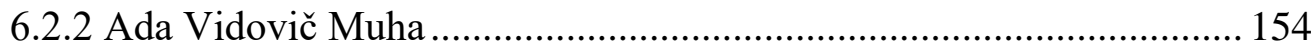

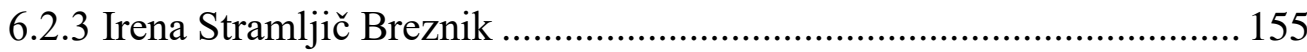

6.3 Feminativi kot iztočnice v slovarjih ............................................................ 156

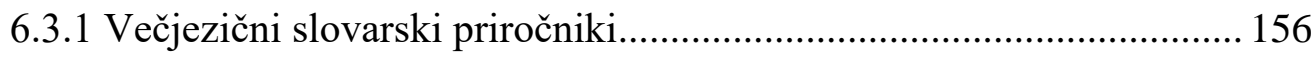

6.3.2 Enojezični jezikovni priročniki ............................................................ 159

7 TVORBA FEMINATIVOV IZ OBČNOIMENSKE PODSTAVE .............. 161

7.1 Poimenovanja oseb ......................................................................................... 161

7.1.1 Prva izdaja Slovarja slovenskega knjižnega jezika ............................. 162 
7.1.1.1 Feminativi, nastali z zamenjavo celotnega ali le izglasnega dela moškospolskega obrazila z ženskospolskim ob isti podstavi

7.1.1.2 Feminativi, nastali $\mathrm{z}$ dodajanjem ženskospolskega obrazila tvorjenkam moškega spola

7.1.2.1 Feminativi, nastali $\mathrm{z}$ dodajanjem ženskospolskega obrazila tvorjenkam moškega spola

7.1.2.2 Feminativi, nastali $\mathrm{z}$ zamenjavo celotnega ali le izglasnega dela moškospolskega obrazila z ženskospolskim ob isti podstavi 223

7.1.3 Slovar novejšega besedja slovenskega jezika 228

7.1.3.1 Feminativi, nastali $\mathrm{z}$ dodajanjem ženskospolskega obrazila tvorjenkam moškega spola 230

7.1.3.2 Feminativi, nastali z zamenjavo celotnega ali le izglasnega dela moškospolskega obrazila z ženskospolskim ob isti podstavi.

7.1.4 Druga izdaja Slovarja slovenskega knjižnega jezika

7.1.4.1 Feminativi, nastali $\mathrm{z}$ zamenjavo celotnega ali le izglasnega dela moškospolskega obrazila z ženskospolskim ob isti podstavi

7.1.4.2 Feminativi, nastali $\mathrm{z}$ dodajanjem ženskospolskega obrazila tvorjenkam moškega spola

7.2 Poimenovanja živali .272

7.2.1 Prva izdaja Slovarja slovenskega knjižnega jezika .272

7.2.1.1 Feminativi, nastali $\mathrm{z}$ dodajanjem ženskospolskega obrazila tvorjenkam moškega spola

7.2.1.2 Feminativi, nastali z zamenjavo celotnega ali le izglasnega dela moškospolskega obrazila $\mathrm{z}$ ženskospolskim ob isti podstavi.

7.2.2 Druga izdaja Slovarja slovenskega knjižnega jezika

7.2.3 Slovar novejšega besedja slovenskega jezika 278

7.3 Primerjalni pregled 278 


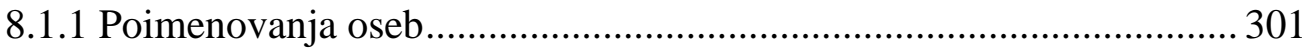

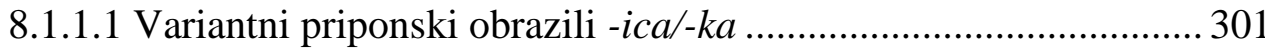

8.1.1.2 Variantni priponski obrazili -inja/-ka ....................................... 326

8.1.1.3 Variantni priponski obrazili -ica/-inja ......................................... 343

8.1.1.4 Variantni priponski obrazili -ica/-(ov)ka ................................... 348

8.1.1.5 Variantni priponski obrazili -a/-inja ....................................... 349

8.1.1.6 Variantni priponski obrazili -inja/-(ar)ka .................................. 350

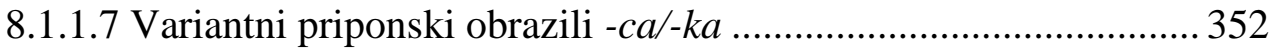

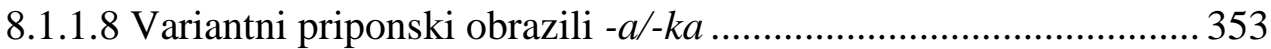

8.1.1.9 Variantni priponski obrazili -inja/-(ov)ka ................................. 354

8.1.1.10 Variantni priponski obrazili -ja/-inja........................................ 354

8.1.1.11 Variantna priponska obrazila -ica/-ja/-ka .............................. 355

8.1.1.12 Variantna priponska obrazila -ica/-inja/-ka ............................. 356

8.1.1.13 Variantna priponska obrazila -inja/-ka/-esa .............................. 357

8.1.1.14 Variantna priponska obrazila -lja/-ulja/-ka .............................. 358

8.1.1.15 Variantna priponska obrazila -ica/-ulja/-(ov)ka ........................ 359

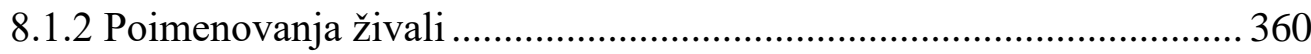

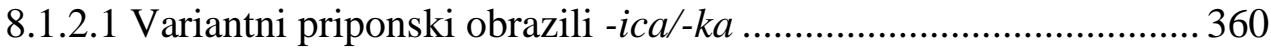

8.1.2.2 Variantni priponski obrazili -ica/-ulja ........................................ 361

8.1.2.3 Variantni priponski obrazili -a/-inja .......................................... 362

8.1.2.4 Variantni priponski obrazili -ica/-inja ......................................... 362

8.1.2.5 Variantni priponski obrazili -inja/-(ov)ka ................................. 363

8.1.2.6 Variantni priponski obrazili -ica/-(ov)ka ................................... 363

8.1.2.7 Variantna priponska obrazila -ica/-lja/-ulja/-(ov)ka.................... 364

8.2 Zamenjava in dodajanje obrazila...................................................... 365

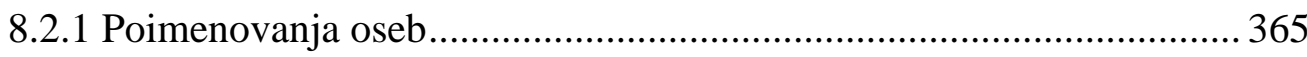

8.2.1.1 Variantni priponski obrazili -inja/-na ....................................... 365

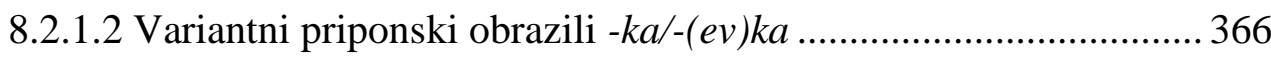

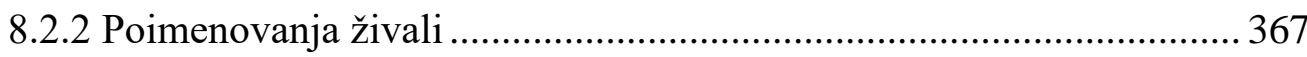


8.3 Zamenjevanje obrazila..............................................................................................368

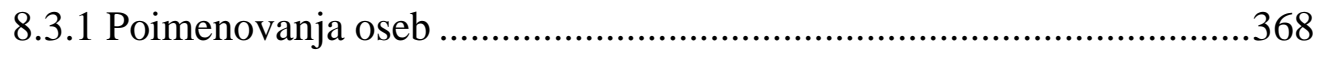

8.3.1.1 Variantni priponski obrazili -ica/-inja ..........................................368

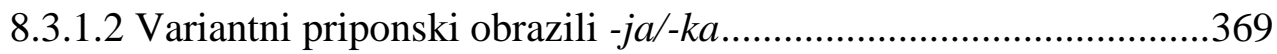

8.3.1.3 Variantni priponski obrazili -ica/-ka ........................................370

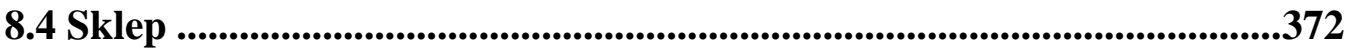

9 OMEJENA TVORBA FEMINATIVOV ................................................374

9.1 Težavnejše vzporedne ženskospolske oblike .........................................375

9.2 Utemeljitve predlaganih ženskospolskih vzporednic ................................378

9.2.1 Prvi sklop: obstoječe ženskospolske vzporednice ..............................378

9.2.2 Drugi sklop: odsotnost ženskospolskih vzporednic............................384

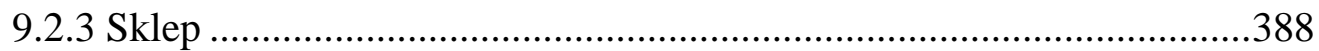

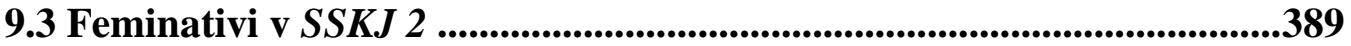

9.4 Feminativi v Sprotnem slovarju slovenskega jezika ................................392

9.5 Feminativi v SSKJ 3 ...............................................................................393

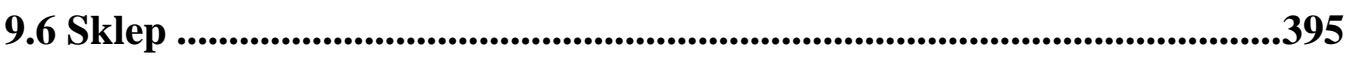

10 TVORBA FEMINATIVOV IZ LASTNOIMENSKE PODSTAVE..........396

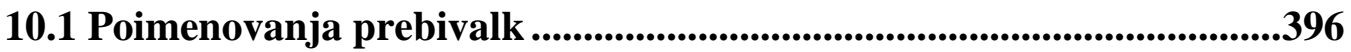

10.1.1 Poimenovanja prebivalk v drugih slovanskih jezikih .......................396

10.1.2 Poimenovanja prebivalk v slovenščini ...........................................397

10.1.2.1 Poimenovanja prebivalk v slovenskih slovnicah skozi zgodovino397

10.1.2.2 Poimenovanja prebivalk v Slovenskem pravopisu .403

10.1.2.2.1 Poimenovanja, nastala $\mathrm{z}$ dodajanjem ženskospolskega obrazila k samostalnikom moškega spola .405

10.1.2.2.2 Poimenovanja, nastala z zamenjavo celotnega ali le izglasnega dela moškospolskega obrazila $\mathrm{z}$ ženskospolskim ob isti podstavi ........408 
10.2.1 Priimkovni feminativi v drugih slovanskih jezikih 411

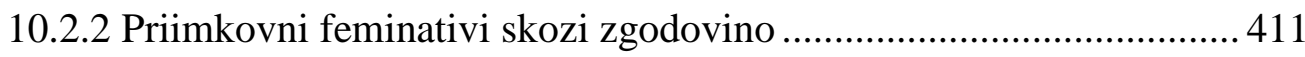

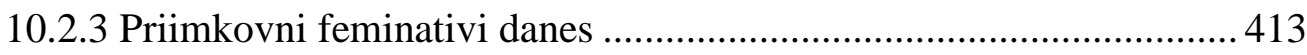

10.2.3.1 Priimkovni feminativi v Slovenskem pravopisu 415

10.2.3.1.1 Priimki, nastali $\mathrm{z}$ dodajanjem ženskospolskega obrazila $\mathrm{k}$ priimkom moškega spola 417

10.2.3.1.2 Priimki, nastali z zamenjavo celotnega ali le izglasnega dela moškospolskega obrazila z ženskospolskim ob isti podstavi 420

10.2.3.2 Priimkovni feminativi po korpusu Gigafida 422

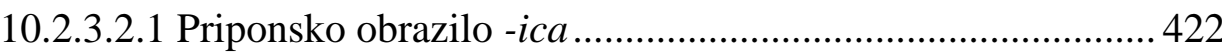

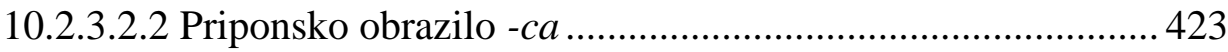

10.2.3.2.3 Priponsko obrazilo -inja..................................................... 424

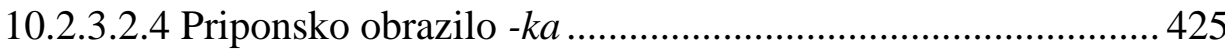

10.2.3.2.5 Priponsko obrazilo $-(\mathrm{ev}) \mathrm{ka}$.................................................. 427

10.2.3.2.6 Priponsko obrazilo -(ov)ka ................................................. 428

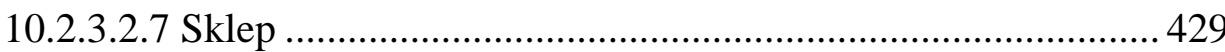

11 NAGLAŠENOST FEMINATIVOV ............................................................ 434

11.1 Feminativi, tvorjeni iz občnoimenske podstave ...............................435

11.1.1 Nenaglašenost priponskega obrazila ............................................. 435

11.1.2 Naglašenost feminativnega priponskega obrazila ........................... 437

11.1.3 (Ne)naglašenost feminativnega priponskega obrazila..................... 437

11.2 Feminativi, tvorjeni iz lastnoimenske podstave ...................................439

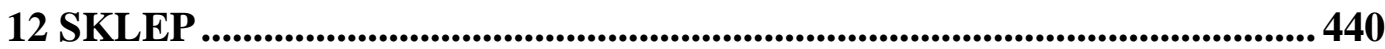

13 VIRI IN LITERATURA ............................................................................. 450 


\section{KAZALO GRAFIKONOV}

Grafikon 1: Funkcijska obremenitev obrazil po pomenskih skupinah $v$ Toporišičevi Slovenski slovnici in Bajčevem Besedotvorju slovenskega jezika izpeljava samostalnika iz glagola 86

Grafikon 2: Funkcijska obremenitev obrazil po pomenskih skupinah $v$ Toporišičevi Slovenski slovnici in Bajčevem Besedotvorju slovenskega jezika izpeljava samostalnika iz pridevniške besede

Grafikon 3: Funkcijska obremenitev obrazil po pomenskih skupinah $v$ Toporišičevi Slovenski slovnici in Bajčevem Besedotvorju slovenskega jezika tvorba samostalnika iz samostalnika (navadna izpeljava) 92

Grafikon 4: Funkcijska obremenitev obrazil po pomenskih skupinah $v$ Toporišičevi Slovenski slovnici in Bajčevem Besedotvorju slovenskega jezika tvorba samostalnika iz samostalnika (inačenjska ali modifikacijska izpeljava)... 95 Grafikon 5: Funkcijska obremenitev obrazil po pomenskih skupinah $v$ Toporišičevi Slovenski slovnici in Bajčevem Besedotvorju slovenskega jezika skupni pregled (tvorba samostalnika iz glagola, pridevniške besede in samostalnika - navadna in inačenjska ali modifikacijska izpeljava) .................. 96

Grafikon 6: Zastopanost feminativnih priponskih obrazil 145

Grafikon 7: Feminativi $v$ SSKJ 1 glede na način tvorbe 162

Grafikon 8: Zamenjevalna feminativna priponska obrazila $v$ SSKJ 1 164

Grafikon 9: Dodajalna feminativna priponska obrazila $v$ SSKJ 1 185

Grafikon 10: Feminativi glede na način tvorbe v Novejši slovenski leksiki ...... 212 Grafikon 11: Dodajalna feminativna priponska obrazila $v$ Novejši slovenski leksiki

Grafikon 12: Zamenjevalna feminativna priponska obrazila $v$ Novejši slovenski leksiki 223

Grafikon 13: Feminativi v SNBSJ glede na način tvorbe 229

Grafikon 14: Dodajalna feminativna priponska obrazila po SNBSJ 230

Grafikon 15: Zamenjevalna feminativna priponska obrazila $v$ SNBSJ 238

Grafikon 16: Feminativi v SSKJ 2 glede na način tvorbe 244

Grafikon 17: Zamenjevalna feminativna priponska obrazila $v$ SSKJ 2. 245 
Grafikon 18: Dodajalna feminativna priponska obrazila $v$ SSKJ 2

Grafikon 19: Ženskospolska poimenovanja živali $v$ SSKJ 1 glede na način tvorbe 272

Grafikon 20: Dodajalna feminativna priponska obrazila za poimenovanja živali v SSKJ 1 273

Grafikon 21: Zamenjevalna feminativna priponska obrazila za poimenovanja živali $v$ SSKJ 1 275

Grafikon 22: Poimenovanja za prebivalke v SP (2001) glede na način tvorbe .. 404 Grafikon 23: Feminativna priponska obrazila pri poimenovanjih za prebivalke $v$ SP (2001). 405

Grafikon 24: Zastopanost feminativnih priponskih obrazil pri tvorbi poimenovanj za prebivalke $z$ dodajalnim načinom 406

Grafikon 25: Zastopanost feminativnih priponskih obrazil pri tvorbi poimenovanj za prebivalke z zamenjevalnim načinom 409

Grafikon 26: Priimkovni feminativi v SP (2001) glede na način tvorbe 416

Grafikon 27: Tvorba priimkovnih feminativov 417

Grafikon 28: Priimkovni feminativi, tvorjeni $z$ dodajanjem ženskospolskega obrazila 418

Grafikon 29: Priimkovni feminativi, tvorjeni z zamenjavo moškospolskega priponskega obrazila z ženskospolskim.

Grafikon 30: Zastopanost dodajalnih obrazil - primerjava med SP in Gigafido (v odstotkih)

Grafikon 31: Zastopanost zamenjevalnih obrazil - primerjava med SP in Gigafido (v odstotkih) 433

Grafikon 32: Naglašenost feminativnih priponskih obrazil 439 


\section{KAZALO PREGLEDNIC}

Preglednica 1: Zastopanost moškospolskih poimenovanj za »tipično ženske» poklice v primerjavi z ženskospolskimi po jezikovnih korpusih 51

Preglednica 2: Zastopanost ženskospolskih poimenovanj za poklice v jezikovnih virih

Preglednica 3: Funkcijska obremenitev feminativnih priponskih obrazil po pomenskih skupinah - izpeljava samostalnika iz glagola. 84

Preglednica 4: Funkcijska obremenitev feminativnih priponskih obrazil po pomenskih skupinah - izpeljava samostalnika iz pridevniške besede. 87

Preglednica 5: Funkcijska obremenitev feminativnih priponskih obrazil po pomenskih skupinah - izpeljava samostalnika iz samostalnika, navadna izpeljava

Preglednica 6: Funkcijska obremenitev feminativnih priponskih obrazil po pomenskih skupinah - izpeljava samostalnika iz samostalnika, modifikacijska izpeljava

Preglednica 7: Zastopanost feminativnih priponskih obrazil po Toporišiču in Bohoriču

Preglednica 8: Zastopanost feminativnih priponskih obrazil po Toporišiču in Zagajšku

Preglednica 9: Zastopanost feminativnih priponskih obrazil po Toporišiču in Pohlinu

Preglednica 10: Zastopanost feminativnih priponskih obrazil po Toporišiču in Vodniku 124

Preglednica 11: Zastopanost feminativnih priponskih obrazil po Toporišiču in Dajnku

Preglednica 12: Zastopanost feminativnih priponskih obrazil po Toporišiču in Metelku

Preglednica 13: Zastopanost feminativnih priponskih obrazil po Toporišiču in Muršcu 128

Preglednica 14: Zastopanost feminativnih priponskih obrazil po Toporišiču in Malavašiču 
Preglednica 15: Zastopanost feminativnih priponskih obrazil po Toporišiču in Potočniku.....

Preglednica 16: Zastopanost feminativnih priponskih obrazil po Toporišiču in Majarju

Preglednica 17: Zastopanost feminativnih priponskih obrazil po Toporišiču in Navratilu. 132

Preglednica 18: Zastopanost feminativnih priponskih obrazil po Toporišiču in Janežiču

Preglednica 19: Zastopanost feminativnih priponskih obrazil po Toporišiču in Miklošiču 134

Preglednica 20: Zastopanost feminativnih priponskih obrazil po Toporišiču in Šumanu (1881) 135

Preglednica 21: Zastopanost feminativnih priponskih obrazil po Toporišiču in Šumanu (1884) 136

Preglednica 22: Zastopanost feminativnih priponskih obrazil po Toporišiču in Končniku

Preglednica 23: Zastopanost feminativnih priponskih obrazil po Toporišiču in Schreiner-Bezjaku. 138

Preglednica 24: Zastopanost feminativnih priponskih obrazil po Toporišiču in Brezniku (1934) 140

Preglednica 25: Zastopanost feminativnih priponskih obrazil po Toporišiču in Slovenski slovnici (1956)

Preglednica 26: Zastopanost feminativnih priponskih obrazil po Toporišiču in Bajcu 143

Preglednica 27: Primerjalni pregled zastopanosti feminativnih priponskih obrazil 144

Preglednica 28: Obrazilna drugačnost - dodajalni način 146

Preglednica 29: Obrazilna drugačnost - zamenjevalni način 147

Preglednica 30: Primerjalni pregled feminativnih priponskih obrazil (SS in SSKJ 1). 163

Preglednica 31: Zamenjava moškospolskih priponskih obrazil s feminativnimi v SSKJ 1 164 
Preglednica 32: Sinteza obrazilne produktivnosti - zamenjevalni način (SSKJ 1)

Preglednica 33: Sinteza obrazilne produktivnosti - zamenjevalni način ob moškospolskih izglasjih (SSKJ 1)

Preglednica 34: Družljivost feminativnih priponskih obrazil z izglasji moškospolskih poimenovanj $v$ SSKJ 1 186

Preglednica 35: Sinteza obrazilne produktivnosti-dodajalni način (SSKJ 1) .. 199 Preglednica 36: Sinteza obrazilne produktivnosti - dodajalni način k izglasju podstave (SSKJ 1) 208

Preglednica 37: Primerjalni pregled feminativnih priponskih obrazil (SS in NSL)

Preglednica 38: Družljivost feminativnih priponskih obrazil $z$ izglasji moškospolskih poimenovanj v Novejši slovenski leksiki

Preglednica 39: Sinteza obrazilne produktivnosti - dodajalni način (Novejša slovenska leksika)

Preglednica 40: Sinteza obrazilne produktivnosti - dodajalni način ob izglasjih podstav (Novejša slovenska leksika)

Preglednica 41: Zamenjava moškospolskih priponskih obrazil s feminativnimi $v$ Novejši slovenski leksiki 223

Preglednica 42: Sinteza obrazilne produktivnosti - zamenjevalni način (Novejša slovenska leksika) 225

Preglednica 43: Sinteza obrazilne produktivnosti - zamenjevalni način ob moškospolskih izglasjih (Novejša slovenska leksika).....

Preglednica 44: Primerjalni prikaz feminativnih priponskih obrazil (SS in SNBSJ)

Preglednica 45: Družljivost feminativnih priponskih obrazil $z$ izglasji moškospolskih poimenovanj $v$ SNBSJ

Preglednica 46: Sinteza obrazilne produktivnosti-dodajalni način (SNBSJ) .. 234 Preglednica 47: Sinteza obrazilne produktivnosti - dodajalni način ob izglasjih podstav (SNBSJ)

Preglednica 48: Zamenjava moškospolskega priponskega obrazila s feminativnim po SNBSJ 238 
Preglednica 49: Sinteza obrazilne produktivnosti - zamenjevalni način (SNBSJ)

Preglednica 50: Sinteza obrazilne produktivnosti - zamenjevalni način ob moškospolskih izglasjih (SNBSJ)

Preglednica 51: Primerjalni pregled feminativnih priponskih obrazil (SS in SSKJ 2).

Preglednica 52: Zamenjava moškospolskih priponskih obrazil s feminativnimi $v$ SSKJ 2 246

Preglednica 53: Sinteza obrazilne produktivnosti - zamenjevalni način (SSKJ 2)

Preglednica 54: Sinteza obrazilne produktivnosti - zamenjevalni način ob

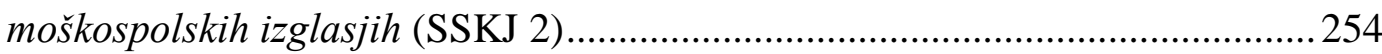

Preglednica 55: Družljivost feminativnih priponskih obrazil $z$ izglasji moškospolskih poimenovanj $v$ SSKJ 2 257

Preglednica 56: Sinteza obrazilne produktivnosti-dodajalni način (SSKJ 2)...263 Preglednica 57: Sinteza obrazilne produktivnosti - dodajalni način k izglasju podstave (SSKJ 2)

Preglednica 58: Dodajalna feminativna priponska obrazila pri tvorbi poimenovanj živali $v$ SSKJ 1 273

Preglednica 59: Zamenjava moškospolskega priponskega obrazila z ženskospolskim pri tvorbi poimenovanj živali v SSKJ 1 276

Preglednica 60: Primerjalni prikaz feminativov glede na način tvorbe .278 Preglednica 61: Primerjalni pregled družljivosti feminativnih priponskih obrazil z izglasji moškospolskih samostalnikov po pomenskih skupinah 279 Preglednica 62: Sinteza obrazilne produktivnosti - dodajalni način (primerjalni prikaz) 284

Preglednica 63: Sinteza obrazilne produktivnosti - dodajalni način k izglasju podstave (primerjalni prikaz)..... 288

Preglednica 64: Primerjalni prikaz zamenjave moškospolskih priponskih obrazil s feminativnimi po pomenskih skupinah.... 290

Preglednica 65: Sinteza obrazilne produktivnosti - zamenjevalni način (primerjalni prikaz) 295 
Preglednica 66: Sinteza obrazilne produktivnosti - zamenjevalni način ob moškospolskih izglasjih (primerjalni prikaz) ..................................................... 296

Preglednica 67: Variantni priponski obrazili -ica in -ka................................... 323

Preglednica 68: Variantni priponski obrazili -inja in -ka ............................... 340

Preglednica 69: Variantni priponski obrazili -ica in -inja ............................... 347

Preglednica 70: Variantni priponski obrazili -ica in -(ov)ka ............................ 349

Preglednica 71: Variantni priponski obrazili -a in -inja .................................. 350

Preglednica 72: Variantni priponski obrazili -inja in -(ar)ka............................ 351

Preglednica 73: Variantni priponski obrazili -ca in -ka.................................. 353

Preglednica 74: Variantni priponski obrazili -a in -ka..................................... 353

Preglednica 75: Variantni priponski obrazili -inja in -(ov)ka........................... 354

Preglednica 76: Variantni priponski obrazili -ja in -inja ................................. 355

Preglednica 77: Variantna priponska obrazila -ica, -ja in -ka........................... 356

Preglednica 78: Variantna priponska obrazila -ica, -inja in -ka....................... 357

Preglednica 79: Variantna priponska obrazila -inja, -ka in -esa ...................... 358

Preglednica 80: Variantna priponska obrazila -lja, -ulja in -ka ........................ 358

Preglednica 81: Variantna priponska obrazila -ica, -ulja in -(ov)ka .................. 359

Preglednica 82: Variantni priponski obrazili -ica in -ka pri poimenovanjih živali

Preglednica 83: Variantni priponski obrazili -ica in -ulja pri poimenovanjih živali 361

Preglednica 84: Variantni priponski obrazili -a in -inja pri poimenovanjih živali

Preglednica 85: Variantni priponski obrazili -ica in -inja pri poimenovanjih živali 363

Preglednica 86: Variantni priponski obrazili -inja in -(ov)ka pri poimenovanjih živali 363

Preglednica 87: Variantni priponski obrazili -ica in -(ov)ka pri poimenovanjih živali 364

Preglednica 88: Variantna priponska obrazila -ica, -lja, -ulja in -(ov)ka pri poimenovanjih živali .365

Preglednica 89: Variantni priponski obrazili -inja in -na ................................ 366 
Preglednica 90: Variantni priponski obrazili -ka in -(ev)ka.

Preglednica 91: Variantni priponski obrazili -ica in -(ev)ka pri poimenovanjih živali 367

Preglednica 92: Variantna priponska obrazila -ica, -ulja in -(ev)ka pri

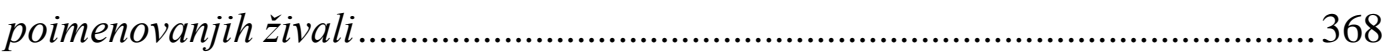

Preglednica 93: Variantni priponski obrazili -ica in -inja...................................369

Preglednica 94: Variantni priponski obrazili -ja in -ka...................................... 370

Preglednica 95: Variantni priponski obrazili -ica in -ka .................................... 372

Preglednica 96: Omejena tvorba feminativov ...................................................... 376

Preglednica 97: Zastopanost feminativnih priponskih obrazil pri tvorbi poimenovanj za prebivalke 401

Preglednica 98: Poimenovanja za prebivalke, nastala $z$ dodajanjem ženskospolskega obrazila samostalnikom moškega spola 406 Preglednica 99: Poimenovanja za prebivalke, nastala z zamenjavo celotnega ali le izglasnega dela moškospolskega obrazila z ženskospolskim ob isti podstavi ..... 409 Preglednica 100: Priimkovni feminativi, nastali z dodajanjem ženskospolskega obrazila priimkom moškega spola 418 Preglednica 101: Priimkovni feminativi, nastali z zamenjavo celotnega ali le izglasnega dela moškospolskega obrazila z ženskospolskim ob isti podstavi ..... 421 Preglednica 102: Priimkovni feminativi, tvorjeni s priponskim obrazilom -ica .. 422 Preglednica 103: Priimkovni feminativi, tvorjeni s priponskim obrazilom -ca ...424 Preglednica 104: Priimkovni feminativi, tvorjeni s priponskim obrazilom -ka ... 425 Preglednica 105: Priimkovni feminativi, tvorjeni s priponskim obrazilom -(ev)ka 427

Preglednica 106: Priimkovni feminativi, tvorjeni s priponskim obrazilom -(ov)ka 428

Preglednica 107: Priimkovni feminativi, nastali z dodajanjem ženskospolskega obrazila $k$ priimkom moškega spola - primerjava med Slovenskim pravopisom in korpusom Gigafida

Preglednica 108: Priimkovni feminativi, nastali z zamenjavo celotnega ali le izglasnega dela moškospolskega obrazila z ženskospolskim ob isti podstavi primerjava med Slovenskim pravopisom in korpusom Gigafida 


\section{UVOD}

\subsection{Opredelitev problema}

Stališče družbe do posameznega spola in s tem do družbenih razlik med žensko in moškim se odraža na posameznih mikroravneh vsakdanjega življenja, tudi v jeziku. Glede rabe slovničnih spolov Slovenska slovnica (Toporišič 2004: 266) pravi, da je »moški spol slovnično nezaznamovan nasproti ženskemu, zato se v primerih, ko je jasno, za kateri spol gre, samostalniške besede in oblike moškega spola lahko rabijo namesto ženskih«. Dejstvo, da se namesto ženskih poimenovanj za osebe lahko uporabljajo moška, ki da so nezaznamovana, lahko razložimo s tem, da ima slovnični spol možnost posploševanja; tako poimenovanje za moški ne referira več na naravni spol, temveč izraža pomensko sestavino »spolsko nevtralno«. V taki opredelitvi vloge slovničnega spola kot nadspola v jezikovnem sistemu vidijo nekateri zapostavljanje ženske oz. ženskega spola (Bešter 1997: 11). V Sloveniji se je začelo o tovrstnih problemih razmišljati šele v devetdesetih letih 20. stoletja (Žagar, Milharčič Hladnik 1995, Bešter 1997, Vidovič Muha 1997), sprva s pobudo o upoštevanju ženskega spola v zakonskih besedilih v ljubljanski mestni upravi, kasneje pa s pripravo priporočil za izogibanje seksistične rabe jezika; slednje med drugim omogoča dosledna raba feminativov.

Tvorjenje feminativov, ženskih oblik pri moških poimenovanjih za delujoče osebe, tj. poklice, nazive, čine itd., a tudi za živali, je tipična besedotvorna možnost slovenščine in drugih slovanskih jezikov ${ }^{1}$ (Korošec 1989: 443), pri čemer je mogoča tvorba iz občnoimenske in lastnoimenske podstave (Jež 1997a: 115). Toporišič v Slovenski slovnici (2004: 183) feminative definira kot ženski par moškemu in jih obravnava znotraj inačenjske (modifikacijske) izpeljave. Podobno velja tudi v preostalih slovanskih jezikih (npr. Ćorić 1982, Mluvnice češtiny 1986, Koneski 2003, Klajn 2003, Zemska 2006). Tako so tovrstne tvorjenke rezultat drugotnega besedotvornega postopka - nastopajo zgolj kot ženski par k že obstoječemu moškemu imenu (Korošec 1998: 77-79).

\footnotetext{
${ }^{1}$ Možnost tovrstne tvorbe obstaja tudi v neslovanskih jezikih, denimo v nemščini (npr. der Lehrer $\rightarrow$ die Lehrerin).
} 
Feminativi se po Toporišiču tvorijo s priponskimi obrazili $-a /-a ́$, -ica/-ica, -ja, -ulja, -inja/-inja, -ka, -ovka in -ična, vendar je v slovenščini lahko parno žensko poimenovanje pri višje razvitih večjih bitjih izraženo tudi s posebno besedo (npr. mož - žena, oče - mati, hlapec-dekla ...). Ob tem Irena Stramljič Breznik (2004: 18, po Vidovič Muha 1997) opozarja, da poimenovanja ženskih oseb sodijo med nemodifikacijske izpeljanke, kadar gre za biološko (dojilja) ali sociološko zaznamovanost (perica) in pri tvorjenkah ženskega spola za živali, če ni moškospolskega ustreznika (brenčalka).

Feminativi se $\mathrm{v}$ slovenščini tvorijo na dva načina: (a) $\mathrm{z}$ dodajanjem ženskospolskega obrazila tvorjenkam moškega spola; (b) z zamenjavo celotnega ali le izglasnega dela moškospolskega obrazila z ženskospolskim ob isti podstavi (Toporišič 1966: 98, Stramljič Breznik 1994/95, Korošec 1998, Jež 1998: 225226; enako tudi v drugih slovanskih jezikih - Ćorić 1982, Koneski 2003, Klajn 2003, Zemska 2006). Dodajalna feminativna priponska obrazila je mogoče razvrstiti glede na to, s katerimi tipičnimi soglasniškimi izglasji moškospolskih obrazil se družijo, zamenjevalna obrazila pa glede na to, katera moškospolska obrazila zamenjujejo. Kljub temu pa nekateri jezikoslovci pri zamenjavi moškospolskega priponskega obrazila $\mathrm{z}$ ženskospolskim kot načinu modifikacijske izpeljave vidijo očitno podrejanje tvorbe poimenovanj za ženske osebe poimenovanjem za moške, npr. pravnica, zdravnica, delavka - take tvorjenke je mogoče razumeti kot navadne izpeljanke iz samostalnika $\mathrm{z}$ besedotvornim pomenom 'nosilka povezave'. Na to opozarja Irena Stramljič Breznik (2004: 18), ki se sklicuje na Vidovič Muho (1997: 71; 2003: 180), mnenja glede tega pa so deljena tudi $\mathrm{v}$ nekaterih drugih slovanskih jezikih (npr. Barić 1987, Štebih Golub 2010).

\subsection{Namen in cilji doktorske disertacije}

V doktorski disertaciji bomo preučevali feminative v slovenskem jeziku. Del disertacije bo namenjen tvorbeni produktivnosti feminativnih priponskih obrazil glede na zastopanost po pomenskih skupinah, pogojenih s tvorbo iz samostalniških, pridevniških in glagolskih podstav. Pričakujemo, da je tvorbena 
obremenitev ženskospolskih obrazil sicer zelo velika, vendar bo na podlagi gradiva ugotovljeno, ali obstaja prepoznavna funkcijska diferenciacija. Nanjo bomo posebej pozorni pri tvorbi feminativov. S tem se želimo osredotočiti tudi na družbeno prepoznavnost žensk, kot jo je mogoče razbrati iz slovenskega jezikovnega sistema. Gre za dve temeljni razsežnosti: žensko kot biološko in žensko kot sociološko bitje. Besedotvorje predstavlja tisto področje, ki pri drugi od obeh omenjenih razsežnosti omogoča prepoznavanje zakrite hierarhizacije ali izražene družbene hierarhizacije po spolu, kar bo predstavljajo poseben vidik analize feminativov.

Namen disertacije je ugotoviti funkcijsko produktivnost feminativnih priponskih obrazil in njihovo pojavnost potrditi s pomočjo sodobne korpusne metode, ki omogoča statistično relevantnejšo in večjo verodostojnost prikaza realnega stanja na različnih področjih jezikovne rabe. $\mathrm{V}$ ta namen bosta uporabljena milijardni korpus Gigafida in njegova uravnotežena različica Kres. V okviru feminativne tvorbe želimo za vsa produktivna obrazila ugotoviti, s katerimi tipičnimi izglasji moških oblik se družijo oz. katera moškospolska obrazila zamenjujejo. Zanimivo bo tudi prepoznavanje morebitne vrednostne hierarhije pri odločanju, katero od možnih obrazil se bo utrdilo pri npr. poklicnem poimenovanju ali opravljanju določene družbeno (ne)pomembne vloge. Jezikovna resničnost namreč zrcali tudi družbeno resničnost; jezik predstavlja zanesljivo znamenje vsakršnih družbenih sprememb.

$\mathrm{Na}$ osnovi teoretičnih izhodišč nameravamo $\mathrm{v}$ empiričnem delu disertacije slediti naslednjim ciljem:

- raziskati pojavnost feminativnih priponskih obrazil $\mathrm{z}$ variantami po besedotvornih pomenskih skupinah;

- ugotoviti, katero priponsko obrazilo je pri tvorbi feminativov absolutno frekventnejše;

- ugotoviti, kateri način tvorjenja feminativov v slovenščini prevladuje, z dodajanjem feminativnega priponskega obrazila samostalniku moškega spola ali z zamenjavo moškospolskega obrazila z ženskospolskim;

- raziskati tvorbo feminativov iz občnoimenske podstave ter ugotoviti podobnosti oz. razlike v sistemu tvorbe pri poimenovanjih oseb in živali; 
- ugotoviti, ali obstajajo pomenski in formalni razlogi, ki govorijo v korist tipu zamenjevalnih feminativov ali vzporedni nemodifikacijski tvorbi ženskih oblik;

- razvrstiti feminativna priponska obrazila glede na to, $\mathrm{s}$ katerimi tipičnimi soglasniškimi izglasji moškospolskih obrazil se družijo kot dodajalna feminativna obrazila oz. katera moškospolska priponska obrazila zamenjujejo kot zamenjevalna;

- ob tvorbi feminativov iz občnoimenske podstave raziskati tudi tvorbo iz lastnoimenske podstave ob poimenovanjih prebivalk in priimkovnih feminativih;

- besedotvorno analizirati 500 ženskospolskih oblik priimkov iz Slovenskega pravopisa, kar bo predstavljalo izhodišče za korpusno analizo priimkovnih feminativov iz Gigafide in primerjavo gradiva iz obeh virov.

0.2.1 Teza doktorske disertacije

V disertaciji bomo poskušali potrditi naslednje teze:

- Jože Toporišič v Slovenski slovnici (2004: 183) navaja naslednja feminativna priponska obrazila: -a/-á, -ica/-ica, -ja, -úlja, -inja/-inja, -ka, -ovka in -íčna. V novejših virih pa se pojavljajo še druga priponska obrazila, s katerimi tvorimo feminative. To velja za tvorbo iz občnoimenske in lastnoimenske podstave.

- Pregled zastopanosti feminativnih priponskih obrazil (po Toporišiču -a/-á, -ica/-ica, -ja, -ulja, -inja/-ínja, -ka, -ovka in -íčna) po pomenskih skupinah kaže, da je najbolj produktivno priponsko obrazilo -ka, ki po Bajčevem Besedotvorju slovenskega jezika nastopa kar v 18 pomenskih skupinah od skupno 27 (torej v 67 \%), po Toporišičevi Slovenski slovnici (2004) pa v $10(37 \%)$. Pričakujemo, da so tudi feminativi v slovenskem jeziku v glavnem tvorjeni s priponskim obrazilom $-k a$ in njegovimi variantami. ${ }^{2}$

\footnotetext{
2 Furdik v monografiji Slovenska slovotvorba (2004: 41) uporablja termin perintegracija. Perintegracijo definira kot prerazporeditev morfemske meje med besedotvorno podstavo in »šibkejšim« obrazilom, pri čemer se pojavijo razširjene variante pripon. Po Mluvnice češtiny 
- Kot že rečeno, se feminativi tvorijo na dva načina. V slovenskem jeziku prevladuje dodajanje moškospolskega obrazila z ženskospolskim ob isti podstavi.

- Dosedanje analize feminativnih priponskih obrazil (Stramljič Breznik 1992, 1994/95, Vidovič Muha 1997, Korošec 1998) izpostavljajo tipična izglasja, ki se jim feminativna obrazila dodajajo, oz. moškospolska priponska obrazila, ki jih ženskospolska zamenjujejo. Tako je v ospredju dodajanje priponskega obrazila $-k a$ tvorjenkam moškega spola na izglasja $-\check{c},-d,-j,-n,-r,-\check{s},-t,-v$ (brusačka, doktorandka, čuvajka, kapitanka, dreserka, bombaška, absolventka, detektivka); priponski obrazili -a in -na se dodajata izglasjem na $-\check{c}$ (gostača, dedična); -ica tistim s $-\check{c}$, $-l j$ in $-r$ (beračica, ravnateljica, bobnarica); -inja pa $\mathrm{s}-k,-g,-h \mathrm{v}$ izglasju (prerokinja, boginja, varuhinja). Novejši viri in obsežnejša raziskava bodo izpostavili še druga možna izglasja, enako velja za moškospolska obrazila, ki jih ženskospolska zamenjujejo. Raziskave za zdaj izpostavljajo priponsko obrazilo -ica, ki zamenjuje -ik (basnica), ter -ka, ki zamenjuje moškospolsko obrazilo -ec (borka) z variantami.

- Pojav prevzete leksike in $\mathrm{s}$ tem poimenovanj za dejavnosti vodi $\mathrm{k}$ ambivalentnosti pravil, potrjenih izključno na domačih in že ustaljenih leksemih. Tako se pogosto ob pojavu leksema moškega spola uveljavi dvojnica (tutorka/tutorica; koordinatorka/koordinatorica). Posebej bo treba preveriti, ali se razvrstitvena pravila ravnajo po pravilih izglasij v domačih besedah ali gre za nove pojave.

- Po Toporišiču (1981: 92-93) tvorba feminativov ni vedno mogoča, vendar novejši viri za primere, ki jih navaja kot težavne, že ponujajo ustrezne ženskospolske vzporednice k moškospolskim. Hkrati pa lahko za primere, ki so še vedno vprašljivi, glede na soglasniška izglasja moškospolskih obrazil, s katerimi se družijo dodajalna feminativna obrazila, oz. katera moškospolska priponska obrazila zamenjujejo kot zamenjevalna, predvidimo ustrezni feminativ.

(1986: 218) lahko imajo obrazila ob popolni ohranitvi vseh funkcij različne variante. Pomembne so zlasti t. i. razširjene variante priponskih obrazil, tj. skupek povezovalnega morfema in dejanske pripone. Slednja pogosto nastopa kot samostojno obrazilo. 
0.2.2 Pričakovani izvirni znanstveni prispevki

Doktorska disertacija bo opozorila na t. i. variantna oz. vzporedna feminativna obrazila; ${ }^{3}$ za različna priponska obrazila ob isti podstavi pri istopomenskih tvorjenkah se namreč uporablja poimenovanje vzporedna/tekmovalna/konkurenčna obrazila (Stramljič Breznik 1994, Slovenski pravopis 2001), po Toporišiču (1973) pa variantna obrazila. Med ženskospolskimi poimenovanji npr. za poklice se pri številnih primerih podstavi lahko ob enakem pomenu dodata dve različni obrazili (glede na podatke iz obeh izdaj Slovarja slovenskega knjižnega jezika, Slovenskega pravopisa, Slovarja novejšega besedja slovenskega jezika in korpusa Gigafida), v nekaj primerih pa celo tri različna ženskospolska priponska obrazila (npr. dekanka - dekanica - dekanja). Med analiziranimi primeri pa zasledimo tudi take, kjer so pari besed s konkurenčnimi obrazili nastali z zamenjavo moškospolskega obrazila. Po korpusni analizi, z upoštevanjem večpomenskosti nekaterih tvorjenk in z razvrstitvijo feminativnih priponskih obrazil glede na to, $\mathrm{s}$ katerimi tipičnimi soglasniškimi izglasji moškospolskih obrazil se družijo kot dodajalna feminativna obrazila oz. katera moškospolska priponska obrazila zamenjujejo kot zamenjevalna, bomo predlagali feminativ, ki je glede na sistem tvorbe ustreznejši, hkrati pa bomo ob tem upoštevali tudi pogostnost rabe.

Naslednja predlagana rešitev je povezana s Toporišičevo raziskavo iz leta 1981, ki pravi, da tvorba feminativov v slovenščini vedno ni mogoča, zlasti ne $\mathrm{z}$ ustreznim istovrstnim obrazilom. Dokazali bomo, da k primerom, za katere po avtorjevih trditvah ni mogoče najti ženskospolske ustreznice, $\mathrm{v}$ sodobnem knjižnem jeziku feminativi v glavnem že obstajajo ali pa njihovo obliko lahko predvidimo. S korpusno analizo bomo skušali dokazati, da je raba nekaterih med njimi že dokaj pogosta.

\footnotetext{
${ }^{3}$ Pojem vzporedno priponsko obrazilo je treba ločiti od t. i. vzporedne podstave (Vidovič Muha 1997: 72; 2011: 408), ki je za tvorbo poimenovanj ženskega in moškega spola enaka, pri čemer vedno velja človeško+. Gre za tvorbo iz glagola, pridevnika, izjemoma tudi samostalnika in s tem za besedotvorni pomen vršilka dejanja, nosilka lastnosti, povezave.
} 
Želimo, da bi doktorska disertacija s predstavljenimi izhodišči odprla nov pogled na feminative in pomembno prispevala $\mathrm{k}$ razmisleku o neseksistični rabi jezika.

\subsection{Predpostavke in morebitne omejitve}

Prvo omejitev predstavljata različni interpretaciji besedotvornih pomenov V slovenskem jeziku. Toporišič v Slovenski slovnici (2004: 161-182) na podlagi stavčnočlenske strukture predvideva šest oziroma sedem (če upoštevamo kategorijo časa kot samostojno) pomenskih skupin. Besedotvorne pomene kot $\mathrm{v}$ pripono pretvorjene prvine pomenske podstave - propozicije - stavčne povedi razume in predstavlja Ada Vidovič Muha $\mathrm{v}$ Slovenskem skladenjskem besedotvorju (2011: 82), kjer je za izhodišče besedotvornih pomenov upoštevan skladenjski vidik. Zaradi ohranjanja enotne besedotvornopomenske kategorije, tvorjene $\mathrm{z}$ isto besedotvorno vrsto, bomo $\mathrm{v}$ disertaciji dosledno upoštevali Toporišičev model besedotvornih pomenov.

Omejitev predstavljajo tudi različne obravnave feminativov kot modifikacijskih oz. kot navadnih izpeljank ( $\mathrm{v}$ slovenskem in slovanskem besedotvorju). Tradicionalno slovensko besedotvorje z Jožetom Toporišičem feminative uvršča med modifikacijske izpeljanke, medtem ko Ada Vidovič Muha meni, da gre za inačenjsko izpeljavo le, kadar feminativno priponsko obrazilo dodajamo moškospolskemu poimenovanju bitja (npr. učitelj : učitelj-ica), medtem ko t. i. zamenjevalni način tvorbe feminativov zavrača, saj meni, da gre $v$ tem primeru za navadno izpeljanko ob vzporedni podstavi tipa nobelov-ec : nobelov$k a$. V disertaciji bomo skušali najti argumente, ki bolj podpirajo prvi ali drugi pristop.

Tudi gradivo iz korpusov Gigafida in Kres pomeni omejitev raziskovanja, saj ti sicer zelo obsežni zbirki vsebujeta le besedila, ki so izšla med letoma 1990 in 2011 (Logar Berginc idr. 2012: 35). 


\subsection{Predvidene metode raziskovanja}

$\mathrm{Na}$ področju besedotvorja $\mathrm{v}$ slovenščini so raziskave feminativne tvorbe redke, celovite predstavitve in pregleda tovrstnih izrazov pa sploh ni. Feminative v svoji Slovenski slovnici (2004) kot primer inačenjske (modifikacijske) izpeljave pojmuje Jože Toporišič, kot modifikacijske izpeljanke jih v več znanstvenih člankih in monografijah obravnava tudi Irena Stramljič Breznik (1992, 1994/95, 2010). Drugače k feminativom pristopa Ada Vidovič Muha, ki zamenjevalni način tvorbe feminativov v monografiji Slovensko skladenjsko besedotvorje (2011) zgolj omeni kot nesprejemljiv primer modifikacijske izpeljave. Tvorbo feminativov, zlasti iz lastnoimenske podstave, pa $\mathrm{v}$ nekaj člankih predstavi Marija Jež. O feminativih v slovenskem vojaškem jeziku je razmišljal Tomo Korošec (1998), prav tako kot o modifikacijskih izpeljankah. Posamezni zborniki, kot na primer Neseksistična raba jezika (1995) in XXXIII. Seminar slovenskega jezika, literature in kulture (1997), se sicer posvečajo položaju žensk v kulturi in jeziku oz. problemu seksistične rabe jezika; nekateri prispevki kot eno od možnosti neseksistične jezikovne rabe obravnavajo prav feminative (npr. Vidovič Muha 1997, Jakopin 1997, Bešter 1997). Poleg navedenega dosedanje raziskave temeljijo na gradivu Slovarja slovenskega knjižnega jezika (1998) in Slovenskega pravopisa (2001). Prav zato obstaja potreba po natančni raziskavi in predstavitvi feminativov v sodobnem slovenskem in slovanskem jezikoslovju, podkrepljena $\mathrm{z}$ gradivom iz novejših jezikovnih priročnikov (Slovar novejšega besedja slovenskega jezika, druga izdaja Slovarja slovenskega knjižnega jezika) in korpusov (Gigafida, Kres).

Pregled domače in tuje znanstvene literature je osnova za oblikovanje parametrov empiričnega raziskovalnega dela, kar bo temeljni del disertacije. Kot gradivo bomo uporabili slovnice slovenskega jezika od 16. do 20. stoletja ter aktualno Toporišičevo Slovensko slovnico (2004). Primerjali bomo, s katerimi ženskospolskimi priponskimi obrazili se $\mathrm{v}$ posameznih slovnicah, $\mathrm{v}$ primerjavi $\mathrm{s}$ Toporišičevo, lahko tvorijo feminativi. Primerjava bo pokazala, katero priponsko obrazilo je skozi zgodovino najproduktivnejše pri tvorbi feminativov. 
Izhodišče za nadaljnjo raziskavo feminativov v sodobnem slovenskem jeziku pa predstavljajo jezikovni priročniki Slovar slovenskega knjižnega jezika (1. izdaja 1998, dalje SSKJ 1; 2. izdaja 2014, dalje SSKJ 2), Slovenski pravopis (2001, dalje SP), Novejša slovenska leksika (2009, dalje NSL), Slovar novejšega besedja slovenskega jezika (2013, dalje SNBSJ) ter korpusa Gigafida in Kres. Zanimivo bo opazovati produktivnost feminativnih priponskih obrazil, tvorbo feminativov $\mathrm{z}$ zamenjavo moškospolskega obrazila $\mathrm{z}$ ženskospolskim oz. $\mathrm{z}$ dodajanjem ženskospolskega priponskega obrazila izglasju samostalnikov moškega spola ter na podlagi tvorbnega sistema in upoštevanja rabe ponuditi ustreznejše možnosti ob variantnih ali konkurenčnih obrazilih.

\section{SOCIOLOŠKI PRISTOP: DRUŽBENO VREDNOTENJE SPOLOV}

Študije jezika in spola so izjemno kompleksna tema, ki se prepleta skozi različna znanstvena področja, od jezikoslovja do psihologije in sociologije, posega pa tudi na izredno občutljivo področje družbeno-kulturnih in etičnih norm (Kranjc, Ožbot 2013: 233). Še ne popolnoma razrešeno, a za našo disertacijo pomembno je vprašanje (ne)seksistične rabe jezika, pri katerem se pogosto srečamo s pojmoma seksizem in feminizem ter njunimi izpeljankami.

\subsection{Feminizem proti seksizmu}

Sprva je beseda seksizem označevala dejanja, diskurze in vedenja, ki degradirajo ženske kot osebnosti in njihovo integriteto. V začetku 21. stoletja je taka definicija še vedno aktualna, a razširjena na vprašanje dveh (ali več) obstoječih družbenih spolov. Feministična sociološka teorija namreč ni enotna $v$ definiciji seksizma. Esencialistični ${ }^{4}$ pogled poudarja pomembnost biološkega spola (ang. sex), konstruktivizem pa daje težo zlasti družbeno pripisanemu spolu (ang. gender). Pri tem zagovarja tezo, da se ne rodimo kot ženske in moški, temveč to v družbi šele postanemo. Kategoriji moški in ženska sta tako razumljeni

\footnotetext{
${ }^{4}$ Esencializem predvideva, da so določeni pojavi neizogibni, naravni, univerzalni in biološko določeni (DeLamater in Hyde 1998: 10).
} 
kot glagol (npr. moški ni nekaj, kar si, moški je tisto, kar počneš). V osnovi izhajata obe navedeni razumevanji iz vprašanja biološkega spola: prva tradicija se na tej točki ustavi, druga pa gradi na tistem, kar posamezniku ali posameznici zaradi biološko prepoznanega spola nalaga in od njega pričakuje družba (Kuhar 2001: 116). Lana F. Rakow in Laura A. Wackwitz (1998: 99; povz. po Kuhar 2001: 116) razlagata seksizem kot prvotni sistem prepričanj dominantne kulture, ki se nanaša na družbeni spol; to je sistem vrednot, norm in vedenja, ki temelji na podrejanju žensk moškim. Anthony Giddens (1993: 762, povz. po Kuhar 2001: 117) pa $\mathrm{v}$ definiciji omenja vedenje in prepričanje, ki izhajata iz biološko prepoznanega spola posameznika. Seksizem razume kot zagovarjanje spolne neenakosti oz. ga pojmuje kot vsako vedenje ali prepričanje, ki posamezniku ali posameznici glede na biološki spol pripisuje neresnične lastnosti ali zanika sposobnosti.

Razlage seksizma so v slovenskih jezikovnih priročnikih precej splošne. Po Velikem slovarju tujk (2002: 1035) je seksizem 'zapostavljanje pripadnikov nasprotnega spola, navadno žensk'. SSKJ 2 pa seksizem razlaga kot 'miselnost ali ravnanje, ki temelji na zapostavljanju pripadnikov določenega spola, navadno žensk'. V tej smeri razmišlja tudi Maca Jogan (2001: 1), ki definira seksizem kot celoto stališč, prepričanj, vzorcev delovanj in praktičnih vsakdanjih delovanj, ki temeljijo na strogem ločevanju dejavnosti po spolu ter podeljujejo posameznikom posebne neenake lastnosti glede na spol.

Ena od reakcij na seksizem je feministično gibanje. Prve definicije feminizma izvirajo s konca 19. in začetka 20. stoletja. Slovarji so ga v začetku definirali kot stanje feminilnosti in poženščenosti, nato kot stališče, ki je naklonjeno pravicam žensk. V splošno rabo za označevanje političnega gibanja pa je pojem feminizem prišel okoli leta 1910. Danes je pojem že tako uveljavljen v vsakdanji rabi, da ga uporabljajo celo za označevanje stila oblačenja ali načina vedenja. Iskanje korenin feminizma se po navadi začne pri predpostavki, da je to aktivna želja po spreminjanju položaja žensk $\mathrm{v}$ družbi, $\mathrm{v}$ nadaljevanju pa feminizem obvelja za tovrstno gibanje. Feminizem je torej raznolika zbirka socialnih teorij, političnih gibanj in moralnih filozofij, pretežno motiviranih z izkušnjami žensk, zlasti v socialnem, političnem in ekonomskem kontekstu. 
Feminizem se kot socialno gibanje osredotoča na zmanjšanje in izničenje neenakosti med spoloma ter promoviranje interesov in pravic $\mathrm{v}$ družbi (Jalušič 1992: 121-125).

Veliki slovar tujk (2002: 332) pa feminizem razlaga kot 1. 'gibanje, ki zagovarja politično, družbeno in ekonomsko enakopravnost med spoloma $\mathrm{v}$ javnem in zasebnem življenju'; 2. 'smer $\mathrm{v}$ literarni vedi, ki se ukvarja $\mathrm{s}$ preučevanjem diskriminacije in emancipacije žensk v književnosti'; 3. 'pojavljanje ženskih spolnih značilnosti pri moškem'; 4. 'pomehkuženost'. Po Leksikonu politike (Sruk 1995: 101) je feminizem 'pojmovanje o uveljavljanju ženske enakopravnosti z moškimi; različne družbenokulturne in moralnopolitične koncepcije, ki imajo za cilj osamosvajanje in osvobajanje žensk'. SSKJ 1 in SSKJ 2 definirata feminizem kot 1 . 'gibanje žensk za enakopravnost z moškimi' in kot 2. 'pojavljanje ženskih značilnosti, lastnosti pri moškem', kot feministko pa označujeta 'žensko, ki si prizadeva za enakopravnost z moškimi'. Ob vseh definicijah pa Silvija Borovnik (1995: 16) opozarja na skrajno površno razlago iz Verbinčevega Slovarja tujk iz leta 1982, kjer feminizem pomeni: 1. 'razne buržoazne teorije, ki zagovarjajo formalno družbeno-politično enakopravnost žene', 2. 'ženskost pri moških, zlasti pri homoseksualcih', v figurativnem smislu pa naj bi beseda pomenila 'pomehkuženost'. Njegova razlaga kaže na to, da socialistična družba feminističnih gibanj ni jemala za svoja, saj naj bi bilo v njej žensko vprašanje idealno rešeno. V resnici pa je feminizem v socialistični družbi veljal za buržoazno, odpadniško in škodljivo družbeno gibanje (Borovnik 1995: 21). Iz povedanega lahko sklenemo, da so se feministične ideje izražale $v$ t. i. ženskih gibanjih in da so bila tovrstna prizadevanja $\mathrm{v}$ zgodovini različno, pogosto celo z odporom sprejeta.

\subsubsection{Zgodovina ženskega gibanja}

Žensko gibanje je kolektivno organizirano delovanje za spremembo položaja žensk; njegove korenine segajo v čas razsvetljenstva, kasneje pa ga je praktično spodbujala francoska revolucija $\mathrm{z}$ zahtevo po upoštevanju načela enakosti za oba spola. Od začetkov v 18. stoletju so bile nosilke ženskega gibanja 
samostojne posebne ženske organizacije ali ženski odseki v mešanih političnih strankah ali organizacijah. Žensko gibanje je pogosto bilo povezano z gibanji zoper druge oblike neenakosti in zatiranja, zlasti zoper razredno, rasno in nacionalno. V 19. stoletju se je žensko gibanje razvijalo zlasti v Evropi in Severni Ameriki, ${ }^{5}$ v 20. stoletju pa je postalo svetovno. Žensko gibanje v praktičnem in teoretskem utemeljevanju v začetku ni bilo enotno: vodilna struja je zagovarjala družbeno enakost med spoloma in težila $\mathrm{k}$ odpravljanju različnih oblik diskriminacije žensk, manjšinska pa je poudarjala razlike, oprte predvsem na materinstvo in posebnosti žensk, in je bila konservativna. Konec 20. stoletja je prišlo do večje strpnosti med obema strujama, kar večinoma označujemo kot feminizem. Mednarodno povezovanje žensk pa se je začelo že v 19. stoletju z mednarodnim kongresom $\mathrm{v}$ Parizu in drugo internacionalo ter se nadaljevalo $\mathrm{v}$ prvi polovici 20. stoletja; okrepilo se je zlasti po drugi svetovni vojni. V drugi polovici 20. stoletja je glavna nosilka svetovnega ženskega gibanja OZN, ki si prizadeva za odpravljanje diskriminacije po spolu z razglasitvijo desetletja za ženske, s konvencijo o odpravi vseh oblik diskriminacije žensk, s strategijo za izboljšanje položaja žensk ... (Jogan 2001: 229-232). Večja zgodovinska feministična gibanja $\mathrm{v}$ državah Zahoda predstavljajo tri valove feminizma.

Prvi val feminizma se je tako v 18. in 19. stoletju posvečal zlasti neprimerni in neenakopravni vzgoji žensk; negiral je vlogo narave v konstituciji spolnih razlik in poudaril, da so družbene okoliščine usodne za položaj žensk (Ule 2009: 70). Prizadeval si je zlasti za odpravo nekaterih najbolj krivičnih asimetrij med spoloma v političnem in zakonskem sistemu. Feministke so v Veliki Britaniji in ZDA dosegle odpravo nekaterih diskriminatornih zakonov in uvedbo ženske volilne pravice (Plemenitaš 2012: 170). V glavnem je šlo za prizadevanje za enake pravice žensk v primerjavi z moškimi na ekonomskem, političnem in socialnem področju (Jogan 2001: 230). Ženske so se borile tudi za enakopraven dostop do izobrazbe in služb ter proti statusu ženske znotraj zakonske zveze, pridobljenem s poroko. Feminizem prvega vala je ustvaril novo politično identiteto žensk in zmagal pri zahtevah po ženskih zakonskih pravicah in javnem delovanju. Prvi val

\footnotetext{
${ }^{5} \mathrm{~V}$ letih od 1830 do 1850 je bilo zelo povezano s protisuženjskim gibanjem; ker pa ženske niso imele političnih pravic, s svojimi zahtevami proti suženjstvu niso mogle vplivati na politiko (Leskošek 2004: 89).
} 
je torej trajal vse od prvih pobud do konca druge svetovne vojne (Leskošek 2004: 90). Zametke prvega vala tako zaznamujeta Christine de Pizan $\mathrm{z}$ besedilom Mesto dam in Olympe de Gouges z Deklaracijo pravic ženske in državljanke iz leta 1791. Naslednjega leta je sledilo delo Zagovor pravic ženske, v katerem je Mary Wollstonecraft prikazala svoj pogled na pridobitve francoske revolucije (Bock 2004: 89). Prvo polovico 20. stoletja pa so zaznamovala dela Virginie Woolf (Lastna soba) in Simone de Beauvoir (zlasti Drugi spol).

Drugi val feminizma $\mathrm{v}$ šestdesetih letih je bil $\mathrm{v}$ znamenju slogana »osebno je politično«, saj so bila v ospredju vprašanja, povezana $\mathrm{z}$ nadzorom žensk nad lastnimi življenji in telesi, kot so pravica do splava, kontracepcije, dostopnost karierne poti ... Feministka drugega vala Jo Freeman opozarja, da seksizem temelji na dveh osrednjih predpostavkah, ki sta osnovani na konceptu razlik med moškimi in ženskami: 1. da so moški pomembnejši od žensk, saj opravljajo za družbo nujnejše delo; 2. ženske služijo za pomoč in zabavo moškim (Plemenitaš 2012: 170-171). Drugi val je kot enega ključnih problemov prepoznal tudi nasilje nad ženskami, hkrati pa se je »valovanje« širilo na druga področja: v znanstveno in teoretsko raziskovanje, v praktično delovanje državnih institucij ter $\mathrm{v}$ nacionalne in mednarodne politike. $\mathrm{V}$ osemdesetih letih pa je nasilje nad ženskami postalo pogost predmet proučevanja ženskih, psiholoških, socioloških in drugih študij - vstopilo je $\mathrm{v}$ akademsko sfero (Dobnikar 2009: 98-99). V feminizmu sedemdesetih in osemdesetih let lahko izluščimo dve smeri tematizacije problema: prva smer je značilna za ameriški feminizem, osredinja pa se na spremembe družbenih okoliščin, ki konstituirajo ženske kot podrejeni spol, hkrati pa je z zgoraj navedenim sloganom izrazito politična. Druga smer se je osredotočila na individualno, psihično konstitucijo ženskosti in je kot taka izrazito nepolitična. Promoviral jo je predvsem francoski feminizem z nosilkama Luce Irigaray in Julijo Kristevo (Ule 2009: 71). Hkrati pa iz tega časa izhaja $\mathrm{v}$ sedemdesetih in osemdesetih letih intenzivno zanimanje za pisanje žensk $\mathrm{z}$ raziskovanjem feministične literarne teorije, $\mathrm{v}$ okviru katere sta se razvili dve nasprotujoči si poziciji: eno zastopa angloameriška feministična literarna teorija, drugo pa francoska. Prva zagovarja predvsem literarni realizem in opisovanje osebnih izkušenj z žensko kot zgledom moči, aktivnosti, upora, druga pa 
izpostavlja literarni modernizem $\mathrm{s}$ poudarjeno neopredeljenostjo in večpomenskostjo besedila (Mesec 2009: 136). ${ }^{6}$ Iz drugega vala feminizma izhaja tudi Robin Lakoff s knjigo Jezik in mesto ženske iz leta 1975. Nemoč tipično ženskega govora vidi kot produkt družbene enakopravnosti, ki ženski omejuje dostop do družbene moči (Plemenitaš 2012: 172).

Tretji val feminizma vključuje heterogenost ženskih identitet, obenem pa poudarja samozavest in doseganje družbene moči (Plemenitaš 2012: 170). Pripadnice tretjega vala postavljajo vprašanja ženskosti in žensk v širša izhodišča pravičnosti, ki se vežejo na neenakosti, a ne le spolne (Leskošek 2009: 120). Poleg feminizma tretjega vala se je proti koncu 20. in na začetku 21. stoletja kot delo postfeminističnih teorij $\mathrm{v}$ zahodnem svetu začel uveljavljati nepolitični feminizem, imenovan tudi feminizem razlik. Eno najbolj znanih del s tega področja je delo Johna Graya Moški so z Marsa, ženske so z Venere. Na področju jezikoslovne znanosti pa se v to paradigmo vključuje Deborah Tannen s svojim najbolj znanim delom Ženske in moški v pogovoru: sploh me ne razumeš. Avtoričina glavna teza je, da ženske in moški pri govorjenju uporabljajo različne stile, pri čemer je največji problem posledično povzročanje nesporazumov v vsakdanjem življenju ali na delovnem mestu. Zaključuje pa, da sta sicer moški in ženski stil govorjenja različna, a še vedno enakovredna. Zdravnica Luann Brizendine pa s svojo knjigo Ženski možgani iz leta 2007 utemeljuje razlike med ženskimi in moškimi možgani zlasti pri delovanju hormonov in tako v svoje razlage vnaša precej biološkega redukcionizma in determinizma (Plemenitaš 2012: 172). Novi val feminističnih aktivistk pa se od prejšnjih razlikuje tudi po tem, da se vse manj ukvarja $z$ vprašanji o spolnih razlikah in vedno tesneje povezuje teorijo $\mathrm{z}$ aktivizmom. Te skupine so sicer obdržale cilje prvega in drugega vala feminizma, zlasti v polju telesa, nasilja, pornografije, prostitucije, saj jih je vedno znova treba obujati in aktivirati (Leskošek 2009: 119).

\subsubsection{Mednarodno povezovanje žensk}

\footnotetext{
${ }^{6}$ Natančen prikaz obeh struj, angloameriške in francoske, s predstavnicami in njihovimi deli ponuja Toril Moi v Politiki spola/teksta.
} 
Mednarodno organiziranje bojev za ženske pravice ima svoj začetek v 19. stoletju. Prva mednarodna konferenca o pravicah žensk je bila leta $1888 \mathrm{v}$ Parizu; istega leta se je $\mathrm{v}$ ZDA sestal mednarodni svet žensk ob podpori mednarodne krščanske ženske organizacije. V začetku 20. stoletja pa je Klara Zetkin organizirala mednarodne konference socialističnih žensk. Mednarodni svet žensk je imel svoj sedež v Zürichu in se je v glavnem ukvarjal s socialnimi in ekonomskimi vprašanji, zavzemal pa se je tudi za volilno pravico. Leta 1902 so se na Mednarodni ženski volilni konferenci v Washingtonu že oblikovale ideje, ki so kasneje postale del Konvencije Združenih narodov o odpravi vseh oblik diskriminacije žensk. Tradicionalni položaj žensk v smislu plačane delovne sile in javnih položajev pa je spremenila prva svetovna vojna; takrat je namreč zelo narasla zaposlenost žensk, povečale pa so se tudi mednarodne ženske aktivnosti, ki so promovirale mir. Leta 1919 so kot delegatke želele sodelovati na mirovni konferenci in kot zaposlene v Društvu narodov, ustanovljenem 1919. Naslednjega leta je Mednarodna liga za žensko volilno pravico sprejela listino o ženskih pravicah, ki je vključevala politične, osebne, družinske, izobraževalne, ekonomske in moralne pravice; vsi ukrepi so bili vključeni tudi v univerzalne ter regionalne sporazume in druge akte. Po drugi svetovni vojni se je število mednarodnih ženskih organizacij še povečalo, v veliko državah so ženske že imele volilno pravico in bile zastopane $\mathrm{v}$ javni sferi. Šestdeseta leta prejšnjega stoletja je zaznamoval vzpon neofeminističnega gibanja $\mathrm{v}$ Zahodni Evropi in ZDA ter številnih ženskih gibanj in organizacij po vsem svetu. Zahodno in kasneje svetovno feministično gibanje je nato $\mathrm{v}$ sedemdesetih in osemdesetih letih zelo pripomoglo $\mathrm{k}$ uzakonjanju pravic žensk na nacionalnih ravneh, $\mathrm{k}$ razpravi o enakih možnostih in k uvedbi nekaterih tovrstnih ukrepov. Omeniti pa je treba še dva sporazuma: Mednarodni pakt o ekonomskih, socialnih in kulturnih pravicah ter Mednarodni pakt o državljanskih in političnih pravicah. Številni drugi dokumenti, nastali kasneje, pa zadevajo posebne vidike življenja žensk: odpravo diskriminacije v vzgoji, zagotavljanje enakega plačila, zatiranje trgovine z ljudmi in izkoriščanja prostitucije, pravice $\mathrm{v}$ zvezi z državljanstvom poročenih žensk, politične pravice žensk, zaščito žensk in otrok v oboroženem spopadu ter pravice migracijskih delavcev in njihovih družin. Leta 1979 je načelo nediskriminacije na 
osnovi spola postalo predmet Konvencije o odpravi vseh oblik diskriminacije žensk, ki pa je bil obremenjen s pridržki velikega števila držav. Na svetovni konferenci Združenih narodov leta 1993 so bile države pozvane k umiku pridržkov. Prav to konferenco, predhodnico uspešne ženske konference leta 1995 v Pekingu, številne avtorice označujejo kot prelomno točko v boju za človekove pravice žensk. Tu so namreč ženske civilnodružbene organizacije in aktivistke uspele premakniti glavne mednarodne organizacije za človekove pravice v smeri posvečanja pozornosti pravicam žensk. Iz pregleda je razvidno, da pravice žensk niso bile avtomatično priznane kot univerzalne (Jalušič 2004: 42-47).

\subsection{3 Ženske v Evropski uniji}

Zavzemanje za enakopravnost evropskih žensk se odraža $\mathrm{v}$ številnih dokumentih. Že Rimska pogodba iz leta 1957 je predpisala načelo, da morajo ženske in moški za enako delo prejeti enako plačilo. Na prvi Evropski ministrski konferenci o enakosti žensk in moških leta 1986 je bila sprejeta Resolucija o politiki in strategijah za doseganje enakosti v političnem življenju in $\mathrm{v}$ postopku odločanja, na naslednji konferenci leta 1989 pa Resolucija o politiki za pospeševanje doseganja resnične enakosti žensk in moških. Svet Evrope je leta 1988 sprejel Deklaracijo o enakosti žensk in moških, na podlagi tega pa je bilo leta 1990 pripravljeno Poročilo Ministrskega odbora članicam Sveta Evrope za odpravo seksistične rabe jezika (Žagar, Milharčič Hladnik 1995: 7). Amsterdamska pogodba je leta 1997 zahtevala integracijo načela enakosti spolov v vse svoje aktivnosti, Lizbonska pogodba pa je deset let kasneje okrepila načelo enakosti z njegovo vključitvijo med vrednote in cilje EU ter z integracijo načela enakosti spolov v vse politike EU (Umek Venturini 2013: 16). Na evropski regionalni ravni je za varstvo človekovih pravic najpomembnejši sistem mednarodnih instrumentov, sprejetih pod okriljem Sveta Evrope, ki si kot politična organizacija, katere cilji so spodbujanje demokracije, človekovih pravic in pravne države, s svojim delovanjem prizadeva tudi za spoštovanje enakosti žensk in moških. Med pomembnejšimi dokumenti je Evropska konvencija o varstvu človekovih pravic in temeljnih svoboščin, ki zagotavlja nediskriminatorno 
uživanje pravic in svoboščin ne glede na spol. Vprašanje enakega obravnavanja in enakih možnosti spolov ureja tudi Evropska socialna listina, s tem ko prepoveduje diskriminacijo pri uresničevanju tistih pravic, ki jih ščiti; poudarja namreč, da so pravice zagotovljene brez razlikovanja glede na spol. Evropska unija in zlasti Evropska komisija spodbujata in podpirata mnogo projektov, raziskovalnih in izobraževalnih dejavnosti, lobiranj ter mednarodnih povezovanj, pri čemer je namen pospeševanje in izvajanje načela enakosti spolov $\mathrm{v}$ različnih sferah ekonomskega, političnega in družbenega življenja. Enaka obravnava spolov je načelo temeljne pogodbe EU - Amsterdamske pogodbe - in mnogo direktiv, uveljavljenih $\mathrm{v}$ nacionalnih zakonodajah držav članic. EU se je $\mathrm{z}$ vprašanjem enakih možnosti spolov soočila že ob ustanovitvi; do leta 2004 je bilo sprejetih osem direktiv in njihovih dopolnitev o enaki obravnavi moških in žensk pri zaposlovanju in socialni varnosti. Ukrepi EU pa bodo v prihodnosti osredinjeni na učinkovito izvajanje zakonodaje na področju socialne varnosti, izrabe očetovskega dopusta, zaščite materinstva in delovnega časa (Gortnar, Salecl 2004: 115-118).

Leta 1998 je Evropska komisija ustanovila posebno delovno skupino, ki je leto pozneje objavila poročilo o položaju žensk v evropskih raziskovalnih politikah. Na podlagi njenih priporočil je bila istega leta ustanovljena Helsinška skupina o ženskah in znanosti (aprila 2013 preimenovana v Helsinško skupino o spolih v raziskavah in inovacijah), v kateri ima svoje mesto tudi Slovenija; po tem zgledu je bila na Slovenskem namreč ustanovljena Komisija za ženske v znanosti. Kasneje, leta 2002, je bilo na osnovi nacionalnih poročil držav članic objavljeno skupno poročilo o nacionalnih politikah o ženskah in znanosti v Evropi, ki je vključevalo 30 držav. Na podlagi navedenih aktivnosti je Evropska komisija leta 2001 pripravila akcijski načrt za znanost in družbo, ki je predlagal štiri pobude: 1 . ustanovitev evropske platforme znanstvenic, 2. pripravo nabora indikatorjev, ki bi merili položaj žensk v evropskih raziskavah, 3. analizo vloge žensk v znanosti v zasebnem sektorju, 4. analizo položaja znanstvenic v Srednji in Vzhodni Evropi ter na Baltiku, in to $\mathrm{v}$ državah, ki niso sodelovale $\mathrm{v}$ poročilu iz leta 2000. Leta 2002 je Evropska komisija ustanovila ekspertno telo ENWISE za pripravo analize položaja znanstvenic na teh območjih. Poročilo so objavili dve leti kasneje in pomeni kolektivni pogled na položaj žensk v znanosti, upoštevajoč nacionalne 
razlike. Tudi slovenska Komisija za ženske v znanosti je od začetka sodelovala z ENWISE. Nato je Evropska komisija leta 2006 ustanovila ekspertno skupino, ki je analizirala trenutno situacijo, identificirala dobre prakse in učinkovite ukrepe posameznih držav ter jih objavila v poročilu. Po novi študiji iz leta 2008 pa se je izkazalo, da je napredek v smeri enakosti spolov počasen, zato je Evropska komisija svoje aktivnosti preusmerila k organizacijam, kjer znanstvenice delajo. V prihodnje bi bilo dobro okrepiti prizadevanja za enake možnosti v raziskovalnih organizacijah in se usmeriti k naslednjim ciljem: 1. povečanju števila žensk v znanosti, 2. prenovitvi raziskovalnih organizacij in 3. poglabljanju znanja o vprašanjih spolov. $\mathrm{S}$ temi cilji bi morali biti podprti programi v prihajajočem Okvirnem programu EU - Obzorju 2020 (Umek Venturini 2013: 17-19).

\subsection{Položaj žensk na Slovenskem}

Žensko gibanje na Slovenskem je razčlenjeno in razvejano glede na različna institucionalna, socialna, kulturna merila: poleg značilnosti, ki so skupne gibanju $\mathrm{v}$ drugih evropskih državah, ima tudi nekaj posebnosti, predvsem povezavo z narodnoobrambnim delovanjem (Jogan 2001: 232). Ženske so zahtevale pravice in opozarjale na svoj družbeni položaj, pri čemer so se identificirale $\mathrm{z}$ emancipacijskimi in feminističnimi gibanji po svetu (Leskošek 2004: 89).

\subsubsection{Zgodovina ženskega gibanja na Slovenskem}

Žensko gibanje se je začelo z ustanovitvijo prve ženske podružnice CirilMetodove družbe leta $1887 \mathrm{v}$ Trstu; ${ }^{7}$ njen cilj je bilo zlasti narodnoobrambno delovanje. V Trstu je 1897 začel izhajati tudi prvi slovenski ženski list Slovenka. Konec 19. in začetek 20. stoletja je zaznamovalo ustanavljanje številnih ženskih društev, organizacij, klubov in zvez. Pomembno vlogo do začetka druge svetovne vojne je imelo Društvo slovenskih učiteljic z zahtevami po enakopravnosti na

\footnotetext{
${ }^{7}$ Pozivi k organiziranju so se začeli že ob koncu 19. stoletja, pridružili so se jim tudi nekateri moški. Prvo tovrstno društvo je bilo Evangelijsko žensko društvo (1856), pred Ciril-Metodovo družbo pa še Gospejino društvo krščanske ljubezni (1882) (Leskošek 2004: 92).
} 
delovnem mestu in v zasebnem življenju; hkrati je to društvo zahtevalo splošno volilno pravico in delovalo narodnoobrambno (Jogan 2001: 232-237). Že od devetdesetih let 19. stoletja do druge svetovne vojne pa je potekal tudi konstanten boj, z občasnimi mirnimi obdobji, za volilno pravico. Pridobitev volilne pravice je bila v programu večine ženskih društev. O tem so pisale v časopisu Slovenka in govorile na različnih zborovanjih. Do druge svetovne vojne so se borile tudi proti celibatu učiteljic in drugih uradnic, za civilni zakon, razvezo in pravico do splava, veliko akcij pa je bilo povezanih z izobraževanjem. Hitro so postavile več zahtev po dostopu do izobrazbe. Borile so se proti takrat prevladujočemu mnenju, da ženske obiskujejo višje šole zato, ker je to moderno, in ne zaradi sposobnosti. Protestirale so ob ukinjanju višjih dekliških šol in gimnazij, nasprotovale so tudi nedostopnosti Turnerjevih štipendij za dekleta (Leskošek 2004: 99-101). Humanitarno in narodnoobrambno pa je delovala večina nastalih društev v času NOB. ${ }^{8}$ Po osvoboditvi je bila že s prvo ustavo FLRJ zagotovljena vsestranska enakopravnost spolov (Jogan 2001: 232-237). Na Slovenskem je torej razvoj feminizma specifičen, saj je po drugi svetovni vojni tesno povezan z razvojem socialistične družbe kot sestavnega dela Jugoslavije. Slovenske ženske so dobile volilno pravico skupaj s preostalimi jugoslovanskimi ženskami takoj po drugi svetovni vojni. ${ }^{9}$ Enakost med moškimi in ženskami je namreč bila ves čas socializma del uradnega ideološkega diskurza (Plemenitaš 2012: 170). ${ }^{10} \mathrm{~V}$ prvih letih po vojni je pomembno mobilizacijsko vlogo pri utrjevanju nove oblasti in tudi emancipacijskem programu imela AFŽ, ki je kot sestavni del OF skrbela za politično vzgojo žensk in reševala praktična ženska vprašanja. Kmalu se je AFŽ

\footnotetext{
${ }^{8}$ Med drugo svetovno vojno so se mnoge aktivistke ženskega gibanja vključile v protifašistično delovanje, druge so delovale $\mathrm{v}$ različnih humanitarnih organizacijah, delale $\mathrm{z}$ ranjenci in vojnimi sirotami, nekatere pa so se pridružile vojaškemu odporu proti fašizmu (Leskošek 2004: 103).

${ }^{9} \mathrm{O}$ posebnih ženskih organizacijah, ki bi se ukvarjale le s pridobitvijo volilne pravice žensk pri nas, ne moremo govoriti, so pa obstajale ženske organizacije, ki so se ukvarjale tudi s tem vprašanjem, npr. Društvo slovenskih učiteljic, Splošno žensko društvo, Alijansa ženskih pokretov ter Zveza delavskih žena in deklet. A mnenja so bila deljena: nekatere ženske so menile, da morajo ženske politične pravice dobiti avtomatično, druge pa so bile prepričane, da jih je na to treba pripraviti z izobraževanjem (Antić Gaber 2004: 69). Je pa splošna volilna pravica bila pridobljena pozno v primerjavi z Avstralijo (1902), a še vedno zgodaj v primerjavi s Švico (1971) (Antić Gaber, Mencin 1992: 103).

${ }^{10}$ Pri tem pa Silvija Borovnik (1995: 21) opozarja, da je v socializmu veljal feminizem za škodljivo družbeno gibanje. Za socializem je namreč ozaveščena, razmišljujoča in za svoje pravice boreča se ženska bila nevarna. Zato tolikšna skrb za ženski socialistični aktivizem, ki se je kazala v proizvodnji pionirk, partijskih sekretark ipd.
} 
preoblikovala $\mathrm{v}$ Zvezo ženskih društev Jugoslavije, ta pa $\mathrm{v}$ Konferenco za družbeno aktivnost žensk do leta 1976, ko je njeno vlogo prevzel Svet za vprašanja družbenoekonomskega in političnega položaja žensk (Jogan 2001: 232237). Osemdeseta leta so bila čas, ki je $\mathrm{z}$ razgibanim civilnodružbenim delovanjem nudil dobro okolje za ponovno vrnitev feminizma in ženskega gibanja. Ženske so ponovno začele ustvarjati svoje avtonomne prostore, v katerih so lahko govor oblikovale po svoji podobi, ga zapolnjevale z lastnimi vsebinami in pomeni. Izkazalo se je, da je enakopravnost spolov le napol uspešen projekt prejšnjih oblasti. Razvile so se različne civilnodružbene organizacije in skupine, ki so z mnogo akcijami opozarjale na položaj žensk, začela pa se je tudi teoretska produkcija, katere rezultat so predmetne ali področne študije spola ter ženske študije na fakultetah (Leskošek 2004: 107-108). Kot eno od ovir, ki poglablja napačen vtis o krizi feminizma ne le v javnosti, ampak tudi znotraj feminizma samega, je pomanjkanje medgeneracijske povezanosti (Leskošek 2009: 120). Tudi Maca Jogan (2001: 242) opozarja, da je značilnost ženskega gibanja v Sloveniji nizka stopnja sodelovanja in povezovanja različno usmerjenih skupin.

\subsubsection{Vloga Slovenk v javnem življenju}

Ženske so se aktivneje začele vključevati $\mathrm{v}$ javno življenje $\mathrm{v}$ tridesetih letih 19. stoletja, ko so se zanje postopoma začeli odpirati zlasti umetniški prostori. Sredi 19. stoletja so začele objavljati sestavke v različnih časopisih, sprva omejene na literarno kritiko, kasneje pa so začele pisati strokovne članke, kmalu tudi o ženskah in njihovi vlogi. Dostop do časopisov z možnostjo objavljanja je bil ključen za organiziranje žensk na Slovenskem. Bolj argumentirani pozivi k ženskemu gibanju pa so se pojavljali v že omenjenem časopisu Slovenka, ki ga je urejala Marica Nadlišek Bartol. Šlo je za pozive žensk k shodu, kjer bi se problematiziralo žensko vprašanje, in pozive k ustanovitvi ženskega društva, ki bi moralo sodelovati s tujimi tovrstnimi organizacijami. Društva so pogosto organizirala predavanja, tečaje in izobraževanja (Leskošek 2004: 90-91, 96). Načini izražanja volje, mnenj in zahtev žensk na Slovenskem so bili v prvi polovici 20. stoletja različni: pogosto so organizirale shode in javna zborovanja, 
pripravljale peticije, lobirale pri oblasteh in poslancih ipd. Dolgo se niso smele vključevati v politiko, javno delovanje pa sta oteževala še nadzor in cenzura. Pred drugo svetovno vojno in med njo so bile usmerjene $\mathrm{v}$ protifašistično delovanje, ob tem pa so še zmeraj opozarjale na neenakosti, ki so se kazale v vsakdanjem življenju. Novejša zgodovina ženskega gibanja pa se prične v sedemdesetih letih prejšnjega stoletja, ko se je začelo pojavljati vprašanje feminizma v socializmu (Leskošek 2009: 113-115). V socialističnem obdobju posebnega organiziranja žensk ni bilo, so pa sredi osemdesetih let nastale prve ženske skupine - prva takšna skupina je bila Ženska sekcija pri Sociološkem društvu, ustanovljena leta 1984. Leto kasneje je bila ustanovljena prva samostojna ženska skupina Lilith, ki je z diskusijami o ženski seksualnosti, nasilju nad ženskami in o identiteti žensk poglobila nelagodje $\mathrm{v}$ družbi in povzročila buren odziv medijev (Antić Gaber 1997: 207). Leta 1992 je bil ustanovljen Urad za žensko politiko, leta 2001 pa se je preimenoval v Urad za enake možnosti (Plemenitaš 2012: 170); v devetdesetih je tudi sicer nastalo precej ženskih društev in zasebnih zavodov. Tako so se razvile številne civilnodružbene skupine in organizacije, ki so z mnogo akcijami opozarjale na položaj žensk, hkrati pa se je začela širiti tudi teoretska produkcija, katere rezultat so predmetne ali področne študije spola in ženske študije na različnih fakultetah. Feministke pa so se tudi sicer vključevale v javna dogajanja aktualizirale so mnogo tem, kot so nasilje, revščina, položaj migrantov, Romov, tujcev, homoseksualcev ipd. (Leskošek 2009: 116-117). Večina novih skupin in društev si je prizadevala za razkrivanje in sistematično odpravljanje spolne diskriminacije na področjih, ki so bila $\mathrm{v}$ že omenjenem prvem valu feminizma $\mathrm{v}$ ozadju, hkrati pa so se borila za ohranjanje že pridobljenih pravic. Zlasti v osemdesetih, še bolj pa v devetdesetih letih se je na Fakulteti za družbene vede v Ljubljani $\mathrm{v}$ raziskovanju in $\mathrm{v}$ pedagoškem delu posvečala posebna pozornost položaju žensk. V univerzitetnem izobraževanju sociologov so se oblikovali novi predmeti (npr. Žensko vprašanje v zgodovini, Podobe žensk v množičnih medijih, Seksizem, telesnost, čustvenost, Sociologija spolov) in posebni študijski programi V okviru podiplomskega študija (npr. Seksizem kot sodobna tradicija). Na Filozofski fakulteti v Ljubljani pa je razpisan podiplomski študijski program Ženske študije in feministična teorija (Jogan 2001: 242). 


\subsubsection{Položaj žensk v znanosti na Slovenskem}

V devetdesetih letih prejšnjega stoletja se je v Evropi povečalo zanimanje za položaj žensk v znanosti, zlasti za njihovo spolno neuravnoteženo udeležbo v znanstvenih in akademskih karierah. Dostop do znanosti v šolah in univerzah se je sicer izboljšal za ženske in moške, a tega ne moremo reči za dostop žensk do znanstvene kariere; za uravnoteženje žensk in moških bi bile potrebne ciljno usmerjene politike in spodbude (Umek Venturini 2013: 16).

Vprašanje enakih možnosti v znanosti je v Sloveniji prvi sprožil Urad slovenske komisije za UNESCO, ki je leta 1994 organiziral okroglo mizo o ženskah v znanosti in raziskovanju, nato pa dve leti kasneje financiral prvo večjo raziskavo o položaju žensk v znanosti na Slovenskem. Po zgledu Helsinške skupine je bila leta 2001 ustanovljena Komisija za uveljavitev vloge žensk v znanosti, kasneje preimenovana $\mathrm{v}$ Komisijo za ženske $\mathrm{v}$ znanosti. Člani so prihajali iz različnih sektorjev dela, znanstvenih ved in ustanov, vedno pa sta bili članici tudi predstavnica Javne agencije za raziskovalno dejavnost RS in predstavnica Statističnega urada RS; z obema institucijama je komisija pomembno sodelovala pri prizadevanju za odpravo diskriminatornih okoliščin pri pridobivanju sredstev za raziskovalno delo oz. z možnostjo pridobivanja pomembnih podatkov, ki so bili podlaga za aktivnosti v Sloveniji in poročanja na ravni EU. Hkrati pa je komisija dajala pripombe in dopolnitve za strateške dokumente in pravne akte, ves čas pa si je prizadevala tudi za aktivno sodelovanje $\mathrm{Z}$ mediji. S številnimi pobudami in predlogi je sodelovala $\mathrm{z}$ Univerzama $\mathrm{V}$ Ljubljani in Mariboru ter $\mathrm{z}$ ARRS, organizirala mrežna srečanja, mednarodne okrogle mize in sestanke, na katerih so bile potrjene potrebe po večjem medsebojnem povezovanju in sodelovanju vseh, ki se ukvarjajo s problematiko spolov. Pogosto je šlo za neuspešno prizadevanje po vključevanju problematike spolne neenakosti v ciljne raziskovalne projekte. Od leta 2003 pa se komisija ukvarja tudi s spremljanjem in obravnavo statističnih podatkov o plačah v javnih raziskovalnih zavodih glede na spol, izobrazbo in znanstveni naziv. Temeljna ugotovitev je, da so v povprečju ženske plače nižje od moških pri doseženi enaki izobrazbi. Komisija je sodelovala tudi $\mathrm{v}$ Nacionalnem odboru projekta za 
vzpostavitev srednjeevropskega centra za ženske in mlade $\mathrm{v}$ znanosti in pri pripravi Resolucije o Nacionalnem razvojnoraziskovalnem programu 2006-2010; pri slednjem je dosegla prvo vključitev problematike enakih možnosti žensk in moških v znanosti v strateški dokument o raziskovalni dejavnosti v Sloveniji. Verjetno se je prav glede na njene aktivnosti Urad za enake možnosti pri Vladi RS leta 2007 odločil organizirati posvet Ženske v znanosti in raziskovanju. Kljub temu prizadevanja za enakovredno vlogo žensk v znanosti še niso dosegla zadanih ciljev, so pa v grobem postavljeni pravni okviri, o vlogi žensk v znanosti pa se pogosteje razpravlja. Komisija je leta 2011 sprejela v nadaljevanju (v 2.3 (Ne)seksistična raba $\mathrm{v}$ slovenskem jeziku, natančneje $\mathrm{v}$ 2.3.1 Razprave o seksizmu $\mathrm{v}$ slovenskem jeziku) predstavljene Interne smernice za spolno občutljivo rabo jezika (Umek Venturini 2013: 19-24). Vstop žensk v akademsko izobraževanje in raziskovalno ter znanstveno delo je potekal in še poteka $\mathrm{v}$ družbenih okoliščinah, v katerih se počasi razkrajajo seksistični vzorci, v njih pa se še očitno ohranjajo značilnosti dolgotrajne spolne delitve dela z žensko podrejenostjo (Jogan 2013: 9). Mirjana Ule (2013: 15) meni, da obstaja cela vrsta ovir za uveljavljanje žensk $\mathrm{v}$ znanosti, zaradi česar se izgubljajo ženski intelektualni potenciali; to pomeni izgubo za znanost in celotno družbo. Diskriminacijo opaža zlasti $\mathrm{v}$ obliki netransparentnosti $\mathrm{v}$ odločanju o napredovanjih, pri podeljevanju raziskovalnih sredstev, ocenjevanju odličnosti, recenzijskih postopkih, kadrovanju na pomembne položaje ipd.

\subsubsection{Slovenske feministične literarnovedne raziskave}

V slovenskem prostoru so se tovrstne raziskave začele dokaj pozno, a zanimanje za feministično literarno vedo vse bolj narašča. Kot predhodnico takih raziskav lahko imenujemo Marjo Boršnik. V sedemdesetih in osemdesetih letih prejšnjega stoletja je nastalo nekaj raziskav, ki so se posvečale bodisi pisateljicam bodisi ženskim literarnim likom. Premislek o zaznamovanosti pisateljic in njihovih del z lastnim spolom je šele leta 1995 ponudila Silvija Borovnik s knjigo Pišejo ženske drugače?, s tem vprašanjem pa se je ukvarjala tudi v svoji doktorski 
disertaciji. ${ }^{11}$ Spoznanja tuje feministične literarne teorije je predstavila $\mathrm{v}$ začetku devetdesetih let revija Literatura, ki je leta 1994 objavila odlomke iz knjig Toril Moi, K. M. Newtona, Susan Gubar in Sandre M. Gilbert. Besedila je uredila in s spremno opombo opremila Ženja Leiler, ki je napisala tudi razpravo Ž kot ženska. Številne študije iz feministične teorije pa so bile objavljene v reviji Delta, v okviru istoimenske založbe pa so izšle tudi knjige, ki predstavljajo izhodišče številnih feminističnih literarnih raziskav: Drugi spol Simone de Beauvoir, Mesto dam Christine de Pizan in Tri gvineje Virginie Woolf. Študije o slovenskih pesnicah je objavljala Irena Novak Popov, ki je predsedovala 23. simpoziju Obdobja, kjer je bilo med predlogi za referate mogoče zaslediti tudi feministično branje kratke proze. Literaturo žensk so sicer raziskovale tudi Alojzija Zupan Sosič, Valerija Vendramin, Irena Svetek idr. Kot najpomembnejše delo feministične literarne teorije pa Katja Mihurko Poniž (2005: 92) izpostavlja knjigo Valerije Vendramin Shakespearove sestre: feminizem, psihoanaliza, literatura. O podobah ženskosti v slovenski in svetovni književnosti so pisali Miran Hladnik, Blanka Bošnjak, Silvija Borovnik, Aleksandra Derganc, Katja Mihurko Poniž idr., o manj znanih ali celo pozabljenih avtoricah slovenske in evropske literature pa Igor Grdina, Metka Zupančič, Nataša Hrastnik, Miran Hladnik, Silvija Borovnik, Alojzija Zupan Sosič, Katja Mihurko Poniž, Helga Glušič, Irena Novak Popov, Mira Delavec, Jožica Čeh Steger (Mihurko Poniž 2005: 87-95).

\section{LINGVOKULTUROLOŠKI PRISTOP ${ }^{12}$}

O enakopravnosti med spoloma se govori v družbenih sferah, kjer je enakopravnost na tako visoki ravni, da se je posamezniki zavedajo; zavedajo se

\footnotetext{
${ }^{11}$ Silvija Borovnik (1995: 10) zavrača misli o zgolj velikih ustvarjalcih v slovenski književnosti, ampak opozarja tudi na številne ustvarjalke $\mathrm{z}$ nemalo objavami, kar dokazuje $\mathrm{z}$ natančnim prikazom slovenske ženske književnosti.

${ }^{12}$ Lingvokulturologija se je kot samostojna disciplina uveljavila v devetdesetih letih 20. stoletja in je povezana s sociolingvistiko, psiholingvistiko, leksikologijo, sintakso idr., najtesneje pa je povezana $\mathrm{z}$ etnolingvistiko, a za razliko od nje pojave proučuje na sinhroni ravni (Dragićević 2010: 9). Po Eriki Kržišnik (2008: 34) lingvokulturološki vidik skuša prikazati sočasno kulturno samozavedanje neke (jezikovne) skupnosti, njeno mentaliteto, vrednote itd. Anna Wierzbicka pa izpostavlja misli Edwarda Sapirja (Wierzbicka 1997: 1, povz. po Sapir 1949: 162), ki najbolje opišejo povezavo med jezikom in kulturo, tj. jezik je simbolični vodič po kulturi, besedišče je pokazatelj kulture ljudi, jezikoslovje pa je pomembno za metodologijo humanističnih znanosti.
} 
razlik, ki jih prinaša neenaka obravnava glede na spol (Kozmik in Salecl 1999, povz. po Zurc 2004: 39). Dejstvo je, da se stališče družbe do posameznega spola in s tem do družbenih razlik med žensko in moškim odraža na posameznih ravneh vsakdanjega življenja. Zato ne preseneča precejšnje zanimanje raziskovalcev tudi za proučevanje razlik med spoloma, kot se kažejo v jeziku.

\subsection{Zapostavljanje ženskega spola v tujih jezikih}

Na Zahodu se je že sredi sedemdesetih let 20. stoletja pojavilo t. i. feministično jezikoslovje, ki želi jezikovne pojave, tipične za t. i. patriarhalne jezike, ne le opisati, ampak tudi spremeniti in tako narediti ženski spol bolj prepoznaven. $\mathrm{V}$ tovrstnih delih je mogoče najti kritiko jezikovnega sistema in rabe jezika. Predlogi so v glavnem bili upoštevani v besedilih ekonomske in politične propagande, kjer je pomembno pridobiti naslovnika, v nekaterih državah pa so jim prisluhnili tudi državni uradi in $\mathrm{v}$ skladu $\mathrm{s}$ tem spremenili svoje uradovanje (Bešter 1997: 11). Osvoboditev subjekta pa zahteva takšno rabo jezika, ki ni podvržena določilom, kakršna podjarmijo ali celo izničijo spolno razliko (Irigaray 1995: 32).

\subsubsection{Angleški jezik}

Cheris Kramarae opredeljuje seksizem v angleškem jeziku kot način, po katerem je angleško besedišče struktura, organizirana tako, da poveličuje moškost in zanemarja, trivializira in omalovažuje ženskost. Dale Spender pa trdi, da je angleščino dobesedno izdelal moški in je še vedno $\mathrm{v}$ glavnem pod moškim nadzorom (Moi 1999: 159). Tako je že v 16. stoletju pisatelj in slovničar Thomas Wilson ugotovil, da je $\mathrm{v}$ jeziku bolj naravno moške izraze postavljati pred ženske oziroma namesto njih, češ da so tudi v naravnem redu moški pomembnejši od žensk. Tako je utemeljeval besedne zveze tipa moški in ženska, mož in žena, brat in sestra, kjer je moški postavljen na prvo mesto. Prevlada moškega spola se je dodatno utrdila dvesto let kasneje, ko je slovničar John Kirkby formuliral 88 slovničnih pravil; eno od teh pravil pravi, da je moški spol bolj vsestranski in v 
primerjavi z ženskim vseobsegajoč. Od takrat je v angleškem jeziku popolnoma normalno, da se, če je spol neznan oziroma se govori na splošno, uporablja bolj vsesplošen moškospolski zaimek (Speer 2005: 149-151). Leta 1850 se je pojavil alternativni zaimek oni (»they«), kar je izzvalo polemiko, o (ne)upravičenosti uporabe zaimka on (»he«) pa se je razpravljalo celo v britanskem parlamentu. Sprejet je bil sklep, da omenjeni zaimek najprimerneje opredeljuje tako moški kot ženski spol. Tako sta izraza »man« in »he«, ki označujeta moškega oz. njegov osebni zaimek, prešla $\mathrm{v}$ splošno rabo kot označevalca občečloveškega (Speer 2005: 149-150). Kljub temu pa se angleščina pri oznakah funkcij in poklicev, zlasti pri besedah, ki vsebujejo spolno zaznamovane morfeme, kot sta -man ali -ess, vse bolj nagiba $\mathrm{k}$ rabi nevtralnih leksemov, na primer chair namesto chairman. Oznake za nekatere poklice vztrajajo v ženski obliki, vendar se kot generična oznaka, ki vključuje tako ženske kot moške predstavnike danega poklica, navadno uporablja izključno leksem, ki je izvorno moški (Kranjc, Ožbot 2013: 236). Zapostavljenost ženskega spola se v angleškem jeziku kaže s pripono -man ali predpono man-. Primer take besede je angl. mankind s pomenom 'človeštvo'. Besedo so na zahtevo smernic Unesca (1987), ki preprečujejo spolno občutljivo rabo jezika, zamenjali s poimenovanjem, ki nosi isti pomen (a ponovno je večina tovrstnih poimenovanj s sestavino -man-: humanity, humankind, human race). Različno označevanje družbenega spola je problem mnogo jezikov, tudi angleščine, npr. philosopher : lady philosopher 'filozof' : 'filozofinja'. Znano je, da $\mathrm{v}$ več jezikih to rešujejo tako, da pred samostalnik moškega spola dodajajo ali besedo, ki označuje žensko, ali pa pripono/predpono. Angleški jezik, podobno kot francoski, dodaja lady, kar je vidno iz že zapisanega primera, poleg tega dodaja pri tvorjenkah tudi pripono -woman, congresswoman 'kongresnica' (Ščuka 2014: 82). Paula Zupanc (2009: 133) pa ugotavlja, da je Velika Britanija tista, ki s svojim jezikom po zgledu ZDA vse bolj uveljavlja enakovrednost izrazov ženskega in moškega spola. Za vsako oznako osebe namreč stojita oba osebna ali svojilna zaimka in tako oznanjata prisotnost in enakovrednost obeh spolov. 


\subsubsection{Francoski jezik}

Tudi V francoščini velja pravilo nezaznamovanosti v odnosu do zaznamovanosti - moški slovnični spol je nezaznamovan v nasprotju z ženskim (Zupanc 2009: 127). Luce Irigaray (1995: 17-18) za francoski jezik ugotavlja, da že stoletja velja, da je tisto, kar je vredno, označeno z moškim spolom. Oporeka jezikoslovcem, ki trdijo, da je slovnični spol nevtralen, neodvisen od spolnih označb. Meni, da žensko označujejo izrazi, ki jo predstavljajo kot objekt v razmerju do moškega subjekta. Vsak samostalnik $v$ francoščini ima namreč inherenten moški ali ženski slovnični spol. Pri samostalnikih, ki poimenujejo živa bitja, se slovnični spol načeloma ujema z naravnim spolom (Riegel idr. 1999: 150-172). Feministke pa so na seksizem v francoskem jeziku opozarjale od 19. stoletja, a odziva države ali strokovnjakov ni bilo. $\mathrm{Na}$ prelomu stoletja je pisateljica Marie-Louise Gagneur, da bi rešila slovnične zagate pri ženskih oblikah poklicev, od Francoske akademije zahtevala, naj predlaga ustrezne ženske oblike poimenovanj. Ko je leta 1981 oblast v Franciji prevzela levica, je bilo precej pomembnih funkcij v vladi zaupanih ženskam, ki so se začele zavedati, da v francoščini ni ženskih oblik za večino funkcij, ki so jih opravljale. Dve leti kasneje je bil tako potrjen zakon o poklicni enakopravnosti žensk in moških, ki je med drugim prepovedoval omembo kakršnekoli preference glede spola $\mathrm{v}$ ponudbah za delo. Leta 1984 je ministrica za pravice žensk Yvette Roudy ustanovila komisijo za terminologijo, navezano na aktivnosti žensk, vlada pa je komisijo pooblastila, da ustvari nova ali oživi stara ženskospolska poimenovanja. Delo komisije je naletelo na negodovanje, češ da je feminizacija poimenovanj nesmiselna. Nato je leta 1997 levičarska vlada sklenila, da se morajo v administrativnih besedilih uporabljati feminizirane oblike poimenovanj, če funkcijo opravljajo ženske. Vlada je pooblastila Nacionalni inštitut za francoski jezik, naj poda mnenje o možnostih poenotenja in posplošitve feminiziranih poimenovanj, inštitut pa je nato izdal priročnik feminizacije poimenovanj $\mathrm{v}$ francoščini. Ta med drugim ponuja ustrezne besedotvorne postopke. Videti je, da so tovrstne jezikovne spremembe $\mathrm{v}$ Franciji redno predmet medijskih in političnih obravnav (Baudino 2001: 370-379). Francoske feministke pa še vedno menijo, da 
bi ženske $\mathrm{v}$ jezik lahko vnesle novo pomenskost, ki bi temeljila na ženskih izkustvenih svetovih in zavezništvih med njimi. Poleg neologizmov, ki bi neposredno zrcalili žensko subjektiviteto, predlagajo tudi reforme, ki bi ženski spol zaznamovale na slovnični ravni, npr. nove zaimke. Opozarjajo na specifične potrebe žensk, ki jih obstoječe jezikovne forme pogosto ne morejo zadovoljiti. V francoskem jeziku moški spol vedno prevladuje $\mathrm{v}$ sintaksi (npr. onadva sta poročena - ils sont maries), srednji ali tako imenovani nevtralni spol pa se izraža $\mathrm{z}$ istim zaimkom ali z isto obliko kot moški ( $\mathrm{grmi}$ - il tonne, kjer je osebni zaimek il moškega spola) (Irigaray 1995: 20, 30).

\subsubsection{Nemški jezik}

Že leta 1873 je Hedwig Dohm v svojih besedilih dosledno uporabljala ženskospolska poimenovanja, ki so bila $v$ tistem času zelo neobičajna, medtem ko so danes sestavni del nezaznamovanega besedja. V Zvezni republiki Nemčiji so nato $\mathrm{v}$ osemdesetih letih prejšnjega stoletja bili sprejeti dokumenti, ki jamčijo enakopravno obravnavo moških in žensk v pravnih besedilih in uradnem jeziku. Moška oblika se celo ne sme šteti kot tista s širšim pomenom, nevtralna, ki lahko vključuje ženski in moški spol (Mihajlević, Štebih Golub 2010: 193-194). V Nemčiji je Delovna skupina za jezik v zakonodaji izdelala obsežno študijo z navodili za neseksistično jezikovno rabo, ki je bila sprejeta kot parlamentarni dokument leta 1987 in je vodilo pri sestavljanju nove zakonodaje (Žagar, Milharčič Hladnik 1995: 8). V nemškem jeziku je sicer možna ženskospolska izpeljanka iz poimenovanja moškega spola $\mathrm{z}$ dodajanjem priponskega obrazila -in, vendar z negativno zgodovinsko konotacijo, saj so se tovrstne oblike tradicionalno uporabljale za poimenovanje žene moškega z nazivom (Cameron 2002: 93).

\subsection{Spolno (ne)občutljiva raba v slovanskem jezikoslovju}

Feministično jezikoslovje je razmeroma nova disciplina $\mathrm{v}$ vseh slovanskih jezikih. Proučuje jezikovno diskriminacijo žensk, analizira položaj 
žensk v jeziku, tj. pravičnost in učinkovitost jezikovnih struktur. Drugi vidik zanimanja so jezikovno vedenje in komunikacijske strategije moških in žensk.

V srbskem jeziku moški spol velja za nezaznamovanega. Rabo spolno (ne)občutljivega jezika v Srbiji pri imenovanju poklicev je predstavil Nikola Bajić (2012: 124-125). V srbščini se moška oblika pri določenih poklicih uporablja tudi za ženske. Razprave o feminizaciji jezika potekajo šele v zadnjih letih; politika se $\mathrm{s}$ tem ne ukvarja, jezikoslovci pa $\mathrm{v}$ glavnem podpirajo slovnično nezaznamovanost moškega spola - pravilna in $\mathrm{z}$ zakoni določena je raba generičnega moškega spola. Edini primer standardiziranega poklica $\mathrm{v}$ ženski obliki, ki ga je Bajić zasledil, je medicinska sestra, ki pa nima moškospolske ustreznice. Na zapostavljenost (celo posmeh!) ženskega spola v srbskem jeziku opozarja tudi Hana Ćopić (2012: 216), za Ivana Klajna (1996: 48) pa so tovrstne (ženskospolske) oblike neobičajne in neustaljene; kot take med drugim navaja primere docentkinja/docentica, arhitektica, advokatica. Ana Kuzmanović Jovanović (2013: 1-4) vidi razlog za tako stanje tudi v ženskah samih, ki se zaradi usidranega patriarhalnega modela srbske družbe izogibajo uvajanju in dosledni uporabi ženskospolskih oblik. Kljub temu pa enakopravnost spolov počasi (uradno) vstopa $\mathrm{v}$ srbsko družbo. Tako je Uprava za spolno enakopravnost Ministrstva za delo in socialne zadeve Republike Srbije leta 2012 opozorila na jezikovno diskriminacijo in priporočila spolno razlikovanje $\mathrm{v}$ jeziku. S tem vprašanjem pa se še vedno ne ukvarjajo druge državne institucije, zato raba ženskospolskih oblik ostaja omejena.

Tudi v hrvaščini je moški spol nezaznamovan, saj lahko vključuje ženske osebe, medtem ko se ženski spol nanaša izključno na ženske (Babić 2006: 82). Na Hrvaškem se je v osemdesetih letih 20. stoletja razpravljalo o položaju žensk v družbi, ob tem pa tudi o uporabi ženskospolskih poimenovanj. Osamljene primere bork za pravice žensk pa najdemo že v 19. stoletju, ko so na področju celotne Avstro-Ogrske zahteve po sodelovanju žensk v javnem življenju bile vse glasnejše. Prelomnico predstavlja članek Mihajla Janjanina z naslovom Gospođa profesor (Gospa profesor) iz leta 1934, v katerem avtor opozarja, da gre pri oblikah iz naslova za t. i. atentat na jezik; če je namreč v jeziku že uveljavljenih nekaj ženskospolskih poimenovanj za poklice, potem ni ovir za nastanek novih 
(Mihajlević, Štebih Golub 2010: 193). Nato je leta 1955 Zlatko Vince napisal članek Drugarica direktor, gospođa profesor ili drugarica direktorica, gospođa profesorica, v katerem se je zavzel za uporabo ženskospolskih oblik (Babić 2006: 83). Pomemben premik pa predstavlja leta 2003 sprejet Zakon o enakopravnosti spolov, ki predvideva preprečevanje diskriminacije $\mathrm{v}$ jeziku, med drugim tudi $\mathrm{v}$ oglasih za delo. Analiza oglasnih besedil je sicer pokazala, da se ta odredba uveljavlja zelo počasi (Mihajlević, Štebih Golub 2010: 193-194).

O seksizmu v češčini je razmišljala Světla Čmejrkova (1995: 44). Domneva, da moški in ženske ne uporabljajo oblik obeh spolov enako, kar je pogojeno tudi z zgodovinskim razvojem jezika. V devetdesetih letih je na Češkem nastala vrsta študij o tej temi (t. i. študije spola), zanimanje za ta vprašanja pa je povzročila krepitev feminističnega gibanja. O seksizmu v jeziku se piše zlasti v zadnjih desetletjih, ko se ženske vse bolj zavedajo svoje »nevidnosti« in se sprašujejo o svojem deležu v t. i. patriarhalnem modelu jezika. Tudi v češčini se pojavlja vprašanje rabe moškega spola kot »nevtralnega«, tj. tistega, ki ga uporabimo, kadar želimo zajeti moške in ženske. Na to opozarja Pavel Eisner v Knjigah o češčini, kjer pravi, da je tudi češčina primer patriarhalnega modela jezika. Čmejrkova (1995: 52-53) meni, da bi vnašanje sprememb, s katerimi bi seksistično rabo jezika odpravili ali vsaj zmanjšali, delovalo zelo okorno. So pa vsakršne tovrstne spremembe zanimive s sociološkega in jezikoslovnega vidika.

Tudi v poljščini in slovaščini velja moški spol za nezaznamovanega, univerzalnega, tistega s širšim pomenom, ki lahko vključuje tako moške kot tudi ženske, medtem ko ženskospolski samostalniki za poimenovanja oseb vključujejo zgolj ženske. Analiza oglasov za delo v poljskem in slovaškem jeziku kaže zgolj na rabo moškospolskih oblik, pri čemer nagovarjajo moške in ženske. Vedno pa ob moškospolskih oblikah ni mogoče ugotoviti, ali gre zgolj za osebe moškega spola ali osebe obeh spolov (npr. Sprejeli smo dva nova zaposlena; pri tem je mogoče dvoje: ali sporočevalec ne želi razkriti spola in namenoma uporabi nevtralno obliko moškega spola ali pa so dejansko zaposlili dva moška). Vrzeli pri nastajanju ženskospolskih oblik nastajajo zlasti pri poklicih, ki veljajo za tradicionalno moške (gasilec, pilot), ali pri poimenovanjih visokih družbenih položajev oz. funkcij (premier, ambasador). Kljub naraščanju žensk v omenjenih 
poklicih vseeno prevladujejo moškospolske oblike (Karwatowska, SzpyraKozłowska 2005: 17-18). Primerjava poljščine in slovaščine pa kaže, da so v slednji bolj uveljavljena in $\mathrm{v}$ ustreznih jezikovnih priročnikih zabeležena ženskospolska poimenovanja. V poljščini se sicer vprašanje rabe ženskospolskih oblik odpira v zadnjih stotih letih, ko so ženske začele opravljati poklice, ki so pred tem bili »rezervirani« izključno za moške. Vendarle pa je nekatere ženskospolske oblike mogoče zaslediti že v 18. stoletju, npr. nauczycielka in aktorka (Markowski 1995: 1). Razprave o seksizmu v jeziku segajo na Poljskem v začetek 20. stoletja in odpirajo troje vprašanj: izpeljava ženskospolskih oblik, pregibanje in skladnja (Kubiszyn-Mędrala 2007: 31). V slovaščini pa je v zadnjih desetletjih viden porast ženskospolskih oblik v jezikovnih priročnikih, medtem ko so bili v starejših izdajah tovrstni izrazi v glavnem prezrti (Sokolova 2007: 26).

Drugače je $v$ ruščini, kjer so bila še do nedavnega poimenovanja za duhovne poklice, nazive, prestižne družbene položaje izražena zgolj $\mathrm{Z}$ moškospolskimi oblikami. Ženske so bile poimenovane z zvezami tipa ženska državni tožilec, ženska - trener ipd. V sodobnem ruskem jeziku pa se tvorba feminativov, tudi s pritokom novotvorjenk, širi, s tem pa se veča tudi število ženskospolskih poimenovanj oseb in priložnosti za njihovo uporabo. Enako velja za ukrajinščino (поетка) in beloruščino (лаборантка) (Нещименко 2003: 305-306).

\section{3 (Ne)seksistična raba v slovenskem jeziku}

Položaj ženskih imen oz. Ženskih oblik $\mathrm{v}$ družbi je odvisen od jezikovnosistemskih možnosti, s katerimi lahko izražamo spolska razmerja, in od naravnanosti družbe v njihovo rabo ali nerabo. Slovenski jezik ima popolnoma razvit sistem za izražanje ustreznih spolskih razmerij, njihovo jezikovno udejanjanje pa je odvisno od pripravljenosti uporabnikov jezika in je neposredno povezano s psihosocialnimi dejavniki (Jež 1997a: 229).

\subsubsection{Razprave o seksizmu v slovenskem jeziku}


Glede rabe slovničnih spolov Slovenska slovnica (Toporišič 2004: 266) pravi, da je »moški spol slovnično nezaznamovan nasproti ženskemu, zato se $\mathrm{v}$ primerih, ko je jasno, za kateri spol gre, samostalniške besede in oblike moškega spola lahko rabijo namesto ženskih«. Dejstvo, da se namesto ženskih poimenovanj za osebe lahko uporabljajo moška, ki da so nezaznamovana, lahko razložimo s tem, da ima slovnični spol možnost posploševanja; tako poimenovanje za moški ne referira več na naravni spol, temveč izraža pomensko sestavino »spolsko nevtralno«. V taki opredelitvi vloge slovničnega spola kot nadspola $\mathrm{v}$ jezikovnem sistemu vidijo nekateri zapostavljanje ženske oz. ženskega spola. Feminizem kot teoretski pristop je poskušal najti svoje mesto na področju osmislitve družbenega položaja žensk v Sloveniji. Konec osemdesetih let prejšnjega stoletja je izšlo nekaj publikacij s tega področja; v njih je mogoče najti pisanja, ki se spogledujejo s sodobnimi tokovi t. i. zahodnega feminizma (Antić Gaber 1997: 207).

V Sloveniji se je začelo o tovrstnih problemih konkretno razmišljati šele $\mathrm{v}$ devetdesetih letih s pobudo o upoštevanju ženskega spola $\mathrm{v}$ zakonskih besedilih v ljubljanski mestni upravi, kasneje pa sta Igor Ž. Žagar in Mirjam Milharčič Hladnik za Urad za žensko politiko pri Vladi Republike Slovenije pripravila priporočila za izogibanje seksistične rabe jezika. Slednjo opredeljujeta kot »sistematično rabo moške (slovnične) oblike namesto in na mestu ženske, zapostavljanje, zamolčevanje oz. neomenjanje žensk v korist moških in uporabo žaljivih stereotipov ter prispodob«. Njuna priporočila so bila javno obravnavana $\mathrm{v}$ polemični razpravi. Temeljni problem, na katerega sta opozorila in se z njim ne srečujemo le v slovenščini, temveč tudi v večini drugih jezikov, je dejstvo, da so večinoma vsi pravni in administrativni akti napisani le v moški obliki (npr. Razpis za delovno mesto direktorja). Če je pomembno, da so sporočila namenjena tako moškim kot ženskam, ni nič manj pomembno, kako so oblikovana. Večino človeških zmožnosti je namreč mogoče najti pri moških in ženskah. Ob tem se avtorja sprašujeta, zakaj je treba ženske zmeraj opisovati glede na njihovo zunanjost in t. i. »ženske kvalitete«, moške pa glede na intelektualne sposobnosti in profesionalni položaj. Takšen odnos je po njunem mnenju ne le nepotreben, temveč tudi žaljiv, saj stereotipizira podobo in družbeni položaj žensk. Podton takšnega sporočila je, da so način, kakovost in teža razmišljanja ženske ali 
moškega drugačni, in da ima mnenje moškega, ker je pač opisan glede na svoje intelektualne sposobnosti, večjo težo kot mnenje ženske. Vztrajata, da se je treba truditi za obravnavo moških in žensk $\mathrm{z}$ enakim spoštovanjem in za priznavanje enakih človeških lastnosti obema spoloma. Poleg tega bi se morali izogibati izrazom, ki so odkrito razlikovalni in podcenjevalni (namesto šibki spol je bolje reči ženske, namesto lepša polovica oziroma boljša polovica pa soproga, žena) (Žagar, Milharčič Hladnik 1995: 12-13).

Po omenjeni razpravi o neseksistični rabi jezika je bila na pobudo Vere Kozmik, direktorice Urada za žensko politiko, oblikovana posebna strokovna skupina, ki naj bi se ukvarjala z vprašanji jezikovne enakopravnosti moških in žensk. Pri tem bi se zavzemala za pripravo obojespolne redakcije standardne klasifikacije poklicev in obojespolne redakcije šolske zakonodaje, ki je že bila v parlamentarnem postopku. Vendar pa delo skupine ni zaživelo (Stabej 1997: 64). Leta 1995 je Državni zbor Republike Slovenije sprejel sklep o obojespolni redakciji šolske zakonodaje, za kar je moralo poskrbeti Ministrstvo za šolstvo in šport RS, ki je predalo nalogo Uradu za žensko politiko. Državni zbor je nato oceno obojespolne oblike prepustil Delovni skupini za jezikovno načrtovanje in jezikovno politiko pod vodstvom Brede Pogorelec. Skupina je menila, da konkretna obojespolna redakcija ni najboljša; tako je državni zbor sprejel prvotno, »seksistično obliko«. Po mnenju omenjene delovne skupine bi bilo treba problem ponovno proučiti in se dogovoriti za pravila, ki bi veljala za vso zakonodajo. Po burnem letu 1995 je vprašanje seksistične rabe jezika potonilo v pozabo; s tem se je ukvarjal le še Urad za žensko politiko. Slednjemu je leta 1997 v sodelovanju z Zavodom RS za statistiko uspelo oblikovati standardno klasifikacijo poklicev skoraj dosledno v obojespolni redakciji. Njena moč je zlasti v tem, da tvorce razbremenjuje negotovosti, ki jo imajo pri tvorbi ali uporabi ženskih poimenovanj v razpisih in drugih besedilih. Pričakuje se, da bo omogočala naravnejši prehod k doslednejšemu obojespolnemu oblikovanju besedil (Stabej 1997: 67, 68).

$\mathrm{Na}$ problem seksistične rabe jezika so se nato odzvali na 33. Seminarju slovenskega jezika, literature in kulture Ženska v slovenskem jeziku, literaturi in kulturi leta 1997. Takrat je Ada Vidovič Muha (1997: 78) povzela, da se na Slovenskem v določenih krogih piše in govori o jezikovni diskriminaciji žensk 
oziroma o t. i. seksističnem jeziku. Opozorila je, da je glede hkratne rabe poimenovanj za ženske in moške nujno upoštevati zunajjezikovne okoliščine. Obe poimenovanji sta tako ustrezni v vsaj dveh primerih: a) nagovor, neposredni ali posredni (mediji), občinstva obeh spolov; b) če želimo poudariti oba spola. Hkrati pa je ugotavljala, da je mogoče govoriti tudi o nezaznamovanosti ženskega spola, kadar gre za poimenovanja čustvenih, navadno slabšalnih lastnosti (prismoda, reva, klepetulja ...). Nadalje se je spraševala, zakaj je nezaznamovanost po spolu $\mathrm{v}$ večini primerov homonimna $\mathrm{z}$ obliko za moški spol, in to razložila, da je pojav mogoče utemeljevati $\mathrm{z}$ vsaj izhodiščno manjšo morfemsko obremenjenostjo oblike za moški spol. Pojmovni svet, ki ga izoblikujejo poimenovanja žensk z različnih vidikov, ima namreč dve temeljni razsežnosti: žensko kot biološko bitje, pri čemer poimenovanja ne izkazujejo glede na spol hierarhiziranih družbenih vrednostnih meril, in žensko kot družbeno bitje, kjer je hierarhizacija teh meril mogoča v zakriti ali izraženi obliki. O zakriti hierarhizaciji govorimo v primeru feminativov, ko poimenovanje ženske tvorimo iz poimenovanja vzporedne dejavnosti moškega. Dejansko gre za časovno poimenovalno zaporednost, pogojeno z izhodiščno vezanostjo dejavnosti pretežno ali celo zgolj na moško osebo (Vidovič Muha 1997: 70). O izraženi družbeni hierarhizaciji po spolu pa govorimo, ko poimenovanje ženske, besedotvorno motivirano s poimenovanjem položaja, poklica ali kako drugače izpostavljene družbene dejavnosti moškega, pomeni v prvi vrsti ali samo (zakonsko) ženo. Z vstopanjem žensk v celovit položajni, poklicni in sploh javni svet se je število takih poimenovanj zmanjšalo, so pa tovrstni izrazi vseeno uvrščeni med feminative, čeprav ni nujno, da predstavljajo ženskospolske dvojice moškospolskih podstav. Včasih je priponsko obrazilo pomenilo razločevalno vlogo (npr. kapetanica 'kapetanova žena' in kapetanka 'ženska oblika od kapetan') (Vidovič Muha 1997: 70).

Po nekaj letih medijskega zatišja je bil v Delovi Sobotni prilogi leta 2003 objavljen Stabejev članek Ene in drugi, v katerem avtor analizira aktualno stanje (ne)seksistične rabe slovenskega jezika. Ugotavlja, da se v pravnih besedilih kljub omenjenim pobudam obojespolna poimenovanja niso uveljavila. Tudi on opaža, da je pri razpisih za delovna mesta omenjanje obeh spolov še vedno precej redko; do enake ugotovitve smo prišli tudi v nadaljevanju pričujoče raziskave. Vendarle 
pa je viden napredek v smeri dosledne rabe ženskih poimenovanj pri izobrazbenih in poklicnih nazivih. Poimenovanja v obeh spolih uporablja tudi vedno več javnih osebnosti, na primer v parlamentu (Stabej 2003: 26).

Leta 2008 pa so bile v Uradnem listu objavljene Nomotehnične smernice, ki so pravnomočna usmeritev za oblikovanje normativnih dokumentov. Po njih uporaba zgolj moškega spola $\mathrm{v}$ predpisih $\mathrm{v}$ primerih, kjer je sicer možna tudi uporaba ženskega spola, temelji na tem, da gotovo ne gre za predpis, ki se nanaša samo na moške, temveč zgolj za oznako oseb, katerih spol ni (vnaprej) znan in je za pomen določbe razlikovanje sicer nepomembno. Enako se z generičnim pomenom včasih uporablja samo ženski spol, ker moška oblika slovnično sploh ni možna (npr. stranka). Pri tem uporaba enega ali drugega spola oziroma zgledovanje po spolu ne ustvarja nikakršne pravne ali vsebinske razlike, razen če je to zaradi vsebine izrecno posebej potrebno in hoteno. Kljub temu raba in kopičenje (večinoma) samo moških oznak spola oseb v predpisih lahko zbuja vtis, kot da so ženske pri normiranju in izražanju v predpisih spregledane, kar je - ne samo pri nas - vodilo do večje uporabe označevanja oseb v obeh spolih v pravnih predpisih (Nomotehnične smernice 2008: 74-76). Da je tema še vedno aktualna, dokazujejo novejše razprave, na primer Interne smernice za splošno občutljivo rabo jezika Renate Šribar (2010), ki Nomotehnične smernice označi kot neustrezne. Izpostavi predloge za spolno nediskriminatorno rabo samostalnikov, ki označujejo osebe, priporočila za stavčno sintakso, s katero se je mogoče izogniti seksistični rabi jezika. Nomotehnične smernice zavračata tudi Simona Kranjc in Martina Ožbot (2013: 234), ob čemer se sprašujeta o smiselnosti vztrajanja pri obojespolni obliki v formalnih besedilih. Različna mnenja kažejo, da ni enoznačnih in dokončnih interpretacij, temveč je jezik sistem, odprt za spremembe (Leskošek 2002: 23).

2.3.2 Ženskospolska poimenovanja v uradovalnih besedilih in pravnih aktih

Rabo izrazov za poimenovanje družbenega položaja ženskih oseb v zapisanih uradovalnih besedilih je predstavila Marja Bešter (1997: 9-23). V analizo je zajela besedila parlamenta, sodstva, policije, vojske, šolstva, zdravstva, 
pošte, bank, podjetij, različnih društev, političnih strank in Cerkve. Gre za besedila, katerih zgradbo določa sporočevalec sam, in obrazce, v katere je treba le vpisati zahtevane podatke. Izsledki kažejo, da so ženska poimenovanja $\mathrm{v}$ besedilnih vrstah, kot so obvestila, vabila in podobno, rabljena $\mathrm{v}$ nagovoru, podpisu, torej v delih, kjer se vzpostavlja in končuje odnos med sporočevalcem in naslovnikom, redko pa v preostalem besedilu. $\mathrm{V}$ obrazcih pa se poimenovanja za ženske pojavljajo redkeje, kot bi pričakovali. Med 185 pregledanimi obrazci jih je približno 10 \% vsebovalo tudi ženske oblike. Če je naslovnik množičen, je sicer poimenovan s parnimi oblikami, ki so lahko dolge/polne ali kratke. Dolge/polne je mogoče najti predvsem $\mathrm{v}$ nagovorih (Spoštovane članice in člani!), redkeje $\mathrm{v}$ obrazcih; v slednjih so pogostejše kratke oblike, s katerimi se prihrani prostor (predsednik/ca). Pri tem sta končnica oz. priponsko obrazilo od moške oblike ločena z vezajem (državljan-ka), s poševnico (zaposlen/a), z oklepajem (rojen $(a)$ ).

Tudi slovenska ustava je napisana le v moškem spolu, razen nekaterih izjem (Zupanc 2009: 131). Analiza posameznih členov ustave kaže, da začetni členi sicer dosledno upoštevajo moško- in ženskospolsko obliko, po 43. členu pa se razkrije paradoksalnost pri oblikah državljan, tujec, poslanec, sodnik ... Očitne so spolne implikacije, zlasti pri državnih funkcijah, ki bi jih, po dokumentu sodeč, lahko opravljali samo moški, poimenovanja, kot so državljan, tujec ipd., pa izključujejo dobršen del populacije. Poslovnik Državnega zbora RS (četrti odstavek 115. člena) $\mathrm{v}$ besedilu členov zakona določa (obvezno) uporabo ženskega in moškega spola $\mathrm{v}$ prvih členih oziroma (posameznih) poglavjih predloga zakona, ki določajo temeljne subjekte predloga zakona, z navedbo, da se v nadaljnjem besedilu uporabi »naslavljanje« v moškem spolu.

Zelo odmeven pa je v letu 2018 sprejet sklep Senata Filozofske fakultete Univerze $\mathrm{v}$ Ljubljani, na podlagi katerega šteje ženski spol kot nevtralen in zapoveduje, da se v pravnih aktih fakultete v naslednjih treh letih uporablja samo ženski spol. Na problematičnost določila, da »V pravilniku uporabljeni moški slovnični spol velja za oba spola«, so namreč večkrat opozarjali posamezni oddelki na fakulteti. Senat je zato sklenil ustanoviti delovno skupino, ki je pripravila predlog spolno občutljive rabe jezika $\mathrm{v}$ internih pravilnikih fakultete. Skupina je Senatu predlagala sklep, da se $\mathrm{v}$ enem od uvodnih členov pravnih 
aktov Filozofske fakultete zapiše ena od naslednjih dikcij: $\gg \mathrm{V}$ pravilniku uporabljen ženski slovnični spol (študentka, učiteljica itn.) se nanaša na kateri koli spol« ali »V pravilniku uporabljen moški slovnični spol (študent, učitelj itn.) se nanaša na kateri koli spol«. Skupina je predlagala, da se različici uporabljata izmenično, vendar se v istem pravilniku uporablja le ena od obeh različic. Ker so bili vse od ustanovitve fakultete vsi njeni pravilniki pisani izključno v moški slovnični obliki, je skupina predlagala, da se naslednja tri leta nove pravilnike sprejema v ženski slovnični obliki, nato pa izmenično (Kuhar, spletni vir). ${ }^{13}$

Kozma Ahačič (spletni vir) ${ }^{14}$ domneva, da so rešitev sprejeli po zgledu katere od sicer redkih univerz $\mathrm{v}$ tujini, a opozarja, da pri tem niso upoštevali oblikoslovnih in skladenjskih značilnosti slovenščine. Ahačič spremembo označuje kot enega najbolj avtoritarnih jezikovnih ukrepov v zadnjih desetletjih, morda celo stoletjih. Spolno (ne)občutljive rabe jezika namreč ni mogoče povezovati le s sprejemanjem oziroma zavračanjem nezaznamovanosti moškega spola ali problematičnimi edninskimi poimenovanji oseb le $\mathrm{v}$ moški obliki, marveč gre za širši, celovitejši problem. Rešitev bi po mnenju avtorja morala biti dovolj uglašena z naravo slovenskega jezika, da bi onemogočala nesporazume in nepotrebna norčevanja iz primerov, do katerih lahko prihaja. Umetno poseganje $\mathrm{v}$ že ustaljene jezikovne vzorce namreč ni enako dopolnjevanju že ustaljenih jezikovnih oblik. Ob tem se lahko spomnimo na primer uvajanja ženskospolskih poimenovanj za poklice (denimo: direktor $\rightarrow$ direktorica), ki so ob uvedbi naletela na posmehovanje in dvom, a so se obdržala in ustalila, saj so sledila naravi slovenske slovnice. Avtorji sklepa rešitve niso iskali v okviru obstoječih možnosti, ampak so se odločili poseči v jedro slovenskega jezika. Situacija s slovnično kategorijo spola v slovenščini nikakor ni tako enostavna, kot se zdi na prvi pogled, saj v slovenščini spolno nevtralno ne deluje samo moški spol, ampak v določenih položajih tudi ženski (priča je povedala) in srednji (dete se je rodilo), medtem ko srednji v določenih položajih deluje kot ženski (dekle je šlo po vodo). Od spola izhodiščnega samostalnika pa je odvisno ujemanje pridevnika ali

\footnotetext{
${ }^{13}$ Roman Kuhar: Marija Novak, študent slovenščine (odziv na članek K. Ahačiča »Janez Novak, študentka slovenščine«). Vir: http://www.ff.uni-lj.si/novice/Marija_Novak_student_slovenscine_ odziv_na_clanek_K_Ahacica_Janez_Novak_studentka_slovenscine (pridobljeno 27.6. 2018).

${ }^{14}$ Kozma Ahačič: Janez Novak, študentka slovenščine. Vir: https://www.delo.si/novice/slovenija/ janez-novak-studentka-slovenscine-54157.html (pridobljeno 27. 6. 2018).
} 
deležnika v spolu v najrazličnejših pozicijah. Dodaten zaplet nastane pri nevtralnosti spola, če je osebek zložen ali združen z zaimkom, denimo Maja in Janez sta študirali. Problem se pojavi tudi pri zaimkih $k d o$ in $k d o r$, npr. Kdo je upravičena do ponovnega opravljanja izpita? ter Kdor ni opravila vseh obveznosti, ne more napredovati v višji letnik. Vse to so vprašanja, ki še niso dovolj raziskana in preizkušena. Ahačič zaključuje, da je sprememba slovničnih zakonitosti brez realne jezikovne podlage neživljenjska in pomeni veliko nazadovanje v dojemanju jezika, pa tudi njegovih sociolingvističnih značilnosti.

$\mathrm{Na}$ članek Kozme Ahačiča se je odzval dekan Filozofske fakultete Univerze v Ljubljani Roman Kuhar (spletni vir), ${ }^{15}$ ki avtorju očita zgrešeno poanto sklepa Senata Filozofske fakultete in njegovo netočno navajanje. Kuhar pojasnjuje, da je delovna skupina delovala vključujoče in predlagala, da se v internih pravilnikih fakultete uporabljeni ženski ali moški slovnični spol »nanaša na kateri koli spol«. Zgornjo dikcijo je namreč delovna skupina predlagala prav zaradi zavedanja občutka nenagovorjenosti oseb, za katere se avtor članka zavzema oz. boji, da so bile izpuščene. Kuhar pojasnjuje, da je popolnoma jasno, da tovrsten sklep ne bo odpravil spolne diskriminacije, vendar so pomembna tudi simbolna sporočila. V instituciji, kjer so $\mathrm{v}$ ospredju humanistične vrednote enakosti, svobode in solidarnosti, se tovrstni sklep zdi skladen s temeljnimi vrednotami. Odgovarja, da bodo po Ahačiču problematično poved »Kdor $n i$ opravila vseh obveznosti, ne more napredovati v višji letnik« preprosto zapisali: »Študentka, ki ni opravila vseh obveznosti ..." ali »Študent, ki ni opravil vseh obveznosti ... «. Kuhar se z Ahačičem vseeno strinja, da k pravičnejši družbi ne bo prispevala prevlada večine nad manjšino ali manjšine nad večino, je pa dolžnost večine, da misli tudi na pravice manjšin. Zato je treba tudi v jeziku najti rešitve, ki bodo izkazovale vključevanje vseh med nami sobivajočih delov družbe tako, da se bodo čutili ustrezno nagovorjeni. Interni akti fakultete bodo v moški slovnični obliki zadovoljivo nagovarjali tiste osebe, ki moški spol razumejo kot nevtralen, $\mathrm{v}$ ženski slovnični obliki pa tiste, ki temu nasprotujejo. Res je, da sklep ne omogoča

\footnotetext{
${ }^{15}$ Roman Kuhar: Marija Novak, študent slovenščine (odziv na članek K. Ahačiča »Janez Novak, študentka slovenščine«). Vir: http://www.ff.uni-lj.si/novice/Marija_Novak_student_slovenscine_ odziv_na_clanek_K_Ahacica_Janez_Novak_studentka_slovenscine (pridobljeno 27.6. 2018).
} 
enakega hkratnega zadovoljstva vseh, a vendar odpravlja prejšnje stanje, po katerem so bile ženske v najboljšem primeru le opomba pod črto.

Svoje pomisleke pa je ob Ahačiču izrazila tudi Saška Štumberger (spletni vir), ${ }^{16}$ ki meni, da tako hitenje in odločanje brez širše razprave ni v skladu z načeli sodobne in dialoške fakultete. Opozarja na tri dele besedila, pri katerih ima pomisleke, s tem pa zavrača nekatera Kuharjeva zgoraj zapisana pojasnila:

1. Besedna zveza kateri koli spol v pravnih besedilih Slovenski pravni red pozna zgolj moški in ženski spol, zveza kateri koli spol pa omogoča interpretacije, ki niso $\mathrm{v}$ skladu s slovenskim pravnim redom. Že omenjene Nomotehnične smernice take besedne zveze ne poznajo, ne najdemo je niti v Študijskem redu Univerze v Ljubljani, članica katere je Filozofska fakulteta. O tem, da zakonodaja pozna le moški in ženski spol, lahko preberemo tudi $\mathrm{v}$ publikaciji Pravno priznanje spola v Sloveniji.

2. Spolno nevtralna raba ženskega slovničnega spola

Raba ženskega slovničnega spola v pravnih besedilih, ki sodijo med strokovna in znanstvena besedila, ni običajna. Raba moškega slovničnega spola za opisovanje spolno mešanih skupin pa prevladuje tudi v publicističnih besedilih.

3. Želja po uravnoteženosti rabe moškega in ženskega slovničnega spola v (pravnih) besedilih Filozofske fakultete

Moški slovnični spol ni trenutna neuravnoteženost, nezaznamovanost slovnične kategorije moškega spola je namreč del slovenskega jezikovnega sistema. Saška Štumberger v jeziku ne pozna nobene tendence po uravnoteženosti rabe moškega in ženskega slovničnega spola, kot jo želi doseči sprejeti dokument. O želji po uravnoteženosti rabe slovničnih spolov so sociologi pisali že v devetdesetih letih prejšnjega stoletja, o čemer smo v tem poglavju že govorili.

Avtorica sklene, da uvajanje ženskega slovničnega spola za vse spole deluje izključevalno. Na jezikovni ravni se to kaže z izključevanjem moških članov skupine, izključevalen pa je bil tudi postopek odločanja na Filozofski fakulteti. Zato ne verjame, da bodo take jezikovne spremembe prispevale k boljši

\footnotetext{
${ }^{16}$ Saška Štumberger: Transspolnost na »filofaksu«: Študentka Janez Novak, padli ste na izpitu pri profesorici Božo Repe! Vir: https://www.portalplus.si/2729/transspolnost-na-filofaksu/ (pridobljeno 27. 6. 2018).
} 
družbi, nasprotno - v njih je vedno bolj prepoznavna težnja po izključevanju vseh, ki razmišljajo drugače od trenutnega razpoloženja odločevalcev.

\subsection{3 Ženskospolska poimenovanja za poklice}

V družbi je bila delitev dela in osebnostnih lastnosti po spolu strogo zamejena in nadzorovana tako, da je bila moškim dodeljena javna sfera $s$ hierarhično višjim mestom ter nadrejenim položajem $\mathrm{v}$ javnem in zasebnem okolju. Ženskam je $\mathrm{v}$ glavnem bila določena vloga bitja, ki je prvotno mati in gospodinja (Jogan 2001: 1). Delno, z izjemo točke b), je to vidno v prikazu poklicnih dejavnosti $\mathrm{v}$ delih slovenskih protestantskih piscev, ki kaže, da se ženskospolske oblike pojavljajo pri poklicih, ki označujejo a) izdelovanje oblačil in hkrati pokrivajo medsebojno povezane dejavnosti, kot sta šivanje in krojenje (žnidarica, šivilja, šivkinja ...); b) nujno potrebo za vse sloje (apotekarica); c) poimenovanja s samostalniško podstavo iz živalskih imen (ribička); č) poklice, za katere je značilen podrejeni odnos (služabnica); d) poimenovanja, ki so del cerkvene terminologije (abtašica); e) kmetijska opravila (kmetica). Soobstoj poimenovanj obeh spolov kaže, da so nekatere poklice lahko opravljale tudi ženske, čeprav je ženska različica uresničevala več pomenov (npr. 'žena vršilca poklicne dejavnosti') (Merše 2013: 228-239). Ženske pa naj bi se še zmeraj pogosteje zaposlovale v zdravstvu, vzgoji in izobraževanju, sociali in storitvenih dejavnostih, vpliv patriarhata pa je mogoče čutiti na področju tehnike, obrambe, prometa in politike. Tradicionalna delitev na moška in ženska dela je privedla do delitve na moške in ženske poklice (Sedmak, Medarić 2007: 19); tudi zato, ker ženske pogosteje opravljajo dela, ki so podaljšek gospodinjskih opravil. Med področja, kjer je zastopanost žensk nizka in ki veljajo za moško domeno, sodijo menedžment, znanost, gradbeništvo, politika in policija.

\subsubsection{Klasifikacija poklicev po Kroupovi}

Libuše Kroupova (1980: 208) pa poudarja dejstvo, ki velja za vse jezike: spremembe $\mathrm{v}$ jeziku so namreč tesno povezane $\mathrm{z}$ družbenimi spremembami. To 
velja tudi za ženskospolska poimenovanja poklicev, ki so povezana z vse večjo vlogo žensk v družbi. Število tovrstnih poimenovanj raste $\mathrm{v}$ odvisnosti od razširjenosti poklicev in specializacije žensk, opravljanja pomembnih funkcij, raznih interesnih dejavnosti ipd. Omenja več različnih oblik poklicev, ki jih ženske opravljajo, zato zanje obstajajo ustrezna ženskospolska poimenovanja: ${ }^{17}$

1. Stalne strokovne poklice:

- teoretične in praktične duhovne poklice: a) $\mathrm{v}$ družboslovju (lingvistka, historička), b) $\mathrm{v}$ medicini in farmaciji (doktorka), c) $\mathrm{v}$ naravoslovju (bioložka), č) v matematiki (statistička), d) v tehniki (tehnička), e) v poljedelstvu (rostlinařka);

- praktične duhovne poklice: a) $\mathrm{v}$ šolstvu (učitelka), b) v drugih strokah (advokatka);

- praktične poklice: a) v zdravstvu (sestra), b) v uporabni umetnosti in likovni praksi (maskerka, aranžerka), c) v obveščanju, posredništvu in oglaševanju (hlasatelka, tlumočnice), č) v administraciji (referentka), d) v prometu (železničařka), e) v komunikaciji (telefonistka), f) v trgovini (prodavačka), g) druge funkcije (skladnice);

- priročne praktične poklice: a) v službah (holička), b) v proizvodnji, povezani s popravili (mechanička), c) v proizvodnji, povezani s prodajo (kloboučnice).

2. Stalne poklice: a) praktične poklice (trafikantka); b) pomožne praktične poklice (kolporterka); c) priročne praktične poklice (pradlena, myčka).

3. Priložnostne poklice: a) strokovne (recenzentka); b) praktične (pořadatelka).

4. Ženske poklice v industriji: a) priročne poklice, strokovne in stalne (tkadlena, soustružnice); b) stalne praktične poklice (kreslička, manipulantka); c) duhovne poklice, strokovne in stalne (technička, projektantka).

\footnotetext{
${ }^{17}$ Povzemamo avtoričine konkretne primere ženskospolskih poimenovanj v češkem jeziku.
} 
5. Poklice v kmetijstvu: a) stalne priročne poklice (krmička, dojička); b) priročne poklice, strokovne in stalne (traktoristka, kombajnistka); c) praktične poklice, strokovne in stalne (zootechnička, mechanizatorka) (Kroupova 1980: 212-213).

\subsubsection{Klasifikacija poklicev po Statističnem uradu $R S$}

Glede na podatke Statističnega urada $R S$ pa lahko poklicne feminative razdelimo v naslednje skupine:

1. Vojaški poklici (alpinka, brigadirka, častnica, jurišnica ...).

2. Zakonodajalci/zakonodajalke, visoki uradniki/visoke uradnice, menedžerji/menedžerke

- zakonodajalci/zakonodajalke (ministrica, poslanka, premierka ...);

- visoki državni uradniki/visoke državne uradnice (ambasadorka, atašejka, guvernerka, konzulka ...);

- visoki uradniki/visoke uradnice interesnih organizacij (svetovalka);

- direktorji/direktorice in člani/članice uprave družbe (članica, direktorica, pomočnica, prokuristka, rektorica ...);

- menedžerji/menedžerke proizvodnih in operativnih enot družbe (dekanica, prodekanica, producentka, ravnateljica, založnica ...).

3. Strokovnjaki/strokovnjakinje

- strokovnjaki/strokovnjakinje fizikalnih, kemijskih, matematičnih, tehnično-tehnoloških ved (astronavtka, farmacevtka, inženirka, informatičarka, matematičarka, projektantka, statističarka ...);

- zdravstveni strokovnjaki/zdravstvene strokovnjakinje, strokovnjaki/strokovnjakinje biomedicinskih, bioloških, biotehniških ved (anatomistka, botaničarka, primarijka ...); 
- strokovnjaki/strokovnjakinje za vzgojo in izobraževanje (knjižničarka, predavateljica, šolnica, učiteljica, vzgojiteljica ...);

- drugi strokovnjaki/druge strokovnjakinje (arhivarka, bančnica, bibliotekarka, lektorica, odvetnica, pevka, revizorka ...).

4. Tehniki/tehnice in drugi strokovni sodelavci/druge strokovne sodelavke

- tehniki/tehnice tehničnih strok (balanserka, fotografka, kontrolorka, opazovalka, pilotka, programerka, snemalka ...);

- tehniki/tehnice in asistenti/asistentke $\mathrm{v}$ zdravstvu, biomedicini, biologiji, biotehniki ipd. (asistentka, fizioterapevtka, optičarka ...);

- pomočniki/pomočnice vzgojiteljev/vzgojiteljic, inštruktorji/ inštruktorice, učitelji/učiteljice praktičnega pouka (laborantka);

- komercialni, poslovnoupravni, javnoupravni strokovni sodelavci/komercialne, poslovnoupravne, javnoupravne strokovne sodelavke ipd. (agentka, cenilka, dražbarka, komercialistka, posrednica, potnica, referentka, špediterka ...).

5. Uradniki/uradnice

- uradniki/uradnice za pisarniško poslovanje (administratorka, posredovalka, stenografka, strojepiska, telefaksistka ...);

- uradniki/uradnice za poslovanje s strankami (blagajničarka, cestninarka, izterjevalka, izvršiteljica, krupjejka, menjalka ...).

6. Poklici za storitve, prodajalci/prodajalke

- poklici za storitve (bolničarka, ekonomka, nadzornica, natakarica, oskrbnica, policistka, prostitutka, spremljevalka, vodnica ...);

- modeli, prodajalci/prodajalke, demonstratorji/demonstratorke (akviziterka, manekenka, modelka ...).

7. Kmetovalci/kmetovalke, gozdarji/gozdarke, ribiči/ribičke, lovci/lovke (čebelarka, dreserka, drevesničarka, gojiteljica, hmeljarka, poljedelka, povrtninarka, ribogojka ...). 
8. Poklici za neindustrijski način dela

- rudarji/rudarke, gradbinci/gradbinke ipd. (betonerka, fasaderka, kamnolomka, minerka, pirotehnica, tlakovalka, zidarka ...);

- kovinarji/kovinarke, strojni mehaničarji/strojne mehaničarke ipd. (hišnica, jedrarka, kovačica, livarka, orodjarka, puškarka ...);

- finomehaniki/finomehaničarke, rokodelci/rokodelke, tiskarji/ tiskarke ipd. (bižuteristka, draguljarka, lončarka, steklarka ...);

- drugi poklici za neindustrijski način dela (kletarka, mesarka, modistka ...).

9. Upravljalci/upravljalke strojev in naprav, industrijski izdelovalci/industrijske izdelovalke in sestavljalci/sestavljalke

- upravljalci/upravljalke procesnih strojev in naprav (geovrtalka, talilka ...);

- upravljalci/upravljalke strojev za proizvodnjo izdelkov in sestavljalci/sestavljalke izdelkov (barvarka, embalerka, kartonažerka, rezalka ...);

- vozniki/voznice, upravljalci/upravljalke transportnih naprav in premičnih strojev (čolnarka, mornarka, signalistka ...).

10. Poklici za preprosta dela

- poklici za preprosta prodajna, storitvena in komunalna dela (biljeterka, čistilka, ključarka, krošnjarka, kurirka, nosačica, smetarka, strežnica ...).

2.3.3.3 Ženskospolska poimenovanja za poklice v jezikovnih virih

Kot že rečeno, so poimenovanja ženske poklicne dejavnosti tvorjena iz poimenovanja vzporedne dejavnosti moškega, pri čemer gre za časovno 
poimenovalno zaporednost. To dokazuje tudi analiza 553 ženskospolskih poimenovanj za poklice, izpisanih s Statističnega urada $R S$ (spletni vir) ${ }^{18}$ in $N S L$, nato pa preverjanih po SSKJ 1, SSKJ 2, SP in korpusih Gigafida, Nova beseda in Fidaplus.

Od vseh 553 ženskospolskih poklicnih poimenovanj, kolikor smo jih zbrali s pregledom seznama poklicev, objavljenega na spletni strani Statističnega urada $R S$, in iz NSL, je 257 (46,5 \%) takih, ki jih navaja tudi SSKJ 1 kot samostojna slovarska gesla, večinoma v pomenu 'ženska oblika od ...' ali 'ženska, ki ...' (administratorka, agentinja/agentka, agronomka, arhivarka, arhitektka, artistka, asistentka, astronomka, bibliotekarka, biljeterka, biologinja, blagajničarka, bolničarka, botaničarka, brigadirka, brivka, cvetličarka, čarovnica, čebelarica/čebelarka, čipkarica, čistilka, članica, čuvajka, dekanica, dekoraterka, delavka, demonstratorka, detektivka, dežnikarica, direktorica, dirigentka, dostavljavka, dreserka, družabnica, duhovnica, ekonomistka, ekonomka, farmacevtka, filozofinja, fizioterapevtka, fotografinja/fotografka, fotoreporterka, frizerka, garderoberka, gasilka, geologinja, glasbenica, gostiteljica, graditeljica, grobarka, guvernerka, higieničarka, hišnica, igralka, ilustratorka, informatorka, instrumentalistka, inšpektorica, inštruktorica, inženirka, izdelovalka, izposojevalka, izvajalka, izvedenka, izvršiteljica, jezikoslovka, kalkulantka, kapitanka, kemičarka, keramičarka, kiparka, kletarica, ključarica/ključarka, klobučarka, knjigovezka, knjigovodkinja, knjižničarka, komentatorka, komercialistka, kontrolorka, kopistka, koreografinja/koreografka, korespondentka, kostumografinja/kostumografka, kozmetičarka, kritičarka, krmarica, krojačica, krošnjarka, krznarka, kuharica, kurirka, laborantka, lekarnarica/lekarnarka, lektorica, likalka, lončarica, lovica/lovka, manekenka, manikerka, manipulantka, maserka, maskerka, matematičarka, mešalka, meteorologinja, ministrica, misijonarka, mlekarka, modelarka, modelka, mojstrica/mojstrovka, montažerka, nabiralka, načelnica, nadzornica, napovedovalka, natakarica, navijalka, negovalka, novinarka, oblikovalka, ocenjevalka, odpravnica, odvetnica, opazovalka, operaterka,

${ }^{18}$ Statistični urad Republike Slovenije. Vir: http://www.stat.si/statweb (pridobljeno junija 2017). 
organizatorica/organizatorka, oskrbnica, oskrbovalka, paznica, pedikerka, pekovka, perutninarka, pesnica, pevka, pilotka, pisateljica, planšarica, plesalka, pletilja/pletilka, pobiralka, pogrebnica, policistka, polnilka, pometačica, pomočnica, poslanka, poslovodkinja, posrednica, posredovalka, povezovalka, potnica, pralka, pravnica, predavateljica, predsednica, predstojnica, premierka, preparatorka, prevajalka, prodajalka, psihologinja, radiotelegrafistka, ravnateljica, raziskovalka, razkuževalka, raznašalka, recenzentka, receptorka, redaktorica, rediteljica, referentka, rejnica, reševalka, režiserka, ribička, risarka, rokavičarka, scenaristka, scenografka, sekretarka, sestavljavka, skladateljica, skladiščnica, skrbnica, slaščičarka, slikarica/slikarka, snovalka, sobarica, sociologinja, sodelavka, sodnica, solistka, specialistka, spremljevalka, sprevodnica, stenodaktilografka, stenografinja/stenografka, strelka, strežnica, strojepiska, strokovnjakinja, svétnica, svetovalka, šivalka, športnica, tajnica, tapetnica, tehnica, telefonistka, teleprinteristka, terapevtka, tiskarka, tkalka, točajka, tolmačica/tolmačka, tožilka, trenerka, trgovka, učiteljica, umetnica, upraviteljica, upravljavka, upravnica, uradnica, urarka, urednica, urejevalka, usmerjevalka, ustvarjalka, vaditeljica, valjavka, varilka, vedeževalka, veleposlanica, veterinarka, vezilja, voditeljica, vodnica, vojakinja, voznica, vratarica/vratarka, vrtnarica, vzdrževalka, vzgojiteljica, zakonodajalka, založnica, zastopnica, zbiralka, zdravnica, zelenjavarica, zgodovinarica/zgodovinarka, zidarka, zobozdravnica). Prav vsa poimenovanja so zabeležena tudi v SSKJ 2.

Za 204 od skupnih 553 (37\%) poklicev je v SSKJ 1 navedeno zgolj moškospolsko poimenovanje (to so alpinec, aktuar, akviziter, ambasador, analitik, animator, anketar, antikvar, antropolog, apreter, aranžer, astrolog, astronavt, ataše, avtoelektričar, avtoličar, avtomehanik, avtoprevoznik, balanser, bančnik, bankir, barvar, belivec, biblicist, brusilec, carinik, cenilec, cestninar, cineast, častnik, čevljar, člankar, čolnar, črkoslikar, davkar, deklarant, dezinsektor, dimnikar, dokumentalist, draguljar, dramatik, dražbar, drevesničar, ekolog, ekspert, elektroinštalater, elektromehanik, elektromonter, energetik, finančnik, finomehanik, fizik, galanterist, genetik, geodet, geofizik, gojitelj, govedorejec, gozdar, gradbinec, graver, hidravlik, hmeljar, homeopat, iluzionist, 
informatik, inkasant, inštalater, izolater, izterjevalec, jurišnik, kalivec, kalupar, kancler, karikaturist, kartograf, kinooperater, klepar, ključavničar, kmetovalec, knjigotiskar, komik, konjerejec, konservator, konstruktor, konzul, koordinator, korektor, korepetitor, kovač, kretničar, kriminalist, krojilec, krupje, lasuljar, ličar, loščilec, major, manager, maslar, mazalec, mehanik, menjalec, mesar, mizar, moderator, monter, mornar, motorist, načrtovalec, nastavljavec, navigator, normirec, nosač, notar, obdelovalec, obhodnik, oglar, oljar, opremljevalec, optik, orodjar, ostrilec, ovčerejec, označevalec, plakater, podčastnik, polagalec, polirec, politolog, poljedelec, posojevalec, potapljač, poustvarjalec, prašičerejec, pravobranilec, predelovalec, predilec, pregledovalec, preiskovalec, premikač, primarij, pripravljavec, prodekan, producent, programer, projektant, prokurist, prorektor, računalnikar, razvijalec, razvrščevalec, rejec, rektor, restavrator, retušer, revizor, rezalec, rezkalec, ribogojec, rudar, sadjar, sedlar, sekač, serviser, signalist, sirar, sladoledar, slikopleskar, smetar, snemalec, sprejemalec, statistik, stavec, steklar, stilist, stotnik, strugar, svečar, špediter, talivec, tehnolog, testeninar, tlakovalec, uglaševalec, urbanist, usnjar, varnostnik, vicekonzul, videotehnik, vinar, vinogradnik, vodar, vódnik, vremenar, vrvar, zastekljevalec, zlatar, zobar, zoolog, zootehnik, zvonar, železokrivec, živinorejec), za razliko od SSKJ 1 pa ženskospolsko poimenovanje k poklicu moškega spola za prav te 204 poklice že navaja nekoliko novejši vir SP (alpinka, aktuarka, akviziterka, ambasadorka, analitičarka, animatorka, anketarica, antikvarka, antropologinja, apreterka, aranžerka, astrologinja, astronavtka, atašejka, avtoelektrikarica, avtoličarka, avtomehaničarka, avtoprevoznica, balanserka, bančnica, bankirka, barvarka, belivka, biblicistka, brusilka, carinica, cenilka, cestninarica, cineastinja, častnica, čevljarica, člankarica, črkoslikarka, čolnarka, davkarica, deklarantka, dezinsektorka, dimnikarica, dokumentalistka, draguljarica, dramatičarka, dražbarica, drevesničarka, ekologinja, ekspertinja, elektroinštalaterka, elektromehaničarka, elektromonterka, energetičarka, finančnica, finomehaničarka, fizičarka, galanteristka, genetičarka, geodetinja, geofizičarka, gojiteljica, govedorejka, gozdarka, gradbinka, graverka, hidravličarka, hmeljarka, homeopatinja, iluzionistka, informatičarka, inkasantka, inštalaterka, izolaterka, izterjevalka, jurišnica, kalivka, kaluparka, 
kanclerica/kanclerka, karikaturistka, kartografinja, kinooperaterka, kleparka, ključavničarka, kmetovalka, knjigotiskarka, komičarka, konjerejka, konservatorka, konstruktorica, konzulka, koordinatorica, korektorica, korepetitorka, kovačica, kovinarka, kretničarka, kriminalistka, krojilka, krupjejka, lasuljarka, ličarka, loščilka, majorka, menedžerka, maslarica, mazalka, mehanikarica/mehaničarka, menjalka, mesarka, mizarka, moderatorka, monterka, mornarka, motoristka, načrtovalka, nastavljavka, navigatorica, normirka, nosačica, notarka, obdelovalka, obhodnica, oglarka, oljarka, opremljevalka, optičarka, orodjarka, ostrilka, ovčerejka, označevalka, plakaterka, podčastnica, polagalka, polirka, politologinja, poljedelka, posojevalka, potapljačica, poustvarjalka, prašičerejka, pravobranilka, predelovalka, predilka, pregledovalka, preiskovalka, premikačka, primarijka, pripravljavka, prodekanka, producentka, programerka, projektantka, prokuristka, prorektorica, računalničarka, razvijalka, razvrščevalka, rejka, rektorica, restavratorka, retušerka, revizorka, rezalka, rezkalka, ribogojka, rudarka, sadjarka, sedlarka, sekačka, serviserka, signalistka, sirarka, sladoledarica/sladoledarka, slikopleskarka, smetarka, snemalka, sprejemalka, statističarka, stavka, steklarka, stilistka, stotnica, strugarka, svečarka, špediterka, talivka, tehnologinja, testeninarka, tlakovalka, uglaševalka, urbanistka, usnjarka, varnostnica, vicekonzulka, videotehnica, vinarka, vinogradnica, vodarka, vódnica, vremenarka, vrvarka, zastekljevalka, zlatarka, zobarka, zoologinja, zootehnica, zvonarka, železokrivka, živinorejka). Nekaj teh poimenovanj pa že ponuja SSKJ 2, to so ambasadorka, analitičarka, animatorka, anketarica, antropologinja, aranžerka, astrologinja, astronavtka, atašejka, bančnica, bankirka, cenilka, častnica, davkarica, ekologinja, ekspertinja, finančnica, fizičarka, homeopatinja, kanclerka, kmetovalka, komičarka, konservatorka, konzulka, koordinatorica, korektorica, korepetitorica, kriminalistka, krupjejka, majorka, moderatorka, motoristka, načrtovalka, notarka, opremljevalka, politologinja, potapljačica, pravobranilka, pregledovalka, preiskovalka, primarijka, prodekanica, producentka, projektantka, prokuristka, prorektorica, računalničarka, rektorica, restavratorka, revizorka, snemalka, sprejemalka, stotnica, tehnologinja, varnostnica, vinogradnica in vremenarka. Vsa do zdaj navedena ženskospolska 
poimenovanja poklicev (257 tistih, ki so v SSKJ 1 navedena kot samostojna gesla, in 204 tiste, za katere SSKJ 1 navaja zgolj obliko za moški spol, so pa ženskospolske oblike zabeležene v $S P$ ) pa najdemo tudi v vseh treh korpusih: Gigafida, Nova beseda in Fidaplus. ${ }^{19}$

30 primerov (ali 5,5\% od vseh 553 primerov) je takih, za katere ne v SSKJ 1 in tudi ne v SP ni poklicnega feminativa, navedena je zgolj moškospolska oblika (betoner, dietetik, emajler, fasader, general, jermenar, kamnolomec, kamnosek, krovec, livar, miner/minerec, mlinar, parketar, pirotehnik, pleskar, policaj, puškar, solinar, steklobrusilec, steklopihalec, sušilničar, svetilničar, šolnik, štukater, teracer, tesar, vulkanizer, zakovičar, žarilec, žičar), zato pa jih nekaj že najdemo v SSKJ 2 (dietetičarka, generalka, policajka in šolnica). Ženskospolske oblike za teh 30 primerov so navedene na Statističnem uradu $R S$, vendar jih 16 od 30 (53\%) ne najdemo v nobenem od korpusov Fidaplus, Nova beseda in Gigafida (betonerka, emajlerka, fasaderka, jermenarka, kamnolomka, parketarka, pirotehnica, puškarka, steklobrusilka, sušilničarka, svetilničarka, štukaterka, teracerka, zakovičarka, žarilka, žičarka). Pet poklicev od $30(16 \%) \mathrm{z}$ zelo nizkim številom konkordanc najdemo zgolj v korpusu Gigafida (kamnosekinja, krovka, livarka, steklopihalka, vulkanizerka). Preostalih devet poklicnih feminativov od 30 (30\%) je v vseh treh korpusih dokaj pogostih (dietetičarka, generalica/generalka, minerka, mlinarica, pleskarka, policajka, solinarka, šolnica, tesarka).

40 poklicev od skupno $553(7 \%)$ je bilo navedenih zgolj na seznamu Statističnega urada $R S$, SSKJ 1 in $S P$ pa nista navajala ne moško- in ne ženskospolske oblike (anatomist - anatomistka, avdiolog - avdiologinja, avtomatik - avtomatičarka, balzamer - balzamerka, biomehanik biomehaničarka, biometrik - biometričarka, bižuterist - bižuteristka, črevar črevarka, deratizator - deratizatorka, ekonometrik - ekonometričarka, elektronadzornik - elektronadzornica, embaler - embalerka, fonotekar fonotekarka, fotogrametrik - fotogrametričarka, fotograver - fotograverka, geovrtalec - geovrtalka, impregnator - impregnatorka, jedkalec - jedkalka,

${ }^{19}$ Do podatkov v vseh treh korpusih smo dostopali julija 2017. 
koder - koderka, kozjerejec - kozjerejka, obzidovalec - obzidovalka, odčitovalec - odčitovalka, odpremljevalec - odpremljevalka, ofsettiskar - ofsettiskarka, optometrist $^{20}$ - optometristka, plemenitilec - plemenitilka, pnevmatik pnevmatičarka, povečevalec - povečevalka, sitotiskar - sitotiskarka, solopevec solopevka, sovoditelj - sovoditeljica, spajalec - spajalka, supermodel supermodelka, tapiserist - tapiseristka, telefaksist - telefaksistka, vbrizgovalec vbrizgovalka, videokontrolor - videokontrolorka, vodogradbenik vodogradbenica, vpenjalec - vpenjalka, zmanjševalec - zmanjševalka). Med navedenimi pa sta v SSKJ 2 že zabeleženi sovoditeljica in supermodelka, seveda z ustreznima moškospolskima vzporednicama sovoditelj in supermodel, od zgolj moškospolskih pa zmanjševalec. Vse oblike, tako moško- kot ženskospolske, smo preverili po vseh treh korpusih. Ugotovili smo, da korpusi navajajo le devet ženskospolskih poimenovanj od $40(22,5 \%)$ za te poklice (biomehaničarka, povečevalka, sitotiskarka, solopevka, sovoditeljica, spajalka, supermodelka, tapiseristka). Za nekatera poimenovanja pa korpusi niso izkazali niti moškospolske oblike (fonotekar, fotogrametrik, geovrtalec, koder, obzidovalec, odpremljevalec, telefaksist).

Zasledili smo tudi primere, ko je zgolj moškospolsko poimenovanje bilo navedeno v SSKJ 1 in SSKJ 2, v SP pa tega poklica ni bilo mogoče zaslediti niti za moški spol; takih besed je bilo pet od vseh 553 (1\%): biofizik, biokemik, jedrar, kartonažer, kemigraf. Vsi trije korpusi so izkazali moško- in ženskospolsko obliko za biofizik - biofizičarka in biokemik - biokemičarka, za poklice jedrar, kartonažer in kemigraf pa zgolj moškospolsko poimenovanje. Zgodilo se je tudi, da posamezne besede ni bilo v SSKJ 1, je pa bila v SP (moško- in ženskospolsko poimenovanje); takih primerov je bilo 12 od vseh 553 (2\%) (akupunkturist akupunkturistka, arhivist - arhivistka, filigranist - filigranistka, kiropraktik kiropraktičarka, naturščik - naturščica, obramboslovec - obramboslovka, povrtninar - povrtninarka, videotekar - videotekarka, vizažist - vizažistka, vnašalec - vnašalka, zastavljalničar - zastavljalničarka, zdravitelj -

\footnotetext{
${ }^{20}$ Moškospolsko poimenovanje optometrist $\mathrm{v}$ pomenu 'strokovnjak za merjenje dioptrije in predpisovanje očesnih pripomočkov' najdemo v Sprotnem slovarju slovenskega jezika, a brez ustrezne ženskospolske vzporednice.
} 
zdraviteljica). V korpusih najdemo vse navedene oblike, in to za oba spola, pa tudi SSKJ 2 že ponuja nekaj moško- in ženskospolskih (naturščica, obramboslovka, vizažistka, vnašalka, zdraviteljica) ter samo moškospolske: akupunkturist, arhivist, kiropraktik, povrtninar. Za štiri besede od vseh 553 (0,7 \%) SSKJ 1 navaja zgolj ženskospolsko obliko: modistinja/modistka, pometalka, prostitutka, servirka (v SP servirec in servirka, v SSKJ 2 pa tudi že pometalec in prostitut). Ugotavljamo, da vsi trije korpusi navajajo tudi moškospolske oblike, vendar z zelo majhnim številom konkordanc (največ po Gigafidi modist in prostitut - $32 \mathrm{oz} .286$ konkordanc).

Preglednica 1: Zastopanost moškospolskih poimenovanj za »tipično ženske» poklice $v$ primerjavi z ženskospolskimi po jezikovnih korpusih

\begin{tabular}{|l|l|l|l|}
\hline Poklic & Fidaplus & Nova beseda & Gigafida \\
\hline modist & 3 konkordance & 1 konkordanca & 32 konkordanc \\
\hline modistinja & 51 konkordanc & 3 konkordance & 107 konkordanc \\
\hline modistka & 45 konkordanc & 19 konkordanc & 202 konkordanci \\
\hline prostitut & 17 konkordanc & 3 konkordance & 286 konkordanc \\
\hline prostitutka & 864 konkordanc & 336 konkordanc & 10.493 konkordanc \\
\hline pometalec & 2 konkordanci & 0 konkordanc & 11 konkordanc \\
\hline pometalka & 1 konkordanca & 3 konkordance & 2 konkordanci \\
\hline servirec & 0 konkordanc & 1 konkordanca & 1 konkordanca \\
\hline servirka & 4 konkordance & 6 konkordanc & 24 konkordanc \\
\hline
\end{tabular}

Ugotavljamo dvoje: novejši jezikoslovni viri (že $S P$ in $S S K J$ 2, še bolj pa korpusi) beležijo več poklicnih feminativov kot starejši (SSKJ 1); zgolj ženskospolska poimenovanja poklicev so $\mathrm{v}$ manjšini (1 \% od vseh zajetih $\mathrm{v}$ raziskavo), vendar je pri tem pojavnost moškospolskih oblik prav tako pogojena $\mathrm{s}$ časovno zaporednostjo izida/objave jezikovnega vira oz. priročnika.

Izraženo družbeno hierarhizacijo pa smo opazili pri zapisu ženskospolskih poimenovanj v SSKJ 1, SSKJ 2 in SP. SSKJ 1 je namreč za 13 (2,3 \%) od 553 primerov navajal zgolj pomen zakonske žene, ne pa poklicne dejavnosti, kot jo za veliko poimenovanj poznamo danes, npr. bankirka, 
čevljarica/čevljarka, davkarica, dimnikarica, generalka/generalica (v pomenu 'zakonska žena' tudi v SP), gozdarica (tudi SP), kovačica, majorka, mesarica (tudi $S P)$, mlinarica (tudi SP), načelnica, notarka, stotnica. V pomenu 'žena' so prav vse navedene besede v SSKJ 1 in SSKJ 2 označene s kvalifikatorjem zastar. ali star. Vsa ženskospolska poimenovanja vojaških poklicev Novejša slovenska leksika že navaja $\mathrm{z}$ opombo čin (generalka/generalica, majorka, stotnica); nekateri feminativi tudi v SSKJ 2 ne označujejo zgolj žene, ampak ob tem še opravljanje dejavnosti oz. poklica (bankirka, davkarica, generalica/generalka, majorka, načelnica, notarka, stotnica). Vsa poimenovanja pa najdemo na seznamu poklicev na spletni strani Statističnega urada $R S$, torej gre za pomen 'poklic' in ne '(zakonska) žena'.

Šest primerov od skupno 553 (guvernerka, kapitanka, lekarnarica/lekarnarka, ministrica, sodnica, svétnica) je v SSKJ 1 in SSKJ 2 navedenih kot poklicna dejavnost in (zakonska) žena, torej $\mathrm{v}$ obeh pomenih, vendar je pomen 'žena' zaznamovan s kvalifikatorjem star. Tako potrjujemo trditev Ade Vidovič Muhe, namreč da se je število poimenovanj, označujočih zgolj zakonsko ženo, v sodobnem slovenskem jeziku zmanjšalo oz. jih že SSKJ 1, najstarejši jezikovni vir, ki smo ga uporabili v raziskavi, označuje kot zastarele.

Preglednica 2: Zastopanost ženskospolskih poimenovanj za poklice $v$ jezikovnih virih

\begin{tabular}{|l|c|c|c|c|}
\hline Feminativ & SSKJ 1 & SP & SSKJ 2 & Korpusi \\
\hline administratorka & $\checkmark$ & $\checkmark$ & $\checkmark$ & $\checkmark$ \\
\hline agentinja/agentka & $\checkmark$ & $\checkmark$ & $\checkmark$ & $\checkmark$ \\
\hline agronomka & $\checkmark$ & $\checkmark$ & $\checkmark$ & $\checkmark$ \\
\hline alpinka & & $\checkmark$ & & $\checkmark$ \\
\hline aktuarka & & $\checkmark$ & & $\checkmark$ \\
\hline akupunkturistka & & $\checkmark$ & & $\checkmark$ \\
\hline akviziterka & & $\checkmark$ & & $\checkmark$ \\
\hline ambasadorka & & $\checkmark$ & $\checkmark$ & $\checkmark$ \\
\hline analitičarka & & $\checkmark$ & $\checkmark$ & $\checkmark$ \\
\hline anatomistka & & & & \\
\hline animatorka & & $\checkmark$ & $\checkmark$ & $\checkmark$ \\
\hline anketarka & & & $\checkmark$ & $\checkmark$ \\
\hline antikvarka & & $\checkmark$ & & $\checkmark$ \\
\hline antropologinja & & $\checkmark$ & $\checkmark$ & $\checkmark$ \\
\hline apreterka & & $\checkmark$ & & $\checkmark$ \\
\hline aranžerka & & $\checkmark$ & $\checkmark$ & $\checkmark$ \\
\hline
\end{tabular}




\begin{tabular}{|c|c|c|c|c|}
\hline Feminativ & SSKJ 1 & $S P$ & SSKJ 2 & Korpusi \\
\hline arhivarka & $\checkmark$ & $\checkmark$ & $\checkmark$ & $\checkmark$ \\
\hline arhivistka & & $\checkmark$ & & $\checkmark$ \\
\hline arhitektka & $\checkmark$ & $\checkmark$ & $\checkmark$ & $\checkmark$ \\
\hline artistka & $\checkmark$ & $\checkmark$ & $\checkmark$ & $\checkmark$ \\
\hline asistentka & $\checkmark$ & $\checkmark$ & $\checkmark$ & $\checkmark$ \\
\hline astrologinja & & $\checkmark$ & $\checkmark$ & $\checkmark$ \\
\hline astronavtka & & $\checkmark$ & $\checkmark$ & $\checkmark$ \\
\hline astronomka & $\checkmark$ & $\checkmark$ & $\checkmark$ & $\checkmark$ \\
\hline atašejka & & $\checkmark$ & $\checkmark$ & $\checkmark$ \\
\hline avdiologinja & & & & $\checkmark$ \\
\hline avtoelektričarka & & $\checkmark$ & & $\checkmark$ \\
\hline avtoličarka & & $\checkmark$ & & $\checkmark$ \\
\hline \multicolumn{5}{|l|}{ avtomatičarka } \\
\hline avtomehaničarka & & $\checkmark$ & & $\checkmark$ \\
\hline avtoprevoznica & & $\checkmark$ & & $\checkmark$ \\
\hline balanserka & & $\checkmark$ & 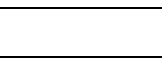 & $\checkmark$ \\
\hline \multicolumn{5}{|l|}{ balzamerka } \\
\hline bančnica & & $\checkmark$ & $\checkmark$ & $\checkmark$ \\
\hline bankirka & & $\checkmark$ & $\checkmark$ & $\checkmark$ \\
\hline barvarka & & $\checkmark$ & & $\checkmark$ \\
\hline belivka & & $\checkmark$ & & $\checkmark$ \\
\hline \multicolumn{5}{|l|}{ betonerka } \\
\hline biblicistka & & $\checkmark$ & & $\checkmark$ \\
\hline bibliotekarka & $\checkmark$ & $\checkmark$ & $\checkmark$ & $\checkmark$ \\
\hline biljeterka & $\checkmark$ & $\checkmark$ & $\checkmark$ & $\checkmark$ \\
\hline biofizičarka & & & & $\checkmark$ \\
\hline biokemičarka & & & & $\checkmark$ \\
\hline biologinja & $\checkmark$ & $\checkmark$ & $\checkmark$ & $\checkmark$ \\
\hline biomehaničarka & & & & $\checkmark$ \\
\hline \multicolumn{5}{|l|}{ biometričarka } \\
\hline \multicolumn{5}{|l|}{ bižuteristka } \\
\hline blagajničarka & $\checkmark$ & $\checkmark$ & $\checkmark$ & $\checkmark$ \\
\hline bolničarka & $\checkmark$ & $\checkmark$ & $\checkmark$ & $\checkmark$ \\
\hline botaničarka & $\checkmark$ & $\checkmark$ & $\checkmark$ & $\checkmark$ \\
\hline brigadirka & $\checkmark$ & $\checkmark$ & $\checkmark$ & $\checkmark$ \\
\hline brivka & $\checkmark$ & $\checkmark$ & $\checkmark$ & $\checkmark$ \\
\hline brusilka & & $\checkmark$ & & $\checkmark$ \\
\hline carinica & & $\checkmark$ & & $\checkmark$ \\
\hline cenilka & & $\checkmark$ & $\checkmark$ & $\checkmark$ \\
\hline cestninarica & & $\checkmark$ & & $\checkmark$ \\
\hline cineastinja & & $\checkmark$ & & $\checkmark$ \\
\hline cvetličarka & $\checkmark$ & $\checkmark$ & $\checkmark$ & $\checkmark$ \\
\hline čarovnica & $\checkmark$ & $\checkmark$ & $\checkmark$ & $\checkmark$ \\
\hline častnica & & $\checkmark$ & $\checkmark$ & $\checkmark$ \\
\hline čebelarica/čebelarka & $\checkmark$ & $\checkmark$ & $\checkmark$ & $\checkmark$ \\
\hline
\end{tabular}




\begin{tabular}{|c|c|c|c|c|}
\hline Feminativ & SSKJ 1 & $S P$ & SSKJ 2 & Korpusi \\
\hline čevljarica & & $\checkmark$ & & $\checkmark$ \\
\hline čipkarica & $\checkmark$ & $\checkmark$ & $\checkmark$ & $\checkmark$ \\
\hline čistilka & $\checkmark$ & $\checkmark$ & $\checkmark$ & $\checkmark$ \\
\hline članica & $\checkmark$ & $\checkmark$ & $\checkmark$ & $\checkmark$ \\
\hline člankarica & & $\checkmark$ & & $\checkmark$ \\
\hline čolnarka & & $\checkmark$ & & $\checkmark$ \\
\hline črkoslikarka & & $\checkmark$ & & $\checkmark$ \\
\hline \multicolumn{5}{|l|}{ črevarka } \\
\hline čuvajka & $\checkmark$ & $\checkmark$ & $\checkmark$ & $\checkmark$ \\
\hline davkarica & & $\checkmark$ & $\checkmark$ & $\checkmark$ \\
\hline dekanica & $\checkmark$ & $\checkmark$ & $\checkmark$ & $\checkmark$ \\
\hline deklarantka & & $\checkmark$ & & $\checkmark$ \\
\hline dekoraterka & $\checkmark$ & $\checkmark$ & $\checkmark$ & $\checkmark$ \\
\hline delavka & $\checkmark$ & $\checkmark$ & $\checkmark$ & $\checkmark$ \\
\hline demonstratorka & $\checkmark$ & $\checkmark$ & $\checkmark$ & $\checkmark$ \\
\hline \multicolumn{5}{|l|}{ deratizatorka } \\
\hline detektivka & $\checkmark$ & $\checkmark$ & $\checkmark$ & $\checkmark$ \\
\hline dezinsektorka & & $\checkmark$ & & $\checkmark$ \\
\hline dežnikarica & $\checkmark$ & $\checkmark$ & $\checkmark$ & $\checkmark$ \\
\hline dietetičarka & & & $\checkmark$ & $\checkmark$ \\
\hline dimnikarica & & $\checkmark$ & & $\checkmark$ \\
\hline direktorica & $\checkmark$ & $\checkmark$ & $\checkmark$ & $\checkmark$ \\
\hline dirigentka & $\checkmark$ & $\checkmark$ & $\checkmark$ & $\checkmark$ \\
\hline dokumentalistka & & $\checkmark$ & & $\checkmark$ \\
\hline dostavljavka & $\checkmark$ & $\checkmark$ & $\checkmark$ & $\checkmark$ \\
\hline draguljarica & & $\checkmark$ & & $\checkmark$ \\
\hline dramatičarka & & $\checkmark$ & $\checkmark$ & $\checkmark$ \\
\hline dražbarica & & $\checkmark$ & & $\checkmark$ \\
\hline dreserka & $\checkmark$ & $\checkmark$ & $\checkmark$ & $\checkmark$ \\
\hline drevesničarka & & $\checkmark$ & & $\checkmark$ \\
\hline družabnica & $\checkmark$ & $\checkmark$ & $\checkmark$ & $\checkmark$ \\
\hline duhovnica & $\checkmark$ & $\checkmark$ & $\checkmark$ & $\checkmark$ \\
\hline ekologinja & & $\checkmark$ & $\checkmark$ & $\checkmark$ \\
\hline \multicolumn{5}{|l|}{ ekonometričarka } \\
\hline ekonomistka & $\checkmark$ & $\checkmark$ & $\checkmark$ & $\checkmark$ \\
\hline ekonomka & $\checkmark$ & $\checkmark$ & $\checkmark$ & $\checkmark$ \\
\hline ekspertinja & & $\checkmark$ & $\checkmark$ & $\checkmark$ \\
\hline elektroinštalaterka & & $\checkmark$ & & $\checkmark$ \\
\hline elektromehaničarka & & $\checkmark$ & & $\checkmark$ \\
\hline elektromonterka & & $\checkmark$ & & $\checkmark$ \\
\hline \multicolumn{5}{|l|}{ elektronadzornica } \\
\hline \multicolumn{5}{|l|}{ emajlerka } \\
\hline \multicolumn{5}{|l|}{ embalerka } \\
\hline energetičarka & & $\checkmark$ & & $\checkmark$ \\
\hline farmacevtka & $\checkmark$ & $\checkmark$ & $\checkmark$ & $\checkmark$ \\
\hline
\end{tabular}




\begin{tabular}{|c|c|c|c|c|}
\hline Feminativ & SSKJ 1 & $S P$ & SSKJ 2 & Korpusi \\
\hline \multicolumn{5}{|l|}{ fasaderka } \\
\hline filigranistka & & $\checkmark$ & & $\checkmark$ \\
\hline filozofinja & $\checkmark$ & $\checkmark$ & $\checkmark$ & $\checkmark$ \\
\hline finančnica & & $\checkmark$ & $\checkmark$ & $\checkmark$ \\
\hline finomehaničarka & & $\checkmark$ & & $\checkmark$ \\
\hline fizičarka & & $\checkmark$ & $\checkmark$ & $\checkmark$ \\
\hline fizioterapevtka & $\checkmark$ & $\checkmark$ & $\checkmark$ & $\checkmark$ \\
\hline \multicolumn{5}{|l|}{ fonotekarka } \\
\hline $\begin{array}{l}\text { fotografinjal } \\
\text { fotografka }\end{array}$ & $\checkmark$ & $\checkmark$ & $\checkmark$ & $\checkmark$ \\
\hline \multicolumn{5}{|l|}{ fotogrametričarka } \\
\hline \multicolumn{5}{|l|}{ fotograverka } \\
\hline fotoreporterka & $\checkmark$ & $\checkmark$ & $\checkmark$ & $\checkmark$ \\
\hline frizerka & $\checkmark$ & $\checkmark$ & $\checkmark$ & $\checkmark$ \\
\hline galanteristka & & $\checkmark$ & & $\checkmark$ \\
\hline garderoberka & $\checkmark$ & $\checkmark$ & $\checkmark$ & $\checkmark$ \\
\hline gasilka & $\checkmark$ & $\checkmark$ & $\checkmark$ & $\checkmark$ \\
\hline generalka & & & $\checkmark$ & $\checkmark$ \\
\hline genetičarka & & $\checkmark$ & & $\checkmark$ \\
\hline geodetinja & & $\checkmark$ & & $\checkmark$ \\
\hline geofizičarka & & $\checkmark$ & & $\checkmark$ \\
\hline geologinja & $\checkmark$ & $\checkmark$ & $\checkmark$ & $\checkmark$ \\
\hline \multicolumn{5}{|l|}{ geovrtalka } \\
\hline glasbenica & $\checkmark$ & $\checkmark$ & $\checkmark$ & $\checkmark$ \\
\hline gojiteljica & & $\checkmark$ & & $\checkmark$ \\
\hline gostiteljica & $\checkmark$ & $\checkmark$ & $\checkmark$ & $\checkmark$ \\
\hline govedorejka & & $\checkmark$ & & $\checkmark$ \\
\hline gozdarka & & $\checkmark$ & & $\checkmark$ \\
\hline gradbinka & & $\checkmark$ & & $\checkmark$ \\
\hline graditeljica & $\checkmark$ & $\checkmark$ & $\checkmark$ & $\checkmark$ \\
\hline graverka & & $\checkmark$ & & $\checkmark$ \\
\hline grobarka & $\checkmark$ & $\checkmark$ & $\checkmark$ & $\checkmark$ \\
\hline guvernerka & $\checkmark$ & $\checkmark$ & $\checkmark$ & $\checkmark$ \\
\hline hidravličarka & & $\checkmark$ & & $\checkmark$ \\
\hline higieničarka & $\checkmark$ & $\checkmark$ & $\checkmark$ & $\checkmark$ \\
\hline hišnica & $\checkmark$ & $\checkmark$ & $\checkmark$ & $\checkmark$ \\
\hline hmeljarka & & $\checkmark$ & & $\checkmark$ \\
\hline homeopatinja & & $\checkmark$ & $\checkmark$ & $\checkmark$ \\
\hline igralka & $\checkmark$ & $\checkmark$ & $\checkmark$ & $\checkmark$ \\
\hline ilustratorka & $\checkmark$ & $\checkmark$ & $\checkmark$ & $\checkmark$ \\
\hline iluzionistka & & $\checkmark$ & & $\checkmark$ \\
\hline \multicolumn{5}{|l|}{ impregnatorka } \\
\hline informatičarka & & $\checkmark$ & & $\checkmark$ \\
\hline informatorka & $\checkmark$ & $\checkmark$ & $\checkmark$ & $\checkmark$ \\
\hline inkasantka & & $\checkmark$ & & $\checkmark$ \\
\hline
\end{tabular}




\begin{tabular}{|c|c|c|c|c|}
\hline Feminativ & SSKJ 1 & $S P$ & SSKJ 2 & Korpusi \\
\hline instrumentalistka & $\checkmark$ & $\checkmark$ & $\checkmark$ & $\checkmark$ \\
\hline inšpektorica & $\checkmark$ & $\checkmark$ & $\checkmark$ & $\checkmark$ \\
\hline inštalaterka & & $\checkmark$ & & $\checkmark$ \\
\hline inštruktorica & $\checkmark$ & $\checkmark$ & $\checkmark$ & $\checkmark$ \\
\hline inženirka & $\checkmark$ & $\checkmark$ & $\checkmark$ & $\checkmark$ \\
\hline izdelovalka & $\checkmark$ & $\checkmark$ & $\checkmark$ & $\checkmark$ \\
\hline izolaterka & & $\checkmark$ & & $\checkmark$ \\
\hline izposojevalka & $\checkmark$ & $\checkmark$ & $\checkmark$ & $\checkmark$ \\
\hline izterjevalka & & $\checkmark$ & & $\checkmark$ \\
\hline izvajalka & $\checkmark$ & $\checkmark$ & $\checkmark$ & $\checkmark$ \\
\hline izvedenka & $\checkmark$ & $\checkmark$ & $\checkmark$ & $\checkmark$ \\
\hline izvršiteljica & $\checkmark$ & $\checkmark$ & $\checkmark$ & $\checkmark$ \\
\hline \multicolumn{5}{|l|}{ jedkalka } \\
\hline \multicolumn{5}{|l|}{ jedrarka } \\
\hline \multicolumn{5}{|l|}{ jermenarka } \\
\hline jezikoslovka & $\checkmark$ & $\checkmark$ & $\checkmark$ & $\checkmark$ \\
\hline jurišnica & & $\checkmark$ & & $\checkmark$ \\
\hline kalivka & & $\checkmark$ & & $\checkmark$ \\
\hline kalkulantka & $\checkmark$ & $\checkmark$ & $\checkmark$ & $\checkmark$ \\
\hline kaluparka & & $\checkmark$ & & $\checkmark$ \\
\hline \multicolumn{5}{|l|}{ kamnolomka } \\
\hline kamnosekinja & & & & $\checkmark$ \\
\hline kanclerka & & $\checkmark$ & $\checkmark$ & $\checkmark$ \\
\hline kapitanka & $\checkmark$ & $\checkmark$ & $\checkmark$ & $\checkmark$ \\
\hline karikaturistka & & $\checkmark$ & & $\checkmark$ \\
\hline kartografinja & & $\checkmark$ & & $\checkmark$ \\
\hline \multicolumn{5}{|l|}{ kartonažerka } \\
\hline kemičarka & $\checkmark$ & $\checkmark$ & $\checkmark$ & $\checkmark$ \\
\hline \multicolumn{5}{|l|}{ kemigrafka } \\
\hline keramičarka & $\checkmark$ & $\checkmark$ & $\checkmark$ & $\checkmark$ \\
\hline kinooperaterka & & $\checkmark$ & & $\checkmark$ \\
\hline kiparka & $\checkmark$ & $\checkmark$ & $\checkmark$ & $\checkmark$ \\
\hline kiropraktičarka & & $\checkmark$ & & $\checkmark$ \\
\hline kleparka & & $\checkmark$ & & $\checkmark$ \\
\hline kletarica & $\checkmark$ & $\checkmark$ & $\checkmark$ & $\checkmark$ \\
\hline ključarica/ključarka & $\checkmark$ & $\checkmark$ & $\checkmark$ & $\checkmark$ \\
\hline ključavničarka & & $\checkmark$ & & $\checkmark$ \\
\hline klobučarka & $\checkmark$ & $\checkmark$ & $\checkmark$ & $\checkmark$ \\
\hline kmetovalka & & $\checkmark$ & $\checkmark$ & $\checkmark$ \\
\hline knjigotiskarka & & $\checkmark$ & & $\checkmark$ \\
\hline knjigovezka & $\checkmark$ & $\checkmark$ & $\checkmark$ & $\checkmark$ \\
\hline knjigovodkinja & $\checkmark$ & $\checkmark$ & $\checkmark$ & $\checkmark$ \\
\hline knjižničarka & $\checkmark$ & $\checkmark$ & $\checkmark$ & $\checkmark$ \\
\hline \multicolumn{5}{|l|}{ koderka } \\
\hline komentatorka & $\checkmark$ & $\checkmark$ & $\checkmark$ & $\checkmark$ \\
\hline
\end{tabular}




\begin{tabular}{|c|c|c|c|c|}
\hline Feminativ & SSKJ 1 & $S P$ & SSKJ 2 & Korpusi \\
\hline komercialistka & $\checkmark$ & $\checkmark$ & $\checkmark$ & $\checkmark$ \\
\hline komičarka & & $\checkmark$ & $\checkmark$ & $\checkmark$ \\
\hline konjerejka & & $\checkmark$ & & $\checkmark$ \\
\hline konservatorka & & $\checkmark$ & $\checkmark$ & $\checkmark$ \\
\hline konstruktorica & & $\checkmark$ & & $\checkmark$ \\
\hline kontrolorka & $\checkmark$ & $\checkmark$ & $\checkmark$ & $\checkmark$ \\
\hline konzulka & & $\checkmark$ & $\checkmark$ & $\checkmark$ \\
\hline koordinatorica & & $\checkmark$ & $\checkmark$ & $\checkmark$ \\
\hline kopistka & $\checkmark$ & $\checkmark$ & $\checkmark$ & $\checkmark$ \\
\hline korektorica & & $\checkmark$ & $\checkmark$ & $\checkmark$ \\
\hline $\begin{array}{l}\text { koreografinjal } \\
\text { koreografka }\end{array}$ & $\checkmark$ & $\checkmark$ & $\checkmark$ & $\checkmark$ \\
\hline korepetitorka & & $\checkmark$ & $\checkmark$ & $\checkmark$ \\
\hline korespondentka & $\checkmark$ & $\checkmark$ & $\checkmark$ & $\checkmark$ \\
\hline $\begin{array}{l}\text { kostumografinjal } \\
\text { kostumografka }\end{array}$ & $\checkmark$ & $\checkmark$ & $\checkmark$ & $\checkmark$ \\
\hline kovačica & & $\checkmark$ & & $\checkmark$ \\
\hline kovinarka & & $\checkmark$ & & $\checkmark$ \\
\hline \multicolumn{5}{|l|}{ kozjerejka } \\
\hline kozmetičarka & $\checkmark$ & $\checkmark$ & $\checkmark$ & $\checkmark$ \\
\hline kretničarka & & $\checkmark$ & & $\checkmark$ \\
\hline kriminalistka & $x$ & $\checkmark$ & $\checkmark$ & $\checkmark$ \\
\hline kritičarka & $\checkmark$ & $\checkmark$ & $\checkmark$ & $\checkmark$ \\
\hline krmarica & $\checkmark$ & $\checkmark$ & $\checkmark$ & $\checkmark$ \\
\hline krojačica & $\checkmark$ & $\checkmark$ & $\checkmark$ & $\checkmark$ \\
\hline krojilka & & $\checkmark$ & & $\checkmark$ \\
\hline krošnjarka & $\checkmark$ & $\checkmark$ & $\checkmark$ & $\checkmark$ \\
\hline krovka & & & & $\checkmark$ \\
\hline krupjejka & & $\checkmark$ & $\checkmark$ & $\checkmark$ \\
\hline krznarka & $\checkmark$ & $\checkmark$ & $\checkmark$ & $\checkmark$ \\
\hline kuharica & $\checkmark$ & $\checkmark$ & $\checkmark$ & $\checkmark$ \\
\hline kurirka & $\checkmark$ & $\checkmark$ & $\checkmark$ & $\checkmark$ \\
\hline laborantka & $\checkmark$ & $\checkmark$ & $\checkmark$ & $\checkmark$ \\
\hline lasuljarka & & $\checkmark$ & & $\checkmark$ \\
\hline $\begin{array}{l}\text { lekarnarical } \\
\text { lekarnarka }\end{array}$ & $\checkmark$ & $\checkmark$ & $\checkmark$ & $\checkmark$ \\
\hline lektorica & $\checkmark$ & $\checkmark$ & $\checkmark$ & $\checkmark$ \\
\hline ličarka & & $\checkmark$ & & $\checkmark$ \\
\hline likalka & $\checkmark$ & $\checkmark$ & $\checkmark$ & $\checkmark$ \\
\hline livarka & & & & $\checkmark$ \\
\hline lončarica & $\checkmark$ & $\checkmark$ & $\checkmark$ & $\checkmark$ \\
\hline loščilka & & $\checkmark$ & & \\
\hline lovica/lovka & $\checkmark$ & $\checkmark$ & $\checkmark$ & $\checkmark$ \\
\hline majorka & & $\checkmark$ & $\checkmark$ & $\checkmark$ \\
\hline manekenka & $\checkmark$ & $\checkmark$ & $\checkmark$ & $\checkmark$ \\
\hline
\end{tabular}




\begin{tabular}{|c|c|c|c|c|}
\hline Feminativ & SSKJ 1 & $S P$ & SSKJ 2 & Korpusi \\
\hline manikerka & $\checkmark$ & $\checkmark$ & $\checkmark$ & $\checkmark$ \\
\hline manipulantka & $\checkmark$ & $\checkmark$ & $\checkmark$ & $\checkmark$ \\
\hline maserka & $\checkmark$ & $\checkmark$ & $\checkmark$ & $\checkmark$ \\
\hline maskerka & $\checkmark$ & $\checkmark$ & $\checkmark$ & $\checkmark$ \\
\hline maslarica & & $\checkmark$ & & $\checkmark$ \\
\hline matematičarka & $\checkmark$ & $\checkmark$ & $\checkmark$ & $\checkmark$ \\
\hline mazalka & & $\checkmark$ & & $\checkmark$ \\
\hline $\begin{array}{l}\text { mehanikarical } \\
\text { mehaničarka }\end{array}$ & & $\checkmark$ & & $\checkmark$ \\
\hline menedžerka & & $\checkmark$ & $\checkmark$ & $\checkmark$ \\
\hline menjalka & & $\checkmark$ & & $\checkmark$ \\
\hline mesarka & & $\checkmark$ & & $\checkmark$ \\
\hline mešalka & $\checkmark$ & $\checkmark$ & $\checkmark$ & $\checkmark$ \\
\hline meteorologinja & $\checkmark$ & $\checkmark$ & $\checkmark$ & $\checkmark$ \\
\hline minerka & & & & $\checkmark$ \\
\hline ministrica & $\checkmark$ & $\checkmark$ & $\checkmark$ & $\checkmark$ \\
\hline misijonarka & $\checkmark$ & $\checkmark$ & $\checkmark$ & $\checkmark$ \\
\hline mizarka & & $\checkmark$ & & $\checkmark$ \\
\hline mlekarka & $\checkmark$ & $\checkmark$ & $\checkmark$ & $\checkmark$ \\
\hline mlinarica & & & & $\checkmark$ \\
\hline modelarka & $\checkmark$ & $\checkmark$ & $\checkmark$ & $\checkmark$ \\
\hline modelka & $\checkmark$ & $\checkmark$ & $\checkmark$ & $\checkmark$ \\
\hline moderatorka & & $\checkmark$ & $\checkmark$ & $\checkmark$ \\
\hline modistinja/modistka & $\checkmark$ & $\checkmark$ & $\checkmark$ & $\checkmark$ \\
\hline mojstrica/mojstrovka & $\checkmark$ & $\checkmark$ & $\checkmark$ & $\checkmark$ \\
\hline montažerka & $\checkmark$ & $\checkmark$ & $\checkmark$ & $\checkmark$ \\
\hline monterka & & $\checkmark$ & & $\checkmark$ \\
\hline mornarka & & $\checkmark$ & & $\checkmark$ \\
\hline motoristka & & $\checkmark$ & $\checkmark$ & $\checkmark$ \\
\hline nabiralka & $\checkmark$ & $\checkmark$ & $\checkmark$ & $\checkmark$ \\
\hline načelnica & $\checkmark$ & $\checkmark$ & $\checkmark$ & $\checkmark$ \\
\hline načrtovalka & & $\checkmark$ & $\checkmark$ & $\checkmark$ \\
\hline nadzornica & $\checkmark$ & $\checkmark$ & $\checkmark$ & $\checkmark$ \\
\hline napovedovalka & $\checkmark$ & $\checkmark$ & $\checkmark$ & $\checkmark$ \\
\hline nastavljavka & & $\checkmark$ & & $\checkmark$ \\
\hline natakarica & $\checkmark$ & $\checkmark$ & $\checkmark$ & $\checkmark$ \\
\hline naturščica & & $\checkmark$ & $\checkmark$ & $\checkmark$ \\
\hline navigatorica & & $\checkmark$ & & $\checkmark$ \\
\hline navijalka & $\checkmark$ & $\checkmark$ & $\checkmark$ & $\checkmark$ \\
\hline negovalka & $\checkmark$ & $\checkmark$ & $\checkmark$ & $\checkmark$ \\
\hline normirka & & $\checkmark$ & & $\checkmark$ \\
\hline nosačica & & $\checkmark$ & & $\checkmark$ \\
\hline notarka & & $\checkmark$ & $\checkmark$ & $\checkmark$ \\
\hline novinarka & $\checkmark$ & $\checkmark$ & $\checkmark$ & $\checkmark$ \\
\hline obdelovalka & & $\checkmark$ & & $\checkmark$ \\
\hline
\end{tabular}




\begin{tabular}{|c|c|c|c|c|}
\hline Feminativ & SSKJ 1 & $S P$ & SSKJ 2 & Korpusi \\
\hline obhodnica & & $\checkmark$ & & $\checkmark$ \\
\hline oblikovalka & $\checkmark$ & $\checkmark$ & $\checkmark$ & $\checkmark$ \\
\hline obramboslovka & & $\checkmark$ & $\checkmark$ & $\checkmark$ \\
\hline \multicolumn{5}{|l|}{ obzidovalka } \\
\hline ocenjevalka & $\checkmark$ & $\checkmark$ & $\checkmark$ & $\checkmark$ \\
\hline \multicolumn{5}{|l|}{ odčitovalka } \\
\hline odpravnica & $\checkmark$ & $\checkmark$ & $\checkmark$ & $\checkmark$ \\
\hline \multicolumn{5}{|l|}{ odpremljevalka } \\
\hline odvetnica & $\checkmark$ & $\checkmark$ & $\checkmark$ & $\checkmark$ \\
\hline \multicolumn{5}{|l|}{ ofsettiskarka } \\
\hline oglarka & & $\checkmark$ & & $\checkmark$ \\
\hline oljarka & & $\checkmark$ & & $\checkmark$ \\
\hline opazovalka & $\checkmark$ & $\checkmark$ & $\checkmark$ & $\checkmark$ \\
\hline operaterka & $\checkmark$ & $\checkmark$ & $\checkmark$ & $\checkmark$ \\
\hline opremljevalka & & $\checkmark$ & $\checkmark$ & $\checkmark$ \\
\hline optičarka & & $\checkmark$ & & $\checkmark$ \\
\hline \multicolumn{5}{|l|}{ optometristka } \\
\hline $\begin{array}{l}\text { organizatorical } \\
\text { organizatorka }\end{array}$ & $\checkmark$ & $\checkmark$ & $\checkmark$ & $\checkmark$ \\
\hline orodjarka & & $\checkmark$ & & $\checkmark$ \\
\hline oskrbnica & $\checkmark$ & $\checkmark$ & $\checkmark$ & $\checkmark$ \\
\hline oskrbovalka & $\checkmark$ & $\checkmark$ & $\checkmark$ & $\checkmark$ \\
\hline ostrilka & & $\checkmark$ & & $\checkmark$ \\
\hline ovčerejka & & $\checkmark$ & & $\checkmark$ \\
\hline označevalka & & $\checkmark$ & & $\checkmark$ \\
\hline \multicolumn{5}{|l|}{ parketarka } \\
\hline paznica & $\checkmark$ & $\checkmark$ & $\checkmark$ & $\checkmark$ \\
\hline pedikerka & $\checkmark$ & $\checkmark$ & $\checkmark$ & $\checkmark$ \\
\hline pekinja & & & & $\checkmark$ \\
\hline perutninarka & $\checkmark$ & $\checkmark$ & $\checkmark$ & $\checkmark$ \\
\hline pesnica & $\checkmark$ & $\checkmark$ & $\checkmark$ & $\checkmark$ \\
\hline pevka & $\checkmark$ & $\checkmark$ & $\checkmark$ & $\checkmark$ \\
\hline pilotka & $\checkmark$ & $\checkmark$ & $\checkmark$ & $\checkmark$ \\
\hline \multicolumn{5}{|l|}{ pirotehnica } \\
\hline pisateljica & $\checkmark$ & $\checkmark$ & $\checkmark$ & $\checkmark$ \\
\hline plakaterka & & $\checkmark$ & & $\checkmark$ \\
\hline planšarica & $\checkmark$ & $\checkmark$ & $\checkmark$ & $\checkmark$ \\
\hline \multicolumn{5}{|l|}{ plemenitilka } \\
\hline plesalka & $\checkmark$ & $\checkmark$ & $\checkmark$ & $\checkmark$ \\
\hline pleskarka & & & & $\checkmark$ \\
\hline pletilja/pletilka & $\checkmark$ & $\checkmark$ & $\checkmark$ & $\checkmark$ \\
\hline \multicolumn{5}{|l|}{ pnevmatičarka } \\
\hline pobiralka & $\checkmark$ & $\checkmark$ & $\checkmark$ & $\checkmark$ \\
\hline podčastnica & & $\checkmark$ & & $\checkmark$ \\
\hline pogrebnica & $\checkmark$ & $\checkmark$ & $\checkmark$ & $\checkmark$ \\
\hline
\end{tabular}




\begin{tabular}{|c|c|c|c|c|}
\hline Feminativ & SSKJ 1 & $S P$ & SSKJ 2 & Korpusi \\
\hline polagalka & & $\checkmark$ & & $\checkmark$ \\
\hline policajka & & & $\checkmark$ & $\checkmark$ \\
\hline policistka & $\checkmark$ & $\checkmark$ & $\checkmark$ & $\checkmark$ \\
\hline polirka & & $\checkmark$ & & $\checkmark$ \\
\hline politologinja & & $\checkmark$ & & $\checkmark$ \\
\hline poljedelka & & $\checkmark$ & & $\checkmark$ \\
\hline polnilka & $\checkmark$ & $\checkmark$ & $\checkmark$ & $\checkmark$ \\
\hline pomočnica & $\checkmark$ & $\checkmark$ & $\checkmark$ & $\checkmark$ \\
\hline pometačica & $\checkmark$ & $\checkmark$ & $\checkmark$ & $\checkmark$ \\
\hline pometalka & $\checkmark$ & $\checkmark$ & $\checkmark$ & $\checkmark$ \\
\hline poslanka & $\checkmark$ & $\checkmark$ & $\checkmark$ & $\checkmark$ \\
\hline poslovodkinja & $\checkmark$ & $\checkmark$ & $\checkmark$ & $\checkmark$ \\
\hline posojevalka & & $\checkmark$ & & $\checkmark$ \\
\hline posrednica & $\checkmark$ & $\checkmark$ & $\checkmark$ & $\checkmark$ \\
\hline posredovalka & $\checkmark$ & $\checkmark$ & $\checkmark$ & $\checkmark$ \\
\hline potapljačica & & $\checkmark$ & $\checkmark$ & $\checkmark$ \\
\hline povečevalka & & & & $\checkmark$ \\
\hline povezovalka & $\checkmark$ & $\checkmark$ & $\checkmark$ & $\checkmark$ \\
\hline povrtninarka & & $\checkmark$ & & $\checkmark$ \\
\hline potnica & $\checkmark$ & $\checkmark$ & $\checkmark$ & $\checkmark$ \\
\hline poustvarjalka & & $\checkmark$ & & $\checkmark$ \\
\hline pralka & $\checkmark$ & $\checkmark$ & $\checkmark$ & $\checkmark$ \\
\hline prašičerejka & & $\checkmark$ & & $\checkmark$ \\
\hline pravnica & $\checkmark$ & $\checkmark$ & $\checkmark$ & $\checkmark$ \\
\hline pravobranilka & & $\checkmark$ & $\checkmark$ & $\checkmark$ \\
\hline predavateljica & $\checkmark$ & $\checkmark$ & $\checkmark$ & $\checkmark$ \\
\hline predelovalka & & $\checkmark$ & & $\checkmark$ \\
\hline predilka & & $\checkmark$ & & $\checkmark$ \\
\hline predsednica & $\checkmark$ & $\checkmark$ & $\checkmark$ & $\checkmark$ \\
\hline predstojnica & $\checkmark$ & $\checkmark$ & $\checkmark$ & $\checkmark$ \\
\hline pregledovalka & & $\checkmark$ & $\checkmark$ & $\checkmark$ \\
\hline preiskovalka & & $\checkmark$ & $\checkmark$ & $\checkmark$ \\
\hline premierka & $\checkmark$ & $\checkmark$ & $\checkmark$ & $\checkmark$ \\
\hline premikačka & & $\checkmark$ & & $\checkmark$ \\
\hline preparatorka & $\checkmark$ & $\checkmark$ & $\checkmark$ & $\checkmark$ \\
\hline prevajalka & $\checkmark$ & $\checkmark$ & $\checkmark$ & $\checkmark$ \\
\hline primarijka & & $\checkmark$ & $\checkmark$ & $\checkmark$ \\
\hline pripravljavka & & $\checkmark$ & & $\checkmark$ \\
\hline prodajalka & $\checkmark$ & $\checkmark$ & $\checkmark$ & $\checkmark$ \\
\hline prodekanka & & $\checkmark$ & $\checkmark$ & $\checkmark$ \\
\hline producentka & & $\checkmark$ & $\checkmark$ & $\checkmark$ \\
\hline programerka & & $\checkmark$ & & $\checkmark$ \\
\hline projektantka & & $\checkmark$ & $\checkmark$ & $\checkmark$ \\
\hline prokuristka & & $\checkmark$ & $\checkmark$ & $\checkmark$ \\
\hline prorektorica & & $\checkmark$ & $\checkmark$ & $\checkmark$ \\
\hline
\end{tabular}




\begin{tabular}{|c|c|c|c|c|}
\hline Feminativ & SSKJ 1 & $S P$ & SSKJ 2 & Korpusi \\
\hline prostitutka & & $\checkmark$ & $\checkmark$ & $\checkmark$ \\
\hline psihologinja & $\checkmark$ & $\checkmark$ & $\checkmark$ & $\checkmark$ \\
\hline \multicolumn{5}{|l|}{ puškarka } \\
\hline računalničarka & & $\checkmark$ & $\checkmark$ & $\checkmark$ \\
\hline radiotelegrafistka & $\checkmark$ & $\checkmark$ & $\checkmark$ & $\checkmark$ \\
\hline ravnateljica & $\checkmark$ & $\checkmark$ & $\checkmark$ & $\checkmark$ \\
\hline raziskovalka & $\checkmark$ & $\checkmark$ & $\checkmark$ & $\checkmark$ \\
\hline razkuževalka & $\checkmark$ & $\checkmark$ & $\checkmark$ & $\checkmark$ \\
\hline raznašalka & $\checkmark$ & $\checkmark$ & $\checkmark$ & $\checkmark$ \\
\hline razvijalka & & $\checkmark$ & & $\checkmark$ \\
\hline razvrščevalka & & $\checkmark$ & . & $\checkmark$ \\
\hline recenzentka & $\checkmark$ & $\checkmark$ & $\checkmark$ & $\checkmark$ \\
\hline receptorka & $\checkmark$ & $\checkmark$ & $\checkmark$ & $\checkmark$ \\
\hline redaktorica & $\checkmark$ & $\checkmark$ & $\checkmark$ & $\checkmark$ \\
\hline rediteljica & $\checkmark$ & $\checkmark$ & $\checkmark$ & $\checkmark$ \\
\hline referentka & $\checkmark$ & $\checkmark$ & $\checkmark$ & $\checkmark$ \\
\hline rejka & & $\checkmark$ & & $\checkmark$ \\
\hline rejnica & $\checkmark$ & $\checkmark$ & $\checkmark$ & $\checkmark$ \\
\hline rektorica & & $\checkmark$ & $\checkmark$ & $\checkmark$ \\
\hline restavratorka & & $\checkmark$ & $\checkmark$ & $\checkmark$ \\
\hline reševalka & $\checkmark$ & $\checkmark$ & $\checkmark$ & $\checkmark$ \\
\hline retušerka & & $\checkmark$ & & $\checkmark$ \\
\hline revizorka & & $\checkmark$ & $\checkmark$ & $\checkmark$ \\
\hline rezalka & & $\checkmark$ & & $\checkmark$ \\
\hline rezkalka & & $\checkmark$ & & $\checkmark$ \\
\hline režiserka & $\checkmark$ & $\checkmark$ & $\checkmark$ & $\checkmark$ \\
\hline ribička & $\checkmark$ & $\checkmark$ & $\checkmark$ & $\checkmark$ \\
\hline ribogojka & & $\checkmark$ & & $\checkmark$ \\
\hline risarka & $\checkmark$ & $\checkmark$ & $\checkmark$ & $\checkmark$ \\
\hline rokavičarka & $\checkmark$ & $\checkmark$ & $\checkmark$ & $\checkmark$ \\
\hline rudarka & & $\checkmark$ & & $\checkmark$ \\
\hline sadjarka & & $\checkmark$ & & $\checkmark$ \\
\hline scenaristka & $\checkmark$ & $\checkmark$ & $\checkmark$ & $\checkmark$ \\
\hline scenografka & $\checkmark$ & $\checkmark$ & $\checkmark$ & $\checkmark$ \\
\hline sedlarka & & $\checkmark$ & & $\checkmark$ \\
\hline sekačka & & $\checkmark$ & & $\checkmark$ \\
\hline sekretarka & $\checkmark$ & $\checkmark$ & $\checkmark$ & $\checkmark$ \\
\hline servirka & $\checkmark$ & $\checkmark$ & $\checkmark$ & $\checkmark$ \\
\hline serviserka & & $\checkmark$ & & $\checkmark$ \\
\hline sestavljavka & $\checkmark$ & $\checkmark$ & $\checkmark$ & $\checkmark$ \\
\hline signalistka & & $\checkmark$ & & $\checkmark$ \\
\hline sirarka & & $\checkmark$ & & $\checkmark$ \\
\hline sitotiskarka & & & & $\checkmark$ \\
\hline skladateljica & $\checkmark$ & $\checkmark$ & $\checkmark$ & $\checkmark$ \\
\hline skladiščnica & $\checkmark$ & $\checkmark$ & $\checkmark$ & $\checkmark$ \\
\hline
\end{tabular}




\begin{tabular}{|c|c|c|c|c|}
\hline Feminativ & SSKJ 1 & $S P$ & SSKJ 2 & Korpusi \\
\hline skrbnica & $\checkmark$ & $\checkmark$ & $\checkmark$ & $\checkmark$ \\
\hline sladoledarka & & $\checkmark$ & & $\checkmark$ \\
\hline slaščičarka & $\checkmark$ & $\checkmark$ & $\checkmark$ & $\checkmark$ \\
\hline slikarica/slikarka & $\checkmark$ & $\checkmark$ & $\checkmark$ & $\checkmark$ \\
\hline slikopleskarka & & $\checkmark$ & & $\checkmark$ \\
\hline smetarka & & $\checkmark$ & & $\checkmark$ \\
\hline snemalka & & $\checkmark$ & $\checkmark$ & $\checkmark$ \\
\hline snovalka & $\checkmark$ & $\checkmark$ & $\checkmark$ & $\checkmark$ \\
\hline sobarica & $\checkmark$ & $\checkmark$ & $\checkmark$ & $\checkmark$ \\
\hline sociologinja & $\checkmark$ & $\checkmark$ & $\checkmark$ & $\checkmark$ \\
\hline sodelavka & $\checkmark$ & $\checkmark$ & $\checkmark$ & $\checkmark$ \\
\hline sodnica & $\checkmark$ & $\checkmark$ & $\checkmark$ & $\checkmark$ \\
\hline solinarka & & & & $\checkmark$ \\
\hline solistka & $\checkmark$ & $\checkmark$ & $\checkmark$ & $\checkmark$ \\
\hline solopevka & & & & $\checkmark$ \\
\hline sovoditeljica & & & $\checkmark$ & $\checkmark$ \\
\hline spajalka & & & & $\checkmark$ \\
\hline specialistka & $\checkmark$ & $\checkmark$ & $\checkmark$ & $\checkmark$ \\
\hline sprejemalka & & $\checkmark$ & $\checkmark$ & $\checkmark$ \\
\hline spremljevalka & $\checkmark$ & $\checkmark$ & $\checkmark$ & $\checkmark$ \\
\hline sprevodnica & $\checkmark$ & $\checkmark$ & $\checkmark$ & $\checkmark$ \\
\hline statističarka & & $\checkmark$ & & $\checkmark$ \\
\hline stavka & & $\checkmark$ & & $\checkmark$ \\
\hline steklarka & & $\checkmark$ & & $\checkmark$ \\
\hline \multicolumn{5}{|l|}{ steklobrusilka } \\
\hline steklopihalka & & & & $\checkmark$ \\
\hline stenodaktilografka & $\checkmark$ & $\checkmark$ & $\checkmark$ & $\checkmark$ \\
\hline $\begin{array}{l}\text { stenografinjal } \\
\text { stenografka }\end{array}$ & $\checkmark$ & $\checkmark$ & $\checkmark$ & $\checkmark$ \\
\hline stilistka & & $\checkmark$ & $\checkmark$ & $\checkmark$ \\
\hline stotnica & & $\checkmark$ & $\checkmark$ & $\checkmark$ \\
\hline strelka & $\checkmark$ & $\checkmark$ & $\checkmark$ & $\checkmark$ \\
\hline strežnica & $\checkmark$ & $\checkmark$ & $\checkmark$ & $\checkmark$ \\
\hline strojepiska & $\checkmark$ & $\checkmark$ & $\checkmark$ & $\checkmark$ \\
\hline strokovnjakinja & $\checkmark$ & $\checkmark$ & $\checkmark$ & $\checkmark$ \\
\hline strugarka & & $\checkmark$ & & $\checkmark$ \\
\hline supermodelka & & & $\checkmark$ & $\checkmark$ \\
\hline \multicolumn{5}{|l|}{ sušilničarka } \\
\hline svečarka & & $\checkmark$ & & $\checkmark$ \\
\hline \multicolumn{5}{|l|}{ svetilničarka } \\
\hline svétnica & $\checkmark$ & $\checkmark$ & $\checkmark$ & $\checkmark$ \\
\hline svetovalka & $\checkmark$ & $\checkmark$ & $\checkmark$ & $\checkmark$ \\
\hline špediterka & & $\checkmark$ & & $\checkmark$ \\
\hline šivalka & $\checkmark$ & $\checkmark$ & $\checkmark$ & $\checkmark$ \\
\hline šolnica & & & $\checkmark$ & $\checkmark$ \\
\hline
\end{tabular}




\begin{tabular}{|c|c|c|c|c|}
\hline Feminativ & SSKJ 1 & $S P$ & SSKJ 2 & Korpusi \\
\hline športnica & $\checkmark$ & $\checkmark$ & $\checkmark$ & $\checkmark$ \\
\hline \multicolumn{5}{|l|}{ štukaterka } \\
\hline tajnica & $\checkmark$ & $\checkmark$ & $\checkmark$ & $\checkmark$ \\
\hline talivka & & $\checkmark$ & & $\checkmark$ \\
\hline tapetnica & $\checkmark$ & $\checkmark$ & $\checkmark$ & $\checkmark$ \\
\hline tapiseristka & & & & $\checkmark$ \\
\hline tehnica & $\checkmark$ & $\checkmark$ & $\checkmark$ & $\checkmark$ \\
\hline tehnologinja & & $\checkmark$ & $\checkmark$ & $\checkmark$ \\
\hline \multicolumn{5}{|l|}{ telefaksistka } \\
\hline telefonistka & $\checkmark$ & $\checkmark$ & $\checkmark$ & $\checkmark$ \\
\hline teleprinteristka & $\checkmark$ & $\checkmark$ & $\checkmark$ & $\checkmark$ \\
\hline \multicolumn{5}{|l|}{ teracerka } \\
\hline terapevtka & $\checkmark$ & $\checkmark$ & $\checkmark$ & $\checkmark$ \\
\hline tesarka & & & & $\checkmark$ \\
\hline testeninarka & & $\checkmark$ & & $\checkmark$ \\
\hline tiskarka & $\checkmark$ & $\checkmark$ & $\checkmark$ & $\checkmark$ \\
\hline tkalka & $\checkmark$ & $\checkmark$ & $\checkmark$ & $\checkmark$ \\
\hline tlakovalka & & $\checkmark$ & & $\checkmark$ \\
\hline točajka & $\checkmark$ & $\checkmark$ & $\checkmark$ & $\checkmark$ \\
\hline tolmačica/tolmačka & $\checkmark$ & $\checkmark$ & $\checkmark$ & $\checkmark$ \\
\hline tožilka & $\checkmark$ & $\checkmark$ & $\checkmark$ & $\checkmark$ \\
\hline trenerka & $\checkmark$ & $\checkmark$ & $\checkmark$ & $\checkmark$ \\
\hline trgovka & $\checkmark$ & $\checkmark$ & $\checkmark$ & $\checkmark$ \\
\hline učiteljica & $\checkmark$ & $\checkmark$ & $\checkmark$ & $\checkmark$ \\
\hline uglaševalka & & $\checkmark$ & & $\checkmark$ \\
\hline umetnica & $\checkmark$ & $\checkmark$ & $\checkmark$ & $\checkmark$ \\
\hline upraviteljica & $\checkmark$ & $\checkmark$ & $\checkmark$ & $\checkmark$ \\
\hline upravljavka & $\checkmark$ & $\checkmark$ & $\checkmark$ & $\checkmark$ \\
\hline upravnica & $\checkmark$ & $\checkmark$ & $\checkmark$ & $\checkmark$ \\
\hline uradnica & $\checkmark$ & $\checkmark$ & $\checkmark$ & $\checkmark$ \\
\hline urarka & $\checkmark$ & $\checkmark$ & $\checkmark$ & $\checkmark$ \\
\hline urbanistka & & $\checkmark$ & & $\checkmark$ \\
\hline urednica & $\checkmark$ & $\checkmark$ & $\checkmark$ & $\checkmark$ \\
\hline urejevalka & $\checkmark$ & $\checkmark$ & $\checkmark$ & $\checkmark$ \\
\hline usmerjevalka & $\checkmark$ & $\checkmark$ & $\checkmark$ & $\checkmark$ \\
\hline usnjarka & & $\checkmark$ & & $\checkmark$ \\
\hline ustvarjalka & $\checkmark$ & $\checkmark$ & $\checkmark$ & $\checkmark$ \\
\hline vaditeljica & $\checkmark$ & $\checkmark$ & $\checkmark$ & $\checkmark$ \\
\hline valjavka & $\checkmark$ & $\checkmark$ & $\checkmark$ & $\checkmark$ \\
\hline varilka & $\checkmark$ & $\checkmark$ & $\checkmark$ & $\checkmark$ \\
\hline varnostnica & & $\checkmark$ & $\checkmark$ & $\checkmark$ \\
\hline \multicolumn{5}{|l|}{ vbrizgovalka } \\
\hline vedeževalka & $\checkmark$ & $\checkmark$ & $\checkmark$ & $\checkmark$ \\
\hline veleposlanica & $\checkmark$ & $\checkmark$ & $\checkmark$ & $\checkmark$ \\
\hline veterinarka & $\checkmark$ & $\checkmark$ & $\checkmark$ & $\checkmark$ \\
\hline
\end{tabular}




\begin{tabular}{|c|c|c|c|c|}
\hline Feminativ & SSKJ 1 & $S P$ & SSKJ 2 & Korpusi \\
\hline vezilja & $\checkmark$ & $\checkmark$ & $\checkmark$ & $\checkmark$ \\
\hline vicekonzulka & & $\checkmark$ & & $\checkmark$ \\
\hline \multicolumn{5}{|l|}{ videokontrolorka } \\
\hline videotehnica & & $\checkmark$ & & $\checkmark$ \\
\hline videotekarka & & $\checkmark$ & & $\checkmark$ \\
\hline vinarka & & $\checkmark$ & & $\checkmark$ \\
\hline vinogradnica & & $\checkmark$ & $\checkmark$ & $\checkmark$ \\
\hline vizažistka & & $\checkmark$ & $\checkmark$ & $\checkmark$ \\
\hline vnašalka & & $\checkmark$ & $\checkmark$ & $\checkmark$ \\
\hline vodarka & & $\checkmark$ & & $\checkmark$ \\
\hline voditeljica & $\checkmark$ & $\checkmark$ & $\checkmark$ & $\checkmark$ \\
\hline vodnica & $\checkmark$ & $\checkmark$ & $\checkmark$ & $\checkmark$ \\
\hline vódnica & & $\checkmark$ & & $\checkmark$ \\
\hline \multicolumn{5}{|l|}{ vodogradbenica } \\
\hline vojakinja & $\checkmark$ & $\checkmark$ & $\checkmark$ & $\checkmark$ \\
\hline voznica & $\checkmark$ & $\checkmark$ & $\checkmark$ & $\checkmark$ \\
\hline \multicolumn{5}{|l|}{ vpenjalka } \\
\hline vratarica/vratarka & $\checkmark$ & $\checkmark$ & $\checkmark$ & $\checkmark$ \\
\hline vremenarka & & $\checkmark$ & $\checkmark$ & $\checkmark$ \\
\hline vrtnarica & $\checkmark$ & $\checkmark$ & $\checkmark$ & $\checkmark$ \\
\hline vrvarka & & $\checkmark$ & & $\checkmark$ \\
\hline vulkanizerka & & & & $\checkmark$ \\
\hline vzdrževalka & $\checkmark$ & $\checkmark$ & $\checkmark$ & $\checkmark$ \\
\hline vzgojiteljica & $\checkmark$ & $\checkmark$ & $\checkmark$ & $\checkmark$ \\
\hline zakonodajalka & $\checkmark$ & $\checkmark$ & $\checkmark$ & $\checkmark$ \\
\hline \multicolumn{5}{|l|}{ zakovičarka } \\
\hline založnica & $\checkmark$ & $\checkmark$ & $\checkmark$ & $\checkmark$ \\
\hline zastavljalničarka & & $\checkmark$ & & $\checkmark$ \\
\hline zastekljevalka & & $\checkmark$ & & $\checkmark$ \\
\hline zastopnica & $\checkmark$ & $\checkmark$ & $\checkmark$ & $\checkmark$ \\
\hline zbiralka & $\checkmark$ & $\checkmark$ & $\checkmark$ & $\checkmark$ \\
\hline zdraviteljica & & $\checkmark$ & $\checkmark$ & $\checkmark$ \\
\hline zdravnica & $\checkmark$ & $\checkmark$ & $\checkmark$ & $\checkmark$ \\
\hline zelenjavarica & $\checkmark$ & $\checkmark$ & $\checkmark$ & $\checkmark$ \\
\hline $\begin{array}{l}\text { zgodovinarical } \\
\text { zgodovinarka }\end{array}$ & $\checkmark$ & $\checkmark$ & $\checkmark$ & $\checkmark$ \\
\hline zidarka & $\checkmark$ & $\checkmark$ & $\checkmark$ & $\checkmark$ \\
\hline zlatarka & $\checkmark$ & $\checkmark$ & $\checkmark$ & $\checkmark$ \\
\hline \multicolumn{5}{|l|}{ zmanjševalka } \\
\hline zobarka & & $\checkmark$ & & $\checkmark$ \\
\hline zobozdravnica & $\checkmark$ & $\checkmark$ & $\checkmark$ & $\checkmark$ \\
\hline zoologinja & & $\checkmark$ & & $\checkmark$ \\
\hline zootehnica & & $\checkmark$ & & $\checkmark$ \\
\hline zvonarka & & $\checkmark$ & & $\checkmark$ \\
\hline žarilka & & & & \\
\hline
\end{tabular}




\begin{tabular}{|l|c|c|c|c|}
\hline Feminativ & SSKJ 1 & SP & SSKJ 2 & Korpusi \\
\hline železokrivka & & $\checkmark$ & & $\checkmark$ \\
\hline žičarka & & $\checkmark$ & & \\
\hline živinorejka & & $\checkmark$ & & $\checkmark$ \\
\hline
\end{tabular}

Pregledali smo tudi spletni rastoči Slovar slovenskega knjižnega jezika (dalje SSKJ 3, spletni vir) $^{21}$ in opazili zgolj eno novo ženskospolsko poimenovanje poklica, ki ga $\mathrm{v}$ raziskavo vključenih virih nismo zasledili, to je alergologinja. Nekatera že v drugih virih zabeležena poimenovanja pa v SSKJ 3 nastopajo z drugačnimi pomenskimi razlagami: hišnica 'ženska, ki se poklicno ukvarja z manjšimi vzdrževalnimi deli, opravili in skrbi za urejenost stavbe in njene okolice' (v SSKJ 2 'ženska, ki opravlja manjša oskrbniška dela v večstanovanjski hiši' in 'hišnikova žena'); cvetličarka 'ženska, ki se poklicno ukvarja s prodajo, vzgojo okrasnih rastlin in njihovo uporabo v šopkih, okrasitvah' (v SSKJ 2 'ženska, ki goji cvetlice ali jih prodaja'); čistilka 1. 'ženska, ki se poklicno ukvarja s čiščenjem', 1.1 'ženska, ki čisti' (SSKJ 2: 'ženska, ki se poklicno ukvarja s čiščenjem'); čembalistka 'ženska, ki igra čembalo, navadno kot poklicna glasbenica' (po SSKJ 2 'ženska, ki igra čembalo'); podobno oboistka 'ženska, ki igra oboo, navadno kot poklicna glasbenica' (v SSKJ 2 samo 'ženska, ki igra oboo'). Opažamo, da so poimenovanja v SSKJ 3 razložena kot poklic (in ne zgolj opravljanje dejavnosti kot v SSKJ 2).

\subsubsection{4 Ženskospolska poimenovanja za poklice v razpisih za delo}

Ženska bi morala imeti zagotovljene enake možnosti in obravnavo kot moški pri zaposlovanju, usposabljanju, napredovanju, prekvalifikaciji, izobraževanju, zaslužku, odsotnostih z dela, delovnem času in odpovedi pogodbe o zaposlitvi. Delodajalec tako ne bi smel razpisati nobenega prostega delovnega mesta samo za en spol, razen če je določen spol pogoj za opravljanje dela (Mežnar 2009: 669-670). Poraja se vprašanje, ali se bo na razpis za delovno mesto vodovodarja odzvala ženska oz. ali bo razpis za delovno mesto čistilke pritegnil moškega. Uporaba obeh oblik bi nakazala, da se za razpisano delovno mesto

21 Slovar slovenskega knjižnega jezika. Vir: https://fran.si/iskanje?FilteredDictionaryIds=201\& View=1\&Query=\%2A (pridobljeno 1. 7. 2018). 
lahko potegujeta oba. Preverili smo, kako se konkretne rešitve udejanjajo danes. Zanimala nas je raba ženskospolskih poimenovanj za poklice $\mathrm{v}$ razpisih, objavljenih na spletni strani Zavoda RS za zaposlovanje (spletni vir). ${ }^{22}$ Do razpisov smo dostopali 18. maja 2012 (1317 razpisov) in nato še 5. julija 2017 (2692 razpisov).

Vsak razpis je sestavljen iz naziva delovnega mesta, imena delodajalca, datuma objave, kraja upravne enote delovnega mesta in podatka o objavi na več uradih. Vsebino razpisa lahko odpremo s klikom na naziv delovnega mesta in preberemo podrobnosti. Zanimali so nas zlasti nazivi delovnega mesta. V vseh razpisih z 18. maja 2012 je v nazivu oznaka M/Ž, kar pomeni, da je delovno mesto namenjeno tako moškim kot ženskam. Vse oglase tega dne smo pregledali, da bi ugotovili, kolikokrat je navedeno tudi ženskospolsko poimenovanje poklica ali celo zgolj ženskospolsko. Ugotovili smo, da 1144 (87 \%) od 1317 oglasov navaja zgolj poimenovanje poklica za moški spol. Pri 53 (4 \%) oglasih je šlo za poklic vodja, pri katerem menimo, da ženskospolska oblika vodkinja še ni uveljavljena (sedem konkordanc po Gigafidi, medtem ko je ne beleži noben jezikovni priročnik). ${ }^{23}$ Med preostalimi razpisi jih je 75 (6\% vseh oglasov) vsebovalo zgolj ženskospolsko poimenovanje (administratorka, administrativna delavka, čistilka, kozmetičarka, kuharica, kuhinjska pomočnica, likarica konfekcionarka, medicinska sestra, natakarica, poslovalka, poslovna asistentka, prodajalka, servirka, snažilka, sobarica/čistilka, socialna oskrbovalka, svetovalka za zlato, šivilja, tajnica). V 14 (1,06 \%) oglasih je bilo ženskospolsko poimenovanje poklica nakazano $\mathrm{z}$ obrazilom $-k a$, navadno za poševnico (npr. aranžer/ka, čistilec/ka, gozdar/ka, instalater/ka, kovinar/ka, monter/ka, plesalec/ka, pomivalec/ka, prodajalec/ka, receptor - $k a, \quad$ socialni/a oskrbovalec/ka, vrtnar/ka, upravljalec/ka - vzdrževalec/ka na liniji, zavarovalni kandidat $(k a))$, v $11(0,8 \%)$ s priponskim obrazilom -ica, pogosto za poševnico (npr. kuhar/ica, natakar/ica, učitelj/-ica kitare, učitelj/-ica kontrabasa,

\footnotetext{
22 Zavod RS za zaposlovanje. Vir: https://www.ess.gov.si/iskalci_zaposlitve/prosta_ delovna_mesta (pridobljeno 18. 5. 2012 in 5. 7. 2017).

23 Da se v slovenščini kaže potreba po ženski ustreznici $\mathrm{k}$ moškemu poimenovanju vodja, ugotavlja tudi Peter Weiss (2014: 163). Meni, da je glede na že uveljavljene oblike računovodkinja, zborovodkinja ipd. najustreznejši izraz vodkinja, zavrača pa nekatere druge predloge, denimo vodjinja ali obliko vodja kar za oba spola.
} 
zavarovalni zastopnik(ica)) in v enem z obrazilom -inja (tehnolog/-inja). ${ }^{24} \mathrm{~V} 19$ primerih $(1,44 \%$ vseh oglasov) sta bili navedeni obe obliki, torej moško- in ženskospolska: administrator/administratorka, čistilec/čistilka, komercialist/komercialistka, kuhar/kuharica, muzejski vodnik/vodnica, natakar/natakarica, poslovni sekretar/poslovna sekretarka, poslovodja/poslovodkinja, pralci/pralke vozil, prodajalec/prodajalka, ravnatelj/ravnateljica. Generalno gledano torej prevladujejo zgolj moškospolske navedbe poklicev; enakovredna raba žensko- in moškospolskega poimenovanja ne dosega niti $2 \%$ vseh primerov.

Podobno opažamo po pregledu razpisov, objavljenih 5. julija 2017. Ponovno oznaka $\mathrm{M} / \check{Z}$ pri vseh razpisih kaže na dostopnost posameznega delovnega mesta za ženske in moške. Kljub tej oznaki pa je pri enem razpisu bilo izrecno zapisano, da želijo zaposliti samo žensko (natakar - ženske), pri enem pa so želeli zaposliti izključno moškega (električar - moški). Moško- in ženskospolska oblika sta $\mathrm{v}$ celoti izpisani pri 33 primerih oz. 1,22\% (denimo cvetličar/cvetličarka, čistilec/čistilka, delavci/delavke za ročno pakiranje, frizer/frizerka, kuhar/kuharica, natakar/natakarica, osebna asistentka/asistent, pomožni delavec/delavka v gradbeništvu, poslovodja/poslovodkinja, prodajalec/prodajalka, vojak/vojakinja, učitelj/učiteljica strokovno teoretičnih predmetov, srednješolski učitelj/srednješolska učiteljica, voznik/voznica, vzgojitelj/vzgojiteljica). Pri 22 primerih je šlo za poimenovanja s sestavino vodja (računovodja, delovodja, gradbeni delovodja, samostojni računovodja, knjigovodja, izmenovodja, poslovodja, trgovski poslovodja, žerjavovodja) ali samo vodja (38 primerov). Opažamo, da je pri 43 razpisih (1,6 \%) ženskospolsko poimenovanje osebe zgolj nakazano s priponskim obrazilom: v 31 primerih z -ica (kuhar-ica, natakar-ica, pomočnik-ica vzgojiteljice, vzgojitelj-ica, učitelj(ica), varnostnik-ica, visokošolski učitelj-ica), pri 11 primerih s -ka (čistilec/-ka, električar-ka, prodajalec-ka, strokovni delavec/-ka) in zgolj pri enem z -inja (picopek-inja). Zgolj ženskospolsko poimenovanje osebe pa smo zasledili pri 104 primerih $(3,8 \%)$, in to kljub oznaki $\mathrm{M} / \mathrm{Z}$ (2. učiteljica $v 1$. razredu, čistilka,

\footnotetext{
24 Vsi primeri so zapisani tako, kot so bili navedeni na spletnih straneh Zavoda RS za zaposlovanje, torej vključno s pravopisnimi in drugimi napakami.
} 
snažilka, sobarica, strežnica, diplomirana medicinska sestra, medicinska sestra, srednja medicinska sestra, snažilka oz. gospodinja, socialna oskrbovalka, natakarica, gospodinja oskrbovalka, pomočnica vzgojiteljice, prodajalka, šivilja, učiteljica, varuhinja). Preostala poimenovanja so zgolj moškospolska (v 2450 razpisih, kar predstavlja $91 \%$ ), med njimi najdemo tudi šiviljca in gospodinjca.

Koliko žensk bi se prijavilo na razpis z navedeno zgolj moškospolsko obliko, se sprašuje tudi Aleksandra Kanjuo Mrčela (1992: 77-87), ob tem pa raziskuje razloge za manjše število žensk na vodilnih položajih v primerjavi z moškimi, čeprav je očitno, da imajo ženske vse potrebne formalne pogoje za vertikalno poklicno mobilnost. ${ }^{25}$ Razloge za to vidi $\mathrm{v}$ kulturnih obrazcih in prevladujočih vrednotah $\mathrm{v}$ družbi, $\mathrm{v}$ družbeno sprejemljivih pričakovanjih do moških in žensk, v različnih socialnih kontekstih življenja moških in žensk. Ni pa to specifično za Slovenijo, ampak je problem tudi v drugih delih sveta, ne glede na politično ali ekonomsko ureditev. Za moške so tako rezervirane vloge, ki izražajo dinamičnost, ambicioznost, iniciativnost, agresivnost, moč, samozavest, ženske pa naj bi imele vloge, v katerih so prisotne čustvenost, nežnost, odvisnost, kooperativnost, pasivnost. Njihove vloge so vezane na otroke, dom in družino, s čimer so potisnjene v zasebno sfero, dostop do javne sfere in uveljavljanje v njej pa sta jim otežena. Če ženska izstopi iz zasebne sfere, po navadi opravlja dela, ki so nadaljevanje domačih opravil (skrb za druge - šolstvo, zdravstvo ...). Mrčela meni, da spol onemogoča ali vsaj otežuje ženskam profesionalno napredovanje in doseganje visokih položajev. Tiste, ki jim vendarle uspe, so s svojim spolom stigmatizirane. Kanjuo Mrčela pa nadalje v novejši razpravi (2007: 547, 568) ugotavlja, da so se $\mathrm{v}$ zadnjih desetletjih na trgih delovne sile v Evropi zgodile pomembne spremembe $\mathrm{v}$ smeri vse večje enakopravne udeležbe žensk na področju plačanega dela. Eden od štirih stebrov evropskih smernic zaposlovanja je namreč postala prav enakost spolov. Mrčela ugotavlja, da so ženske v Sloveniji v povprečju vključene v plačano zaposlitev še bolj, kot je to značilno za Evropsko

\footnotetext{
${ }^{25}$ Silvija Borovnik (1995: 22-23) opaža, da so se socialistične ženske zaposlovale v glavnem v nizko akumulativnih in delovno najintenzivnejših industrijskih panogah - tekstilni, obutveni, tobačni, predelovalni ... A nadalje ugotavlja, da se tudi $\mathrm{v}$ razviti Sloveniji proizvodnja in administracija naslanjata na žensko delovno silo; še naprej pa je ženska domena družinsko in gospodinjsko delo.
} 
unijo. ${ }^{26}$ Vseeno pa položaj moških in žensk na trgu delovne sile vztrajno določajo horizontalna in vertikalna segregacija plačanega dela, razlike $\mathrm{v}$ dohodkih in neenaka delitev gospodinjskega dela. Ženske so postavljene $\mathrm{v}$ manj ugoden ekonomski položaj in izpostavljene večjim tveganjem, bolj kot moškim jim je onemogočena izbira med različnimi dejavnostmi in poklici. Še vedno pa je ženskam oteženo napredovanje na najvišje vodilne položaje, v zadnjih letih pa je v Sloveniji celo opazno hitrejše naraščanje brezposelnosti žensk in počasnejše povečevanje njihovega zaposlovanja. Tako je videti, da bo tudi na Slovenskem moral biti cilj politike ohranjanje enakopravnosti spolov na trgu delovne sile in ob delitvi dela (Kanjuo Mrčela 2007: 568).

Problem pa ni le morebitna popolna izključenost ženskospolskih poimenovanj $\mathrm{v}$ razpisih, temveč tudi način zapisa le-teh. Boris Kern in Helena Dobrovoljc sta $\mathrm{v}$ jezikovni svetovalnici Inštituta za slovenski jezik Frana Ramovša ZRC SAZU objavila članek o podčrtaju (spletni vir), ${ }^{27} \mathrm{v}$ katerem navajata različne načine krajšanja zapisa ženske oblike ob moški, ko v besedilu prihaja do pomanjkanja prostora: s poševnico in vezajem (avtor/-ica); s poševnico (zaposlen/a); $\mathrm{z}$ oklepajem in vezajem $(\operatorname{rojen}(-a)) ; \mathrm{z}$ oklepajem $(\operatorname{rojen}(a)) ; \mathrm{z}$ vezajem (stanujoč-a). Pojasnjujeta, da vseh pet navedenih možnosti zapisa predvideva obstoj izključno moške ali ženske spolne identitete, torej identitete znotraj binarnega spolnega sistema. Obstajajo pa tudi osebe, ki se ne identificirajo (izključno) z moškim ali ženskim spolom in katerih spolna identifikacija presega binarni spolni sistem. V zadnjih nekaj letih se tako za vključitev nebinarnih spolnih identitet med oblikama za moški in ženski spol pojavlja podčrtaj: Obiskovalke_ci so se udeležile_i izleta ali Povabili_e so ga_jo k sodelovanju. Pojav ni značilen le za slovenščino, ampak za več jezikov, v katerih je spol veliko bolj izražen kot npr. v angleščini - to so po mnenju obeh avtorjev tudi nemščina

\footnotetext{
${ }^{26}$ Da je stopnja delovne aktivnosti žensk višja od povprečja držav EU in je počasi naraščala po osamosvojitvi Slovenije, ugotavljata tudi Černigoj Sadar in Verša (2002: 428), hkrati pa opažata, da je v Sloveniji in državah EU značilna visoka spolna segregacija na trgu delovne sile, ki je delno posledica spolno segregiranega izobraževalnega sistema.

${ }^{27}$ Helena Dobrovoljc, Boris Kern: Pisanje moških in ženskih oblik in uporaba podčrtaja za izražanje »spolne nebinarnosti«. Vir: https://svetovalnica.zrc-sazu.si/topic/2247/pisanjemo\%C5\%A1kih-in-\%C5\%BEenskih-oblik-in-uporaba-pod\%C4\%8Drtaja-za-izra\%C5\%BEanjespolne-nebinarnosti (pridobljeno julija 2018).
} 
in slovanski jeziki. Avtorja opozarjata, da je ta način omejen le na pisno sporazumevanje, opažata pa tudi nekaj omahovanj $\mathrm{v}$ zapisu: kakšno naj bo zaporedje navajanja moških in ženskih oblik ter kaj navesti za podčrtajem (celotno obrazilo -ica ali le - ca). Zaporednost moške in ženske oblike ni bistvena, je pa $\mathrm{v}$ primerih učitelj_ica, režiser_ka smiselno najprej navesti moško obliko zaradi ničtega obrazila pri moškem spolu oziroma neobstojnega samoglasnika (prišel_a), če izhajamo iz jezikoslovnega ali pravopisnega premisleka. Od splošnega uporabnika pa ne moremo pričakovati poznavanja besedotvornih pravil, zato je razumljivo, da se je v primeru podčrtajev sorazmerno močno uveljavilo le navajanje spremenljivega končnega dela, torej: zdravnik_ca ali $z$ dravnica_k. Med zapisom s poševnico, oklepaji in podčrtaji je tako bistvena pomenska razlika: poševnice in oklepaji predvidevajo le dve spolni identiteti (ali moško ali žensko), s podčrtajem pa pisci zajamejo cel spekter različnih spolnih identitet.

Saška Štumberger (spletni vir) ${ }^{28}$ pa opozarja na vse razsežnosti uvajanja podčrtaja $\mathrm{v}$ slovenski jezik za izražanje spolne nebinarnosti. Tematika izražanja spola v slovanskih jezikih je zapletena in je uvajanje novega ločila ne rešuje. Pri presojanju novosti (knjižnega jezika) je treba upoštevati jezikovno rabo, jezikovni sistem, izročilo in gospodarnost. Zavrača zgoraj navedeno trditev, da je raba podčrtaja že uveljavljena $\mathrm{v}$ nemščini in slovanskih jezikih. $\mathrm{V}$ nemških besedilih lahko podčrtaj res najdemo tudi za izražanje spolne nebinarnosti, vendar pa to ni edina možnost; uporablja se tudi zvezdica, npr. ein*e gut ausgebildete*r Akademiker*in (dobesedni prevod: en*a dobro izobražen*a akademik*inja). Poleg podčrtaja in zvezdice je $\mathrm{v}$ nemščini razširjen tudi veliki I sredi besede, npr. StudentInnen. Za nemščino na spletu najdemo različna priporočila za rabo spolno nevtralnega jezika, vendar pa pravopis teh možnosti ne sprejema niti ne prepoveduje. Rabi velikega I Svet za pravopis pripiše stilistične značilnosti in opozarja, da je taka raba omejena na določena področja nemškega jezika in ni tako splošno razširjena, da bi jo morali sprejeti v pravopis. Ker pa se je raba podčrtaja kljub zapletenosti in nedorečenosti razširila tudi na področje

\footnotetext{
${ }^{28}$ Saška Štumberger: Transspolnost v slovenščini: Bomo nekoč pisali "povabili_e so ga_jo $k$ sodelovanju"? Vir: https://www.portalplus.si/mobile/2668/uvajanje-podcrtaja-za-izrazanje-spolnenebinarnosti (pridobljeno julija 2018).
} 
znanstvenih publikacij, avtorico skrbi, da bomo v prihodnje prisiljeni uporabljati tak jezik: Povabili_e so ga_jo $k$ sodelovanju. Meni namreč, da tak jezik ne vključuje celotne družbe, kot prepričujejo Jezikovna svetovalnica in tisti, ki novi izrazni način uveljavljajo, ampak odvrača od branja, še bolj pa od pisanja. Šele čas pa bo pokazal, ali se bodo tovrstne oblike v rabi uveljavile, vsekakor pa kažejo potrebo po načinu zapisovanja, pri katerem (zgolj) moškospolske oblike ne bodo samoumevne, četudi so slovnično (ne pa tudi družbeno) nevtralne.

\subsubsection{Priporočila za neseksistično rabo jezika}

Olga Kunst Gnamuš (1995: 261) opominja, da obstajajo pravila, ki v besedilu omogočajo prilagajanje oblik naravnemu spolu nanosnika: (1) to je razvito (hkratno) dvospolno poimenovanje vlog, poklicev, položajev, naslovov (kmet/kmetica, predsednik/predsednica); (2) pri pokazani rabi samostalniških zaimkov se spol poimenovanja in osebne glagolske oblike prilagajajo naravnemu spolu pokazane bitnosti (ti si bila poslanka/ti si bil poslanec); (3) spol samostalnika, ki poimenuje naslove, vloge ali položaje, se ravna po spolu samostalnika, ki poimenuje nanosnik, kateri to vlogo ali položaj zaseda. V slovenskem jeziku se namreč $s$ stališča spolno občutljive rabe jezika kot problematične kažejo naslednje kategorije: moško poimenovanje za žensko osebo, srednjespolsko poimenovanje za žensko osebo, žensko poimenovanje za moško osebo, generična raba moškega spola in priimki ženskih oseb v pridevniški svojilni obliki - slednje je pogosto za označevanje ženskih oseb, ne pa tudi moških. Vseh pet omenjenih kategorij se pojavlja v strokovnih razpravah o spolno občutljivi rabi jezika ali drugače imenovani (ne)seksistični rabi jezika (Kranjc, Ožbot 2013: 234).

\subsubsection{Neseksistična raba jezika}

Igor Ž. Žagar in Mirjam Milharčič Hladnik v že omenjenem zborniku Neseksistična raba jezika predlagata naslednje rešitve: 
a) Uporaba obeh oblik v pravno-administrativnih dokumentih (npr. Dijak oz. dijakinja ima med šolanjem pravico prestopiti v drugo šolo). Vidovič Muha pri tem ugotavlja (1997: 78), da je glede hkratne rabe poimenovanj za ženske in moške nujno upoštevati zunajjezikovne okoliščine. Obe poimenovanji sta ustrezni v vsaj dveh primerih: 1) nagovor, neposredni ali posredni (mediji), občinstva obeh spolov; 2) če želimo poudariti oba spola. Marja Bešter (1997: 12) pri tem opozarja na možnost, da bi ženska bila imenovana prva.

b) Uporaba nevtralne oblike (npr. oseba, ki je nosilka pravice ...).

c) Uporaba kreativne metode, kar pomeni, da $\mathrm{v}$ besedilu izmenično uporabljamo tako dvojno, tj. moško in žensko, kot tudi nevtralno obliko (npr. Kdor lahko dokaže, da je njegov oz. njegova ...).

d) Četrta možnost je s stališča enakopravne zastopanosti žensk in moških v jeziku sicer nezadovoljiva; gre za t. i. pravne definicije, ki na začetku in na koncu besedila nedvoumno zagotavljajo, da se dano besedilo kljub formulaciji, ki obeh spolov eksplicitno ne omenja, obrača tako na moške kot tudi na ženske (npr. Z »uslužbencem« so razumljeni vsi sodelavci in sodelavke ministrstva ...) (Žagar, Milharčič Hladnik 1995: 10-11).

Domačnosti in pokroviteljskemu tonu se moramo izogibati tudi pri naslavljanju in poimenovanju, kjer ženske in moške obravnavamo enako (npr. $G$. Marolt in Sonja). Žensk ne bi smeli preprosto identificirati $\mathrm{z}$ njihovimi družbenimi vlogami žena, mater, sestra ali hčera, razen če so te družbene vloge predmet razprave. Izogibali naj bi se torej primerom kot: Janez Marolt in njegova žena Martina. Oba spola naj bi uporabljali kot samostojna in samoiniciativna, ne le kot privesek enega k drugemu. Izogibamo se primerom kot: Janez Marolt se je $z$ ženo in otroki preselil $v$ Ameriko. Prav tako moramo obojim enako priznati zasluge za rezultate, ki so jih dosegli, in ne zaradi rezultatov, ki so jih dosegle njihove partnerke ali partnerji (npr. Jana Klemenčič, katere mož je redni profesor za srednjeveško zgodovino in dekan filozofske fakultete, je bila izvoljena v naziv docentke za primerjalno književnost). Izogibati bi se morali še formulacijam, ki 
vzdržujejo in vsiljujejo preživele stereotipe, da je mesto poročene ženske lahko le doma v kuhinji (Žagar, Milharčič Hladnik 1995: 13-15).

\subsubsection{Interne smernice za splošno občutljivo rabo jezika}

Predloge za neseksistično rabo jezika daje tudi Renata Šribar (2010). Splošno načelo je, da se pri poimenovanju oseb, poklicev itd. praviloma izogibamo rabe generičnega moškega spola. Tako predlaga uporabo množinskega samostalnika: s tem se izognemo spolno diskriminatorni samostalniški obliki v množini. Ta pristop lahko uporabimo $\mathrm{v}$ tekstu, ki je formalen (npr. delavstvo namesto delavci), ali v tekstu, ki vključuje osebni slog (npr. študentarija namesto študenti). Nadalje priporoča uporabo glagolnika kot samostalniške besede ali uporabo nadomestnega samostalnika, ki ni v »nezaznamovanem« (tj. generičnem) moškem spolu. Opozarja, da je predlagana raba možna le, kadar to ustreza vsebini (npr. »S historične perspektive je arhivarstvo pomembno opravilo." in »Arhivarjenje je s historične perspektive pomembno opravilo." namesto »S historične perspektive opravlja arhivar pomembno opravilo.« ali »S historične perspektive opravljajo arhivarji pomembno opravilo.«). Naslednji predlog avtorice se nanaša na rabo samostalnikov, ki označujejo osebe, v ženski in moški obliki, in sicer:

- $\quad$ v tekstu, ki je formalen, a hkrati vključuje zahtevo po stilu, uporabimo obe obliki v celovitem zapisu (npr. ženske in moški/moški in ženske) ali najdemo izraz, ki je množinski (npr. poslušalstvo);

- $\quad \mathrm{v}$ tekstu, ki vključuje osebni slog, lahko poleg zgoraj navedenih različic uporabimo obe spolno zaznamovani obliki $\mathrm{v}$ ednini (npr. profesor in profesorica, bralka in bralec);

- $\quad \mathrm{v}$ tekstu, ki je administrativne narave (vključno z zakonskimi besedili), lahko uporabimo okrajšave za drugo spolno zaznamovano obliko samostalnika (npr. ministrica/-er ali minister/-ica).

Če ženska oblika samostalnika izraža osebo in stvar (naslovnik/naslovnica), je treba utrjevati pomen, ki označuje osebo (Šribar 2013: 
159). Pri rabi samostalnika človek in preostalih slovničnih pokazateljev spola, ki se nanj naslanjajo (»kdor«, »Vsak«) v stavkih, s katerimi želimo tretjeosebno in tako posplošeno opisati določeno mnenje ali situacijo, nastopi moška skladnja in $\mathrm{s}$ tem $\mathrm{z}$ vidika ozaveščanja razmerij spola absurdna situacija, ko začne ženska govoriti kot moški (npr.: »Ana pravi: 'Človek je pač prisiljen ukrepati v skladu s situacijo.'«). Temu se lahko izognemo z opuščanjem takšnega načina izražanja ali, v primeru ženske govorke, s posplošeno rabo samostalnika ženska (npr. »Ženska je pač prisiljena ukrepati v skladu s situacijo.«).

Renata Šribar (2010: 4-5) poda tudi predloge za stavčno sintakso, s katero se izognemo spolno diskriminatorni rabi jezika. Ko se glagolska oblika ravna po samostalniku, lahko zamenjamo vrstni red spolno zaznamovanih samostalnikov tako, da je glagolska oblika enkrat ženska, drugič moška (npr. »informacije, ki so jih podale respondentke in respondenti« in »informacije, ki so jih podali respondenti in respondentke«). Ta primer spolno občutljive rabe jezika ustreza slovničnemu načelu, da se glagolska oblika lahko ravna po »naravnem« spolu, in to tistem, ki je v stavku bližje glagolu. Ko pa gre za subjekt, ki je spolno raznoliko sestavljen in se $\mathrm{v}$ skladu $\mathrm{s}$ pravili slovnice glagol spolno diskriminatorno izrazi $\mathrm{z}$ moško končnico (npr. »Parlamentarke Zares in parlamentarec SDS so se odločili, da ne bodo glasovali.«ali »Tina, Maja in Švrk so šli na sprehod.«), ${ }^{29}$ je priporočljivo običajno sintakso razgraditi, da se diskriminatornemu pravilu izognemo (npr. »Parlamentarke Zares so se odločile, da ne bodo glasovale, enako velja za parlamentarca SDS.« ali »Tina in Maja sta šli na sprehod, s sabo sta vzeli Švrka.«). Pri uporabi dvojine, ki se nanaša na Ženski stavčni subjekt, uporabljamo končnico glagola $-i$, saj se specifičnost slovenščine za izražanje dvojine ob nanašanju na dve ženski tudi pri glagolu ne bi smela izgubiti (npr. »Šli sva v kino.«). Kadar je torej možno, naj se glagol v skladu s slovničnim pravilom ujema z ženskim spolom, da bo tudi oblika glagola izražala spolno občutljivo rabo jezika (Šribar 2013: 159).

\footnotetext{
${ }^{29} \mathrm{Na}$ ta problem je opozorila tudi Irena Stramljič Breznik (2018: 34-39), ko je s korpusno metodo preverjala stereotip ženske ne povedo nič pametnega. Raziskavo je izpeljala na podlagi ustreznega izbora glagolov govorjenja in njihovega pojavljanja v Gigafidi. Ob teh glagolih so dejansko prevladovale moškospolske oblike, ker so tovrstni deležniki verjetno po frekvenci vselej višje kot ženskospolski - zaradi moškega spola kot nezaznamovanega in zaradi povedka v moškem spolu, ko gre za priredno zloženi osebek različnih spolov.
} 
2.3.5 Pomanjkljivosti neseksistične rabe jezika

Hkrati sta v že omenjeni razpravi Žagar in Hladnik opozorila na težave, ki se lahko pojavijo pri uvajanju »neseksističnega izrazoslovja«, to je uporabi moške in ženske oblike, v pravno-administrativne akte:

a) Nedvoumnost zakona: če so novi zakoni napisani z rabo dvojne (moške in ženske) oblike ali celo z rabo kreativne metode, lahko pride do nejasnosti, kadar se novonapisani zakon sklicuje na že obstoječi zakon, napisan le v moški obliki.

b) Skladnost s pravnim jezikom: nujno je, da je pravno besedilo mogoče tudi ustno in ne le pisno citirati. S kopičenjem zlasti skrajšanih moških in ženskih oblik, npr. učenec/ka, bi bilo to praktično nemogoče.

c) Razumljivost - uvajanje dvojnih oblik prinaša tudi težave na nivoju skladnje (ujemanja), ki ne prispevajo k razumljivosti besedila. Primer Učna pogodba obsega: priimek in ime, dan, mesec in leto rojstva, stalno bivališče učenca/učenke in staršev oziroma drugega/druge zakonitega/zakonite zastopnika/zastopnice učenca/učenke, če je učenec/učenka mladoleten/mladoletna kaže, da tako besedilo postane skorajda neberljivo (Žagar, Milharčič Hladnik 1995: 11-12).

Tudi Marko Stabej (1997: 63) ugotavlja, da bi dosledno uveljavljanje rabe obojnih oblik povzročalo hude skladenjske zadrege, ki se mu zdijo skoraj nerešljive.

Podobno velja tudi v drugih slovanskih jezikih. Kubiszyn-Mędrala (2007: 31) navaja razloge, zakaj se ženskospolske oblike v poljščini niso uveljavile ali sploh ne obstajajo $\mathrm{k}$ določenim moškospolskim poimenovanjem oseb:

1. Morfološko-semantični dejavniki - preprečevanje polisemije, npr. szoferka lahko pomeni 'žensko šoferja' ali 'šoferjevo kabino'.

2. Morfološko-fonetični dejavniki - nastanek težko izgovorljivih soglasniških skupin, npr. archite[ktk]a, adiu[nktk]a. 
3. Socialno-psihološki dejavniki - za pomembnejše funkcije in ugledne položaje se še vedno raje uporabljajo moškospolska poimenovanja.

4. Pragmatično-funkcionalni dejavniki - možnost uporabe samostalnika moškega spola v odnosu do žensk v titularnih frazah, npr. mecen Anna Zawadzka.

V slovenščini imamo samostalnike $\mathrm{s}$ pomenom oseb $\mathrm{z}$ bolj ali manj pomembno družbeno vlogo, ki ne poznajo obojespolnih oblik ali pa so te na novo izumljene in nerodne, npr. modrec (na spletnih forumih in družabnih omrežjih že modrinja), pisec/piska. Drugi samostalniki s pomenom osebe s spremembo $\mathrm{v}$ ženski spol pomenijo stvar (strojnik/strojnica) ali stvar in osebo obenem (naslovnik/naslovnica, popotnik/popotnica). Samostalniki z zgolj žensko obliko, npr. žrtev, lahko na ravni leksike kažejo na družbeno-kulturno vlogo žensk, čeprav najdemo tudi take, ki imajo samo moško obliko (npr. butec, čeprav po korpusih Janes in Gigafida že butka). Iz feministične lingvistične perspektive je indikativno tudi oblikoslovno (vsaj morfemsko, če že ne besedotvorno) pravilo, kako iz moškospolske oblike samostalnika narediti žensko. Gre za postavitev moške oblike kot normativne osnove, ki s priponskim obrazilom postane ženska, a je pretežno to žensko dopolnilo pomensko vezano na manjšo družbeno-kulturno vrednost pomena, npr. inšpektor-ica, miličnik/-ica, prijatelj-ica - obrazilo je enako kot pri tvorbi manjšalnic samostalnikov v ženski slovnični obliki. Druga priponska obrazila, npr. -ja pri dekanji, se Renati Šribar ne zdijo sporna. Nadalje omenja še spolno pristranski slovnični pravili v skladnji: 1) ravnanje glagola po moškem spolu, če stavčni osebek sestavlja skupina žensk in žival moškega spola (Tinka, Manja, Marina in pes Ron so šli na sprehod.); 2) samostalniki in zaimki s pomenom občečloveškega in osebnega, ki so slovnično moško zaznamovani, usklajeni s pravilom generičnega moškega spola s pomenom veljavnosti za oba spola (človek, ljudje, kdo, kateri, koga, kdor, nekdo itd.) (Šribar 2013: 152-153). 


\section{LINGVISTIČNI PRISTOP}

\subsection{Besedotvorni pomeni samostalniških tvorjenk v slovenistiki}

3.1.1 Besedotvorni pomeni $\mathrm{v}$ starejših slovenskih slovnicah $\mathrm{s}$ posebnim poudarkom na pomenski skupini feminativi

Pomensko skupinjenje samostalniških tvorjenk je bilo $\mathrm{v}$ zgodovini slovenskega besedotvorja zelo različno. Besedotvorje obravnava že Adam Bohorič v prvi slovenski slovnici Zimske urice proste, in to v poglavju o imenih (samostalnikih in pridevnikih), glagolih in prislovih. Po Melanchthonovi slovnici povzema pet pomenskih skupin: 1) očetna imena moškega spola (Lamberger); tukaj sočasno prikaže tudi danes imenovano tvorbo feminativov s primerom Lambergar $\rightarrow$ Lambergarica), 2) svojilna imena (Shajrerjovu), 3) manjšalnice (krajlizh, krajlizhiza), 4) izimenke oz. imena iz imen z več podskupinami - snov, zunanjost (oblezhen), željnost (vinen), obilnost (kamenit, pameten), tvornost (vuzhliv), trpni pomen (nenavidliv), mesta drevja (hrastje, verbje), vsebovalniki stvari (perniza), 5) števniki (Bohorič 1987: 91-93).

Z Vodnikovo slovnico Pismenost in Grammatika za perve šole iz leta 1811 se po Vidovič Muhi (1988: 33) začenja obdobje slovensko-nemške normativne protistave, po Ramovšu pa je to $» \mathrm{~V}$ resnici prva slovenska pisana slovnica« (Stramljič Breznik 1999a: 216). V poglavju Isobrasenje besed, kjer Vodnik obravnava tvorjenost samostalnikov, je iz druženja obrazil, ki dajejo tvorjenkam enak pomen, mogoče razbrati naslednje pomenske skupine: 1) poseben stan (devištvo), 2) posebna lastnost (sladkoba), 3) posebna dela (služba), 4) posebne umetnosti in stanovi (kovaštvo), 5) prostor (pogorišče, kovačnica), 6) orodje (omelo, kadilo), 7) snov (teletina), 8) manjšalnost (hišica, miška, dlačica), 9) stopnjevanost, poudarjenost (hlapčon, bogatin), 10) slabšalnost (kmetavz, lenuh, babura), 11) poimenovanja prebivalcev (Kamničan, Grajanka, Doblanka), 12) dejanje (lučaj), 13) skupna imena (družina, bratovščina) (Vodnik 1811: 148150). Za razliko od Vodnika je Peter Dajnko v slovnici Lehrbuch der windischen Sprache iz leta 1824 strnjeno prikazal najpogostejše pomene v 13 točkah: 1) parna 
poimenovanja živih bitij (telec - telica, žrebec - žrebica), 2) moškospolska poimenovanja narodnostnih pripadnikov (Polak, Nemec), 3) delujoče moške osebe ter druge osebe in živali (bojak, svinjar), 4) delujoče ženske osebe ter druge osebe in živali (mačiha, gosanca), 5) dejanje ali stanje, ki ga izražajo abstraktni samostalniki (gnilad, oblast), 6) snovi, izdelki, pripravki (pijača, vžitek), 7) orodja, naprave moškega, ženskega ali srednjega spola (kresalo, vejanca), 8) skupna imena (živina), 9) kraj, prostor (škofija, kovačnica), 10) meso (teletina), koža in izločki ljudi in živali (svinšak, vrablinjak), 11) manjšalnice (njivica, detece), 12) stvari določenega stanja, lastnosti in poimenovanja (belak, jablan), 13) imena služb, dostojanstev, ver (keršanstvo), spretnosti (školia) (Dajnko 1824: 72-74). Strnjenega prikaza pomenskih skupin za samostalniške izpeljanke se je lotil tudi Jožef Muršec v svoji Kratki slovenski slovnici za pervence iz leta 1847. Izpostavi naslednje: 1) manjšalnost (nitica, nitka, ročica), 2) slabšalnost (črnuh, potepuh), 3) feminativi (Cafovka, učenka, Nemka), 4) opravkar (kolar), 5) prostor/delavnica (brusarnica), 6) meštrija (pisarija), 7) umetnost (kolarstvo), 8) dejanje (kovanje), 9) plača za delo ali dača (mesarnina), 10) breg, hosta ino kdo tam živi (brezovjak), 11) orodje ali ona/žival (drenovka), 12) voda, ki tam izvira (brinovica), 13) vino, ki tam rase (brezovščina), 14) les (kostanjovina), 15) skupno (zborno) ime (ilovje), 16) kraj, mesto (hrastoviše) (Muršec 1847: 70-75).

Drugačen pristop znova ubere Fran Malavašič v Slovenski slovnici za prve slovenske šole $v$ mestih in na deželah (1849), ki obuja Vodnikov princip razvrstitve nastalih tvorjenk, saj združuje obrazila s tipično soglasniško sestavino. Posebej sicer druži le tista obrazila, s katerimi nastanejo "pomanjševavne imena«, in tista, ki se uporabljajo za »povekšovanje imen«, poseben razdelek pa nameni še tvorbi lastnih imen, imenom prebivalcev ter tvorbi feminativov. Vključno $\mathrm{Z}$ naštetimi sicer lahko iz razvrstitve obrazil in podanih primerov razberemo naslednje besedotvorne pomene: 1) skupna imena (drevje, kamnje), 2) stanje (hudobija), 3) feminativi (grešnica, oslica), 4) prostor (drevarnica, zidarija), 5) dejanje (molitev), 6) snov (kurjava), 7) lastnost (zloba), 8) moške osebe (tlačan), 9) orodja (stergula), 10) posode za vodo, vode (deževnica), 11) manjšalnost (miška, drevesce), 12) poudarjenost, stopnjevanost (bogatin, glavan), 13) slabšalnost (kmetavz) (Malavašič 1849: 92-108). 
Kmalu po Malavašičevi je izšla slovnica Matije Majarja z naslovom Slovnica za Slovence (1850), ki besedotvorje obravnava v kratkem poglavju Pomen slov. Opazno je prevzemanje pravil in primerov po že predstavljeni Murščevi slovnici; enako velja za pomenske skupine, saj so identične Murščevim. Druženje obrazil po pomenskih skupinah pa nadaljuje Anton Janežič v Slovenski slovnici s kratkim pregledom slovenskega slovstva iz leta 1854. Pregled izdaje iz leta 1864 namreč kaže, da avtor tvorjene samostalnike druži v devet pomenskih skupin in pri vsaki navaja produktivna priponska obrazila: 1) osebe po rodu, opravilih ali lastnostih (krojač, bahač), 2) dejanja z ozirom ali brez ozira na način in učinek (pisava, tolažba), 3) shrambe, prostori in planišča (mesnica, igrališče), 4) snov, orodje, sredstvo (gorjača, hruščevec), 5) kakovost in čigavost, družbe in stanovi (vojvodina, sramota), 6) množine ali zborne obilnosti - skupna imena (goščava, perutnina), 7) manjšalnice (kruhec, nožek), 8) vekšavna obrazila stopnjevanost, poudarjenost, slabšalnost (glavina, deklusina), 9) tuja lastna imena (Longobardi - Dolgobradci) (Janežič 1864: 116-127).

Leta 1881 je Josip Šuman izdal Slovensko slovnico po Miklošičevi primerjalni, ki je slovensko izobraženstvo seznanila z rezultati Miklošičevih primerjalnih raziskovanj. Šuman druži samoglasniške pripone po načelu prvotne ali drugotne tvorbe, nato pa še druga obrazila, tako da jih povezuje na podlagi soglasniške sestavine. Ponekod navaja zgolj konkretne primere tvorjenk, drugod pa izpostavi tudi pomen. Tako lahko razberemo naslednje pomenske skupine: prvotna tvorba: 1) činitelj - nomen agentis (govoritelj, zijak), 2) orodje instrumentum (kopišče), 3) moški samostalniki (smrkelj, kašelj), 4) ženski samostalniki (perilja, šivilja), 5) dejanje - nomina actionis (brušnja, grožnja), 6) stvarni pomen - concret (tepnja, kopanja), 7) zborno ime (gospoda); drugotna tvorba: 8) lastnost, čast (bogatija, grdoba), 9) opravilo (goljufija, beračija), 10) dežela (domačija, županija), 11) manjšalnice (prtič, kraljiček), 12) pojemski samostalniki (dobrota, blagost), 13) ženska imena iz moških (boginja, volčica), 14) obilost (bogastvo), 15) mlado živinče (zajče, vnuče), 16) človek po kraju (Dunajec) (Šuman 1881: 193-248).

Besedotvorje obravnava tudi Slovenska slovnica z naukom, kako se pišejo pisma in opravilni sestavki avtorja Petra Končnika, ki je izšla leta 1883 na 
Dunaju. Tvorba besed je poleg glasoslovja, pravopisa in skladja zajeta v prvem delu. Izsamostalniško, izpridevniško in izglagolsko tvorbo samostalnikov je podal z navajanjem tipičnih obrazil naslednjih pomenskih skupin: 1) osebe po rodu, opravilu in svojstvu (mlinar, pisatelj), 2) način, dejanje, svojstvo, stanje (lenoba, služba), 3) shramba, prostor, kraj (čitalnica, vodnjak), 4) snov, orodje (ogledalo, govedina), 5) »množica enakih stvari in reči« - skupna imena (drevje), 6) manjšalnice za moški, ženski in srednji spol (bratec, sestrica), 7) slabšalnice (požeruh, smrduh) (Končnik 1883: 16-22). Leta 1968 izdana Slovenska slovnica treh avtorjev, Mirka Rupla, Antona Bajca, Rudolfa Kolariča, nadaljuje strnjeno navajanje pomenskih skupin v poglavju o izpeljavi samostalnikov: 1) imena delujočih oseb (kuhar, kadilka), 2) imena, ki pomenijo glagolsko dejanje (govorjenje, volitev), 3) imena, ki pomenijo učinek glagolskega dejanja (zgradba, izvleček), 4) imena, ki zaznamujejo kraj (kovačija, čitalnica), 5) orodna imena (česalnik, brisača), 6) skupna imena (zlatnina, divjad), 7) manjšalna imena (kozarček, nitka), 8) večalna imena (deklina, bradač), 9) slabšalna imena (klepetulja, požeruh), 10) pojmovna imena (blaginja, bogastvo), 11) imena ženskih bitij (boginja, bralka), 12) imena prebivalcev (meščan, planinec), 13) imena rastlin (planika), 14) snovna imena (govedina, cepivo), 15) imena za mero in ceno (mostnina), 16) imena, ki posnemajo naravne glasove (hehet, topot) (Rupel idr. 1968: 151-152).

\subsubsection{Pomenske skupine samostalniških izpeljank po Antonu Bajcu}

Slovensko tradicionalno besedotvorje (po zgledu Miklošiča) sicer izhaja iz priponskih obrazil s karakterističnim glasom in nato ob različnih podstavah ugotavlja pomenske kategorije tvorjenk z istim obrazilom (Toporišič 2006: 219). Vendar pa smo s pregledom nekaterih slovnic dokazali, da njihovi avtorji že poskušajo strnjeno prikazati pomenske skupine za posamezno besedotvorno vrsto. Tako je tudi Anton Bajec v monografiji Besedotvorje slovenskega jezika (1950) v poglavju Pripone po njih pomenu strnjeno navedel 24 pomenskih skupin: 1) nomina actionis - imena, ki zaznamujejo glagolsko dejanje (gibanje, menjava), 2) nomina agentis - imena delujočih oseb, nosilcev glagolskega dejanja (čuvar, 
pisatelj), 3) nomina acti - imena, ki pomenijo učinek glagolskega dejanja (cvrtje, žaganje), 4) nomina loci - imena, ki zaznamujejo kraj (domovanje, pisarna), 5) nomina instrument - orodna imena (česalnik, odbijač), 6) kolektiva - zbirna imena (brinje, golazen), 7) deminutiva - manjšalna imena (mucika, bratec), 8) avgmentativa - večalna imena (babura, deklina), 9) pejorativa - slabšalna imena (klepetulja, grdavš), 10) abstrakta - pojmovna imena, lastnosti (zdravje, siromačija), 11) sorodstvena imena (mati), ${ }^{30} 12$ ) imena moških oseb (tenorist), 13) imena ženskih oseb (boginja), 14) imena prebivalcev (meščan, Slovenec), 15) imena mladičev (kozle), 16) imena ptičev (golob), 17) imena rastlin in rastlinskih delov (mladika, korenika), 18) snovna imena (govedina, hrastovina), 19) mere in cene (hranarina, desetak), 20) obseg, meja glagolskega dejanja (lučaj), 21) splošna pripadnost (mlinar, graščak), 22) imena, ki posnemajo naravne glasove (hehet, hohot), 23) substantivizacija pridevnikov (dolgin, površnik), 24) konkretizacija abstrakt (bresti-brod) (Bajec 1950: 127-128).

\subsubsection{Model Jožeta Toporišiča}

Interpretacija besedotvornih pomenov je v slovenistiki dvoja. Pričujoča raziskava se osredotoča na izpeljavo kot besedotvorni način in izhaja iz besedotvornih pomenov, kot jih predstavlja model Jožeta Toporišiča, ki pomenske skupine samostalniških tvorjenk povezuje s pomenskostjo stavčnih členov, pri čemer se besedotvorne pomenske skupine opirajo na enakofunkcijska obrazila (Toporišič 1992: 9, 2004: 161-182). Toporišič je v učbeniku Slovenski knjižni jezik 2 (1972) obdelal 13 pomenskih skupin tvorjenk s priponskim obrazilom: 1) imena delujočih oseb ali orodij (čistilec, bodalo), 2) imena poklicev (lovec, vzgojitelj), 3) imena nosilcev lastnosti (lenuh, brkež), 4) dejanja ali stanja (košnja, molitev, sodba), 5) rezultat glagolskega dejanja (povest, beračija), 6) lastnost (modrost, čistoča), 7) kraj ali mesto (pisarna, spalnica), 8) snov in vrsta snovi (govedina, cepivo), 9) skupna imena (listje, grmovje), 10) ženski par moškemu imenu (golobica, pisateljica), 11) imena majhnih bitij (zajček, klobuček), 12) imena, ki izražajo velikost (možak, deklina), 13) imena, ki izražajo zaničevanje,

\footnotetext{
${ }^{30}$ Sicer netvorjenka.
} 
podcenjevanje, prezir (potepuh, babež) (Toporišič 1972: 96-99). Število pomenskih skupin je zmanjšal v Slovenski slovnici (1976, 2004); navadne izpeljanke lahko, upoštevajoč izpeljavo samostalnika iz glagola, pridevniške besede in samostalnika, razvrstimo $\mathrm{v}$ šest pomenskih skupin: 1. pomenska skupina - vršilec (sam. < glag.), nosilec (sam. < prid.), opravkar (sam. < sam.); 2. pomenska skupina - vršilnik dejanja (sam. < glag.), nosilnik lastnosti (sam. < prid.), opravljalnik (sam. < sam.); 3. pomenska skupina - dejanje (sam. < glag.), lastnost (sam. < prid.; sam. < sam.); 4. pomenska skupina - rezultat dejanja (sam. < glag.), popredmetena lastnost (sam. < prid.; sam. < sam.); 5. pomenska skupina - mesto oz. čas dejanja (sam. < glag.), prostor oz. čas (sam. < prid.; sam. < sam.); 6. pomenska skupina - snov (sam. < glag.; sam. < prid.; sam. < sam.). Modifikacijske izpeljanke pa so po Toporišiču (2004: 183-187) razvrstljive v osem pomenskih skupin: feminativi in maskulinativi, skupna imena, stopnjevanost oziroma poudarjenost, mladič oziroma nedoraslo, manjšalno, ljubkovalnomanjšalno, slabšalnomanjšalno (ironično) in slabšalno. Toporišič (2004: 161-187) obrazila v posamezni pomenski skupini razvrsti še po spolu.

\subsubsection{Model Ade Vidovič Muhe}

Besedotvorne pomene kot $\mathrm{v}$ pripono pretvorjene prvine pomenske podstave - propozicije - stavčne povedi pa razume in predstavlja Ada Vidovič Muha v Slovenskem skladenjskem besedotvorju (2011: 82), kjer je za izhodišče besedotvornih pomenov upoštevan skladenjski vidik. Glede na pomensko podstavo povedi je mogoče besedotvorni pomen tvorjenk ločiti na dve veliki skupini: tisto, ki izkazuje pretvorbeno povezavo s propozicijo oziroma pomensko podstavo povedi, in na tisto, ki takšne povezave ne izkazuje. V slednjo med drugim sodijo tudi modifikacijske izpeljanke. Po Vidovič Muhi (2011: 85-86) tako V primerjavi s Toporišičevim (2004: 161-182) modelom za navadno izpeljavo velja naslednje: $\mathrm{z}$ besedotvornim pomenom dejanja, lastnosti in stanja se pretvorbeno povezuje povedje, $\mathrm{z}$ vršilcem dejanja, nosilcem lastnosti in opravkarjem se povezuje prvi delovalnik, s slednjim se povezujejo tudi besedotvorni pomeni vršilnik, nosilnik in opravljalnik. Od neprvih delovalnikov 
sta relevantna tožilniški, povezan s pomenom rezultat dejanja, in orodniški, povezan s sredstvom oziroma snovjo. Okoliščine časa so pretvorbeno povezane $\mathrm{z}$ besedotvornim pomenom časa, okoliščine kraja pa s pomenom mesta oziroma prostora. Modifikacijske izpeljanke torej ostajajo zunaj pretvorbene povezave s sestavinami propozicije; gre za lastnostno in količinsko pridevniško modifikacijo jedra (Vidovič Muha 2011: 97-98).

\subsection{Funkcijska obremenitev feminativnih priponskih obrazil po pomenskih skupinah}

Zanimala nas je funkcijska obremenitev priponskih obrazil, ki jih Toporišič (2004: 183) navaja pri tvorbi feminativov v slovenščini, po pomenskih skupinah. Gre za obrazila -a/-á, -ica/-íca, -ja, -ulja, -inja/-ínja, -ka, -ovka in -íčna. ${ }^{31}$ Obravnavane so tvorba samostalnika iz glagola, tvorba samostalnika iz pridevnika (oboje navadna izpeljava) in tvorba samostalnika iz samostalnika navadna in modifikacijska izpeljava. Pojavnost obrazil po šestih Toporišičevih pomenskih skupinah smo najprej preverili po Toporišičevi Slovenski slovnici (2004), nato pa še po Bajčevem Besedotvorju slovenskega jezika (1950).

31 Priponska obrazila $\mathrm{v}$ tem poglavju obravnavamo tako, kot jih navaja Toporišič; torej -ična, čeprav gre za dodajanje feminativnega obrazila -na k moškospolskemu izglasju na -(i)č, in -ovka, četudi gre za varianto obrazila $-k a$, torej $-(o v) k a$. 


\subsubsection{Izpeljava samostalnika iz glagola}

Preglednica 3: Funkcijska obremenitev feminativnih priponskih obrazil po pomenskih skupinah - izpeljava samostalnika iz glagola

\begin{tabular}{|c|c|c|c|c|c|c|c|c|c|c|c|c|}
\hline & \multicolumn{2}{|c|}{ Vršilec } & \multicolumn{2}{|c|}{ Vršilnik } & \multicolumn{2}{|c|}{ Dejanje } & \multicolumn{2}{|c|}{ Rezultat } & \multicolumn{2}{|c|}{ Mesto/Čas } & \multicolumn{2}{|c|}{ Snov } \\
\hline VIR & Toporišič & Bajec & Toporišič & Bajec & Toporišič & Bajec & Toporišič & Bajec & Toporišič & Bajec & Toporišič & Bajec \\
\hline$-a /-a ́$ & spaka & skaza & $\check{z} a g a$ & kosa & zapora & bera & postava & guba & I & I & sipa & $m e \check{s} a^{32}$ \\
\hline -ica/-íca & grabljica & dojica $^{33}$ & bodica & cvetica & I & omedlevica & I & I & I & / & / & I \\
\hline$-j a$ & vodja & gonja $^{34}$ & I & odeja & reja & hoja & izdaja & izdaja & staja & staja $^{35}$ & $/$ & $m e l j a^{36}$ \\
\hline$-u l j a$ & klepetulja & blebetulja & I & kopulja $^{37}$ & I & I & I & I & I & I & I & I \\
\hline -inja/-inja & dedinja & I & I & / & I & I & I & stopinja & I & kuhinja & I & I \\
\hline$-k a$ & I & dojka & zibka & pokrivka & I & bitka & I & spletka & I & vračka ${ }^{38}$ & I & polivka \\
\hline$-o v k a$ & I & I & I & I & I & I & I & I & I & I & I & I \\
\hline -ična & I & 1 & 1 & 1 & 1 & 1 & $/$ & I & 1 & 1 & 1 & 1 \\
\hline
\end{tabular}

32 Po Bajcu (1950: 8) iz glagola mešati v pomenu 'jed'.

${ }^{33}$ Po Bajcu (1950: 100) 'dojnica'.

${ }^{34}$ Po Bajcu (1950: 10) 'hotljiva ženska', iz glagola goniti.

${ }^{35}$ Po Bajcu (1950: 11) 'stanje, stajališče'.

${ }^{36}$ Po Bajcu (1950: 10) 'žito za mletje, moka'.

${ }^{37}$ Po Bajcu (1950: 36) 'motika'.

${ }^{38}$ Po Bajcu (1950: 93) 'proga med njivama, na kateri vračajo živino'. 
1. Obrazilo - $a$ je pri Toporišiču in Bajcu zastopano v pomenski skupini vršilec (spaka; skaza), pri čemer pri tovrstnih tvorjenkah opažamo stilno zaznamovanost, na kar opozarja tudi Irena Stramljič Breznik (1999a: 133), ki govori o okrepljeni slabšalnosti, saj se ti primeri nanašajo na moškega in žensko. Druge pomenske skupine so vršilnik (žaga; kosa), dejanje (zapora; bera), rezultat (postava; guba) in snov (sipa; meša).

2. Po Bajcu (1950: 100) »glagolskih izvedenk ni dosti«. Priponsko obrazilo -ica po obeh virih nastopi le v pomenskih skupinah vršilec (grabljica; dojica) in vršilnik (bodica; cvetica). Pri Bajcu se je obrazilo pojavilo tudi pri pomenski skupini dejanje (omedlevica).

3. Obrazilo -ja smo zasledili $\mathrm{v}$ obeh proučevanih virih pri naslednjih pomenskih skupinah: vršilec (vodja; gonja), dejanje (reja; hoja), rezultat (pri obeh izdaja) in mesto/čas (pri obeh staja). Bajec navaja tudi primere za pomenski skupini vršilnik (odeja) in snov (melja) ter ugotavlja, da izpeljanke iz glagola s tem obrazilom najpogosteje pomenijo glagolsko dejanje oz. osebo ali stvar, ki to dejanje opravlja (Bajec 1950: 11).

4. Priponsko obrazilo -ulja je pri Toporišiču in Bajcu zastopano v pomenski skupini vršilec (klepetulja; blebetulja), v Bajčevem Besedotvorju pa še v pomenski skupini vršilnik (kopulja). Toporišič (1973: 241) in Bajec (1950: 36) opažata slabšalnost $v$ pomenski skupini vršilec, kar potrjujejo njuni konkretni primeri.

5. Obrazilo -inja se pri Toporišiču pojavi v pomenski skupini vršilec (dedinja), pri Bajcu pa je mogoče najti primere izpeljank za pomenski skupini rezultat (stopinja) in mesto/čas (kuhinja).

6. Pri priponskem obrazilu $-k a$ je primerom $\mathrm{v}$ obeh proučevanih virih skupna le pomenska skupina vršilnik (zibka; pokrivka). V Toporišičevi Slovenski slovnici se obrazilo $-k a$ ne pojavi $\mathrm{v}$ nobeni drugi pomenski skupini, pri Bajcu pa najdemo primere kar v petih skupinah: vršilec (dojka), dejanje (bitka), rezultat (spletka), mesto/čas (vračka) in snov (polivka). Po Bajcu (1950: 93) so pri tem obrazilu »menda prvotna nomina acti«, številnejša nomina agentis in redka nomina actionis. 
7. Za obrazili -ovka in -ična noben proučevani vir ne navaja primerov za izglagolsko izpeljavo samostalnika.

Grafikon 1: Funkcijska obremenitev obrazil po pomenskih skupinah $v$ Toporišičevi Slovenski slovnici in Bajčevem Besedotvorju slovenskega jezika izpeljava samostalnika iz glagola

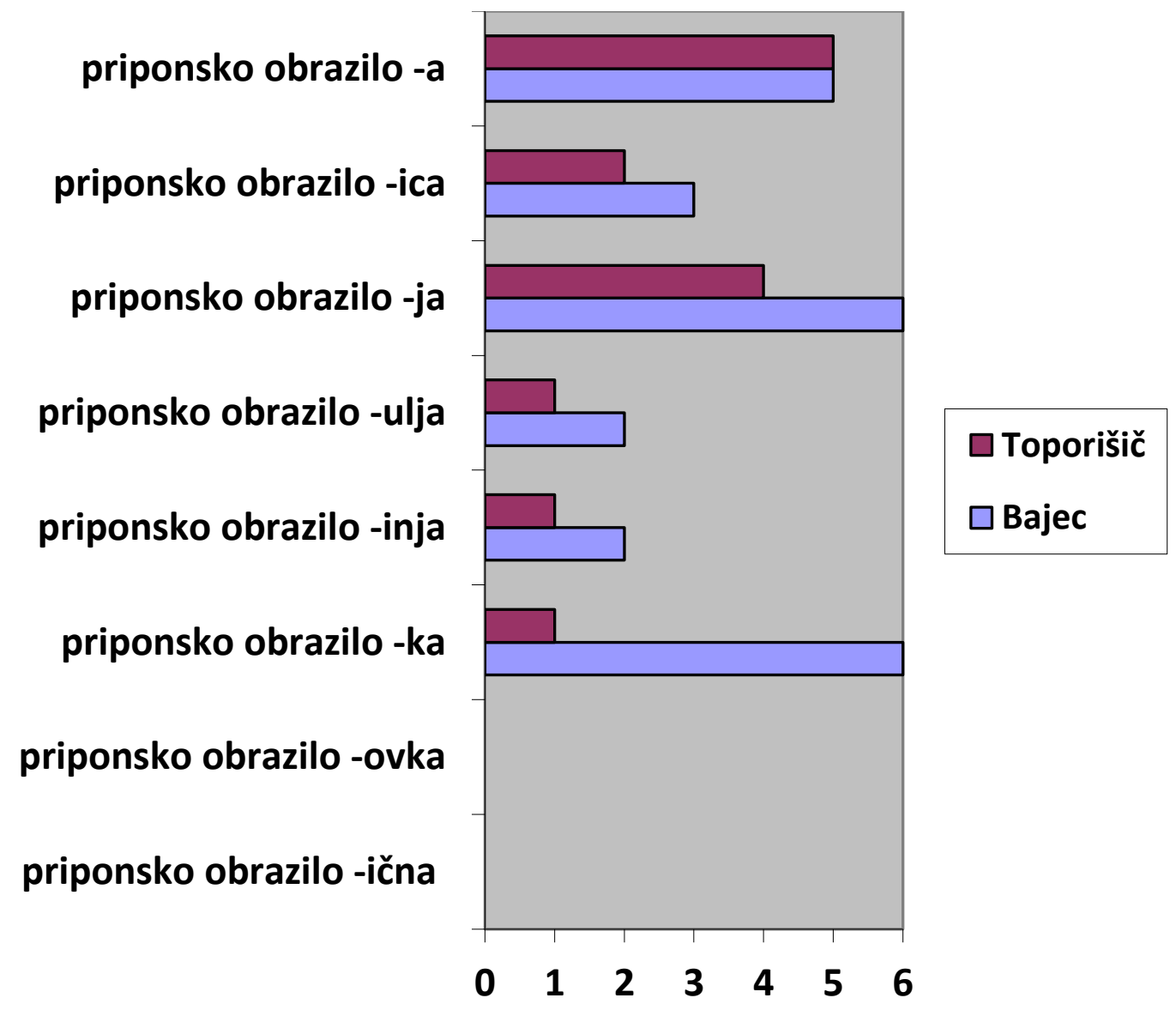

Iz zgornjega grafikona je razviden največji odmik pri priponskih obrazilih $-j a$ in $-k a$. Pri prvem je zastopanost obrazila pri Bajcu višja za dve pomenski skupini (vršilnik in snov), pri drugem pa kar za pet pomenskih skupin (vršilec, dejanje, rezultat, mesto/čas in snov). Opažamo še, da sta obrazili -ja in $-k a$ pri Bajcu zastopani v vseh šestih pomenskih skupinah, obrazili -ovka in -ična pa se ne pri Bajcu ne pri Toporišiču ne pojavita v nobeni skupini. 


\subsubsection{Izpeljava samostalnika iz pridevniške besede}

Preglednica 4: Funkcijska obremenitev feminativnih priponskih obrazil po pomenskih skupinah - izpeljava samostalnika iz pridevniške besede

\begin{tabular}{|c|c|c|c|c|c|c|c|c|c|c|c|c|}
\hline $\begin{array}{l}\text { POMENSKA } \\
\text { SKUPINA }\end{array}$ & & silec & & ilnik & Last & & $\begin{array}{r}\text { Konkr } \\
\text { las }\end{array}$ & $\begin{array}{l}\text { izirana } \\
\text { lost }\end{array}$ & Mes & /Čas & & ov \\
\hline VIR & Toporišič & Bajec & Toporišič & Bajec & Toporišič & Bajec & Toporišič & Bajec & Toporišič & Bajec & Toporišič & Bajec \\
\hline$-a /-a ́$ & dežurna & I & debela & I & aroganca & I & klasika & I & osnovna & I & I & I \\
\hline -ical-ica & ljubica & samica & mladica & leskovica ${ }^{39}$ & naglica & krivica & dnevnica & dnevnica & $\begin{array}{l}\text { čajnical } \\
\text { svečnica }\end{array}$ & temnica & deževnica & ilovica \\
\hline$-j a$ & I & I & I & I & suša & suša & / & I & prepadnja & gošča & I & tolšča \\
\hline -ulja & skopulja & črnulja & grenkulja & krivulja & I & I & I & I & I & I & I & I \\
\hline -inja/-inja & I & I & / & svetinja $^{40}$ & I & blaginja & I & I & I & pustinja & I & I \\
\hline$-k a$ & sivka & krmljenka $^{41}$ & fižolovka & pisanka & 1 & I & I & I & I & jutrenjka ${ }^{42}$ & ilovka & prežganka \\
\hline -ovka & I & I & I & I & I & I & I & I & I & I & I & I \\
\hline -ična & $/$ & 1 & I & I & I & 1 & 1 & I & I & I & 1 & I \\
\hline
\end{tabular}

${ }^{39}$ Po Bajcu (1950: 103) 'šiba'.

${ }^{40}$ Po Bajcu (1950: 47) lahko pomeni 'svetnico, posvečeno stvar, svetišče'.

${ }^{41}$ Po Bajcu (1950: 93) 'pitana svinja'.

42 Po Bajcu (1950: 94) 'dopoldan'. 
1. Priponsko obrazilo - $a$ zasledimo le pri Toporišiču za pomenske skupine nosilec (dežurna), nosilnik (debela), lastnost (aroganca), konkretizirana lastnost (klasika) in mesto/čas (osnovna).

2. Bajec (1950: 100) pravi, da je -ica »ena najpogostejših in najtvornejših slovenskih pripon«, kar dokazuje pojavnost v obeh virih, saj je zastopana v vseh pomenskih skupinah: nosilec (ljubica; samica), nosilnik (mladica; leskovica), lastnost (naglica; krivica), konkretizirana lastnost (oboje dnevnica), mesto/čas (čajnica/svečnica; temnica), snov (deževnica; ilovica).

3. Priponsko obrazilo -ja oba vira navajata pri pomenskih skupinah lastnost (v obeh suša) in mesto/čas (prepadnja; gošča), pri Bajcu pa najdemo še primer za pomensko skupino snov (tolšča).

4. Obrazilo -ulja se $\mathrm{v}$ obeh virih pojavi pri pomenskih skupinah nosilec (skopulja; črnulja) in nosilnik (grenkulja; krivulja). Irena Stramljič Breznik (1994: 34, 65) opaža tipično slabšalnost, kadar to obrazilo zaznamuje žensko; to potrjujejo iz obeh virov izpisani primeri; ob podspolski kategoriji neživo so tovrstne tvorjenke slogovno nezaznamovane.

5. Za priponsko obrazilo -inja navaja primere zgolj Bajec, in to za pomenske skupine nosilnik (svetinja), lastnost (blaginja) in mesto/čas (pustinja).

6. Obrazilo $-k a$ je pri obeh virih produktivno za pomenske skupine nosilec (sivka; krmljenka), nosilnik (fižolovka; pisanka) in snov (ilovka; prežganka), pri Bajcu pa še za pomensko skupino mesto/čas (jutrenjka).

7. Priponski obrazili -ovka in -ična tudi pri izpeljavi samostalnikov iz pridevniških besed ne nastopita $\mathrm{v}$ nobeni pomenski skupini $\mathrm{v}$ nobenem proučevanem viru. 
Grafikon 2: Funkcijska obremenitev obrazil po pomenskih skupinah $v$ Toporišičevi Slovenski slovnici in Bajčevem Besedotvorju slovenskega jezika izpeljava samostalnika iz pridevniške besede

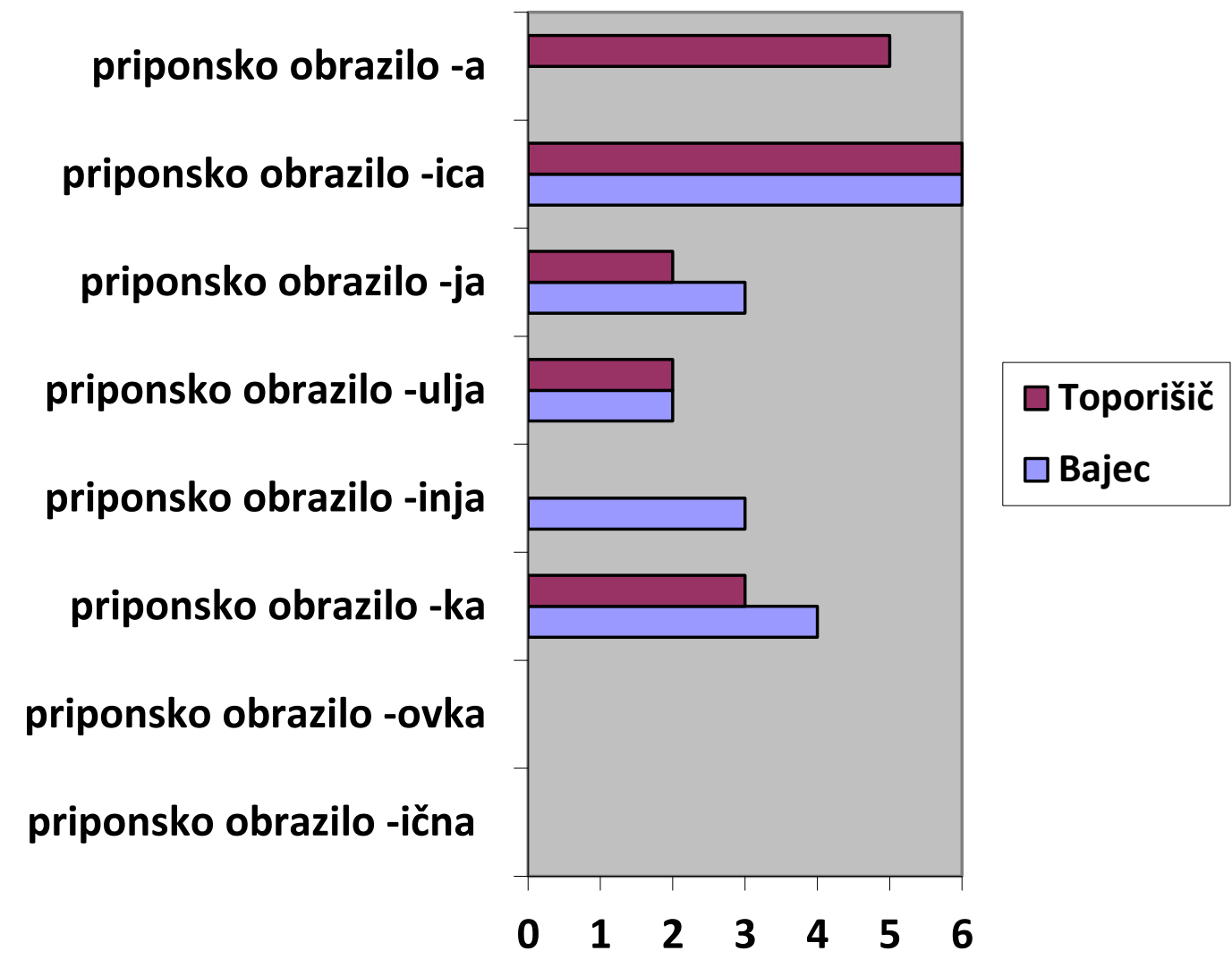

Zgornji grafikon kaže razliko $\mathrm{v}$ funkcijski obremenitvi po pomenskih skupinah pri priponskih obrazilih $-a$ (v korist Toporišičeve slovnice za pet pomenskih skupin) ter $-j a$ in $-k a$ (v korist Bajčevega Besedotvorja slovenskega jezika, pri vsakem obrazilu za eno pomensko skupino). Ugotavljamo tudi, da je priponsko obrazilo -ica po obeh virih zastopano $\mathrm{v}$ vseh šestih pomenskih skupinah, medtem ko se -ovka in -ična ne pojavita v nobeni. Priponska obrazila ženskega spola so v pomenski skupini za nosilca lastnosti manj pogosta prav zato, ker je večina tvorjenk po nastanku samo ženska vzporednica tvorjenkam moškega spola - feminativ. Tako so te tvorjenke samostojnopomenske in so $\mathrm{v}$ glavnem dveh vrst: a) vezane na biološko tipične lastnosti ženskih človeških bitij; b) žensko živalsko bitje - strokovni termini (sivka, krmljenka) (Stramljič Breznik 1994: 23). 


\subsubsection{Izpeljava samostalnika iz samostalnika}

\subsubsection{Navadna izpeljava}

Preglednica 5: Funkcijska obremenitev feminativnih priponskih obrazil po pomenskih skupinah - izpeljava samostalnika iz samostalnika, navadna izpeljava

\begin{tabular}{|c|c|c|c|c|c|c|c|c|c|c|c|c|c|c|c|c|c|c|}
\hline $\begin{array}{l}\text { POMENSKA } \\
\text { SKUPINA }\end{array}$ & \multicolumn{2}{|c|}{ Opravkar } & \multicolumn{2}{|c|}{ Prebivalec } & \multicolumn{2}{|c|}{ Član ali ud } & \multicolumn{2}{|c|}{$\begin{array}{c}\text { Nosilec } \\
\text { značilnosti }\end{array}$} & \multicolumn{2}{|c|}{ Opravljalnik } & \multicolumn{2}{|c|}{ Lastnost } & \multicolumn{2}{|c|}{$\begin{array}{c}\text { Konkretizirana } \\
\text { lastnost }\end{array}$} & \multicolumn{2}{|c|}{ Mesto/Čas } & \multicolumn{2}{|c|}{ Snov } \\
\hline VIR & T. & B. & T. & B. & T. & B. & T. & B. & T. & B. & T & B. & T & B. & T. & B. & T. & B. \\
\hline$-a /-\dot{a}$ & $/$ & 7 & 7 & 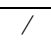 & $/$ & $/$ & 7 & $/$ & $/$ & 7 & 7 & 7 & 7 & 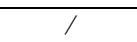 & sreda & $/$ & 7 & I \\
\hline$-i c a /-i c a$ & 7 & 7 & 7 & 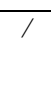 & 7 & 7 & 7 & $/$ & $\begin{array}{c}\text { bohori- } \\
\text { čica }\end{array}$ & krampica $^{43}$ & 7 & 7 & 7 & 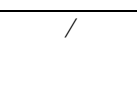 & apnica & gorica $^{44}$ & $/$ & drožica ${ }^{45}$ \\
\hline$-j a$ & 1 & $l i \check{s} a^{46}$ & $/$ & $/$ & $/$ & 1 & 7 & $/$ & $/$ & $d u \check{s} a$ & 7 & 7 & 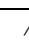 & 1 & $/$ & duplja $^{47}$ & $/$ & I \\
\hline$-u l j a$ & I & 1 & I & 1 & 1 & I & 1 & nosulja ${ }^{48}$ & / & košulja $^{49}$ & 1 & 1 & 7 & I & / & / & 1 & I \\
\hline -inja/-inja & $/$ & $/$ & 1 & 1 & klarisinja & 1 & 7 & $/$ & $/$ & črepinja & 7 & 7 & 7 & $\begin{array}{c}\text { milosti- } \\
\text { nja }^{50}\end{array}$ & 1 & 1 & I & 1 \\
\hline$-k a$ & štajerka & 1 & amaconka & 1 & $/$ & $\begin{array}{c}\text { magda- } \\
\text { lenka }\end{array}$ & 7 & liska & smučka & katarinka $^{5 I}$ & 7 & 1 & & $/$ & 1 & kletka & $/$ & I \\
\hline -ovka & / & / & grmovka & / & / & / & 7 & $/$ & / & / & 7 & 7 & 7 & / & $/$ & / & 1 & / \\
\hline -ićna & / & bratična $^{52}$ & I & I & $/$ & I & 1 & $/$ & $/$ & I & 7 & 1 & 7 & I & I & / & I & I \\
\hline
\end{tabular}

${ }^{43}$ Po Bajcu (1950: 103) 'rovnica', kar po SSKJ 1 pomeni 'orodje s ploskim, spodaj ravnim rezilom za kopanje'.

${ }^{44}$ Po Bajcu (1950: 101) 'vinograd, dvorišče pred hlevom'.

${ }^{45}$ Po Bajcu (1950: 101) 'hlebčki kvasa'.

${ }^{46}$ Po Bajcu (1950: 10) 'krava z liso'.

${ }^{47}$ Po Bajcu (1950: 10) 'duplo'.

48 Po Bajcu (1950: 36) 'ženska z velikim nosom'.

${ }^{49}$ Po Bajcu (1950: 36) 'vrsta koša'.

${ }^{50}$ Po Bajcu (1950: 47) 'miloščina'.

${ }^{51}$ Po Bajcu (1950: 94) 'sadje, zrelo ob godu tistega svetnika'.

52 Po Bajcu (1950: 40) 'bratova hči'. 
1. Priponsko obrazilo - $a$ je zastopano zgolj pri Toporišiču v pomenski skupini mesto/čas (sreda). Da je to obrazilo sicer v pomenski skupini opravkar zelo redko, opaža Irena Stramljič Breznik (1999a: 155), a tudi v drugih pomenskih skupinah ni zastopano.

2. Obrazilo -ica je pri obeh virih produktivno $\mathrm{v}$ pomenskih skupinah opravljalnik (bohoričica; krampica) in mesto/čas (apnica; gorica), pri Bajcu pa še v pomenski skupini snov (drožica).

3. Priponsko obrazilo -ja se je pri navadni izpeljavi samostalnika iz samostalnika izkazalo kot produktivno le pri Bajcu v pomenskih skupinah opravkar (liša), opravljalnik (duša) in mesto/čas (duplja).

4. Podobno kot za obrazilo -ja se je pokazalo tudi za priponsko obrazilo -ulja, ki je s primeri zastopano samo pri Bajcu, in to $\mathrm{v}$ pomenskih skupinah nosilec lastnosti (nosulja) in opravljalnik (košulja).

5. Obrazilo -inja se pri Toporišiču pojavi v pomenski skupini član ali ud (klarisinja), pri Bajcu pa v pomenskih skupinah opravljalnik (črepinja) in konkretizirana lastnost (milostinja).

6. Priponsko obrazilo - $k a$ je, upoštevajoč oba proučevana vira, produktivno v pomenski skupini opravljalnik (smučka; katarinka), samo pri Toporišiču v pomenskih skupinah opravkar (štajerka) in prebivalec (amaconka), pri Bajcu pa $\mathrm{v}$ pomenskih skupinah član ali ud (magdalenka), nosilec značilnosti (liska) in mesto/čas (kletka).

7. Obrazilo -ovka smo zasledili le pri Toporišiču v pomenski skupini prebivalec s primerom grmovka.

8. Drugače je pri priponskem obrazilu -ična, ki ga je mogoče najti le pri Bajcu s primerom za pomensko skupino opravkar (bratična). 
Grafikon 3: Funkcijska obremenitev obrazil po pomenskih skupinah $v$ Toporišičevi Slovenski slovnici in Bajčevem Besedotvorju slovenskega jezika tvorba samostalnika iz samostalnika (navadna izpeljava)

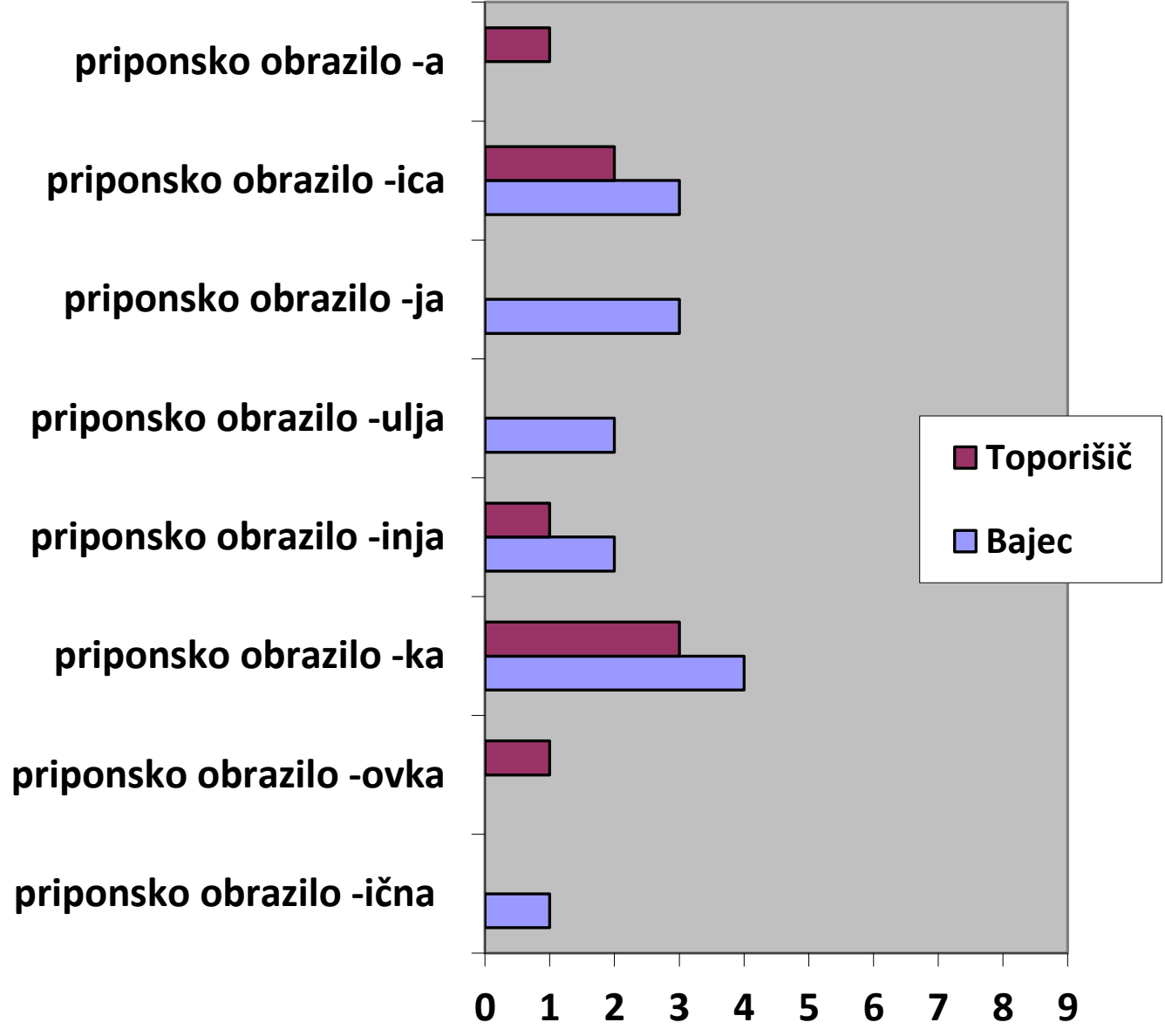

Zgornji grafikon kaže odstopanja med obema viroma pri produktivnosti več obrazil. Priponski obrazili - $a$ in -ovka nastopata v po eni pomenski skupini le pri Toporišiču, obrazili -ulja in -ična pa le pri Bajcu (-ulja $\mathrm{v}$ dveh pomenskih skupinah, -ična $\mathrm{v}$ eni). Priponska obrazila -ica, -inja in $-k a$ pa so $\mathrm{v}$ Bajčevem Besedotvorju slovenskega jezika zastopana $\mathrm{v}$ po eni pomenski skupini več kot $\mathrm{v}$ Toporišičevi Slovenski slovnici. 


\subsubsection{Inačenjska ali modifikacijska izpeljava}

Preglednica 6: Funkcijska obremenitev feminativnih priponskih obrazil po pomenskih skupinah - izpeljava samostalnika iz samostalnika, modifikacijska izpeljava

\begin{tabular}{|c|c|c|c|c|c|c|c|c|c|c|c|c|c|c|c|c|}
\hline $\begin{array}{l}\text { POMENSKA } \\
\text { SKUPINA }\end{array}$ & \multicolumn{2}{|c|}{ Feminativi } & \multicolumn{2}{|c|}{ Skupna imena } & \multicolumn{2}{|c|}{ Stopnjevanost } & \multicolumn{2}{|c|}{$\begin{array}{c}\text { Mladič, } \\
\text { nedoraslo }\end{array}$} & \multicolumn{2}{|c|}{ Manjšalno } & \multicolumn{2}{|c|}{$\begin{array}{l}\text { Ljubkovalno- } \\
\text { manjšalno }\end{array}$} & \multicolumn{2}{|c|}{ Slabšalnomanjšalno } & \multicolumn{2}{|c|}{ Slabšalno } \\
\hline VIR & Toporišič & Bajec & Toporišič & Bajec & T. & B. & T. & B. & Toporišič & Bajec & Toporišǐč & Bajec & T. & Bajec & T. & Bajec \\
\hline$-a /-\dot{a}$ & Franca & I & gospoda & I & I & 1 & I & 1 & I & I & I & I & I & I & Verona & 1 \\
\hline$-i c a /-i c a$ & тисіса & kraljica & I & I & 1 & 1 & telica & / & hišica & dušica & grdobica & račica & knjižica & I & 1 & 1 \\
\hline$-j a$ & županja & 1 & 1 & 1 & I & 1 & 1 & 1 & 1 & 1 & 1 & I & 1 & 1 & 1 & I \\
\hline- -ulja & volkulja & vragulja & 1 & lasulja & 1 & 1 & 1 & 1 & 1 & 1 & 1 & 1 & 1 & 1 & jezikulja & travulja $^{53}$ \\
\hline -inja/-ínja & grofinja & boginja & I & I & I & I & I & I & I & 1 & I & 1 & / & 1 & I & I \\
\hline$-k a$ & gostačka & ciganka & I & I & I & I & I & I & nogavička & nitka & devička & punčka & / & $k v a c ̌ k a^{54}$ & I & 1 \\
\hline$-o v k a$ & pekovka & I & I & I & I & I & I & I & I & 1 & 1 & I & I & I & I & I \\
\hline -íčna & grofična & kraljična & 1 & 1 & $/$ & 1 & 1 & 1 & 1 & 1 & 1 & 1 & 1 & 1 & 1 & 1 \\
\hline
\end{tabular}

${ }^{53}$ Po Bajcu (1950: 36) 'slaba trava'.

${ }^{54}$ Po Bajcu (1950: 94) iz kvaka, kar pomeni 'kljuka'. 
1. Priponsko obrazilo - $a$ je po Toporišiču zastopano v pomenskih skupinah feminativi (Franca), skupna imena (gospoda) in slabšalno (Verona). Pri Bajcu tovrstnih primerov nismo zasledili.

2. Obrazilo -ica najdemo pri obeh virih $\mathrm{v}$ pomenskih skupinah feminativi (mucica; kraljica), manjšalno (hišica; dušica), ljubkovalnomanjšalno (grdobica; račica), samo pri Toporišiču pa še v pomenskih skupinah mladič, nedoraslo (telica) in slabšalnomanjšalno (knjižica).

3. Priponsko obrazilo -ja se pojavi le pri Toporišiču pri modifikacijskih izpeljankah kot feminativ (županja).

4. Obrazilo -ulja oba vira navajata pri pomenskih skupinah feminativi (volkulja; vragulja) in snov (jezikulja; travulja), samo Bajec pa še v pomenski skupini skupno ime s primerom lasulja.

5. Priponsko obrazilo -inja $\mathrm{v}$ obeh proučevanih virih nastopa zgolj kot feminativ (grofinja; boginja).

6. Obrazilo $-k a$ se $\mathrm{v}$ obeh virih pojavi $\mathrm{v}$ pomenskih skupinah feminativi (gostačka; ciganka), manjšalno (nogavička; nitka), ljubkovalnomanjšalno (devička; punčka). Pri Bajcu pa je mogoče najti še primer za pomensko skupino slabšalnomanjšalno (kvačka).

7. Priponsko obrazilo -ovka navaja le Toporišič v Slovenski slovnici, in to pri feminativih (pekovka).

8. Tudi obrazilo -ična nastopa le kot feminativ, a v obeh proučevanih virih (grofična; kraljična). 
Grafikon 4: Funkcijska obremenitev obrazil po pomenskih skupinah $v$ Toporišičevi Slovenski slovnici in Bajčevem Besedotvorju slovenskega jezika tvorba samostalnika iz samostalnika (inačenjska ali modifikacijska izpeljava)

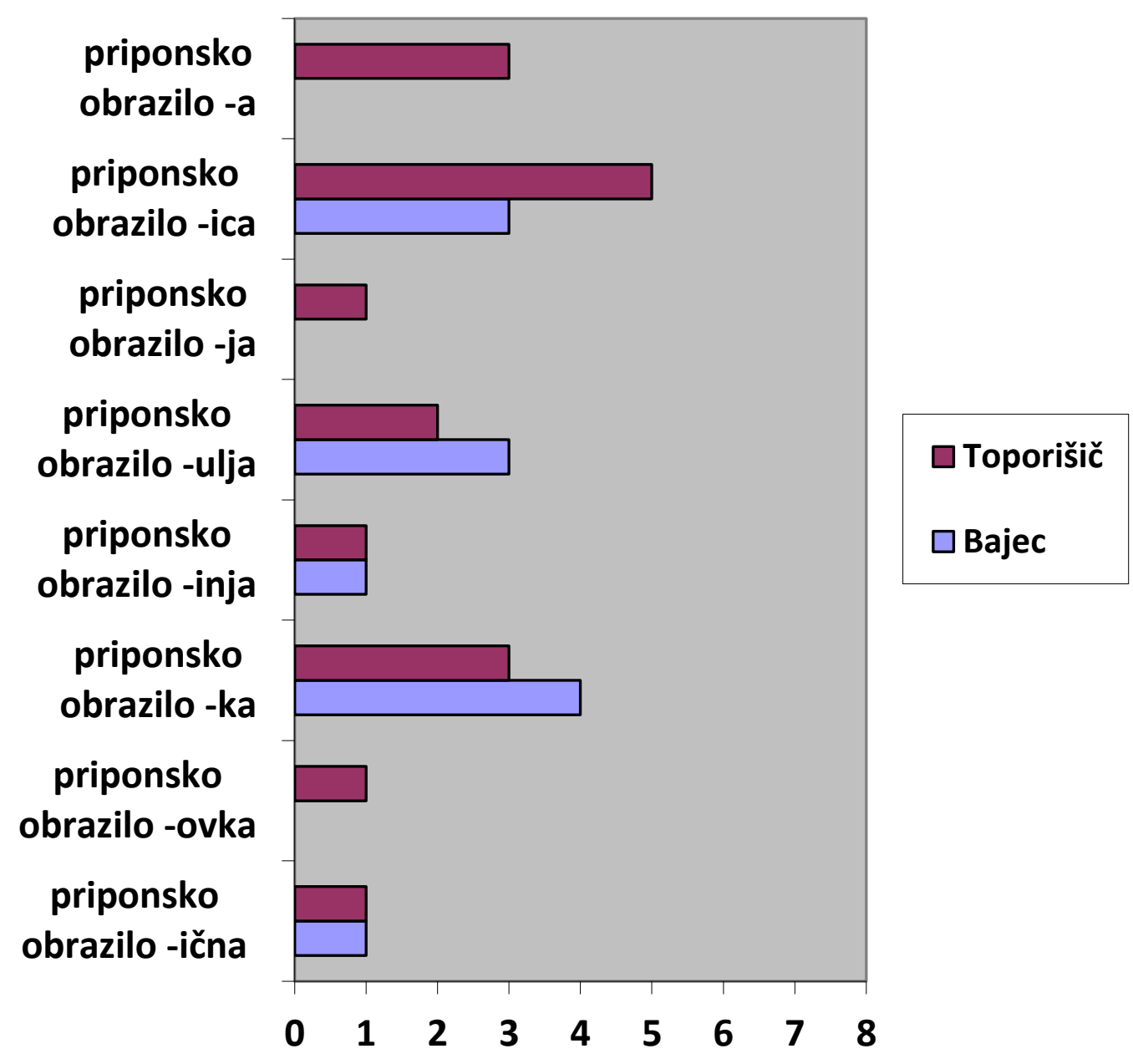

Opažamo, da se nekatera priponska obrazila pojavljajo zgolj pri Toporišiču: $-a \mathrm{v}$ treh pomenskih skupinah ter -ja in -ovka $\mathrm{v}$ po eni pomenski skupini. Razlike je mogoče zaznati tudi pri drugih obrazilih; tako je priponsko obrazilo -ica zastopano pri Toporišiču v petih pomenskih skupinah, pri Bajcu le v treh. Obratno se zgodi pri obrazilih -ulja in $-k a$, saj pri Bajcu najdemo po eno pomensko skupino več. 


\subsubsection{Skupni pregled}

Grafikon 5: Funkcijska obremenitev obrazil po pomenskih skupinah $v$ Toporišičevi Slovenski slovnici in Bajčevem Besedotvorju slovenskega jezika skupni pregled (tvorba samostalnika iz glagola, pridevniške besede in samostalnika - navadna in inačenjska ali modifikacijska izpeljava)

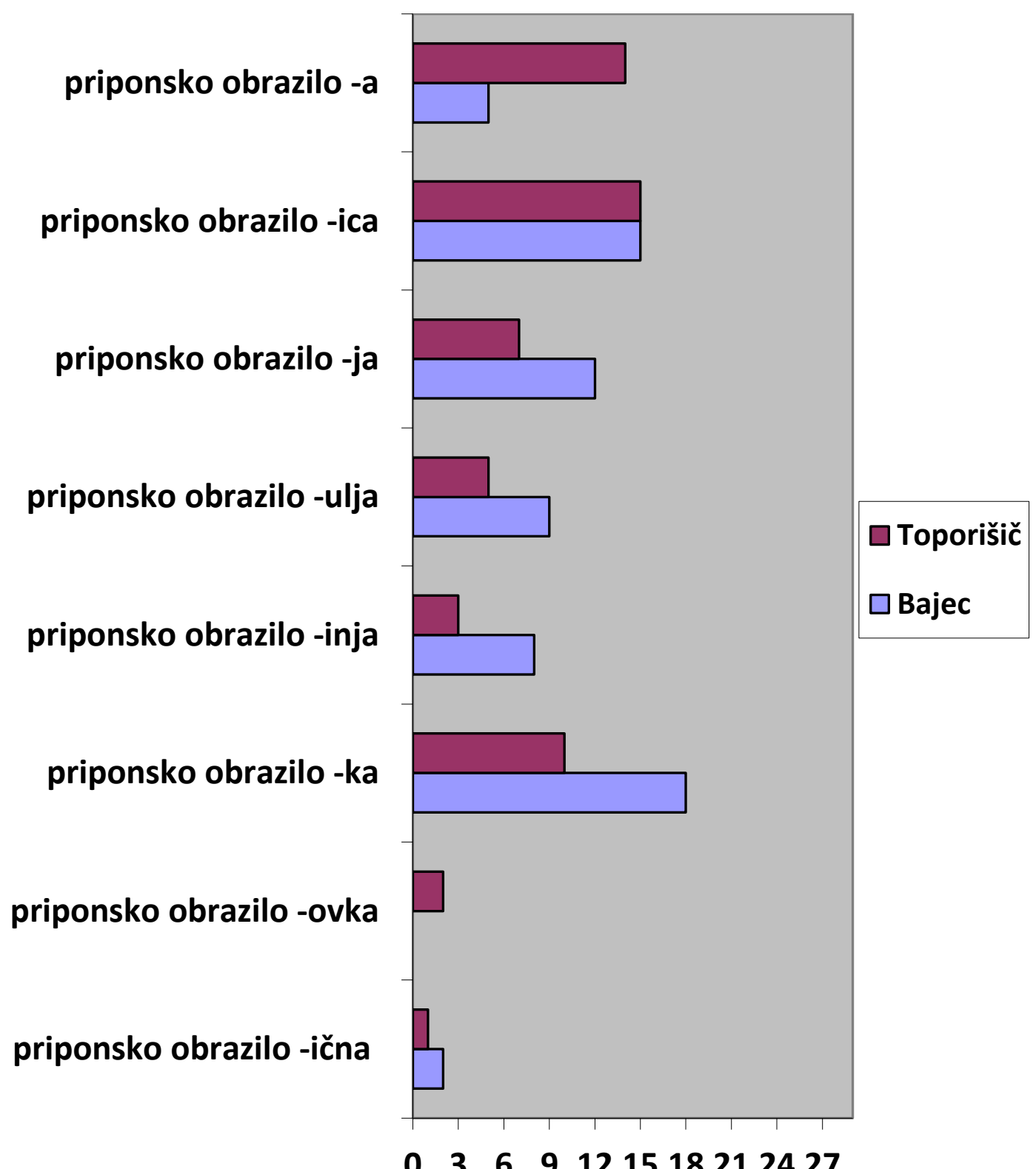

$\begin{array}{llllll}0 & 3 & 6 & 9 & 121518212427\end{array}$ 
Iz skupnega pregleda funkcijske obremenitve priponskih obrazil, ki po Toporišičevi Slovenski slovnici tvorijo feminative, je razvidno, da je sicer najbolj produktivno obrazilo - $k a$, ki po Bajcu nastopa kar v 18 pomenskih skupinah od skupno 27 (torej v 67 \%), po Toporišiču pa v 10 (37 \%). Kot izjemno produktivno se je izkazalo tudi priponsko obrazilo -ica, ki je zastopano, glede na oba proučevana vira, kar v 15 pomenskih skupinah (56 \%). Najmanj produktivni sta obrazili -ovka in -ična, ki v glavnem nastopata pri pomenski skupini feminativi.

\section{TVORBA FEMINATIVOV V SLOVANSKIH JEZIKIH}

Toporišič torej feminative obravnava kot modifikacijske izpeljanke. Ugotavljamo, da jih enako proučuje literatura drugih slovanskih jezikov. V vseh slovanskih jezikih je opazna tvorba ženskospolskih oblik za poimenovanja bitij feminativov; precej ustaljena je že v češkem in slovaškem jeziku, kjer je trdno zasidrana v jezikovnem sistemu. Priporočila za spolno razlikovanje v jeziku so vse pogostejša tudi v srbščini in hrvaščini. Drugače je v ruščini, kjer so bila še do nedavnega poimenovanja za duhovne poklice, nazive, prestižne družbene položaje izražena zgolj z moškospolskimi oblikami. Ženske so bile poimenovane $\mathrm{z}$ zvezami tipa ženska - državni tožilec, ženska - trener ipd. V sodobnem ruskem jeziku pa se tvorba feminativov, tudi s pritokom novotvorjenk, širi, s tem pa se veča število ženskospolskih poimenovanj oseb in priložnosti za njihovo uporabo. Enako velja za poljščino (zlasti novotvorjenke, npr. outsider - outsiderka, meteorolog - meteorolożka), ukrajinščino (поетка) in beloruščino (лаборантка) (Neščimenko 2003: 305-306).

\subsection{Vzhodnoslovanski jeziki}

\subsubsection{Ruski jezik}

V ruščini se samostalniki za osebe ženskega spola pretežno izpeljujejo iz ustreznih moškospolskih samostalnikov. Glavni feminativni priponski obrazili sta - $\kappa a$ in -uu̧a, ki se dodajata samostalnikom moškega spola ali zamenjujeta 
moškospolska priponska obrazila, pri čemer se -ка lahko razširi v -овка, -енка ali -анка. Kot manj produktivno Slovnica ruskega knjižnega jezika (1968: 96) navaja priponsko obrazilo -uxa, ki označuje ali ženski poklic ali ženo pripadnika kakšnega poklica. Samostalniki za ženske osebe $\mathrm{z}$ obrazilom -ua so pred oktobrsko revolucijo lahko pomenili samo ženo pripadnika kakega poklica, v sodobnem jeziku pa pomenijo žensko, ki opravlja ta poklic (Jakopin 1968: 9899). Po Zemski (2006: 262-268) samostalniki ženskega spola, nastali iz ustreznih samostalnikov moškega spola, označujejo živa bitja ženskega spola. Med samostalniki moškega in ženskega spola s pomenom osebe sta mogoči dve semantični zvezi:

- Uporaba samostalnikov moškega spola za poimenovanje moških, samostalnikov ženskega spola pa za poimenovanje žensk. Sem sodijo poimenovanja oseb glede na narodno pripadnost, kraj prebivanja ali rojstva (он коренной Москвич, она коренная Москвичка, Жаклин Франиуженка. Ni mogoče reči: Катя - Москвич ali Жаклин Француз). V tej skupini je semantična sestava samostalnikov moškega in ženskega spola enaka, to je Москвич 'prebivalec (ali domačin) Moskve' + 'moški'; Москвич + ка = 'prebivalec (ali domačin) Moskve' + 'ženska'.

- Samostalniki moškega spola imajo obči pomen in se lahko uporabljajo za poimenovanje moških in ženskih oseb; samostalniki ženskega spola se lahko uporabijo le za imenovanje žensk. Gre za poimenovanja poklicev, zaposlitev ... (учитель = 'poimenovanje osebe glede na dejavnost', учитель + ница $=$ 'poimenovanje osebe glede na dejavnost' + 'oseba ženskega spola').

Samostalniki ženskega spola so tvorjeni iz ustreznih samostalnikov moškega spola (za poimenovanje oseb) s pomočjo različnih priponskih obrazil. Tovrstna poimenovanja nastanejo na dva načina:

1. Dodajalni način tvorbe feminativov:

- Obrazilo -ица kot dodajalno tvori poimenovanja živali: тигр - тигрица, волк-волчица, орел-орлица. 
- Feminativno priponsko obrazilo -ница se dodaja izglasjem na -(me)л (учитель - учительница, писатель - писательница, председатель председательница).

- Priponsko obrazilo - uxa dodajamo k izglasjem na - $(\mu) u \kappa$, pri čemer pride do glasovne premene (дворник - дворничиха), in izglasjem na -(a)p (повар - повариха); tvori tudi ženskospolska poimenovanja živali: слонслониха, лебедь - лебедиха.

- Obrazilo -я se pojavlja ob izglasjih na -(y)н (певун - певуня, шалун шалуня).

- Feminativno obrazilo -ка je dodajalno k izglasjem na -(ен)m (студент студентка), -(е)р (пионер - пионерка), -(и)ч (Москвич-Москвичка), pojavi se lahko ob netvorjenih podstavah, zlasti pri poimenovanjih prebivalk (Швед - Шведка, Латыш - Латышка, Казах - Казашка), tvori tudi poimenovanja živali (голубь - голубка, глухарь - глухарка).

- Obrazilo -шиа nastopa ob izglasjih moškospolskih poimenovanj na -(o)p (кондуктор - кондукторша, доктор - докторша; v drugem primeru beseda lahko pomeni 'zdravnikova žena' ali 'zdravnica').

2. Zamenjevalni način tvorbe feminativov:

- Obrazilo -ица zamenja moškospolsko obrazilo -ец (красавец красавица, упрямец-упрямица).

- Priponsko obrazilo -чица lahko zamenjuje moškospolsko obrazilo -щчик (сортировщчик - сортировщчича, наладчик - наладчища, вуфетчик вуфетчииа).

- Feminativno priponsko obrazilo -ница oziroma -ица pa lahko zamenja obrazili -ник ali -ик (колхозник - колхозница, школьник - школьница, умник-умница).

- Obrazilo -ка zamenjuje priponski obrazili -ец in -ин (Литовец Литовка, Естонец - Естонка, комсомолец - комсомолка, Киевлянин - Киевлянка). 


\subsubsection{Beloruski jezik}

Beloruščina se je v (ne)rabi ženskospolskih oblik dolgo zgledovala po ruščini, zlasti med leti 1930 in 1950. Harbacki (2016: 7-15) o feminizaciji piše kot o uporabi ženskospolskih priponskih obrazil, zlasti za poimenovanja poklicev, funkcij, nazivov žensk ipd. Opozarja, da v pogovornem jeziku obstajajo številne feminativne oblike, niso pa uveljavljene $\mathrm{v}$ knjižnem jeziku; zavzema se za dosledno rabo feminativov. Za najpogostejši feminativni priponski obrazili $\mathrm{v}$ beloruskem jeziku veljata $\boldsymbol{- \kappa} \boldsymbol{a}$ in -iца . Feminativi so tudi po beloruski slovnici uvrščeni med modifikacijske izpeljanke, tvorjeni pa so lahko na dva načina:

1. Dodajalni način tvorbe feminativov:

- Kot kažejo primeri, je dodajalno feminativno obrazilo -ица (пэдагог пэдагогища, вірусоляг - вірусалягища).

- Tudi obrazilo -ница je dodajalno, in to k izglasju na -(це)ль (натхніцель - натхніцельнища, будзіцель - будзіцельнища).

- Priponsko obrazilo -ja dodajamo k izglasju moškospolskih poimenovanj

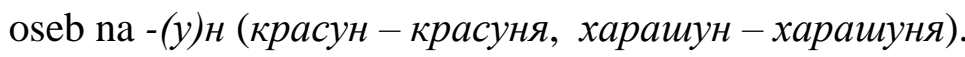

- Feminativno obrazilo -іня dodajamo $\mathrm{k}$ netvorjenim ali zloženim podstavam (граф - графіня, фатаграф - фатаграфіня). Obrazilo je lahko variantno $\mathrm{k}$ priponskemu obrazilu -циฺа (npr. акадэмица акадэміня).

- Kot dodajalno pa v glavnem nastopa priponsko obrazilo - $\kappa \boldsymbol{a}$, ki se dodaja $\mathrm{k}$ izglasjem moškospolskih samostalnikov na -ap (аптэкар - аптэкарка, лектар - лектарка), -(эн)m (студэнт - студэнтка) in -(іс)m (піяніст - піяністка).

- Dodajalno je še prevzeto obrazilo -эca/-eca (вікант - вікантэса, крытык - крытылкеса), ki se pojavlja tudi kot variantno k feminativnemu obrazilu -ка (npr. вікантэса - вікантка).

2. Zamenjevalni način tvorbe feminativov: 
- Obrazilo -iц̧a zamenja moškospolsko obrazilo -iк (настаунік настауніияа).

- Priponsko obrazilo -ница pa zamenjuje moškospolsko priponsko obrazilo -ник (будаўник - будаўница, чарайник - чараўница).

- Feminativno obrazilo -ка zamenjuje obrazilo -ец (Амерыканец Амерыканка).

\subsubsection{Ukrajinski jezik}

Tudi v ukrajinščini narašča število ženskospolskih poimenovanj oseb, tvorjenih iz vzporednih moškospolskih samostalnikov. Feminativi so tvorjeni s priponskimi obrazili -иця, -ниця, -ка, -ивка in -иня (поетка, членкиня) (Jermolenko 1999: 238). To je razvidno tudi iz pregleda zastopanosti feminativov v jezikovnih priročnikih, v glavnem slovarjih ukrajinskega jezika, kot ga je pripravila Arhangelska (2014: 58-70). Tudi ona opaža, da so feminativi stalnica v pogovornem jeziku, ne pa tudi v knjižnem. Iz primerov, ki jih navaja, je razvidna tvorba feminativov na oba možna načina.

1. Dodajalni način tvorbe feminativov:

- Obrazilo -ниця dodajamo moškospolskim samostalnikom na -(a)p (друкар - друкарниця) in na -(o)s (виртуоs - виртуозниця).

- Priponsko obrazilo -ка se dodaja k izglasjem na -(a)ч (видповидач видповидачка, утикач - утикачка), -(а)р (архвар - архварка), -(е)р (кошкодер - кошкодерка), -(о)р (автор - авторка, актор - акторка), -(ан)m (дилетант - дилетантка, бенефициант - бенефициантка), -(ен)m (пациент - пациентка), -(ис)m (телеграфист телеграфистка, арфист - арфистка), -(те)л (вихователька), -(о)н (шпион - шпионка), -(о)s (виртуоs - виртуокка). Pri dodajanju k izglasju $-(н и) \kappa$ pride do glasovne premene $k \mathrm{v} \check{c}$ (беллюдник беллюдничка). 
2. Zamenjevalni način tvorbe feminativov:

- Priponsko obrazilo -иця zamenjuje moškospolsko priponsko obrazilo -aч (видавач-видавичя).

- Feminativno obrazilo -ниця zamenjuje moškospolski priponski obrazili -ач (видавач - видавниця, доглядач - доглядниия) in -тел (виховател виховниця).

Avtorica opozori tudi na pojavnost tekmovalnih/konkurenčnih

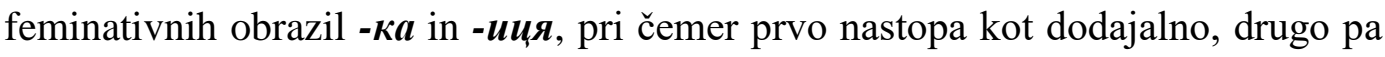
kot zamenjevalno (видавачка - видавиия), kot dodajalni pa sta variantni obrazili -ка in -ниця (друкарниця - друкарка). Opažamo tudi možnost izlastnoimenske tvorbe ob primeru Американець - Американка.

\subsection{Zahodnoslovanski jeziki}

\subsection{1 Češki jezik}

V češčini so feminativi obravnavani kot modifikacijske izpeljanke. Definirani so kot poimenovanja ženskih oseb, tvorjena iz moškospolskih. V glavnem gre za poimenovanja oseb (nekaterim moškospolskim poimenovanjem ni mogoče najti ustrezne ženskospolske vzporednice, na primer chytrak, milaček 'ljubljenec, ljubček'), manj za poimenovanja živali (ženskospolskih ustreznic večinoma ni za neudomačene živali - skřivan 'škrjanec', vrana 'vrana', kanĕ 'kanja'). Ženskospolska poimenovanja oseb so lahko občnoimenska (frezařka, zelinařka, soustružnice, jeřabnice, mladice, krasovice, bĕloška) ali lastnoimenska (prebivalke - Vesničanka, Pražanka). Dolgo so tovrstna poimenovanja označevala le soprogo (kovařka, majorka, učitelova). V tem pomenu se v sodobnem češkem jeziku tovrstna poimenovanja ne uporabljajo več. Obrazila, najproduktivnejša za

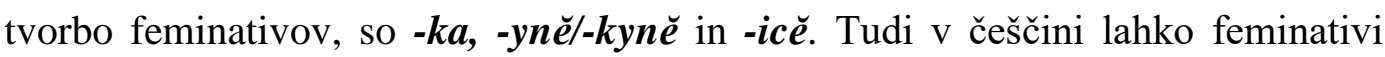
nastajajo na dva načina: 
1. Dodajalni način tvorbe feminativov:

- Feminativno obrazilo -ice je dodajalno zlasti pri tvorbi ženskospolskih poimenovanj za živali (holubice, medvĕdice, pavice, slonice, tygrice).

- Priponsko obrazilo - $k \boldsymbol{a}$ najpogosteje tvori feminative iz samostalnikov moškega spola na $-(a) k$ in $-(i) k$, pri čemer pride do palatalizacije: $k u \check{r} a c ̌ k a$, žebračka; botanička, pravnička. Obrazilo -ka se poleg navedenih lahko dodaja tudi $\mathrm{k}$ izglasjem na -(te)l (skladatelka, spisovatelka), -(a)č

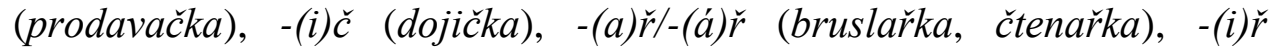
(kresliřka, maliřka), -(a)n (venkovanka, Slovanka), -(is)t (cyklistka, optimistka), -(en)t (absolventka, abonentka).

- Neproduktivno je priponsko obrazilo -na, saj se pojavi le pri primeru kněžna. Varianti -ovna in -ezna se pojavita pri tvorbi feminativov kralovna, cisařovna; princezna.

- Redko so občnoimenski feminativi tvorjeni s priponskim obrazilom -ova; $\mathrm{v}$ preteklosti je to obrazilo tvorilo poimenovanja soprog oseb, ki so opravljale določen poklic: učitelova, doktorova, tovarnikova. Vendar pa je priponsko obrazilo -ova zelo produktivno pri tvorbi priimkovnih feminativov (Novakova, Horačkova, Ditetova).

2. Zamenjevalni način tvorbe feminativov:

- Moškospolski obrazili -ik in -nik zamenjuje feminativno obrazilo -ice, ki je drugo najproduktivnejše feminativno obrazilo $\mathrm{v}$ češčini (mladice, zdravotnice; dělnice, čišnice, jeřabnice, soustružnice).

- Feminativno obrazilo $-\boldsymbol{k a}$ zamenjuje moškospolsko obrazilo $-(e) c$ (cvičenec - cvičenka; mišenka, snoubenka, Japonka, Slovinka, Němka); ob primerih Slovak, Brňan so feminativi Slovenka, Brněnka izpeljani z varianto -enka, ki zamenja moškospolsko priponsko obrazilo -ak oz. -an.

- Zamenjevalno je tudi obrazilo -ynĕ/-kynĕ, ki tvori izključno feminative. Nastopa lahko kot konkurenčno obrazilo priponskega obrazila -ka: přitelka - pritelkynĕ, ctitelka - ctitelkynĕ. Pri tem ima prednost obrazilo -ynĕ, kadar se samostalnik moškega spola konča na -g: chirurgynĕ, dramaturgynĕ. 
Varianta -kynĕ se uporablja pri tvorbi feminativov iz samostalnikov moškega spola na -ce (spravkyně, obhajkyně) in -ec (lovkyně, plavkyně) (Mluvnice češtiny 1986: 304-307).

Mluvnice češtiny (1986: 308) pa nasprotni pojav, tvorbo maskulinativov, obravnava kot obrobno. Etimologija odkriva tovrstno tvorbo pri primerih kmotr, manžel iz ženskospolskih oblik kmotra 'botra', manželka 'soproga'. Jasna pa je izpeljava moškospolskih oblik iz samostalnikov ženskega spola v primerih vdova - vdovec, srna - srnec, opice - opičak, žaba-žabak, veverka - veverčak, labut' labut'ak; redko je moškospolsko priponsko obrazilo -er: husa - houser, kača kačer.

\subsubsection{Slovaški jezik}

V slovaščini so feminativi prav tako definirani kot vrsta modifikacijskih izpeljank (lekarka, filologička, plavkyňa) (Furdik 2004: 85). Sokolova (2007: 2628) kot najproduktivnejša feminativna priponska obrazila v slovaščini označuje -ka (absolventka, cyklistka, mliekarka, choreografka, kapitánka, občianka, učitel'ka, speváčka, epileptička, družka); -ička (chirurgička, filologička); -yn̆a (sudkyn̆a, otrokyňa); -ica (chovanica, snúbenica, zverenica, samopašnica, klebetnica). Manj produktivna so obrazila -iná, -ovná, -ezná, -ná (švagriná, gazdiná, královná, princezná, šlachtičná), zelo redka pa -aňa, -era, -anda (hlupaňa, chudera, fešanda). Tudi v slovaščini se pojavljajo variantna ali konkurenčna obrazila, npr. domovnica/domovnička, chovanica/chovanka, chudera/chuderka, tanečnica/tanečnička, zverenica/zverenka. Opažamo, da so feminativi znova tvorjeni z dodajalnim oz. zamenjevalnim načinom.

1. Dodajalni način tvorbe feminativov:

- Feminativno obrazilo $-\boldsymbol{k} \boldsymbol{a}$ se dodaja $\mathrm{k}$ izglasjem moškospolskih samostalnikov na -(a)k: spevak - spevačka; -(i)k: kmotrik - kmotrička, pracovník - pracovnička, právnik - právnička, pri čemer pride do 
glasovne premene; -(a)r (mliekar - mliekarka); -(en)t (absolvent absolventka); -(is)t (cyklist - cyklistka). Za najpomembnejšo pa velja varianta -ička, ki tvori feminative iz prevzetih moškospolskih samostalnikov z izglasjem $-g$ (chirurg $\rightarrow$ chirurgicka, filolog $\rightarrow$ filologička).

- Dodajalno je obrazilo -ina, ki v slovaščini poleg nazivov (gazdiná) označuje tudi sorodstvo (švagriná).

- Obrazilo -(k)yйa se lahko dodaja izglasjem na -k, -g, -h (otrok - otrokyňa, kolega - kolegyňa, vrah-vrahyňa).

- Priponsko obrazilo -ova kot dodajalno lahko označuje dvoje, npr. majstrová 1. 'mojstrova žena', 2. 'lastnica delavnice'.

2. Zamenjevalni način tvorbe feminativov:

- Precej redko pri tvorbi feminativov je v slovaščini obrazilo -(n)ica, zamenjuje pa moškospolsko priponsko obrazilo -nik (šikovník-šikovnica, čarodejník - čarodejnica) ali -ec (snúbenec - snúbenica, chovanec chovanica).

- Zamenjevalno je tudi feminativno obrazilo $-\boldsymbol{k a}$ ob moškospolskem priponskem obrazilu -ec, npr. chovanec $\rightarrow$ chovanka, birmovanec $\rightarrow$ birmovanka.

- Za produktivnejše velja priponsko obrazilo -(k)yn̆a, ki zamenjuje moškospolski priponski obrazili -ca (obhajca - obhajkyňa, predchodca predchodkyn̆a, spravodajca - spravodajkyn̆a) in -ec (plavec - plavkyn̆a, predchodca - predchodkyňa), pri čemer prihaja do soglasniških premen ( $c$ $\rightarrow k)$.

- Obrazili -an̆a in -ena pa sta redki (babrák-babran̆a, starec-starena).

\subsubsection{Poljski jezik}

Tudi v poljskem jeziku so feminativi definirani kot ženskospolska poimenovanja, nastala iz moških z ustreznimi ženskospolskimi priponskimi 
obrazili. Feminative v poljščini je med drugim podrobneje raziskovala Paulina Pycia (2011: 98-105), ki kot najproduktivnejša priponska obrazila za tvorbo feminativov izpostavi -ka, -i(y)ni, -ica, kot redkejša pa -owa, -ina, -anka, -ówka, -essa; ohranjene so tudi oblike tipa pani magister, pani inżynier, pani Nowak. Feminativi v poljskem jeziku lahko nastajajo na dva načina:

1. Dodajalni način tvorbe feminativov:

- Obrazilo -a se druži s priponskimi obrazili -ny (chrzestny - chrzestna); -owy (księgowy - księgowa); -ski (spóźnialski - spóźnialska); -acy (przewodniczacy - przewodniczaca). Redkeje se obrazilo -a dodaja moškospolskim priponskim obrazilom -nik (bezwstydnik - bezwstydnica), -arz (spryciarz - spryciara), -och (pieszczoch - pieszczocha), -iś (strojniś - strojnisia). Zanimiv je primer minister - ministra, saj se po navadi $\mathrm{k}$ izglasjem na - $r$ dodaja priponsko obrazilo - $k a$ (denimo monter - monterka) (Grochowska, Wierzbicka 2015: 51).

- Drugo najpogostejše feminativno priponsko obrazilo je -(n)ica/-yca, ki nastopa kot dodajalno samo $\mathrm{k}$ izglasjem z -en: uczeń - uczennica.

- Najproduktivnejše je priponsko obrazilo - $k \boldsymbol{a}$ z variantami -anka (hrabia hrabianka), -atka (mąż - mężatka), -ówka (Żyd- Żydówka). Priponsko obrazilo $-k a$ se druži z naslednjimi moškospolskimi obrazili: -ik/-yk (chemik - chemiczka); -graf (geograf - geografka); -man (narkoman narkomanka); -er (kelner - kelnerka); -(a)tor (dyrektor - dyrektorka); -at (delegat - delegatka); -ata (akrobata - akrobatka); -ita/-yta (hipokryta hipokrytka); -ista (pacyfista - pacyfistka); -ant (gwarant - gwarantka); -ent (asystent - asystentka); -acz (podawacz - podawaczka); -ak (śpiewak - śpiewaczka); -czyk (olimpijczyk - olimpijka); -iciel/-yciel (donosiciel donosicielka); -nik (redko; osadnik - osadniczka). Tudi v poljščini pri tvorbi feminativov s - $k a$ prihaja do več glasovnih premen, pri dodajalnem načinu tvorbe gre v glavnem za premene soglasnikov: $k, g, c h \rightarrow c z, \dot{z}, s z$, npr. ważniak $\rightarrow$ ważniaczka, kierownik $\rightarrow$ kierowniczka, socjolog $\rightarrow$ socjolożka, filolog $\rightarrow$ filolożka. 
- Priponsko obrazilo -essa je le dodajalno in je prevzeto iz francoščine: baron-baronessa, patron - patronessa, poeta-poetessa.

- Obrazilo -owa tvori feminative, ki poimenujejo nazive ali položaje (cesarz - cesarzowa, doktor - doktorowa) in sorodstvene vezi (brat - bratowa, syn-synowa).

2. Zamenjevalni način tvorbe feminativov:

- Drugo najpogostejše obrazilo je -ica. Največkrat zamenjuje moškospolski obrazili -nik in -ec (pomocnik - pomocnica, robotnik - robotnica; siostrzeniec - siostrzenica).

- Obrazilo -ka zamenjuje moškospolsko obrazilo -ec (redko; cyrkowiec cyrkówka) ali -in (Amerykanin - Amerykanka).

- Zelo produktivno za tvorbo feminativov je priponsko obrazilo -ini/-yni, ki zamenjuje moškospolski priponski obrazili -ca (npr. dozorca-dozorczyni, pogromca - pogromczyni) in -ec (bywalec - bywalczyni, strzelec strzelczyni).

\subsection{Južnoslovanski jeziki}

4.3.1 Srbski jezik

Božo Ćorić (1982, povz. po Štebih Golub 2011: 43) modifikacijsko izpeljavo definira kot tvorbeni način določanja razlike v spolu kot sposobnost jezika za tvorbo poimenovanj bitij ženskega spola glede na poimenovanje moškega spola. Med t. i. mocijske sufikse pa ne sodijo tista priponska obrazila, ki označujejo ženo. Taki sta tudi sicer zelo produktivni feminativni obrazili -uц厶a in -ка (баниц̧а, цุариц̧а, кралјиц̧а, докторка), ki pa $\mathrm{v}$ navedenih primerih označujeta drugačen odnos med žensko in moškim. Tovrstni izrazi niso feminativi in jih ne moremo obravnavati kot modifikacijske izpeljanke; je pa veliko besed takih, ki lahko pomenijo zakonsko ženo ali žensko, ki opravlja neki poklic ali dejavnost (Ćorić 1982: 13). Med modifikacijske izpeljanke pa feminative prišteva tudi Ivan Klajn (2003: 9-10), pri čemer se sklicuje na Ćorića. Feminative definira 
kot poimenovanja za ženske osebe in živali, izpeljana iz moških, kot najpogostejša priponska obrazila pa navaja -ица, -ка, -ињa in -кињa. О feminativih pravi: »O modifikacijskih priponah imamo prvenstveno knjigo Boža Ćorića (1982) ob drugih delih, npr. Ćorić 1979, Matijašević 1970, Ristić 1983. Modifikacijske pripone so nekoliko blizu 'slovničnim', saj se vežejo na slovnični spol kot bistveno značilnost samostalnikov. Vedno odražajo naravni spol (монах 'menih' in монахиға 'nuna' sta dva leksema, ker označujeta dve različni bitji v stvarnem svetu) in se jim ne more oporekati status t. i. pravih pripon. Modifikacijske pripone po pravilu tvorijo žensko obliko iz moške (to so predvsem $-и ц а,-\kappa a,-и њ a,-\kappa и њ a)$, a pri tvorbi poimenovanj za živali je lahko smer tvorbe tudi obratna, npr. жабаu. Po zgledu Boškovića Ćorić (1982) razlikuje dva tipa modifikacijske izpeljave: integralno, kadar celotno poimenovanje osebe moškega spola preide v sestav ženskega poimenovanja (роб - робињ $a)$, in supletivno, pri kateri se moškospolsko obrazilo zamenja z ženskospolskim (npr. cmapau старица).« Ćorić (1982: 12) poimenovanja oseb deli v več podskupin: nomina agentis et professionis, nomina attributiva, nomina nationalia et regionalia, pripadniki socialnih skupin, govornih področij, sorodstvenih vezi ... Delitev seveda velja tudi za ženskospolska poimenovanja - feminative. Kot manj produktivna feminativna priponska obrazila pri Ćoriću (1982) zasledimo - $a$ (pri izglasju -(а)ч: правдач - правдача, хајкач - хајкача; ob izglasju -(а)p: редар редара, врачар - врачара), -уша (дјевер - дјеверуша, алат - алатуша) in -ja (рођак-рођача, луђак-луђача). Znova lahko govorimo o dveh načinih tvorbe:

1. Dodajalni način tvorbe feminativov:

- Priponsko obrazilo -ица je med produktivnejšimi. Dodaja se lahko netvorjenim podstavam (лав - лавица) ali takim z izglasjem na $-($ а)ч (играч - играчица), -(те)љ (пријатељ - пријатељица), -(а)к (тежактежачица), -(и)н (домађин - домађиница), -(а)р (цесар - цеесарица), -(а)ш (комедијаш - комедијашица).

- Priponsko obrazilo - ињa se dodaja nemotiviranim podstavam (ускок ускокињ $a)$ ali k izglasjem na -(а)к (селјак-селјакињ $a)$. Obrazilo nastopa zgolj kot dodajalno. 
- Obrazilo -киња se dodaja nemotiviranim samostalnikom moškega spola (цесар - цесаркиња).

- Obrazilo -ка je dodajalno $\mathrm{k}$ izglasjem na -тель (хранитељ хранитељка), -(и)ђ (стричевиђ - стричевиђка), -(а)н (муслиманка, клепртоманка), -(а)p, -(е)p, -(о)р (болничарка, фризерка, професорка).

Kot dodajalno je konkurenčno/vzporedno priponskemu obrazilu -uц̧a (лјубителка - лјубителјица), kadar gre za dodajanje k moškospolskemu obrazilu -mess.

2. Zamenjevalni način tvorbe feminativov:

- Priponsko obrazilo -ица zamenjuje moškospolska obrazila -au (caмau самица), -ак (рођак - рођица), -ик (ученик - ученица), -ник (радник радница), -ин (домађин - домађица), -иђ (племиђ - племица); redko nastopa $\mathrm{v}$ povezavi z drugimi priponskimi obrazili, npr. -ин (домађин домађица). Tudi pri zamenjevalnem načinu sta -иц̧a in $-\kappa a$ konkurenčni/vzporedni (злочиница - злочинка), podobno -иц̧а, -ка in -иња (племица - племка - племкиња).

- Priponsko obrazilo -кињa lahko zamenjuje moškospolska obrazila -au (поморач - поморкиња), -ник (коморник-коморкиња) in -ин (селјанин - селјанинкиња).

- Obrazilo -ка zamenjuje moškospolska obrazila -аи (Словенка, злочинка), -ин (варошанка, грађанка), -иђ (племиђ - племка), -ик (redki primeri: залјублјеник - залјублјенка); priponsko obrazilo -ак zamenjuje samo v primeru пасторка (Klajn 2003: 113-140, Ćorić 1982).

\subsubsection{Hrvaški jezik}

Eugenija Barić (1997: 304) s soavtorji Hrvatske gramatike govori o t. i. mocijski tvorbi, ki pomeni tvorbo samostalnikov enega spola iz samostalnikov drugega spola, pri čemer gre najpogosteje za tvorbo ženskospolskih samostalnikov iz moškospolskih (npr. direktor - direktorica, lav - lavica, zubar zubarica, redkeje obratno, npr. lisica - lisac, patka - patak, tetka-tetak), tovrstne 
dvojice pa poimenuje parni samostalniki. Stjepan Babić (1991, povz. po Mihajlević 2010: 192) definira feminative kot tvorjenke, ki pomenijo žensko bitje nasproti moškemu. Tovrstni izrazi označujejo interes, stalno ali priložnostno ukvarjanje s čim, nosilke funkcije ali lastnosti, pripadnice filozofskih smeri, vere, družbenega ali verskega združenja. Ob poimenovanjih tipa starac - starica ali tkalac - tkalja sta mogoči dve razlagi: prva, da so iz iste podstave z različnimi priponskimi obrazili izpeljani samostalniki $\mathrm{z}$ razliko $\mathrm{v}$ spolu, in druga, da je poimenovanje za žensko osebo izpeljano iz podstave poimenovanja za moško osebo. Babić se bolj nagiba k drugi razlagi (Štebih Golub 2011: 2). Tako se torej tudi $\mathrm{v}$ hrvaščini pojavi podoben problem pojmovanja modifikacijskih izpeljank kot v slovenščini. Eugenija Barić (1987: 10, 1988: 43) namreč opozarja, da so poimenovanja za ženske osebe izpeljana neposredno iz poimenovanj za moške osebe samo v primeru dodajanja ženskospolskega obrazila tvorjenki moškega spola (car - carica, pletač - pletačica); kadar pa ženskospolsko priponsko obrazilo zamenja celotno moškospolsko obrazilo, gre za izpeljavo iz skupne osnovne besede (starac - starica; v tem primeru priponsko obrazilo -ica zamenja obrazilo - $a c$; gre za neposredno izpeljavo poimenovanja za žensko osebo starica iz pridevnika star in ne iz samostalnika starac). Če se pri poimenovanju ženske ohrani del moškospolskega obrazila, gre še zmeraj za neposredno tvorbo iz poimenovanja moškega spola (liječnik - liječnica, kjer se ohrani -n) (Barić 1988: 44). Kot drugo težavo pa izpostavi večpomenskost tvorjenk (obveznica kot oseba ali kot vrednostni papir). Priponska obrazila, s katerimi so $\mathrm{v}$ hrvaščini tvorjena poimenovanja ženskih oseb, so -a, -ača, -ica, -inja, -ka, -kinja, -lja, -ulja. Niso pa vsa našteta obrazila enako plodna: kot najfrekventnejše E. Barić (1987: 12, 1997: 310) izpostavlja priponsko obrazilo -ica, sledijo -ka, -inja in -kinja. Do podobnih ugotovitev sta prišla tudi Helmut Weinberger (2003: 173) in Barbara Štebih Golub (2011: 49). Weinberger primerja hrvaški in srbski jezik ter ugotavlja, da so $\mathrm{v}$ hrvaščini feminativi $\mathrm{v}$ glavnem tvorjeni $\mathrm{z}-i c a, \mathrm{v}$ srbščini pa $\mathrm{s}-k i n j a$ in $-k a$ (asistentica - asistentkinja, korespondentica - korespondentkinja, koristica koristkinja, profesorica - profesorka, studentica - studentkinja/studentka). Vedno pa v hrvaščini tvorba feminativov z -ica ni mogoča, če tvorjenka s tem priponskim obrazilom $\mathrm{v}$ jeziku že obstaja oz. je ustaljena; zato lahko feminativna 
poimenovanja nastajajo tudi s -kinja ali $-k a$ (npr. crnica pomeni 'vrsto črne zemlje', zato crnkinja; plavica pomeni 'skušo', zato plavka ipd.).

Barbara Štebih Golub (2011: 50-51) in Stjepan Babič (1991: 152-154, 256) delita tvorbo feminativov $\mathrm{v}$ hrvaščini glede na način:

1. Dodajalni način tvorbe feminativov:

- Priponsko obrazilo - $\boldsymbol{a}$ se tako dodaja samostalnikom moškega spola na -ø $($ kum - kuma $),-(a) \check{c}(i z m e t a c ̌-i z m e t a c ̌ a),-(e) k($ cucek - cucka $)$.

- Obrazilo -ača se dodaja netvorjenim podstavam (muž - mužača).

- Za priponsko obrazilo -ica je značilno dodajanje k samostalnikom

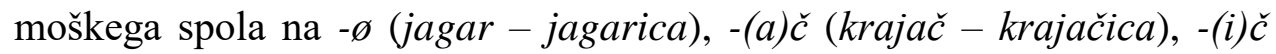
(ribič - ribičica), -(te)lj (obranitelj - obraniteljica), -(ite)l (mamitel mamitelica), -(a)r (čuvar - čuvarica), -(e)r (kelner - kelnerica), -(o)r (doktor - doktorica), -(a)̌̌ (citraš - citrašica), -(an)t (debitant debitantica), -(en)t (agent-agentica), -(is)t (artist-artistica).

- Obrazilo -čica lahko dodamo k -ø (prorok-proročica).

- Priponsko obrazilo -arica nastopa kot dodajalno $\mathrm{k}$ samostalnikom moškega spola na -ø (drugar - drugarica), sicer pa je po Babiću (1991: 178) to manj produktivno obrazilo.

- Priponsko obrazilo -inja se lahko dodaja moškospolskim samostalnikom na -ø (bog - boginja), -(a)k (mužak - mužakinja) in -(ja)k (prosjak prosjakinja).

- Obrazilo -kinja se dodaja samostalnikom moškega spola na -ø (soldat soldatkinja).

- Kot zelo produktivno se izkaže priponsko obrazilo $-\boldsymbol{k} \boldsymbol{a}$, ki se lahko dodaja k moškospolskim samostalnikom na -ø (fazan - fazanka), -(i)č (ribič ribička), -(̌̌a)n (Zagrepčan - Zagrepčanka), -(ja)n (seljan - seljanka), -(a)r (frinjar-frinjarka), -(i)š (lotriš - lotriška).

- Obrazilo -ina se dodaja zgolj samostalnikom na -(ja)k (rođak-rođakina).

- Obrazilo -iša dodajamo samo k -ø (prorok-prorokiša).

2. Zamenjevalni način tvorbe feminativov: 
- Obrazilo -čica zamenjuje moškospolsko obrazilo -avec (igravec igravčica).

- Priponsko obrazilo -ica zamenjuje moškospolska obrazila -ac (glumac glumica), -avec (bajavec-bajavica) in -ik (bolesnik-bolesnica).

- Obrazilo -ka lahko zamenjuje moškospolska obrazila -ac (brodolomac brodolomka), -alec (strugalec - strugalka), -anec (Indijanec - Indijanka), -inec (Dalmatinec - Dalmatinka), -avec (bajavec - bajavka), -in (kršćanin - kršćanka), -janik (dvorjanik-dvorjanka) (Babić 1991: 152-154, 256).

\subsubsection{Makedonski jezik}

Kiril Koneski (2003: 65-67) prav tako uvršča feminative med modifikacijske izpeljanke. Definira jih kot poimenovanja oseb (redko živali) ženskega spola, izpeljana iz primernih poimenovanj za osebe moškega spola. Pri tem so lahko tvorjene iz netvorjenk (крал, лав) ali izpeljank (учител, работник); slednje najpogosteje poimenujejo vršilca dejavnosti ali nosilca lastnosti. Koneski opozarja tudi na izraze, ki označujejo osebe ženskega spola, vendar niso nastali iz moškospolskih vzporednic, temveč zanje obstajajo, podobno kot v slovenščini, posebna poimenovanja - мајка, сестра. Teh besed seveda ne štejemo $\mathrm{k}$ feminativom. Za feminative po Koneskem veljata dve pomenski razlagi: a) воспитувачка 'ženska воспитувач', pri čemer se ženskospolsko priponsko obrazilo samo doda samostalniku moškega spola, brez kakih drugih sprememb; tovrstna tvorba se lahko razume kot modifikacijska izpeljava; b) воспитувачка 'ženska, ki воспитува' - tovrstno tvorbo pa lahko smatramo tudi kot izglagolsko izpeljanko, torej tvorjeno neposredno iz glagola in ne iz moškospolske vzporednice. V nadaljevanju pravi, da druga interpretacija velja samo za ženskospolska poimenovanja, pri katerih tradicionalno moškospolska vzporednica ni mogoča (веsилка, наречница) ali pa to ni možno zaradi naravnih vzrokov (родилка, доилка), in če gre za tradicionalno ženske poklice oz. dejavnosti (чистачка). Zato se poimenovanja ženskih oseb, nastala iz primernih moškospolskih poimenovanj, obravnavajo kot modifikacijske izpeljanke. Izpostavi pa primer берберка kot ponazoritev večpomenskosti ('ženska berber' in 
'berberjeva žena'), kar je mogoče zaznati tudi $\mathrm{v}$ drugih slovanskih jezikih. Najpogostejša priponska obrazila za tvorbo feminativov v makedonskem jeziku so -ка, -инка, -ица, -(н)ица, -(н)ичка, in to $\mathrm{z}$ dodajalnim ali zamenjevalnim načinom.

1. Dodajalni način tvorbe feminativov:

- Priponsko obrazilo -ица tvori poimenovanja za živali (биволицุa, гулабица, лавища, соколища, слонища, врабица, sајачища) in osebe. Lahko nastopa kot dodajalno (грофиц̧а, божица, бароницุа, кралицุа, шефиияа); redko se pojavlja razširjena pripona - poleg namuu̧a tudi памовица.

- Priponsko obrazilo -ињa nastopi le v nekaj primerih (кнегиња, хероиња, монахиња), sicer pa je po Koneskem neproduktivno za tvorbo feminativov.

- S priponskim obrazilom $-\boldsymbol{\kappa} \boldsymbol{a}$ lahko tvorimo poimenovanja oseb in živali (мајмун - мајмунка). Obrazilo se najpogosteje dodaja osnovam, ki se končajo na soglasnik; pri tem lahko nastopijo glasovne premene na stiku osnove in priponskega obrazila (сосед - сосетка, близнак - близначка). Najpogosteje pa feminativi na - $\kappa a$ nastanejo z dodajanjem ženskospolskih priponskih obrazil poimenovanjem moških na $-(m e)$, $-(a) p,-(a)$ : претседателка, учителка, библиотекарка, гимнастичарка, продавачка. Z obrazilom -ка tvorimo tudi izpeljanke iz prevzetih besed спикерка, партнерка, шампионка, професорка, емигрантка, асистентка, пијанистка.

- Tudi pri obrazilu -(и)ичка gre za dodajanje priponskega obrazila $-\kappa a$ moškospolskim samostalnikom na $-(н) и \kappa(-н и \kappa+-\kappa a \rightarrow-н и ч к а$ s premeno $k \mathrm{v} c$ ). Koneski opozori tudi na variantna priponska obrazila (благајницаблагајничка; sаробенища - sаробеничка; придружнища придружничка), vendar je $\mathrm{v}$ makedonskem jeziku $\mathrm{v}$ vsakdanji rabi pogostejša oblika z - (н)ичка.

- Obrazilo -инка tvori manjše število feminativov: робинка, слугинка, Влаинка, Гркинка, Чехинка. 
2. Zamenjevalni način tvorbe feminativov:

- Priponsko obrazilo $-\boldsymbol{\kappa} \boldsymbol{a}$ zamenjuje moškospolska priponska obrazila $-и н$ (Бугарин - Бугарка), -ец (младинец - младинка, Македонеи Македонка) in - $а$ (судијка, војвотка).

- Tudi feminativno obrazilo -ица nastopa kot zamenjevalno, kadar nadomesti moškospolsko obrazilo -ец (вдовец - вдовица, самец самица, стареи - старица).

- Obrazilo -(н)ица lahko zamenjuje priponsko obrazilo -(н)ик: грешник грешница, предавник - предавница. Po Koneskem se tovrstna tvorba razume tudi kot dodajanje priponskega obrazila $-a \mathrm{k}$ moškospolskemu obrazilu $-(\mu) u \kappa$, pri čemer pride do glasovne premene $k \mathrm{v} c$.

\subsubsection{Bolgarski jezik}

Feminative v bolgarskem jeziku je proučevala Vasilka Radeva (1991: 153-154). Tudi v bolgarščini so ženskospolska poimenovanja bitij tvorjena iz moškospolskih, prav tako na dva načina: $\mathrm{z}$ dodajanem ženskospolskega priponskega obrazila samostalniku moškega spola (лекар - лекарка, пенсионер пенсионерка) ali $\mathrm{z}$ zamenjavo moškospolskega priponskega obrazila z Ženskospolskim (Арменец - Арменка, селянин - селянка). Ženskospolska poimenovanja oseb so navadno zastopana s pomensko razlago 'ženska, ki'. Feminativi so $\mathrm{v}$ bolgarskem jeziku tvorjeni s priponskimi obrazili -киня in -ица.

1. Dodajalni način tvorbe feminativov:

- Moškospolskemu samostalniku se lahko dodaja tudi priponsko obrazilo -ица (кмет - кметица, кум - кумица, крал - кралица, цуар - иุарица).

- Priponsko obrazilo -иня je dodajalno, v glavnem k netvorjenim podstavam (граф - графиня, Хериог - Херчогиня, роб - робиня).

- Feminativno obrazilo -киня nastopa kot dodajalno (царкиня, ратајиня). 
- Priponsko obrazilo -кa se dodaja samostalnikom moškega spola, ki se končajo na -(a)p (билкар - билкарка, sнахар - sнахарка), -(а)ч (кроячкроячка, продавач - продавачка), -(те)л (служител - служителка, управител - управителка), -(ис)m (артист - астистка, журналист журналистка), -(ан)m (дипломант - дипломантка, лаборант лаборантка), -(ен)m (асистент - асистентка, абсолвент абсолвентка, штудент - штудентка), -(е)p/-(ие)p (касиер касиерка, моделиер - моделиерка), -(o)p/-(то)р (коректор коректорка, редактор - редакторка). Kadar se moškospolski samostalnik konča na izglasje $-\kappa$, pride do glasovne premene $-k \mathrm{v}-\check{c}:-(a) \kappa$ (дебелак - дебелачка, добряк - добрячка), -(u)к (историк историчка, хитик - хитичка), -(ови)к (кадровик - кадровичка, плановик - плановичка), -(ни)к (ударник - ударничка, уредник уредничка). С̆e pa se moškospolski samostalnik konča z izglasjem -g, pride do glasovne premene $-g$ v -ž (биолог - биоложка, педагог педагожка, психолог - психоложка).

2. Zamenjevalni način tvorbe feminativov:

- Priponsko obrazilo -ка zamenjuje moškospolski obrazili -ец (Арменец Арменка, Германеи - Германка, Африканец - Африканка) in -ин (гражданин - гражданка, селянин-селянка).

- Zamenjevalno je tudi obrazilo -иня (слуга - слугиня).

- Feminativno obrazilo -киня zamenjuje moškospolski priponski obrazili -ец (борец - боркиня, Немец - Немкиня) in -ин (Русин - Рускиня, Турчин-Туркиня).

- Priponsko obrazilo -ица lahko zamenja obrazili -ец in -ик (певец певица, храненик-храненица).

\subsection{Sklep}

Ugotavljamo, da ob slovnični nezaznamovanosti moškega spola tvorba in raba feminativov vedno bolj, čeprav $\mathrm{v}$ nekaterih jezikih počasneje in $\mathrm{z}$ veliko 
ovirami, vstopata $\mathrm{v}$ slovanski jezikovni prostor. Znanstvena literatura drugih slovanskih jezikov feminative obravnava kot modifikacijske izpeljanke in omenja dva načina tvorbe: $\mathrm{z}$ dodajanjem ženskospolskega obrazila tvorjenkam moškega spola in z zamenjavo celotnega ali le izglasnega dela moškospolskega obrazila z ženskospolskim ob isti podstavi. Nekateri slovenski jezikoslovci sicer pri zamenjevalnem načinu vidijo očitno podrejanje tvorbe poimenovanj za ženske osebe poimenovanjem za moške - take tvorjenke je mogoče razumeti kot navadne izpeljanke. Na to opozarja Irena Stramljič Breznik (2004), ki se sklicuje na Vidovič Muho (1997, 2003); mnenja glede tega so deljena tudi v nekaterih drugih slovanskih jezikih (npr. Barić 1987, Mihajlević in Štebih Golub 2010). V različnih slovanskih jezikih opažamo tudi pojav t. i. variantnih ali konkurenčnih obrazil ter izobčno- in izlastnoimenske tvorbe. Kot najproduktivnejši feminativni priponski obrazili pa se v prav vseh slovanskih jezikih kažeta -ica in -ka z variantami.

\section{ZGODOVINSKI PREGLED DISTRIBUCIJE FEMINATIVNIH PRIPONSKIH OBRAZIL V SLOVENŠČINI}

\subsection{V slovnicah od Bohoričeve (1584) do Toporišičeve (2004)}

Slovnice kot jezikovna znanstvena oz. strokovna dela obravnavajo slovenski jezikovni sistem. Ob temeljnih slovniških delih priročniške narave in pisanih z znanstvenoraziskovalnega vidika so se zlasti od 2. polovice 19. stoletja za osnovno in srednje šolstvo pisale tudi učbeniške slovnice, ki so upoštevale jezikoslovna načela temeljnih slovnic (Vidovič Muha 1998: 79). Ada Vidovič Muha (1988: 33-51) nadalje ugotavlja, da so se vprašanja, povezana $z$ besedotvorjem $\mathrm{v}$ slovenskem jeziku, v zgodovini obravnavala $\mathrm{v}$ treh obdobjih:

1. Obdobje slovensko-nemške normativne protistave: traja od Vodnikove slovnice 1811 do Miklošičeve Primerjalne slovnice slovanskih jezikov.

2. Oblikoslovno-pomensko (analitično) obdobje: zaznamuje ga Miklošič, na njegovi teoriji pa kasneje gradita Anton Breznik in Anton Bajec. 
3. Skladenjskopomensko (sintetično) obdobje: začne se pozno, z razpravo Jožeta Toporišiča Besedotvorna teorija in s poglavji o besedotvorju v njegovi Slovenski slovnici.

Drugače, neodvisno od besedotvorne jezikovne ravnine, je slovnice klasificirala Jana Zemljarič Miklavčič: glede na metajezik posameznih del. Ugotavlja, da je slednji v zgodovinskem obdobju latinščina pri Bohoriču in Hipolitu, nemščina pri Gutsmanu, Pohlinu, Kopitarju, Šmigocu, Dajnku, Metelku, Murku, Potočniku, Janežiču, Navratilu, slovenščina pri Vodniku, Muršcu in Malavašiču, slovenščina in nemščina pri Zelenku (Zemljarič Miklavčič 1999: 245-246). Pri tem se osredotoča zgolj na obdobje od začetkov, torej od prve slovnice, do leta 1850 . K spisku naj dodamo še avtorje nemško in slovensko pisanih slovnic 19. in 20. stoletja: Potočnik, Navratil, Miklošič (pri vseh treh nemščina) in Janežič, Šuman, Schreiner-Bezjak, Breznik, Toporišič (slovenščina). ${ }^{55}$

$\mathrm{Da}$ bi proučili tvorbo feminativov $\mathrm{v}$ slovensko in nemško pisanih slovnicah slovenskega jezika, smo pregledali naslednje slovnice (navedene po abecednem redu glede na priimek avtorja): Adam Bohorič: Arcticae horulae succisivae. Zimske urice proste (1584, izdaja iz leta 1987); Anton Breznik: Slovenska slovnica za srednje šole (izdaje iz leta 1916, 1924 in 1934); Peter Dajnko: Lehrbuch der Windischen Sprache (1824); Anton Janežič: Slovenska slovnica s kratkim pregledom slovenskega slovstva ter $z$ malim cirilskim in glagoliškim berilom za Slovence (1854); Matija Majar: Pravila kako izobraževati ilirsko narečje i u obče slavenski jezik (1848); Fran Malavašič: Slovenska slovnica za prve slovenske šole $v$ mestih in na deželah (1849); Franc Metelko: Lehrgebäude der Slowenischen Sprache im Königreiche Illyrien und in den benachbarten Provinzen (1825); Fran Miklošič: Vergleichende Stammbildungslehre der slavischen Sprachen (1875); Jožef Muršec: Kratka slovenska slovnica za pervence (1847); Ivan Navratil: Kurze Sprachlehre mit einer möglichst vollständigen Rechtschreibung der slovenischen Sprache, nebst einem praktischen Anhange enthaltend (1850); Marko Pohlin: Kraynska

\footnotetext{
55 Irena Stramljič Breznik je proučevala oblikovanje poimenovanj za besedne vrste v slovensko pisanih slovnicah med leti 1791 in 1854 (Stramljič Breznik 1999) ter besedotvorje in njegovo izrazje v slovensko pisanih slovnicah 19. stoletja (Stramljič Breznik 1996).
} 
grammatika (1781); Blaž Potočnik: Grammatik der slowenischen Sprache (1849);

Schreiner-Bezjak: Slovenska jezikovna vadnica za tesno združeni poduk v slovnici, pravopisu in spisju (1903-1905); Josip Šuman: Slovenska slovnica po Miklošičevi primerjalni (1881); Josip Šuman: Slovenska slovnica za srednje šole (1884); Valentin Vodnik: Pismenost in Grammatika za perve šole (1811); Mihael Zagajšek: Slovennska grammatika oder Georg Sellenko's Wendische Sprachlehre (1791).

Osredotočamo se zgolj na tvorbo feminativov v navedenih slovnicah. Slovničarji sicer ne pišejo o feminativih, temveč o samostalnikih ženskega spola, ki označujejo osebo ali žival, pri tem pa izpostavljajo izpeljavo tovrstnih poimenovanj iz samostalnikov moškega spola.

\section{1) Adam Bohorič: Zimske urice proste}

Prvo slovensko slovnico je sicer slovenska slovstvena zgodovina pogosto ocenjevala kot jezikoslovno šibko delo, pretirano naslonjeno na Melanchthonovo latinsko slovnico, zaradi česar niso mogle biti spoznane posebnosti slovenščine (Pogorelec 1984: 211). Kozma Ahačič (2007: 69) pa poudarja, da je bila kljub temu napredna, ker je sledila tedanjim splošnim evropskim smernicam $\mathrm{v}$ slovničarstvu, ${ }^{56}$ hkrati pa postavlja slovenščino na deseto mesto med evropskimi ljudskimi jeziki, ki so dobili svojo slovnico. Bohoričeva slovnica vključuje oblikoslovje z značilnostmi besedotvorja v delu Oblikoslovje (De etymologia). ${ }^{57}$ $\mathrm{V}$ poglavju Vrstnost (De specie) ponazarja osnovne besedotvorne principe $\mathrm{v}$ slovenščini; izpostavi tvorbo manjšalnic in izlastnoimenskih svojilnih pridevnikov. Pri posameznih besednih vrstah je avtor predstavil več obrazil in besedotvornopomenskih kategorij (Stramljič Breznik 2010: 186-187). Ob omenjenih najdemo tudi ženskospolsko poimenovanje prebivalke: Lublančica. Zanimivo je tudi poglavje Podoba (Figura), ki zajema kategorije simplex (preprosto) - composita (zloženo) - decomposita (izzložensko), ponazorjene s

\footnotetext{
${ }^{56}$ Slovnica je bila razpeta med težnjo po dokazovanju ujemanja slovenščine z latinsko gramatiko na eni strani ter zavedanja o razlikah med slovenščino in latinščino na drugi strani. Slovničarji so takrat namreč dokazovali urejenost posameznih jezikov s poudarjanjem, da imajo enaka pravila kot latinščina. Bolj kot jim je to uspelo, bolj so jezik povzdignili (Ahačič 2007: 71).

${ }^{57}$ Prevodi so povzeti po Toporišičevi izdaji iz leta 1987.
} 
primeri za vsako besedno vrsto. Edina primera občnoimenskih feminativov, ki ju Bohorič navaja, sta levinja in kojnka (Bohorič 1987: 65, 91-100). Opažamo, da so bila obrazilna razmerja v zgodovini precej drugačna od današnjih. Pri Bohoriču navedena feminativna oblika kojnka se namreč precej razlikuje od današnje, zabeležene v SSKJ 1 in SSKJ 2 ter drugih jezikovnih priročnikih (kobila). Na različnih mestih slovnice navedeni feminativi izkazujejo tudi najproduktivnejše tvorbene modele ženskih parov $\mathrm{v}$ slovenskem knjižnem jeziku 16. stoletja. Navedeni zgledi kažejo na izpeljavo iz lastno- (priimki, poimenovanja prebivalk) in občnoimenskega moškospolskega poimenovanja ter na tvorbo iz prevzetega in domačega samostalnika.

Preglednica 7: Zastopanost feminativnih priponskih obrazil po Toporišiču in Bohoriču

\begin{tabular}{|l|l|l|l|l|l|l|l|l|}
\hline $\begin{array}{l}\text { Obrazila po } \\
\text { SS (2004) }\end{array}$ & -a & -ica & -ična & -inja & -ja & -ka & -ovka & -ulja \\
\hline Toporišič & Polda & davkarica & grofična & dedinja & županja & brucka & pekovka & volkulja \\
\hline Bohorič & $/$ & Lambergarica & $/$ & levinja & $/$ & kojnka & $/$ & $/$ \\
\hline
\end{tabular}

Primerjava s Toporišičevimi zgledi kaže, da so obema viroma za tvorbo feminativov skupna priponska obrazila -ica (pri Bohoriču omenjena zgolj kot tvorna za poimenovanja prebivalk), -inja in $-k a$ s po enim zgledom po Bohoriču. ${ }^{58}$ Opažamo, da so v Bohoričevi slovnici navedeni feminativi tvorjeni na oba načina: z zamenjavo moškospolskega obrazila ali njegovega dela z ženskospolskim (zamenjava -ič z -ica: Lublančič - Lublančica) ter z dodajanjem ženskospolskih obrazil -ica, -inja in -ka samostalniku moškega spola (Lambergar Lambergarica, lev - levinja, konj - kojnka). Kot zamenjevalno torej nastopa le obrazilo -ica, medtem ko so vsa tri produktivna obrazila lahko dodajalna.

Sicer pa številna moška poimenovanja, izkazana v slovenskih knjižnih izdajah 16. stoletja, ostajajo brez ženskih parov, za kar običajno obstajajo pomenski in zgodovinski razlogi (npr. ahar, galjot; papež, škof; arhangellarhanjel; antitrinitar). Samo moškim vršilcem dejanj so pripadala

\footnotetext{
${ }^{58}$ Majda Merše (2013: 240) po pregledu večjega števila virov piscev 16. stoletja ugotavlja, da je v tem obdobju osnovni tvorbeni model izpeljava iz iste podstave $\mathrm{z}$ dodajanjem feminativnega priponskega obrazila -ica, obrazili - $k a$ in -inja pa sta bili redkejši.
} 
nekatera mesta v cerkveni hierarhiji (npr. papež, škof). Nekaterih poklicev in opravil v zgodovini, ki jo neposredno ali skozi biblijsko perspektivo zrcalijo dela slovenskih protestantskih piscev 16. stoletja, ženske niso opravljale (npr. nekaterih vojaških poklicev). Brez ženskega para so tako bila:

- Številna moška poimenovanja z negativno ali ekspresivno vsebino, npr. divjak, izdajicalizdavec;

- moška poimenovanja, ki označujejo službe in položaje $\mathrm{v}$ cerkveni hierarhiji (npr. apostol, superintendent, izpovednik/spovednik), neredko opredeljena z zgodovinskimi dejstvi (Kristus je imel dvanajst učencev apostolov, zato žensko parno poimenovanje v okviru osnovnega pomena ni možno);

- poimenovanja pripadnikov različnih skupin in sekt: antikrišt, antitrinitar, arijan in cvinglijaner, donatist;

- poimenovanja, ki se nanašajo na dejavnost konkretnih oseb moškega spola (npr. izveličar, ki se nanaša na Kristusa); moškega spola sta poimenovanji za nevidno duhovno bitje, ki pooseblja zlo (hudič, zludi, satan), in za nevidno dobro duhovno bitje: angel in arhangel/arhanjel, serafin (Merše 2008: 45-46).

\section{2) Mihael Zagajšek: Slovenska grammatika oder Georg Sellenkos Windische Sprachlehre}

Slovenska grammatika oder Georg Sellenkos Windische Sprachlehre iz leta 1791 je Zagajškovo edino natisnjeno delo, ki ga je Kopitar kritiziral, da je »unter aller Kritik«, Matija Čop pa je menil, da je »kajpada prvi, seve zelo neroden poizkus, učiti slovensko slovnico v slovenskem jeziku«. Slomšek je izjavil, da »se lotijo slavniga dela, ino spišejo pervi na Štajerskem pismenost ali gramatiko nemško slovensko, po kateri se lehko Nemci Slovenšine, Slovenci pa Nemšine naučijo. Natisnil njo je v Celi 1791 Franc Jenko. Ime so preminili, ino Jurj Zelenko imenovali.« Mnogi so delo precej kritizirali, češ da avtor ni imel dovolj jezikovnega znanja in poznavanja preostalih slovenskih narečij, obsodili so ga posnemanja Pohlina in Gutsmana. Kidrič pa je opozoril, da je Zagajšek prvi 
Slovenec, ki je dodal za slovensko slovnico k nemškemu razpravljalnemu jeziku še slovenskega (prej sta bila uporabljena le nemški in latinski jezik) (Golob 2009: 24-27). Podobno ugotavlja tudi Irena Stramljič Breznik (1999b: 108) - da je Zagajšek, sicer ob močni naslonitvi na nemščino, utiral pot slovenskemu izrazju. Njegova slovnica je razdeljena na pet delov: To Prabofreknost, To Glasamirryo,

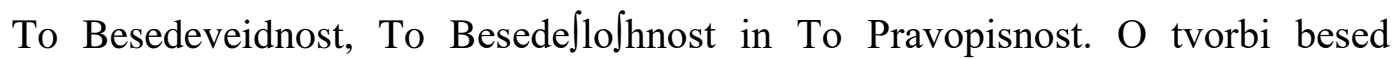
Zagajšek piše v dodatku oziroma Perdav'ku s podnaslovom Od tih korrenninskih besed, inu odrastenja tih odrastikov, inu tih v'kuppisstav'lenih besed. Poglavje je razdeljeno na tri podpoglavja: Od odpellannja tih sammostojozhih besed, Od odpellannja, inu pomennjenja tih zhasnih besed in Od tih v'kupisstav'lenih besed. Zagajšek za podstavo tvorjenke uporablja izraza korrenninska alli deblinska beseda, izpeljavno obrazilo pa imenuje konzhna zharzhva, tudi is'hod. V prvem poglavju so našteta obrazila, s katerimi se tvorijo samostalniki in pridevniki iz samostalniških, pridevniških in glagolskih podstav. Priponska obrazila so razporejena po abecednem vrstnem redu. Ugotavljamo, da se ženskospolska poimenovanja iz samostalnikov moškega spola tvorijo z -ica (krall - krallizza, tatizza, tettizza), -inja (boginja), -ka (bryv'ka) (Zagajšek 1791: 233-237).

Preglednica 8: Zastopanost feminativnih priponskih obrazil po Toporišiču in Zagajšku

\begin{tabular}{|l|l|l|l|l|l|l|l|c|}
\hline $\begin{array}{l}\text { Obrazila po } \\
\text { SS (2004) }\end{array}$ & -a & -ica & -ična & -inja & -ja & -ka & -ovka & -ulja \\
\hline Toporišič & Polda & davkarica & grofična & dedinja & županja & brucka & pekovka & volkulja \\
\hline Zagajšek & $/$ & kraljica & $/$ & boginja & $/$ & hinavka & $/$ & $/$ \\
\hline
\end{tabular}

Pregled in primerjava obeh virov kažeta naslednje: v obeh je mogoče zaslediti primere feminativov, tvorjenih s priponskimi obrazili -ica, -inja in $-k a$. Ugotavljamo, da tudi pri Zagajšku feminativi nastajajo na dva načina: $\mathrm{z}$ zamenjavo moškospolskega obrazila z ženskospolskim (tu Zagajšek izpostavi

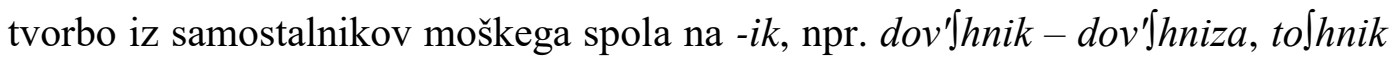
- to@hniza, izpostavili pa bi tudi zamenjavo priponskega obrazila -ec s - $k a^{59}$ (npr.

${ }^{59}$ Zagajšek (1791: 221) sicer piše o priponskem obrazilu -anka in ne -ka. 
pijanka, pregnanka) $)^{60}$ in $\mathrm{z}$ dodajanjem ženskospolskega obrazila samostalniku moškega spola (po Zagajšku -inja s primerom boginja ter -ica s primerom krallizza). Ugotavljamo torej, da obrazili $-i c a$ in $-k a$ pri Zagajšku nastopata kot zamenjevalni, -inja in -ica pa kot dodajalni priponski obrazili, in to le pri tvorbi občnoimenskih feminativov.

\section{3) Marko Pohlin: Kraynska grammatika}

Po Kidriču je Kraynska grammatika Marka Pohlina, 1803 (prva izdaja 1768), »nebogljen otrok nekritičnosti in površnega šolanja ob slabih vzorih in ni mogla tvoriti trajnega znanstvenega temelja za preporod slovenskega književnega jezika« (Kidrič 1929-1938: 160). Pohlin je svojo slovnico vezal na živi jezik tedanje Ljubljane, ne da bi upošteval protestantsko tradicijo in njena vrednostna merila, njegovo besedotvorje pa je predstavljalo dobro podlago kasnejši Metelkovi slovnici (Vidovič Muha 1998: 80). Kljub mnogo spodrsljajem je Pohlin s svojimi odkritji v jezikovnem delu opravil zahtevno delo, iz katerega so črpali slovenski slovničarji do Kopitarja. V njegovem delu se resda odražajo neenotni, vendar že novejši nazori, ki so značilni zlasti za nemške slovničarje 17. in 18 . stoletja. Sicer se izkaže kot dober poznavalec slovenskega besedotvorja. Obravnava ga samostojno in ne skupaj z oblikoslovjem. Izpeljavo besed je opisal glede na podstave in sufikse ter istočasno opozarjal na glasovne premene (Orožen 1971: 250-253). V poglavju o izpeljavi samostalnikov tako Pohlin govori o tvorbi samostalnikov ženskega spola in poudari, da se delujoče osebe ženskega spola tvorijo z -ica (klobzharica, sidariza, pastariza) ali -avka (poshlushavka). Samostalniki, ki označujejo prebivalke države ali dežele, imajo priponsko obrazilo -ka ali -ica (Shtajerka, Lublanzanka; Krayniza). Podobno velja za poimenovanja, »ki se ravnajo po poklicu in značilnostih moških«, na primer porozhniza, Jmerdlivka (Pohlin 2003: 268).

\footnotetext{
${ }^{60}$ Zagajšek pravi, da se priponsko obrazilo $-k a$ druži z moškospolskimi samostalniki na -ev'z, - $a v^{\prime} z$, -iv'z, -ov'z, -uv'z, -yv'z (hinnav'z - hinnav'ka, la〕hniv'z - la hniv'ka, smarkov'z - smarkov'ka,

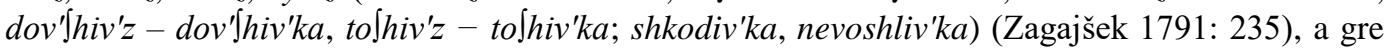
tudi $\mathrm{v}$ teh primerih za zamenjavo $-e c \mathrm{~s}-k a$.
} 
Preglednica 9: Zastopanost feminativnih priponskih obrazil po Toporišiču in Pohlinu

\begin{tabular}{|l|l|l|l|l|l|l|l|l|}
\hline $\begin{array}{l}\text { Obrazila po } \\
\text { SS (2004) }\end{array}$ & -a & -ica & -ična & -inja & -ja & -ka & -ovka & -ulja \\
\hline Toporišič & Polda & davkarica & grofična & dedinja & županja & brucka & pekovka & volkulja \\
\hline Pohlin & $/$ & sidarica & $/$ & $/$ & $/$ & smrdljivka & $/$ & $/$ \\
\hline
\end{tabular}

Obema viroma, Pohlinovi in Toporišičevi slovnici, sta pri tvorbi feminativov skupni le priponski obrazili $-i c a$ in $-k a$. Pohlin sicer izpostavi še obrazilo - $a v k a$, vendar pri tem razume izpeljavo poimenovanj ženskih oseb iz glagola in ne iz samostalnika moškega spola. Priponsko obrazilo -ica pri Pohlinu nastopa kot dodajalno $\mathrm{k}$ izglasjem moškospolskih samostalnikov na -(a)r (sidar sidariza) in zamenjevalno k moškospolskemu obrazilu -ec (Kraynez-Krayniza). Obrazilo - $k a$ nastopa zgolj kot zamenjava moškospolskega obrazila -ec (Shtajerec - Shtajerka). Opažamo tudi, da je Pohlin pozoren na občno- in lastnoimensko tvorbo ženskospolskih vzporednic.

\section{4) Valentin Vodnik: Pismenost ali Gramatika sa perve shole}

Narodnemu jeziku naklonjeno razpoloženje $\mathrm{v}$ Ilirskih provincah je vplivalo na nastanek prve slovensko pisane slovnice, ki je izšla leta 1811, to je Vodnikova Pismenost ali Gramatika sa perve shole. Z njo se po Vidovič Muhi (1988: 33) začne obdobje slovensko-nemške normativne protistave. S pregledno zasnovano učbeniško slovnico je Vodnik začel oblikovati slovensko jezikovno izrazje. Besedotvorje je obdelal $\mathrm{v}$ poglavju Izobrazenje besed; poglavje je pomembno, ker je zraslo iz Vodnikovega dobrega poznavanja slovenskega besedja in njegovih obravnav besednih družin (Trunkelj 1991: 10). Tvorbo »ženskih imen« je Vodnik analiziral v podpoglavju Izobrazenje imen (Vodnik 1811: 148-153). Avtor je v prikazovanju imenskih besedotvornih zakonitosti uporabil sintetično metodo: izhajal je iz skupnega pomena tvorjenk, ki jim ga lahko dodeljujejo različna obrazila (Stramljič Breznik 1999a: 181). Poimenovanja za ženske se po Vodniku tvorijo s priponskimi obrazili -ajka, -akina, -ačica, -anka, -avka, -ejka, -edka, -dka, -ekina, -eška, -etla, -ina, -ica, -uta. Iz primerov, 
ki jih Vodnik navaja, pa je razvidno, da se feminativi lahko tvorijo z obrazili -ica (kovačica), -inja (rojakinja), -ka (čuvajka), -la (zmikavtla), -na (vajvodna).

Preglednica 10: Zastopanost feminativnih priponskih obrazil po Toporišiču in Vodniku

\begin{tabular}{|l|l|l|l|l|l|l|l|c|}
\hline $\begin{array}{l}\text { Obrazila po } \\
\text { SS (2004) }\end{array}$ & -a & -ica & -ična & -inja & -ja & -ka & -ovka & -ulja \\
\hline Toporišič & Polda & davkarica & grofična & dedinja & županja & brucka & pekovka & volkulja \\
\hline Vodnik & $/$ & kovačica & $/$ & rojakinja & $/$ & čuvajka & $/$ & $/$ \\
\hline
\end{tabular}

Presek priponskih obrazil iz Toporišičeve in Vodnikove slovnice kaže, da se $\mathrm{v}$ obeh pojavijo feminativi, tvorjeni $\mathrm{z}$-ica, -inja in -ka; poleg teh pa Vodnik navaja še primere za priponski obrazili -la in -na, ki pri Toporišiču nista posebej izpostavljeni. Pri Vodniku je tako opozorjeno na lastnoimenske (Doblanka, Krajnica, Turkina) in občnoimenske feminative, nastajajo pa lahko z zamenjavo moškospolskega obrazila $\mathrm{z}$ ženskospolskim ali z dodajanjem ženskospolskega priponskega obrazila samostalniku moškega spola. Kot zamenjevalna nastopajo priponska obrazila -ica, ki zamenjuje moškospolski obrazili -ik (vabnik - vabnica) in -ec (Kranjec - Kranjica), -ka, ki zamenjuje priponsko obrazilo -ec, npr. videcvidka, in -na, ki zamenja moškospolsko obrazilo -a (vojvodna). Kot dodajalna nastopajo skoraj vsa navedena priponska obrazila, torej -ica (k izglasjem na - $(a) c ̌$ kovačica, -(a)r malnarica), -inja (k izglasjem podstave na - $k$ pekinja, - $h$ Lahinja), -ka (k izglasjem na -(a)j čuvajka, -(a)n Ločanka oz. k podstavi na -d medvedka), -la (k izglasjem na -(av)t zmikavtla, -(av)z kmetavzla). Opažamo tudi drugačnost obrazilnih razmerij (Toporišič pekovka, Vodnik pekinja).

\section{5) Peter Dajnko: Lehrbuch der windischen Sprache}

Dvajseta leta 19. stoletja je zaznamovala t. i. črkarska pravda, katere rezultat sta slovnici Lehrbuch der windischen Sprache (Peter Dajnko, 1824) in Lehrgebaude der slavischen Sprache (Fran Metelko, 1825); obe slovnici sta skušali upoštevati Kopitarjeva slovničarska načela, po fonološkem načelu pa sta želeli reformirati bohoričico. Dajnkova slovnica je razdeljena na dva dela: v prvem z naslovom Von der Wortforchung je obdelal besedoslovje, v drugem delu 
(Von der Wortfügung) pa skladnjo. Njegov prispevek predstavlja velik delež k sistematiki slovenskega besedotvorja prve polovice 19. stoletja in po izčrpnem strukturnem prikazu celo presega svojega sodobnika Metelka (Stramljič Breznik 1999a: 182). Besedotvorje je obdelano v prvem delu, natančneje v poglavju o besednih vrstah in njihovem pregibanju (Wurzelwörter). Dajnko je ob posamezni besedni vrsti predstavil tudi njeno tvorbo; pri sestavi svojega besedotvornega poglavja je združil teoretična in praktična načela takratne slavistične avtoritete $\mathrm{z}$ domačo slovenistično tradicijo in lastno jezikoslovno pronicljivostjo. Iz njegovega popisa priponskih obrazil (Dajnko 1824: 48-72), ki tvorijo samostalnike, lahko razberemo, da »ženska poimenovanja oseb, izpeljana iz moških«, nastajajo z obrazili -ica (grešnica, pomočnica), -inja (prerokinja), -ja (bedača), -ka (Slovenka), -kinja (častitelkinja), -ovca (mesarovca), -ovka (Čehovka).

Preglednica 11: Zastopanost feminativnih priponskih obrazil po Toporišiču in Dajnku

\begin{tabular}{|l|l|l|l|l|l|l|l|l|}
\hline $\begin{array}{l}\text { Obrazila po } \\
\text { SS (2004) }\end{array}$ & -a & -ica & -ična & -inja & -ja & -ka & -ovka & -ulja \\
\hline Toporišič & Polda & davkarica & grofična & dedinja & županja & brucka & pekovka & volkulja \\
\hline Dajnko & $/$ & grešnica & $/$ & prerokinja & bedača & Slovenka & Židovka & $/$ \\
\hline
\end{tabular}

Opažamo, da so obema proučevanima viroma skupna feminativna priponska obrazila -ica (davkarica, grešnica), -inja (dedinja, prerokinja), -ka (Slovenka) in -ovka (pekovka, Židovka). Poleg teh pri Vodniku zasledimo še ženskospolski priponski obrazili, ki ju pri Toporišiču ne zaznamo, to sta -kinja in -ovca. Feminativi so pri Dajnku tvorjeni $\mathrm{z}$ dodajanjem ženskospolskega priponskega obrazila samostalniku moškega spola: -ica k izglasjem podstave na - $b$ (golobica), -d (medvedica), -l (oslica), -lj (kraljica), -r (cesarica), -s (psica), - $t$ (kertica); -inja $\mathrm{k}$ izglasju podstave -k (prerokinja); -ja $\mathrm{k}$ izglasju na $-(a) k$ (bedača); -ka k izglasju podstave na - $h$ (Čehka); -kinja $\mathrm{k}$ izglasjem podstav na - $h$ (Čehkinja), -l (prijatelkinja); -ovca $\mathrm{k}-(a) r$ (mesarovca) in -(a)č (kovačovca); -ovka k izglasjem podstav na $-d$ (Židovka) in - $h$ (Čehovka). Kot zamenjevalna nastopijo obrazila -ica (-ec: samec - samica; -ik: pomočnik - pomočnica), -ka (-ec: Slovenec - Slovenka) in -kinja (-ec: Slovenec - Slovenkinja). Med primeri zasledimo občnoimenske in lastnoimenske feminative. Znova opažamo drugačna 
obrazilna razmerja (Dajnko: medvedica, SSKJ 1: medvedka; Dajnko: Nemkinja, SP 2001: Nemka; Dajnko: Čehka, Čehovka, SP 2001: Čehinja; Dajnko: prijatelkinja, SSKJ 1, SP 2001: prijateljica; Dajnko: mesarovca, kovačovca, SSKJ 1, SP 2001: mesarka, kovačica).

\section{6) Fran Metelko: Lehrgebaude der slavischen Sprache}

Metelkovo slovnico Lehrgebaude der slavischen Sprache iz leta 1825 zaznamuje spoznanje o odvisnosti razvrstitve priponskih obrazil od pomena podstave (Vidovič Muha 1988: 34). Irena Stramljič Breznik (1999a: 184) pa ugotavlja, da gre za po obsegu in vsebini najpopolnejši prikaz slovenskega besedotvorja $\mathrm{z}$ začetka 19. stoletja. Izbrano gradivo je Metelko vrednotil na podlagi sinhrone metode in protistave $\mathrm{z}$ nemščino - oboje izkazujejo prav izpostavljeni zgledi iz njegovega besedotvorja. V besedotvornem delu je za metodološki vzor izbral slovnico Dobrovskega ${ }^{61}$ (Honzak - Jahić 2003: 344). Tvorbo samostalnikov Metelko obravnava v poglavju Bildung des Substantivs (ženskospolski samostalniki v posebnem razdelku na straneh 66-68). Predstavitev izpeljevanja kaže na bogato gradivo, urejeno na podlagi priponskih obrazil. Opažamo, da so feminativi tvorjeni z obrazili -ica (golobica, voznica ...), -inja (boginja, kneginja), -ja (županja), -ka (hinavka, pevka, starka ...), -ulja (volkulja).

Preglednica 12: Zastopanost feminativnih priponskih obrazil po Toporišiču in Metelku

\begin{tabular}{|l|l|l|l|l|l|l|l|l|}
\hline $\begin{array}{l}\text { Obrazila po } \\
\text { SS (2004) }\end{array}$ & -a & -ica & -ična & -inja & -ja & -ka & -ovka & -ulja \\
\hline Toporišič & Polda & davkarica & grofična & dedinja & županja & brucka & pekovka & volkulja \\
\hline Metelko & $/$ & golobica & $/$ & boginja & županja & starka & $/$ & volkulja \\
\hline
\end{tabular}

\footnotetext{
${ }^{61}$ Predstavnik prve generacije čeških preroditeljev Dobrovsky ni bil najbolj naklonjen tvorjenju, zlasti ne tvorbi strokovnega izrazja. Menil je, naj se splošnorabljeni prevzeti strokovni izrazi ohranjajo, v primeru primanjkljajev in s tem povezane razvojne dinamike češke knjižne leksike pa je razvil naslednjo strategijo: (a) prevzemanje iz slovanskih jezikov v smislu morfemskega prevajanja, (b) novotvorba, ki naj ji bo vodilo in prvi korektiv, 1. upoštevanje splošne rabe, 2. češko knjižnojezikovno izročilo (izpisovanje iz starejših čeških besedil), 3. struktura češkega jezika kot podlaga za zakonitost tvorbe, 4. splošna razumljivost zaradi ozira na recepcijske zmožnosti naslovnikov (Honzak - Jahić 2003: 344).
} 
Sklenemo lahko, da je obema proučevanima viroma skupna tvorba feminativov s priponskimi obrazili -ica, -inja, -ja, -ka in -ulja. Dodajalna so po Metelku vsa feminativna priponska obrazila, torej - $k a$ (izglasja na - $d$ medvedka, -(a)j čuvajka, -r mramorka, -(a)n Litijanka), -ica (k izglasjem -b golobica, -(a)č kovačica, -g družica, -l prijatelica, -(a)r platnarica, -š tovarišica, -t Hrovatica), -inja (k izglasjem na -f grofinja, -k Turkinja, -s Rusinja, -z Francozinja), -ja (k izglasju na -(a)n županja) in -ulja (k izglasju na - $k$ volkulja); zamenjevalni pa sta le obrazili -ica (-ec: Krajnec - Krajnica, -ik: najemnik - najemnica) in -ka (-ec Gorenjka). Tudi pri Metelku je mogoče feminative tvoriti iz občnoimenske in lastnoimenske podstave, kot kažejo navedeni primeri.

\section{7) Jožef Muršec: Kratka slovenska slovnica za pervence}

Kratka slovenska slovnica za pervence je bila objavljena leta 1847 . V obsegu 89 strani jo je pripravil Jožef Muršec. Irena Stramljič Breznik (1999a: 183-184) ob pregledu ugotavlja, da avtor v ospredje ne postavlja postopka tvorbe, temveč njegov rezultat. Njegovi predhodniki, zlasti je to vidno pri Pohlinu, Zagajšku, Vodniku in Metelku, so se trudili dati čim bolj natančen popis vseh besedotvornih obrazil tako, da so jih nizali po kriteriju besednovrstnosti tvorjenk, hkrati pa so za preglednost skrbeli z abecednim razvrščanjem obrazil po njihovih izglasjih. Muršec se tvorbi besed sicer posveča v skromnem obsegu, toda treba mu je priznati kakovosten premik, ki se kaže s težnjo po sistematični predstavitvi tvorjenk na podlagi pomena (Stramljič Breznik 1999a: 189). Muršec namreč že na začetku izpostavi pomenski kriterij pri razvrščanju tvorjenk. V poglavju Premena imen pravi, da se premena »iz možkega spola v ženski zgodi, le možke izhode v Ženske premeniš ino še zrodne čerke prerodiš巛. Našteje obrazila -ača (potepača), -ica (krojačica, svilarica), -inja (Gerkinja, grofinja, človekinja), -ja (županja), -ka (Slovenka, tlačanka), -ovka (Cafovka, Gomilšakovka), -ulja (volkulja). 
Preglednica 13: Zastopanost feminativnih priponskih obrazil po Toporišiču in Muršcu

\begin{tabular}{|l|l|l|l|l|l|l|l|l|}
\hline $\begin{array}{l}\text { Obrazila po } \\
\text { SS (2004) }\end{array}$ & -a & -ica & -ična & -inja & -ja & -ka & -ovka & -ulja \\
\hline Toporišič & Polda & davkarica & grofična & dedinja & županja & brucka & pekovka & volkulja \\
\hline Muršec & $/$ & krojačica & $/$ & grofinja & županja & učenka & Cafovka & volkulja \\
\hline
\end{tabular}

Obema viroma je za tvorbo feminativov skupnih precej obrazil: -ica, -inja, -ja, -ka, -ovka in -ulja. Kot zamenjevalni nastopata obrazili -ica (zamenjuje moškospolsko priponsko obrazilo -ik, npr. bolnica) in -ka (zamenjuje obrazilo -ec, npr. Slovenka), kot dodajalna pa -ica (k izglasjem na -(a)č kovačica, -g družica, -k račica, -lj kraljica, -(a)r pisarica, -t tatica), -inja (k izglasjem na -f grofinja, -(a)k bedakinja, -z Francozinja), -ja (k izglasju na -(a)n županja), -ka (k izglasju na -(i)n bogatinka), -ovka (k izglasjem na -c Pišečovka, -f Cafovka, -k Strajnšakovka), -ulja (k izglasju na -k volkulja). Opažamo, da so tudi pri Muršcu feminativi tvorjeni iz občno- in lastnoimenske podstave.

\section{8) Fran Malavašič: Slovenska slovnica za perve slovenske šole v mestih in na deželi}

Leta 1849 je nastala Malavašičeva Slovenska slovnica za perve slovenske šole $v$ mestih in na deželi, prva slovnica po prelomnem letu 1848, ko je prišla slovenščina v šole. Napisana je v slovenščini, sestavljena iz dveh delov: v prvem razdelku zajema oblikoslovje, $\mathrm{v}$ drugem pa poveže besedotvorje in skladnjo. V dodatku govori o pravopisu in besedilnih vrstah. Irena Stramljič Breznik (1999a: 218-219) ugotavlja, da se je zgledoval po Metelkovi slovnici, kar je razvidno iz podobne razvrstitve obrazil, ki jih Malavašič imenuje končni zlog. Iz popisa priponskih obrazil in iz posebnega podpoglavja z naslovom Zlaga ženskih imen (Malavašič 1849: 92-113) lahko razberemo, da se feminativi tvorijo s priponskimi obrazili -ica (grešnica, kmetica), -inja (boginja, grofinja), -ka (starka, rejenka). V poglavju Zlaga ženskih imen pa kot taka Malavašič omenja obrazila -ca (romarca), -ica (mlinarica), -inja (grofinja), -ja (županja), -ka (tlačanka), pri tvorbi ženskih oblik priimkov k moškim pa navede obrazila -evka (Zagorčevka), -ovka (Gornikovka), -ulja (Volkulja). 
Preglednica 14: Zastopanost feminativnih priponskih obrazil po Toporišiču in Malavašiču

\begin{tabular}{|l|l|l|l|l|l|l|l|l|}
\hline $\begin{array}{l}\text { Obrazila po } \\
\text { SS (2004) }\end{array}$ & -a & -ica & -ična & -inja & -ja & -ka & -ovka & -ulja \\
\hline Toporišič & Polda & davkarica & grofična & dedinja & županja & brucka & pekovka & volkulja \\
\hline Malavašič & $/$ & kmetica & $/$ & boginja & županja & starka & Gornikovka & Volkulja \\
\hline
\end{tabular}

Tudi primerjava Malavašičeve in Toporišičeve slovnice kaže na številna, obema viroma skupna, priponska obrazila, ki tvorijo feminative: -ica, -inja, -ja, -ka, -ovka in -ulja. Poleg naštetih pa pri Malavašiču najdemo še obrazilo -evka s primerom Zagorčevka, kar kaže na avtorjevo upoštevanje preglasa in opozarjanje tudi na tovrstno tvorbo. Med produktivnimi obrazili se moškospolskemu samostalniku dodajajo priponska obrazila -ca (k izglasju na -(a)r romarca), -ica (k izglasjem na -b golobica, -(a)č kovačica, -g družica, -l oslica, -lj kraljica, -(a)r kolarica, -s psica, -š tovaršica, -t kmetica), -inja (k izglasjem na -f grofinja, - $g$ boginja, -k Turkinja, -s Rusinja, -z Francozinja), -ja (k izglasju na -(a)n županja), -ka (k izglasjem na -d medvedka, -(a)j čuvajka, -r mramorka, -v žerjavka, -ž gožka), -ovka (k izglasju na -(i)k Gornikovka), -ulja (k izglasju -k Volkulja - kot lastnoimenski feminativ). Moškospolsko priponsko obrazilo ali njegov del pa lahko zamenjujeta obrazili -ica (-ec: plevec-plevica, -ik: grešnik-grešnica) in -ka (-ec: hinavec - hinavka). Navedeni primeri kažejo na feminativno tvorbo iz občnoimenske in lastnoimenske podstave.

\section{9) Blaž Potočnik: Grammatik der slowenischen Sprache}

Istega leta, 1849, je izšla Grammatik der slowenischen Sprache Blaža Potočnika. Avtor v uvodu želi v skladu s historično pozicijo slovenščine po letu 1848 povzdigniti slovenski jezik, ga spraviti »iz zadnje klopi v razredu slovanskih jezikov« (Zemljarič Miklavčič 1999: 249). Avtor v prvem delu z naslovom Wortbildung und Wortbiegung (Potočnik 1949: 5-9) v zelo kratkem poglavju piše o besedotvorju. Iz njegovega popisa pripon razberemo, da se feminativi tvorijo $\mathrm{z}$ 
obrazili -ca (mlinarca), -ica (kovačica), -inja (vojakinja), -ka (bogatinka), -nja (Turknja), -ulja (Novakulja).

Preglednica 15: Zastopanost feminativnih priponskih obrazil po Toporišiču in Potočniku

\begin{tabular}{|l|l|l|l|l|l|l|l|l|}
\hline $\begin{array}{l}\text { Obrazila po } \\
\text { SS (2004) }\end{array}$ & -a & -ica & -ična & -inja & -ja & -ka & -ovka & -ulja \\
\hline Toporišič & Polda & davkarica & grofična & dedinja & županja & brucka & pekovka & volkulja \\
\hline Potočnik & $/$ & kovačica & $/$ & vojakinja & $/$ & bogatinka & $/$ & Novakulja \\
\hline
\end{tabular}

Feminativi so po Toporišičevi in Potočnikovi slovnici tvorni z obrazili -ica, -inja, -ka in -ulja. Ob naštetih pa Potočnik navede še obrazilo -nja s konkretnim primerom Turknja; to priponsko obrazilo bi v sodobnem slovenskem knjižnem jeziku bilo -inja (SP 2001: Turkinja). Kot dodajalna so zastopana vsa po Potočniku produktivna obrazila, torej -ca (k izglasju na -(a)r mlinarca), -ica (k izglasjem na -b golobica, -(a)č beračica, -(a)r kotlarica), -inja (k izglasjem na -k vojakinja), -ka (k izglasju na -(i)n bogatinka), -ulja (k izglasju na -(a)k Novakulja). Zamenjevalni sta le dve od navedenih feminativnih priponskih obrazil, to sta -ica (zamenjuje -ik, npr. grešnik-grešnica) in -ka (zamenjuje -ec, npr. delavec - delavka). Potočnikovi primeri poleg občnoimenskih nakazujejo tudi lastnoimenske feminative (priimkovne feminative, poimenovanja prebivalk).

\section{0) Matija Majar: Slovnica za Slovence}

Naslednjega leta, 1850, je izšla Slovnica za Slovence Matije Majarja, razdeljena na tri dele: Naukoslovje, Slovnico in Pravopis. V predgovoru Majar pojasni, da je pri snovanju upošteval Murščevo slovnico. Besedotvorje je obdelano v poglavju Pomen slov v obliki popisa obrazil (41-43). V njem so ženskospolska priponska obrazila zajeta pri posameznih moškospolskih obrazilih. Tako pri priponskem obrazilu -ar prvič zasledimo obrazili -ica (lončarica) in -ka (ovčarka), pojavita se tudi pri drugih obrazilih, ki tvorijo poimenovanja oseb moškega spola $(-e c,-i k)$. Pri obrazilih $-a c ̌$ in $-a k$ se pojavi še obrazilo -inja (beračinja, junakinja). 
Preglednica 16: Zastopanost feminativnih priponskih obrazil po Toporišiču in Majarju

\begin{tabular}{|l|l|l|l|l|l|l|l|l|}
\hline $\begin{array}{l}\text { Obrazila po } \\
\text { SS (2004) }\end{array}$ & -a & -ica & -ična & -inja & -ja & -ka & -ovka & -ulja \\
\hline Toporišič & Polda & davkarica & grofična & dedinja & županja & brucka & pekovka & volkulja \\
\hline Majar & $/$ & lončarica & $/$ & beračinja & $/$ & ovčarka & $/$ & $/$ \\
\hline
\end{tabular}

Toporišiču in Majarju so pri tvorbi feminativov skupna priponska obrazila -ica, -inja in -ka. Majar v primerjavi s predhodniki napravi korak dlje, saj navede moškospolska obrazila, ki se jim ženskospolska priponska obrazila dodajajo oziroma jih zamenjujejo. Kot dodajalna tako nastopijo vsa tri navedena priponska obrazila -ica (k izglasjem na -(a)č kovačica, -(ite)lj učiteljica in -(a)r lončarica), -inja (k izglasjem na -(a)č beračinja, -(a)k junakinja) in -ka (k izglasju na -(a)r ovčarka), kot zamenjevalni pa, kot že pri Majarjevih predhodnikih, samo -ica (-ik: sodnik - sodnica) in -ka (-ec: starec - starka). Znova so obrazilna razmerja drugačna od današnjih (Majar: beračinja, SSKJ 1: beračica), primeri feminativov pa so pri Majarju zgolj občnoimenski.

\section{1) Ivan Navratil: Kurze Sprachlehre mit einer möglichst vollständigen Rechtschreibung der slovenischen Sprache}

Istega leta, to je 1850, je izšla tudi Navratilova slovnica Kurze Sprachlehre mit einer möglichst vollständigen Rechtschreibung der slovenischen Sprache, nebst einem praktischen Anhange enthaltend: mehrere Vorladungen von Zeugen und Angeschuldigten, Protokollsköpfe, dann Fragen und Antworten, Urtheile u. s. w. in slovenischer und deutscher Sprache. Avtor že v uvodu (in naslovu) sporoča, da je slovenščina postala dovoljeni jezik na sodiščih, kar je privedlo sodne uradnike v položaj, da morajo znati pravilno slovensko govoriti in pisati. Spodbujen prav od teh uradnikov se je odločil, da jim bo v pomoč pripravil jezikovni priročnik, s katerim si bodo lahko na hitro pomagali (Zemljarič Miklavčič 1999: 248). Navratil besedotvorje obravnava v poglavju Wörterbildung (Navratil 1850: 40). Iz zelo kratkega poglavja je razvidno, da se feminativi po Navratilu lahko tvorijo z obraziloma -ica (tožnica, pomočnica) in -ka (Slovenka, Dalmatinka). 
Preglednica 17: Zastopanost feminativnih priponskih obrazil po Toporišiču in Navratilu

\begin{tabular}{|l|l|l|l|l|l|l|l|l|}
\hline $\begin{array}{l}\text { Obrazila po } \\
\text { SS (2004) }\end{array}$ & -a & -ica & -ična & -inja & -ja & -ka & -ovka & -ulja \\
\hline Toporišič & Polda & davkarica & grofična & dedinja & županja & brucka & pekovka & volkulja \\
\hline Navratil & $/$ & tožnica & $/$ & $/$ & $/$ & Slovenka & $/$ & $/$ \\
\hline
\end{tabular}

Primerjava tvornosti feminativov po Toporišiču in Navratilu ponovno kaže, da sta najpogostejši priponski obrazili, ki tvorita poimenovanja bitij ženskega spola, -ica in -ka, saj sta edini, ki ju oba obravnavana vira navajata. Obe nastopata kot zamenjevalni (-ica zamenjuje moškospolski priponski obrazili -ik, npr. pomočnica, in -ec, npr. Korošica; -ka pa lahko zamenjuje samo obrazilo -ec, npr. Dalmatinka), dodajalno pa je pri Navratilu samo obrazilo -ka (k izglasju na -(a)n Litijanka). Tvorba feminativov je pri Navratilu izobčno- in izlastnoimenska.

\section{2) Anton Janežič: Slovenska slovnica s kratkim pregledom slovenskega} slovstva

Po mnenju Irene Stramljič Breznik (1999a: 220) je kot šolska slovnica najpomembnejša Slovenska slovnica s kratkim pregledom slovenskega slovstva iz leta 1854, ki jo je spisal Anton Janežič. Avtor se sicer precej naslanja na Metelka in Miklošiča, gre pa za popolnoma predelano slovnico, dopolnjeno z ugotovitvami novejših, tudi mladogramatičnih jezikoslovnih raziskav (Vidovič Muha 1998: 80). Slovnica je izšla v več izdajah; pregledali smo prvo izdajo (1854) in ugotovili, da je sestavljena iz več poglavij in posebnega dodatka $\mathrm{z}$ naslovom Pregled slovenskega slovstva, ki je posvečen zgodovini slovenskega jezika. Besedotvorje je Janežič obravnaval skupaj z oblikoslovjem v poglavju Zlaganje samostavnih imen. V tem delu je opazno zgledovanje po Metelku: Janežič je priponska obrazila imenoval končnice, od številnih Metelkovih pa je jemal le najpogostejša obrazila (Toporišič 1996: 310). Ugotavljamo, da so za tvorbo »ženskih imen« po Janežiču produktivna obrazila -a (glavača), -ica (beračica), -inja (junakinja, vojšakinja), -ka (teržanka, vaščanka). Omenimo še poglavje Zlaga ljudstvinih imen (Janežič 1854: 16-17), v katerem Janežič piše o tvorbi ženskih oblik priimkov iz moških ter o poimenovanjih prebivalk. Za to se uporabljajo obrazila 
-ica (Kranjica), -inja (Potočnjikinja), -ka (Jaklinka), -ovka (Perkovka). Janežič torej loči tvorbo feminativov glede na to, ali so izpeljani iz občno- ali lastnoimenske podstave.

Preglednica 18: Zastopanost feminativnih priponskih obrazil po Toporišiču in Janežiču

\begin{tabular}{|l|l|l|l|l|l|l|l|l|}
\hline $\begin{array}{l}\text { Obrazila po } \\
\text { SS (2004) }\end{array}$ & -a & -ica & -ična & -inja & -ja & -ka & -ovka & -ulja \\
\hline Toporišič & Polda & davkarica & grofična & dedinja & županja & brucka & pekovka & volkulja \\
\hline Janežič & glavača & beračica & $/$ & junakinja & $/$ & vaščanka & Perkovka & $/$ \\
\hline
\end{tabular}

Primerjava Janežičeve in Toporišičeve slovnice kaže, da so obema skupna feminativna priponska obrazila -a, -ica, -inja, $-k a$ in -ovka. Priponsko obrazilo -ica se dodaja izglasjem na -(a)č (kovačica), -(a)r (pisarica), -s (psica), zamenjuje pa priponsko obrazilo -ec (Korošec - Korošica). Obrazilo -ka kot dodajalno nastopi pri izglasjih moškospolskih samostalnikov na -(a)n (teržanka), zamenjuje pa moškospolsko priponsko obrazilo -ec (lažnjivec - lažnjivka). Priponsko obrazilo - $a$ nastopa zgolj kot dodajalno k izglasju na -(a)̌̌ (glavač glavača). Enako velja za obrazili -inja, ki se dodaja k izglasju na -(a)k (vojakinja), in -ovka, ki se dodaja k izglasju na -k (Perkovka).

\section{3) Fran Miklošič: Vergleichende Grammatik}

Druga knjiga Miklošičeve slovnice Vergleichende Grammatik je posvečena besedotvorju. Prvo poglavje je Miklošič naslovil Predstavitev (Einleitung). Sledi razdelitev na dva dela. Prvi se imenuje Nauk o tvorbi nominalnih osnov (Lehre von der bildung der nominalstämme) in je razdeljen na več poglavij in podpoglavij. Miklošič izvede delitev na poglavja na podlagi zloženosti oziroma nezloženosti osnove. Drugo poglavje je posvečeno tvorbi zloženih osnov (Lehre von der bildung der componierten nominalstämme). Kot kompozite Miklošič upošteva zloženke, sklope, sestavljenke, tvorjenke iz predložne zveze. Sledi drugi del, kjer gre za analizo tvorbe glagolskih osnov (Nauk o tvorbi glagolskih osnov). Znova lahko najprej preberemo uvod oziroma Predstavitev, sledi pa razdelitev na dve poglavji. Prvo obravnava tvorbo 
nedoločniških osnov. Glede na razdeljenost v podpoglavja opazimo delitev na šest vrst. Drugo poglavje predstavi nauk o tvorbi sedanjiških osnov. Knjigo o besedotvorju Miklošič zaključi s poglavji Dodatek in popravek, Krajšave in Vsebina (vsebinsko kazalo). Iz vsebinskega kazala je razvidna delitvena dvodelnost tvorjenk: temeljna ločitev je besednovrstna, saj obravnava na eni strani tvorbo imenskih osnov, med katere avtor uvršča osnove samostalnika, pridevnika, posebej navaja števnik, zaimek, členek, na drugi strani pa glagolskih (Vidovič Muha 1992: 176). Na podlagi navedenih primerov ugotavljamo, da se feminativi po Miklošiču tvorijo s priponskimi obrazili -ica (predica), -inja (boginja), -ka (delavka), -ovka (levovka), -ulja (vragulja).

Preglednica 19: Zastopanost feminativnih priponskih obrazil po Toporišiču in Miklošiču

\begin{tabular}{|l|l|l|l|l|l|l|l|l|}
\hline $\begin{array}{l}\text { Obrazila po } \\
\text { SS (2004) }\end{array}$ & -a & -ica & -ična & -inja & -ja & -ka & -ovka & -ulja \\
\hline Toporišič & Polda & davkarica & grofična & dedinja & županja & brucka & pekovka & volkulja \\
\hline Miklošič & $/$ & predica & $/$ & boginja & $/$ & delavka & levovka & vragulja \\
\hline
\end{tabular}

Toporišičevi in Miklošičevi slovnici so skupna feminativna priponska obrazila -ica, -inja, -ka in -ulja. Priponsko obrazilo -ica se dodaja k izglasjem na -b (golobica), -d (medvedica), -g (božica), -k (volčica), -l (oslica), -(ite)lj (roditeljica), -(a)r (gospodarica), -s (psica), -t (kmetica), zamenjuje pa moškospolsko obrazilo -ik (grešnica). Obrazilo -inja tudi pri Miklošiču nastopa zgolj kot dodajalno $\mathrm{k}$ izglasjem podstav na $-d$ (sosedinja), -f (grofinja), - $g$ (boginja), -h (menihinja), -k (Grkinja), -n (poganinja), $-r$ (botrinja), -(o)v (Židovinja). Priponsko obrazilo $-k a$ zamenjuje moškospolsko obrazilo -ec (dolanka), dodaja pa se k izglasjem na -(i)č (Pavlička) in -d (medvedka). Obrazilo -ovka se dodaja izglasjem na - $d(\check{Z}$ idovka) in -v (levovka). Priponsko obrazilo -ulja dodajamo k izglasjem na -č (rogačulja), -g (vragulja), -k (volkulja). Glede na navedene primere pa lahko sklenemo tudi, da so pri Miklošiču feminativi tvorjeni iz občno- in lastnoimenske podstave.

14) Josip Šuman: Slovenska slovnica po Miklošičevi primerjalni 
Slovenska slovnica po Miklošičevi primerjalni iz leta 1881 avtorja Josipa Šumana je razdeljena na štiri dele: glasoslovje (Lautlehre), pregiboslovje (Flexionslehre), besedotvoritev (Etymologie) in skladnjo (Syntax). Irena Stramljič Breznik (1999a: 225) poudarja, da je Šuman v svoji slovnici slovensko izobraženstvo seznanil z rezultati Miklošičevih primerjalnih raziskovanj, kar lahko opazimo tudi pri razdelitvi Šumanovega dela o besedotvorju v poglavja in podpoglavja. Za našo raziskavo je pomemben tretji del o besedotvorju, za katerega Šuman kot nemško ustreznico navede izraz Etymologie, s čimer nakaže na povezanost vede o tvorjenju besed $\mathrm{z}$ vedo o njihovem izvoru. Za tvorbo »ženskih imen iz moških« se uporabljajo priponska obrazila -ica (božica, volčica, vratarica, kovačica, krtica, kraljica, rogačica, tatica, medvedica), -inja (boginja, kneginja, sosedinja) in -ka (dolanka, gorjanka, medvedka, slovenka, sicer tudi slovenkinja). Feminativi so po Šumanu tvorjeni tudi z obrazili -ična (gospodična), -ovka (levovka), -ulja (volkulja, rogačulja, vragulja).

Preglednica 20: Zastopanost feminativnih priponskih obrazil po Toporišiču in Šumanu (1881)

\begin{tabular}{|l|l|l|l|l|l|l|l|l|}
\hline $\begin{array}{l}\text { Obrazila po } \\
\text { SS (2004) }\end{array}$ & -a & -ica & -ična & -inja & -ja & -ka & -ovka & -ulja \\
\hline Toporišič & Polda & davkarica & grofična & dedinja & županja & brucka & pekovka & volkulja \\
\hline $\begin{array}{l}\text { Šuman } \\
(1881)\end{array}$ & $/$ & vratarica & gospodična & boginja & $/$ & medvedka & levovka & volkulja \\
\hline
\end{tabular}

Obema viroma skupna, za tvorbo feminativov produktivna, so priponska obrazila -ica, -ična, -inja, -ka, -ovka in -ulja. Priponsko obrazilo -ulja se lahko dodaja izglasjem na -(a)č (rogačulja), -g (vragulja), -k (volkulja), obrazilo -ovka izglasjem na $-d$ (Židovka) in -v (levovka), -inja pa izglasjem podstav na $-d$ (sosedinja), -g (boginja), -k (Grkinja). Priponski obrazili -ica in -ka sta zamenjevalni in dodajalni. Obrazilo -ica se dodaja izglasjem na -b (golobica), $-(a) c ̌$ (kovačica), -d (medvedica), - $g$ (družica), -k (volčica), -l (oslica), -lj (kraljica), -(a)̌̌ (ošterijašica), -t (kmetica), zamenjuje pa priponski obrazili -ec $($ samec - samica) in -ik (grešnik - grešnica). Priponsko obrazilo -ka se dodaja izglasjem na -(i)̌́ (Pavlička), -d (medvedka), zamenjuje pa moškospolsko obrazilo -ec (dolanec-dolanka). Tudi pri Šumanu lahko govorimo o obrazilni drugačnosti 
(Šuman: levovka, sosedinja, SSKJ 1: levinja, soseda), o tvorbi lastnoimenskih in občnoimenskih feminativov ter o variantnih ali konkurenčnih obrazilih ob isti podstavi (medvedka-medvedica).

\section{5) Josip Šuman: Slovenska slovnica za srednje šole}

Leta 1884 je izšla Šumanova Slovenska slovnica za srednje šole, ki velja za izvleček njegove Slovenske slovnice po Miklošičevi primerjalni. Slovnico sestavljajo štiri enote: Glasništvo, Pregibovanje, Slovotvorje in Skladnja. Slovotvorje, poglavje, namenjeno tvorbi besed, obsega dva dela: Tvoritev glagolskih debel in Tvoritev imen. Šuman besede ali slovesa izvaja iz korenov in debel. Deblo je koren ali s priponko podaljšan koren (Šuman uporabi termin priponka). Za nas je zanimiva izpeljava v slovenščini, ki jo Šuman predstavi tako, da najprej obdela samoglasniške priponke po načelu prvotne ali drugotne tvorbe, nato pa še druga obrazila, ki so združena $\mathrm{v}$ skupino na podlagi soglasniške sestavine. Šuman (1884: 100-110) pravi, da »ženska imena iz moških« tvorijo obrazila -ica (krtica, oslica, Korošica), -inja (boginja), -ka (medvedka, dolanka), -ovka (Židovka) in -ulja (volkulja).

Preglednica 21: Zastopanost feminativnih priponskih obrazil po Toporišiču in Šumanu (1884)

\begin{tabular}{|l|l|l|l|l|l|l|l|l|}
\hline $\begin{array}{l}\text { Obrazila po } \\
\text { SS (2004) }\end{array}$ & -a & -ica & -ična & -inja & -ja & -ka & -ovka & -ulja \\
\hline Toporišič & Polda & davkarica & grofična & dedinja & županja & brucka & pekovka & volkulja \\
\hline $\begin{array}{l}\text { Šman } \\
(1884)\end{array}$ & $/$ & kmetica & $/$ & boginja & $/$ & medvedka & levovka & $/$ \\
\hline
\end{tabular}

Skupna obema viroma so feminativna priponska obrazila -ica, -inja, -ka, -ovka in -ulja. Obrazilo -ica se dodaja izglasjem na -(a)č (kovačica), -l (oslica) in -t (krtica), zamenjuje pa moškospolsko priponsko obrazilo -ec (Korošec Korošica). Obrazilo -inja je le dodajalno k izglasjem na -g (boginja), -(a)k (vezakinja). Enako velja za priponski obrazili -ulja, ki se dodaja izglasju na $-k$ (volkulja), in -ovka, ki se dodaja izglasjem podstav na -d (Židovka) in -v (levovka). Priponsko obrazilo -ka lahko dodamo zgolj izglasju na -d (medvedka), zamenjuje 
pa obrazilo -ec (Slovenec - Slovenka). Znova gre tako za občnoimenske kot tudi lastnoimenske feminative.

16) Peter Končnik: Slovenska slovnica z naukom, kako se pišejo pisma in opravilni sestavki

Leta 1883 je na Dunaju izšla Slovenska slovnica z naukom, kako se pišejo pisma in opravilni sestavki avtorja Petra Končnika. Slovnica je doživela več ponatisov, ki so $\mathrm{v}$ primerjavi $\mathrm{s}$ prvo izdajo brez sprememb, in ima izrazito praktično učbeniško naravo (Stramljič Breznik 1999a: 223). Razdeljena je na štiri dele: Slovnico, Oblikoslovje, Skladnjo in Vaje v spisju. Tvorjenje besed je poleg glasoslovja, pravopisa in skladja zajeto v prvem delu. Tvorba samostalnikov je podana prek pravil ob naštetih tipičnih obrazilih določene pomenske skupine. Končnik (1883: 15) podaja naslednjo opredelitev: »Besede so korenike ali rastlike. Nekatere rastlike priraščajo po glasovnej menjavi naravnost iz korenik.« Podobno kot Janežič tudi Končnik uporabi termin obrazilo, kot podpomenko pa še izraz priponka. Tvorba feminativov je omenjena $\mathrm{v}$ poglavju Izpeljava samostalnikov. Končnik najprej piše o tvorbi poimenovanj za osebe moškega spola iz samostalnika, pridevnika in glagola, nato pa opozori še na tvorjenje Ženskospolskih poimenovanj z obrazili -ica, -inja in -ka (Končnik 1883: 16).

Preglednica 22: Zastopanost feminativnih priponskih obrazil po Toporišiču in Končniku

\begin{tabular}{|l|l|l|l|l|l|l|l|l|}
\hline $\begin{array}{l}\text { Obrazila po } \\
\text { SS (2004) }\end{array}$ & -a & -ica & -ična & -inja & -ja & -ka & -ovka & -ulja \\
\hline Toporišič & Polda & davkarica & grofična & dedinja & županja & brucka & pekovka & volkulja \\
\hline Končnik & $/$ & kopačica & $/$ & divjakinja & $/$ & Bečanka & $/$ & $/$ \\
\hline
\end{tabular}

Obema viroma skupna so priponska obrazila -ica, -inja in $-k a$, ki se tudi sicer v slovnicah 19. stoletja kažejo kot najpogostejša, ko govorimo o feminativni tvorbi. Vsa tri nastopajo pri Končniku samo kot dodajalna: -ica k izglasju - $(a) \check{c}$ (kopačica), -ka k izglasju -(a)n (Bečanka) in -inja k izglasju -(a)k (divjakinja). 
17) Schreiner-Bezjak: Slovenska jezikovna vadnica za tesno združeni poduk $v$ slovnici, pravopisju in spisju

Na začetku 20. stoletja, v letih 1903-1905, je izšla Slovenska jezikovna vadnica za tesno združeni poduk $v$ slovnici, pravopisju in spisju (SchreinerBezjak). Gre za nekoliko drugačen vidik besedotvorne obravnave: $\mathrm{z}$ vajami in primeri, podkrepljenimi s pravili. V vadnici v poglavju Sklanjatev, podpoglavju Samostalnik, najdemo vajo, kjer je treba $\mathrm{z}$ obrazili -ica, -inja in -ka iz samostalnikov moškega spola (berač, krojač, Celjan, pomočnik, roditelj, osel, pes, kristjan, pekar, rešitelj, golob, upravitelj) tvoriti samostalnike ženskega spola. V isti nalogi je treba tvoriti tudi samostalnike ženskega spola, ki poimenujejo prebivalca države ali pokrajine (Slovenec, Nemec, Kranjec, Štajerec, Primorec). Opažamo, da sta se avtorja omejila na tvorbo feminativov zgolj s tremi priponskimi obrazili, to so -ica, -inja in -ka, kar potrjujejo tudi pravila, navedena v nadaljevanju. Posebno poglavje z naslovom Izpeljava ženskih samostalnikov iz moških je posvečeno tvorbi feminativov. Kot primere avtorja navajata: mesar $\rightarrow$ mesarica, vrtnar $\rightarrow$ vrtnarica, romar $\rightarrow$ romarica, graščak $\rightarrow$ graščakinja, junak $\rightarrow$ junakinja, Ljubljančan $\rightarrow$ Ljubljančanka in Mariborčan $\rightarrow$ Mariborčanka. Za primeri je navedeno in s krepkim tiskom poudarjeno pravilo, da iz mnogo moških samostalnikov tvorimo ženske tako, da jim dodamo feminativna obrazila -ica, -inja in -ka (Schreiner-Bezjak 1927: 8-9).

Preglednica 23: Zastopanost feminativnih priponskih obrazil po Toporišiču in Schreiner-Bezjaku

\begin{tabular}{|l|l|l|l|l|l|l|l|l|}
\hline $\begin{array}{l}\text { Obrazila po } \\
\text { SS (2004) }\end{array}$ & -a & -ica & -ična & -inja & -ja & -ka & -ovka & -ulja \\
\hline Toporišič & Polda & davkarica & grofična & dedinja & županja & brucka & pekovka & volkulja \\
\hline $\begin{array}{l}\text { Schreiner- } \\
\text { Bezjak }\end{array}$ & $/$ & grešnica & $/$ & težakinja & $/$ & $\begin{array}{c}\text { Mariborčan- } \\
k a\end{array}$ & $/$ & $/$ \\
\hline
\end{tabular}

Znova so Toporišičevi in Schreiner-Bezjakovi slovnici pri feminativni tvorbi skupna le ženskospolska priponska obrazila -ica, -inja in -ka. Priponsko obrazilo -ica se po drugem obravnavanem viru lahko dodaja izglasjem na $-(a) \breve{c}$ (beračica), -l (oslica), -(ite)lj (ljubiteljica), -(a)r (romarica), -s (psica), zamenjuje 
pa moškospolsko priponsko obrazilo -ik (grešnica). Obrazilo -inja je le dodajalno $\mathrm{k}$ izglasju na -(̌̌a)k (graščakinja), obrazilo $-k a$ pa $\mathrm{k}$ izglasju na $-(\check{c} a) n$ (Ljubljančanka). Ponovno je na podlagi navedenih primerov mogoče govoriti o občnoimenskih in lastnoimenskih feminativih.

\section{8) Anton Breznik: Slovenska slovnica za srednje šole}

Če med slovnicami Antona Breznika najprej pregledamo Slovensko slovnico za srednje šole iz leta 1916, ugotovimo, da je del, namenjen besedotvorju, avtor naslovil kot Debloslovje. Pripono imenuje tudi deblotvorna imenska končnica. Posebej loči deblotvorne glagolske pripone (tiste, ki tvorijo glagolsko deblo). Sledijo obravnava izpeljave, reduplikacije in sestave. V tem poglavju Breznik obravnava tudi pomenoslovje in izvor jezika ter govori o tropih in figurah, česar znotraj besedotvornega dela po navadi ne srečamo. V naslednji, sicer tretji, izdaji Slovenske slovnice za srednje šole iz leta 1924 Breznik besedotvorni del že naslovi z Besedotvorje. Kot v zgoraj omenjeni izdaji se tudi v tej avtor posveti izpeljavi, sestavi pa znotraj poglavja o podvojitvi. V besedotvorni del so ponovno vključena poglavja o izvoru jezika (Pomenoslovje in izvor jezika, Besede tujega izvora) ter o tropih in figurah ( $\mathrm{O}$ rabi besed: pravi pomen ter tropi in figure). V izdaji iz leta 1934, ki je služila kot vir v pričujoči raziskavi, je Breznik del, namenjen besedotvorju, naslovil Besedoslovje. V njem se posveti izpeljavi, »sestavi« in s predlogi zloženim besedam. Posebna poglavja so znova namenjena pomenoslovju in izvoru besed (Besedni zaklad, Besede tujega izvora). $\mathrm{V}$ uvodu poglavja Besedoslovje je Breznik uporabil termina osnova kot »tisti del besede, ki se pri oblikovanju ne spreminja« (Breznik 1934: 157), in obrazilo (v slovnici iz leta 1916 uporabi izraza deblo in sklonilo, »to je tista končnica, s katero se tvorijo skloni« (Breznik 1916: 170)). V podpoglavju Izpeljava Breznik popiše priponska obrazila pri samostalnikih. Opažamo, da feminative tvorijo -ica (družica), -inja (boginja), -ja (gostja), -ka (meščanka), -na (gospodična), -ulja (volkulja) (Breznik 1934: 159-166). 
Preglednica 24: Zastopanost feminativnih priponskih obrazil po Toporišiču in Brezniku (1934)

\begin{tabular}{|l|l|l|l|l|l|l|l|c|}
\hline $\begin{array}{l}\text { Obrazila po } \\
\text { SS (2004) }\end{array}$ & -a & -ica & -ična & -inja & -ja & -ka & -ovka & -ulja \\
\hline Toporišič & Polda & davkarica & grofična & dedinja & županja & brucka & pekovka & volkulja \\
\hline $\begin{array}{l}\text { Breznik } \\
(1934)\end{array}$ & $/$ & kraljica & cesarična* & junakinja & gostja & mě̌čanka & $/$ & volkulja \\
\hline
\end{tabular}

Glede feminativne tvorbe so obema proučevanima viroma skupna priponska obrazila -ica, -inja, -ja, $-k a$ in -ulja. Razlika je vidna pri tvorbi feminativov z obrazilom -ična po Toporišiču oziroma -na po Brezniku. Avtorja navajata iste ali vsaj sorodne primere, pri čemer Toporišič izhaja iz podstave denimo grof, Breznik pa grofič. Poleg naštetih pa za razliko od Toporišiča Breznik izpostavi še priponsko obrazilo -ilja. Kot dodajalna pri Brezniku nastopajo priponska obrazila -ica (k izglasjem na -(a)č kovačica, -g družica, -lj kraljica, -t kmetica), -inja (k izglasjem na -g boginja, -k svakinja), -ja (k izglasju na -t gostja), -ka (k izglasju na -(a)n meščanka) in -ulja (k izglasju na -k volkulja). Zamenjevalno je pri Brezniku le obrazilo -ka (-ec: Slovenka).

\section{9) Rupel, Bajec, Kolarič, Šolar: Slovenska slovnica}

Leta 1956 je izšla Slovenska slovnica štirih avtorjev, v glavnem Breznikovih učencev; pregledali smo izdajo iz leta 1968. Besedilo glede na Breznikove slovnice ne prinaša novosti; Vidovič Muha (1998: 81) ocenjuje, da v primerjavi z evropskim oz. celo svetovnim jezikoslovnim dogajanjem pomeni zaostajanje. Primere tvorbe feminativov najdemo $\mathrm{v}$ podpoglavju Izpeljava samostalnikov. Ugotavljamo, da se »imena ženskih delujočih oseb« tvorijo s priponskima obraziloma -ica (grabljica) in -ka (igralka, kadilka), imena ženskih bitij pa s feminativnimi obrazili -ica (golobica, tatica), -inja (boginja) in -ka (bralka, Slovenka, točajka, bogatinka, gostačka). Kot eno najplodnejših pa avtorji slovnice izpostavijo priponsko obrazilo -ica. 
Preglednica 25: Zastopanost feminativnih priponskih obrazil po Toporišiču in Slovenski slovnici (1956)

\begin{tabular}{|l|l|l|l|l|l|l|l|l|}
\hline $\begin{array}{l}\text { Obrazila po SS } \\
(2004)\end{array}$ & -a & -ica & -ična & -inja & -ja & -ka & -ovka & -ulja \\
\hline Toporišič & Polda & davkarica & grofična & dedinja & županja & brucka & pekovka & volkulja \\
\hline $\begin{array}{l}\text { Slovenska } \\
\text { slovnica 1956 }\end{array}$ & $/$ & grabljica & $/$ & boginja & $/$ & bralka & $/$ & $/$ \\
\hline
\end{tabular}

Toporišičevi Slovenski slovnici ter slovnici štirih avtorjev so skupna naslednja feminativna priponska obrazila: $-i c a$, -inja in $-k a$. Navedena obrazila so se že v več virih izkazala za najproduktivnejša, tvorijo pa lahko občnoimenske in lastnoimenske feminative. Vsa tri so po Slovenski slovnici 1968 dodajalna: -ica se dodaja k izglasjem na -b (golobica), -t (tatica); -inja k izglasju na -g (boginja); -ka pa k izglasjem na -(a)č (gostačka), -(a)j (točajka), -(i)n (bogatinka). Kot zamenjevalni nastopita obrazili $-k a$, ki zamenjuje moškospolsko obrazilo -ec (kadilec-kadilka), in -ica, ki prav tako zamenja obrazilo -ec (grabljica).

\subsection{Bajčevem Besedotvorju slovenskega jezika}

20. stoletje zaključimo z delom Antona Bajca Besedotvorje slovenskega jezika (1950). Da je besedotvorni ustroj slovenskega jezika zelo zanimiv in bogat, dokazujejo prav njegova sistematična dela. Njegova obdelava v glavnem temelji na gradivu knjižnega jezika, prvi zvezek, osredotočen na izpeljavo samostalnikov, pa je sicer mogoče razumeti predvsem kot učbenik in pripomoček za tvorbo novih izrazov v terminologiji (Orožen 1960: 25). Toporišič sicer pravi, da sodobni jezikoslovec $\mathrm{V}$ njegovi obravnavi besedotvorja pogreša večjo teoretično ozaveščenost, metodološke inovacije nasproti Miklošiču, boljšo preglednost, doslednejše ločevanje med sinhronijo in diahronijo, med knjižnojezikovnim in narečnim. A priznati je treba, da iz strukturalne sodobnosti ni mogoče spreminjati »okusa« diahronične in genetične polpreteklosti (Toporišič 1967: 4). Bajec je pri obravnavi izpeljave samostalnikov ohranil delitev soglasniških priponskih obrazil po mestu izgovora soglasnika. Dobra stran monografije je predvsem veliko število primerov, ki pa jih navaja preveč mehanično, kar po abecednem redu ne glede na 
pomen, starost, izvor (Trunkelj 1991: 19); na to opozori tudi Šolar (1951: 142). Avtor je vzel Miklošičevo osnovo in nanjo postavljal svoje besedotvorje; s tem poglavjem se namreč po Miklošiču nihče ni ukvarjal sistematično. Njegove ugotovitve so povzele šolske slovnice, a tovrstna poglavja niso mogla zadovoljiti ne praktičnih ne teoretičnih potreb. Priponska obrazila, ki po Bajcu tvorijo feminative, so:

- Priponsko obrazilo -ica je sicer po Bajcu eno najpogostejših in najtvornejših slovenskih priponskih obrazil in je tudi v drugih slovanskih jezikih močno izpodrinilo priponsko obrazilo $-k a$, tako Bajec. Obrazilo -ica med drugim dela iz moških imen ženska: bog - božica, drug družica, golob - golobica, jagnje - jagnjica, jereb - jerebica, kmet kmetica, kralj - kraljica, krt - krtica, mezeg - mezgica, osel - oslica, mramor-mramorica, pastir-pastirica, (prepel) - prepelica, pes - psica, rak-račica, (vever) - veverica, tat-tatica, tele - telica, volk-volčica, varih - varišica, žrebe - žrebica. Bajec izpostavi naslednje »formante«, s katerimi se druži obrazilo -ica: $\mathrm{z}$ dodajanjem k -(a)r: dolinarica, kuščarica, gospodarica, jajčarica, jerebičarica, mesarica ('žena' in 'sekira'), mlekarica, mrharica, vratarica; z zamenjavo -ik: glasnica, hotnica, jetnica, jezičnica, krstnica, krščenica, krvnica, mesečnica, plodnica, pohotnica, pomočnica, porodnica, prejemnica, prešuštnica, prošnjica; z dodajanjem k -(a)č: kovačica, rogačica, vojačica ('družica'); z dodajanjem oz. z zamenjavo -(ə)c: jarčica; junica, grlica; $\mathrm{z}$ dodajanjem $\mathrm{k}$ -(o)r: botrica, lotrica in -(ite)lj: prositeljica, učiteljica.

- Obrazilo -inja po Bajcu tvori »ženska imena« (boginja, botrinja, lenuhinja, levinja, nečakinja, prvakinja, robinja, vnukinja, vojvodinja), vidimo, da v glavnem z dodajalnim načinom.

- S priponskim obrazilom $-\boldsymbol{k} \boldsymbol{a}$ delamo »iz moških imen ženska«. Obrazilo $-k a$ »ustreza naslednjim moškim formantom« (jih zamenjuje): -ək: pastorka, osebenjka, nadevka, povedka, duška, jarčka, mačka (po Bajcu redka tvorba); -əc: delavka, dolinka, Slovenka, Nemka, lovka, zajka (»nastopa redno«); dodaja se k izglasjem na -(i)n: domačinka, trpinka, gizdalinka, bogatinka, potepinka; -(a)n: gorjanka, Furlanka, Norvežanka, 
ciganka; -(a)̌̌: gostačka, postopačka, Mihačka (»redno, najrajši ob priimkih«); -(i)̌̌: pozovička, »sicer često ob priimkih«: Pavlička; -(a)j: strežajka, čuvajka; še ob drugih obrazilih: devojka, debeluška, vohunka, zlasti pri imenih in priimkih: Herodežka, Mahnečka, Slabečka.

- Obrazilo -na se dodaja samostalnikom moškega spola na -(i)̌c (bratična, dedična, gospodična, kraljična).

- Priponsko obrazilo -ulja tvori poimenovanja za ženske osebe (vragulja, potepulja) in živalske samice (volkulja).

Preglednica 26: Zastopanost feminativnih priponskih obrazil po Toporišiču in Bajcu

\begin{tabular}{|l|l|l|l|l|l|l|l|l|}
\hline $\begin{array}{l}\text { Obrazila po } \\
\text { SS (2004) }\end{array}$ & -a & -ica & -ična & -inja & -ja & -ka & -ovka & -ulja \\
\hline Toporišič & Polda & davkarica & grofična & dedinja & županja & brucka & pekovka & volkulja \\
\hline Bajec & $/$ & kraljica & kraljična* $^{*}$ & prerokinja & $/$ & ciganka & $/$ & vragulja \\
\hline
\end{tabular}

Pregled gradiva v Besedotvorju slovenskega jezika kaže na pojavnost priponskih obrazil -ica, -ična, -inja, -ka in -ulja $\mathrm{v}$ obeh delih, tudi $\mathrm{v}$ Toporišičevi Slovenski slovnici. Opozoriti pa moramo, da Bajec namesto obrazila -ična navaja priponsko obrazilo -na, ob tem pa poda primere, enake Toporišičevim. Opažamo tudi, da avtor mnogo več pozornosti posveti priponskima obraziloma -ica in $-k a$, saj le za njiju natančno navede tudi moškospolska priponska obrazila, ki se jim ti dve obrazili dodajata oziroma jih zamenjujeta. Priponsko obrazilo -ica se tako po Bajcu lahko dodaja izglasjem na -b (golobica), -(a)č (rogačica), -g (božica), -(ite)lj (prositeljica), -r (botrica), zamenjuje pa moškospolski obrazili -ec (junica) in -ik (prejemnica). Priponska obrazila -inja, -na in -ulja so samo dodajalna. Obrazilo -inja se po Bajcu dodaja k izglasjem na -b (robinja), -g (boginja), -(u)h (lenuhinja), -k (nečakinja), -r (botrinja), -v (levinja). Priponsko obrazilo -na se dodaja zgolj moškospolskim samostalnikom z izglasjem -(i)č (gospodična). Obrazilo -ulja dodajamo $\mathrm{k}$ izglasjem moškospolskih samostalnikov na $-g$ (vragulja), -k (rakulja) in -p (potepulja). Priponsko obrazilo -ka se pri Bajcu dodaja izglasjem na -(a)č (postopačka), -(u)h (debeluška), -(a)j (strežajka), -(i)n (domačinka), zamenjuje pa moškospolski obrazili -ec (delavka) in -ek (mačka). Tudi pri Bajcu zasledimo primere občnoimenskih in lastnoimenskih feminativov. 


\subsection{Primerjalni pregled}

Preglednica 27: Primerjalni pregled zastopanosti feminativnih priponskih obrazil

\begin{tabular}{|c|c|c|c|c|c|c|c|c|}
\hline $\begin{array}{l}\text { Obrazila } \\
\text { po SS } \\
(2004)\end{array}$ & $-a$ & $-i c a$ & -ična & -inja & $-j a$ & $-k a$ & -ovka & -ulja \\
\hline Toporišič & Polda & davkarica & grofična & dedinja & županja & brucka & pekovka & volkulja \\
\hline Bohorič & / & $\begin{array}{c}\text { Lamberga- } \\
\text { rica }\end{array}$ & 1 & levinja & 1 & kojnka & 1 & I \\
\hline Zagajšek & I & kraljica & I & boginja & I & hinavka & $/$ & I \\
\hline Pohlin & I & sidarica & I & I & I & smrdljivka & / & / \\
\hline Vodnik & I & kovačica & 1 & rojakinja & I & čuvajka & I & I \\
\hline Dajnko & I & grešnica & I & prerokinja & bedača & Slovenka & Židovka & I \\
\hline Metelko & I & golobica & 1 & boginja & županja & starka & 1 & volkulja \\
\hline Muršec & I & krojačica & I & grofinja & županja & učenka & Cafovka & volkulja \\
\hline Malavašič & / & kmetica & 1 & boginja & županja & starka & $\begin{array}{c}\text { Gornik- } \\
\text { ovka }\end{array}$ & Volkulja \\
\hline Potočnik & I & kovačica & I & vojakinja & 1 & bogatinka & 1 & $\begin{array}{c}\text { Novak- } \\
\text { ulja }\end{array}$ \\
\hline Majar & 1 & lončarica & I & beračinja & 1 & ovčarka & / & I \\
\hline Navratil & 1 & tožnica & 1 & I & 1 & Slovenka & I & I \\
\hline Janežič & $\begin{array}{c}\text { glava- } \\
\check{c} a\end{array}$ & beračica & I & junakinja & / & vaščanka & Perkovka & / \\
\hline Miklošič & / & predica & I & boginja & I & delavka & levovka & vragulja \\
\hline $\begin{array}{l}\text { Šuman } \\
1881\end{array}$ & / & vratarica & $\begin{array}{c}\text { gospod- } \\
\text { ična }\end{array}$ & boginja & / & medvedka & / & volkulja \\
\hline $\begin{array}{l}\text { Šuman } \\
1884\end{array}$ & I & kmetica & I & I & I & medvedka & I & / \\
\hline Končnik & / & kopačica & / & divjakinja & / & Bečanka & / & I \\
\hline $\begin{array}{l}\text { Schreiner- } \\
\text { Bezjak }\end{array}$ & I & grešnica & 1 & težakinja & I & $\begin{array}{c}\text { Mariborčan- } \\
k a\end{array}$ & I & / \\
\hline Breznik & I & kraljica & cesarična & junakinja & gostja & meščanka & I & volkulja \\
\hline $\begin{array}{l}\text { Slovenska } \\
\text { slovnica } \\
1956\end{array}$ & I & grabljica & 1 & boginja & 1 & bralka & I & I \\
\hline Bajec & / & kraljica & kraljična & boginja & I & ciganka & I & vragulja \\
\hline
\end{tabular}

Kot najrodnejši, torej zastopani v prav vseh, tj. 21 obravnavanih virih, nastopata feminativni priponski obrazili $-i c a$ in $-k a, \mathrm{z} 18$ pojavitvami jima sledi obrazilo -inja. Kot najmanj produktivni sta se izkazali priponski obrazili - $a$ z zgolj dvema pojavitvama in -na (po Toporišiču sicer -ična) s štirimi. Spodnji grafikon 
prikazuje zastopanost posameznih feminativnih priponskih obrazil po slovnicah slovenskega jezika (vključno s Toporišičevo Slovensko slovnico in Bajčevim Besedotvorjem slovenskega jezika).

Grafikon 6: Zastopanost feminativnih priponskih obrazil

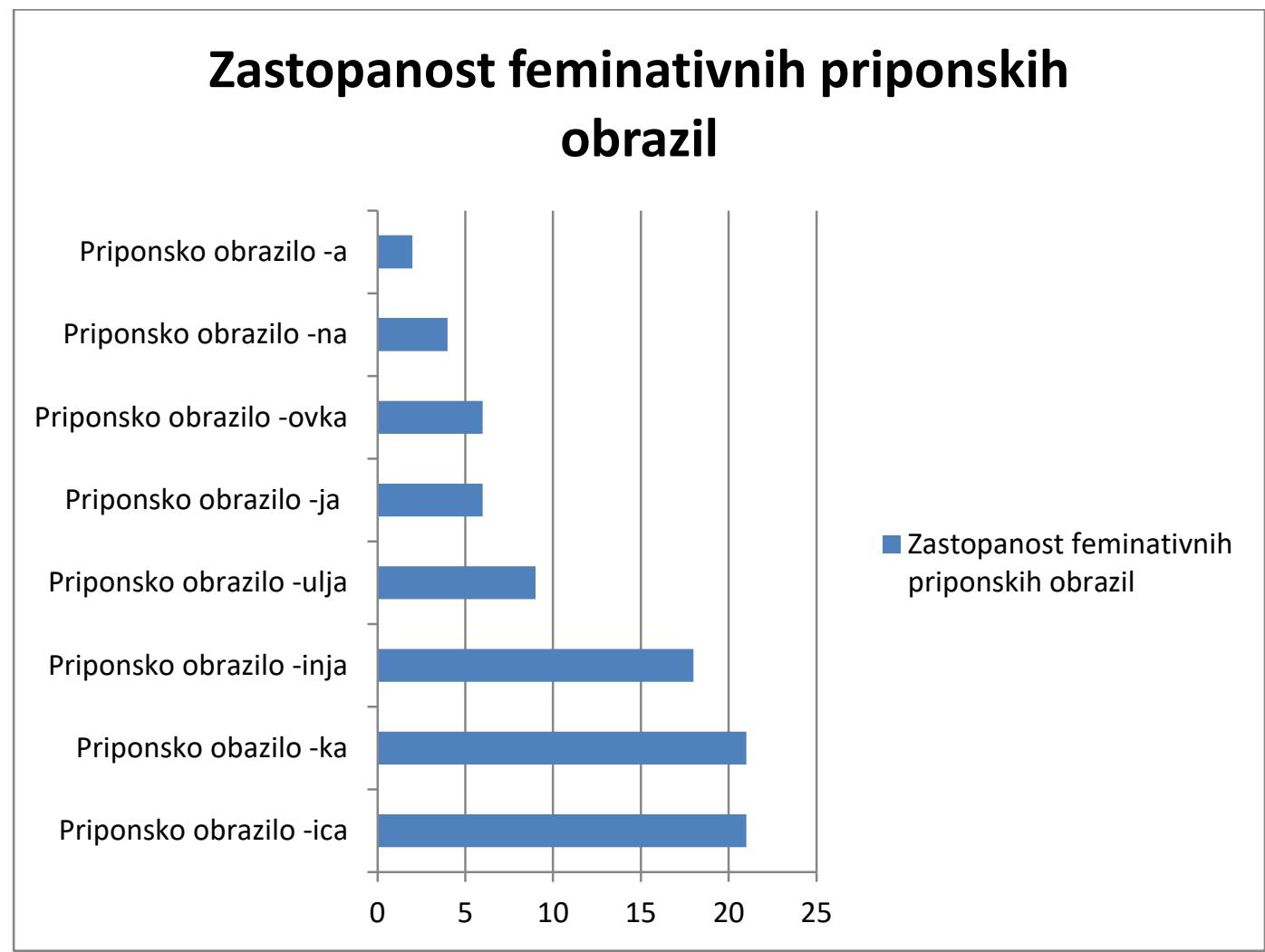

Tvorbo iz lastno- in občnoimenske podstave obravnavajo Bajčevo Besedotvorje slovenskega jezika in vse $\mathrm{v}$ tem poglavju obravnavane slovnice, razen Zagajškove in Majarjeve. Večinoma gre za tvorbo priimkovnih feminativov (Cafovka, Novakulja) ali ženskospolskih poimenovanj za prebivalke (Kranjica).

Ob koncu tega pregleda pa želimo izpostaviti še nekaj drugačnih obrazil v primerjavi z današnjimi. Spodnja preglednica prikazuje posebnosti, ki smo jih zaznali ob pregledu slovenskih slovnic skozi zgodovino. Z ležečim tiskom so napisane besede, uveljavljene $\mathrm{v}$ sodobnem jeziku in navedene $\mathrm{v}$ sodobnih jezikovnih virih. 
Preglednica 28: Obrazilna drugačnost - dodajalni način

\begin{tabular}{|c|c|c|c|c|c|c|c|c|}
\hline $\begin{array}{l}\text { Obrazilna } \\
\text { razmerja }\end{array}$ & $-c a$ & $-i c a$ & -inja & -kinja & $-k a$ & $-o v c a$ & -ovka & -ulja \\
\hline$-(a) \check{c}$ & I & I & $\begin{array}{l}\text { beračinja } \\
\text { beračica }\end{array}$ & I & I & $\begin{array}{c}\text { kovač- } \\
\text { ovca } \\
\text { kovačica }\end{array}$ & I & $\begin{array}{l}\text { rogačulja } \\
\text { rogača } \\
\text { rogačka }\end{array}$ \\
\hline$-d$ & 1 & $\begin{array}{c}\text { medvedica } \\
\text { medvedka }\end{array}$ & $\begin{array}{c}\text { sosedinja } \\
\text { soseda }\end{array}$ & 1 & 1 & I & $\begin{array}{c}\text { Židovka } \\
\text { Židinja }\end{array}$ & / \\
\hline$-h$ & I & I & I & $\begin{array}{l}\text { Čehkinja } \\
\text { Čehinja }\end{array}$ & $\begin{array}{l}\text { Čehka } \\
\text { Čehinja }\end{array}$ & I & $\begin{array}{l}\text { Čehovka } \\
\text { Čehinja }\end{array}$ & I \\
\hline$-k$ & I & $\begin{array}{c}\text { račica } \\
\text { rakovka }\end{array}$ & $\begin{array}{l}\text { pekinja } \\
\text { pekovka }\end{array}$ & I & I & I & I & $\begin{array}{c}\text { Novakulja } \\
\text { Novakovka; } \\
\text { rakulja } \\
\text { rakovka }\end{array}$ \\
\hline $\begin{array}{l}-l \\
(-l j)\end{array}$ & I & I & 1 & $\begin{array}{l}\text { prijatel- } \\
\text { kinja } \\
\text { prijatelj- } \\
\text { ica }\end{array}$ & I & I & / & 1 \\
\hline$-n$ & I & I & $\begin{array}{l}\text { poganinja } \\
\text { poganka }\end{array}$ & I & / & I & I & I \\
\hline$-(a) r$ & $\begin{array}{c}\text { romarca } \\
\text { romarica } \\
\text { mlinarca } \\
\text { mlinarica }\end{array}$ & $\begin{array}{l}\text { pisarica } \\
\text { pisarka }\end{array}$ & I & I & 1 & $\begin{array}{c}\text { mesar- } \\
\text { ovca } \\
\text { mesarka }\end{array}$ & 1 & I \\
\hline$-r$ & I & I & $\begin{array}{c}\text { botrinja } \\
\text { botra }\end{array}$ & I & I & I & I & I \\
\hline$-v$ & I & I & I & I & 1 & 1 & $\begin{array}{c}\text { levovka } \\
\text { levinja }\end{array}$ & 1 \\
\hline
\end{tabular}

1. Opazili smo, da ima $\mathrm{v}$ slovenskih slovnicah skozi zgodovino prednost priponsko obrazilo - $c a$ pred obrazilom -ica, kadar gre za dodajanje $\mathrm{k}$ moškospolskemu izglasju na -(a)r (romarca pri Malavašiču, mlinarca pri Potočniku).

2. Priponsko obrazilo -ica je ob izglasjih podstave na $-d$ ali $-k$ ter ob $-(a) r$ nastopalo namesto obrazila -ka (medvedica pri Dajnku namesto medvedke, pisarica po Muršcu namesto pisarke) in njegovih variant (račica pri Muršcu, danes rakovka).

3. Ugotovili smo, da je feminativno obrazilo -inja $\mathrm{v}$ zgodovini nastopalo namesto različnih obrazil: ob izglasju na -(a)č namesto obrazila -ica (beračinja v Majarjevi slovnici), ob izglasjih podstave na $-d$ in $-r$ namesto $-a$ (sosedinja, botrinja - obe $\mathrm{v}$ Miklošičevi slovnici, sosedinja še pri Šumanu, botrinja pri Bajcu), ob - $k$ namesto -ovka (pekinja pri Vodniku) ter pri -n namesto -ka (poganinja po Miklošiču).

4. Ženskospolsko obrazilo -kinja se dodaja k izglasju podstave na - $h$ (Čehkinja $\mathrm{v}$ Dajnkovi slovnici namesto današnje Čehinje) in -l (prijatelkinja po Dajnku namesto prijateljice $\mathrm{v}$ sodobnih virih). 
5. Priponsko obrazilo $-k a$ se pojavi namesto obrazila -inja ob podstavi na $-h$ (Čehka v Dajnkovi slovnici namesto Čehinje).

6. Posebnost je priponsko obrazilo -ovca, ki ga ob analizi feminativov v sodobnih jezikovnih virih sploh nismo zasledili, skozi zgodovino pa je nadomeščalo obrazilo -ica ob izglasju na $-(a) \check{c}$ (kovačovca pri Dajnku) in $-k a$ ob moškospolskem izglasju na -(a)r (mesarovca prav tako samo pri Dajnku).

7. Priponsko obrazilo -ovka nastopi ob izglasjih podstav na $-d,-h$ in $-v$, in to zmeraj namesto obrazila -inja (Židovka, Čehovka - obe pri Dajnku, prva tudi pri Miklošiču in Šumanu, levovka pri Miklošiču in Šumanu) - morda gre za izhajanje iz svojilnega pridevnika na $-o v$ in nato dodajanje obrazila $-k a$, čeprav avtorji slovnic tovrstne tvorbe ne omenjajo.

8. Ugotavljamo, da feminativno obrazilo -ulja nastopi namesto priponskega obrazila $-k a$ in njegovih variant, in to ob izglasjih na -(a)č (rogačulja pri Miklošiču in Šumanu) in - $k$ (Novakulja pri Potočniku, rakulja pri Bajcu).

Spodnja preglednica pa prikazuje, katera ženskospolska obrazila so $\mathrm{v}$ zgodovini zamenjevala moškospolska priponska obrazila in so glede na obrazilno razmerje drugačna od današnjih.

Preglednica 29: Obrazilna drugačnost - zamenjevalni način

\begin{tabular}{|c|c|c|c|c|c|c|c|c|}
\hline $\begin{array}{l}\text { Obrazilna } \\
\text { razmerja }\end{array}$ & $-c a$ & $-i c a$ & -inja & -kinja & $-k a$ & $-o v c a$ & -ovka & -ulja \\
\hline$-e c$ & I & $\begin{array}{l}\text { Koroškinja } \\
\text { Korošica }\end{array}$ & I & $\begin{array}{c}\text { Nemkinja } \\
\text { Nemka } \\
\text { Slovenkinja } \\
\text { Slovenka }\end{array}$ & 1 & I & I & 1 \\
\hline
\end{tabular}

Pri zamenjevalnem načinu tvorbe feminativov smo opazili manj posebnosti: priponsko obrazilo -kinja zamenja moškospolsko obrazilo -ec pri tvorbi iz lastnoimenske podstave, kjer bi v sodobnem jeziku kot zamenjevalno pričakovali ženskospolsko obrazilo $-k a$ (Nemkinja v Dajnkovi slovnici, Slovenkinja pri Dajnku in Miklošiču) oz. -ica (Koroškinja pri Dajnku).

Ugotavljamo, da predstavljena drugačna obrazilna razvrstitev vendarle ni zmeraj $\mathrm{v}$ popolnem nasprotju $\mathrm{s}$ tvorbo $\mathrm{v}$ sodobnem jeziku, če upoštevamo rezultate obrazilne produktivnosti v poglavju Tvorba feminativov $v$ slovenščini iz 
občnoimenske podstave (7.3 Primerjalni pregled); drugačni od današnjih so včasih le primeri, ki jih avtorji pregledanih slovnic slovenskega jezika navajajo. Ženskospolsko obrazilo $-c a$ se tako $\mathrm{v}$ slovenskih slovnicah skozi zgodovino dodaja k izglasju na -(a)r, kar je sicer v skladu s tvorbo v sodobnem knjižnem jeziku; priponsko obrazilo - $c a$ smo, kot bomo videli, zasledili le pri enem poimenovanju osebe, tvorjenem iz občnoimenske podstave, in to prav pri moškospolskem izglasju na $-(a) r{ }^{62}$ Tudi priponsko obrazilo -ica je ob izglasju na $-(a) r \mathrm{v}$ sodobnem jeziku zastopano $\mathrm{z}$ visokim številom primerov; res pa ob izglasjih na $-d$ ali $-k$, kadar gre za poimenovanje oseb, ne nastopi (le pri poimenovanjih živali, denimo velblodica, volčica - kot kažeta tudi primera račica in medvedica v slovenskih slovnicah, torej gre tudi tukaj za ujemanje). Drugače pa je s priponskim obrazilom -inja, ki se ob izglasju na $-(a) \check{c}$ v sodobnih jezikovnih virih, ko gre za tvorbo feminativov, res ne pojavi, ob izglasjih na $-r$ pa zelo redko (le en primer). Pogosto pa nastopi pri netvorjenkah z izglasjem podstave na $-d$. Priponsko obrazilo -kinja v sodobnem jeziku ne nastopi kot dodajalno, temveč zgolj kot zamenjevalno ( $\mathrm{v}$ slovnicah $\mathrm{v}$ zgodovini jezika pa se pojavi pri dodajalnem načinu tvorbe feminativov). Obrazilo $-k a$ nastopi ob izglasju na $-h$, kjer bi v sodobnem jeziku kot pogostejše pričakovali obrazilo -inja (to priponsko obrazilo ob izglasju na $-h$ namreč potrjuje nekaj več primerov kot $-k a$ ). Obrazila -ovca pa ob pregledu sodobnih jezikovnih virov nismo zasledili pri nobenem primeru. Feminativno priponsko obrazilo - ovka nastopi ob izglasjih podstav na $-d$, $-k,-r$ in $-t$, kar se le delno ujema s tvorjenkami iz slovnic skozi zgodovino slovenskega jezika. Podobno je z obrazilom -ulja, ki se v sodobnem slovenskem jeziku dodaja le $\mathrm{k}$ netvorjenkam $\mathrm{z}$ izglasji na $-c$ ali $-g$ (torej drugače kot $\mathrm{v}$ pregledanih slovnicah).

Priponsko obrazilo -kinja pa je edino, ki $\mathrm{v}$ tej analizi nastopi kot zamenjevalno - tudi v novejših jezikovnih virih se -kinja ob tvorbi feminativov pojavi le pri zamenjevalnem načinu. Zamenja moškospolsko obrazilo -ec, in to ob primerih, kjer bi $\mathrm{v}$ sodobnem knjižnem jeziku pričakovali ženskospolsko priponsko obrazilo -ka oz. -ica. Sodobni jezikovni viri pa kažejo, da pri

${ }^{62}$ Zato pa je priponsko obrazilo - $c a$ po $S P$ (2001: 119) produktivno za manjšalnice 2. ženske sklanjatve (klopca, stvarca), pojavlja se tudi pri ženskih osebnih imenih (Polonca, Špelca). 
občnoimenski tvorbi feminativov priponsko obrazilo $-e c$ večinoma zamenjujeta obrazili -ica $(4,5 \%)$ in -ka (95\%); -kinja nastopi le pri $0,5 \%$ primerov.

\section{TEORETIČNA IZHODIŠČA OBRAVNAVE FEMINATIVOV}

\subsection{Obravnava feminativov v sodobnem slovenskem knjižnem jeziku}

Osredotočili smo se na feminative, nastale iz občnoimenske podstave, v posebnem poglavju pa kot primer tvorjenja iz lastnoimenske podstave predstavljamo poimenovanja prebivalk in priimkovne feminative $\mathrm{v}$ slovenščini.

\subsubsection{Slovenska slovnica o feminativih (Toporišič 2004)}

Toporišič v Slovenski slovnici (2004: 183) feminative definira kot ženski par moškemu. Obravnava jih znotraj inačenjske (modifikacijske) izpeljave. Za tvorbo feminativov navaja naslednja priponska obrazila s primeri: -a/-á (Franca, Jožefa, Joža, Polda, frklja, smrklja; gospa), -ica/-íca (davkarica, prijateljica, junica, mucica, kegljačica; gospodarica, grabljica, golobica, Kranjica, lisica, jerebica, žrebica, telica), -ja (županja), -úlja (volkulja), -inja/-ínja (gospodinja, grofinja, biologinja, dedinja, kustosinja, vojakinja, vojvodinja), -ka (gostačka, brucka, domačinka, garderoberka, dolginka, hribovka, barbarka, ciganka, točajka, slavistka, mačka, mladenka, bralka, goljufivka, medvedka), -ovka (pekovka, Jerasovka, gadovka) in -íčna (gospodična, grofična, cesarična, kraljična). Vendar pa opozarja, da je parno žensko poimenovanje pri višje razvitih večjih bitjih pogosto izraženo s posebno besedo (mož - žena, oče - mati, hlapec dekla ...).

6.1.2 Tvorba feminativov po Adi Vidovič Muhi

Irena Stramljič Breznik sicer pojmuje izpeljanke ženskega spola, ki zaznamujejo osebe ali živali ženskega spola, kot dodajalne oziroma zamenjevalne 
feminative, vendar opozarja, da o tem v sodobni slovenski besedotvorni teoriji ni enotnega mnenja (Stramljič Breznik 2004: 18). Pri tem se sklicuje na Vidovič Muho. Slednja namreč zavrača po besedotvornem delu v Toporišičevi Slovenski slovnici očitno podrejanje tvorbe poimenovanj za ženske osebe poimenovanjem za moške osebe tudi $\mathrm{v}$ primerih, ko gre za vzporedno tvorbo (za tvorbo $\mathrm{z}$ zamenjevanjem moškospolskega priponskega obrazila z ženskospolskim), na primer pravnica, zdravnica, delavka (Vidovič Muha 2003: 180). V članku Prvine družbene prepoznavnosti ženske prek poimenovalne tipologije njenih dejavnosti, lastnosti Vidovič Muha (1997: 71) sicer navaja, da tradicionalno besedotvorje feminative uvršča med modifikacijske tvorjenke (kot smo že ugotovili, je tako tudi v večini drugih slovanskih jezikov), ugotavlja pa, da jih »verjetno lahko obravnavamo kot navadne izpeljanke iz samostalnika $\mathrm{z}$ besedotvornim pomenom 'nosilka povezave'« (Vidovič Muha 1997: 71). V monografiji Slovensko skladenjsko besedotvorje iz leta 2011 pa se isti avtorici prištevanje feminativov med modifikacijske izpeljanke sploh ne zdi dopustno. Pojasnjuje namreč, da pri tvorbi feminativov gre za obraziljenje jedra skladenjske podstave in ne določujoče sestavine (Vidovič Muha 2011: 30).

Vidovič Muha (1997: 71-74, 2011: 409-412) tvorjenke kot poimenovanja žensk na podlagi motivirajoče besede loči v štiri skupine:

1) V prvo uvršča samostalnike ženskega spola, tvorjene iz samostalnikov moškega spola; obravnava jih, za razliko od Toporišiča, kot navadne izpeljanke iz samostalnika $\mathrm{z}$ besedotvornim pomenom nosilka povezave. Kot priponska obrazila, s katerimi tovrstni izrazi nastanejo, navaja -a (glavana), -(ar)ka (fizičarka), -esa (klovnesa), -ica (apotekarica), -ina (heroina), -inja (rojakinja), -isa (diakonisa), -ja (gostja), -ka (alpinistka), -(ov)ka (pekovka), -na (gospodična), -ulja (vragulja).

2) V drugo skupino sodijo redki primeri tvorbe samostalnika moškega spola s podkategorijo spola človeško+ iz samostalnikov ženskega spola z enako podkategorijo - gre za maskulinative, pri čemer se je kot tvorno za zdaj izkazalo le obrazilo -ec (šiviljec).

3) Tretja skupina obsega tvorjenke $\mathrm{z}$ besedotvornim pomenom vršilka dejanja, nosilka lastnosti, povezave, pri čemer je podstava za tvorbo 
poimenovanj moškega in ženskega spola enaka (t. i. vzporedna podstava); obrazila za tvorbo iz glagola so -ica (žanjica), -ka (igralka), -nica (odvetnica), iz pridevnika -ica (dolžnica), -ka (gojenka), -nica (svetnica), iz samostalnika pa -ejka (Evropejka), -ka (Azijka), -nica (tapetnica).

4) V zadnjo skupino sodijo tvorjenke kot poimenovanja žensk ali moških, ki so nastale iz različnih podstav, $v$ nobenem primeru pa ne moremo poiskati skupne motivirajoče besede - gre za tvorjenke, katerih podstava lahko motivira samo poimenovanje žensk oz. samo poimenovanja moških. Poimenovanja žensk so lahko dveh tipov:

- predmetnostna referenca je vezana na ženske glede na biološko funkcijo (nosečnica) ali na vedenjske (družbene) vzorce: tvorjenke iz glagola z obrazili -ica (grabljica), -ilja (pletilja), iz samostalnika z -inja (klarisinja), -inka (uršulinka); pri slednjih je teoretično mogoče tvoriti poimenovanja za moške, a jih realnost in iz nje izhajajoča jezikovna raba ne izpričujeta;

- tvorjena poimenovanja so sicer ženskega spola, vendar se načeloma kot lastnostne oznake zlasti v vlogi povedkovnika lahko uporabljajo za oba spola; obrazila so pri tem čustveno zaznamovana: -a (čveka), -ulja (klepetulja).

\subsubsection{Tvorba feminativov po Ireni Stramljič Breznik}

Ob zgoraj navedenem pa Irena Stramljič Breznik (2004: 18) dodaja, da poimenovanja ženskih oseb sodijo med nemodifikacijske izpeljanke, kadar gre za biološko (dojilja) ali sociološko zaznamovanost (perica) in pri tvorjenkah ženskega spola za živali, če ni moškospolskega ustreznika (brenčalka). Ob tem pa navede še dva načina tvorbe poimenovanj za osebe (in tudi živali) ženskega spola (Stramljič Breznik 1994/95: 289):

1) Z dodajanjem ženskospolskega obrazila tvorjenkam moškega spola feminativna obrazila, ki se dodajajo, je mogoče razvrstiti glede na to, s katerimi tipičnimi soglasniškimi izglasji moškospolskih obrazil se družijo. Tako se priponski obrazili $\boldsymbol{- a}$ in $\boldsymbol{- n} \boldsymbol{a}$ dodajata obrazilom, katerih v izglasju 
je -č: gostača, dedična; -ica tistim s -̌c, -lj in -r: beračica, braniteljica, ravnateljica, bobnarica, pastirica, direktorica, diktatorica; -inja se druži s podstavami ali obrazili moškospolskih tvorjenk s $k, g, h$ v izglasju, na primer prerokinja, varuhinja, boginja; -ka se lahko dodaja obrazilnim izglasjem na $-\check{c},-d,-j,-r,-t,-v$ : brusačka, doktorandka, čuvajka, balinarka, reporterka, dreserka, kurbirka, demonstratorka, aspirantka, absolventka, detektivka.

2) Z zamenjavo celotnega ali le izglasnega dela moškospolskega obrazila $z$ ženskospolskim ob isti podstavi - feminativna obrazila, ki zamenjujejo obrazila moškega spola: priponsko obrazilo -ica zamenjuje -ik, npr. basnica $\mathrm{v}$ pomenu 'basnopiska', ter - $\boldsymbol{k} \boldsymbol{a}$ moškospolsko obrazilo -ec (borka). Do zamenjave dela obrazila moškega spola $\mathrm{s}-k a$ in -ica pride pri tvorbi feminativov tistih izpeljank, katerih končni del večzložnega obrazila je -ec ter pri -nik. Tako obrazilo -ka zamenjuje -ec: -(V)lec (dajalka, gojilka), -(V)vec (kegljavka, hvalivka, pevka). Najpogostejša je tvorba feminativov $\mathrm{z}$ dodajanjem ženskospolskih obrazil, pri čemer prevladujejo tvorjenke $\mathrm{s}$ $-k a$, ki predstavljajo dobro četrtino vseh ženskih ustreznic k moškemu spolu (Stramljič Breznik 1992: 421-422).

\subsubsection{Obravnave drugih jezikoslovcev}

Tomo Korošec (1989: 443) tvorjenje ženskih poimenovanj pri moških poimenovanjih za delujoče osebe, tj. poklice, nazive, čine itd., imenuje za tipično slovensko besedotvorno možnost. Tvorbo feminativov Korošec (1998: 77-79) razume kot drugotni besedotvorni postopek, v katerem je tvorjenka zgolj ženski par k že obstoječemu moškemu imenu. Tudi on navaja oba zgoraj omenjena načina tvorbe feminativov, pri čemer kot daleč najmočnejši način izpostavlja dodajanje priponskega obrazila $-k a$ tvorjenkam moškega spola na izglasja $-r$ (jurišarka, minerka, inšpektorka), -t (adjutantka, rezervistka), -n (kapitanka), -š (bombaška). Opozori pa tudi na tvorjenke, ki sicer nastanejo z zamenjavo ženskega priponskega obrazila z moškim, vendar ne po običajnem paralelizmu (kot tipičen priponski par omenja obrazili -nica in -nik), ker bi nekatere tako 
tvorjene besede lahko pomensko zavajale predvsem znotraj stroke (sam se v razpravi osredotoča na slovenski vojaški jezik in zato navaja tovrstne primere): na primer brzostrelka pomeni 'avtomatsko orožje', zato se mu zdi ustreznejši izraz brzostrelkinja; generalka pomeni tudi 'gledališko predstavo', zato je bolje uporabiti izraz generalinja ipd. Korošec (1989: 443) pa že izpostavlja tudi problem t. i. variantnih obrazil s primeri bombaška-bombašica-bombašinja.

Tudi po Mariji Jež (1998: 224) so feminativi samostalniške in posamostaljene besede, ki predstavljajo ženski par moškemu in $\mathrm{v}$ glavnem nastajajo $\mathrm{v}$ besedotvornem postopku iz moškospolske besedotvorne podstave in ustreznega priponskega obrazila, npr. davkar - davkarica. Pri tem se podstava za feminativ davkarica razvezuje kot davkar ženska ali ženski davkar, iz tega pa izhaja tvorbeni vzorec davkar $\mathrm{m} \rightarrow$ davkar ž. A tudi Marija Jež opozarja, da pogledi na besedotvorno in pomensko uvrščanje feminativov še niso enotni in ustaljeni. Omahovanja se kažejo zlasti pri uvrščanju v posebno besedotvorno skupino ali $\mathrm{k}$ navadnim izpeljankam. Posebno vprašanje pa je, ali lahko k feminativom uvrščamo ženskospolske izpeljanke iz glagola in pridevnika, npr. grabljica, perica, žanjica, plevica, naročnica, pomočnica, sodnica, ker pri njih ne gre za modifikacijsko tvorbo, ampak navadno izpeljavo. Toporišič namreč v Slovenski slovnici (1976) nekatere primere navaja tako pri izglagolski kot pri izsamostalniški modifikacijski tvorbi (grabljica, dedinja, gospodinja), s čimer po M. Jež (1998: 226) potrjuje, da je nekatere feminative res mogoče imeti za navadne ali za modifikacijske izpeljanke (dedovati: a) tisti, ki deduje $\rightarrow$ dedič; b) tista, ki deduje $\rightarrow$ dedinja). Podobno razmišlja tudi Vidovič Muha (zgoraj). Opozoriti pa je treba tudi na poimenovanja, ki nimajo ustreznega pomenskega para v obliki za moški spol, npr. dojilja, porodnica - besedotvorne podstave so namreč le hipotetične. Glede na to bi bilo smiselno take primere uvrstiti med navadne izglagolske ali izpridevniške izpeljanke. Iz vsega tega sledi, da so feminativi tista ženskospolska poimenovanja, ki so na besedotvorni in pomenski ravni parna moškim. Med feminative ne sodijo primeri, ki predstavljajo par le na besedotvorni ravni, ne pa hkrati tudi na pomenski (Jež 1998: 227). 


\subsection{Pomenske tipologije feminativov $v$ slovenščini}

\subsubsection{Majda Merše}

Majda Merše (2008: 31-44) je v svojem prispevku zarisala obseg rabe ženskospolskih poimenovanj oseb v slovenskem knjižnem jeziku 16. stoletja. Čeprav ženski pari ne spremljajo vseh moških poimenovanj, je tudi pri njih mogoče razlikovati dve osnovni skupini:

1. lastnoimenska (npr. Egipter-Egipterica, Jud-Judinja) in

2. občnoimenska poimenovanja, ki jih je mogoče nadalje členiti na več podskupin. Mednje spadajo pari, ki označujejo:

- poklicna poimenovanja (npr. kuhar - kuharica, mlinar - mlinarica), v okviru teh tudi parna poimenovanja, ki označujejo položaje v družbeni strukturi (npr. cesar-cesarica, kralj-kraljica),

- parna (izglagolska) poimenovanja vršilcev različnih dejavnosti (npr. besednik-besednica, bojnik-bojnica),

- parna poimenovanja nosilcev lastnosti ali stanja (grešnik - grešnica, nevernik-nevernica),

- parne izsamostalniške tvorjenke, ki označujejo pripadnike in pripadnice različnih skupnosti (purgar-purgarica),

- pari samostalniške rabe pridevnika moškega spola in ženska obrazilna tvorjenka: npr. hudobni/hudobnik in hudobnica, ki se parno ne moreta povezovati, saj ju razdvaja pomen samostalnika ženskega spola 'mrzlica',

- vzporedne izpeljanke moških poimenovanj v cerkveni hierarhiji (priol priolovka oz. prior - priorivica ter apat, tudi abat, apt in opat-abačica, tudi abtašica), ki s poimenovanjem predstojnikov posredno kažejo na obstoj različnih (moških in ženskih) samostanskih redov,

- parna poimenovanja sorodstvenih in drugih razmerij (boter - botra),

- živalska poimenovanja (golob-golobica).

\subsubsection{Ada Vidovič Muha}


Vidovič Muha (1997: 74-76) je podala poskus pomenske tipologije obravnavanih poimenovanj za ženske $\mathrm{z}$ vidika nekaterih pogostih ključnih leksemov:

1. poklicna ali kakšna druga intelektualna dejavnost - gre za intelektualne poklice, ki so nastali kot posledica predpisanega univerzitetnega šolanja; pri tem opažamo primere feminativov, tvorjenih $\mathrm{z}$

a) besedotvorno podstavo za poimenovanja žensk, motivirana $\mathrm{s}$ poimenovanji moških: -(ar)ka (matematičarka), -ica (inštruktorica), -inja (geologinja), -ka (recenzentka);

b) vzporedno (besedotvorno) podstavo za poimenovanje žensk in moških: -ica (upravnica), -ka (profesionalka), -nica (predsednica); ${ }^{63}$

2. poklicna ali kakšna druga predvsem fizična dejavnost:

a) poimenovanja žensk, motivirana $\mathrm{s}$ poimenovanji moških: -(ar)ka (mehaničarka), -ica (pastirica), -ka (brusačka);

b) vzporedna (besedotvorna) podstava za poimenovanje žensk in moških: $-k a($ čistilka);

3. lastnost (duševna, značajska ali izvirajoča iz določenih opredelitev), stanje:

a) poimenovanja žensk, motivirana s poimenovanji moških: -(ar)ka (alkoholičarka), -ica (ljubiteljica), -inja (potepuhinja), -ka (državljanka);

b) vzporedna (besedotvorna) podstava za poimenovanje žensk in moških: -ica (dolžnica), -ka (birmanka);

4. poimenovanja telesnih lastnosti po Vidovič Muhi (1997: 76) načeloma nastajajo iz vzporedne podstave: -(en)ka (mladenka), -ica (dolgoprstnica), -ka (dolgolaska), -(ov)ka (grbovka).

\subsubsection{Irena Stramljič Breznik}

63 Vidovič Muha ne piše o dodajalnem oz. zamenjevalnem načinu tvorbe feminativov, pač pa o poimenovanjih žensk, motiviranih s poimenovanji moških (samo te prišteva med feminative) ter o vzporedni besedotvorni podstavi za poimenovanje žensk in moških. 
Irena Stramljič Breznik (2013: 269-270) pa feminative iz Pohlinovega slovarja Tu malu besedishe treh jezikov (1781) pomensko druži v naslednje skupine:

1. Feminativi, ki so rezultat danosti, v kateri obstaja parskost kot realna možnost, pogosto zasnovana na tipičnem dejanju ali sorodstvenem razmerju (gledovz - gledovka, rednik - redniza, gospodar - gospodina, gospodizhezh-gospodizhna ...).

2. Feminativi kažejo možno obojespolsko dejavnost, poklic (farbar farbarza, budivz-budnica, kuhar-kuharza ...).

3. Feminativ izraža zakonsko ženo (kovazh - kovazhiza, kluzhar kluzharica).

4. Feminativ je prebivalska vzporednica (Celan - Celanka, Celovzhan Celovzhanka, Lublanzhan - Lublanzhanka ...).

5. Feminativi kažejo realno parskost $\mathrm{z}$ obrobja družbenih skupin (berazh berazhiza, bogovz - bogovka, hotnik - hotniza ...).

6. Feminativi kažejo realno parskost, ki je rezultat pozitivnih lastnosti (lube luba, lubez-lubeza ...).

7. Feminativi kažejo realno parskost znotraj družbenih skupin, ki so zaznamovane s telesnimi ali duševnimi motnjami (ezlavz - ezlavka, abotnek-abotneza, bolnik-bolniza ...).

\subsection{Feminativi kot iztočnice v slovarjih}

Pregledali smo nekatere večjezične in enojezične slovarje ter druge jezikovne priročnike, pri tem pa smo bili pozorni na zapis feminativov kot (ne)samostojnih slovarskih iztočnic ter na tvorbo iz občno- in lastnoimenske podstave.

\subsubsection{Večjezični slovarski priročniki}

Register v Dalmatinovi Bibliji (1584) sodi med prve slovenske slovarske poskuse. Jakob Rigler (1967: 104) njegovo avtorstvo po primerjavi jezika in 
pisave sicer pripisuje Bohoriču, čigar latinsko-nemško-slovenski slovarček kot dodatek k slovnici Zimske urice proste je izgubljen. »Dalmatinov« Register prinaša zgolj en feminativ, ki je naveden kot samostojna iztočnica - levinja. Za druga moškospolska poimenovanja oseb ali živali ženskospolske ustreznice niso navedene ne kot samostojne iztočnice ne kot »dodatek« k iztočnici moškega spola. Hieronim Megiser pa je v svoj slovar med drugim vključil besedje iz prevoda Biblije 1584 in besedje, zajeto v sezname Bohoričeve slovnice, sicer pa gre za splošno znano in pogosto uporabljano besedje (Merše 2013: 179). Tudi v Megiserjevem štirijezičnem (nemško-latinsko-slovensko-italijanskem, 1592) slovarju kot prvem obsežnejšem slovarskem prikazu slovenskega jezika so feminativi samostojne iztočnice, npr. kmetiza, služabnica, vnuka. ${ }^{64} \mathrm{Nismo}$ pa zasledili feminativov, tvorjenih iz lastnoimenskih podstav (kljub moškospolskim poimenovanjem Nemec, Francoz ...). Kasneje, v 18. stoletju, Marko Pohlin v slovarju Tu malu besedishe treh jesikov (1781), ki velja za prvi tiskani slovenski slovar s slovenskimi iztočnicami in predstavlja zgled ter pomemben jezikovni vir številnim kasnejšim jezikoslovcem in slovaropiscem (Stabej 1974: 250), obravnava feminative kot samostojne iztočnice; to velja za ženskospolska poimenovanja, tvorjena iz občnoimenske (kuharza, ferkozarza, gerbavka) ali lastnoimenske osnove (Koroshela, Koroshiza, Krajniza). Feminativi kot samostojna slovarska gesla nastopajo tudi v slovarju Dictionarium slavocarniolicum Blaža Kumerdeja (iz občnoimenske podstave npr. lakomiza, abotniza, garjavka, iz lastnoimenske Koroshiza, Krajniza). Ožbalt Gutsman v svojem slovarju Deutsch-windisches Wörterbuch iz leta 1789 navaja izobčnoimenske (medvedinja, posedniza, berazhinja - berazhka) feminative kot samostojna slovarska gesla. Dosledno pa ne navaja ženskospolskih ustreznic pri moškospolskih poimenovanjih oseb, tvorjenih iz lastnoimenske podstave (Nemez, Franzos, toda Krainjiza).

V začetku 19. stoletja se je Valentin Vodnik trudil, da bi v svoj slovar zajel besedje s celotnega slovenskega ozemlja, čeprav se je oziral tudi po tujejezičnih virih (Stabej 1966: 42). Tudi v njegovem Slovenskem besednjaku

${ }^{64}$ Majda Merše (2009: 257) pri feminativih opaža uveljavljen besedotvorni model, to je tvorba $\mathrm{z}$ obrazilom -ica. 
(1806-1817) feminativi, izpeljani iz občnoimenske podstave (prejemniza, prerokina, prodajavka), nastopajo kot samostojne iztočnice. Drugače je z besedjem Urbana Jarnika, ki ga literarna zgodovina proglaša za mešanico med kranjskim knjižnim jezikom in ziljskim narečjem, in to $\mathrm{z}$ velikim številom nemških izposojenk (Pogačnik 1990: 189). Njegov etimološki slovar (1832) obravnava feminative kot samostojna slovarska gesla (npr. najemniza, posablivka, sopotniza); enako velja za tvorbo iz lastnoimenske podstave (Nemka, Lahinja, Krajniza). Za razliko od njega pa v slovensko-nemškem slovarju Antona Murka (1833) feminativi ne nastopajo kot samostojne iztočnice, pač pa so pri samostalnikih moškega spola, ki poimenujejo osebe ali živali, dodana zgolj priponska obrazila za tvorbo ženskospolskih vzporednic (npr. baron $\rightarrow$ možni dve variantni/konkurenčni obrazili -inja in -iza; golob $\rightarrow-i z a)$, občasno je zapisana cela ženskospolska vzporednica (pri geslu prijatel - prijatelkinja). Pogosto pa so poimenovanja oseb podiztočnice pri samostalniškem geslu, ki označuje dejanje (npr. kuha $\rightarrow$ kuhar, tokrat $\mathrm{z}$ besedo kuhariza). Navajanje feminativov torej $\mathrm{v}$ tem slovarju ni dosledno. Anton Janežič je svoj Popolni ročni slovar slovenskega in nemškega jezika, ki ga je Fran Levec (1889: 700) označil za dovolj kritičnega in bogatega, izdal leta 1850. Tudi $\mathrm{v}$ tem jezikovnem priročniku so feminativi predstavljeni kot samostojne iztočnice (malikovavka, opatica, admiralica). Kadar gre za poimenovanja oseb, nastala iz lastnoimenske podstave, pa feminativi nastopajo zgolj kot podiztočnice (h geslu Nemec - Nemka). Tudi Cigaletov nemško-slovenski slovar (1860) z zgledovanjem po Vodnikovem slovarju ponuja feminative, tvorjene iz občnoimenske podstave (npr. konjederka, plemenitnica, kmetica), kot samostojne slovarske iztočnice ali kot podiztočnice pri moškospolskem poimenovanju (iz občnoimenske podstave npr. tergavka, jemavka, iz lastnoimenske podstave npr. Nemka). Pleteršnikov slovar je zadnji večji slovar slovenskega jezika, ki je nastal v času, ko je bila naša leksikografija na isti ravni kot leksikografija drugih slovanskih narodov, predstavlja pa pomemben vir za kasnejši enojezični Slovar slovenskega knjižnega jezika (Hajnšek - Holz 1997: 105). Feminativi kot samostojna slovarska gesla so zastopani tudi v Pleteršnikovem Slovensko-nemškem slovarju (1893), in to kot 
tvorjenke iz občnoimenske podstave (brusarica, carica, duhovnica), medtem ko lastnoimenskih feminativov slovar ne prinaša.

\subsubsection{Enojezični jezikovni priročniki}

Tik pred koncem 19. stoletja je izšel Slovenski pravopis Frana Levca (1899). Pomemben vir Levcu predstavlja omenjeni Pleteršnikov slovar, pri čemer pa navedba nekaterih prevzetih in domačih besed razodeva Levčevo veliko poznavanje takratnega pojmovnega sveta in izostren občutek za bogatitev besedja s prevzetimi besedami (Bokal 2000: 16). V slovarskem delu pravopisa so feminativi, tako občno- kot tudi lastnoimenski, navedeni kot podiztočnice $\mathrm{k}$ moškospolski ustreznici (občnoimenski npr. dedič - dedična, hinavec - hinavka, nečak - nečakinja; lastnoimenski npr. Afričan - Afričanka, Američan Američanka) ali ob drugem samostalniku (npr. grad - graščak - graščakinja, milijon - milijonar - milijonarka) v slovarskem geslu. Leksikografsko neenotnost pri prikazu besed v tem jezikovnem priročniku opaža tudi Ljudmila Bokal (2000: 24). Enako kot Levčev feminative obravnavata tudi Breznikov ter BreznikRamovšev Slovenski pravopis (1920; 1935, denimo boter - botrica; demagog demagoginja). Prvega Toporišič (1975: 102) ocenjuje kot manj uspešnega s teoretičnega in taktičnega stališča, drugega pa kot bolj prilagojenega realnemu obstoječemu jeziku, sicer pa je tudi zanj značilnih veliko spodrsljajev (Toporišič 1991: 115). Slovenski pravopis iz leta 1950 je izdala Slovenska akademija znanosti in umetnosti, izdajo pa sta priredila Inštitut za slovenski jezik in Zavod za kulturo slovenskega jezika. Prirejen je po Breznik-Ramovševem pravopisu iz leta 1935 in se v navajanju feminativov od omenjenega vira ne razlikuje. Leta 1962 je Pravopisna komisija pri SAZU pripravila nov pravopisni priročnik, ki pa feminative obravnava enako kot predhodni pravopisni priročniki. Med pravopisoma iz let 1950 in 1962 ni veliko razlik; podobna sta si po obsegu in tudi po pravopisni vsebini (Gložančev 1997: 95). Če je bil tisti iz leta 1950 velik napredek, čeprav še daleč od popolnosti (Bajec 1958: 145), drugi iz leta 1962 po Urbančičevi (1964: 118) oceni ne more biti normativen, njegova praktična vrednost pa je omejena. V Glonarjevem Slovarju slovenskega jezika (1936) 
feminativi sicer nastopajo kot iztočnice (levinja 'samica leva'), vendar pri poimenovanju oseb pogosto ne pomenijo ženske, ki opravlja poklic/dejavnost, ampak ženo, npr. generalica 'generalova žena', kraljica 'kraljeva žena'.

Vprašanje navajanja feminativov kot iztočnic je bilo pereče tudi pri pripravi geslovnika slovarskega dela Slovenskega pravopisa (2001). Po Nastji Vojnovič (1995: 245) je bil izražen nov predlog, da v redakcijah občnih imen ženskospolske parne vzporednice (feminativi) moškim izpeljankam ne bi bile več samostojne iztočnice, kot so bile doslej. Iztočnice bi ostale le izpeljanke ženskega spola s priponskimi obrazili s samostojnim pomenom. To vprašanje je izpostavil tudi Janez Dular (2003b: 126), ki je navajanje feminativov kot podiztočnic opredelil celo kot enega od problemov, glede katerih so sestavljavci Slovenskega pravopisa najteže našli kompromis. Občnoimenske iztočnice so razvrščene po abecedi, in ko jih uporabnik išče, ne razmišlja o tem, katera priponska obrazila za izpeljanke ženskega spola imajo samostojni pomen in katera ga nimajo. Res bo feminative lahko našel tudi kot podiztočnice $\mathrm{v}$ redakcijah, zlasti če bo na tako navajanje opozorjen v uvodu. Način sestavljanja geslovnika, po katerem bi bili feminativi podiztočnice, bi rahljal sistemskost, h kateri sicer teži geslovnik oziroma prikaz redakcij v slovarju. Pri razvrstitvi besedotvornih pripon v Slovenski slovnici Jožeta Toporišiča (2004) so feminativi uvrščeni med modifikacijske izsamostalniške izpeljanke. V isti skupini je še osem podskupin besed, npr. skupna imena, manjšalne besede, slabšalne in še druge, ki so po sedanjem dogovoru vse iztočnice. S tem argumentom N. Vojnovič meni, da je za pravopisni slovar dobro ohraniti načelo, da se vse modifikacijske izpeljanke obravnavajo enako. Besede, na primer magister, magistra, magistrica, so po takratnem načinu sestavljanja geslovnika samostojne enote, ker so predvidene za samostojne iztočnice. V samostojnih geselskih člankih so namreč potrebni podatki (slovnični, normativni, stilistični, pomenski) lahko najbolj pregledno predstavljeni, pri čemer je treba upoštevati, da je ženskih modifikacijskih izpeljank k moškemu paru včasih nepričakovano celo več in da imajo različno stilno vrednost, na primer pri besedi bruc so ženske oblike brucka, bruculja in bruclja. Bruc in brucka sta v SSKJ 1 označena z oznako žargonsko, bruculja in bruclja pa s kvalifikatorjem žarg., slabš. Čeprav je obseg pravopisnega slovarja 
omejen, Nastja Vojnovič meni, da zgolj zaradi prihranka prostora ni treba feminativov prikazovati kot podiztočnice. Glede na podatek, da je med 507 izglagolskimi izpeljankami s pomenom vršilca dejanja 92 feminativov, pa razume, da je misel o feminativih kot podiztočnicah vabljiva. Nazadnje je prevladalo stališče, da je treba število podiztočnic zaradi večje preglednosti omejiti (Vojnovič 1995: 245-246).

Kljub temu pa SNBSJ iz leta 2013 obravnava feminative kot samostojne slovarske iztočnice, npr. dizajnerka. Podobno je s prikazom feminativov v SSKJ 1 (1970-1991), kjer so samostojna gesla in imajo tudi različne razlage. Pri domačih, zlasti pa pri prevzetih besedah je samo spolska razlika pokazana s sklicevalno razlago 'ženska oblika od', na primer desničarka 'ženska oblika od desničar', dentistka 'ženska oblika od dentist'. Razlaga je lahko tudi bolj samostojna: harfistka 'ženska, ki igra harfo', čeprav je navedeno tudi geslo harfist z razlago 'kdor igra harfo'. Pri nekaterih feminativih so geselski članki obsežni, na primer pri geslu delavka, ali pa ima geslo pomen časovno ali kako drugače označen, denimo geslo ministrica ima pomen 'ženska oblika od minister' neoznačen, podpomen 'ministrova žena' pa ima oznako starinsko. Tudi v SSKJ 2 (2014) so feminativi samostojna slovarska gesla. Za razliko od prve izdaje spolska razlika ni več prikazana s sklicevalno razlago ženska oblika od. Razlaga je samostojnejša s pomensko sestavino ženska, ki. Še vedno pa so pri nekaterih feminativih geselski članki obsežnejši ali pa ima geslo pomen časovno ali drugače zaznamovan.

\section{TVORBA FEMINATIVOV IZ OBČNOIMENSKE PODSTAVE}

\subsection{Poimenovanja oseb}

Zbrali in analizirali smo gradivo iz različnih jezikovnih priročnikov: SSKJ 1, NSL, SNBSJ in SSKJ 2. Izločili smo tista poimenovanja, ki označujejo zgolj zakonsko ženo, saj to niso ženskospolske vzporednice k moškospolskim 
poimenovanjem bitij (npr. sodnikovka 'sodnikova žena'), prav tako nismo obravnavali navadnih izpeljank (aprilčica, dojnica, fatalka, nosečka ...). ${ }^{65}$

\subsubsection{Prva izdaja Slovarja slovenskega knjižnega jezika}

S spletne verzije SSKJ $1^{66}$ smo izpisali izraze, ki v pomenskem delu vsebujejo besedne zveze ženska (ki) ali ženska oblika od. Izpisani feminativi so tvorjeni zgolj iz občnoimenske podstave. Skupaj smo izpisali in analizirali 1939 feminativov, od tega jih je 1093 (56 \%) nastalo z zamenjevalnim, 846 (44\%) pa z dodajalnim načinom.

Grafikon 7: Feminativi $v$ SSKJ 1 glede na način tvorbe

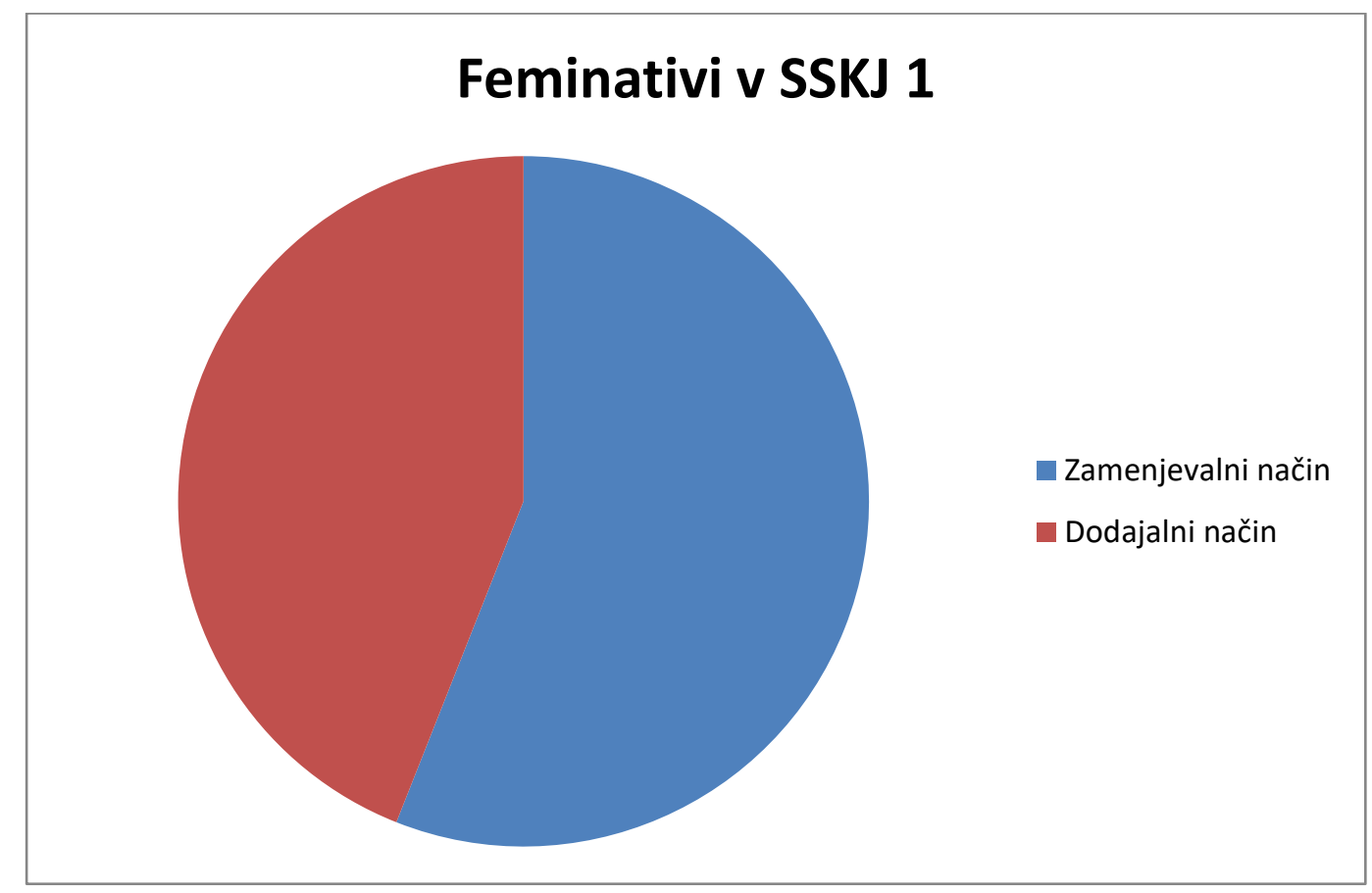

${ }^{65}$ Glede na stopnjo tvorjenosti, lastnost glede na število tvorbenih postopkov (Toporišič 1992: 313), smo pri vseh feminativih izhajali iz moškospolskega poimenovanja, pri slednjem pa smo za določanje pomenskih skupin vršilec, nosilec, opravkar upoštevali neposrednega prednika. Denimo pri primeru upornica smo pri moškospolskem poimenovanju upornik izhajali iz pridevnika uporen in ne iz samostalnika upor. Pri primerih, kjer smo težje določili neposrednega prednika moškospolskega poimenovanja bitja (npr. divjak iz glagola divjati ali iz pridevnika divji), smo preverili geselske članke v Slovenskem etimološkem slovarju (Snoj 2016).

${ }^{66}$ Po Dularju (2003a: 183) sicer SSKJ 1 vseh tedaj znanih feminativov ni upošteval (kot primere avtor navede častnico, oficirko, računalnikarico). 
V celoti gledano pa so, v primerjavi s Slovensko slovnico (2004), nova feminativna priponska obrazila -(ar)ica, -kinja, -(ar)ka, -(ev)ka in -esa.

Preglednica 30: Primerjalni pregled feminativnih priponskih obrazil (SS in SSKJ 1)

\begin{tabular}{|c|c|}
\hline Slovenska slovnica (2004) & SSKJ 1 \\
\hline$-a$ & $-a$ \\
\hline$-i c a$ & $-i c a$ \\
\hline$-j a$ & $-j a$ \\
\hline$-u l j a$ & $-u l j a$ \\
\hline- inja & - inja \\
\hline$-k a$ & $-k a$ \\
\hline$-o v k a$ & $-(o v) k a$ \\
\hline$-i c ̌ n a$ & $-n a$ \\
\hline & $-(a r) i c a$ \\
\hline & $-(a r) k a$ \\
\hline & $-e s a$ \\
\hline & $-(e v) k a$ \\
\hline & $-k i n j a$ \\
\hline
\end{tabular}

7.1.1.1 Feminativi, nastali $\mathrm{z}$ zamenjavo celotnega ali le izglasnega dela moškospolskega obrazila z ženskospolskim ob isti podstavi

Gre za večinski, 56-odstotni delež feminativov, izpisanih iz SSKJ 1. 667 besed $(62 \%)$ je nastalo s priponskim obrazilom -ka, $405(37 \%) \mathrm{z}$-ica, osem $(0,7$ $\%) \mathrm{s}-k i n j a$, pet $(0,5 \%) \mathrm{z}-u l j a$, pet $(0,5 \%) \mathrm{z}$-inja, dva primera $(0,2 \%) \mathrm{z}-j a$ in eden $\mathrm{z}-(\operatorname{ar}) i c a(0,1 \%)$. 


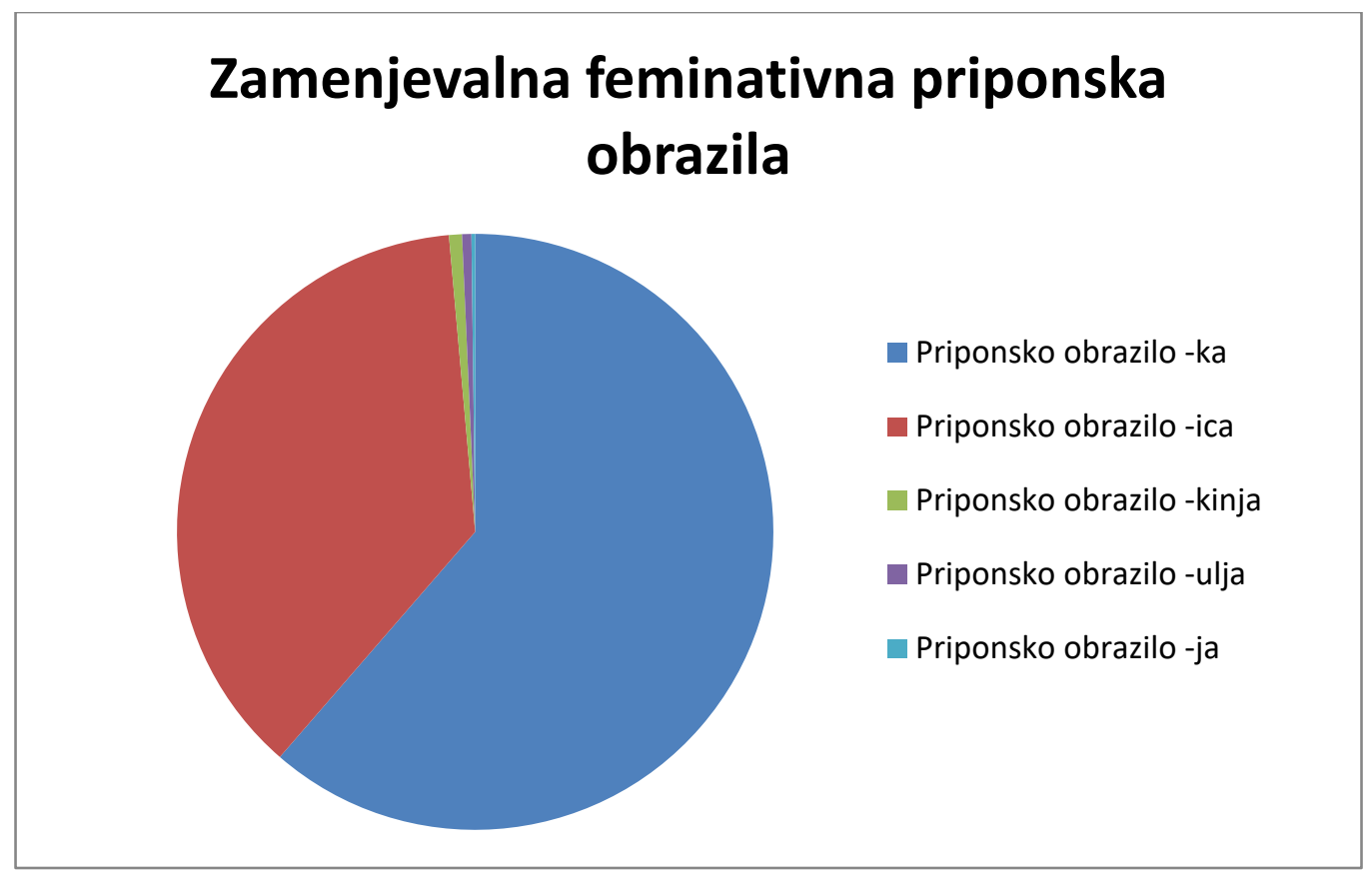

Opažamo, da zgolj kot zamenjevalno priponsko obrazilo nastopa le feminativno obrazilo -kinja (delovodkinja, knjigovodkinja, pevovodkinja, plemkinja, poslovodkinja, računovodkinja, vidkinja, zborovodkinja), saj ga med dodajalnimi nismo zasledili.

Spodnja preglednica prikazuje moškospolska obrazila, ki jih zgoraj navedena feminativna priponska obrazila zamenjujejo.

Preglednica 31: Zamenjava moškospolskih priponskih obrazil s feminativnimi $v$ SSKJ 1

\begin{tabular}{|c|c|c|c|c|c|}
\hline \multirow[t]{2}{*}{ OBRAZILO } & \multirow{2}{*}{$\begin{array}{l}\text { OBRAZILO } \\
\text { MOŠKEGA } \\
\text { SPOLA }\end{array}$} & \multirow{2}{*}{$\begin{array}{l}\text { IZGLASJE } \\
\text { PODSTAVE }\end{array}$} & \multicolumn{3}{|c|}{ PRIMERI TVORJENK } \\
\hline & & & $\begin{array}{l}\text { FEMINATIV } \\
\text { IZ VRŠILCA }\end{array}$ & $\begin{array}{l}\text { FEMINATIV } \\
\text { IZ NOSILCA }\end{array}$ & $\begin{array}{l}\text { FEMINATIV IZ } \\
\text { OPRAVKARJA }\end{array}$ \\
\hline \multirow[t]{9}{*}{$-i c a$} & \multirow[t]{9}{*}{$-e c$} & $-d$ & predica & / & I \\
\hline & & $-g$ & I & ubožica & I \\
\hline & & $-n j$ & žanjica & I & I \\
\hline & & $-l$ & I & došlica & 1 \\
\hline & & $-m$ & tekmica & samica & / \\
\hline & & $-n$ & I & mučenica & 1 \\
\hline & & $-p$ & 1 & slepica & $/$ \\
\hline & & $-r$ & $/$ & norica & $/$ \\
\hline & & $-t$ & 1 & 1 & krasotica \\
\hline
\end{tabular}




\begin{tabular}{|c|c|c|c|c|c|}
\hline & & $-v$ & lovica & jalovica & 1 \\
\hline & & $-z$ & molzica & / & / \\
\hline & $-a \check{c}$ & $-l j$ & grabljica & / & I \\
\hline & $-e k$ & $-l$ & I & prišlica & / \\
\hline & -ček & $-b$ & 1 & ljubica & 1 \\
\hline & & $-j$ & 1 & dvojčica & / \\
\hline & & $-l$ & 1 & malčica & palčica \\
\hline & $-i k$ & $-n j$ & I & prednjica & prošnjica \\
\hline & & $-n$ & pesnica & bledičnica & blagajnica \\
\hline & $-n i k$ & $-b$ & uporabnica & I & I \\
\hline & & $-c$ & I & I & miličnica \\
\hline & & $-\check{c}$ & plačnica & 1 & I \\
\hline & & $\overline{-\check{s} \check{c}}$ & 1 & 1 & učiteljiščnica \\
\hline & & $-d$ & brodnica & $/$ & I \\
\hline & & $-j$ & I & I & naraščajnica \\
\hline & & $-l j$ & poveljnica & I & I \\
\hline & & $-p$ & upnica & I & I \\
\hline & & $-r$ & coprnica & / & darnica \\
\hline & & $-t$ & posetnica & nečistnica & tapetnica \\
\hline & & $-v$ & prebolevnica & I & / \\
\hline & & $-z$ & paznica & I & / \\
\hline & & $-\check{z}$ & tolažnica & / & / \\
\hline & - in & $-\check{c}$ & / & domačica & / \\
\hline & $-e \check{z}$ & $-l$ & 1 & podlica & 1 \\
\hline & & $-n$ & I & dolgočasnica & / \\
\hline & & $-v$ & $/$ & revica & $/$ \\
\hline$-j a$ & - ilec & $-t$ & pletilja & I & / \\
\hline & & $-z$ & vezilja & 1 & 1 \\
\hline -ulja & $-a \check{c}$ & $-d$ & gobezdulja & / & 1 \\
\hline & & $-k$ & jezikulja & / & / \\
\hline & $-u h$ & $-d$ & smrdulja & $/$ & / \\
\hline & & $-p$ & I & skopulja & / \\
\hline & $-a v s$ & $-n$ & 1 & črnulja & $/$ \\
\hline -inja & $-a$ & $-g$ & sluginja & / & 1 \\
\hline & $-i \bar{c}$ & $-d$ & dedinja & $/$ & $/$ \\
\hline & $-a r$ & $-k$ & / & / & pametnjakinja \\
\hline$-k i n j a$ & $-e c$ & $-d$ & vidkinja & / & / \\
\hline & $-i \check{c}$ & $-m$ & / & I & plemkinja \\
\hline$-k a$ & $-e c$ & $-b$ & / & bebka & / \\
\hline & & $-d$ & telovadka & sladkosnedka & $/$ \\
\hline & & $-j$ & 1 & tujka & gimnazijka \\
\hline
\end{tabular}




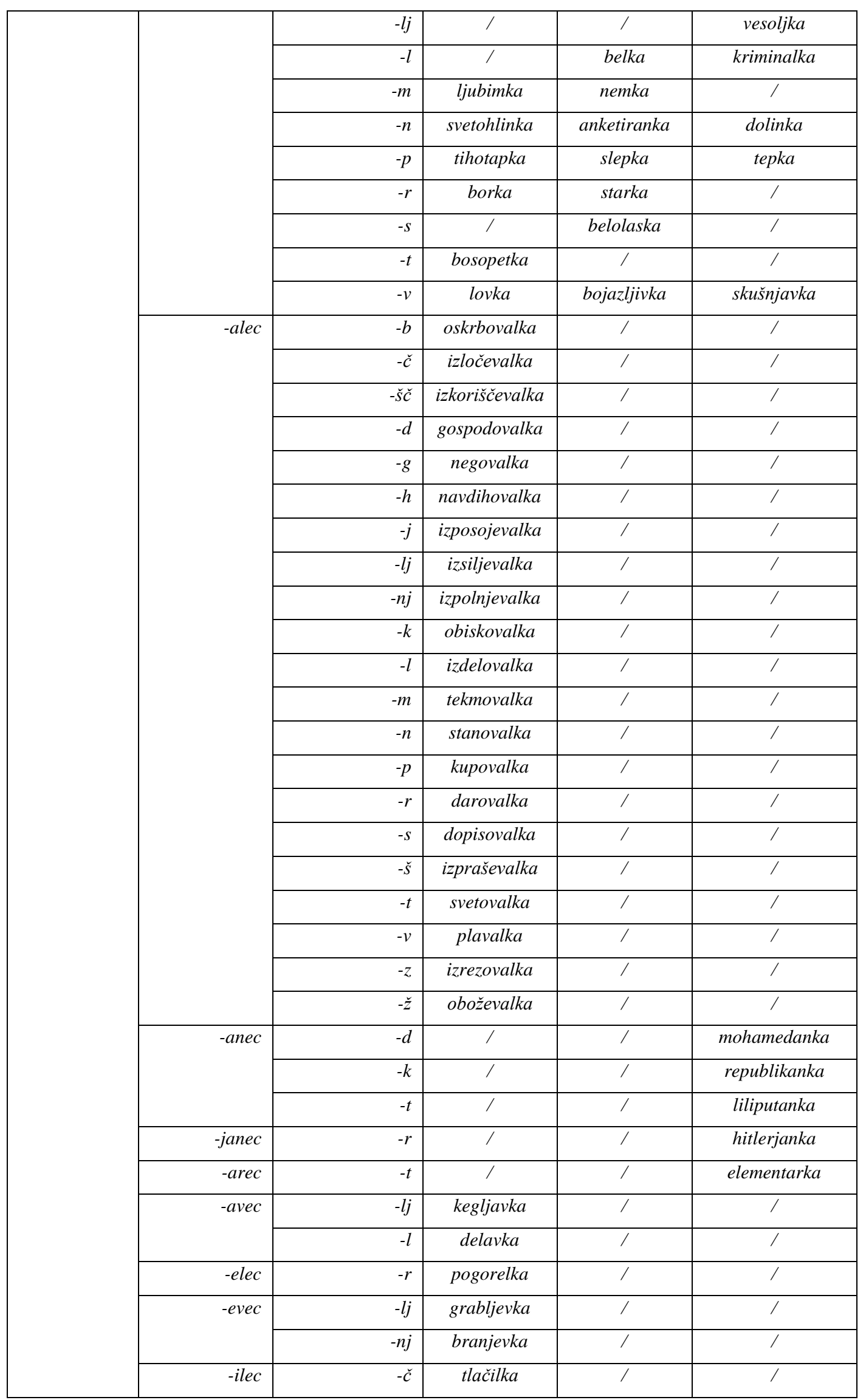




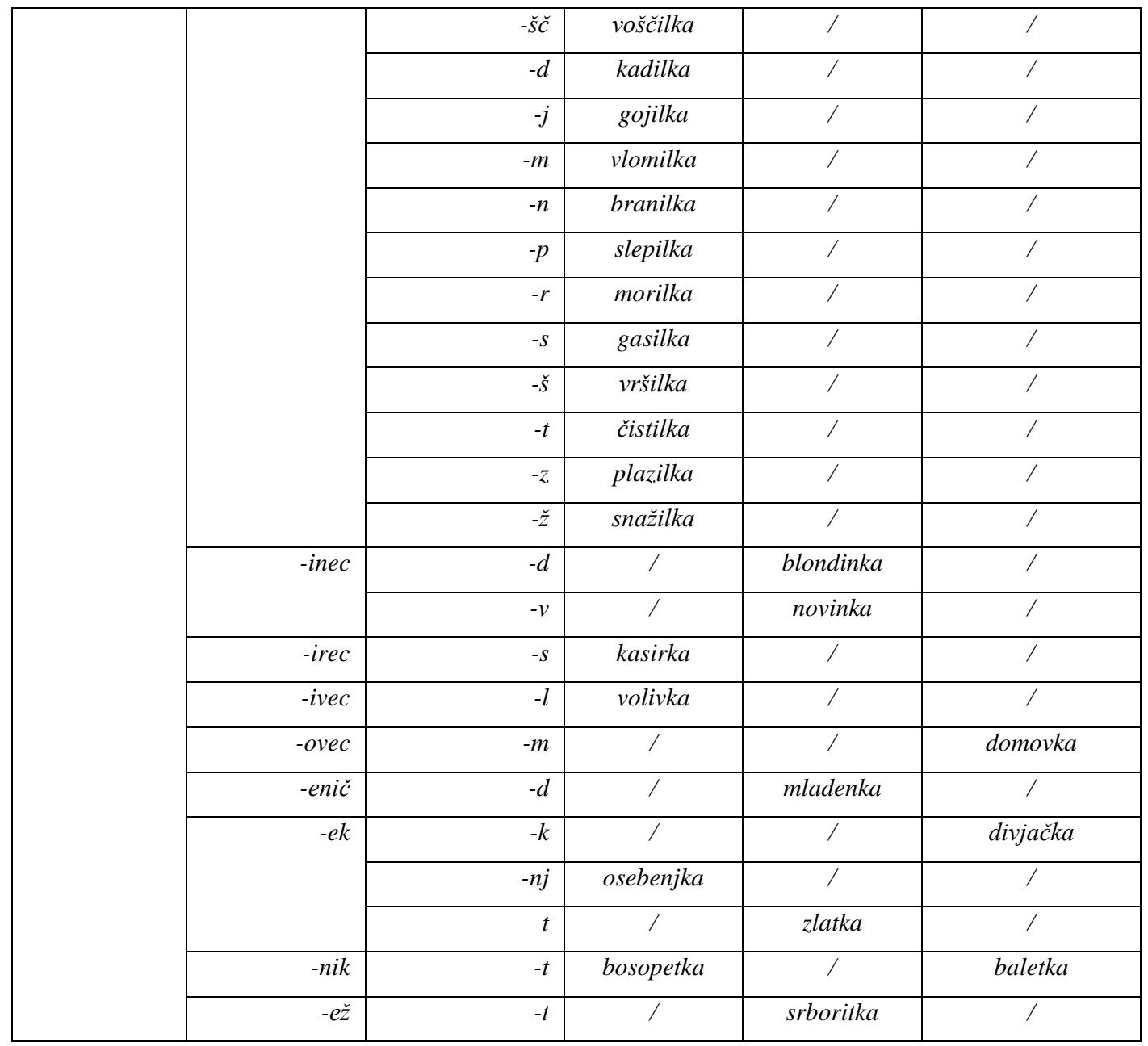

1. Obrazilo -ica zamenjuje moškospolska obrazila:

- $\quad-\boldsymbol{a}$, če je izglasje podstave na -g (en primer: kolegica);

- $\quad$ ec za vršilca iz glagolov na -C-ti/-em oz. - V-ti/-em ob različnih izglasjih podstav (trije feminativi: molzica, predica, žanjica), -ovati/-ujem ob izglasju podstave na -m (samo tekmica), -iti/-im oz. -eti/-em, če je izglasje podstave na $-v$ (dva primera: lovica, plevica), za nosilca lastnosti, kadar se podstava konča na $-g$, pri čemer pride do palatalizacije (le božica in ubožica), pri nosilcu z izglasjem na -g (samo nagica), -l (en feminativ: došlica), -m (le samica), -n (mučenica; tudi z -ik), -p (zgolj slepica), -r (dva primera: norica, starica) in $-v$ (samo jalovica) ter za opravkarja pri izglasju domače podstave na -t (krasotica in lepotica);

- $-\boldsymbol{a c}$ za vršilca iz glagolov na -ati/-am, če je izglasje podstave -lj (samo grabljica); 
- $\quad$-ek za nosilca lastnosti z izglasjem na -l (zgolj prišlica);

- $\quad$ - ček za nosilca lastnosti ob izglasju podstave na -b (samo ljubica), -j (le $d v o j c ̌ i c a),-l$ (zgolj malčica) in pri opravkarju ob izglasju na -l (palčica); pri zadnjih treh primerih se iz moškospolskega obrazila -ček ohrani - $\check{c}$, tako da gre za dodajanje obrazila -ica $\mathrm{k}-\check{c}$;

- $-\boldsymbol{i k}$ pri vršilcu iz glagolov na -iti/-im (pesnica), pri nosilcu lastnosti z izglasjem podstave na $-n j$ (samo prednjica), $-n$ (190 feminativov: besednica, betežnica, bojevnica, bolnica, brigadnica, čarovnica, deležnica, desetletnica, devetdesetletnica, dobavnica, dobitnica, dobrotnica, dolžnica, dopisnica, društvenica, družabnica, družbenica, družnica, državnica, duhovnica, dvajsetletnica, dvojnica, dvornica, dvospolnica, fizkulturnica, glasbenica, glasnica, gnusnica, godbenica, gornica, gozdovnica, grešnica, gromovnica, hišnica, izdajnica, jetičnica, književnica, kolednica, kolhoznica, komornica, kopališčnica, krščenica, krvnica, kulturnica, likovnica, ljubavnica, martrnica, mesečnica, mladoletnica, mladostnica, molznica, mučenica, načelnica, nadzornica, najemnica, namestnica, naročnica, naslednica, naslovnica, nasprotnica, nedoletnica, nesmrtnica, nevoljnica, ničemnica, ničemurnica, obrtnica, odbornica, odličnica, odpravnica, osemdesetletnica, oskrbnica, pametnica, petdesetletnica, petindvajsetletnica, petinsedemdesetletnica, petnajstletnica, pobudnica, pocestnica, podpisnica, podpornica, podrepnica, pogodbenica, pogrebnica, pokojnica, polkovnica, polnoletnica, pomočnica, popotnica, poprečnica, porotnica, posameznica, poslanica, posmrtnica, posrednica, potnica, poverjenica, povratnica, pravnica, predhodnica, prednica, predstavnica, predstojnica, prejemnica, prešuštnica, prevodnica, priletnica, priležnica, pripadnica, pripovednica, pripravnica, prisklednica, privatnica, prometnica, prvoletnica, pubertetnica, puščavnica, rajnica, razbojnica, razrednica, razsodnica, redovnica, rejnica, rentnica, rě̌enica, rešnica, rodnica, samorastnica, sedemdesetletnica, sedemnajstletnica, skrbnica, služabnica, skladiščnica, slehernica, smrtnica, sodnica, sodobnica, sorodnica, sovražnica, spodbudnica, spokornica, sprevodnica, sramotnica, starostnica, stoletnica, 
strežnica, svečenica šestdesetletnica, šestnajstletnica, športnica, štiridesetletnica, štirinajstletnica, taboriščnica, tabornica, tajnica, tožnica, trebušnica, tretjerazrednica, tretjerednica, tridesetletnica, trinajstletnica, ubežnica, udarnica, umetnica, upornica, upravnica, uradnica, ustanovnica, verižnica, vernica, vrstnica, vzornica, začetnica, zadružnica, zagovornica, zakonolomnica, zakupnica, zamudnica, zapornica, zaročnica, zarotnica, zasebnica, zastopnica, zaščitnica, zaupnica, zavetnica, zaveznica, zavodnica, znanstvenica, zvezdnica, žlahtnica) in pri opravkarju z izglasjem podstave na -n (blagajnica), - $n j$ (dve tvorjenki: priprošnjica, prošnjica), nastopi tudi pri sestavljeni podstavi (šest primerov: somišljenica, sopodpisnica, sopogodbenica, sopotnica, sovrstnica, veleposlanica), zloženkah (krivoprisežnica, krvosramnica, zobotehnica) in netvorjenih podstavah (tehnica);

- $-(\boldsymbol{n}) \boldsymbol{i k}^{67}$ za vršilca iz glagolov na -ati/-am pri izglasju podstave na -̌́ (plačnica), -p (prestopnica, upnica), -r (coprnica) ali -v (prebolevnica), ob -ati-im (pribežnica), iz -iti/-im z izglasjem podstave na - $b$ (en primer: uporabnica), -č (povzročnica), -d (sedem feminativov: brodnica, ponudnica, rednica, srednica, urednica, vodníca, zvodnica), -r (govornica, pobornica, stvarnica), -t (koristnica, posetnica), - $v$ (zdravnica), $-z$ (paznica, prevoznica, voznica) ali -ž (tolažnica, vložnica, založnica), iz -ovati-ujem (dopustnica, godovnica, predsednica), iz glagolov na -evati/-ujem z izglasjem podstave na -lj (poveljnica), iz -etil-am (imetnica), iz -V-čil-em (postrežnica), za nosilca lastnosti z izglasjem podstave na -t (sedem tvorjenk: desetnica, nečistnica, nezvestnica, prekletnica, stotnica, svetnica, ujetnica) in za opravkarja z izglasjem podstave na -c (miličnica, stričnica), -šč (učiteljiščnica), -j (naraščajnica, tečajnica), -r (darnica), -t (izletnica, jetnica po glasovni premeni, lastnica,

${ }^{67}$ Kot merilo razločevanja med moškospolskima priponskima obraziloma -nik in -ik Irena Stramljič Breznik (1991: 22-24) omenja dva principa besedotvornega postopka: 1) racionalnost, kar pomeni izhajati iz podstave, ki izrazno in pomensko čim bolj ustreza tvorjenki; 2) ekonomičnost, tj. uporabiti morfemsko čim manj sestavljeno obrazilo. K izpridevniški tvorbi $\mathrm{s}$ priponskim obrazilom -ik smo tako šteli primere, pri katerih obstaja ustrezni pridevnik na -en. Če tovrstni pridevnik ne obstaja, pa z obrazilom -nik nastajajo izglagolske in izsamostalniške tvorjenke, pri izpridevniških pa se podstavni pridevnik ne konča na -en. Pri tem pa feminativno priponsko obrazilo -ica zamenja samo del priponskega obrazila, to je -ik, ohrani pa - $n$ - iz moškospolskega obrazila. 
odvetnica, posestnica, svétnica, tapetnica), -z (koruznica); tudi pri zloženkah (pet primerov: prestolonaslednica, ranocelnica, srboritnica, tolstoritnica, zobozdravnica) in sestavljenkah (devet feminativov: podnajemnica, podpredsednica, sobesednica, sobojevnica, sogovornica, solastnica, sopredsednica, sotrudnica, sovoznica); pri prav vseh primerih se ohrani - $n$ iz moškospolskega priponskega obrazila, zato gre za dodajanje feminativnega obrazila -ica k prav temu soglasniku;

- -in za nosilca z izglasjem podstave na -č (samo domáčcica);

- $-\boldsymbol{e z ̌ ~ p r i ~ n o s i l c u , ~ c ̌ e ~ j e ~ i z g l a s j e ~ p o d s t a v e ~ n a ~ - ~} l$ (samo podlica), -n (33 tvorjenk: bistroumnica, čemernica, dolgočasnica, dolgoprstnica, izbirčnica, kratkočasnica, malomarnica, malovrednica, naivnica, nemarnica, nemirnica, nepotrebnica, neprevidnica, nevednica, nevrednica, nezadovoljnica, ničvrednica, nizkotnica, ogabnica, ostudnica, ošabnica, porednica, posebnica, predrznica, priskutnica, sitnica, skrivnostnica, slaboumnica, sladkosnednica, spodobnica, tečnica, togotnica, zlobnica); v nekaterih primerih priponsko obrazilo -ež nastopa kot variantno z -ik (abotnica, bednica, blaznica, bledičnica, blodnica, božjastnica, brezbožnica, brezsrčnica, brezumnica, brezvestnica, debeloličnica, debeloritnica, dolgočasnica, gorečnica, hotnica, hudobnica, hudomušnica, imenitnica, jezičnica, krepostnica, krvoločnica, lahkomiselnica, lakomnica, ljubosumnica, malopridnica, nadebudnica, nadležnica, nadobudnica, nasilnica, nasladnica, nečimrnica, nedolžnica, negodnica, nehvaležnica, nenasitnica, nespametnica, nesramnica, nesrečnica, neumnica, nevernica, nevšečnica, oblastnica, okrutnica, pobožnica, pohotnica, povprečnica, požrešnica, pravičnica, prevratnica, prevzetnica, pridobitnica, radovednica, razkošnica, razsipnica, razumnica, razvratnica, rdečeličnica, samosilnica, samotnica, sebičnica, skoporitnica, slabotnica, sladostrastnica, srečnica, starokopitnica, strahopetnica, trdosrčnica, verolomnica, zahtevnica, zavistnica, zavratnica, zoprnica takih je 72 feminativov); tudi pri nosilcu z izglasjem podstave na $-v$ (samo revica). 
2. Priponsko obrazilo -(ar)ica zamenjuje moškospolsko priponsko obrazilo - $a$ pri primeru gazdarica, pri čemer je izglasje podstave na $-d$.

3. Feminativno priponsko obrazilo -ja zamenjuje obrazilo -ilec pri vršilcu dejanja iz glagola na -C-ti/-em ob izglasju podstave na $-t$ ali $-z$ (pletilja, vezilja). Ker se del moškospolskega obrazila ohrani, se feminativno priponsko obrazilo -ja doda k $-l$.

4. Feminativno priponsko obrazilo -ulja zamenja moškospolska obrazila:

- $\quad-\boldsymbol{a c ̌}$ za vršilca dejanja iz glagolov na -ati/-am z izglasjem podstave na $-d$ oz. -k (gobezdulja in jezikulja);

- $\quad \boldsymbol{u h}$ za vršilca iz glagola na -eti/-im z izglasjem podstave na - $d$ (smrdulja) in za nosilca lastnosti z izglasjem podstave na -p (samo skopulja);

- -avs pri nosilcu lastnosti, če je izglasje podstave na - $n$ (zgolj en feminativ: črnulja).

5. Priponsko obrazilo -inja nastopa kot zamenjava moškospolskega obrazila:

- $\quad-\boldsymbol{a}$ pri vršilcu dejanja iz glagola na -iti/-im ob izglasju podstave na -g (le sluginja), pri netvorjeni podstavi z izglasjem na -g (zgolj koleginja) ter pri sestavljeni osnovi (nadvojvodinja);

- -ič pri vršilcu dejanja iz glagola na -ovati/-ujem, kadar je izglasje podstave na $-d$ (en primer: dedinja);

- - ar pri opravkarju z izglasjem podstave na - $k$ (samo pametnjakinja).

6. Obrazilo -kinja zamenjuje moškospolski priponski obrazili:

- $\quad$-ec pri vršilcu dejanja z izglasjem podstave na -d (vidkinja);

- $\quad$-ič pri opravkarju z izglasjem podstave na -m (plemkinja). 
To feminativno priponsko obrazilo zamenjuje tudi moškospolsko priponsko obrazilo -ja pri zloženkah delovodkinja, knjigovodkinja, pevovodkinja, poslovodkinja, računovodkinja, zborovodkinja.

7. S priponskim obrazilom $-\boldsymbol{k} \boldsymbol{a}$ zamenjujemo moškospolska obrazila: ${ }^{68}$

- $\quad$ ec za vršilca iz glagolov na -iti/-im z izglasjem podstave na - $d$ (telovadka), -n (svetohlinka), -p (tihotapka), -r (borka, licemerka), -t (bosopetka), -v (hinavka, lovka), na -ati/-am ob izglasju podstave na -l (strelka), -r (animirka, pakirka, servirka), -eti/-em z izglasjem na -d (vsevedka - tudi $\mathrm{z}$ dodajalnim načinom), na -C-ati/-C-am ob izglasju podstave na -m (ljubimka), -izirati/-iziram z izglasjem - $r$ (proletarka), za nosilca lastnosti iz podstave na $-b($ bebka $){ }^{69}-d$ (sladkosnedka ${ }^{70}$ - tudi z dodajalnim načinom), -j (tujka, zamejka), -l (belka, fevdalka, intelektualka, klerikalka, liberalka, orientalka, personalka, profesionalka, sentimentalka), -m (gluhonemka, inozemka po krnitvi iz pridevnika, nemka, samka), -n (177 feminativov: anketiranka, benediktinka, birmanka, blaziranka, črnka, degeneriranka, deložiranka, deportiranka, dojenka, dosluženka, drugorojenka, edinka, edinorojenka, emancipiranka, gojenka, hranjenka, interniranka, izbranka, izgnanka, izgubljenka, izobčenka, izobraženka, izpraševanka, izprijenka, izseljenka, izvedenka, izvoljenka, izvrženka, izžrebanka, jakobinka, koščenka, križanka, krščenka, lahkomišljenka, ljubljenka, ločenka, mešanka, miljenka, mladoporočenka, mučenka, nafrfuljenka, nagovorjenka, nagrajenka, najdenka, nameščenka, napadenka, napihnjenka, napuhnjenka, naslovljenka, nastavljenka, navihanka, nebogljenka, nebrzdanka, negovanka, neotesanka, neugnanka, neznanka, novoporočenka, novorojenka, občudovanka, obdolženka, obešenka, objokanka, oboževanka, obsedenka, obsojenka, obstreljenka, obtoženka, obupanka,

\footnotetext{
${ }^{68}$ Pri zamenjavi upoštevamo načelo racionalnosti in ekonomičnosti (denimo pri -alec zamenjamo samo -ec; tako gre $\mathrm{v}$ vseh primerih po odvzemu moškospolskega -ec za dodajanje $\mathrm{k}$ izglasju na $-(a) l)$.

${ }^{69}$ Iz pridevnika bebast (Snoj 2016: 65).

${ }^{70}$ Iz pridevnika sladkosned.
} 
odlikovanka, odposlanka, okuženka, onesveščenka, operiranka, osamljenka, oskrbovanka, ostriženka, osumljenka, osvobojenka, oškodovanka, pijanka, pitanka, plačanka, podpiranka, poedinka, pogrešanka, pohabljenka, pokvarjenka, polulanka, ponesrečenka, pooblaščenka, poraženka, poročenka, portretiranka, poscanka, posiljenka, poslanka, posvojenka, poškodovanka, potepenka, potuhnjenka, povabljenka, povoženka, prebrisanka, prefriganka, preganjanka, pregnanka, prekanjenka, premaganka, premetenka, pretkanka, prevejanka, priliznjenka, priseljenka, prisiljenka, prismojenka, prismuknjenka, pritepenka, privedenka, privilegiranka, privrženka, prvonagrajenka, prvoobhajanka, prvorojenka, puritanka, rafiniranka, ranjenka, razbrzdanka, razcapanka, razporočenka, razposajenka, razuzdanka, razvajenka, razvezanka, rejenka, rešenka, samaritanka, samozvanka, scrkljanka, sestradanka, slavljenka, soudeleženka, spestovanka, spovedanka, toženka, učenka, udeleženka, ugrabljenka, umazanka, umorjenka, upodobljenka, upokojenka, upravičenka, uscanka, uslužbenka, usmiljenka, usranka, utopljenka, užaljenka, vajenka, varovanka, vprašanka, vrinjenka, vsiljenka, vzdrževanka, zagrizenka, zamaknjenka, zaročenka, zaljubljenka, zapuščenka, zasledovanka, zaspanka, zavarovanka, zelenka, zmedenka, zmešanka, znanka), -p (slepka, zvitorepka), -r (starka), -s (13 feminativov: belolaska, bujnolaska, črnolaska, dolgolaska, dolgonoska, kodrolaska, plavolaska, rdečelaska, rjavolaska, rumenolaska, svetlolaska, temnolaska, zlatolaska), -t (dolgopetka, svetopetka), -v (97 primerov: beloglavka, besedljivka, bojazljivka, brbljavka, brljavka, cmeravka, debeloglavka, domišljavka, domovka, dražljivka, dvomljivka, esesovka, garjavka, gestapovka, gizdavka, glistavka, gobavka, godrnjavka, goljufivka, golšavka, grabljivka, grbavka, grižavka, hotljivka, hribovka, izbirljivka, jalovka, jecavka, jecljavka, jehovka, jezljivka, jokavka, kihavka, kradljivka, krivka, kujavka, kvarljivka, lahkoživka, lažnivka, lišpavka, mutavka, nagajivka, naivka, neubogljivka, neukrotljivka, nevoščljivka, nobelovka, obrekljivka, očarljivka, omahljivka, opravljivka, paglavka, 
pegavka, pohujšljivka, poniglavka, popadljivka, porogljivka, posmehljivka, pozabljivka, prepirljivka, pritlikavka, puhloglavka, pustolovka, radoživka, rjavka, skojevka, smrčavka, smrdljivka, smrkavka, smejavka, sokrivka, spakljivka, spogledljivka, sramežljivka, svojeglavka, šaljivka, šepavka, škodljivka, škrbavka, topoglavka, trdoglavka, trmoglavka, ujedljivka, ušivka, vihravka, vrtoglavka, vsiljivka, zabavljivka, zafrkljivka, zajedavka, zapeljivka, zapravljivka, zasmehljivka, zbadljivka, zijavka, zmerjavka, žvižgavka) in za opravkarja pri izglasju podstave na -j (pet primerov: gimnazijka, licejka, olimpijka, partijka, zamejka), -lj (vesoljka), -l (šest feminativov: ilegalka, komsomolka, kriminalka, provincialka, tekstilka, tercijalka), -n (12 primerov: begunka, bratranka, dolinka, gorjanka, luteranka - slednje tudi $\mathrm{z}$ dodajalnim načinom, medicinka, mladinka, planinka, samostanka, sezonka, terenka, zločinka), - $p$ (tepka), ${ }^{71}-r \quad$ (pomorka, zamorka), -v (primitivka, skušnjavka); tudi pri sestavljenkah (brezdomka, brezverka, soborka, sokrivka, sošolka, součenka, soudeleženka) in zloženkah (bacilonoska, bogomolka, četrtošolka, čudodelka, dlakocepka, dobroživka, drugošolka, hudodelka, jasnovidka, jezikoslovka, kavopivka, konjederka, krivoverka, krvoskrunka, ljudožerka, mesojedka, nižješolka, osmošolka, petošolka, prostovoljka, prvoborka, prvošolka, romanopiska, sedmošolka, sladokuska, snohodka, srednješolka, staroupokojenka, strahopetka, strojepiska, šestošolka, tiholazka, tretješolka, tujerodka, visokošolka, višješolka, vrvohodka, zakonolomka, zvezdoslovka, zvezdoznanka);

- - alec za vršilca dejanja iz glagolov na -ovati-ujem, kadar je izglasje podstave na -b (oskrbovalka, preskrbovalka), -d (gospodovalka, napovedovalka, občudovalka, posredovalka, pripovedovalka), $\quad$-g (negovalka, zmagovalka), -h (navdihovalka, podpihovalka, strahovalka, zasmehovalka), -k (malikovalka, obiskovalka, objokovalka, oblikovalka, obrekovalka, paberkovalka, prerokovalka, prežvekovalka, raziskovalka, sooblikovalka), -l (izdelovalka, pridelovalka, žalovalka), -m (tekmovalka), -n (stanovalka), -p (kupovalka, nakupovalka), -r (darovalka, varovalka,

${ }^{71}$ Iz samostalnika tep (Snoj 2016: 781). 
zborovalka), -s (dopisovalka, glasovalka, popisovalka, prepisovalka, vasovalka), -t (potovalka, svatovalka, svetovalka), -z (izrezovalka, nakazovala, opazovalka, povezovalka, prilizovalka, ukazovalka), na -evati/-ujem ob preglasu z izglasjem podstave na -č (izločevalka, izročevalka, kupčevalka, plačevalka, poročevalka, povzročevalka, prekupčevalka, uničevalka, uresničevalka, varčevalka), -šč (izkoriščevalka, maščevalka, obveščevalka), -j (izposojevalka, presojevalka, razkrojevalka, razširjevalka, urejevalka, usmerjevalka), -lj (izsiljevalka, nadaljevalka, napeljevalka, razdeljevalka, razveseljevalka, spremljevalka, zastrupljevalka), -nj (izpolnjevalka, ocenjevalka, oznanjevalka, prehranjevalka), -š (izpraševalka, izvrševalka, opraševalka, reševalka, vpraševalka), -ž (oboževalka, razkuževalka, vedeževalka, vzdrževalka), na -V-ti/-em (bralka, pralka), na -ati/-em ob izglasju podstave na -j (dajalka, sejalka), -k (skakalka, sukalka, tkalka), -s (česalka, pisalka, plesalka), -t (metalka), -z (vezalka), na -ati/-am ob izglasju podstave na -d (gledalka, napadalka, padalka), -g (pomagalka, požigalka, razlagalka, trgalka, vlagalka, zlagalka), -h (jahalka), -j (bajalka, izdajalka, izvajalka, navijalka, osvajalka, podajalka, preprodajalka, prevajalka, previjalka, prihajalka, prodajalka, proizvajalka, sprehajalka, ubijalka, ustvarjalka, zavijalka), -nj (preganjalka), -k (likalka, mikalka), -m (odjemalka, posnemalka, prevzemalka), -n (ravnalka), -p (kopalka), -r (igralka, izbiralka, jadralka, nabiralka, obiralka, pobiralka, prebiralka, zbiralka), -s (drsalka), -š (donašalka, mešalka, oponašalka, poslušalka, prenašalka, prinašalka, raznašalka), -t (čitalka, letalka, pometalka, šepetalka, vrtalka), -v (izzivalka, plavalka, pomivalka, poznavalka, prebivalka, prešivalka, skrivalka, šivalka, uživalka, vdevalka), -z (plezalka), na -ati/-ujem, kadar je izglasje podstave na $-v$ (snovalka); tudi pri sestavljenkah (protiigralka, soigralka, sooblikovalka, soplesalka, soplezalka, sostanovalka, sotekmovalka, soustvarjalka, transseksualka) in zloženkah (delodajalka, krvodajalka, posojilodajalka, posojilojemalka, soloplesalka, stanodajalka, zakonodajalka); 
- - anec za opravkarja ob izglasju podstave na $-d$ (mohamedanka), $-k$ (dominikanka, republikanka), -t (liliputanka);

- -janec za opravkarja z izglasjem prevzete lastnoimenske podstave na -r (hitlerjanka);

- $\quad$ - arec pri opravkarju s prevzeto podstavo na -t (elementarka);

- - avec pri vršilcu iz glagolov na -ati/-am ob izglasju podstave na - $l$ (delavka, veslavka), -lj (dostavljavka, grabljavka, kegljavka, ponavljavka, pospravljavka, potapljavka, razstavljavka, sabljavka, sestavljavka, upravljavka, valjavka), nastopi tudi pri sestavljenkah (preddelavka, sodelavka);

- -elec pri vršilcu iz glagolov na -eti/-im z izglasjem podstave na - $r$ (pogorelka);

- -enec za vršilca iz glagolov na -evati/-ujem ob izglasju podstave na -nj (kaznjenka);

- -evec za vršilca dejanja iz -ati/-am, če je izglasje podstave na -lj (grabljevka) in iz -ariti/-arim pri izglasju podstave na -nj (branjevka);

- -ilec pri vršilcu dejanja iz glagolov na -iti/-im ob izglasju podstave na -č (tlačilka), -šč (voščilka), -d (grdilka, kadilka), -j (gojilka), -m (krmilka, vlomilka), -n (branilka, hranilka, polnilka, znanilka), -p (slepilka), -r (borilka, morilka, samomorilka, storilka, varilka), -s (gasilka, nosilka, prosilka), -š (vršilka), -t (častilka, čistilka, krotilka, netilka, sramotilka), -z (plazilka), -ž (snažilka, tožilka), na -V-ti/-em (pletilka), tudi pri sestavljenkah (nekadilka) in zloženkah (samohranilka);

- -inec za nosilca iz podstav na -d (blondinka) in -v (novinka);

- -irec pri vršilcu iz glagolov na -irati/-iram ob izglasju podstave na -s (kasirka);

- -vec za vršilca dejanja iz glagolov na -V-til-em (pevka, pivka, števka);

- -ivec za vršilca dejanja iz glagolov na -iti/-im ob izglasju podstave na -l (molivka, volivka) in -V-ti/-em (brivka);

- -ovec za opravkarja z izglasjem podstave na -g (trgovka), -m (domovka), -t (potovka, svatovka);

- -enič pri nosilcu lastnosti iz podstave na -d (mladenka); 
- $\quad$ ek pri nosilcu lastnosti iz podstave na -t (zlatka) in pri opravkarju iz podstave na $-k$ ob glasovni premeni kot manjšalnica (divjačka, kozačka, siromačka), podobno iz podstave na $-\check{c}$ (mladička), tudi pri vršilcu iz glagolov na -C-ovati/-C-ujem (osebenjka);

- -nik ob vršilcu iz glagola na -iti/-im (bosopetka; variantno obrazilo -ec) in pri opravkarju z izglasjem podstave na -t (baletka);

- $\quad$ ež pri nosilcu lastnosti iz podstave na -t (srboritka).

Priponsko obrazilo $-k a$ lahko nastopa kot zamenjevalno tudi pri netvorjenkah (arijka, pastorka, peška, plebejka, potomka, sanitejka, talka).

Analiza kaže, da se za vse tri prve pomenske skupine izpeljank iz glagolske, pridevniške in samostalniške podstave, torej za vršilca, nosilca in opravkarja, pojavita obrazili -ec, ki ga zamenjujeta feminativni priponski obrazili -ica in -ka, ter -nik, ki ga zamenja obrazilo -ica.

\section{Sinteza obrazilne produktivnosti}

Spodnja preglednica prikazuje, katera feminativna priponska obrazila (in v kolikšni meri) zamenjujejo posamezna moškospolska obrazila.

Preglednica 32: Sinteza obrazilne produktivnosti-zamenjevalni način (SSKJ 1)

\begin{tabular}{|r|c|c|c|c|c|c|c|c|}
\hline $\begin{array}{c}\text { MOŠKOSPOLSKO } \\
\text { OBRAZILO }\end{array}$ & \multicolumn{7}{|c|}{ FEMINATIVNO PRIPONSKO OBRAZILO } \\
\cline { 2 - 10 } & - -ica & $-($ ar)ica & $-j a$ & - ulja & - -inja & - kinja & - ka & SKUPAJ \\
\hline$-\boldsymbol{- a}$ & 1 & 1 & $/$ & $/$ & 3 & $/$ & $/$ & $\mathbf{5}$ \\
\hline- -ja & $/$ & $/$ & $/$ & $/$ & $/$ & 6 & $/$ & $\mathbf{6}$ \\
\hline -ec & 18 & $/$ & $/$ & $/$ & $/$ & 1 & 406 & $\mathbf{4 2 5}$ \\
\hline -alec & $/$ & $/$ & $/$ & $/$ & $/$ & $/$ & 181 & $\mathbf{1 8 1}$ \\
\hline -anec & $/$ & $/$ & $/$ & $/$ & $/$ & $/$ & 4 & $\mathbf{4}$ \\
\hline -janec & $/$ & $/$ & $/$ & $/$ & $/$ & $/$ & 1 & $\mathbf{1}$ \\
\hline -arec & $/$ & $/$ & $/$ & $/$ & $/$ & $/$ & 1 & $\mathbf{1}$ \\
\hline -avec & $/$ & $/$ & $/$ & $/$ & $/$ & $/$ & 15 & $\mathbf{1 5}$ \\
\hline
\end{tabular}




\begin{tabular}{|c|c|c|c|c|c|c|c|c|}
\hline \multirow{2}{*}{$\begin{array}{l}\text { MOŠKOSPOLSKO } \\
\text { OBRAZILO }\end{array}$} & \multicolumn{8}{|c|}{ FEMINATIVNO PRIPONSKO OBRAZILO } \\
\hline & $-i c a$ & -(ar)ica & $-j a$ & -ulja & -inja & -kinja & $-k a$ & SKUPAJ \\
\hline -elec & 1 & I & 1 & 1 & 1 & 1 & 1 & 1 \\
\hline -enec & 1 & 1 & 1 & 1 & 1 & 1 & 1 & 1 \\
\hline -evec & 1 & I & 1 & 1 & 1 & 1 & 2 & 2 \\
\hline -ilec & 1 & I & 2 & I & / & / & 32 & 34 \\
\hline -inec & 1 & I & 1 & 1 & 1 & 1 & 2 & 2 \\
\hline -irec & 1 & I & 1 & 1 & I & 1 & 1 & 1 \\
\hline$-v e c$ & 1 & 7 & 1 & 1 & 1 & 1 & 3 & 3 \\
\hline -ivec & 1 & I & 1 & 1 & I & 1 & 3 & 3 \\
\hline -ovec & I & I & 1 & 1 & 1 & 1 & 4 & 4 \\
\hline$-a \check{c}$ & 1 & I & l & 2 & l & l & l & 3 \\
\hline$-i \check{c}$ & 1 & I & 1 & 1 & 1 & 1 & 1 & 2 \\
\hline -enič & I & I & I & I & I & I & 1 & 1 \\
\hline$-u h$ & I & I & 1 & 2 & 1 & 1 & 1 & 2 \\
\hline$-e k$ & 1 & I & / & 1 & 1 & / & 7 & 8 \\
\hline$-\check{c} e k$ & 4 & I & l & l & / & l & I & 4 \\
\hline$-i k$ & $277^{72}$ & I & I & 1 & I & 1 & 1 & 277 \\
\hline$-n i k$ & 68 & I & I & I & I & I & 2 & 70 \\
\hline- in & 1 & I & 1 & 1 & 1 & 1 & I & 1 \\
\hline$-a r$ & 1 & I & I & 1 & 1 & 1 & 1 & 1 \\
\hline$-a v s$ & 1 & I & 1 & 1 & 1 & 1 & 1 & 1 \\
\hline$-e \check{z}$ & $107^{73}$ & I & 1 & 1 & 1 & I & 1 & 108 \\
\hline SKUPAJ & $\mathbf{4 7 8}^{74}$ & 1 & 2 & 5 & 5 & 8 & $668^{75}$ & 1167 \\
\hline
\end{tabular}

${ }^{72}$ Všteti so primeri, kjer kot vzporedno priponsko obrazilo nastopi tudi -ež.

${ }^{73}$ Všteti so primeri, kjer kot vzporedno priponsko obrazilo nastopi tudi $-i k$.

${ }^{74} \mathrm{~V}$ začetku poglavja (str. 163) smo zapisali, da je z obrazilom -ica tvorjenih 405 feminativov. Skupno število tvorjenk v preglednici je višje, ker smo pri obrazilih $-i k$ in $-e z ̌$ šteli 72 primerov, ki so lahko tvorjeni $\mathrm{z}$ obema moškospolskima obraziloma, prav tako smo dvakrat šteli primer mučenica (iz mučenec ali mučenik).

${ }^{75}$ Število tvorjenk s - $k a$ je višje, kot smo zapisali v začetku poglavja, saj smo feminativ bosopetka šteli dvakrat, pri -ec (iz bosopetec) in -nik (iz bosopetnik). 
Analiza je pokazala, da so moškospolska obrazila, ki jih feminativna priponska obrazila zamenjujejo, naslednja:

- $\quad-\boldsymbol{a}$ ob izglasju podstave na $-d$ (ena tvorjenka $\mathrm{z}-($ ar)ica, $\mathrm{tj}$. gazdarica) ali - $g$ (en primer z obrazilom -ica kolegica, tri primeri z -inja, npr. sluginja);

- -ja pri zloženkah, ko kot zamenjevalno ženskospolsko obrazilo nastopi le -kinja, kar potrjuje šest konkretnih primerov (denimo delovodkinja);

- $\quad$ ec pri izglasjih podstav $-b$ (en feminativ s $-k a$ bebka), $-d$ (trije primeri s -ka, npr. telovadka, eden s -kinja: vidkinja), -g (trije primeri z -ica, npr. ubožica), -j (šest feminativov s -ka, denimo gimnazijka), -lj (ena tvorjenka s -ka vesoljka), -l (en primer z -ica: došlica; $16 \mathrm{~s}-k a$, med njimi tekstilka), -m (dva primera $\mathrm{z}$-ica samica; pet s -ka, npr. inozemka), $-n$ (en primer $\mathrm{z}$ -ica: mučenica; 191 primerov s -ka, npr. ranjenka), - $p$ (en primer z -ica: slepica; štirje s -ka: tepka), -r (dva primera z -ica, npr. norica, devet s -ka: pomorka), -s (13 feminativov s $-k a$, denimo bujnolaska), $-t$ (dva primera z -ica, npr. lepotica; trije s -ka, npr. dolgopetka), -v (tri primeri z -ica, denimo jalovica; $101 \mathrm{~s}-k a$, recimo ušivka); nastopi tudi pri zloženih (npr. bacilonoska) in sestavljenih podstavah (npr. sokrivka);

- -alec, kadar je izglasje podstave na $-b$ (dva primera $\mathrm{s}-k a$, npr. oskrbovalka), -č (deset primerov s -ka, denimo izločevalka), -̌̌č (trije primeri s $-k a$, npr. maščevalka), -d (osem tvorjenk $\mathrm{s}-k a$, denimo gospodovalka), -g (osem feminativov s -ka, npr. negovalka), $-h$ (pet feminativov s $-k a$, npr. navdihovalka), -j (24 feminativov s $-k a$, npr. izposojevalka), -lj (sedem tvorjenk s -ka, denimo izsiljevalka), -nj (pet primerov s -ka, npr. ocenjevalka), -k (15 feminativov s -ka malikovalka), -l (trije feminativi $\mathrm{s}-k a$ izdelovalka), $-m$ (štirje primeri $\mathrm{s}-k a, \quad$ npr. tekmovalka), -n (dva primera s -ka stanovalka), $-p$ (tri tvorjenke s -ka kupovalka), -r (11 primerov s $-k a$, denimo darovalka), -s (devet feminativov s -ka, npr. dopisovalka), -š (12 primerov s -ka izpraševalka), - $t$ (9 tvorjenk s -ka metalka), -v (11 feminativov s -ka, npr. plavalka), -z (osem primerov s -ka plezalka), -ž (štirje primeri s -ka, npr. oboževalka); tudi pri zloženkah (delodajalka) in sestavljenkah (soigralka);

- -elec ob izglasju na -r (ena tvorjenka s -ka: pogorelka); 
- -ilec, če je izglasje podstave na -č (ena tvorjenka s -ka: tlačilka), -šč (en feminativ s -ka: voščilka), -d (dva primera s -ka, npr. kadilka), -j (en feminativ s -ka: gojilka), -m (dva primera s -ka, denimo krmilka), -n (štirje feminativi s -ka, npr. branilka), -p (ena tvorjenka s -ka: slepilka), -r (pet primerov s $-k a$, npr. borilka), $-s$ (trije feminativi s $-k a$, npr. nosilka), $-s ̌$ (ena tvorjenka s -ka: vršilka), -t (en primer z -ja pletilja, pet feminativov s $-k a$, npr. čistilka), -z (en feminativ z -ja vezilja, eden s -ka plazilka), -ž (dva primera s -ka, npr. snažilka);

- - anec pri izglasjih podstav na - $d$ (ena tvorjenka s -ka: mohamedanka), $-k$ (dva primera s-ka dominikanka), -t (ena tvorjenka s -ka: liliputanka);

- $\quad$-janec, kadar je izglasje podstave na -r (samo en primer s -ka hitlerjanka);

- $\quad$-enec ob izglasju podstave na -nj (en feminativ s -ka: kaznjenka);

- -inec pri izglasjih podstav na $-d$ (en primer $\mathrm{s}-k a$ : blondinka) in $-v$ (potrjeno z enim primerom s -ka novinka);

- $\quad$-arec, če je izglasje podstave na -t (le en feminativ s -ka elementarka);

- $\quad$-irec ob izglasju podstave na -s (samo en primer s -ka: kasirka);

- -avec pri izglasjih podstav na -lj (11 tvorjenk s -ka, npr. kegljavka), -l (dva primera s-ka, npr. delavka), tudi pri sestavljenkah (sodelavka);

- -evec, kadar je izglasje podstave na $-l j$ ali $-n j$ (oboje potrjeno s po enim primerom s -ka: grabljevka in branjevka);

- -ivec, če je izglasje podstave na $-l$ (dva feminativa s $-k a$, denimo volivka) ali - $v$ (en primer s -ka: brivka);

- -ovec pri izglasju podstave na $-g,-m$ (oboje potrjuje po en feminativ s $-k a$ : trgovka, domovka), -t (dva primera s -ka, npr. potovka);

- $\quad-a \check{c}$ ob izglasjih podstav na $-d$ in $-k$ (po en primer $\mathrm{z}-u l j a$ : gobezdulja, jezikulja), -lj (en feminativ z -ica: grabljica);

- -ič, če je izglasje podstave na -d (en primer $\mathrm{z}$-inja: dedinja), -m (en feminativ s -kinja: plemkinja);

- -enič pri izglasju podstave na -d (ena tvorjenka s -ka: mladenka);

- $-\boldsymbol{u h}$ ob izglasju na $-d$ ali $-p$ (oboje potrjeno s po enim primerom z -ulja: smrdulja in skopulja); 
- $\quad$ ek, kadar je izglasje podstave na -̌̌ (en feminativ s -ka: mladička), -k (trije primeri s -ka, npr. divjačka), -l (samo en primer z -ica: prišlica), -t (en primer s-ka: zlatka);

- - ček pri izglasju podstave na $-b$ in $-j$ (oboje potrjeno s po enim primerom z -ica: ljubica, dvojčica), -l (dva primera z -ica, denimo palčica);

- $-\boldsymbol{i} \boldsymbol{k}$ pri izglasjih podstav na $-n j$ (trije feminativi z -ica, npr. prednjica) in $-n$ (263 ${ }^{76}$ tvorjenk $\mathrm{z}-i c a$, denimo betežnica); nastopi tudi pri netvorjenih (tehnica), zloženih (zobotehnica) in sestavljenih (sopotnica) podstavah;

- -nik ob podstavah na -b (en primer z -ica: uporabnica), -c (dva feminativa z -ica miličnica), -č (tri primeri z -ica, npr. povzročnica), -̌̌č (en feminativ $\mathrm{z}$-ica: učiteljiščnica), -d (osem primerov $\mathrm{z}$-ica ponudnica), -j (dva feminativa z -ica naraščajnica), -lj (en primer z -ica: poveljnica), -p (dva feminativa $\mathrm{z}$-ica upnica), $-r$ (pet primerov z -ica, npr. darnica), - $t$ (18 primerov z -ica dopustnica, le dva s -ka: baletka), -v (trije feminativi z -ica zdravnica), $-z$ (štirje primeri z -ica, npr. paznica), $-\check{z}$ (pet primerov z -ica tolažnica); tudi pri zloženkah (ranocelnica) in sestavljenkah (denimo sovoznica);

- -in, kadar je izglasje podstave na -č (en primer z -ica: domačica);

- - ar pri izglasjih podstav na -k (en primer z -inja: pametnjakinja);

- -avs, kadar je izglasje podstave na -n (ena tvorjenka z -ulja: črnulja);

- $\quad \boldsymbol{e} \boldsymbol{e} \check{z}$, če je izglasje podstave na $-l$ (en primer z -ica: podlica), $-n\left(105^{77}\right.$ primerov z -ica, npr. nemirnica), -t (en feminativ s -ka srboritka), -v (en feminativ z -ica revica).

Opažamo, da pri vseh obrazilih z izglasno sestavino -ec prevladuje zamenjava s priponskim obrazilom $-k a$ (skupaj $\mathrm{s}$ sestavljenimi in zloženimi podstavami 657 primerov ali $96 \%,{ }^{78} \mathrm{z}$-ica pa samo 18 oz. 2,6 \%). Drugače je pri moškospolskih obrazilih -ik in -nik, kjer prednjači zamenjava z -ica (skupno 345

\footnotetext{
${ }^{76}$ Všteti so tudi primeri, pri katerih kot vzporedno moškospolsko obrazilo nastopa -ež.

${ }^{77}$ Všteti so tudi primeri, pri katerih kot vzporedno moškospolsko obrazilo nastopa $-i k$.

78 Vključujemo tudi primere, ko kot moškospolska obrazila nastopajo -alec, -anec, -janec, -arec, -avec, -elec, -evec, -ilec, -inec, -ovec in -vec, saj gre pri le-teh po upoštevanem načelu racionalnosti za zamenjavo moškospolskega obrazila -ec z ženskospolskim $-k a$.
} 
tvorjenk ali $99 \%, \mathrm{~s}-k a$ le dve), podobno velja pri moškospolskem -ěz (z -ica 107 primerov oz. $99 \%, \mathrm{~s}-k a$ le eden).

\section{Sinteza obrazilne produktivnosti - dodajanje k izglasju podstave}

Spodnja preglednica prikazuje, $\mathrm{h}$ katerim izglasjem (podstave ali obrazila) se feminativna priponska obrazila po zamenjavi moškospolskega obrazila dodajo. Vključena je tvorba iz netvorjenih, izpeljanih, zloženih in sestavljenih podstav.

Preglednica 33: Sinteza obrazilne produktivnosti - zamenjevalni način ob moškospolskih izglasjih (SSKJ 1)

\begin{tabular}{|c|c|c|c|c|c|c|c|c|}
\hline \multirow[t]{2}{*}{$\begin{array}{l}\text { IZGLASJE } \\
\text { PODSTAVE }\end{array}$} & \multicolumn{8}{|c|}{$\begin{array}{c}\text { FEMINATIVNO PRIPONSKO } \\
\text { OBRAZILO }\end{array}$} \\
\hline & -(ar)ica & $-i c a$ & $-j a$ & -inja & -kinja & -ulja & $-k a$ & SKUPAJ \\
\hline$-b$ & I & 1 & I & I & I & I & 1 & 2 \\
\hline$-\check{c}$ & 1 & 4 & 1 & 1 & 1 & 1 & 1 & 5 \\
\hline$-d$ & 1 & 1 & I & 2 & 7 & 2 & 9 & 22 \\
\hline$-g$ & 1 & 4 & 1 & 2 & 1 & 1 & I & 6 \\
\hline$-j$ & I & I & I & 1 & 1 & 1 & 9 & 9 \\
\hline$-l j$ & I & 1 & I & I & 1 & I & 2 & 3 \\
\hline$-n j$ & I & 4 & I & I & 1 & 1 & 1 & 5 \\
\hline$-k$ & 1 & I & I & 1 & 1 & 1 & 3 & 5 \\
\hline$-l$ & I & 3 & 2 & 1 & 1 & 1 & 248 & 253 \\
\hline$-m$ & I & 2 & 1 & I & 1 & 1 & 8 & 11 \\
\hline$-n$ & I & 375 & I & I & I & 1 & 204 & 580 \\
\hline$-p$ & 1 & 1 & 1 & 1 & I & 1 & 5 & 7 \\
\hline$-r$ & I & 2 & I & I & I & I & 18 & 20 \\
\hline$-S$ & I & I & I & I & I & I & 17 & 17 \\
\hline$-\check{s}$ & I & I & I & I & I & 1 & 1 & 1 \\
\hline$-t$ & I & 2 & / & / & I & I & 7 & 10 \\
\hline$-v$ & 1 & 4 & I & I & 1 & I & 132 & 136 \\
\hline
\end{tabular}




\begin{tabular}{|r|c|c|c|c|c|c|c|c|}
\hline $\begin{array}{r}\text { IZGLASJE } \\
\text { PODSTAVE }\end{array}$ & \multicolumn{7}{|c|}{ FEMINATIVNO PRIPONSKO OBRAZILO } \\
\cline { 2 - 9 } & $-($ ar)ica & $-i c a$ & $-j a$ & - -inja & - -kinja & - ulja & $-k a$ & SKUPAJ \\
\hline$-z$ & $/$ & 1 & $/$ & $/$ & $/$ & $/$ & 1 & 2 \\
\hline SKUPAJ & 1 & 405 & 2 & 5 & 8 & 5 & 667 & 1093 \\
\hline
\end{tabular}

Obravnavana feminativna priponska obrazila se lahko po odvzemu moškospolskega obrazila dodajajo k izglasjem na:

- $\quad \boldsymbol{b}$ (en feminativ s - $k a$, po tem ko zamenja obrazilo -ec, tj. bebka, in eden z -ica po zamenjavi obrazila -ček, tj. ljubica);

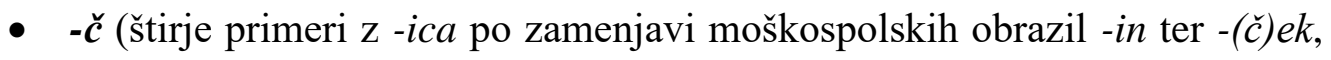
denimo domačica in malčica; en primer s -ka po zamenjavi obrazila -ek: mladička);

- - $\boldsymbol{d}$ (en primer z -(ar)ica po odvzemu obrazila - a gazdarica, en primer z -ica po zamenjavi moškospolskega -ec: predica, dva konkretna primera z -ulja po zamenjavi obrazil -ač in -uh (gobezdulja in smrdulja), dva feminativa z -inja po odvzemu - $a$ oz. -ič (nadvojvodinja, dedinja), sedem primerov s -kinja po zamenjavi obrazila -ja, npr. knjigovodkinja, ter osem primerov s $-k a$ po zamenjavi moškospolskega obrazila $-e c$ oz. -enič: vsevedka, mladenka);

- $\quad-\boldsymbol{g}$ (štirje primeri z -ica po odvzemu obrazil -a kolegica in -ec nagica ter dva primera z -inja po zamenjavi moškospolskega priponskega obrazila - $a$, npr. sluginja);

- $\quad-j$ (devet primerov s - $k a$ po odvzemu obrazila -ec, denimo tujka);

- $\quad-\quad l j$ (en feminativ z -ica po zamenjavi obrazila -ač grabljica ter dva s -ka po zamenjavi moškospolskega -ec, npr. vesoljka);

- $\quad-n j$ (štirje feminativi z -ica po zamenjavi obrazila -ik, npr. prošnjica, in eden s -ka po odvzemu obrazila -ek: osebenjka);

- $-\boldsymbol{k}$ (en feminativ $\mathrm{z}$-inja po zamenjavi priponskega obrazila -ar pametnjakinja, eden $\mathrm{z}$-ulja po odvzemu obrazila -ač jezikulja ter trije s -ka po zamenjavi obrazila -ek, npr. kozačka);

- $\quad-l$ (tri primeri z -ica ob zamenjavi različnih moškospolskih obrazil, npr. došlica, 248 s -ka, npr. izdelovalka; prišteti so primeri zamenjave obrazil 
-alec, -elec in -ilec, ker gre za zamenjavo obrazilne sestavine -ec in s tem dodajanje $\mathrm{k}-l$; podobno tudi dva primera $\mathrm{z}-j a$, npr. vezilja);

- $-\boldsymbol{m}$ (dva primera tvorbe $\mathrm{z}$-ica po zamenjavi obrazila -ec, npr. tekmica, eden s -kinja po zamenjavi -ič plemkinja in osem $\mathrm{s}-k a$, zmeraj po zamenjavi z -ec, denimo nemka);

- -n (največ, tj. 375 primerov z -ica po zamenjavi moškospolskih obrazil -ik dolžnica, -ec mučenica in -ež porednica, en primer z -ulja po odvzemu obrazila -avs črnulja in 204 feminativi s $-k a$ po zamenjavi obrazila -ec, npr. miljenka);

- $\quad-\boldsymbol{p}$ (po en primer $\mathrm{z}$-ica po zamenjavi -ec slepica in -ulja po zamenjavi -uh skopulja ter pet primerov $\mathrm{s}-k a$, pri vseh po odvzemu obrazila $-e c$ : tihotapka);

- $\quad-\boldsymbol{r}$ (dva primera z -ica, npr. norica, ter $18 \mathrm{~s}-k a$, npr. starka, pri obeh po zamenjavi obrazila -ec, pri -ka tudi -ek pastorka);

- $\quad-s$ (17 primerov, tvorjenih z obrazilom - $k a$ po zamenjavi moškospolskega obrazila -ec, denimo plavolaska);

- $\quad-\breve{s}$ (en feminativ s -ka po odvzemu moškospolskega obrazila -ec: peška);

- $-t$ (dva primera $\mathrm{z}$-ica po zamenjavi obrazila -ec krasotica in sedem feminativov s - $k a$ po odvzemu obrazil -ec dolgopetka, -ek zlatka, -nik baletka in -ež srboritka);

- $\quad-\boldsymbol{v}$ (štirje primeri tvorbe z -ica po odvzemu obrazil -ec in -ež, npr. jalovica in revica; 132 primerov $\mathrm{s}-k a$, in to po zamenjavi obrazila (ali njegovega dela) -ec, denimo primitivka);

- $-z$ (po en feminativ $\mathrm{z}-i c a$ in $-k a$, pri obeh po zamenjavi moškospolskega -ec: molzica, tiholazka).

Kot zamenjevalni feminativni priponski obrazili najpogosteje nastopata $-i c a$ in $-k a$. S priponskim obrazilom -ka je skupno tvorjenih 667 feminativov (61 $\%)$; med njimi gre po zamenjavi moškospolskega obrazila največkrat za dodajanje $\mathrm{k}$ izglasjem na $-v(132$ primerov ali $20 \%),-n(204$ primeri oz. 30,5\%) ali na $-l$ (248 feminativov ali $37 \%$ ). Obrazilo -ica tvori 405 feminativov (37\%); po 
zamenjavi moškospolskega priponskega obrazila se najpogosteje dodaja $\mathrm{k}$ izglasjem na - $n$ (374 primerov ali $93 \%$ ).

7.1.1.2 Feminativi, nastali $\mathrm{z}$ dodajanjem ženskospolskega obrazila tvorjenkam moškega spola

Taki feminativi obsegajo $44 \%$ vseh iz SSKJ 1 izpisanih tvorjenk. Med njimi jih je bilo 487 (58 \%) tvorjenih z obrazilom - $k a, 206(24 \%) \mathrm{z}-i c a, 108$ (13 \%) z -inja, dvanajst $(1,4 \%) \mathrm{z}-a$, šest $(0,7 \%) \mathrm{z}-n a$, po tri $(0,3 \%) \mathrm{z}-j a$ in $-e s a$ ter dve $(0,2 \%)$ z $-u l j a$. Kot variante obrazil ${ }^{79}$ so se pojavila -(ar)ica z enim primerom, -(ar)ka z 11 feminativi, -(ev)ka s tremi in -(ov)ka s štirimi primeri tvorjenk.

\section{Grafikon 9: Dodajalna feminativna priponska obrazila v SSKJ 1}

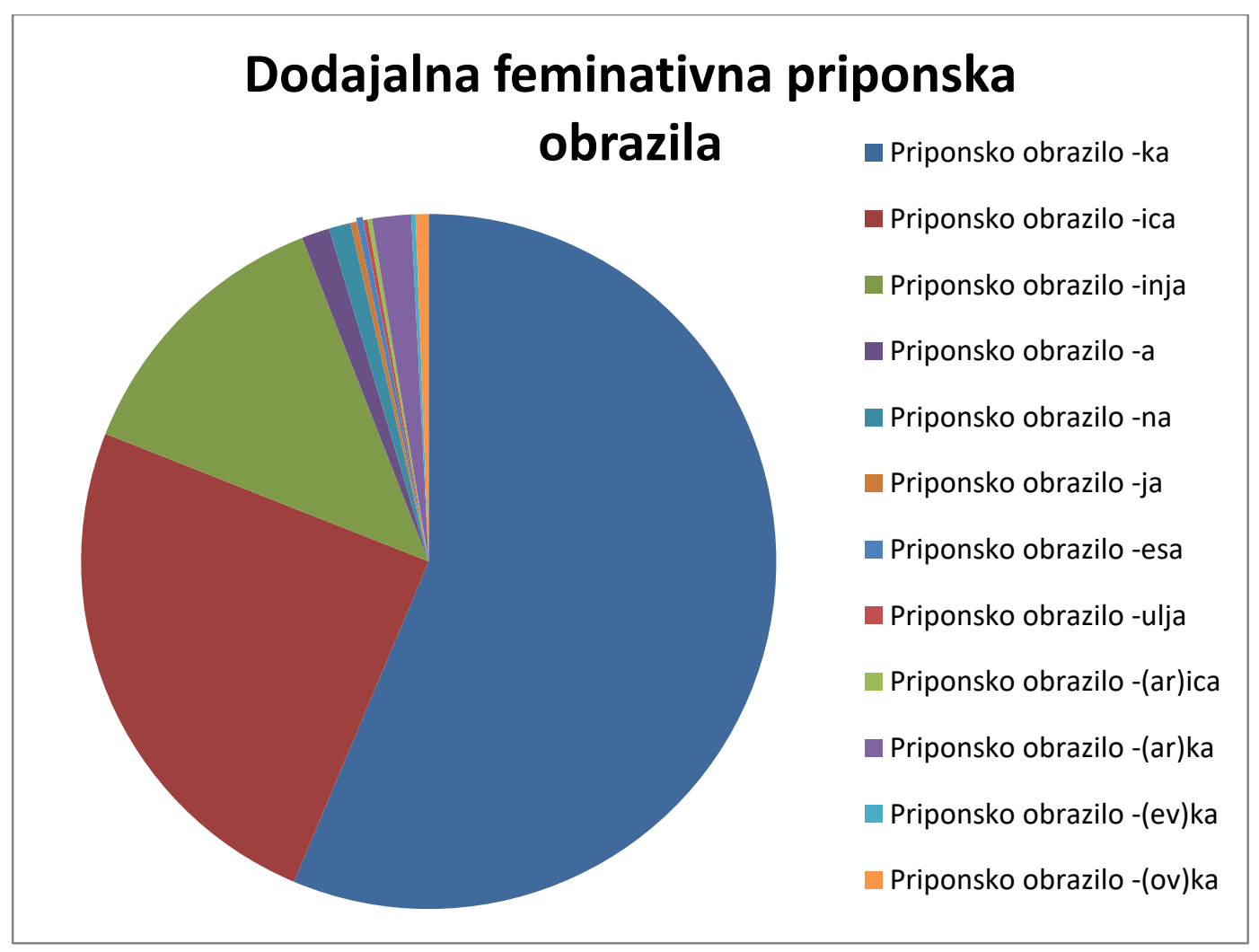

\footnotetext{
${ }^{79}$ Po Mluvnice češtiny (1986: 218) lahko imajo obrazila ob popolni ohranitvi vseh funkcij različne variante. Pomembne so zlasti t. i. razširjene variante priponskih obrazil, tj. skupek povezovalnega morfema, imenovanega spone (Toporišič 1992, povz. po Stramljič Breznik 2004: 34), in dejanske pripone. Slednja pogosto nastopa kot samostojno obrazilo.
} 
Opažamo, da nekatera obrazila nastopajo zgolj kot dodajalna; pri že predstavljenem zamenjevalnem načinu jih namreč nismo zasledili: -na (bratična, cesarična, dedična, gospodična, grofična, kraljična, sestrična, strnična), -a (botra, debeluha, glavana, gostača, lovača, magistra, prismuka, smrduha, soseda, sužnja, trapa, zaletela), -esa (poetesa, princesa, stevardesa), -(ev)ka (hudičevka, zlodejevka), -(ov)ka (mojstrovka, pekovka, škratovka, vragovka, židovka), -(ar)ka (akademičarka, alkoholičarka, astmatičarka, botaničarka, higieničarka, kemičarka, kozmetičarka, kritičarka, metodičarka, političarka, razredničarka).

Spodnja preglednica prikazuje, s katerimi izglasji moškospolskih obrazil se ta obrazila družijo, pri čemer smo zajeli vse tri prve pomenske skupine izpeljank iz glagolske, pridevniške in samostalniške podstave.

Preglednica 34: Družljivost feminativnih priponskih obrazil z izglasji moškospolskih poimenovanj $v$ SSKJ 1

\begin{tabular}{|c|c|c|c|c|}
\hline \multirow[t]{2}{*}{ OBRAZILO } & \multirow{2}{*}{$\begin{array}{l}\text { IZGLASJE } \\
\text { OBRAZILA }\end{array}$} & \multicolumn{3}{|c|}{ PRIMERI TVORJENK } \\
\hline & & $\begin{array}{c}\text { FEMINATIV IZ } \\
\text { VRŠILCA }\end{array}$ & $\begin{array}{c}\text { FEMINATIV IZ } \\
\text { NOSILCA }\end{array}$ & $\begin{array}{l}\text { FEMINATIV IZ } \\
\text { OPRAVKARJA }\end{array}$ \\
\hline \multirow[t]{5}{*}{$-a$} & $-(a) \check{c}$ & gostača & / & / \\
\hline & $-(u) h$ & smrduha & debeluha & / \\
\hline & $-(u) k$ & / & prismuka & / \\
\hline & $-(e) l$ & zaletela & / & / \\
\hline & $-(a) n$ & / & / & glavana \\
\hline \multirow[t]{9}{*}{-ica } & $-(a) \check{c}$ & jahačica & / & tenisačica \\
\hline & $-($ ate $) l j$ & predavateljica & / & / \\
\hline & -(ite)lj & gostiteljica & / & pokroviteljica \\
\hline & $-(j a) n$ & / & / & dvorjanica \\
\hline & $-(a) r$ & čuvarica & $/$ & abecedarica \\
\hline & $-(i) r$ & pastirica & / & I \\
\hline & $-(o) r$ & I & / & direktorica \\
\hline & $-($ ato $) r$ & donatorica & / & / \\
\hline & $-(a) \check{s}$ & / & / & rokometašica \\
\hline \multirow[t]{5}{*}{-inja } & $-(u) h$ & oderuhinja & debeluhinja & / \\
\hline & $-(a) k$ & / & prostakinja & vojakinja \\
\hline & $-(j a) k$ & / & odličnjakinja & korenjakinja \\
\hline & $-(e) k$ & I & prišlekinja & I \\
\hline & $-(i) k$ & I & akademikinja & / \\
\hline
\end{tabular}




\begin{tabular}{|c|c|c|c|c|}
\hline & $-(u) k$ & I & / & hajdukinja \\
\hline & $-(a) l$ & rivalinja & I & / \\
\hline & $-(a) r$ & I & I & bojarinja \\
\hline & $-(a) \check{s}$ & pristašinja & bogatašinja & mejašinja \\
\hline & $-(a) t$ & kandidatinja & I & aristokratinja \\
\hline & $-(a n) t$ & I & / & bakhantinja \\
\hline & $-(e) t$ & I & I & katehetinja \\
\hline & $-(e n) t$ & regentinja & / & I \\
\hline & $-(o) t$ & I & l & patriotinja \\
\hline & $-(i s) t$ & I & I & turistinja \\
\hline$-j a$ & $-(a) n$ & l & l & županja \\
\hline & $-(u) n$ & pestunja & I & / \\
\hline$-k a$ & $-(a) \check{c}$ & bahačka & / & brkačka \\
\hline & $-(j a) \check{c}$ & gonjačka & l & l \\
\hline & $-(i) \check{c}$ & vodička & mladička & I \\
\hline & $-(a n) d$ & doktorandka & I & I \\
\hline & $-(u) h$ & potepuška & črnuška & l \\
\hline & $-(a) j$ & strežajka & l & l \\
\hline & $-(u) j$ & / & / & buržujka \\
\hline & $-(e) l$ & l & / & modelka \\
\hline & $-(a) n$ & l & velikanka & deželanka \\
\hline & $-(\check{c} a) n$ & l & l & nebeščanka \\
\hline & $-(j a) n$ & I & I & dvorjanka \\
\hline & $-(i j a) n$ & I & modrijanka & cistercijanka \\
\hline & $-(l j a) n$ & / & / & državljanka \\
\hline & $-(m a) n$ & / & l & hlačmanka \\
\hline & $-(i) n$ & trpinka & bogatinka & capinka \\
\hline & $-($ ali $) n$ & gizdalinka & / & pobalinka \\
\hline & $-($ oli $) n$ & smrkolinka & l & I \\
\hline & $-($ ari $) n$ & vojarinka & I & I \\
\hline & $-(o) n$ & potegonka & I & I \\
\hline & $-(u) n$ & vohunka & grdunka & I \\
\hline & $-(a) r$ & bičarka & desetarka & dninarka \\
\hline & $-(e) r$ & dreserka & I & garderoberka \\
\hline & $-($ ate $) r$ & dekoraterka & / & I \\
\hline & $-(i) r$ & I & / & brigadirka \\
\hline & $-(o) r$ & kontrolorka & I & senatorka \\
\hline
\end{tabular}




\begin{tabular}{|c|c|c|c|c|}
\hline & $-($ ato $) r$ & agitatorka & novatorka & I \\
\hline & $-(u) r$ & I & I & nemčurka \\
\hline & $-(a) \check{s}$ & / & bogataška & / \\
\hline & $-(a) t$ & delegatka & / & diplomatka \\
\hline & $-(a n) t$ & emigrantka & / & komedijantka \\
\hline & $-(a s) t$ & I & / & entuziastka \\
\hline & $-(a v) t$ & $/$ & I & kozmonavtka \\
\hline & $-(e) t$ & I & I & asketka \\
\hline & $-(e n) t$ & asistentka & inteligentka & I \\
\hline & $-(e v) t$ & / & / & terapevtka \\
\hline & $-(i) t$ & favoritka & I & banditka \\
\hline & $-(o) t$ & l & l & patriotka \\
\hline & $-(i s) t$ & telefonistka & oportunistka & zboristka \\
\hline$-(a r) k a$ & $-(i) k$ & kritičarka & razredničarka & alkoholičarka \\
\hline$-(e v) k a$ & $-(i) \check{c}$ & ribičevka & hudičevka & I \\
\hline$-n a$ & $-(i) \check{c}$ & dedična & I & cesarična \\
\hline
\end{tabular}

1. Priponsko obrazilo - $\boldsymbol{a}$ nastopa kot dodajalno k izglasjem obrazil na:

- -(a)č pri vršilcu iz glagolov na -iti/-im (dve tvorjenki: gostača, lovača);

- $-(\boldsymbol{u}) \boldsymbol{h}$ pri vršilcu, ki ima v podstavi glagole na -eti/-im (zgolj smrduha), in pri nosilcu z izglasjem podstavnega pridevnika na -l (le debeluha);

- $\quad-(\boldsymbol{u}) \boldsymbol{k}$ za nosilca lastnosti (prismuka);

- -(e)l pri vršilcu, kadar je glagolska podstava na -eti/-im (samo zaletela);

- -(a)n pri opravkarju iz domače podstave (en primer: glavana);

- $\quad \boldsymbol{- \boldsymbol { \theta }}$ (sužnja, trapa, magistra, botra), tudi pri sestavljenkah (soseda).

2. Obrazilo -ica dobijo tvorjenke, katerih izglasje moškospolskih priponskih obrazil se konča na:

- -(a)č pri vršilcu iz glagolskih podstav na -iti/-im (tri tvorjenke: belačica, krojačica, vozačica), -ati/-am (deset feminativov: grabljačica, jahačica, kegljačica, kopačica, plavačica, pometačica, sabljačica, tekačica, trgačica, veslačica), -ati/-em (dva primera: mazačica, skakačica) in opravkarju iz domače ali prevzete podstave (beračica, tenisačica); 
- -(ate)lj za vršilca dejanja iz glagolov na -ati/-em (le pisateljica), -ati/-am (šest primerov: predavateljica, predlagateljica, prijateljica, ravnateljica, skladateljica, slušateljica);

- -(ite) $\boldsymbol{l} j$ za vršilca iz podstave glagola na -iti/-im (30 feminativov: braniteljica, dobaviteljica, gostiteljica, graditeljica, hraniteljica, izumiteljica, izvršiteljica, ljubiteljica, mučiteljica, nositeljica, odgojiteljica, osvoboditeljica, posvojiteljica, povzročiteljica, predstaviteljica, prirediteljica, rediteljica, rešiteljica, roditeljica, služiteljica, stvariteljica, tlačiteljica, tožiteljica, učiteljica, ugrabiteljica, upraviteljica, ustanoviteljica, vaditeljica, voditeljica, vzgojiteljica) in na -C-ti/-em (dva primera: iznajditeljica, najditeljica) ter za opravkarja iz domače podstave (pokroviteljica), nastopi pa tudi pri zloženkah (prvoboriteljica) in sestavljenkah (soustanoviteljica);

- -(ja)n pri opravkarju iz domače podstave (samo dvorjanica);

- -(a)r pri vršilcu dejanja iz glagolov na -ati/-am (20 tvorjenk: citrarica, čipkarica, čuvarica, klekljarica, kotalkarica, kuharica, likarica, natakarica, padarica, pridigarica, romarica, roparica, slikarica, šolarica, tipkarica, veslarica, vlačugarica, vladarica, voskarica, žveglarica), -ariti/-arim (24 feminativov: cunjarica, čebelarica, dninarica, glavarica, gobarica, gospodarica, hlevarica, kelnarica, kletarica, kokošarica, kramarica, krmarica, krčmarica, lončarica, mešetarica, mlekarica, nemškutarica, ovčarica, pisarica, planšarica, sleparica, spletkarica, vratarica, žeparica) in -ovati/-ujem (osebenjkarica, politikarica) ter pri opravkarju iz domačih in prevzetih podstav (53 tvorjenk: abecedarica, apotekarica, bajtarica, cigararica, coklarica, copatarica, cvetličarica, časnikarica, debeluharica, dežnikarica, domarica, gostilničarica, gruntarica, harmonikarica, jajčarica, ječarica, kajžarica, ključarica, kočarica, kofetarica, košarkarica, kravarica, lectarica, lekarnarica, lutkarica, medičarica, mokarica, odbojkarica, orglarica, pobožnjakarica, popevkarica, poštarica, preužitkarica, rožarica, slivarica, sobarica, solatarica, straniščarica, struparica, svinjarica, šivankarica, učenjakarica, užitkarica, vračarica, vražarica, vrtičkarica, zapisnikarica, 
zdraharica, zelenjadarica, zelenjavarica, zeliščarica, zeljarica, zgodovinarica), tudi pri zloženkah (samovladarica) in sestavljenkah (sovladarica);

- $\quad$-(i)r za vršilca iz glagolskih podstav na -C-ti/-em (samo pastirica);

- -(o)r za opravkarja iz prevzetih podstav (osem primerov: dezinfektorica, direktorica, ekspeditorica, inšpektorica, inštruktorica, lektorica, profesorica, redaktorica);

- -(ato)r pri vršilcu iz glagolov na -irati/-iram (štiri tvorjenke: diktatorica, donatorica, organizatorica, propagatorica);

- -(a)š pri opravkarju (dva primera: kolašica, rokometašica);

- -o ob izglasju podstave na -č (pešačica, tolmačica), -f (goljufica, grofica, šefica), -g ob glasovni premeni (družica, vražica), -lj (kraljica), -n (ciganica, članica, dekanica), -p (trapica), -r (avtorica, carica, cesarica, dohtarica, doktorica, majerica, marketendarica, ministrica, mojstrica, partnerica), -š (pajdašica, tovarišica), -t (kmetica, opatica, svatica, škratica, tatica), tudi pri sestavljenkah (sodružica).

Naša disertacija je potrdila rezultate raziskav Irene Stramljič Breznik (1994/95) in Ines Voršič (2013), da z dodajalnim obrazilom -ica nikoli ne nastajajo feminativi k nosilcu lastnosti.

3. Obrazilo -(ar)ica se doda izglasju podstave na $-\boldsymbol{k}$ (samo en primer: matematikarica). Izločili smo besede pobožnjakarica, politikarica, učenjakarica in druge podobne, saj v njih kot dodajalno obrazilo nastopa -ica in ne -(ar)ica; v jezikovnih priročnikih so namreč zabeleženi moškospolski samostalniki pobožnjakar, politikar, učenjakar.

4. Obrazilo -ja se doda izglasju podstave na -t (samo primer gostja) ali izglasju obrazila na:

- -(a)n pri opravkarju (le en primer: županja);

- $-(\boldsymbol{u}) \boldsymbol{n}$ pri vršilcu iz glagolskih podstav na -ovati/-ujem (samo pestunja). 
5. Obrazilo -ulja nastopa kot dodajalno k izglasju podstave na -c (bruculja) ali - $g$ (vragulja).

6. Priponsko obrazilo -inja dodajamo k izglasjem obrazila na:

- -(u)h za vršilca iz glagolov na -iti/-im (en feminativ: ovaduhinja), -ati/-am (oderuhinja, potepuhinja, požeruhinja), -eti/-im (en primer: stremuhinja), -ovati--ujem (zgolj varuhinja) in za nosilca iz pridevniške podstave na - $l$ (debeluhinja) oziroma -n (lenuhinja);

- $-(\boldsymbol{a}) \boldsymbol{k}$ pri nosilcu lastnosti (pet feminativov: bedakinja, ${ }^{80}$ divjakinja, ${ }^{81}$ prostakinja, prvakinja, veščakinja) in opravkarju iz domačih podstav (pet tvorjenk: čudakinja, graščakinja, rojakinja, težakinja, vojakinja);

- -(ja)k pri nosilcu lastnosti iz pridevnikov na $-n$ (14 primerov: godovnjakinja, južnjakinja, narodnjakinja, odličnjakinja, pametnjakinja, pobožnjakinja, ponočnjakinja, poštenjakinja, severnjakinja, strokovnjakinja, učenjakinja, vetrnjakinja, vzhodnjakinja, zahodnjakinja) ali -l (samo veseljakinja) ter pri opravkarju (korenjakinja);

- $\quad-(\boldsymbol{e}) \boldsymbol{k}$ pri nosilcu lastnosti (prišlekinja);

- -(i)k za nosilca po krnitvi iz pridevnika (akademikinja);

- $\quad-(\boldsymbol{u}) \boldsymbol{k}$ pri opravkarju (le hajdukinja);

- -(a)l za vršilca iz glagola na -ati/-am (samo en primer: rivalinja);

- -(a)r pri opravkarju (samo bojarinja $\mathrm{v}$ pomenu $\mathrm{v}$ carski Rusiji in $\mathrm{v}$ Romuniji 'visoka plemkinja, plemiška veleposestnica');

- -(a)š pri vršilcu iz glagola na -ati/-anem (pristašinja), pri nosilcu lastnosti iz pridevniških podstav na $-k$ (samo velikašinja) in - $t$ (dva feminativa: bogatašinja, plemenitašinja) ter pri opravkarju (zgolj mejašinja);

- -(a)t za vršilca iz glagola na -irati/-iram (en primer: kandidatinja), tudi za opravkarja (aristokratinja);

- -(an)t pri opravkarju (bakhantinja);

- -(e)t za opravkarja (katehetinja);

${ }^{80}$ Po krnitvi iz pridevnika bedast.

${ }^{81}$ Po Slovenskem etimološkem slovarju iz pridevnika divji (Snoj 2016: 143). 
- $\quad$-(en)t za vršilca iz glagolov na -irati/-iram (agentinja, regentinja);

- $\quad-(\boldsymbol{o}) \boldsymbol{t}$ pri opravkarju iz prevzete podstave (patriotinja);

- -(is)t pri opravkarju iz prevzete podstave (baptistinja, katehistinja, turistinja);

- -o ob izglasno zelo raznolikih podstavah (atletinja, boginja, dijakinja, gostinja, grofinja, herojinja, interpretinja, judinja, junakinja, kirurginja, kneginja, kustodinja, kustosinja, monarhinja, nečakinja, opatinja, orjakinja, pešakinja, prerokinja, robinja, skavtinja, svakinja, šefinja, tragedinja, uskokinja, virtuozinja, vnukinja, židinja); tudi ob sestavljenkah (sosedinja).

Ines Voršič (2013: 173) ugotavlja, da so tovrstni feminativi velikokrat izpeljani iz samostalniških zloženk s sufiksoidnimi in prefiksoidnimi elementi, tudi v kombinaciji ${ }^{82}$ (npr. arheologinja, biologinja, defektologinja, demagoginja, dermatologinja, filologinja, filozofinja, fotografinja, ftiziologinja, geologinja, ginekologinja, koreografinja, logopedinja, meteorologinja, ortopedinja, pedagoginja, pediatrinja, psihiatrinja, psihologinja, psihopatinja, sociologinja, stenografinja, teologinja). Obrazilo -inja pa se lahko dodaja tudi zloženkam (samoukinja) ali sestavljenkam (pravnukinja).

7. Priponsko obrazilo $-\boldsymbol{k} \boldsymbol{a}$ se dodaja izglasjem obrazila na:

- -(a)č pri vršilcu iz glagola na -ati/-am (osem tvorjenk: bahačka, garačka, pohajačka, pomagačka, pometačka, postopačka, pretepačka, prihajačka), -iti/-im (trije primeri: brusačka, glumačka, gostačka), -ati/-im (samo kričačka), -ati/-em (le mazačka) ter za opravkarja iz domače podstave (en primer: brkačka);

- -(ja)č za vršilca iz glagolskih podstav na -iti/-im (samo gonjačka);

\footnotetext{
${ }^{82}$ Gre za skupino zloženk, ki ima v celoti ali le deloma prevzete sestavine; nekatere med njimi so skoraj na stopnji priponskih obrazil, vendar se njihova korenskost dokazuje z zamenljivostjo in kombiniranjem z drugimi koreni. Toporišič $(2004: 188,189)$ del tovrstnih tvorjenk uvršča med medponsko-priponske podredne zloženke, del takih tvorjenk pa obravnava kot samomedponske zloženke, pri katerih končni del postane jedrni, nekončni pa nejedrni del besedne zveze (Voršič 2013: 235)
} 
- -(i)č pri vršilcu iz glagola na -iti/-im (ribička, vodička), -eti/-im (en primer: mrlička), pri nosilcu lastnosti (mladička, slabička);

- -(an)d za vršilca iz glagolskih podstav na -irati/-iram (pri le dveh primerih: doktorandka, preparandka);

- -(u)h pri nosilcu lastnosti, denimo k črnuhu po glasovni premeni črnuška, podobno debeluška, lenuška, staruška, tudi pri vršilcu iz glagolov na -ati/-am (samo potepuška);

- -(a)j za vršilca iz glagolov na -ati/-am (čuvajka), -čil-em (strežajka), -iti/-im (točajka);

- $\quad-(\boldsymbol{u}) \boldsymbol{j}$ za opravkarja (buržujka);

- $\quad-(\boldsymbol{e}) \boldsymbol{l}$ pri opravkarju (modelka);

- -(a)n pri opravkarju (brežanka in tržanka pri palatalizaciji $g \rightarrow \check{z}$, deželanka, faranka, karmeličanka, kastelanka, luteranka, meščanka, občanka, okoličanka, partizanka; katoličanka, otočanka in tlačanka pri palatalizaciji $k \rightarrow \check{c}$; podeželanka, triglavanka, zemljanka) in pri nosilcu (velikanka);

- -(ča)n pri opravkarju (samo tri tvorjenke: evangeličanka, nebeščanka, vaščanka), tudi pri sestavljeni (sovaščanka) in zloženi osnovi (malomeščanka);

- -(ja)n za opravkarja (štirje feminativi: dvorjanka, gorjanka, kristjanka, seljanka);

- -(ija)n za opravkarja (zgolj cistercijanka) in za nosilca (modrijanka);

- -(lja)n pri opravkarju (tri primeri: državljanka, svetovljanka, župljanka);

- -(ma)n za opravkarja (le dva feminativa: hlačmanka, narkomanka);

- -(i)n za vršilca dejanja iz glagolskih podstav na -ati/-am (potepinka), -eti/-im (sotrpinka, trpinka) ter pri nosilcu lastnosti (bogatinka, dolginka, domačinka) in opravkarju (capinka) ${ }^{83}$

- -(ali)n pri vršilcu iz podstave na -ati/-am (le en primer: gizdalinka) ter pri opravkarju (pobalinka);

- -(oli)n za vršilca iz glagola na -ati/-am (smrkolinka);

\footnotetext{
${ }^{83}$ Po Slovenskem etimološkem slovarju (Snoj 2016: 98) iz samostalnika capa.
} 
- -(ari)n za vršilca iz glagolske podstave na -evati/-ujem (vojarinka);

- -(o)n za vršilca iz glagola na -iti/-em (potegonka);

- $-(\boldsymbol{u}) \boldsymbol{n}$ za vršilca dejanja iz glagolov na -ati/-am (le vohunka) in za nosilca lastnosti (samo en feminativ: grdunka);

- -(a)r pri vršilcu dejanja iz glagolskih podstav na -ati/-am (14 primerov: bičarka, citrarka, čuvarka, puntarka, računarka, roparka, sanjarka, slikarka, smučarka, šolarka, špecarka, štoparka, tiskarka, zidarka), -ati/-em (dva primera: pisarka, risarka), -ariti/-arim (17 tvorjenk: čebelarka, dninarka, kiparka, kolesarka, krčmarka, krošnjarka, mešetarka, misijonarka, mlekarka, samotarka, sejmarka, sleparka, spletkarka, šušmarka, vratarka, vrtnarka, žeparka), -irati/-iram (arhivarka, funkcionarka, revolucionarka), -iti/-im (zgolj en primer: stražarka), pri nosilcu lastnosti (samo desetarka) ter pri opravkarju iz prevzetih in domačih podstav (58 feminativov: avtoštoparka, bajtarka, bibliotekarka, blagajničarka, bolničarka, cvetličarka, časnikarka, dacarka, delničarka, desničarka, dnevničarka, gostilničarka, grafičarka, grobarka, gumbničarka, instrumentarka, ječarka, jetničarka, keramičarka, ključarka, klobučarka, knjižničarka, kočarka, komisarka, krznarka, lekarnarka, letoviščarka, levičarka, matematičarka, matičarka, milijonarka, modelarka, mrhovinarka, nogavičarka, novinarka, perutninarka, poglavarka, porodničarka, poštarka, pravljičarka, prosvetarka, reakcionarka, redarka, rokavičarka, slaščičarka, starinarka, štacunarka, tehničarka, torbarka, urarka, veterinarka, vizionarka, vražarka, zapisničarka, zavodarka, zeljarka, zgodovinarka, železničarka);

- -(e)r za vršilca iz glagolov na -irati/-iram (17 tvorjenk: debaterka, dreserka, frizerka, kolporterka, manikerka, maserka, maskerka, pedikerka, reporterka, režiserka, saboterka, simpatizerka, suflerka, šifrerka, šoferka, trenerka, volonterka), -ati/-am (samo sprinterka) in opravkarja iz prevzetih podstav (sedem primerov: garderoberka, kantinerka, kostumerka, montažerka, rekorderka, rekviziterka, šansonjerka), lahko tudi pri zloženkah (fotoreporterka); 
- -(ate)r pri vršilcu iz glagolov na -irati/-iram (dve tvorjenki: dekoraterka, operaterka);

- -(i)r pri opravkarju (trije primeri: brigadirka, hotelirka, oštirka);

- -(o)r za vršilca iz glagolov na -irati/-iram (samo kontrolorka) in za opravkarja iz prevzetih podstav (tri tvorjenke: atentatorka, receptorka, senatorka);

- -(ato)r pri vršilcu dejanja iz prevzetih glagolov na -irati/-iram (15 tvorjenk: administratorka, agitatorka, deklamatorka, demonstratorka, diktatorka, ilustratorka, informatorka, interpretatorka, komentatorka, kreatorka, novatorka, organizatorka, preparatorka, propagatorka, recitatorka);

- -(u)r za opravkarja (le nemčurka);

- -(a)š za nosilca lastnosti (en primer feminativa: bogataška);

- -(a)t ob vršilcu iz glagolov na -irati/-iram (dva primera: delegatka, kandidatka) in pri opravkarju (akrobatka, aristokratka, demokratka, diplomatka, literatka, magnatka);

- -(an)t za vršilca iz prevzetih glagolov na -irati/-iram (19 primerov: aspirantka, debitantka, demonstrantka, denunciantka, diplomantka, diskutantka, emigrantka, hospitantka, intrigantka, kalkulantka, koncertantka, manipulantka, maturantka, protestantka, reflektantka, reprezentantka, simulantka, specializantka, šifrantka), -ati/-am (samo prevarantka) ter za opravkarja (pet feminativov: bakhantka, jubilantka, komedijantka, laborantka, trafikantka);

- -(as)t za opravkarja (entuziastka, fantastka);

- -(av)t pri opravkarju iz prevzete podstave (kozmonavtka);

- -(e)t pri opravkarju (asketka, geodetka);

- -(en)t pri vršilcu iz prevzetih glagolskih podstav na -irati/-iram (18 tvorjenk: abonentka, absolventka, abstinentka, agentka, asistentka, dirigentka, docentka, interesentka, konkurentka, korespondentka, pretendentka, recenzentka, referentka, regentka, rekonvalescentka, repetentka, suplentka, študentka) in pri nosilcu (delinkventka, inteligentka); 
- -(ev)t pri opravkarju iz prevzete podstave (farmacevtka, fizioterapevtka, terapevtka);

- -(i)t pri opravkarju (le banditka) in vršilcu iz glagolov na -izirati/-iziram (favoritka);

- $\quad$-(o)t pri opravkarju (patriotka);

- -(is)t za vršilca iz glagolov na -irati/-iram (15 primerov: aktivistka, anestezistka, fakturistka, koloristka, kopistka, onanistka, penzionistka, publicistka, solistka, statistka, stažistka, šahistka, štipendistka, telefonistka, telegrafistka), -izirati/-iziram (16 tvorjenk: anglistka, ekonomistka, feministka, finalistka, germanistka, idealistka, individualistka, kapitalistka, komercialistka, materialistka, moralistka, privatistka, romanistka, slavistka, specialistka, teroristka), za nosilca lastnosti z izglasjem pridevniške podstave (eksternistka, humanistka, internistka, oportunistka; po krnitvi iz pridevnika tudi juristka, realistka in sindikalistka) ter za opravkarja iz domačih in prevzetih podstav (63 primerov: adventistka, akvarelistka, alpinistka, altistka, altruistka, anarhistka, artistka, ateistka, avanturistka, avtomobilistka, baristka, biciklistka, čelistka, čembalistka, defetistka, dentistka, drogeristka, egoistka, esperantistka, fašistka, filatelistka, flavtistka, gimnazistka, harfistka, instrumentalistka, kabaretistka, kokainistka, kolaboracionistka, komunistka, konservatoristka, kontoristka, koristka, marksistka, mezzosopranistka, miniaturistka, monarhistka, mopedistka, morfinistka, nacistka, nihilistka, novelistka, okulistka, optimistka, organistka, pianistka, policistka, pozitivistka, preparandistka, propagandistka, sadistka, saldakontistka, scenaristka, socialistka, sopranistka, stenotipistka, taksistka, teleprinteristka, teleprintistka, traktoristka, turistka, violinistka, zboristka, žurnalistka), nastopi tudi pri sestavljenkah (antifašistka, kontraaltistka, protifašistka) in zloženkah (radiotelegrafistka);

- -o ob izglasju podstave na -c (brucka), -č (tolmačka), -d (bastardka, hibridka, invalidka, tragedka), -j (patricijka, tolovajka), -k ob glasovni premeni (kozačka), -l (kanibalka, kreolka), -n (albinka, beduinka, ciganka, 
faraonka, kapetanka, kapitanka, manekenka, mecenka, muslimanka, poganka, samaritanka, satanka, šampionka, šijonka, tiranka, veteranka), -r (amaterka, avtorka, barbarka, biljeterka, guvernerka, inženirka, juniorka, kurirka, partnerka, pionirka, poenterka, premierka, sekretarka, seniorka, spikerka, želarka), -t (abiturientka, advokatka, atletka, brinetka, despotka, diletantka, diurnistka, estetka, idiotka, interpretka, klientka, mulatka, pacientka, pedantka, pilotka, poetka, protagonistka, renegatka, skavtka), -v (detektivka). Zasledili smo primer, ko se podstava končuje na $-i$ in se nato podaljša $\mathrm{z}-j$ (parvenijka).

Priponsko obrazilo $-k a$ se lahko dodaja tudi zloženkam (čarodejka, dlakocepka, domoljubka, filozofka, knjigovezka, mesojedka, rodoljubka, sladkosnedka, zlodejka). Nekateri feminativi so izpeljani iz samostalniških zloženk s sufiksoidnimi in prefiksoidnimi elementi (npr. agronomka, anatomka, arhitektka, astronomka, bibliografka, daktilografka, ekonomka, fotografka, geografka, kleptomanka, koreografka, kostumografka, nevropatka, psihopatka, scenografka, stenodaktilografka, stenografka).

8. Obrazilo -(ar)ka dodajamo izglasju obrazila na:

- -(i)k za vršilca iz glagolskih podstav na -izirati/-iziram (kritičarka, političarka), za nosilca lastnosti $\mathrm{s}$ pridevniško podstavo na $-n$ (razredničarka) oz. po krnitvi iz pridevnika (akademičarka) ter za opravkarja iz prevzetih podstav (alkoholičarka, higieničarka, kemičarka);

- -o po krnitvi iz pridevnikov (astmatičarka, metodičarka) in pri opravkarju (botaničarka, kozmetičarka).

Izločili smo primere blagajničarka, grafičarka, keramičarka, matematičarka in tehničarka, saj po jezikovnih priročnikih obstajajo moškospolske oblike na -ar, zato gre $\mathrm{v}$ teh primerih za dodajanje feminativnega priponskega obrazila $-k a$. 
9. Priponsko obrazilo -(ev)ka se uporablja pri izglasju obrazila na -(i)č pri nosilcu (samo hudičevka) in pri vršilcu iz glagola na -iti/-im (samo ribičevka) ter pri zloženih podstavah (zlodejevka).

10. Obrazilo -(ov)ka dodajamo izglasjem podstave na -d (židovka), $-k$ (pekovka), -r (mojstrovka) in -t (škratovka).

11. Priponsko obrazilo - $\boldsymbol{n} \boldsymbol{a}$ se dodaja izglasjem obrazila na:

- -(i)č pri vršilcu iz glagolov na -ovati/-ujem (dedična) ter pri opravkarju (bratična, cesarična, gospodična, grofična, kraljična).

12. Tudi priponsko obrazilo -esa se dodaja netvorjenkam (poetesa, princesa, stevardesa).

Sinteza obrazilne produktivnosti - dodajanje k izglasju obrazila

Spodnja preglednica prikazuje, katera feminativna priponska obrazila (in v kolikšni meri) se lahko dodajajo posameznim izglasjem moškospolskih obrazil. 
Preglednica 35: Sinteza obrazilne produktivnosti-dodajalni način (SSKJ 1)

\begin{tabular}{|c|c|c|c|c|c|c|c|c|c|c|c|c|c|}
\hline \multirow{2}{*}{$\begin{array}{c}\text { IZGLASJE } \\
\text { MOŠKEGA } \\
\text { SPOLA }\end{array}$} & \multicolumn{13}{|c|}{ FEMINATIVNA PRIPONSKA OBRAZILA } \\
\hline & $-a$ & $-i c a$ & $-($ ar)ica & $-j a$ & -ulja & -inja & $-k a$ & $-(a r) k a$ & $-(e v) k a$ & $-(o v) k a$ & $-n a$ & -esa & SKUPAJ \\
\hline$-(a) \check{c}$ & 2 & 17 & I & I & I & I & 14 & 1 & 1 & I & I & I & 33 \\
\hline$-(j a) \check{c}$ & l & I & l & l & I & I & 1 & I & l & l & I & / & 1 \\
\hline$-(i) \check{c}$ & I & I & I & I & I & 1 & 5 & / & 2 & I & 6 & I & 13 \\
\hline$-(a n) d$ & I & I & I & I & I & I & 2 & / & / & I & I & I & 2 \\
\hline$-(u) h$ & 2 & I & l & l & l & 8 & 5 & I & I & I & I & 1 & 15 \\
\hline$-(a) j$ & 1 & I & 1 & I & 1 & I & 3 & 1 & 1 & 1 & 1 & 1 & 3 \\
\hline$-(u) j$ & 1 & 1 & 1 & 1 & 1 & I & 1 & 1 & 1 & 1 & 1 & 1 & 1 \\
\hline$-(a) k$ & I & I & I & I & I & 10 & 1 & 1 & 1 & I & I & I & 10 \\
\hline$-(j a) k$ & I & 1 & I & I & 1 & 16 & I & 1 & I & I & I & I & 16 \\
\hline$-(e) k$ & 1 & 1 & 1 & 1 & 1 & 1 & 1 & 1 & 1 & I & I & I & 1 \\
\hline$-(i) k$ & 1 & 1 & 1 & I & I & 1 & I & 7 & 1 & 1 & I & 1 & 8 \\
\hline$-(u) k$ & 1 & 1 & I & I & I & 1 & I & I & I & I & I & I & 2 \\
\hline$-(a t e) l j$ & I & 7 & 1 & 1 & 1 & I & 1 & I & 1 & I & 1 & I & 7 \\
\hline -(ite)lj & I & 35 & I & I & I & I & 1 & 1 & 1 & 1 & I & I & 35 \\
\hline$-(a) l$ & I & 1 & I & I & I & 1 & I & I & I & I & I & I & 1 \\
\hline
\end{tabular}




\begin{tabular}{|c|c|c|c|c|c|c|c|c|c|c|c|c|c|}
\hline \multirow{2}{*}{$\begin{array}{c}\text { IZGLASJE } \\
\text { MOŠKEGA } \\
\text { SPOLA }\end{array}$} & \multicolumn{13}{|c|}{ FEMINATIVNA PRIPONSKA OBRAZILA } \\
\hline & $-a$ & $-i c a$ & -(ar)ica & $-j a$ & $-u l j a$ & -inja & $-k a$ & $-(a r) k a$ & $-(e v) k a$ & $-(o v) k a$ & $-n a$ & $-e s a$ & SKUPAJ \\
\hline$-(e) l$ & 1 & 1 & 1 & 1 & 1 & I & 1 & 1 & 1 & 1 & 1 & 1 & 2 \\
\hline$-(a) n$ & 1 & 1 & 1 & 1 & I & I & 18 & I & 1 & I & I & I & 20 \\
\hline$-(\check{c} a) n$ & I & I & I & I & 1 & I & 5 & I & 1 & I & I & I & 5 \\
\hline$-(j a) n$ & I & 1 & 1 & I & 1 & I & 4 & 1 & 1 & 1 & 1 & I & 5 \\
\hline$-(i j a) n$ & I & 1 & 1 & I & 1 & I & 2 & I & 1 & I & I & I & 2 \\
\hline$-(l j a) n$ & I & 1 & I & I & 1 & 1 & 3 & 1 & 1 & I & 1 & I & 3 \\
\hline$-(m a) n$ & I & I & 1 & I & 1 & I & 2 & I & I & I & I & I & 2 \\
\hline$-(i) n$ & I & 1 & I & 1 & 1 & I & 7 & 1 & 1 & I & 1 & I & 7 \\
\hline$-($ ali $) n$ & I & 1 & I & 1 & 1 & I & 2 & 1 & 1 & I & 1 & 1 & 2 \\
\hline$-($ oli $) n$ & I & I & I & I & 1 & I & 1 & I & I & I & I & I & 1 \\
\hline$-($ ari $) n$ & I & 1 & 1 & I & 1 & I & 1 & 1 & 1 & 1 & I & I & 1 \\
\hline$-(o) n$ & I & 1 & 1 & 1 & 1 & I & 1 & 1 & 1 & I & I & 1 & 1 \\
\hline$-(u) n$ & I & I & I & 1 & I & I & 2 & I & 1 & I & I & I & 3 \\
\hline$-(a) r$ & I & 101 & I & I & I & 1 & 96 & I & I & I & I & I & 198 \\
\hline$-(e) r$ & I & 1 & 1 & 1 & I & I & 26 & 1 & 1 & 1 & 1 & I & 26 \\
\hline$-($ ate $) r$ & I & 1 & 1 & 1 & 1 & 1 & 2 & 1 & 1 & 1 & 1 & 1 & 2 \\
\hline$-(i) r$ & I & 1 & I & I & 1 & I & 3 & 1 & 1 & I & I & I & 4 \\
\hline
\end{tabular}




\begin{tabular}{|c|c|c|c|c|c|c|c|c|c|c|c|c|c|}
\hline \multirow{2}{*}{$\begin{array}{c}\text { IZGLASJE } \\
\text { MOŠKEGA } \\
\text { SPOLA }\end{array}$} & \multicolumn{13}{|c|}{ FEMINATIVNA PRIPONSKA OBRAZILA } \\
\hline & $-a$ & $-i c a$ & $-($ ar)ica & $-j a$ & - ulja & -inja & $-k a$ & $-(a r) k a$ & $-(e v) k a$ & $-(o v) k a$ & $-n a$ & $-e s a$ & SKUPAJ \\
\hline$-(o) r$ & 1 & 8 & 1 & 1 & l & 1 & 4 & 1 & 1 & 1 & 1 & 1 & 12 \\
\hline$-(a t o) r$ & I & 4 & I & I & I & I & 15 & I & I & I & I & I & 19 \\
\hline$-(u) r$ & I & 1 & 1 & 1 & 1 & 1 & 1 & 1 & 1 & 1 & 1 & 1 & 1 \\
\hline$-(a) \check{s}$ & I & 2 & I & / & I & 5 & 1 & / & 1 & / & I & / & 8 \\
\hline$-(a) t$ & I & I & / & I & I & 2 & 8 & I & / & / & l & l & 10 \\
\hline$-(a n) t$ & 1 & 1 & I & I & I & 1 & 25 & l & 1 & 1 & 1 & I & 26 \\
\hline$-(a s) t$ & I & 1 & 1 & I & I & I & 2 & / & 1 & 1 & 1 & 1 & 2 \\
\hline$-(a v) t$ & 1 & 1 & 1 & 1 & l & 1 & 1 & 1 & 7 & 1 & 1 & 1 & 1 \\
\hline$-(e) t$ & 1 & 1 & 1 & 1 & I & 1 & 2 & 1 & 1 & 1 & 1 & 1 & 3 \\
\hline$-(e n) t$ & 1 & 1 & 1 & I & 1 & 2 & 20 & 1 & 1 & 1 & I & 1 & 22 \\
\hline$-(e v) t$ & 1 & 1 & 1 & 1 & 1 & I & 3 & 1 & 1 & 1 & 1 & 1 & 3 \\
\hline$-(i) t$ & 1 & 1 & 1 & 1 & 1 & I & 2 & 1 & 1 & 1 & 1 & 1 & 2 \\
\hline$-(o) t$ & 1 & 1 & 1 & I & 1 & 1 & 1 & 1 & 1 & 1 & 1 & 1 & 2 \\
\hline$-(i s) t$ & 1 & 1 & 1 & 1 & 1 & 3 & 105 & 1 & 1 & 1 & 1 & I & 108 \\
\hline$-\theta$ & 5 & 30 & 1 & 1 & 2 & 54 & 90 & 4 & 1 & 4 & 1 & 3 & 195 \\
\hline SKUPAJ & 12 & 206 & 1 & 3 & 2 & 108 & 487 & 11 & 3 & 4 & 6 & 3 & 846 \\
\hline
\end{tabular}


Analiza je pokazala, da so izglasja moškospolskih priponskih obrazil, ki se jim feminativna obrazila dodajajo, naslednja:

- K izglasju na -(a)̌̌ se lahko dodajo feminativna obrazila - $a$, ki nastopa pri vršilcu iz glagolov na -iti/-im, potrjeno z dvema primeroma (npr. gostača), -ica, ki prav tako nastopi pri vršilcu iz glagolskih podstav na -iti/-im, a potrjeno z nekaj več, tj. tremi tvorjenkami (npr. belačica), tudi iz podstav na -ati/-am, kar potrjuje deset feminativov, denimo plavačica, in iz -ati/-em, za kar smo zasledili dva primera (npr. skakačica) - skupno torej 15 primerov; nastopi lahko tudi pri opravkarju (dva primera, npr. tenisačica), in -ka, ki kaže zelo podobno sliko: dodajamo ga pri vršilcu iz glagolskih podstav na -ati/-am (osem tvorjenk, med njimi bahačka), -iti/-im (trije feminativi, npr. brusačka), -ati/-im in -ati/-em (pri obojem po en primer: kričačka in mazačka) - skupno torej 13 feminativov -, dodajamo ga tudi opravkarju $\mathrm{z}$ izglasjem podstave na $-k$ (en primer: brkačka).

- Samo priponsko obrazilo - $k a$ nastopa kot dodajalno k izglasju na -(ja) $\check{c}$, in to zgolj pri vršilcu iz glagola na -iti/-im (en feminativ: gonjačka).

- K izglasju moškospolskega samostalnika na -(i)̌̌ dodajamo priponska obrazila -ka (dva primera pri vršilcu iz glagola na -iti/-im, npr. ribička, ter eden pri -eti/-im mrlička, dva primera pri nosilcu, npr. mladička), -(ev)ka (en primer pri nosilcu in eden pri vršilcu: hudičevka in ribičevka) in -na (en primer pri vršilcu iz glagola na -ovati/-ujem dedična in pet primerov pri opravkarju, npr. grofična).

- Priponsko obrazilo - $k a$ je edino produktivno pri tvorbi iz moškospolskih poimenovanj oseb z izglasjem na -(an)d, kar potrjujeta dva primera iz pomenske skupine vršilec, tvorjena iz glagolov na -irati/-iram (npr. doktorandka).

- $\mathrm{K}-(\boldsymbol{u}) \boldsymbol{h}$ kot dodajalna nastopajo tri priponska obrazila: - a pri vršilcu iz glagola na -eti/-im (samo en primer smrduha) ali pri nosilcu z izglasjem podstave na -l (en primer debeluha); -inja $\mathrm{k}$ vršilcu iz zelo raznolikih glagolskih podstav (skupno šest primerov, npr. ovaduhinja), nastopi lahko tudi pri nosilcu iz podstave na $-l$ oz. $-n$ (po en primer: debeluhinja in 
lenuhinja); - $k a$ se dodaja $\mathrm{k}$ vršilcu iz glagolov na -ati/-am (en primer: potepuška) in $\mathrm{k}$ nosilcu $\mathrm{z}$ izglasjem podstave na -l (debeluška), -n (lenuška) in -r (staruška).

- Le feminativno priponsko obrazilo - $k a$ se dodaja k izglasju na -(a)j, in to pri vršilcu iz glagolov na -ati/-am čuvajka, -čil-em strežajka, -iti/-im točajka, vse potrjeno s po enim primerom. Obrazilo - $k a$ je tudi edino, ki nastopi kot dodajalno $\mathrm{k}$ izglasju na $-(\boldsymbol{u}) \boldsymbol{j}$, in to le pri enem primeru za opravkarja (buržujka).

- K izglasju na -(a)k se dodaja samo priponsko obrazilo -inja, in to v dveh pomenskih skupinah (po pet primerov za nosilca in opravkarja, npr. bedakinja in rojakinja).

- Tudi izglasju na -(ja)k lahko dodajamo le feminativno obrazilo -inja, in to $\mathrm{v}$ pomenski skupini nosilec, kadar se podstavni pridevnik konča na - $n$ (štirinajst feminativov, npr. odličnjakinja) ali $-l$ (en feminativ: veseljakinja), ter pri opravkarju (en primer: korenjakinja).

- Podobno velja za izglasje na -(e)k, pri katerem je možna le tvorba z obrazilom -inja, potrjeno z enim primerom za nosilca (prišlekinja).

- Obrazilo, ki se dodaja k izglasju moškospolskega obrazila na -(i)k, je -(ar)ka, in sicer $\mathrm{v}$ pomenskih skupinah nosilec (dva feminativa, npr. razredničarka), vršilec (dva primera, denimo političarka) in opravkar (trije feminativi, npr. alkoholičarka). Zasledili smo tudi primer s feminativnim obrazilom -inja v pomenski skupini nosilec (akademikinja).

- K izglasju na $-(\boldsymbol{u}) \boldsymbol{k}$ se lahko dodajata samo priponski obrazili -inja in -a, kar potrjuje po en primer $\mathrm{v}$ pomenski skupini opravkar oz. nosilec (hajdukinja in prismuka).

- Feminativno priponsko obrazilo -ica je edino, ki se dodaja izglasjem na -(ate)lj (samo en primer za vršilca dejanja iz glagolov na -ati/-em pisateljica in šest primerov iz -ati/-am, npr. predavateljica) in -(ite)lj (30 feminativov iz glagolov na -iti/-im, denimo graditeljica, dva iz -C-ti/-em, npr. najditeljica, in en primer za opravkarja pokroviteljica, tudi pri zloženi in sestavljeni podstavi: prvoboriteljica in soustanoviteljica). 
- Feminativno priponsko obrazilo -inja je edino, ki kot dodajalno nastopa $\mathrm{k}$ izglasju na $-(\boldsymbol{a}) \boldsymbol{l}$, kar potrjuje zgolj en primer v pomenski skupini vršilec (rivalinja).

- Priponski obrazili $-a$ in $-k a$ se dodajata $\mathrm{k}$ izglasju na $-(\boldsymbol{e}) \boldsymbol{l}$ : prvo le pri vršilcu iz glagolske podstave na -eti/-im (en primer zaletela), drugo pa v pomenski skupini opravkar (en feminativ modelka).

- $\mathrm{K}$ izglasju na -(a)n se lahko dodaja priponsko obrazilo -ja, in to $\mathrm{v}$ pomenski skupini opravkar (samo en primer županja), tudi - $a$ pri opravkarju (en primer glavana), veliko pogosteje pa gre za tvorbo s feminativnim obrazilom $-k a$, prav tako $\mathrm{v}$ pomenski skupini opravkar (sedemnajst primerov, npr. faranka), a tudi pri nosilcu (sicer zgolj en feminativ: velikanka).

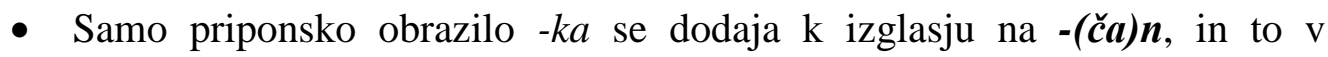
pomenski skupini opravkar (trije primeri, npr. nebeščanka), a tudi $\mathrm{k}$ sestavljeni (sovaščanka) ali zloženi podstavi (malomeščanka).

- K izglasju na -(ja)n kot dodajalni nastopata obrazili -ica (samo en primer za pomensko skupino opravkar: $d$ vorjanica) in $-k a$ (štirje primeri pri opravkarju, npr. dvorjanka).

- Pri opravkarju pa je priponsko obrazilo - $k a$ dodajalno k izglasjem na -(ija)n (en primer: cistercijanka; eden tudi pri nosilcu: modrijanka), -(lja)n (trije primeri, npr. župljanka) in -(ma)n (dva feminativa, npr. hlačmanka).

- Samo priponsko obrazilo - $k a$ nastopa kot dodajalno k izglasju na -(i)n, in to $\mathrm{v}$ vseh treh pomenskih skupinah (po trije primeri za vršilca in nosilca ter eden za opravkarja, denimo potepinka, bogatinka, capinka).

- Podobno velja za izglasja na -(ali)n (pobalinka), -(oli)n (smrkolinka), -(ari)n (vojarinka) in -(o)n (potegonka), kjer prav tako nastopa le obrazilo $-k a$, potrjeno $\mathrm{z}$ enim primerom opravkarja in enim vršilcem za prvo izglasje ter s po enim primerom vršilca za preostala tri izglasja.

- Dve feminativni priponski obrazili se lahko dodajata k izglasju na -(u)n, to sta -ja (samo en primer v pomenski skupini vršilec, in to iz glagola na -ovati/-ujem pestunja) in -ka (po en primer v pomenskih skupinah vršilec slednje iz glagola na -ati/-am vohunka - in nosilec grdunka). 
- Zelo pogosto gre za dodajanje feminativnih obrazil k izglasju -(a)r; kot taka nastopijo naslednja obrazila: -ica $\mathrm{v}$ pomenskih skupinah vršilec (iz glagolov na -ati/-am 20 tvorjenk, npr. citrarica, iz glagolov na -ariti/-arim 24 primerov, npr. cunjarica) in opravkar (53 feminativov, npr. abecedarica) ter pri zloženi in sestavljeni osnovi (samovladarica; sovladarica); -inja nastopi le z enim primerom pri opravkarju (bojarinja), -ka pa se pojavlja pri vršilcu (iz glagolov na -ati/-am 14 primerov, npr. čuvarka, -ati/-em dva primera, npr. risarka, -ariti/-arim 17 tvorjenk, denimo dninarka, iz -irati/-iram trije in -iti/-im en feminativ: arhivarka; stražarka), nosilcu (le en primer: desetarka) in opravkarju (58 tvorjenk, med njimi tudi kočarka).

- $\mathrm{K}$ izglasjema na -(e)r in -(ate)r dodajamo le obrazilo $-k a$ : $\mathrm{k}-(e) r$ pri vršilcu iz glagolov na -irati/-iram (sedemnajst tvorjenk, npr. debaterka) ali -ati/-am (en primer: sprinterka) ter pri opravkarju (sedem feminativov, denimo kantinerka), k izglasju na -(ate)r pa pri vršilcu iz glagolov na -irati-iram (dva primera, npr. dekoraterka).

- $\mathrm{K}$ moškospolskemu poimenovanju osebe z izglasjem na -(i)r se dodajata feminativni priponski obrazili -ica (v pomenski skupini vršilec - en primer pastirica) in -ka (v pomenski skupini opravkar trije primeri, npr. oštirka).

- Priponski obrazili -ica in -ka kot dodajalni nastopata tudi pri izglasju na -(o)r: prva samo v pomenski skupini opravkar ob tvorbi iz prevzetih podstav, kar potrjuje osem tvorjenk (npr. lektorica), in druga pri vršilcu (le en primer: kontrolorka) in opravkarju (trije feminativi, npr. senatorka).

- V pomenski skupini vršilec pa nastopajo feminativi, tvorjeni z dodajanjem priponskih obrazil k moškospolskemu poimenovanju osebe $\mathrm{z}$ izglasjem na -(ato)r: taki sta feminativni obrazili -ica (štiri tvorjenke, npr. propagatorica) in -ka (15 tvorjenk, npr. agitatorka), pri čemer gre v vseh primerih za tvorbo iz glagolskih podstav na -irati/-iram.

- Zgolj obrazilo $-k a$ se dodaja $\mathrm{k}$ izglasju na $-(\boldsymbol{u}) \boldsymbol{r}$; to potrjuje samo en feminativ iz pomenske skupine opravkar (nemčurka).

- K izglasju na -(a)̌̌ dodajamo feminativna priponska obrazila -ica (dva primera v pomenski skupini opravkar, npr. kolašica), -inja (en primer v 
pomenski skupini opravkar mejašinja, trije feminativi pri nosilcu, npr. bogatašinja, in eden pri vršilcu: pristašinja) in -ka (en primer za nosilca: bogataška).

- Obrazili -inja in - $k a$ sta edini, ki kot dodajalni nastopata k izglasju na -(a)t, in to $\mathrm{v}$ pomenskih skupinah vršilec (en primer $\mathrm{z}$-inja kandidatinja, dva $\mathrm{s}$ -ka, npr. kandidatka; zmeraj iz glagolov na -irati/-iram) in opravkar (šest primerov s -ka, denimo aristokratka, eden z -inja: aristokratinja).

- K izglasjem moškospolskega poimenovanja osebe na -(e)t, -(en)t in -(an)t se dodajata samo feminativni obrazili - $k a$ in -inja: $\mathrm{k}$ prvemu le v pomenski skupini opravkar (en primer z -inja katehetinja, dva s -ka asketka), k drugemu pri nosilcu (dva primera s $-k a$, npr. inteligentka) in vršilcu (dva primera $\mathrm{z}$-inja, npr. agentinja, $18 \mathrm{~s}-k a$, npr. abonentka), $\mathrm{k}$ tretjemu pa pri opravkarju (en feminativ z -inja bakhantinja, pet s -ka, denimo jubilantka) in vršilcu (19 primerov s -ka, npr. diplomantka).

- Feminativni obrazili -inja in $-k a$ se lahko dodajata $\mathrm{k}$ izglasju moškospolskega poimenovanja osebe na -(o)t, in to le v pomenski skupini opravkar (po en primer: patriotinja in patriotka).

- Nekoliko več primerov nastaja $\mathrm{z}$ dodajanjem feminativnih obrazil $\mathrm{k}$ izglasju na -(is)t. Taki sta obrazili -inja (sicer zgolj trije primeri za opravkarja, med njimi baptistinja) in -ka (skupno kar 105 tvorjenk, med temi $31 \mathrm{v}$ pomenski skupini vršilec, in to iz glagolov na -irati/-iram (aktivistka) oz. -izirati/-iziram (idealistka), sedem primerov je iz pomenske skupine nosilec, vsi iz pridevniških podstav na $-n$ (npr. eksternistka), in 64 primerov iz skupine opravkar (denimo scenaristka); nastopi tudi pri zloženi (radiotelegrafistka) ali sestavljeni podstavi (antifašistka).

- K izglasjem tvorjenk na $-(\boldsymbol{a s}) \boldsymbol{t},-(\boldsymbol{a v}) \boldsymbol{t}, \mathbf{- ( e v ) t}$ in $-(\boldsymbol{i}) \boldsymbol{t}$ pa nastopi le obrazilo $-k a$, kar potrjujejo primeri v pomenski skupini opravkar (le eden za -(i)t pri vršilcu: fantastka, kozmonavtka, farmacevtka, favoritka).

Ugotavljamo, da sta priponski obrazili -ica in $-k a \mathrm{~s}$ primeri dokaj enakovredno zastopani pri izglasjih obrazil na - č (skupno 47 feminativov; z -ica 
17 primerov ali $36 \%$, s $-k a$ pa 20 primerov ali 42,5\%; pri tem se samo - $k a$ dodaja $\mathrm{k}$ izglasjem na $-(j a) \check{c}$ in $-(i) \grave{c})$. Pri izglasjih na $-k$ prevladuje tvorjenje feminativov z -inja (29 tvorjenk od 37 oz. $78 \%$ ), k izglasjem na -lj pa se dodaja samo -ica (vseh 42 primerov). K izglasjem na $-n$ prevladuje dodajanje feminativnega obrazila $-k a$ (48 primerov od 52, tj. $92 \%$, le eden z -ica). Kadar se moškospolska poimenovanja oseb končajo na izglasje $-r$, gre pri tvorbi feminativov pogosto za dodajanje ženskospolskih priponskih obrazil -ka (147 primerov od skupno $262 \mathrm{oz}$. $56 \%$ ) in -ica (114 primerov ali $43 \%)$; pri tem se k izglasjem na -(e)r, -(ate)r in -(u)r dodaja samo - $k a$. Če pa gre za izglasje na -t, prevladuje dodajanje obrazila -ka (169 primerov od 179, torej $94 \%$, samo deset tvorjenk z -inja). Ugotavljamo torej, da $-k a$ prednjači pri dodajanju k izglasjem obrazil na $-n,-r$ in $-t$, obrazilo -inja pri obrazilnih izglasjih na $-k$, -ica pa pri izglasjih obrazil na $-l j$.

\section{Sinteza obrazilne produktivnosti - dodajanje k izglasju podstave}

Spodnja preglednica prikazuje, katera feminativna priponska obrazila (in v kolikšni meri) se lahko dodajajo posameznim izglasjem podstav. Vključena je tvorba iz netvorjenk ter iz nekaterih zloženih in sestavljenih podstav. 
Preglednica 36: Sinteza obrazilne produktivnosti-dodajalni način k izglasju podstave (SSKJ 1)

\begin{tabular}{|c|c|c|c|c|c|c|c|c|c|c|c|c|c|}
\hline \multirow{2}{*}{$\begin{array}{l}\text { IZGLASJE } \\
\text { PODSTAVE }\end{array}$} & \multicolumn{13}{|c|}{ FEMINATIVNA PRIPONSKA OBRAZILA } \\
\hline & $-a$ & $-i c a$ & $-(a r) i c a$ & $-j a$ & $-u l j a$ & $-i n j a$ & $-k a$ & $-(a r) k a$ & $-(e v) k a$ & $-(o v) k a$ & $-n a$ & -esa & SKUPAJ \\
\hline$-b$ & I & 7 & 1 & 1 & 1 & 1 & 2 & 1 & 1 & 1 & 1 & 1 & 3 \\
\hline$-c$ & 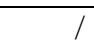 & 1 & 1 & 1 & 1 & 1 & 1 & 1 & 1 & 1 & 1 & 1 & 3 \\
\hline$-\check{c}$ & 1 & 2 & 1 & 1 & 1 & 1 & 1 & 1 & 1 & 1 & 1 & I & 3 \\
\hline$-d$ & 1 & 1 & 1 & 1 & 1 & 7 & 6 & 1 & 1 & 1 & 1 & 1 & 16 \\
\hline$-f$ & 1 & 3 & 1 & 1 & 1 & 6 & 10 & 1 & 1 & 1 & 1 & I & 19 \\
\hline$-g$ & I & 3 & I & I & 1 & 17 & 1 & I & 1 & I & I & 1 & 21 \\
\hline$-h$ & 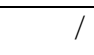 & 1 & $/$ & 1 & l & 1 & l & 1 & 1 & 1 & l & 1 & 1 \\
\hline$-j$ & I & 1 & 1 & I & 1 & 1 & 5 & 1 & 1 & 1 & 1 & I & 7 \\
\hline$-l j$ & 1 & 1 & 1 & 1 & I & 1 & 1 & 1 & 1 & 1 & 1 & 1 & 1 \\
\hline$-n j$ & 1 & 1 & 1 & I & 1 & 1 & 1 & 1 & 1 & 1 & I & I & 1 \\
\hline$-k$ & 1 & 1 & 1 & I & 1 & 11 & 1 & 4 & 1 & 1 & I & 1 & 18 \\
\hline$-l$ & 1 & 1 & 1 & 1 & 1 & 1 & 2 & 1 & I & 1 & 1 & 1 & 2 \\
\hline$-m$ & 1 & 1 & 1 & 1 & 1 & 1 & 4 & 1 & 1 & 1 & 1 & 1 & 4 \\
\hline$-n$ & I & 3 & 1 & 1 & 1 & 1 & 16 & 1 & 1 & 1 & 1 & 1 & 19 \\
\hline
\end{tabular}




\begin{tabular}{|c|c|c|c|c|c|c|c|c|c|c|c|c|c|}
\hline \multirow{2}{*}{$\begin{array}{l}\text { IZGLASJE } \\
\text { PODSTAVE }\end{array}$} & \multicolumn{13}{|c|}{ FEMINATIVNA PRIPONSKA OBRAZILA } \\
\hline & $-a$ & $-i c a$ & $-(a r) i c a$ & $-j a$ & -ulja & -inja & $-k a$ & $-(a r) k a$ & $-(e v) k a$ & $-(o v) k a$ & $-n a$ & $-e s a$ & SKUPAJ \\
\hline$-p$ & 1 & 1 & 1 & I & I & 1 & 1 & I & I & 1 & l & I & 3 \\
\hline$-r$ & 2 & 10 & I & I & 1 & 2 & 16 & 1 & l & 1 & l & I & 31 \\
\hline$-s$ & I & I & 1 & 1 & 1 & 1 & 1 & 1 & 1 & 1 & 1 & 1 & 1 \\
\hline$-\check{s}$ & 1 & 2 & 1 & 1 & 1 & 1 & 1 & 1 & 1 & 1 & 1 & 1 & 2 \\
\hline$-t$ & 1 & 5 & 1 & 1 & 1 & 6 & 23 & 1 & 1 & 1 & 1 & 1 & 37 \\
\hline$-v$ & 1 & 1 & l & I & I & 1 & 1 & l & I & I & l & I & 1 \\
\hline$-z$ & I & l & l & I & 1 & 1 & 1 & l & 1 & 1 & l & I & 2 \\
\hline SKUPAJ & 5 & 30 & $\mathbf{1}$ & 1 & 2 & 54 & 90 & 4 & 1 & 4 & I & 3 & 195 \\
\hline
\end{tabular}


Nekaj obravnavanih feminativnih priponskih obrazil se lahko dodaja tudi k izglasju podstave na:

- $\quad-b$ (dva feminativa s - $k a$ pri tvorbi iz zložene podstave, npr. domoljubka; en primer z -inja iz netvorjene podstave: robinja);

- $\quad-c$ (en primer z obrazilom -ka brucka, po eden tudi z -ulja in -esa: bruculja in princesa; pri vseh naštetih feminativnih obrazilih gre za dodajanje $\mathrm{k}$ netvorjeni podstavi);

- $\quad-\check{c}$ (dva primera z -ica, npr. tolmačica, en feminativ s -ka tolmačka, oboje pri netvorjeni podstavi);

- -d (dva primera s -ka iz zložene podstave, npr. mesojedka; ob sestavljeni podstavi en primer $\mathrm{z}-a$ soseda, ob netvorjenih podstavah pa sedem feminativov z -inja, npr. judinja, štirje primeri s -ka, denimo hibridka, en primer z obrazilom -(ov)ka židovka, eden tudi z -esa stevardesa);

- $\quad f$ (trije primeri z -inja, npr. šefinja, deset primerov s -ka, npr. fotografka; pri vseh gre za sestavino - graf ob tvorbi iz zložene podstave; pri netvorjeni podstavi pa trije primeri z -ica, npr. grofica, trije z -inja, denimo grofinja);

- $\quad-g$ (14 konkretnih primerov z -inja; pri vseh gre za sestavino -log in za tvorbo iz zložene podstave, npr. geologinja; tudi trije feminativi z -ica, npr. vražica, trije z -inja, npr. boginja, eden z -ulja vragulja iz netvorjenih podstav);

- $\quad \boldsymbol{h}$ (en primer tvorbe $\mathrm{z}$-inja, in to iz netvorjene podstave: monarhinja);

- $\quad-j$ (dva feminativa s $-k a$, npr. zlodejka, en primer z -(ev)ka zlodejevka iz zložene podstave; iz netvorjene podstave pa en primer z -inja herojinja, trije s-ka, npr. tolovajka);

- $\quad-l j$ (en feminativ z -ica iz netvorjene podstave: kraljica);

- $\quad-\boldsymbol{n j}$ (en feminativ z - $a$ ob netvorjeni podstavi: sužnja);

- $\quad \boldsymbol{k}$ (en feminativ z -inja pri tvorbi iz zložene podstave: samoukinja; iz netvorjenih podstav pa devet primerov z -inja, npr. uskokinja, po en feminativ s -ka in -(ov)ka (kozačka, pekovka), en primer z -(ar)ica (matematikarica); en feminativ z -inja pri tvorbi iz sestavljene podstave: pravnukinja, štirje feminativi z -(ar)ka, pri čemer pride do glasovne premene $-k \mathrm{v}-\check{c}$, npr. botaničarka); 
- $\quad-l$ (dva konkretna primera s -ka iz netvorjene podstave, npr. kreolka);

- $\quad-\boldsymbol{m}$ (štirje primeri tvorbe s -ka, npr. agronomka);

- $-\boldsymbol{n}$ (pri netvorjenih podstavah trije feminativi $\mathrm{z}$-ica, npr. ciganica, 16 primerov z obrazilom -ka, denimo albinka);

- $\quad-\boldsymbol{p}$ (en primer s -ka iz zložene podstave, npr. dlakocepka; en primer tvorbe $\mathrm{z}-a$ in en primer $\mathrm{z}-i c a$, oboje iz netvorjenih podstav: trapa, trapica);

- $\quad-r$ (dva primera z -inja ob tvorbi iz zložene podstave, npr. pediatrinja; iz netvorjenih podstav dva feminativa $\mathrm{z}-a$, npr. botra, deset $\mathrm{z}-i c a$, npr. carica, 16 primerov s -ka, npr. kurirka, eden z -(ov)ka mojstrovka);

- $\quad$-s (iz netvorjene podstave en feminativ z -inja: kustosinja);

- $\quad-\check{s}$ (dva primera z -ica ob netvorjeni podstavi, npr. pajdašica);

- - $\boldsymbol{t}$ (en primer z -inja psihopatinja, dva primera s -ka nevropatka; pri obeh gre za tvorbo iz zložene podstave; iz netvorjenih podstav pa pet feminativov z -ica, npr. kmetica, prav tako pet z -inja, npr. opatinja, en primer $\mathrm{z}$-ja gostja, 20 feminativov s priponskim obrazilom $-k a$, denimo atletka, po eden z -(ov)ka in -esa: škratovka, poetesa);

- $\quad-\boldsymbol{v}$ (en primer tvorbe s $-k a$, in to iz netvorjene podstave: detektivka);

- $-z$ (en feminativ s -ka iz zložene podstave knjigovezka, en primer z -inja iz netvorjene podstave: virtuozinja).

Pri 195 primerih se feminativna priponska obrazila dodajajo k izglasjem netvorjenih, sestavljenih ali zloženih podstav (kar je 22,5\% vseh primerov, ki nastanejo z dodajalnim načinom tvorbe). Med njimi jih je največ, to je 90 (oz. 47 $\%$ ), tvorjenih z obrazilom -ka, 54 (ali $28 \%$ ) z obrazilom -inja, 30 (16\%) s priponskim obrazilom -ica, pet (3\%) z -a, po štirje (2\%) z - (ov)ka in -(ar)ka, trije $\mathrm{z}-e s a$, dva z -ulja in po eden z -(ev)ka, -(ar)ica in -ja.

\subsubsection{Novejša slovenska leksika}

Leksikalna zbirka Novejša slovenska leksika $v$ povezavi s spletnimi jezikovnimi viri je nastala kot rezultat projektne raziskave Inštituta za slovenski jezik Frana Ramovša ZRC SAZU (2009). Zajeta je leksika, ki se je v slovenščini 
pojavila oziroma uveljavila v obdobju približno zadnjih tridesetih let in še ni bila obravnavana v SSKJ 1. Leksikogramski seznam obsega od A do Ž po vertikalnem in horizontalnem zaporedju razporejenih okrog 15.900 enot, od tega 7600 enobesednih leksemov (Stramljič Breznik 2010: 16-17). S seznama je bilo izpisanih 243 feminativov. Nekatere besede so zapisane na dva načina, na primer pankerica in punkerica. Take primere besed smo šteli le enkrat, navedli pa smo obe možnosti. Največ feminativov, kar 113 (46,5 \%), je nastalo s priponskim obrazilom -ka, $75(31 \%) \mathrm{z}$ obrazilom -ica, 35 (ali $14 \%) \mathrm{z}$-inja, $13(5 \%) \mathrm{z}$ -(ar)ka, po dva primera sta bila najdena za priponski obrazili - $a$ in -ja (vsako 0,8 $\%$ ), po en primer pa za obrazila -esa, -ca in -(ov)ka (vsako 0,4\%). Med izpisanimi tvorjenkami jih je 167 (69 \%) nastalo $\mathrm{z}$ dodajalnimi, 76 (31\%) pa $\mathrm{z}$ zamenjevalnimi obrazili.

Grafikon 10: Feminativi glede na način tvorbe v Novejši slovenski leksiki

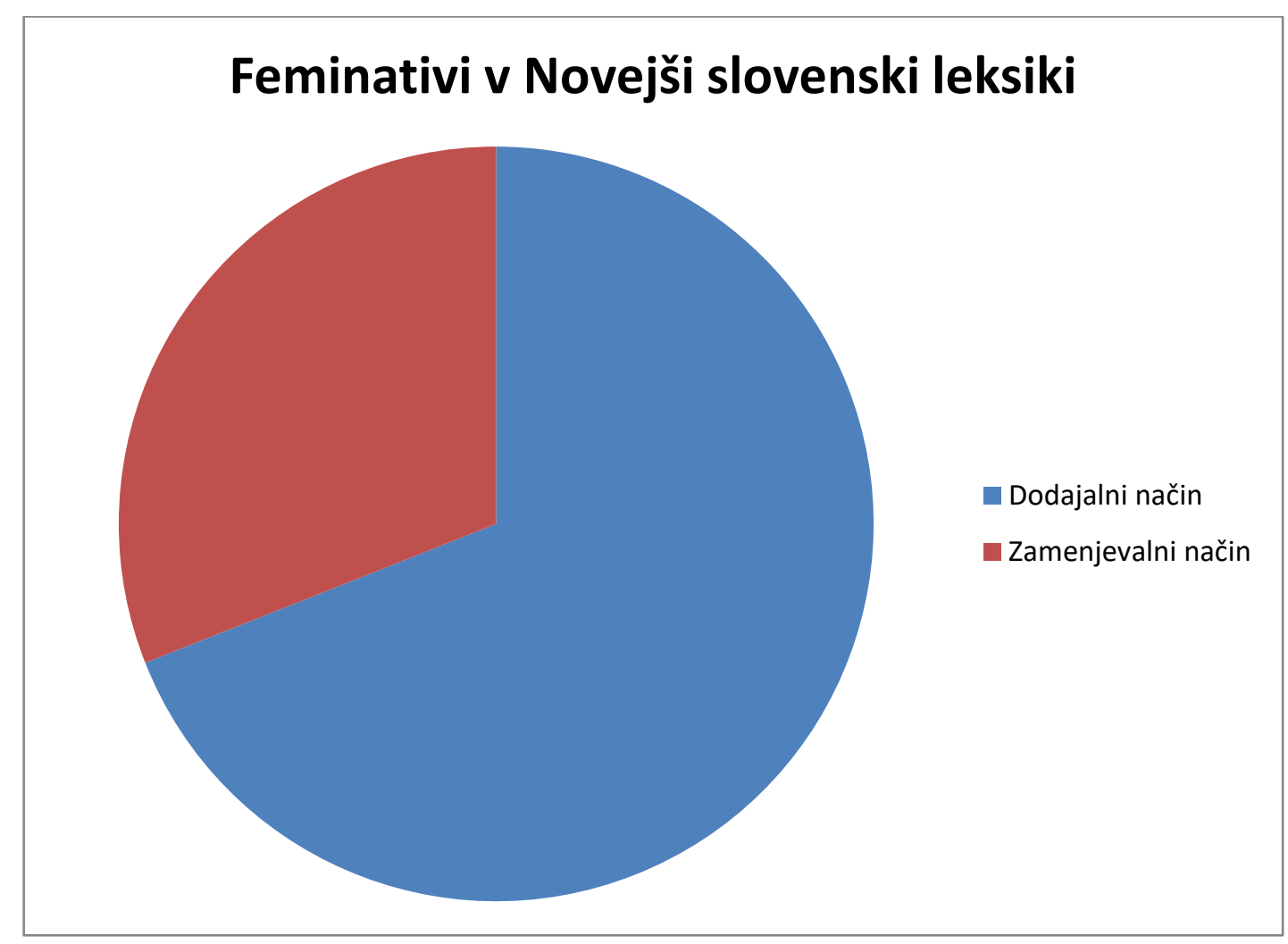

Če primerjamo zastopanost feminativnih priponskih obrazil s Slovensko slovnico (2004), opažamo, da se v Novejši slovenski leksiki pojavijo primeri 
tvorjenk z -(ar)ka, -ca in -esa, ki jih po $S S$ ne zasledimo. Navedena obrazila nastopijo le kot dodajalna.

Preglednica 37: Primerjalni pregled feminativnih priponskih obrazil (SS in NSL)

\begin{tabular}{|c|c|}
\hline Slovenska slovnica (2004) & Novejša slovenska leksika \\
\hline$-a$ & $-a$ \\
\hline$-i c a$ & $-i c a$ \\
\hline$-j a$ & $-j a$ \\
\hline$-u l j a$ & $-i n j a$ \\
\hline$-i n j a$ & $-k a$ \\
\hline$-k a$ & $-(a r) k a$ \\
\hline$-o v k a$ & $-(o v) k a$ \\
\hline$-i c ̌ n a$ & $-e s a$ \\
\hline & $-c a$ \\
\hline
\end{tabular}

7.1.2.1 Feminativi, nastali $\mathrm{z}$ dodajanjem ženskospolskega obrazila tvorjenkam moškega spola

Razvrstimo jih glede na to, s katerimi tipičnimi izglasji moških obrazil se družijo. V analizo je bilo vključenih 167 tvorjenk, nastalih z dodajalnimi obrazili $-a,-c a,-i c a,-j a,-i n j a,-k a,-(a r) k a,-(o v) k a$ in -esa. Od tega jih je 82 (49\%) tvorjenih s priponskim obrazilom $-k a, 35(21 \%) \mathrm{s}$ feminativnim obrazilom -inja, $30(18 \%)$ z obrazilom -ica, $13(7 \%)$ z - (ar)ka, obrazili - $a$ in -ja sta zastopani s po dvema primeroma (vsako $1,2 \%)$ ter -esa, - ca in $-($ ov $) k a$ s po enim $(0,6 \%) .{ }^{84}$

${ }^{84}$ Opažamo, da je v NSL skupno 54 feminativov, tvorjenih z dodajalnim načinom, ki jih $\mathrm{v}$ kasnejšem SSKJ 2 ni. To so anketarica, arbitrica, blogarica, blogerica, člankarica, grafitarica, knjigarnarica, komentatorica, prekrškarica, troskokašica (deset feminativov z -ica); alergologinja, algologinja, antikologinja, arhitektinja, asinja, bibliografinja, biografinja, biotehnologinja, cinikinja, fanatikinja, generalinja, geriatrinja, klasikinja, laikinja, mišičnjakinja, nomadinja (16 primerov z -inja); akupunkturistka, atlanticistka, azilantka, bejbisiterka, biblicistka, bombarderka, bordarka, bulimistka, cineastka, džezistka, genijka, globalistka, golmanka, hipijka, homeopatka, pankerka, psičarka, recesionistka, sponzorka, šminkerka, šopingerka, telebanka, videoartistka, zobarka (24 feminativov s -ka); fanatičarka, genetičarka, nevrotičarka (trije primeri $\mathrm{z}-(a r) k a)$; picopekovka (en primer z -(ov)ka). 
Grafikon 11: Dodajalna feminativna priponska obrazila $v$ Novejši slovenski leksiki

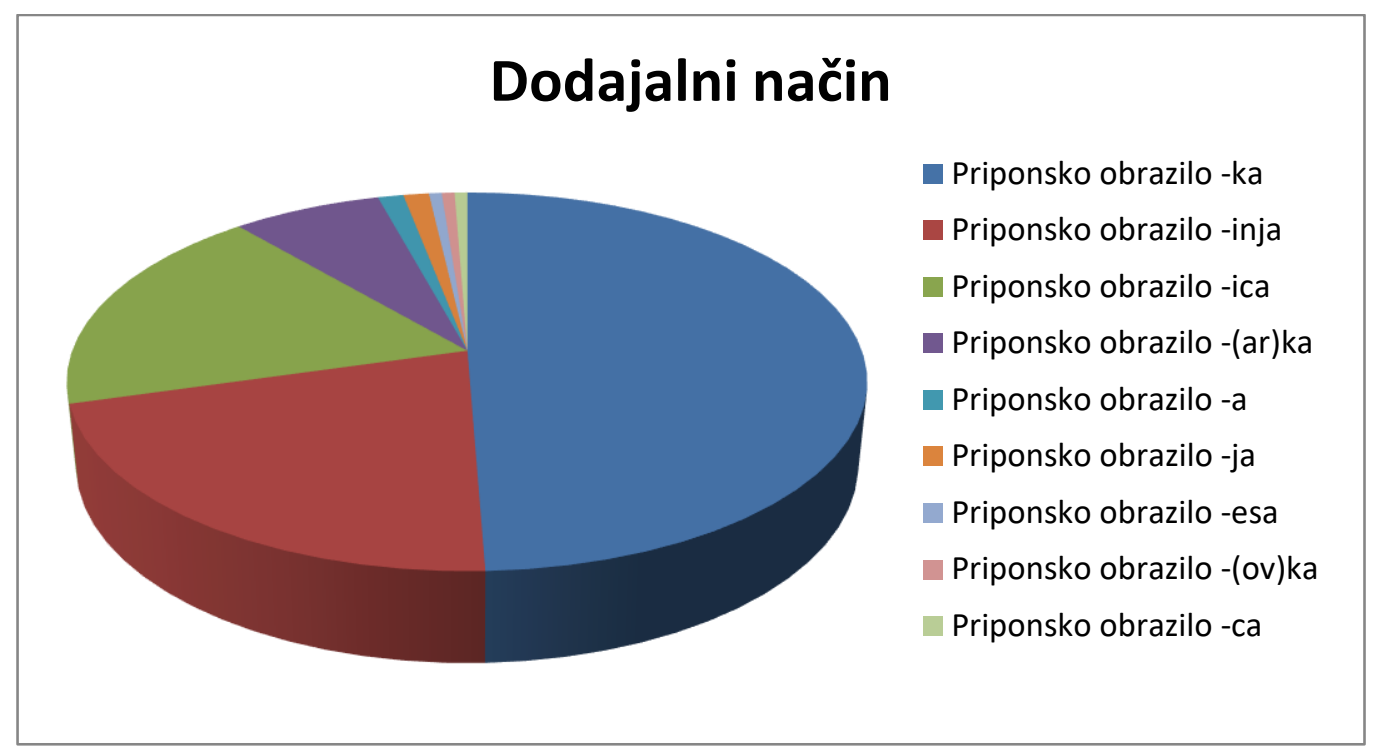

Spodnja preglednica prikazuje družljivost feminativnih priponskih obrazil z izglasji moškospolskih samostalnikov za vse tri pomenske skupine.

Preglednica 38: Družljivost feminativnih priponskih obrazil $z$ izglasji moškospolskih poimenovanj $v$ Novejši slovenski leksiki

\begin{tabular}{|c|c|c|c|c|}
\hline \multirow[t]{2}{*}{ OBRAZILO } & \multirow{2}{*}{$\begin{array}{l}\text { IZGLASJE } \\
\text { OBRAZILA }\end{array}$} & \multicolumn{3}{|c|}{ PRIMERI TVORJENK } \\
\hline & & $\begin{array}{c}\text { FEMINATIV IZ } \\
\text { VRŠILCA }\end{array}$ & $\begin{array}{c}\text { FEMINATIV IZ } \\
\text { NOSILCA }\end{array}$ & $\begin{array}{l}\text { FEMINATIV IZ } \\
\text { OPRAVKARJA }\end{array}$ \\
\hline$-c a$ & $-(a) r$ & 1 & 1 & zobarca \\
\hline \multirow[t]{6}{*}{$-i c a$} & $-(a) \check{c}$ & dirkačica & / & / \\
\hline & -(ite)lj & zdraviteljica & 1 & / \\
\hline & $-(a) r$ & blogarica & 1 & člankarica \\
\hline & $-(e) r$ & blogerica & 1 & pankerica \\
\hline & $-($ ato $) r$ & komentatorica & / & / \\
\hline & $-(a) \check{s}$ & I & / & kajakašica \\
\hline \multirow[t]{2}{*}{-inja } & $-(j a) k$ & I & mišičnjakinja & $/$ \\
\hline & $-(i) k$ & 1 & akademikinja & 1 \\
\hline \multirow[t]{5}{*}{$-k a$} & $-(a) j$ & I & I & policajka \\
\hline & $-(i) j$ & I & primarijka & I \\
\hline & $-(e) l$ & / & / & modelka \\
\hline & $-(a) n$ & / & telebanka & / \\
\hline & $-(m a) n$ & I & 1 & golmanka \\
\hline
\end{tabular}




\begin{tabular}{|c|c|c|c|c|}
\hline & $-(a) r$ & bobnarka & I & anketarka \\
\hline & $-(e) r$ & bombarderka & I & pankerka \\
\hline & $-(i) r$ & l & / & bankirka \\
\hline & $-(o) r$ & debatorka & I & ambasadorka \\
\hline & $-($ ato $) r$ & donatorka & / & / \\
\hline & $-(a n) t$ & debitantka & / & azilantka \\
\hline & $-(i s) t$ & lobistka & I & karateistka \\
\hline & $-(a v) t$ & / & / & astronavtka \\
\hline$-(a r) k a$ & $-(i) k$ & I & I & analitičarka \\
\hline & $-(t i) k$ & I & / & dramatičarka \\
\hline
\end{tabular}

1. Feminativno obrazilo $-\boldsymbol{a}$ se dodaja k netvorjenim podstavam $\mathrm{z}$ izglasjem na $-r$ (cimra) in -s (prfoksa).

2. Priponsko obrazilo - $\boldsymbol{c a}$ dodajamo k opravkarju z izglasjem na -(a)r (zobarca).

3. Priponsko obrazilo -ica se dodaja k izglasjem na:

- -(a)č pri vršilcu dejanja iz glagolov na -ati/-am (dirkačica, navijačica);

- -(ite)lj pri vršilcu iz glagolov na -iti/-im (zdraviteljica) in pri sestavljeni podstavi - sovoditeljica;

- -(a)r za vršilca iz glagolov na -ati/-am (blogarica) in za opravkarja (anketarica, člankarica, grafitarica, knjigarnarica, prekrškarica);

- -(e)r pri vršilcu iz glagolov na -ati/-am (blogerica) in pri opravkarju iz prevzete podstave (darkerica, pankerica, rokerica);

- -(ato)r pri vršilcu dejanja iz glagolov na -irati/-iram (komentatorica, koordinatorica);

- -(a)̌s za opravkarja (kajakašica, ovirašica, troskokašica) in pri zloženi podstavi (dolgoprogašica);

- -o pri izglasjih podstav (arbitrica, frendica, generalica, magistrica, rektorica) ter pri sestavljenih in zloženih podstavah: kantavtorica, nečlanica, prodekanica.

Znova smo potrdili, da $\mathrm{z}$ dodajanjem obrazila -ica ne nastajajo feminativi $\mathrm{k}$ nosilcu lastnosti. Obrazilo -ica $\mathrm{v}$ izpisanih primerih nastopa tudi kot variantno 
priponskemu obrazilu -ka ob isti podstavi (anketarka - anketarica, blogerka blogerica, koordinatorka - koordinatorica, pankerica - pankerka). Kot dodajalno pa obrazilo -ica nastopa tudi pri poimenovanjih horoskopskih znamenj (bikica, rakica).

4. Obrazilo -ja dodamo $\mathrm{k}$ izglasju podstave na $-n$ (dekanja) ali $\mathrm{k}$ sestavljeni podstavi (podžupanja).

5. Obrazilo -inja se dodaja izglasjem na:

- -(ja)k pri nosilcu lastnosti (mišičnjakinja);

- -(i)k pri nosilcu po krnitvi iz pridevnika (akademikinja).

Kot dodajalno pa to obrazilo nastopa tudi $\mathrm{k}$ izglasjem podstave na - $d$ (nomadinja), -f (škofinja), -g (dramaturginja), -k (cinikinja, fanatikinja, klasikinja, laikinja), -l (generalinja), -r (fiziatrinja, geriatrinja), -s (asinja) in -t (adutinja, advokatinja, arhitektinja, ekspertinja, estetinja, kadetinja). Tudi priponsko obrazilo -inja lahko nastopa kot variantno ob isti podstavi (adutinja - adutka). Podobno kot v obeh SSKJ smo tudi v tem viru zasledili feminative, izpeljane iz samostalniških zloženk $\mathrm{s}$ sufiksoidnimi in prefiksoidnimi elementi, tudi $\mathrm{v}$ kombinaciji (ob izglasjih na $-f,-g,-r$ in $-t$ : alergologinja, algologinja, andragoginja, anesteziologinja, antikologinja, astrologinja, bibliografinja, biografinja, biotehnologinja, ekologinja, geografinja, geometrinja, homeopatinja, klimatologinja, komunikologinja, scenografinja).

6. Obrazilo $-k \boldsymbol{a}$ dodajamo k izglasjem na:

- $\quad$-(a)j pri opravkarju (policajka) ${ }^{85}$

- $\quad-(\boldsymbol{i}) \boldsymbol{j}$ pri nosilcu lastnosti (primarijka);

- $\quad-(\boldsymbol{e}) \boldsymbol{l}$ pri opravkarju (modelka) in pri sestavljeni podstavi (supermodelka);

- $\quad-(\boldsymbol{a})$ n za nosilca (telebanka) ${ }^{86}$

- -(ma)n za opravkarja (golmanka);

\footnotetext{
${ }^{85}$ Iz samostalnika policija (Snoj 2016: 563).

${ }^{86} \mathrm{Iz}$ pridevnika telebast (Snoj 2016: 778).
} 
- -(a)r pri vršilcu iz glagolov na -ati/-am (bobnarka, bordarka, deskarka, rolarka) in pri opravkarju (anketarka, knjigarka, koncesionarka, notarka, psičarka, vremenarka, zeliščarka, zobarka); tudi pri poimenovanju horoskopskega znamenja (vodnarka);

- -(e)r pri vršilcu iz glagolov na -ati/-am (blogerka), -irati/-iram (bombarderka, šarmerka, šopingerka, žurerka) in pri opravkarju (akterka, akviziterka, dizejnerka, kanclerka, ${ }^{87}$ managerka, pankerka, performerka, rejverka, šminkerka) ter pri zloženih podstavah (bejbisiterka);

- -(i)r za opravkarja (bankirka, brigadirka);

- -(o)r pri vršilcu iz glagolov na -irati/-iram (debatorka, donorka) in pri opravkarju (ambasadorka);

- -(ato)r za vršilca dejanja iz glagolov na -irati/-iram (donatorka, koordinatorka);

- -(an)t za vršilca iz glagolov na -irati/-iram (debitantka, ministrantka) in za opravkarja (azilantka);

- -(is)t pri vršilcu dejanja iz glagolov na -irati/-iram (lobistka) in pri opravkarju (akupunkturistka, anarhistka, atlanticistka, biblicistka, bulimistka, džezistka, galeristka, globalistka, karateistka, kolumnistka, recesionistka, stilistka, vizažistka, vokalistka), tudi pri zloženih podstavah (videoartistka);

- -(avt) pri opravkarju iz prevzete podstave (astronavtka).

Dodaja se lahko tudi sestavljenkam (prodekanka) in netvorjenkam (adutka, didžejka, genijka, ob podaljšanju osnove z -j tudi atašejka, gurujka, hipijka, japijka, someljejka). Priponsko obrazilo -ka nastopa kot dodajalno tudi $\mathrm{k}$ izglasjem podstav na -l (generalka, konzulka), -m (abrahamka), -n (dekanka, kameleonka, šamanka), -r (klošarka, majorka, premierka, sponzorka), - $t$ (cineastka, homeopatka).

${ }^{87}$ Iz samostalnika kanclija v pomenu 'pisarna, urad' (Snoj 2016: 281). 
7. Obrazilo -(ar)ka se, kot smo ugotovili že pri analizi gradiva iz obeh SSKJ, dodaja $\mathrm{k}$ :

- -(i)k v pomenski skupini opravkar (analitičarka);

- -(ti)k pri opravkarju (dramatičarka);

- -o pri nosilcu (anoreksičarka, bulimičarka, deloholičarka, diabetičarka, dietetičarka, fanatičarka, nevrotičarka, praktičarka, teoretičarka) in opravkarju (bioenergetičarka, genetičarka).

8. Priponsko obrazilo -(ov)ka se doda zloženki na izglasje - $k$ (picopekovka).

9. Obrazilo -esa ponovno nastopi le pri netvorjeni podstavi (klovnesa).

Sinteza obrazilne produktivnosti - dodajanje k izglasju obrazila

Spodnja preglednica prikazuje, katerim izglasjem moškospolskih obrazil se feminativna priponska obrazila lahko dodajajo.

Preglednica 39: Sinteza obrazilne produktivnosti - dodajalni način (Novejša slovenska leksika)

\begin{tabular}{|c|c|c|c|c|c|c|c|c|c|c|}
\hline \multirow{2}{*}{$\begin{array}{c}\text { MOŠKOSPOLSKO } \\
\text { IZGLASJE }\end{array}$} & \multicolumn{10}{|c|}{ FEMINATIVNA PRIPONSKA OBRAZILA } \\
\hline & $-a$ & $-c a$ & $-i c a$ & $-j a$ & -inja & $-k a$ & $-(a r) k a$ & $-(o v) k a$ & $-e s a$ & SKUPAJ \\
\hline$-(a) \check{c}$ & 1 & 1 & 2 & 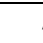 & 1 & 1 & 1 & 1 & 1 & 2 \\
\hline$-(a) j$ & I & I & I & , & I & 1 & I & l & I & 1 \\
\hline$-(i) j$ & I & I & I & 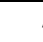 & I & 1 & l & I & I & 1 \\
\hline$-($ ite $) l j$ & 1 & 1 & 2 & 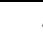 & 1 & 7 & 1 & 1 & 1 & 2 \\
\hline$-(j a) k$ & I & I & I & 7 & 1 & I & I & I & I & 1 \\
\hline$-(i) k$ & 1 & 1 & I & 7 & 1 & 1 & 1 & I & I & 2 \\
\hline$-(t i) k$ & I & I & I & t & I & 1 & 1 & I & I & 1 \\
\hline$-(e) l$ & I & I & I & t & I & 2 & I & I & I & 2 \\
\hline$-(a) n$ & I & I & I & t & l & 1 & I & I & I & 1 \\
\hline$-(m a) n$ & I & I & I & t & I & 1 & I & I & I & 1 \\
\hline$-(a) r$ & I & 1 & 6 & 7 & I & 13 & I & 1 & I & 20 \\
\hline
\end{tabular}




\begin{tabular}{|c|c|c|c|c|c|c|c|c|c|c|}
\hline \multirow{2}{*}{$\begin{array}{l}\text { MOŠKOSPOLSKO } \\
\text { IZGLASJE }\end{array}$} & \multicolumn{10}{|c|}{ FEMINATIVNA PRIPONSKA OBRAZILA } \\
\hline & $-a$ & $-c a$ & $-i c a$ & $-j a$ & -inja & $-k a$ & $-(a r) k a$ & $-(o v) k a$ & $-e s a$ & SKUPAJ \\
\hline$-(e) r$ & I & I & 4 & 7 & I & 15 & I & I & I & 19 \\
\hline$-(i) r$ & I & 1 & I & 7 & I & 2 & 1 & 1 & I & 2 \\
\hline$-(o) r$ & 1 & 1 & I & 7 & I & 3 & I & I & I & 3 \\
\hline$-($ ato $) r$ & 1 & 1 & 2 & 7 & 1 & 2 & 1 & 1 & I & 4 \\
\hline$-(a) \check{s}$ & I & I & 4 & 7 & I & 1 & I & I & I & 4 \\
\hline$-($ an $) t$ & 7 & 1 & l & 7 & 7 & 3 & 1 & I & 1 & 3 \\
\hline$-(i s) t$ & 1 & 1 & 1 & 7 & 1 & 16 & 1 & 1 & 1 & 16 \\
\hline$-(a v) t$ & 7 & 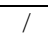 & 1 & 7 & I & 1 & 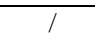 & I & I & 1 \\
\hline-0 & 2 & 1 & 10 & 2 & 33 & 21 & 11 & 1 & 1 & 81 \\
\hline SKUPAJ & 2 & 1 & 30 & 2 & 35 & 82 & 13 & 1 & 1 & 167 \\
\hline
\end{tabular}

Analiza je pokazala, da pri nobenem izglasju obrazili -ica in $-k a$ kot dodajalni ne tvorita feminativov $\mathrm{v}$ vseh treh prvih pomenskih skupinah izpeljank iz glagolske, pridevniške in samostalniške podstave. Izglasja moškospolskih obrazil, ki se jim feminativna priponska obrazila dodajajo, so naslednja:

- K -(a)̌̌ kot dodajalno nastopa zgolj obrazilo -ica (dva primera za vršilca, npr. dirkačica).

- K izglasju -(ite)lj se dodaja priponsko obrazilo -ica (dva primera, denimo zdraviteljica).

- Pri izglasju na -(ja)k kot dodajalno nastopa le priponsko obrazilo -inja, in to samo z enim primerom v pomenski skupini nosilec (mišičnjakinja).

- Pri izglasju na -(i)k se pojavljata feminativni obrazili -(ar)ka (en primer pri nosilcu analitičarka) in -inja (en primer pri nosilcu: akademikinja); -(ar)ka edina tudi pri -(ti)k (dramatičarka).

- Kot dodajalno obrazilo $\mathrm{k}$ izglasju na -(ma)n nastopa le $-k a \mathrm{v}$ pomenski skupini opravkar, kar potrjuje en primer (golmanka).

- K izglasju na -(a)r dodajamo priponska obrazila -ica (potrjuje skupno šest primerov, npr. blogarica), -ka (trinajst primerov, npr. knjigarka; tudi eno poimenovanje horoskopskega znamenja: vodnarka) in $-c a \quad \mathrm{z}$ enim primerom v pomenski skupini opravkar (zobarca). 
- Pri izglasju na -(e)r zasledimo dodajanje priponskih obrazil -ica (en primer $\mathrm{v}$ pomenski skupini vršilec dejanja, tj. blogerica, in trije primeri pri opravkarju, npr. rokerica), -ka (pet primerov v pomenski skupini vršilec, npr. blogerka, in devet za opravkarja, denimo pankerka). S priponskim obrazilom -ica pri vršilcu nastajajo tvorjenke iz glagolov na -ati/-am, s -ka pa poleg teh še iz -irati/-iram. Pri opravkarju pa gre za tvorbo iz prevzetih podstav z različnimi izglasji.

- Priponsko obrazilo - $k a$ kot edino nastopa pri dodajanju k izglasju opravkarja na -(i)r, kar potrjujeta dva feminativa (npr. bankirka).

- Feminativno obrazilo $-k a$ dodajamo tudi $\mathrm{k}$ izglasju moškospolskih poimenovanj na -(o)r (dva primera za vršilca, npr. donorka, in eden za opravkarja: ambasadorka).

- K -(ato)r dodajamo feminativni obrazili -ica (dve tvorjenki za vršilca, npr. komentatorica) in -ka (dva primera za vršilca dejanja, npr. donatorka); pri obeh gre za tvorbo iz prevzetih glagolskih podstav na -irati-iram.

- K izglasju na -(a)š se dodaja feminativno priponsko obrazilo -ica (trije primeri za opravkarja, npr. kajakašica, en primer iz zložene podstave: dolgoprogašica).

- Priponsko obrazilo - $k a$ kot edino dodajamo k izglasjem na -(e)l in -(an)t, kar smo potrdili s po dvema konkretnima primeroma (npr. modelka; azilantka), ter $-(\boldsymbol{a}) \boldsymbol{j},-(\boldsymbol{i}) \boldsymbol{j},-(\boldsymbol{a}) \boldsymbol{n}$ in $-(\boldsymbol{a}) \boldsymbol{t}$, potrjeno s po enim konkretnim primerom (policajka, primarijka, telebanka, astronavtka).

- Nekaj več potrditev smo zasledili pri izglasju -(is)t, ki se mu lahko dodaja le feminativno obrazilo $-k a \mathrm{v}$ pomenskih skupinah vršilec dejanja in opravkar (14 feminativov, npr. lobistka, džezistka); nastopi tudi pri zloženi podstavi (videoartistka).

Večina feminativnih priponskih obrazil je dodajalnih tudi k sestavljenim (trije primeri $\mathrm{z}-i c a$, dva $\mathrm{s}-k a$ ) in zloženim podstavam (trije primeri $\mathrm{z}-i c a$, dva $\mathrm{s}$ $-k a$, eden z $-(o v) k a)$. Produktivni pri poimenovanjih horoskopskih znamenj sta le -ica, kar potrjujeta dva primera tvorjenk, in $-k a \mathrm{z}$ enim primerom. Priponsko 
obrazilo -inja pa izstopa po tvorbi iz samostalniških zloženk s sufiksoidnimi in prefiksoidnimi elementi, tudi v kombinaciji, takih je 16 primerov.

Opažamo podobnost $\mathrm{z}$ obema izdajama SSKJ: tudi v tem viru primeri kažejo, da se priponsko obrazilo - $k a$ pri tvorbi feminativov $\mathrm{v}$ glavnem dodaja $\mathrm{k}$ izglasjem obrazil na $-t$ (vseh 20 primerov), pogosto tudi na $-r$ (39 tvorjenk od 48, tj. $81 \%$, medtem ko z -ica 13 primerov ali $27 \%$ ). Priponsko obrazilo -ica pa je zato edino, ki se dodaja k izglasjem na $-\check{c},-l j$ in $-\check{s}$.

\section{Sinteza obrazilne produktivnosti - dodajanje k izglasju podstave}

Zgornji pregled kaže, da se pri 81 primerih feminativna priponska obrazila dodajajo $\mathrm{k}$ izglasjem podstave, ne $\mathrm{k}$ izglasju obrazila. Spodnja preglednica prikazuje, h katerim izglasjem podstav se feminativna priponska obrazila dodajo.

Preglednica 40: Sinteza obrazilne produktivnosti - dodajalni način ob izglasjih podstav (Novejša slovenska leksika)

\begin{tabular}{|c|c|c|c|c|c|c|c|c|c|c|}
\hline \multirow{2}{*}{$\begin{array}{l}\text { IZGLASJE } \\
\text { PODSTAVE }\end{array}$} & \multicolumn{10}{|c|}{ FEMINATIVNA PRIPONSKA OBRAZILA } \\
\hline & $-a$ & $-c a$ & $-i c a$ & $-j a$ & -inja & $-k a$ & $-(a r) k a$ & $-(o v) k a$ & $-e s a$ & SKUPAJ \\
\hline$-d$ & / & / & 1 & l & 1 & / & / & / & / & 2 \\
\hline$-f$ & I & / & l & l & 5 & / & l & I & I & 5 \\
\hline$-g$ & I & / & I & I & 11 & l & l & I & I & 11 \\
\hline$-j$ & I & I & I & I & I & 7 & I & I & I & 7 \\
\hline$-k$ & I & I & 2 & I & 4 & I & 11 & 1 & I & 18 \\
\hline$-l$ & I & I & 1 & I & 1 & 2 & I & I & I & 4 \\
\hline$-m$ & I & I & I & I & I & 1 & I & I & I & 1 \\
\hline$-n$ & I & I & 2 & 2 & I & 4 & I & I & 1 & 9 \\
\hline$-r$ & 1 & I & 4 & I & 3 & 4 & I & I & I & 12 \\
\hline$-s$ & 1 & I & 1 & I & 1 & I & I & I & I & 2 \\
\hline$-t$ & I & I & I & I & 7 & 3 & I & I & I & 10 \\
\hline SKUPAJ & 2 & I & 10 & 2 & 33 & 21 & 11 & 1 & 1 & 81 \\
\hline
\end{tabular}


Nekaj obravnavanih feminativnih priponskih obrazil se lahko dodaja tudi k izglasju podstave na:

- $-\boldsymbol{d}$ (po en primer z -ica in -inja, pri obeh iz netvorjene podstave: frendica, nomadinja);

- $-f$ (pet primerov z -inja iz netvorjenih, npr. škofinja, in zloženih podstav, npr. geografinja);

- $\quad-g$ (11 konkretnih primerov z -inja iz netvorjenih in zloženih podstav, npr. dramaturginja, astrologinja);

- $\quad-j$ (osem feminativov s -ka, zmeraj iz netvorjene podstave, npr. gurujka);

- $-\boldsymbol{k}$ (en primer z -(ov)ka iz zložene podstave picopekovka, dve poimenovanji horoskopskih znamenj z -ica, npr. bikica, štirje feminativi z -inja, denimo cinikinja, 11 z -(ar)ka, npr. praktičarka);

- $\quad-l$ (po en feminativ z -ica in -inja: generalica in generalinja; dva s -ka, npr. konzulka, v vseh primerih iz netvorjenih podstav);

- $\quad-\boldsymbol{m}$ (en feminativ s - $k a$ iz netvorjene podstave: abrahamka);

- $\quad-\boldsymbol{n}$ (pri sestavljenih podstavah dva feminativa z -ica, npr. nečlanica, štirje primeri s $-k a$ iz sestavljenih in netvorjenih podstav, npr. prodekanka, dekanka);

- $-\boldsymbol{r}$ (štirje primeri $\mathrm{z}$-ica iz netvorjene in sestavljene podstave, npr. magistrica, trije primeri z -inja iz zložene in netvorjene podstave, denimo geometrinja, štirje feminativi $\mathrm{s}-k a$, in to iz netvorjenih podstav, npr. klošarka);

- $\quad-s$ (iz netvorjene podstave en feminativ z -inja: asinja);

- $-\boldsymbol{t}$ (sedem primerov $\mathrm{z}$-inja iz netvorjenih in zloženih podstav, npr. adutinja; homeopatinja, ter trije primeri $\mathrm{s}-k a$ iz netvorjenih podstav, denimo cineastka).

Ugotavljamo, da se $\mathrm{k}$ izglasjem podstav na $-f,-g$ in $-s$ dodaja samo feminativno obrazilo -inja, $\mathrm{k}-j$ in $-m$ pa zgolj obrazilo $-k a$. 
7.1.2.2 Feminativi, nastali $\mathrm{z}$ zamenjavo celotnega ali le izglasnega dela moškospolskega obrazila z ženskospolskim ob isti podstavi

Z zamenjevalnima obraziloma -ica in -ka je nastalo 76 feminativov ali 31 $\%$ vseh izpisanih primerov iz Novejše slovenske leksike. Od teh jih je 45 nastalo z obrazilom -ica (59\%), $31(41 \%)$ pa s $-k a .^{88}$

Grafikon 12: Zamenjevalna feminativna priponska obrazila v Novejši slovenski leksiki

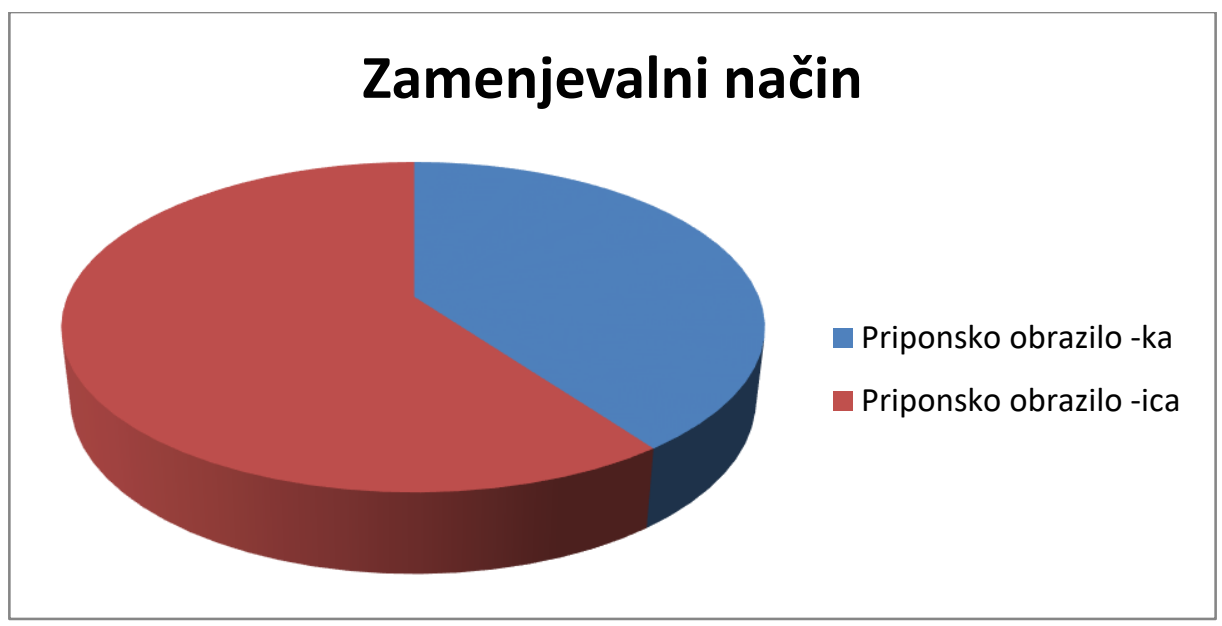

Spodnja preglednica prikazuje, katera moškospolska priponska obrazila lahko zamenjujejo feminativna obrazila v skupinah vršilec, nosilec in opravkar.

Preglednica 41: Zamenjava moškospolskih priponskih obrazil s feminativnimi $v$ Novejši slovenski leksiki

\begin{tabular}{|c|c|c|c|c|c|}
\hline \multirow[t]{2}{*}{ OBRAZILO } & \multirow{2}{*}{$\begin{array}{l}\text { OBRAZILO } \\
\text { MOŠKEGA } \\
\text { SPOLA }\end{array}$} & \multirow{2}{*}{$\begin{array}{l}\text { IZGLASJE } \\
\text { PODSTAVE }\end{array}$} & \multicolumn{3}{|c|}{ PRIMERI TVORJENK } \\
\hline & & & $\begin{array}{l}\text { FEMINATIV } \\
\text { IZ VRŠILCA }\end{array}$ & $\begin{array}{l}\text { FEMINATIV } \\
\text { IZ NOSILCA }\end{array}$ & $\begin{array}{l}\text { FEMINATIV IZ } \\
\text { OPRAVKARJA }\end{array}$ \\
\hline \multirow[t]{5}{*}{$-i c a$} & $-e c$ & $-h$ & l & glušica & I \\
\hline & \multirow[t]{2}{*}{$-\check{c} e k$} & $-n$ & I & dojenčica & I \\
\hline & & $-r$ & I & starčica & I \\
\hline & $-i k$ & $-n$ & I & bančnica & I \\
\hline & -nik & $-b$ & porabnica & I & / \\
\hline
\end{tabular}

${ }^{88}$ NSL beleži tudi 29 feminativov, ki so nastali z zamenjevalnim načinom in jih ni v kasnejšem SSKJ 2. To so avtoprevoznica, brihtnica, elektrotehnica, enakovrednica, glušica, jurišnica, kadrovnica, mikropodjetnica, natančnica, navadnica, nekulturnica, nevladnica, prijaznica, samoplačnica, samozavestnica, starčica, univerzitetnica, vódnica (18 primerov z -ica); begavka, harekrišnovka, heteroseksualka, homoseksualka, knjigoljubka, kudovka, nadlegovanka, obstranka, odštekanka, piska, žgečkljivka (11 primerov s -ka). 


\begin{tabular}{|c|c|c|c|c|c|}
\hline & & $-d$ & vodnica & I & I \\
\hline & & $-l$ & I & I & šolnica \\
\hline & & $-t$ & I & stotnica & I \\
\hline & & $-v$ & kadrovnica & I & I \\
\hline & $-s ̌ c ̌ i k$ & $-r$ & / & I & naturščica \\
\hline & $-e \check{z}$ & $-n$ & I & natančnica & I \\
\hline$-k a$ & $-e c$ & $-j$ & I & I & radijka \\
\hline & & $-n$ & I & odštekanka & biatlonka \\
\hline & & $-r$ & govorka & I & / \\
\hline & & $-s$ & piska & I & I \\
\hline & & $-v$ & / & strašljivka & / \\
\hline & -arec & $-t$ & I & I & parlamentarka \\
\hline & -ilec & $-n$ & cenilka & I & / \\
\hline & & $-v$ & zdravilka & I & I \\
\hline & -inec & $-p$ & I & I & alpinka \\
\hline & -ovec & $-m$ & / & I & abrahamovka \\
\hline
\end{tabular}

1. Priponsko obrazilo -ica zamenjuje moškospolska obrazila:

- $\quad$-ec pri nosilcu, kadar se podstava konča na -h (glušica, suhica);

- -ček za nosilca lastnosti ob podstavi na -n (dojenčica, novorojenčica) in -r (starčica); pri vseh navedenih primerih se ohrani - $\check{c}$ iz moškospolskega obrazila -ček, nato pa se doda ženskospolsko obrazilo -ica;

- $\quad-e \check{z}$ ob nosilcu, ko se podstava konča na izglasje -n (brihtnica, natančnica, navadnica, poslovnica, prijaznica, samozavestnica, uspešnica), ter pri zloženkah (dobrodelnica, enakovrednica) in sestavljenkah (nekulturnica);

- - $\boldsymbol{i k}$ pri nosilcu lastnosti s podstavo na izglasje -n (bančnica, častnica, družbenica, estradnica, gospodarstvenica, jurišnica, mirovnica, naložbenica, odvisnica, podjetnica, pohodnica, potrošnica, povzpetnica, univerzitetnica, varnostnica) ter pri zloženih (avtoprevoznica, elektrotehnica, naravovarstvenica, okoljevarstvenica, videoumetnica) in sestavljenih podstavah (mikropodjetnica, nevladnica);

- $\quad$-nik za vršilca dejavnosti z izglasjem podstave na -v (kadrovnica), -b (porabnica) ali -d (vódnica, vodníca), nosilca na -t (stotnica) in opravkarja na -l (šolnica), tudi pri zloženih podstavah (samoplačnica);

- - -ščik za opravkarja iz prevzete podstave (naturščica). 
2. Obrazilo - $\boldsymbol{k} \boldsymbol{a}$ zamenjuje moškospolska priponska obrazila:

- $\quad \boldsymbol{e c}$ za vršilca dejanja iz glagolov na -iti/-im z izglasjem podstave na -r (govorka) ali iz -ati/-em z izglasjem na $-s$ (piska), za opravkarja $\mathrm{z}$ izglasjem podstave na -j (radijka, televizijka) ali -n (biatlonka), za nosilca z izglasjem na $-l$ (po krnitvi iz pridevnika: genialka, marginalka), - $n$ (nadlegovanka, obstranka, odštekanka), -v (begavka, harekrišnovka, kudovka, negativka, obramboslovka, piarovka, pozitivka, rekreativka, strašljivka, žgečkljivka); tudi pri horoskopskem znamenju (strelka) ter pri zloženi (knjigoljubka, samohodka, tekstopiska) in sestavljeni podstavi (heteroseksualka, homoseksualka);

- - arec pri opravkarju (parlamentarka);

- -ilec za vršilca iz glagolov na -iti/-im (cenilka, zdravilka);

- -inec pri opravkarju (alpinka);

- -ovec za opravkarja (abrahamovka).

\section{Sinteza obrazilne produktivnosti}

Spodnja preglednica prikazuje, katera feminativna priponska obrazila (in v kolikšni meri) zamenjujejo posamezna moškospolska izglasja.

Preglednica 42: Sinteza obrazilne produktivnosti - zamenjevalni način (Novejša slovenska leksika)

\begin{tabular}{|c|c|c|c|}
\hline \multirow{2}{*}{$\begin{array}{l}\text { MOŠKOSPOLSKO } \\
\text { OBRAZILO }\end{array}$} & \multicolumn{3}{|c|}{ FEMINATIVNA PRIPONSKA OBRAZILA } \\
\hline & $-i c a$ & $-k a$ & SKUPAJ \\
\hline$-e c$ & 2 & 26 & 28 \\
\hline -arec & / & 1 & 1 \\
\hline -ilec & I & 2 & 2 \\
\hline -inec & 7 & 1 & 1 \\
\hline -ovec & 1 & 1 & 1 \\
\hline$-\check{c} e k$ & 3 & I & 3 \\
\hline
\end{tabular}




\begin{tabular}{|r|c|c|c|}
\hline \multicolumn{1}{|c|}{$\begin{array}{l}\text { MOŠKOSPOLSKO } \\
\text { OBRAZILO }\end{array}$} & \multicolumn{4}{|c|}{ FEMINATIVNA PRIPONSKA OBRAZILA } \\
\cline { 2 - 4 } & $-i c a$ & $-k a$ & \multicolumn{1}{l|}{ SKUPAJ } \\
\hline$-e \check{z}$ & 10 & $/$ & 21 \\
\hline$-i k$ & 22 & $/$ & $\mathbf{8}$ \\
\hline$-n i k$ & 7 & $/$ & 1 \\
\hline$-\check{c} c ̌ i k$ & 1 & 31 & 76 \\
\hline SKUPAJ & 45 & & $/$ \\
\hline
\end{tabular}

Analiza kaže, da se za vse tri prve pomenske skupine izpeljank iz glagolske, pridevniške in samostalniške podstave, torej za vršilca, nosilca in opravkarja, pojavita zgolj priponsko obrazilo -ec pri zamenjevalnem obrazilu $-k a$ ter -nik pri feminativnem obrazilu -ica. Obrazila, ki jih feminativni priponski obrazili -ica in - $k a$ zamenjujeta, so naslednja:

- Moškospolsko obrazilo -ec lahko zamenjujeta obe feminativni obrazili: -ica pri nosilcu, kadar se podstava konča na - $h$ (dva primera, npr. suhica), - $k a$ pa pri vršilcu iz glagolov na -iti/-im z izglasjem podstave na - $r$ (ena tvorjenka: govorka) ali iz -ati/-em (en primer: piska), pri opravkarju z izglasji podstav na $-j$ (dva feminativa, npr. radijka) in - $n$ (en feminativ: biatlonka) ter pri nosilcu z izglasjem na -l (dva primera, npr. genialka), - $n$ (trije primeri, npr. nadlegovanka), -v (deset tvorjenk, npr. begavka).

- Zgolj feminativno obrazilo - $k a$ lahko zamenjuje moškospolska obrazila -arec, -ilec, -inec in -ovec (pri vseh v pomenski skupini opravkar, le pri obrazilu -ilec pri vršilcu; seveda ob upoštevanju načela ekonomičnosti in racionalnosti, npr. parlamentarka, cenilka, alpinka, abrahamovka).

- Obrazilo -ček zamenjuje le priponsko obrazilo -ica, in to pri nosilcu lastnosti ob podstavi na $-n$ (dva primera, npr. dojenčica) in - $r$ (en primer: starčica).

- Tudi priponski obrazili - $\boldsymbol{e} \check{z}$ in -ik zamenjuje le obrazilo -ica ob nosilcu, ko se podstava konča na izglasje $-n$ (deset primerov $\mathrm{z}-e z ̌$ in $22 \mathrm{z}-i k$, npr. brihtnica, častnica). Pri vršilcu dejanja pa -ica zamenjuje moškospolsko obrazilo -nik (en primer iz glagolske podstave na -ovati/-ujem kadrovnica 
in trije iz -iti/-im, npr. vodníca, pri opravkarju pa dva primera iz različnih podstav, denimo jurišnica) ali -̌̌šik (prav tako en primer za opravkarja, a iz prevzete podstave na $-r$ : naturščica).

Tudi primeri iz tega vira kažejo, da priponsko obrazilo $-k a \mathrm{v}$ glavnem zamenja moškospolsko obrazilo -ec, -ica pa je pogostejša pri zamenjavi moškospolskih -ik, -nik in -ščik.

\section{Sinteza obrazilne produktivnosti - dodajanje k izglasju podstave}

Spodnja preglednica prikazuje, $\mathrm{h}$ katerim izglasjem podstave se feminativna priponska obrazila po zamenjavi moškospolskega obrazila dodajo.

Preglednica 43: Sinteza obrazilne produktivnosti - zamenjevalni način ob moškospolskih izglasjih (Novejša slovenska leksika)

\begin{tabular}{|c|c|c|c|}
\hline \multirow{2}{*}{$\begin{array}{l}\text { IZGLASJE } \\
\text { PODSTAVE }\end{array}$} & \multicolumn{3}{|c|}{ FEMINATIVNO PRIPONSKO OBRAZILO } \\
\hline & $-i c a$ & $-k a$ & SKUPAJ \\
\hline$-b$ & 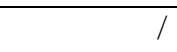 & 1 & 1 \\
\hline$-\check{c}$ & 3 & l & 3 \\
\hline$-\check{-s \check{c}}$ & 1 & 1 & 1 \\
\hline$-d$ & I & 1 & 1 \\
\hline$-h$ & 2 & 1 & 2 \\
\hline$-j$ & / & 2 & 2 \\
\hline$-l$ & / & 7 & 7 \\
\hline$-n$ & 39 & 5 & 44 \\
\hline$-r$ & 1 & 2 & 2 \\
\hline$-s$ & / & 2 & 2 \\
\hline$-v$ & 1 & 11 & 11 \\
\hline SKUPAJ & 45 & 31 & 76 \\
\hline
\end{tabular}

Obravnavana feminativna priponska obrazila se lahko po odvzemu moškospolskega obrazila dodajajo k izglasjem na: 
- $\quad-\boldsymbol{b}$ (en feminativ s - $k a$, po tem ko zamenja obrazilo -ec: knjigoljubka);

- $\quad-\check{c}$ (tri feminativi z -ica po zamenjavi dela moškospolskega obrazila -ček, npr. starčica);

- -šč (en primer z -ica po zamenjavi dela moškospolskega obrazila -ščik: naturščcica);

- $\quad-\boldsymbol{d}$ (en primer s -ka po zamenjavi moškospolskega -ec: samohodka);

- $\quad \boldsymbol{h}$ (dva primera z -ica po odvzemu obrazila -ec, npr. glušica);

- $\quad-j$ (dva primera s -ka po odvzemu obrazila -ec: televizijka);

- $\quad-l$ (sedem primerov s $-k a$; prišteti so primeri zamenjave obrazila -ilec, ker gre za zamenjavo obrazilne sestavine $-e c$ in $\mathrm{s}$ tem dodajanje $\mathrm{k}-l, \mathrm{npr}$. zdravilka);

- -n (največ, tj. 39 primerov z -ica po zamenjavi moškospolskih obrazil -ik in -ež, npr. pohodnica, pet feminativov s $-k a$ po zamenjavi obrazila -ec, npr. odštekanka);

- $\quad-r$ (dva feminativa s -ka po zamenjavi moškospolskega -ec, npr. govorka);

- $-s$ (dva primera, tvorjena z obrazilom - $k a$ po zamenjavi moškospolskega obrazila -ec, denimo tekstopiska);

- $-\boldsymbol{v}$ (11 primerov $\mathrm{s}-k a$, in to po zamenjavi obrazila (ali njegovega dela) -ec, denimo kudovka).

Opažamo, da se feminativno obrazilo -ica po zamenjavi moškospolskih obrazil najpogosteje druži z izglasjem podstave na - $n$ (39 primerov od skupno 45 oz. $86 \%$ ), priponsko obrazilo $-k a$ pa z izglasji na $-l(7$ primerov oz. $23 \%$ ) in $\mathrm{z}-v$ (11 feminativov oz. $35 \%$ ).

\subsubsection{Slovar novejšega besedja slovenskega jezika}

Slovar novejšega besedja slovenskega jezika (2012) je po svoji zgradbi navezovalni, glede na vsebino in namen pa dopolnilni k Slovarju slovenskega knjižnega jezika. Ponuja slovarske prikaze v zadnjih dveh desetletjih nastalih ali oživljenih besed, besednih zvez in pomenov. Vsebuje 6399 besed in besednih zvez, ki niso bile obravnavane v SSKJ 1. Med temi smo izpisali in analizirali 163 
feminativov. Ugotavljamo, da je 107 (66 \%) feminativov nastalo z dodajanjem ženskospolskega obrazila tvorjenkam moškega spola, 56 (34 \%) primerov pa je nastalo z zamenjavo celotnega ali izglasnega dela moškospolskega obrazila $\mathrm{z}$ ženskospolskim ob isti podstavi.

Grafikon 13: Feminativi v SNBSJ glede na način tvorbe

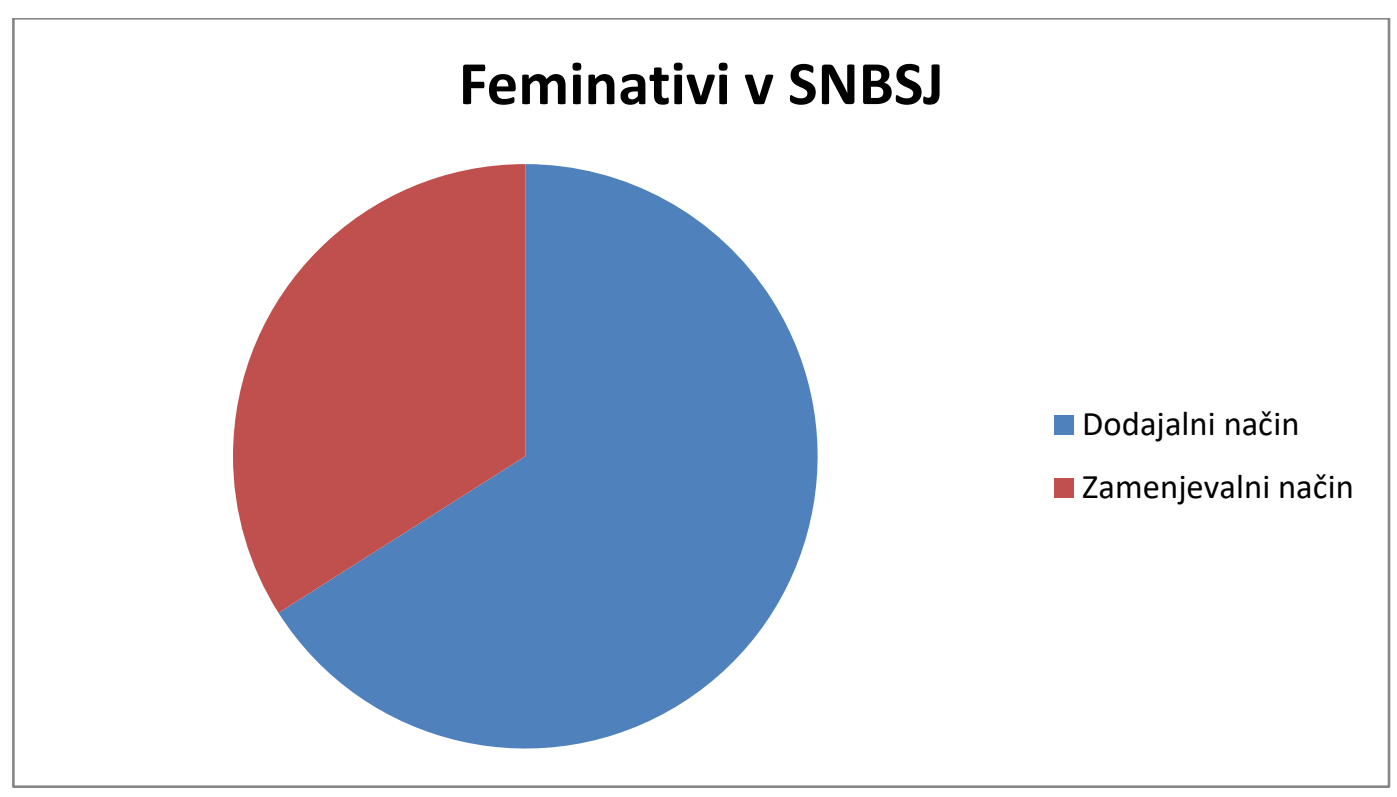

Tudi v Slovarju novejšega besedja sta novost (glede na Slovensko slovnico 2004) samo feminativni priponski obrazili -(ar)ka in -esa.

Preglednica 44: Primerjalni prikaz feminativnih priponskih obrazil (SS in SNBSJ)

\begin{tabular}{|c|c|}
\hline Slovenska slovnica (2004) & Slovar novejšega besedja \\
\hline$-a$ & $-a$ \\
\hline$-i c a$ & $-i c a$ \\
\hline$-j a$ & $-j a$ \\
\hline$-u l j a$ & $-i n j a$ \\
\hline$-i n j a$ & $-(a r) k a$ \\
\hline$-k a$ & $-k a$ \\
\hline- ovka & $-e s a$ \\
\hline$-i c ̌ n a$ & \\
\hline
\end{tabular}


7.1.3.1 Feminativi, nastali $\mathrm{z}$ dodajanjem ženskospolskega obrazila tvorjenkam moškega spola

Skupno je torej na ta način nastalo 66 \% izpisanih besed oziroma 107 feminativov. Opažamo, da je največ, to je 50 primerov ali $47 \%$, nastalo z dodajanjem priponskega obrazila - $k a$. Drugo najpogostejše je obrazilo -inja s 23 primeri (21\%), sledijo -ica s 16 primeri (15\%), -(ar)ka z 11 primeri (10\%), - $a$ in -ja s po tremi primeri ( $3 \%$ ), en feminativ pa je bil tvorjen s priponskim obrazilom -esa.

Grafikon 14: Dodajalna feminativna priponska obrazila po SNBSJ

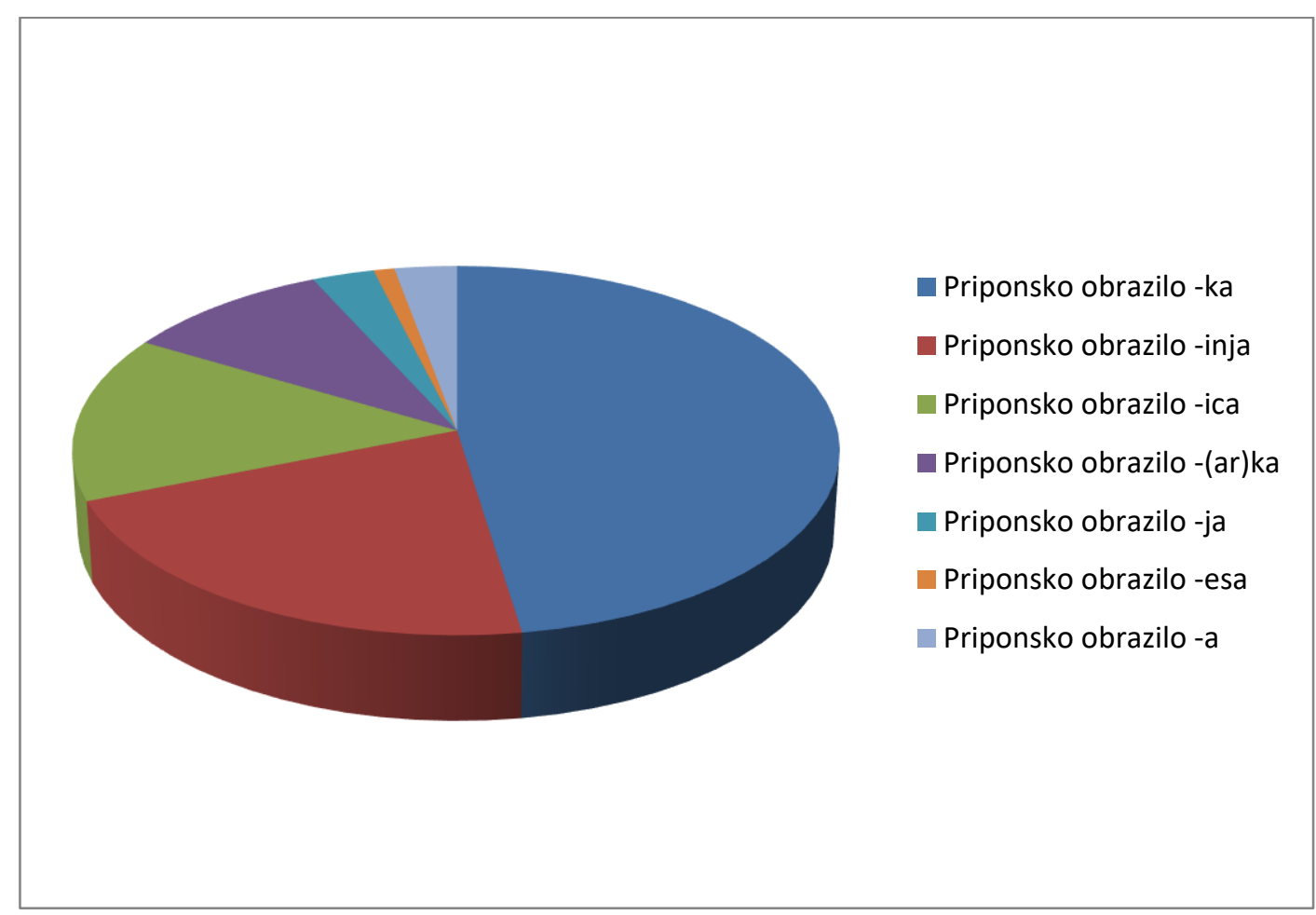

Iz spodnje preglednice je razvidno, katerim izglasjem moškospolskih obrazil se feminativna priponska obrazila lahko dodajajo pri vršilcu, nosilcu in opravkarju. 
Preglednica 45: Družljivost feminativnih priponskih obrazil $z$ izglasji moškospolskih poimenovanj $v$ SNBSJ

\begin{tabular}{|c|c|c|c|c|}
\hline \multirow[t]{2}{*}{ OBRAZILO } & \multirow{2}{*}{$\begin{array}{l}\text { IZGLASJE } \\
\text { OBRAZILA }\end{array}$} & \multicolumn{3}{|c|}{ PRIMERI TVORJENK } \\
\hline & & $\begin{array}{c}\text { FEMINATIV IZ } \\
\text { VRŠILCA }\end{array}$ & $\begin{array}{c}\text { FEMINATIV IZ } \\
\text { NOSILCA }\end{array}$ & $\begin{array}{l}\text { FEMINATIV IZ } \\
\text { OPRAVKARJA }\end{array}$ \\
\hline \multirow[t]{5}{*}{$-i c a$} & $-(a) \check{c}$ & navijačica & / & / \\
\hline & -(ite)lj & zdraviteljica & I & I \\
\hline & $-(e) r$ & I & I & rokerica \\
\hline & $-($ ato $) r$ & koordinatorica & / & I \\
\hline & $-(a) \check{s}$ & I & I & kajakašica \\
\hline -inja & $-(u) h$ & varuhinja & I & I \\
\hline \multirow[t]{11}{*}{$-k a$} & $-(a) j$ & I & I & policajka \\
\hline & $-(i) j$ & / & primarijka & / \\
\hline & $-(a) r$ & štoparka & I & anketarka \\
\hline & $-(e) r$ & debaterka & I & dizajnerka \\
\hline & $-(i) r$ & I & I & bankirka \\
\hline & $-(o) r$ & debatorka & / & ambasadorka \\
\hline & $-($ ato $) r$ & donatorka & I & I \\
\hline & $-(a n) t$ & ministrantka & I & I \\
\hline & $-(a s) t$ & I & I & videastka \\
\hline & $-(i s) t$ & I & I & tekvondoistka \\
\hline & $-(a v) t$ & I & I & astronavtka \\
\hline$-(a r) k a$ & $-(a t i) k$ & / & 1 & tonematičarka \\
\hline
\end{tabular}

1. Priponsko obrazilo -ica dodajamo k izglasjem na:

- -(a)č pri vršilcu dejanja iz glagolov na -ati/-am (samo en primer navijačica);

- -(ite)lj za vršilca iz glagolov na -iti/-im (zdraviteljica);

- -(e)r za opravkarja (darkerica, pankerica, rokerica);

- -(ato)r ob vršilcu iz glagolov na -irati/-iram (koordinatorica);

- -(a)š pri opravkarju (kajakašica, ovirašica);

- $\quad \boldsymbol{o}$ pri izglasjih podstave na -d (frendica), - $l$ (generalica) in - $r$ (magistrica, rektorica). 
Nikoli se ne dodaja $\mathrm{k}$ nosilcu lastnosti, zato pa nastopi ob novopomenskih podstavah (bikica, ovnica, rakica) in sestavljenkah (prodekanica).

2. Priponsko obrazilo -ja se dodaja $\mathrm{k}$ izglasjem podstave na - $n$ (samo dekanja) in sestavljenkam (prav tako na -n: podžupanja, prodekanja).

3. Obrazilo -inja dodajamo k izglasjem na:

- $-(\boldsymbol{u}) \boldsymbol{h}$ pri vršilcu dejanja iz glagolskih podstav na -ovati/-ujem (varuhinja).

Kot dodajalna nastopa še $\mathrm{k}$ izglasjem podstav na $-f$ (škofinja), $-r$ (fiziatrinja) in -t (adutinja, advokatinja, ekspertinja, estetinja, kadetinja). Tudi tukaj so nekateri feminativi izpeljani iz samostalniških zloženk s sufiksoidnimi in prefiksoidnimi elementi (akcentologinja, andragoginja, astrologinja, dialektologinja, ekologinja, geografinja, geometrinja, homeopatinja, kinologinja, nevrobiologinja, numerologinja, plečnikologinja, refleksologinja), dodaja se tudi novopomenskim podstavam (kozoroginja, levinja).

4. Obrazilo -ka dodajamo izglasjem na:

- -(a)j pri opravkarju (policajka);

- $\quad-(\boldsymbol{i}) \boldsymbol{j}$ v pomenski skupini nosilec (primarijka);

- -(a)r pri vršilcu iz glagolov na -ati/-am (rolarka, štoparka) in pri opravkarju (anketarka, knjigarka, notarka, računalničarka), tudi pri novopomenkah (vodnarka);

- -(e)r za vršilca iz glagolskih podstav na -irati/-iram (blokerka, debaterka, šarmerka) ter za opravkarja (dizajnerka, menedžerka, rejverka);

- $\quad$-(i)r pri opravkarju (bankirka);

- -(o)r za vršilca dejanja iz glagolov na -irati/-iram (debatorka) in za opravkarja (ambasadorka);

- -(ato)r ob vršilcu iz glagolov s končnico -irati/-iram (donatorka, koordinatorka); 
- -(an)t pri vršilcu, kadar se podstavni glagol konča na -irati/-iram (ministrantka);

- -(as)t pri opravkarju (videastka);

- -(is)t pri opravkarju (centristka, golfistka, kolumnistka, nutricistka, stilistka, tekvondoistka, vizažistka);

- $\quad$-(av)t pri opravkarju iz prevzete podstave (astronavtka).

Dodajamo jo tudi sestavljenkam (prodekanka, supermodelka, supervizorka), zloženkam (presnojedka) ali izglasjem podstave na -d (nomadka), -j (didžejka), -l (generalka, konzulka), -m (abrahamka), -n (dekanka, kameleonka, ombudsmanka), -r (klošarka, majorka), -t (adutka, ekspertka, nutricionistka). Pri nekaterih tvorjenkah lahko pride do podaljšanja osnove z -j (atašejka, japijka, someljejka).

5. Obrazilo -(ar)ka se dodaja k:

- -o pri nosilcu (anoreksičarka, anorektičarka, bioenergetičarka, bulimičarka, deloholičarka, diabetičarka, dietetičarka, praktičarka, teoretičarka, tetraplegičarka);

- -(ati)k pri opravkarju (tonematičarka).

Nekaj feminativov je nastalo z dodajanjem ženskospolskega priponskega obrazila samo netvorjenim podstavam, npr. -a: bajsa, cimra, prfoksa; -esa: klovnesa.

\section{Sinteza obrazilne produktivnosti}

Spodnja preglednica prikazuje, katerim izglasjem moškospolskih obrazil se feminativna priponska obrazila lahko dodajajo. 
Preglednica 46: Sinteza obrazilne produktivnosti-dodajalni način (SNBSJ)

\begin{tabular}{|c|c|c|c|c|c|c|c|c|}
\hline \multirow{2}{*}{$\begin{array}{l}\text { MOŠKOSPOLSKO } \\
\text { IZGLASJE }\end{array}$} & \multicolumn{8}{|c|}{ FEMINATIVNO PRIPONSKO OBRAZILO } \\
\hline & $-a$ & $-i c a$ & $-j a$ & -inja & $-k a$ & $-(a r) k a$ & $-e s a$ & SKUPAJ \\
\hline$-(a) \grave{c}$ & I & 1 & 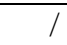 & I & I & I & I & 1 \\
\hline$-(u) h$ & 1 & I & 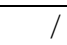 & 1 & I & I & l & 1 \\
\hline$-(a) j$ & I & I & 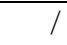 & I & 1 & I & I & 1 \\
\hline$-(i) j$ & I & I & 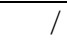 & 1 & 1 & 1 & I & 1 \\
\hline$-(i t e) l j$ & 1 & 1 & 1 & I & I & 1 & I & 1 \\
\hline$-(a t i) k$ & I & I & 1 & I & I & 1 & I & 1 \\
\hline$-(a) r$ & I & I & I & I & 7 & I & 1 & 7 \\
\hline$-(e) r$ & 1 & 3 & 1 & I & 6 & I & 1 & 9 \\
\hline$-(i) r$ & I & l & 1 & I & 1 & 1 & 1 & 1 \\
\hline$-(o) r$ & 1 & I & 1 & 1 & 2 & I & 1 & 2 \\
\hline$-($ ato $) r$ & 1 & 1 & 1 & 1 & 2 & I & 1 & 3 \\
\hline$-(a) \check{s}$ & 1 & 2 & 7 & I & 1 & 1 & 1 & 2 \\
\hline$-($ an $) t$ & I & I & 1 & I & 1 & 1 & 1 & 1 \\
\hline$-(a s) t$ & I & I & 1 & 1 & 1 & I & I & 1 \\
\hline$-(i s) t$ & 7 & I & 7 & I & 7 & I & 1 & 7 \\
\hline$-(a v) t$ & 7 & I & 1 & 1 & 1 & 1 & 1 & 1 \\
\hline-0 & 3 & 8 & 3 & 22 & 20 & 10 & 1 & 67 \\
\hline SKUPAJ & 3 & 16 & 3 & 23 & 50 & 11 & 1 & 107 \\
\hline
\end{tabular}

Analiza kaže, da se feminativna priponska obrazila lahko dodajajo $\mathrm{k}$ naslednjim izglasjem moškospolskih poimenovanj oseb:

- K izglasju na -(a)̌c se lahko dodaja priponsko obrazilo -ica v pomenski skupini vršilec, kadar gre za tvorbo iz glagolskih podstav na -ati/-am (potrjuje le en primer: navijačica).

- $\mathrm{K}-(\boldsymbol{u}) \boldsymbol{h}$ se $\mathrm{v}$ pomenski skupini nosilec lastnosti lahko dodaja le obrazilo -inja (npr. varuhinja). 
- Posebnost je dodajanje ženskospolskega obrazila - $k a$ k izglasju na -(i)j v pomenski skupini nosilec (primarijka) ter -(a)j pri opravkarju (policajka).

- Samo priponsko obrazilo -ica se dodaja izglasjem na -(ite)lj (potrjeno z enim primerom za vršilca dejanja iz glagolske podstave na -iti-im: zdraviteljica) in -(a)̌̌ (dva primera za opravkarja, npr. ovirašica).

- Samo priponsko obrazilo -(ar)ka se dodaja k izglasjem na -(ati)k (potrjeno z enim primerom: tonematičarka).

- Kot dodajalno k izglasjem na -(a)r (dva primera za vršilca, npr. štoparka, in štirje za opravkarja, denimo anketarka, eden iz novopomenske podstave: vodnarka), -(i)r (en feminativ v pomenski skupini opravkar: bankirka), -(o)r (po en primer tvorjenke za vršilca in za opravkarja: debatorka, ambasadorka), -(an)t (en primer v pomenski skupini vršilec: ministrantka), -(as)t za opravkarja (en primer: videastka), -(is)t pri opravkarju (potrjeno s sedmimi primeri, npr. golfistka), -(av)t pri opravkarju (astronavtka) pa nastopa le feminativno obrazilo $-k a$.

- K izglasju -(ato)r se lahko dodajata dve feminativni obrazili, -ica in - $k a$, obe ob vršilcu iz glagolov na -irati-iram (samo ena tvorjenka z -ica in dve s -ka, npr. koordinatorica, donatorka).

- K -(e)r nastopata kot dodajalni obrazili -ica in - $k a$ za vršilca dejanja iz glagolov na -irati/-iram (tri primeri s -ka, npr. blokerka) ter za opravkarja (trije feminativi iz prevzete podstave $\mathrm{z}-i c a$ in trije $\mathrm{s}-k a$, npr. pankerica, dizajnerka).

Nekateri feminativi so izpeljani iz samostalniških zloženk $\mathrm{s}$ sufiksoidnimi in prefiksoidnimi elementi (precej primerov z -inja, iz zložene podstave tudi $-k a$ ) in iz sestavljenih podstav ( $-i c a,-k a$ in $-j a$ ), obrazila -ica, $-k a$ in -inja pa se dodajajo tudi novopomenskim podstavam pri poimenovanjih horoskopskih znamenj. Nekaj feminativov je nastalo $\mathrm{z}$ dodajanjem ženskospolskega priponskega obrazila samo netvorjenim podstavam (- $a$ in -esa).

Znova smo potrdili, da se feminativno priponsko obrazilo - $k a$ dodaja $\mathrm{k}$ izglasjem moškospolskih samostalnikov na $-r$ in $-t$, samo -ica nastopi pri izglasjih na $-\check{c},-l j$ in $-\check{s}$, zgolj $-(a r) k a$ pa pri izglasjih na $-k$. 
Sinteza obrazilne produktivnosti - dodajanje k izglasju podstave

Zasledili smo 67 primerov dodajanja priponskih obrazil k različnim izglasjem podstav. Spodnja preglednica prikazuje, h katerim izglasjem podstave se feminativna priponska obrazila lahko dodajo.

Preglednica 47: Sinteza obrazilne produktivnosti - dodajalni način ob izglasjih podstav (SNBSJ)

\begin{tabular}{|c|c|c|c|c|c|c|c|c|}
\hline \multirow{2}{*}{$\begin{array}{l}\text { IZGLASJE } \\
\text { PODSTAVE }\end{array}$} & \multicolumn{8}{|c|}{ FEMINATIVNO PRIPONSKO OBRAZILO } \\
\hline & $-a$ & $-i c a$ & $-j a$ & -inja & $-k a$ & $-(a r) k a$ & $-e s a$ & SKUPAJ \\
\hline$-d$ & I & 1 & I & I & 2 & I & I & 3 \\
\hline$-f$ & I & I & 1 & 2 & I & I & I & 2 \\
\hline$-g$ & I & I & I & 11 & I & I & I & 11 \\
\hline$-j$ & I & I & I & I & 4 & I & I & 4 \\
\hline$-k$ & I & 2 & I & I & I & 10 & I & 12 \\
\hline$-l$ & I & 1 & 1 & I & 3 & I & I & 4 \\
\hline$-m$ & I & I & 1 & I & 1 & I & I & 1 \\
\hline$-n$ & I & 2 & 3 & I & 4 & I & 1 & 10 \\
\hline$-r$ & 1 & 2 & 1 & 2 & 3 & I & I & 8 \\
\hline$-s$ & 2 & I & I & I & I & I & I & 2 \\
\hline$-t$ & I & l & I & 6 & 3 & I & I & 9 \\
\hline$-v$ & I & I & I & 1 & I & I & I & 1 \\
\hline SKUPAJ & 3 & 8 & 3 & 22 & 20 & 10 & 1 & 67 \\
\hline
\end{tabular}

Nekaj obravnavanih feminativnih priponskih obrazil se lahko dodaja tudi $\mathrm{k}$ izglasju podstave na:

- $\quad-\boldsymbol{d}$ (en primer $\mathrm{z}$-ica iz netvorjene podstave, tj. frendica, ter dva primera $\mathrm{s}$ -ka iz netvorjene oz. zložene podstave, npr. nomadka, presnojedka);

- $\quad f$ (dva feminativa z -inja iz netvorjene in zložene podstave, npr. škofinja, geografinja); 
- $\quad-g$ (11 konkretnih primerov z -inja, med njimi deset iz zloženih podstav, npr. andragoginja, pri enem primeru pa gre za poimenovanje horoskopskega znamenja kozoroginja);

- $\quad-j$ (štirje feminativi s $-k a$ iz netvorjenih podstav, npr. didžejka);

- $-\boldsymbol{k}$ (dve poimenovanji horoskopskih znamenj z -ica, npr. bikica, deset feminativov z -(ar)ka, denimo dietetičarka);

- $-l$ (en feminativ $\mathrm{z}$-ica iz netvorjene podstave, $\mathrm{tj}$. generalica, ter trije primeri s - $k a$ iz sestavljene (npr. supermodelka) oz. netvorjene podstave: konzulka);

- $-\boldsymbol{m}$ (en primer $\mathrm{z}$ Ženskospolskim obrazilom $-k a$ iz netvorjene podstave: abrahamka);

- -n (dva primera z -ja, npr. podžupanja, in trije z -ica iz sestavljene podstave, npr. prodekanica, štirje primeri $\mathrm{s}-k a$ iz sestavljenih in netvorjenih podstav, npr. prodekanka, dekanka, en feminativ $\mathrm{z}$-esa: klovnesa);

- $\quad-\boldsymbol{r}$ (en primer $\mathrm{z}$ - a cimra in dva primera $\mathrm{z}$-ica, npr. rektorica, pri obeh iz netvorjene podstave, trije feminativi $\mathrm{s}-k a$, in to iz sestavljenih ali netvorjenih podstav (npr. supervizorka; majorka), dva konkretna primera z -inja iz zložene in netvorjene podstave, npr. geometrinja; fiziatrinja);

- $\quad-s$ (iz netvorjene podstave dva feminativa z $-a$, npr. bajsa);

- $\quad-\boldsymbol{t}$ (pet primerov s - $k a$ iz netvorjenih podstav, denimo adutka);

- $\quad \boldsymbol{v}$ (eno poimenovanje horoskopskega znamenja z -inja: levinja).

Ponovno opažamo, da se k izglasjem podstav na $-f,-g$ ali $-v$ dodaja samo feminativno priponsko obrazilo -inja, $\mathrm{k}$ izglasjem na $-j,-m$ in $-t$ pa samo $-k a$.

7.1.3.2 Feminativi, nastali $\mathrm{z}$ zamenjavo celotnega ali le izglasnega dela moškospolskega obrazila z ženskospolskim ob isti podstavi

$\mathrm{Na}$ ta način je nastalo 56 primerov feminativov oziroma $35 \%$ izpisanih besed. Ugotavljamo, da jih je večina tvorjena s priponskim obrazilom -ka, to je 30 
primerov ali $54 \%$, preostali feminativi pa so bili tvorjeni z obrazilom -ica (26 primerov ali $46 \%)$.

Grafikon 15: Zamenjevalna feminativna priponska obrazila $v$ SNBSJ

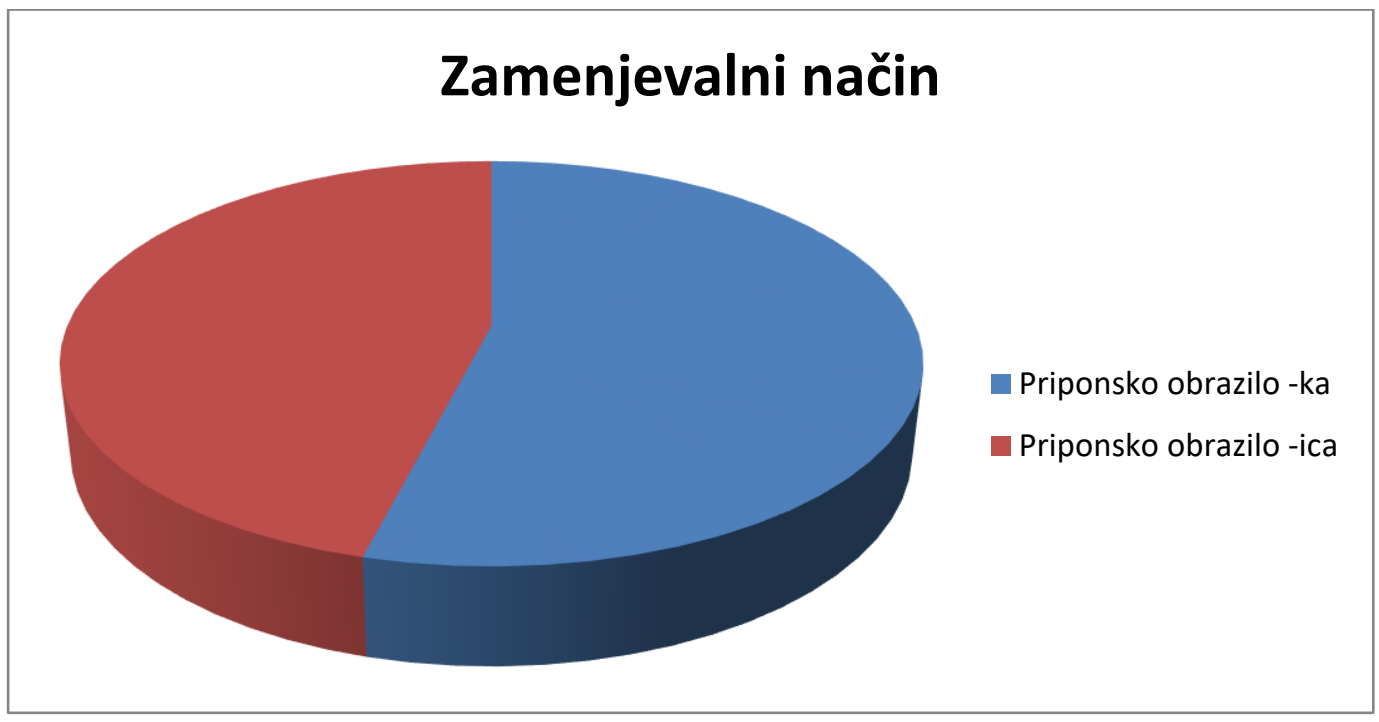

Spodnja preglednica prikazuje, katera moškospolska obrazila lahko feminativna priponska obrazila zamenjujejo pri vršilcu, nosilcu in opravkarju.

Preglednica 48: Zamenjava moškospolskega priponskega obrazila s feminativnim po SNBSJ

\begin{tabular}{|c|c|c|c|c|c|}
\hline \multirow[t]{2}{*}{ OBRAZILO } & \multirow{2}{*}{$\begin{array}{l}\text { OBRAZILO } \\
\text { MOŠKEGA } \\
\text { SPOLA }\end{array}$} & \multirow{2}{*}{$\begin{array}{c}\text { IZGLASJE } \\
\text { PODSTAVE }\end{array}$} & \multicolumn{3}{|c|}{ PRIMERI TVORJENK } \\
\hline & & & $\begin{array}{l}\text { FEMINATIV } \\
\text { IZ VRŠILCA }\end{array}$ & $\begin{array}{l}\text { FEMINATIV } \\
\text { IZ NOSILCA }\end{array}$ & $\begin{array}{l}\text { FEMINATIV IZ } \\
\text { OPRAVKARJA }\end{array}$ \\
\hline \multirow[t]{9}{*}{-ica } & $-e c$ & $-h$ & I & suhica & I \\
\hline & -ček & $-j$ & I & dvojčica & / \\
\hline & & $-n$ & I & dojenčica & I \\
\hline & $-i k$ & $-n$ & I & bančnica & 1 \\
\hline & $-n i k$ & $-b$ & porabnica & I & I \\
\hline & & $-l$ & I & 1 & šolnica \\
\hline & & $-t$ & 1 & stotnica & $/$ \\
\hline & 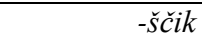 & $-r$ & I & $/$ & naturščica \\
\hline & $-e \check{z}$ & $-n$ & I & obrobnica & / \\
\hline
\end{tabular}




\begin{tabular}{|c|c|c|c|c|c|}
\hline \multirow[t]{10}{*}{$-k a$} & \multirow[t]{4}{*}{$-e c$} & $-j$ & I & I & televizijka \\
\hline & & $-n$ & I & nominiranka & / \\
\hline & & $-r$ & govorka & I & I \\
\hline & & $-v$ & I & alternativka & I \\
\hline & -alec & $-\check{s}$ & vnašalka & 1 & I \\
\hline & -ilec & $-v$ & zdravilka & 1 & I \\
\hline & -inec & $-l$ & / & / & vilinka \\
\hline & -arec & $-t$ & / & I & parlamentarec \\
\hline & \multirow[t]{2}{*}{-ovec } & $-m$ & I & I & abrahamovka \\
\hline & & $-r$ & 1 & 1 & piarovka \\
\hline
\end{tabular}

1. Priponsko obrazilo -ica zamenjuje moškospolska obrazila:

- $\quad$-ec za nosilca lastnosti pri izglasju podstave na $-h$ (suhica);

- - $\check{c} \boldsymbol{e} k$ pri nosilcu, kadar je izglasje podstave na -j (novopomenska podstava: dvojčica) ali -n (dojenčica, tudi pri zloženi podstavi - novorojenčica); pri vseh primerih se -ica doda $\mathrm{k}-\check{c}$, delu moškospolskega obrazila;

- $\quad-i k$ pri nosilcu z izglasjem podstave na -n (bančnica, častnica, družbenica, naložbenica, odvisnica, podjetnica, pohodnica, porabnica, potrošnica, povzpetnica, varnostnica) ter pri zloženih podstavah (naravovarstvenica, okoljevarstvenica, popzvezdnica, videoumetnica);

- -nik pri vršilcu iz glagolov na -iti/-im (porabnica), pri opravkarju (̌̌olnica) in nosilcu (stotnica);

- -ščik pri opravkarju iz prevzete podstave na -r (naturščica);

- $-\boldsymbol{e z ̌ ~ o b ~ n o s i l c u ~ l a s t n o s t i ~} \mathrm{z}$ izglasjem podstave na $-n$ (obrobnica, pokončnica, poslovnica).

2. Obrazilo - $k a$ zamenjuje priponska obrazila:

- $\quad-\quad e c \mathrm{v}$ vseh treh pomenskih skupinah: pri vršilcu iz glagolov na -iti/-im $\mathrm{z}$ izglasjem podstave na $-r$ (govorka), pri opravkarju, kadar je izglasje podstave na $-j$ (radijka, televizijka), ter pri nosilcu z izglasjem na $-l$ 
(genijalka, marginalka), -n (nominiranka) ali -v (alternativka, pozitivka, rekreativka); nastopi tudi pri zloženih (besedilopiska, imenoslovka, krasoslovka, naglasoslovka, narečjeslovka, obramboslovka, plečnikoslovka, psoslovka, samohodka, tekstopiska, varstvoslovka), sestavljenih (biseksualka, neoliberalka, transseksualka) in novopomenskih podstavah (strelka);

- -alec pri vršilcu dejanja iz glagolov na -ati/-am, pri čemer je izglasje podstave na -̌́ (vnašalka);

- -ilec pri vršilcu iz glagolov na -iti/-im, kadar je izglasje podstave na - $v$ (zdravilka);

- $\quad$-inec pri opravkarju z izglasjem podstave na -l (vilinka);

- - arec za opravkarja z izglasjem podstave na -t (parlamentarka);

- -ovec za opravkarja, če je izglasje podstave na -m (abrahamovka) ali -r (piarovka).

\section{Sinteza obrazilne produktivnosti}

Spodnja preglednica prikazuje, katera feminativna priponska obrazila (in v kolikšni meri) zamenjujejo posamezna moškospolska izglasja.

Preglednica 49: Sinteza obrazilne produktivnosti - zamenjevalni način (SNBSJ)

\begin{tabular}{|c|c|c|c|}
\hline \multirow{2}{*}{$\begin{array}{c}\text { MOŠKOSPOLSKO } \\
\text { OBRAZILO }\end{array}$} & \multicolumn{3}{|c|}{ FEMINATIVNO PRIPONSKO OBRAZILO } \\
\hline & $-i c a$ & $-k a$ & SKUPAJ \\
\hline$-e c$ & 1 & 24 & 25 \\
\hline -alec & I & 1 & 1 \\
\hline -ilec & 1 & 1 & 1 \\
\hline -inec & I & 1 & 1 \\
\hline -arec & 1 & 1 & 1 \\
\hline -ovec & I & 2 & 2 \\
\hline$-\check{c} e k$ & 3 & 1 & 3 \\
\hline$-i k$ & 15 & 1 & 15 \\
\hline
\end{tabular}




\begin{tabular}{|l|c|c|c|}
\hline \multicolumn{1}{|c|}{$\begin{array}{c}\text { MOŠKOSPOLSKO } \\
\text { OBRAZILO }\end{array}$} & \multicolumn{3}{|c|}{ FEMINATIVNA PRIPONSKA OBRAZILA } \\
\cline { 2 - 4 } & $-i c a$ & $-k a$ & SKUPAJ \\
\hline$-n i k$ & 3 & $/$ & 1 \\
\hline$-s ̌ c i k$ & 1 & $/$ & 3 \\
\hline$-e \check{z}$ & 3 & $/$ & 56 \\
\hline SKUPAJ & 26 & 30 & 3 \\
\hline
\end{tabular}

Ugotavljamo, da kot zamenjevalni nastopata samo feminativni obrazili -ica in $-k a$, ki lahko zamenjujeta naslednja moškospolska obrazila: -ica zamenjuje -ček pri nosilcu, kadar je izglasje podstave na $-j$ ali - $n$ (oboje potrjeno s po enim primerom nosilca, $-n$ tudi s primerom iz zložene podstave: dvojčica, dojenčica, novorojenčica), -ik pri nosilcu z izglasjem podstave na -n (11 feminativov pri nosilcu, štirje iz zložene podstave: bančnica; popzvezdnica), -nik pri vršilcu, opravkarju in nosilcu (za vse po en primer: porabnica, šolnica, stotnica), -ščik pri opravkarju iz prevzete podstave na -r (ena tvorjenka: naturščica) in -ež ob nosilcu lastnosti z izglasjem podstave na - $n$ (trije feminativi, npr. poslovnica). Priponsko obrazilo - $k a$ pa kot zamenjevalno nastopa pri moškospolskih priponskih obrazilih -alec pri vršilcu dejanja iz glagolov na -ati/-am, pri čemer je izglasje podstave na -š (vnašalka), -ilec pri vršilcu iz glagolov na -iti/-im, kadar je izglasje podstave na - $v$ (ena tvorjenka: zdravilka), -inec pri opravkarju z izglasjem podstave na -l (ena tvorjenka: vilinka), -arec za opravkarja z izglasjem podstave na - $t$ (en primer iz prevzete podstave: parlamentarka), -ovec za opravkarja, če je izglasje podstave na - $m$ ali -r (po en primer iz prevzete podstave: abrahamovka in piarovka).

Moškospolsko obrazilo, ki ga lahko zamenjujeta obe obravnavani feminativni obrazili, je samo -ec: -ica ga zamenja pri nosilcu lastnosti z izglasjem podstave na - $h$ (en primer: suhica), $-k a$ pa ga zamenja pri vršilcu z izglasjem podstave na - $r$ (en primer: govorka) in opravkarju, kadar je izglasje podstave na $-j$ (dva feminativa, npr. radijka), - $l$ (dva primera, denimo genijalka), - $n$ (en primer: nominiranka) ali -v (trije feminativi, med njimi alternativka).

Samo -ica torej zamenjuje moškospolska obrazila -ček, -ik, -nik, -ščik in -ež, kar so pokazali že primeri iz drugih virov, le -ka pa zamenja moškospolska priponska obrazila z izglasno sestavino $-(e) c$. 
Spodnja preglednica pa prikazuje, h katerim izglasjem podstave se feminativna priponska obrazila po zamenjavi moškospolskega obrazila dodajo.

Preglednica 50: Sinteza obrazilne produktivnosti - zamenjevalni način ob moškospolskih izglasjih (SNBSJ)

\begin{tabular}{|c|c|c|c|}
\hline \multirow{2}{*}{$\begin{array}{l}\text { IZGLASJE } \\
\text { PODSTAVE }\end{array}$} & \multicolumn{3}{|c|}{ FEMINATIVNO PRIPONSKO OBRAZILO } \\
\hline & $-i c a$ & $-k a$ & SKUPAJ \\
\hline$-\breve{c}$ & 3 & I & 3 \\
\hline$-d$ & I & 1 & 1 \\
\hline$-\check{s} \breve{c}$ & 1 & I & 1 \\
\hline$-h$ & 1 & I & 1 \\
\hline$-j$ & I & 2 & 2 \\
\hline$-l$ & I & 8 & 8 \\
\hline$-n$ & 21 & 2 & 22 \\
\hline$-r$ & / & 2 & 2 \\
\hline$-s$ & / & 2 & 2 \\
\hline$-v$ & 1 & 13 & 13 \\
\hline SKUPAJ & 26 & 30 & 56 \\
\hline
\end{tabular}

Obravnavana feminativna priponska obrazila se lahko po odvzemu moškospolskega obrazila dodajajo k izglasjem podstav na:

- $\quad-\boldsymbol{d}$ (en feminativ s - $k a$ po zamenjavi obrazila -ec: samohodka);

- - $\check{c}$ (tri primeri z -ica po odvzemu dela moškospolskega obrazila -ček, denimo dojenčica);

- -š̌̌ (en feminativ z -ica po zamenjavi dela moškospolskega obrazila -ščik, tj. naturščica);

- $\boldsymbol{h}$ (en primer tvorbe $\mathrm{z}$-ica po zamenjavi moškospolskega obrazila -ec: suhica);

- $\quad-j$ (dva feminativa s $-k a$ po zamenjavi obrazila $-e c$, npr. televizijka); 
- $\quad-l$ (osem primerov s $-k a$; prišteti so primeri zamenjave obrazil -alec in -ilec, ker gre za zamenjavo obrazilne sestavine -ec in s tem dodajanje $\mathrm{k}-l$, npr. zdravilka);

- -n (največ, tj. 21 primerov z -ica po zamenjavi moškospolskih obrazil -ik in -ež, npr. porabnica; obrobnica, dva feminativa s $-k a$ po zamenjavi obrazila -ec, denimo nominiranka);

- $\quad-\boldsymbol{r}$ (dva feminativa s - $k a$ po odvzemu obrazila -ec, npr. neoliberalka);

- $-s$ (dva primera tvorbe s - $k a$ po zamenjavi moškospolskega obrazila -ec, npr. tekstopiska);

- $\quad-\boldsymbol{v}$ (13 primerov s $-k a$, in to po zamenjavi obrazila -ec, denimo pozitivka).

Tudi primeri iz SNBSJ kažejo, da se k izglasju podstave na $-n$, seveda po odvzemu moškospolskega obrazila, najpogosteje dodaja feminativno obrazilo -ica ( 21 primerov od 25 , torej $80 \%$ ). Obrazilo - $k a$ pa prevladuje, ko gre za dodajanje $\mathrm{k}$ izglasjem podstav na $-v(13$ feminativov od $30 \mathrm{oz} .43 \%)$ in $-l(8$ primerov ali 26 $\%)$.

\subsubsection{Druga izdaja Slovarja slovenskega knjižnega jezika}

S spletne verzije SSKJ 2 smo izpisali izraze, ki v pomenskem delu vsebujejo besedno zvezo ženska (ki) (in ne več ženska oblika od), vendar tako nismo dobili vseh zabeleženih feminativov. Zato smo iskali še $z$ drugimi ključnimi besedami: uslužbenka, pripadnica, pristašinja, samica, delavka, članica, strokovnjakinja, učenka, na koncu pa preverili še geslo ženska. Izpisani feminativi so tvorjeni zgolj iz občnoimenske podstave. Skupaj smo izpisali in analizirali 2229 feminativov, od tega jih je 1193 (53,6\%; v SSKJ 1 pa $56 \%)$ nastalo z zamenjevalnim, 1036 (46,4 \%; v SSKJ 1 nekaj manj, tj. $44 \%$ ) pa z dodajalnim načinom. 
Grafikon 16: Feminativi v SSKJ 2 glede na način tvorbe

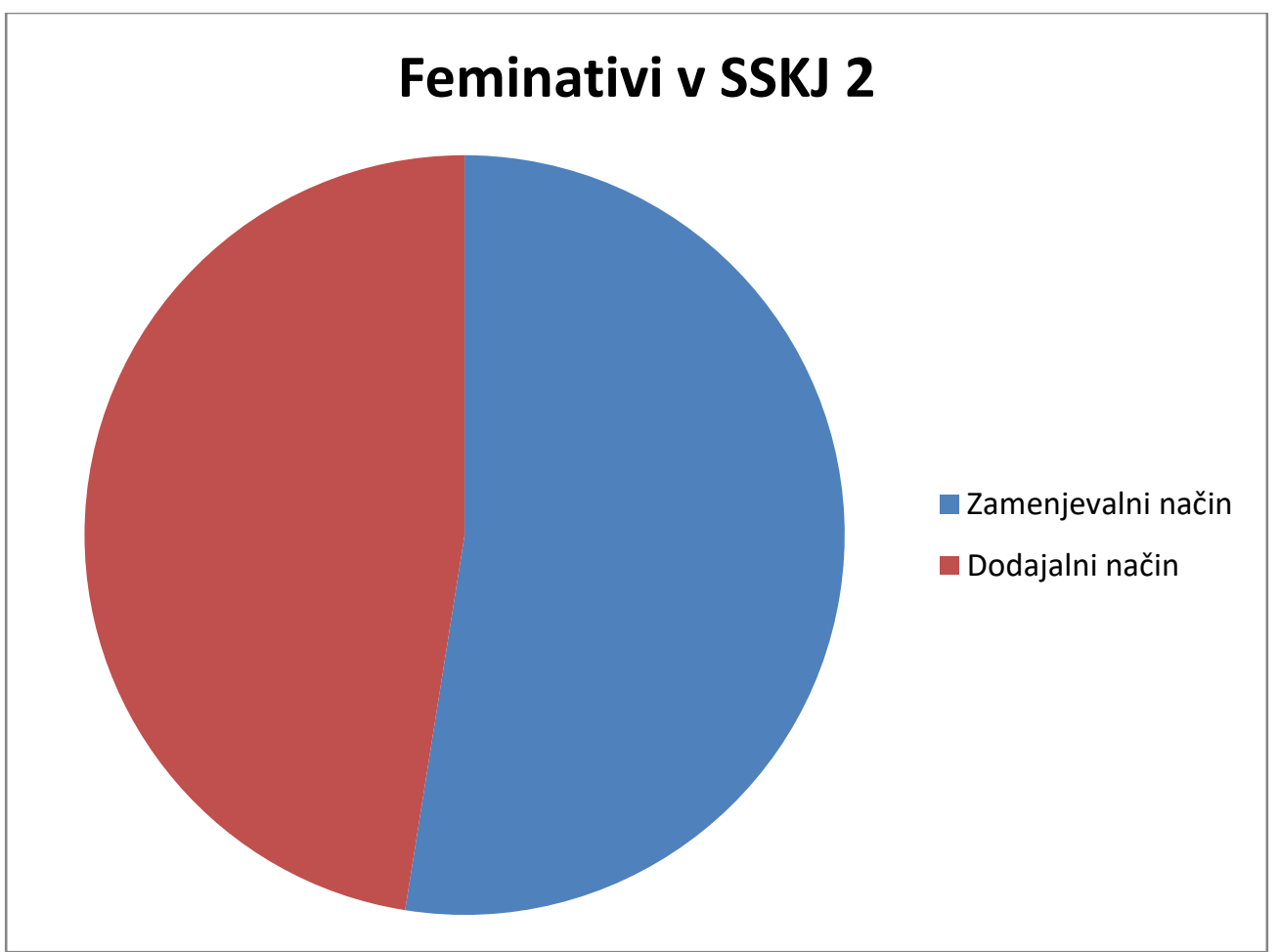

V primerjavi s Slovensko slovnico (2004) so nova feminativna priponska obrazila -(ar)ica, -kinja, -(ar)ka, -(ev)ka in -esa (ni sprememb glede na SSKJ 1).

Preglednica 51: Primerjalni pregled feminativnih priponskih obrazil (SS in SSKJ 2)

\begin{tabular}{|c|c|}
\hline Slovenska slovnica (2004) & SSKJ 2 \\
\hline$-a$ & $-a$ \\
\hline$-i c a$ & $-i c a$ \\
\hline$-j a$ & $-j a$ \\
\hline$-u l j a$ & $-u l j a$ \\
\hline$-i n j a$ & $-i n j a$ \\
\hline$-k a$ & $-k a$ \\
\hline$-o v k a$ & $-($ ov $) k a$ \\
\hline$-i c ̌ n a$ & $-n a$ \\
\hline & $-($ ar $) i c a$ \\
\hline
\end{tabular}




\begin{tabular}{|l|c|}
\hline Slovenska slovnica (2004) & SSKJ 2 \\
\hline & $-(a r) k a$ \\
\hline & $-e s a$ \\
\hline & $-(e v) k a$ \\
\hline & $-k i n j a$ \\
\hline
\end{tabular}

7.1.4.1 Feminativi, nastali $\mathrm{z}$ zamenjavo celotnega ali le izglasnega dela moškospolskega obrazila z ženskospolskim ob isti podstavi

Gre za večinski, 53,6-odstotni delež feminativov, izpisanih iz SSKJ 2. 732 besed (61\%) je nastalo s priponskim obrazilom -ka, $440(37 \%) \mathrm{z}$-ica, osem feminativov s -kinja $(0,7 \%)$, pet $(0,4 \%) \mathrm{z}$-ulja, pet primerov $(0,4 \%) \mathrm{z}$-inja, dva $(0,2 \%) \mathrm{z}-j a$ ter eden $\mathrm{z}-($ ar $)$ ica.

Grafikon 17: Zamenjevalna feminativna priponska obrazila v SSKJ 2

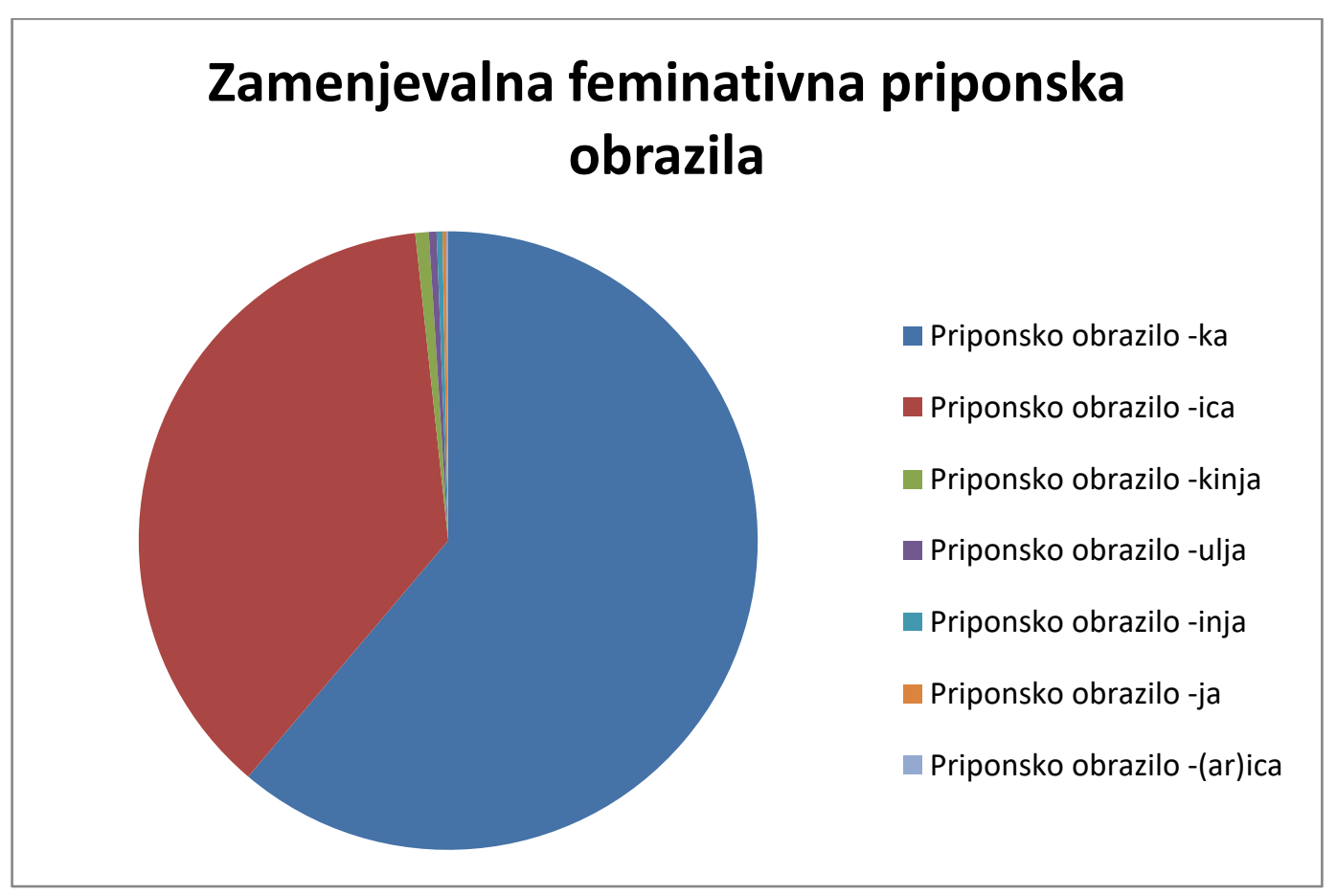

Ugotavljamo, da eno priponsko obrazilo nastopa samo kot zamenjevalno, to je obrazilo -kinja (s primeri, enakimi kot v prvi izdaji slovarja: delovodkinja, 
knjigovodkinja, pevovodkinja, plemkinja, poslovodkinja, računovodkinja, vidkinja, zborovodkinja).

Spodnja preglednica prikazuje moškospolska obrazila, ki jih ta feminativna priponska obrazila zamenjujejo.

Preglednica 52: Zamenjava moškospolskih priponskih obrazil s feminativnimi $v$ SSKJ 2

\begin{tabular}{|c|c|c|c|c|c|}
\hline \multirow[t]{2}{*}{ OBRAZILO } & \multirow{2}{*}{$\begin{array}{l}\text { OBRAZILO } \\
\text { MOŠKEGA } \\
\text { SPOLA }\end{array}$} & \multirow{2}{*}{$\begin{array}{c}\text { IZGLASJE } \\
\text { PODSTAVE }\end{array}$} & \multicolumn{3}{|c|}{ PRIMERI TVORJENK } \\
\hline & & & $\begin{array}{l}\text { FEMINATIV } \\
\text { IZ VRŠILCA }\end{array}$ & $\begin{array}{l}\text { FEMINATIV } \\
\text { IZ NOSILCA }\end{array}$ & $\begin{array}{l}\text { FEMINATIV IZ } \\
\text { OPRAVKARJA }\end{array}$ \\
\hline \multirow[t]{28}{*}{$-i c a$} & \multirow[t]{13}{*}{$-e c$} & $-d$ & predica & I & I \\
\hline & & $-g$ & I & ubožica & I \\
\hline & & $-h$ & / & suhica & I \\
\hline & & $-n j$ & žanjica & I & I \\
\hline & & $-l$ & I & došlica & I \\
\hline & & $-m$ & tekmica & samica & I \\
\hline & & $-n$ & I & mučenica & I \\
\hline & & $-p$ & I & slepica & I \\
\hline & & $-r$ & I & norica & I \\
\hline & & $-s$ & kosica & I & / \\
\hline & & $-t$ & I & I & krasotica \\
\hline & & $-v$ & lovica & jalovica & I \\
\hline & & $-z$ & molzica & I & I \\
\hline & $-a \check{c}$ & $-l j$ & grabljica & I & I \\
\hline & $-e k$ & $-l$ & / & prišlica & / \\
\hline & \multirow[t]{3}{*}{-ček } & $-b$ & / & ljubica & I \\
\hline & & $-j$ & I & dvojčica & I \\
\hline & & $-l$ & I & malčica & palčica \\
\hline & \multirow[t]{2}{*}{$-i k$} & $-n j$ & I & prednjica & prošnjica \\
\hline & & $-n$ & pesnica & odvisnica & blagajnica \\
\hline & \multirow[t]{8}{*}{$-n i k$} & $-b$ & porabnica & I & I \\
\hline & & $-c$ & I & I & miličnica \\
\hline & & $\overline{-\breve{c}}$ & poročnica & I & I \\
\hline & & $-\check{S \check{C} \breve{c}}$ & I & I & učiteljiščnica \\
\hline & & $-d$ & brodnica & I & I \\
\hline & & $-j$ & I & I & naraščajnica \\
\hline & & $-l j$ & poveljnica & I & I \\
\hline & & $-l$ & I & I & šolnica \\
\hline
\end{tabular}




\begin{tabular}{|c|c|c|c|c|c|}
\hline & & $-p$ & upnica & I & / \\
\hline & & $-r$ & coprnica & / & pripornica \\
\hline & & $-S$ & vpisnica & I & / \\
\hline & & $-t$ & zapustnica & varnostnica & tapetnica \\
\hline & & $-v$ & prebolevnica & $/$ & I \\
\hline & & $-z$ & paznica & I & I \\
\hline & & $-\check{z}$ & pritožnica & I & / \\
\hline & $-i n$ & $-\check{c}$ & I & domačica & I \\
\hline & $-e \check{z}$ & $-l$ & I & podlica & 1 \\
\hline & & $-n$ & I & dobrodelnica & 1 \\
\hline & & $-v$ & I & revica & I \\
\hline$-j a$ & -ilec & $-t$ & pletilja & I & I \\
\hline & & $-z$ & vezilja & I & I \\
\hline -ulja & $-a \check{c}$ & $-d$ & gobezdulja & I & I \\
\hline & & $-k$ & jezikulja & I & I \\
\hline & $-u h$ & $-d$ & smrdulja & I & I \\
\hline & & $-p$ & 1 & skopulja & / \\
\hline & $-a v s$ & $-n$ & I & črnulja & $/$ \\
\hline -inja & $-a$ & $-g$ & sluginja & I & I \\
\hline & $-i \check{c}$ & $-d$ & dedinja & I & I \\
\hline & $-a r$ & $-k$ & I & I & pametnjakinja \\
\hline -kinja & $-e c$ & $-d$ & vidkinja & I & / \\
\hline & $-i \check{c}$ & $-m$ & I & I & plemkinja \\
\hline$-k a$ & $-e c$ & $-b$ & I & bebka & I \\
\hline & & $-d$ & telovadka & sladkosnedka & / \\
\hline & & $-j$ & I & tujka & televizijka \\
\hline & & $-l j$ & I & I & vesoljka \\
\hline & & $-l$ & 1 & marginalka & kriminalka \\
\hline & & $-m$ & ljubimka & nemka & / \\
\hline & & $-n$ & svetohlinka & navdušenka & vegetarijanka \\
\hline & & $-p$ & tihotapka & slepka & tepka \\
\hline & & $-r$ & govorka & starka & I \\
\hline & & $-s$ & / & kratkolaska & I \\
\hline & & $-t$ & bosopetka & I & I \\
\hline & & $-v$ & lovka & tožljivka & skušnjavka \\
\hline & -alec & $-b$ & oskrbovalka & I & / \\
\hline & & $-\check{c}$ & izločevalka & I & I \\
\hline & & $-\check{s} \check{c}$ & izkoriščevalka & I & / \\
\hline & & $-d$ & pregledovalka & I & I \\
\hline & & $-g$ & negovalka & 1 & 1 \\
\hline & & $-h$ & navdihovalka & 1 & / \\
\hline
\end{tabular}




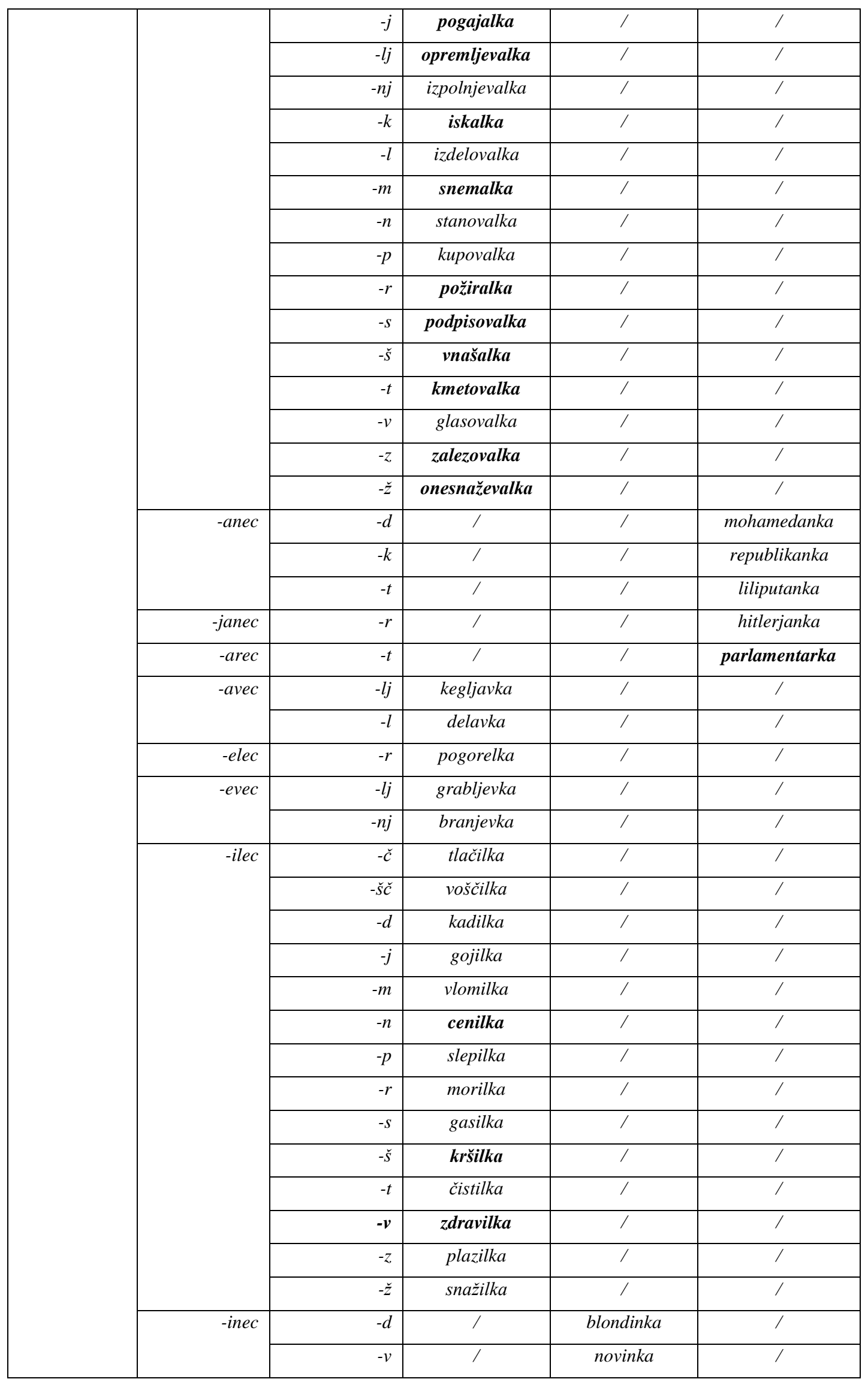




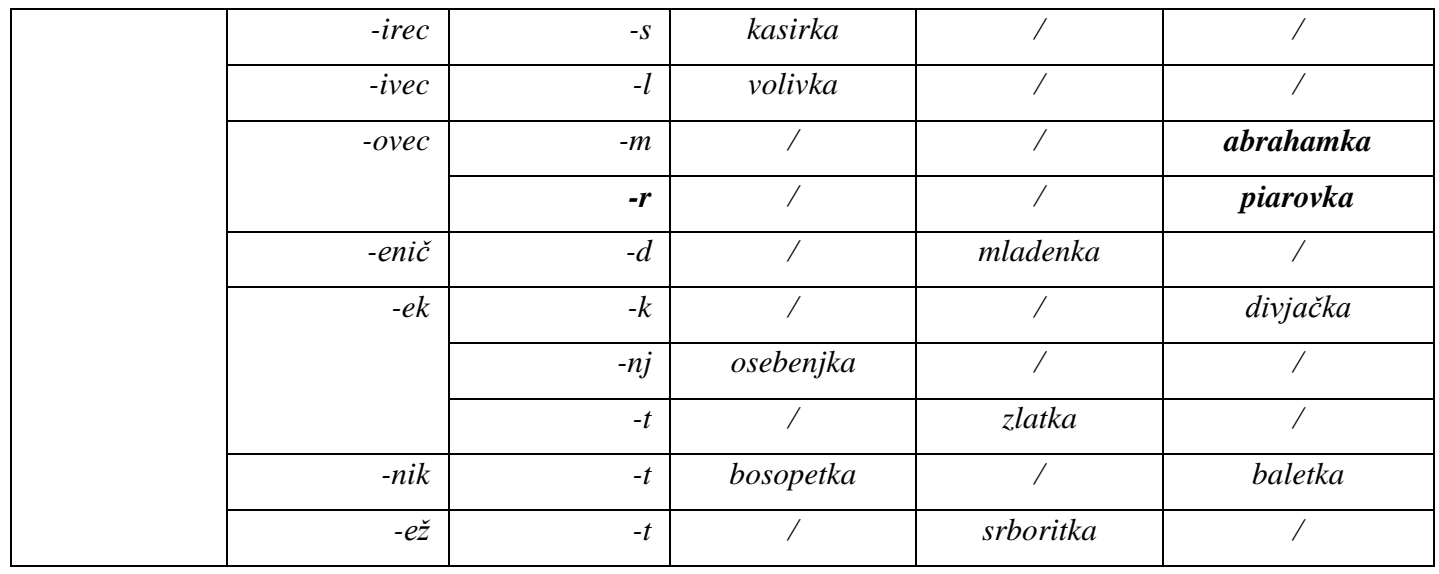

1. V primerjavi s SSKJ 1 so novi primeri zamenjav obrazila -ica $\mathrm{z}$ moškospolskimi obrazili:

- $\quad$ ec za vršilca iz glagolov na -iti/-im z izglasjem podstave na -s (kosica) in pri nosilcu lastnosti, kadar je izglasje podstave na - $h$ (suhica);

- - -ik za nosilca lastnosti na -n (21 primerov: bančnica, častnica, estradnica, finančnica, folklornica, gospodarstvenica, kongresnica, mirovnica, obrobnica, odpadnica, odvisnica, okoljevarstvenica, podložnica, pokončnica, poslovnica, potrošnica, povzpetnica, protestnica, varnostnica, vinogradnica, župnica), tudi pri zloženkah (videoumetnica);

- $\quad$-nik pri vršilcu dejanja iz glagolov na -ati/-am pri izglasju podstave na - č (poročnica), -iti/-im z izglasjem podstave na $-b$ (porabnica), - $t$ (zapustnica), -ž (pritožnica), -ovati/-ujem ob izglasju podstave na $-s$ (vpisnica) in pri opravkarju z izglasji podstave na $-l$ (šolnica) in -r (pripornica), tudi pri sestavljenkah (sourednica), zloženkah (prvokategornica);

- $\quad$ ež pri nosilcu z izglasjem podstave na -n (dobrodelnica, obrobnica).

2. Obrazilo $-\boldsymbol{k} \boldsymbol{a}$ zamenjuje moškospolska priponska obrazila (obravnavamo samo novosti glede na SSKJ 1):

- $\quad$ ec pri vršilcu iz glagolov na -iti/-im z izglasjem podstave na -r (govorka), pri nosilcu lastnosti z izglasjem podstave na -l (genialka, marginalka), -n (gostinka, intervjuvanka, navdušenka, nominiranka, osmoljenka, razgaljenka, zasvojenka), -s (kratkolaska), -v (alternativka, konservativka, 
negativka, oskarjevka, pozitivka, rekreativka, tožljivka) in pri opravkarju z izglasjem podstave na $-j$ (radijka, televizijka) in -n (vegetarijanka), tudi pri zloženkah (besedilopiska, domorodka, imenoslovka, krasoslovka, naglasoslovka, narečjeslovka, obramboslovka, očividka, osnovnošolka, ostrostrelka, presnojedka, samohodka, tekstopiska, varstvoslovka, vremenoslovka);

- -alec za vršilca dejanja iz glagolov na -ati/-am pri izglasju podstave na -j (pogajalka), -lj (opremljevalka), -m (posnemovalka, snemalka, sprejemalka), -r (požiralka), -š (vnašalka), -ati/-em ob izglasju podstave na -k (iskalka), na -ovati/-ujem z izglasjem podstave na - $d$ (pregledovalka, zasledovalka), -s (podpisovalka, zapisovalka), -t (kmetovalka, načrtovalka), -z (zalezovalka), na -evati/-ujem z izglasjem podstave na -j (spodbujevalka), -š (pospeševalka), -ž (onesnaževalka); zasledili smo tudi primere tvorbe pri sestavljeni (biseksualka) in zloženi osnovi (davkoplačevalka);

- -ilec pri vršilcu iz glagolov na -iti/-im z izglasjem podstave na -n (cenilka, plenilka), $-\check{s}(k r s ̌ i l k a)$ in $-v$ (zdravilka), nastopi tudi pri zloženkah (pravobranilka);

- $\quad$ - arec za opravkarja iz prevzete podstave na -t (parlamentarka);

- -ovec za opravkarja iz prevzete podstave na $-m$ (abrahamka, abrahamovka) ali -r (piarovka).

Ugotavljamo, da pri priponskih obrazilih -(ar)ica, -ja, -ulja, -inja, -kinja kot zamenjevalnih SSKJ 2 novih primerov feminativov ne ponuja.

Analiza kaže, da se znova za vse tri prve pomenske skupine izpeljank iz glagolske, pridevniške in samostalniške podstave, torej za vršilca, nosilca in opravkarja, pojavita obrazili -ec pri zamenjevalnih obrazilih -ica in -ka ter -nik pri zamenjevalnem obrazilu -ica.

\section{Sinteza obrazilne produktivnosti}


Spodnja preglednica prikazuje, katera feminativna priponska obrazila (in v kolikšni meri) zamenjujejo posamezna moškospolska obrazila.

Preglednica 53: Sinteza obrazilne produktivnosti-zamenjevalni način (SSKJ 2)

\begin{tabular}{|c|c|c|c|c|c|c|c|c|}
\hline \multirow{2}{*}{$\begin{array}{l}\text { MOŠKOSPOLSKO } \\
\text { OBRAZILO }\end{array}$} & \multicolumn{8}{|c|}{ FEMINATIVNO PRIPONSKO OBRAZILO } \\
\hline & -ica & -(ar)ica & $-j a$ & -ulja & -inja & -kinja & $-k a$ & SKUPAJ \\
\hline$-a$ & 1 & 1 & / & / & 3 & / & I & 5 \\
\hline$-j a$ & I & / & / & / & / & 6 & / & 6 \\
\hline$-e c$ & $20(2)$ & / & / & / & / & 1 & $\begin{array}{l}442 \\
(36)\end{array}$ & $463(38)$ \\
\hline -alec & l & I & / & I & 1 & 1 & $\begin{array}{l}201 \\
(\mathbf{2 0})\end{array}$ & $201(\mathbf{2 0})$ \\
\hline -anec & 1 & 1 & I & I & I & I & 4 & 4 \\
\hline -janec & I & 1 & 1 & 1 & 1 & 1 & 1 & 1 \\
\hline -arec & I & 1 & I & I & I & 1 & $2(1)$ & $2(1)$ \\
\hline -avec & 1 & 1 & 1 & 1 & 1 & 1 & 15 & 15 \\
\hline -elec & 1 & 1 & 1 & 1 & I & 1 & 1 & 1 \\
\hline -enec & I & 1 & I & I & I & I & 1 & 1 \\
\hline -evec & 1 & 1 & 1 & 1 & 1 & 1 & 2 & 2 \\
\hline -ilec & 1 & 1 & 2 & 1 & 1 & 1 & $37(5)$ & $39(5)$ \\
\hline -inec & 1 & 1 & 1 & 1 & 1 & 1 & 2 & 2 \\
\hline -irec & I & I & I & I & I & I & 1 & 1 \\
\hline$-v e c$ & I & 1 & 1 & 1 & I & 1 & 3 & 3 \\
\hline -ivec & I & I & I & I & I & I & 3 & 3 \\
\hline -ovec & I & 1 & I & I & I & I & 7 (3) & $7(3)$ \\
\hline$-a \check{c}$ & 1 & 1 & 1 & 2 & I & 1 & 1 & 3 \\
\hline$-i \check{c}$ & I & I & I & I & 1 & 1 & I & 2 \\
\hline -enič & 1 & 1 & I & I & I & 1 & 1 & 1 \\
\hline$-u h$ & I & 1 & 1 & 2 & I & 1 & 1 & 2 \\
\hline$-e k$ & 1 & I & I & I & I & I & 7 & 8 \\
\hline$-\check{c} e k$ & 4 & 1 & I & 1 & 1 & I & 1 & 4 \\
\hline$-i k$ & $\begin{array}{c}299 \\
(\mathbf{2 2})^{89}\end{array}$ & 1 & I & I & I & 1 & 1 & $299(\mathbf{2 2})$ \\
\hline$-n i k$ & 77 (9) & I & I & I & I & I & 2 & 79 (9) \\
\hline$-i n$ & 1 & I & I & I & I & I & I & 1 \\
\hline
\end{tabular}

${ }^{89}$ Všteti so tudi primeri, ko kot vzporedno moškospolsko priponsko obrazilo nastopa $-e \check{\text { ž }}$ 


\begin{tabular}{|r|c|c|c|c|c|c|c|c|}
\hline $\begin{array}{l}\text { MOŠKOSPOLSKO } \\
\text { OBRAZILO }\end{array}$ & \multicolumn{7}{|c|}{ FEMINATIVNA PRIPONSKA OBRAZILA } \\
\cline { 2 - 10 } & - -ica & $-(a r) i c a$ & $-j a$ & - ulja & - -inja & - -inja & $-k a$ & SKUPAJ \\
\hline$-a r$ & $/$ & $/$ & $/$ & $/$ & 1 & $/$ & $/$ & 1 \\
\hline$-a v s$ & $/$ & $/$ & $/$ & 1 & $/$ & $/$ & $/$ & 1 \\
\hline$-\boldsymbol{e z z}$ & $\begin{array}{c}109 \\
(\mathbf{2})^{\mathbf{9 0}}\end{array}$ & $/$ & $/$ & $/$ & $/$ & $/$ & 1 & $110(\mathbf{2})$ \\
\hline SKUPAJ & $\begin{array}{c}513^{91} \\
(\mathbf{3 5})\end{array}$ & 1 & 2 & 5 & 5 & 8 & $\begin{array}{c}733^{92} \\
(\mathbf{6 5})\end{array}$ & $1267(\mathbf{1 0 0})$ \\
\hline
\end{tabular}

Analiza je pokazala, da so moškospolska obrazila, ki jih feminativna priponska obrazila zamenjujejo, naslednja (če upoštevamo zgolj primere, ki jih ni v SSKJ 1):

- $\quad$-ec pri izglasjih podstav na - $h$ (en primer z -ica pri nosilcu: suhica), -j (dva feminativa s $-k a$ pri opravkarju, npr. radijka), $-l$ (dva primera s $-k a$ pri nosilcu, npr. genialka), - $n$ (šest primerov $\mathrm{v}$ pomenski skupini nosilec, denimo nominiranka, in eden pri opravkarju vegetarijanka, $\mathrm{v}$ vseh primerih s $-k a$ ), $-r$ (en primer s $-k a$ pri vršilcu iz glagolskih podstav na -iti/-im: govorka), -s (en feminativ z -ica pri vršilcu kosica in eden s -ka pri nosilcu kratkolaska), $-v$ (šest primerov $\mathrm{s}-k a$ pri nosilcu, npr. negativka); tudi pri zloženih in sestavljenih podstavah;

- -alec, kadar je izglasje podstave na - $d$ (dve tvorjenki s - $k a$ pri vršilcu, npr. zasledovalka), -j (dva feminativa s - $k a$ pri vršilcu, denimo pogajalka), - $k$ (en primer s -ka: iskalka), -lj (en feminativ s -ka: opremljevalka), -m (tri tvorjenke s -ka, npr. snemalka), -r (en primer s -ka: požiralka), -s (dva feminativa $\mathrm{s}-k a$, npr. zapisovalka), $-\check{s}$ (dva primera $\mathrm{s}-k a$, npr. pospeševalka), -t (dve tvorjenki s -ka, denimo kmetovalka), -z (en primer s -ka: zalezovalka) in -ž (en primer s -ka: onesnaževalka) pri vršilcu;

- -ilec pri vršilcu, če je izglasje podstave na -n (dva feminativa s - $k a$, npr. cenilka), -̌̌ (en primer s -ka: kršilka), -v (en feminativ s -ka: zdravilka);

\footnotetext{
${ }^{90}$ Všteti so tudi primeri, ko kot vzporedno moškospolsko priponsko obrazilo nastopa -ik.

${ }^{91} \mathrm{~V}$ začetku poglavja (str. 245) smo zapisali, da je z obrazilom -ica tvorjenih 440 feminativov. Skupno število tvorjenk v preglednici je višje, ker smo pri obrazilih -ik in -ež šteli 72 primerov, ki so lahko tvorjeni z obema moškospolskima obraziloma, prav tako smo dvakrat šteli primer mučenica (iz mučenec ali mučenik).

${ }^{92}$ Dvakrat smo šteli primer bosopetka (iz bosopetec in bosopetnik).
} 
- $\quad$ - arec pri opravkarju, če je izglasje podstave na - $t$ (le en feminativ s - $k a$ : parlamentarka);

- -ovec pri izglasju podstave na $-m$ (dva primera $\mathrm{v}$ pomenski skupini opravkar, npr. abrahamka), -r (en feminativ pri opravkarju: piarovka);

- $-i k$ pri izglasjih podstav na $-n$ (21 tvorjenk $\mathrm{z}-i c a$ v pomenski skupini nosilec, npr. častnica, en primer iz zložene podstave: videoumetnica);

- -nik ob podstavah na -b (en primer z -ica: porabnica) in - č (en primer z -ica: poročnica) pri vršilcu, -l (en primer z -ica: šolnica), - $r$ (en primer z -ica: pripornica) in -s (en feminativ z -ica: vpisnica) pri opravkarju, -t (en primer $\mathrm{z}$-ica pri vršilcu: zapustnica), -ž (en primer $\mathrm{z}-i c a$ v pomenski skupini vršilec: pritožnica);

- $-e \check{z}$ pri nosilcu, če je izglasje podstave na $-n$ (dva primera $\mathrm{z}$-ica, npr. obrobnica).

V primerjavi s $S S K J 1$ pri zamenjevalnem načinu tvorbe feminativov ni novosti: feminativno obrazilo $-k a \mathrm{v}$ glavnem zamenjuje moškospolska obrazila $\mathrm{s}$ sestavino -ec, -ica pa prevladuje pri zamenjavi moškospolskih priponskih obrazil $-i k,-n i k$ in $-e \check{z}$.

\section{Sinteza obrazilne produktivnosti - dodajanje k izglasju podstave}

Spodnja preglednica prikazuje, $\mathrm{h}$ katerim izglasjem (podstave ali obrazila) se feminativna priponska obrazila po zamenjavi moškospolskega obrazila dodajo. Vključena je tvorba iz netvorjenih, izpeljanih, zloženih in sestavljenih podstav, zajeli pa smo primere iz obeh izdaj SSKJ (s krepkim tiskom so navedeni tisti iz druge izdaje). 
Preglednica 54: Sinteza obrazilne produktivnosti - zamenjevalni način ob moškospolskih izglasjih (SSKJ 2)

\begin{tabular}{|c|c|c|c|c|c|c|c|c|}
\hline \multirow{2}{*}{$\begin{array}{c}\text { IZGLASJE } \\
\text { PODSTAVE }\end{array}$} & \multicolumn{8}{|c|}{ FEMINATIVNA PRIPONSKA OBRAZILA } \\
\hline & $-(a r) i c a$ & -ica & $-j a$ & -inja & -kinja & -ulja & $-k a$ & SKUPAJ \\
\hline$-b$ & l & 1 & / & l & / & / & 1 & 2 \\
\hline$\overline{-c \breve{c}}$ & l & 4 & / & l & / & l & 1 & 5 \\
\hline$-d$ & 1 & 1 & / & 2 & 7 & 2 & $13(4)$ & $26(4)$ \\
\hline$-g$ & / & 4 & / & 2 & 1 & 1 & I & 6 \\
\hline$-h$ & I & 1 & I & 1 & I & 1 & 1 & 1 \\
\hline$-j$ & I & I & I & I & I & I & $11(2)$ & $11(2)$ \\
\hline$-l j$ & I & 1 & I & I & I & 1 & 2 & 3 \\
\hline$-n j$ & I & 4 & I & I & I & I & 1 & 5 \\
\hline$-k$ & I & I & I & 1 & I & 1 & 3 & 5 \\
\hline$-l$ & 1 & 3 & 2 & 1 & 1 & I & $\begin{array}{l}277 \\
(29) \\
\end{array}$ & 282 (29) \\
\hline$-m$ & I & 2 & I & I & 1 & I & $9(1)$ & $12(\mathbf{1})$ \\
\hline$-n$ & I & $\begin{array}{l}408 \\
\mathbf{( 3 3 )} \\
\end{array}$ & I & I & 1 & 1 & $212(8)$ & $621(41)$ \\
\hline$-p$ & I & 1 & 1 & I & I & 1 & 5 & 7 \\
\hline$-r$ & I & 2 & I & I & I & I & $20(2)$ & $22(2)$ \\
\hline$-S$ & I & 1 & I & I & I & I & $20(3)$ & $21(4)$ \\
\hline$-\check{S}$ & I & I & I & I & I & I & 1 & 1 \\
\hline$-t$ & 1 & 2 & 1 & 1 & I & I & 7 & 9 \\
\hline$-v$ & 1 & 4 & I & 1 & I & I & $\begin{array}{l}148 \\
(\mathbf{1 6})\end{array}$ & $152(16)$ \\
\hline$-z$ & I & 1 & I & I & I & I & 1 & 2 \\
\hline SKUPAJ & 1 & $\begin{array}{l}440 \\
\text { (35) }\end{array}$ & 2 & 5 & 8 & 5 & $\begin{array}{l}732 \\
(\mathbf{6 5})\end{array}$ & $1193(\mathbf{1 0 0})$ \\
\hline
\end{tabular}

Obravnavana feminativna priponska obrazila se lahko po odvzemu moškospolskega obrazila dodajajo k izglasjem na:

- $\quad-\boldsymbol{d}$ (štirje primeri s - $k a$ po odvzemu obrazila -ec, npr. presnojedka);

- $\quad \boldsymbol{h}$ (en primer z -ica po zamenjavi obrazila -ec: suhica);

- $\quad-j$ (dva feminativa s $-k a$ po odvzemu obrazila -ec, npr. radijka); 
- $\quad-\quad l$ (29 primerov s - $k a$; prišteti so primeri zamenjave obrazil -alec, -elec in -ilec, ker gre za zamenjavo obrazilne sestavine -ec in s tem dodajanje $\mathrm{k}-l$, denimo požiralka, cenilka);

- $-\boldsymbol{n}$ (največ, tj. 33 primerov z -ica po zamenjavi moškospolskih obrazil -ik in -ež, npr. mirovnica; dobrodelnica, osem feminativov s -ka po zamenjavi obrazila -ec, denimo razgaljenka);

- $\quad-r$ (dva primera s -ka po zamenjavi obrazila -ec, npr. govorka);

- $-s$ (en feminativ, tvorjen z obrazilom -ica kosica, in trije tvorjeni s -ka, npr. tekstopiska, pri obeh po zamenjavi moškospolskega obrazila -ec);

- $-\boldsymbol{v}$ (18 primerov s $-k a$, in to po zamenjavi obrazila (ali njegovega dela) -ec, npr. krasoslovka).

Kot zamenjevalni feminativni priponski obrazili tudi v SSKJ 2 najpogosteje nastopata $-i c a$ in $-k a$. S feminativnim obrazilom $-k a$ je skupno tvorjenih 732 feminativov (61 \%); med njimi gre po zamenjavi moškospolskega obrazila -ec največkrat za dodajanje k izglasjem na - $v$ (148 primerov ali $20 \%)$, - $n$ (212 primerov oz. $29 \%$ ) ali na - $l$ (277 feminativov ali $38 \%$ ). Obrazilo -ica tvori 440 feminativov (37\%); po zamenjavi moškospolskih priponskih obrazil -ik ali -ež se najpogosteje dodaja k izglasjem na - $n$ (408 primerov ali $93 \%$ ).

7.1.4.2 Feminativi, nastali $\mathrm{z}$ dodajanjem ženskospolskega obrazila tvorjenkam moškega spola

Taki feminativi obsegajo 46,4 \% vseh iz SSKJ 2 izpisanih tvorjenk. Med njimi jih je bilo 590 (57 \%) tvorjenih z obrazilom - $k a, 237$ (23\%) z -ica, 145 (14 \%) z -inja, štirinajst $(1,3 \%) \mathrm{z}-a$, šest $(0,6 \%) \mathrm{z}-n a$, po štiri $(0,4 \%) \mathrm{z}-$ ja in -esa, dve $(0,2 \%)$ z -ulja. Kot variante obrazil so se pojavila -(ar)ka s 26 feminativi $(2,5$ $\%)$, -(ev)ka s tremi $(0,3 \%),-(o v) k a$ s štirimi primeri $(0,4 \%)$ in -(ar)ica $\mathrm{z}$ enim primerom. 


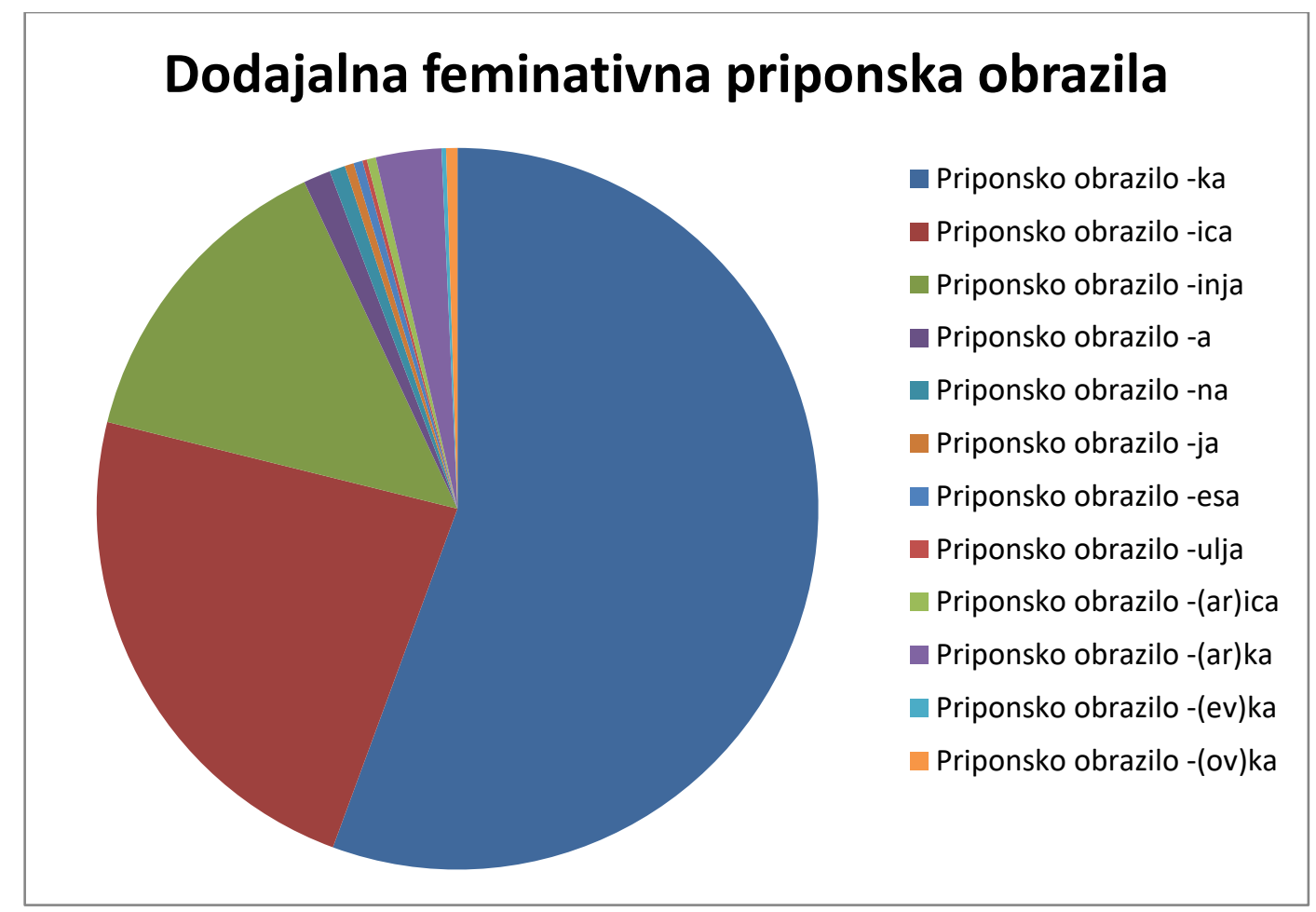

Opažamo, da priponska obrazila -a (bajsa, botra, debeluha, glavana, gostača, lovača, magistra, prfoksa, prismuka, smrduha, soseda, sužnja, trapa, zaletela), -(ar)ka (akademičarka, alkoholičarka, analitičarka, anoreksičarka, astmatičarka, bioenergetičarka, botaničarka, bulimičarka, deloholičarka, diabetičarka, dietetičarka, dramatičarka, fizičarka, higieničarka, kemičarka, komičarka, kritičarka, kozmetičarka, metodičarka, političarka, praktičarka, psihoanalitičarka, razredničarka, teoretičarka, tetraplegičarka, tonematičarka), -(ev)ka (hudičevka, zlodejevka), -(ov)ka (mojstrovka, pekovka, škratovka, vragovka, židovka), -esa (klovnesa, poetesa, princesa, stevardesa) in -na (bratična, cesarična, dedična, gospodična, grofična, kraljična, sestrična, strnična) nastopajo zgolj kot dodajalna.

Spodnja preglednica prikazuje, s katerimi izglasji moškospolskih obrazil se ta obrazila družijo, pri čemer smo zajeli vse tri prve pomenske skupine izpeljank iz glagolske, pridevniške in samostalniške podstave. ${ }^{93}$

\footnotetext{
${ }^{93}$ Novi primeri (glede na SSKJ 1) so označeni s krepkim tiskom.
} 
Preglednica 55: Družljivost feminativnih priponskih obrazil $z$ izglasji moškospolskih poimenovanj $v$ SSKJ 2

\begin{tabular}{|c|c|c|c|c|}
\hline \multirow[t]{2}{*}{ OBRAZILO } & \multirow{2}{*}{$\begin{array}{l}\text { IZGLASJE } \\
\text { OBRAZILA }\end{array}$} & \multicolumn{3}{|c|}{ PRIMERI TVORJENK } \\
\hline & & $\begin{array}{c}\text { FEMINATIV IZ } \\
\text { VRŠILCA }\end{array}$ & $\begin{array}{c}\text { FEMINATIV IZ } \\
\text { NOSILCA }\end{array}$ & $\begin{array}{l}\text { FEMINATIV IZ } \\
\text { OPRAVKARJA }\end{array}$ \\
\hline \multirow[t]{5}{*}{$-a$} & $-(a) \check{c}$ & gostača & l & / \\
\hline & $-(u) h$ & smrduha & debeluha & / \\
\hline & $-(u) k$ & I & prismuka & I \\
\hline & $-(e) l$ & zaletela & / & I \\
\hline & $-(a) n$ & / & / & glavana \\
\hline \multirow[t]{11}{*}{$-i c a$} & $-(a) \check{c}$ & navijačica & / & tenisačica \\
\hline & $-($ ate $) l j$ & pošiljateljica & / & / \\
\hline & $-($ ite $) l j$ & utemeljiteljica & / & pokroviteljica \\
\hline & $-(j a) n$ & $/$ & $/$ & dvorjanica \\
\hline & $-(a) r$ & čuvarica & / & davkarica \\
\hline & $-(e) r$ & / & / & pankerica \\
\hline & $-(i) r$ & pastirica & / & / \\
\hline & $-(o) r$ & selektorica & / & direktorica \\
\hline & $-($ ato $) r$ & koordinatorica & / & / \\
\hline & $-($ ito $) r$ & investitorica & / & / \\
\hline & $-(a) \check{s}$ & / & / & rokometašica \\
\hline \multirow[t]{15}{*}{-inja } & $-(u) h$ & oderuhinja & debeluhinja & I \\
\hline & $-(a) k$ & / & prostakinja & vojakinja \\
\hline & $-(j a) k$ & / & svobodnjakinja & korenjakinja \\
\hline & $-(e) k$ & / & prišlekinja & I \\
\hline & $-(i) k$ & I & akademikinja & I \\
\hline & $-(u) k$ & / & / & hajdukinja \\
\hline & $-(a) l$ & rivalinja & / & / \\
\hline & $-(a) r$ & / & / & bojarinja \\
\hline & $-(a) \check{s}$ & pristašinja & bogatašinja & mejašinja \\
\hline & $-(a) t$ & kandidatinja & / & aristokratinja \\
\hline & $-(a n) t$ & / & / & bakhantinja \\
\hline & $-(e) t$ & / & / & katehetinja \\
\hline & $-(e n) t$ & regentinja & / & / \\
\hline & $-(o) t$ & / & / & patriotinja \\
\hline & $-(i s) t$ & I & I & turistinja \\
\hline$-j a$ & $-(a) n$ & / & / & županja \\
\hline
\end{tabular}




\begin{tabular}{|c|c|c|c|c|}
\hline & $-(u) n$ & pestunja & I & l \\
\hline \multirow[t]{36}{*}{$-k a$} & $-(a) \check{c}$ & bahačka & I & brkačka \\
\hline & $-(j a) \check{c}$ & gonjačka & I & I \\
\hline & $-(i) \check{c}$ & vodička & mladička & I \\
\hline & $-($ an $) d$ & doktorandka & I & I \\
\hline & $-(u) h$ & potepuška & črnuška & I \\
\hline & $-(a) j$ & strežajka & l & policajka \\
\hline & $-(i) j$ & / & primarijka & I \\
\hline & $-(u) j$ & I & I & buržujka \\
\hline & $-(a) l$ & rivalka & I & I \\
\hline & $-(e) l$ & I & I & modelka \\
\hline & $-(a) n$ & I & rimokatoličanka & krajanka \\
\hline & $-(\check{c} a) n$ & I & I & nebeščanka \\
\hline & $-(j a) n$ & I & I & dvorjanka \\
\hline & $-(i j a) n$ & l & modrijanka & cistercijanka \\
\hline & $-(\operatorname{lj} a) n$ & I & / & državljanka \\
\hline & $-(m a) n$ & l & I & hlačmanka \\
\hline & $-(i) n$ & trpinka & bogatinka & capinka \\
\hline & $-($ ali $) n$ & gizdalinka & I & pobalinka \\
\hline & $-($ oli $) n$ & smrkolinka & l & I \\
\hline & $-($ ari $) n$ & vojarinka & I & I \\
\hline & $-(o) n$ & potegonka & I & I \\
\hline & $-(u) n$ & vohunka & grdunka & I \\
\hline & $-(a) r$ & balinarka & desetarka & harmonikarka \\
\hline & $-(e) r$ & aranžerka & / & garderoberka \\
\hline & $-($ ate $) r$ & dekoraterka & I & I \\
\hline & $-(i) r$ & I & I & brigadirka \\
\hline & $-(o) r$ & promotorka & I & senatorka \\
\hline & $-($ ato $) r$ & animatorka & novatorka & mediatorka \\
\hline & $-($ ito $) r$ & investitorka & I & I \\
\hline & $-(u) r$ & I & I & nemčurka \\
\hline & $-(a) \check{s}$ & I & bogataška & I \\
\hline & $-(a) t$ & delegatka & I & diplomatka \\
\hline & $-(a n) t$ & migrantka & I & komedijantka \\
\hline & $-(a s) t$ & l & I & videastka \\
\hline & $-(a v) t$ & I & I & astronavtka \\
\hline & $-(e) t$ & I & I & asketka \\
\hline
\end{tabular}




\begin{tabular}{|c|c|c|c|c|}
\hline & $-(e n) t$ & producentka & inteligentka & / \\
\hline & $-(e v) t$ & / & I & psihoterapevtka \\
\hline & $-(i) t$ & favoritka & / & banditka \\
\hline & $-(i s) t$ & lobistka & oportunistka & basistka \\
\hline & $-(o) t$ & I & / & patriotka \\
\hline$-(a r) k a$ & $-(i) k$ & kritičarka & razredničarka & alkoholičarka \\
\hline & $-(t i) k$ & I & l & dramatičarka \\
\hline & $-(a t i) k$ & l & / & tonematičarka \\
\hline$-(e v) k a$ & $-(i) \check{c}$ & ribičevka & hudičevka & I \\
\hline$-n a$ & $-(i) \check{c}$ & dedična & I & cesarična \\
\hline
\end{tabular}

1. Priponsko obrazilo - $\boldsymbol{a}$ nastopa kot dodajalno na novo samo $\mathrm{k}$ netvorjenkama bajsa in prfoksa (v obeh primerih je izglasje podstave na $-s$ ); preostali primeri feminativov so enaki kot v SSKJ 1.

2. Novi primeri iz SSKJ 2 kažejo, da lahko feminativno priponsko obrazilo -ica dodamo izglasjem na:

- -(a)č za vršilca iz glagolov na -ati/-am (dva feminativa: navijačica, potapljačica);

- -(ate)lj pri vršilcu iz glagolskih podstav na -ati/-am (pošiljateljica, vlagateljica, zbirateljica);

- -(ite)lj pri vršilcu iz podstavnih glagolov na -iti/-im (štirje primeri: utemeljiteljica, kršiteljica, prijaviteljica, zdraviteljica), tudi pri sestavljenkah (sovoditeljica);

- -(a)r pri opravkarju (le dva primera iz domače podstave: davkarica, zaslužkarica);

- -(e)r za opravkarja (tri primeri iz prevzete podstave: darkerica, pankerica, rokerica);

- $\quad$-(o)r pri vršilcu (korektorica, selektorica) $;^{94}$

- -(ato)r pri vršilcu iz glagolov na -irati-iram (samo koordinatorica);

- -(ito)r pri vršilcu iz glagolov na -irati/-iram (zgolj investitorica).

${ }^{94}$ Po krnitvi iz glagolov korigirati oz. selekcionirati (Snoj 2016: 336, 669). 
Kot dodajalna pa -ica nastopa tudi ob izglasjih prevzetih podstav na $-d$ (frendica), -r (magistrica, mentorica, rektorica) ter ob sestavljenkah (nečlanica, soavtorica, sočlanica, somentorica, velemojstrica). Nova glede na SSKJ 1 so tudi poimenovanja horoskopskih znamenj (bikica, ovnica, rakica).

3. Obrazilo -(ar)ica se tako kot v SSKJ 1 dodaja izglasju podstave na -k (znova samo matematikarica), ponovno pa smo izločili besede pobožnjakarica, politikarica, učenjakarica in druge podobne zaradi že navedenih razlogov.

4. Obrazilo -ja se lahko doda izglasjem na:

- $\quad-(\boldsymbol{a}) \boldsymbol{n}$ pri opravkarju (županja);

- $\quad-(\boldsymbol{u}) \boldsymbol{n}$ pri vršilcu iz glagolskih podstav na -ovati/-ujem (pestunja). ${ }^{95}$

Dodajamo ga lahko tudi k izglasjem podstav na - $n$ (dekanja - edini novi primer $\mathrm{v}$ primerjavi s SSKJ 1) in - $t$ (gostja).

5. Priponsko obrazilo -inja dodajamo k izglasjem na:

- $-(j a) k$ pri nosilcu lastnosti z izglasjem pridevniške podstave na - $n$ (nova primera svobodnjakinja, zahodnjakinja), tudi pri sestavljenkah (soimenjakinja).

Kot dodajalno feminativno priponsko obrazilo nastopi tudi pri izglasjih podstav na -f(škofinja), -g (dramaturginja), -t (adutinja, ekspertinja, estetinja, svatinja) in pri sestavljenih podstavah (podprvakinja), pri zloženkah $\mathrm{s}$ sufiksoidno in prefiksoidno sestavino (akcentologinja, andragoginja, antropologinja, astrologinja, dialektologinja, ekologinja, enologinja, epidemiologinja, etnologinja, geografinja, geometrinja, grafologinja, homeopatinja, kinologinja, klimatologinja, komunikologinja, mikrobiologinja, muzikologinja, nevrobiologinja, numerologinja, politologinja, pulmologinja, refleksologinja,

${ }^{95} \mathrm{Ni}$ novosti v primerjavi s SSKJ 1. 
scenografinja, seksologinja, tehnologinja) in pri poimenovanju horoskopskega znamenja (kozoroginja).

6. Priponsko obrazilo - $k \boldsymbol{a}$ nastopa kot dodajalno k izglasjem na (navajamo le nove konkretne primere v primerjavi s $S S K J 1)$ :

- $\quad-(a) j$ pri opravkarju (policajka);

- $\quad$-(i)j pri nosilcu lastnosti (primarijka);

- -(a)l pri vršilcu iz glagolov na -ati/-am (rivalka);

- -(a)n pri opravkarju iz domače podstave (krajanka) in pri nosilcu (rimokatoličanka), nastopi tudi pri sestavljenkah (sokrajanka, po glasovni premeni tudi someščanka);

- -(lja)n pri sestavljenkah (sodržavljanka);

- -(a)r za vršilca iz glagolskih podstav na -ati/-am (pet tvorjenk: balinarka, bobnarka, deskarka, piflarka, rolarka), -ariti/-arim (krmarka, lončarka, vrtnarka) in za opravkarja (sedem primerov: anketarka, harmonikarka, knjigarka, koncesionarka, računalničarka, vremenarka, zeliščarka); tudi pri izrazih za horoskopsko znamenje (vodnarka);

- -(e)r za vršilca iz podstave glagola na -irati/-iram (štirje feminativi: aranžerka, dizajnerka, šarmerka, žurerka), -ati/-am (le blogerka) in za opravkarja (pet primerov: akterka, menedžerka, milijarderka, performerka, rejverka);

- -(o)r za vršilca iz glagolskih podstav na -irati-iram (štiri tvorjenke: donorka, promotorka, revizorka, selektorka);

- -(ato)r pri vršilcu dejanja iz glagolov na -irati/-iram (v vseh devetih primerih gre za prevzete podstave: animatorka, donatorka, imitatorka, improvizatorka, inovatorka, konzervatorka, koordinatorka, moderatorka, restavratorka) in pri opravkarju (mediatorka);

- -(ito)r pri vršilcu dejanja iz glagolov na -irati-iram (v obeh primerih iz prevzetih podstav: investitorka, korepetitorka);

- -(an)t pri vršilcu dejanja iz glagolskih podstav na -irati-iram (migrantka, praktikantka, projektantka, žirantka);

- -(as)t pri opravkarju iz prevzete podstave (videastka); 
- -(av)t za opravkarja (astronavtka);

- -(en)t za vršilca iz glagolov na -irati/-iram (koproducentka, producentka);

- -(ev)t pri opravkarju iz zložene podstave (psihoterapevtka, refleksoterapevtka);

- -(is)t pri vršilcu dejanja iz glagola na -irati/-iram (lobistka), na -iti/-im (slovenistka) in pri opravkarju (basistka, centristka, esejistka, folkloristka, galeristka, humoristka, karieristka, karikaturistka, kitaristka, kolumnistka, kriminalistka, kronistka, motoristka, nudistka, oboistka, perfekcionistka, saksofonistka, stilistka, violistka, violončelistka, vizažistka, vokalistka).

Dodaja se lahko tudi zloženkam (presnojedka, supervizorka) in netvorjenkam (adutka, dekanka, didžejka, ekspertka, frajerka, gurmanka, kameleonka, nomadka, nutricionistka, šamanka, vampirka, veganka, ob podaljšanju osnove z -j tudi atašejka, gurujka, japijka, krupjejka, someljejka).

7. Obrazilo -(ar)ka dodajamo moškospolskim tvorjenkam na:

- -ø za nosilca (12 feminativov: anoreksičarka, bioenergetičarka, bulimičarka, deloholičarka, diabetičarka, dietetičarka, fizičarka, komičarka, praktičarka, psihoanalitičarka, teoretičarka, tetraplegičarka);

- -(i)k za opravkarja (analitičarka);

- -(ti)k pri opravkarju (dramatičarka);

- -(ati)k v pomenski skupini opravkar (tonematičarka).

Pri dodajalnih priponskih obrazilih -ulja, $-(\boldsymbol{e v}) \boldsymbol{k a},-(\boldsymbol{o v}) \boldsymbol{k a},-\boldsymbol{n} \boldsymbol{a}$ ni novosti v primerjavi s SSKJ 1. Pri priponskem obrazilu -esa pa je v primerjavi s SSKJ 1 nov le primer klovnesa.

Analiza je pokazala, da se za vse tri prve pomenske skupine izpeljank iz glagolske, pridevniške in samostalniške podstave, torej za vršilca, nosilca in opravkarja, pojavijo izglasja na $-\check{c},-n,-r$ in $-t$ pri dodajalnem obrazilu $-k a$ ter izglasji $-k$ in $-s ̌$ pri obrazilu -inja 


\section{Sinteza obrazilne produktivnosti - dodajanje k izglasju obrazila}

Spodnja preglednica prikazuje, katera feminativna priponska obrazila (in v kolikšni meri) se lahko dodajajo posameznim moškospolskim izglasjem. ${ }^{96}$

Preglednica 56: Sinteza obrazilne produktivnosti-dodajalni način (SSKJ 2)

\begin{tabular}{|c|c|c|c|c|c|c|c|c|c|c|c|c|c|}
\hline \multirow{2}{*}{$\begin{array}{l}\text { MOŠKO- } \\
\text { SPOLSKO } \\
\text { IZGLASJE }\end{array}$} & \multicolumn{13}{|c|}{ FEMINATIVNA PRIPONSKA OBRAZILA } \\
\hline & $-a$ & $-i c a$ & $-(a r) i c a$ & $-j a$ & -ulja & -inja & $-k a$ & $-(a r) k a$ & $-(e v) k a$ & $-(o v) k a$ & $-n a$ & $-e s a$ & SKUPAJ \\
\hline$-(a) \check{c}$ & 2 & $19(2)$ & I & I & I & I & 14 & I & 1 & I & 1 & I & $35(2)$ \\
\hline$-(j a) \check{c}$ & 1 & I & 1 & 1 & 1 & I & 1 & 1 & 1 & 1 & 1 & I & 1 \\
\hline$-(i) \check{c}$ & 1 & I & 1 & 1 & 1 & 1 & 5 & 1 & 2 & 1 & 6 & I & 13 \\
\hline$-(a n) d$ & 1 & I & 1 & I & I & I & 2 & 1 & I & I & I & I & 2 \\
\hline$-(u) h$ & 2 & 1 & 1 & 1 & 1 & 8 & 5 & 1 & 1 & 1 & 1 & I & 15 \\
\hline$-(a) j$ & 1 & I & I & I & I & I & $4(1)$ & I & I & I & I & I & $4(\mathbf{1})$ \\
\hline$-(i) j$ & 1 & I & I & I & I & I & 1 & I & I & I & I & I & 1 \\
\hline$-(u) j$ & 1 & 1 & 1 & I & 1 & I & 1 & I & 1 & 1 & 1 & I & 1 \\
\hline$-(a) k$ & 1 & I & I & I & I & 10 & I & 1 & I & I & I & I & 10 \\
\hline
\end{tabular}

$\overline{96}$ V oklepaju je s krepkim tiskom zapisano število novih primerov v primerjavi s SSKJ 1. 


\begin{tabular}{|c|c|c|c|c|c|c|c|c|c|c|c|c|c|}
\hline \multirow{2}{*}{$\begin{array}{l}\text { MOŠKO- } \\
\text { SPOLSKO } \\
\text { IZGLASJE }\end{array}$} & \multicolumn{13}{|c|}{ FEMINATIVNA PRIPONSKA OBRAZILA } \\
\hline & $-a$ & $-i c a$ & $-(a r) i c a$ & $-j a$ & - ulja & -inja & $-k a$ & $-(a r) k a$ & $-(e v) k a$ & $-(o v) k a$ & $-n a$ & $-e s a$ & SKUPAJ \\
\hline$-(j a) k$ & 1 & I & I & l & I & $19(3)$ & I & I & I & I & I & / & $19(3)$ \\
\hline$-(e) k$ & I & / & I & I & I & 1 & I & I & I & / & I & / & 1 \\
\hline$-(i) k$ & 1 & I & I & 1 & I & 1 & 1 & 8 (1) & 1 & 1 & 1 & 1 & 9 (1) \\
\hline$-(t i) k$ & 1 & I & 1 & 1 & 1 & I & 1 & 1 & 1 & 1 & 1 & I & 1 \\
\hline$-(a t i) k$ & 1 & I & 1 & 1 & 1 & 1 & 1 & 1 & 1 & 1 & 1 & I & 1 \\
\hline$-(u) k$ & 1 & 1 & 1 & 1 & 1 & 1 & 1 & 1 & 1 & 1 & 1 & 1 & 2 \\
\hline$-($ ate $) l j$ & 1 & $10(3)$ & 1 & 1 & 1 & I & 1 & 1 & 1 & 1 & 1 & I & $10(3)$ \\
\hline -(ite)lj & 1 & $40(5)$ & 1 & 1 & 1 & 1 & 1 & 1 & 1 & 1 & 1 & 1 & $40(5)$ \\
\hline$-(a) l$ & 1 & 1 & 1 & 1 & 1 & 1 & 1 & 1 & 1 & 1 & 1 & 1 & $2(1)$ \\
\hline$-(e) l$ & 1 & 1 & 1 & 1 & 1 & 1 & 1 & 1 & 1 & 1 & 1 & 1 & 2 \\
\hline$-(a) n$ & 1 & 1 & I & 1 & I & 1 & $22(4)$ & 1 & 1 & I & 1 & I & $24(4)$ \\
\hline$-(\check{c} a) n$ & 1 & 1 & 1 & 1 & 1 & 1 & 5 & 1 & 1 & 1 & 1 & 1 & 5 \\
\hline$-(j a) n$ & 1 & 1 & 1 & 1 & 1 & 1 & 4 & 1 & 1 & 1 & 1 & I & 5 \\
\hline$-(i j a) n$ & 1 & 1 & 1 & 1 & 1 & 1 & 2 & 1 & 1 & 1 & 1 & 1 & 2 \\
\hline$-($ lja $) n$ & 1 & 1 & 1 & 1 & 1 & 1 & 4 (1) & 1 & 1 & 1 & 1 & 1 & $4(1)$ \\
\hline$-(m a) n$ & 1 & 1 & 1 & 1 & 1 & 1 & 2 & 1 & 1 & 1 & 1 & 1 & 2 \\
\hline$-(i) n$ & 1 & 1 & 1 & I & 1 & 1 & 7 & 1 & 1 & 1 & 1 & I & 7 \\
\hline
\end{tabular}




\begin{tabular}{|c|c|c|c|c|c|c|c|c|c|c|c|c|c|}
\hline \multirow{2}{*}{$\begin{array}{l}\text { MOŠKO- } \\
\text { SPOLSKO } \\
\text { IZGLASJE }\end{array}$} & \multicolumn{13}{|c|}{ FEMINATIVNA PRIPONSKA OBRAZILA } \\
\hline & $-a$ & $-i c a$ & $-(a r) i c a$ & $-j a$ & - -ulja & -inja & $-k a$ & $-(a r) k a$ & $-(e v) k a$ & $-(o v) k a$ & $-n a$ & $-e s a$ & SKUPAJ \\
\hline$-($ ali $) n$ & 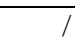 & I & I & I & l & / & 2 & I & I & I & I & / & 2 \\
\hline$-($ oli $) n$ & 1 & I & I & I & / & / & 1 & I & I & / & I & / & 1 \\
\hline$-($ ari $) n$ & 1 & I & l & I & I & I & 1 & 1 & I & I & 1 & I & 1 \\
\hline$-(o) n$ & 1 & I & 1 & 1 & 1 & 1 & 1 & 1 & 1 & 1 & 1 & I & 1 \\
\hline$-(u) n$ & 1 & I & I & 1 & I & 1 & 2 & 1 & 1 & 1 & I & I & 3 \\
\hline$-(a) r$ & 1 & $103(2)$ & 1 & I & I & 1 & 112 (16) & 1 & 1 & 1 & 1 & I & $216(18)$ \\
\hline$-(e) r$ & 1 & 3 & 1 & 1 & I & 1 & $36(\mathbf{1 0})$ & 1 & 1 & 1 & I & I & $39(\mathbf{1 3})$ \\
\hline$-($ ate $) r$ & 1 & 1 & 1 & 1 & 1 & 1 & 2 & 1 & 1 & 1 & 1 & 1 & 2 \\
\hline$-(i) r$ & 1 & 1 & I & 1 & I & I & 3 & 1 & 1 & 1 & 1 & 1 & 4 \\
\hline$-(o) r$ & 1 & $10(2)$ & I & I & I & 1 & $8(4)$ & 1 & 1 & 1 & 1 & I & $18(6)$ \\
\hline$-($ ato $) r$ & 1 & $5(1)$ & 1 & 1 & 1 & 1 & $\begin{array}{c}25 \\
(\mathbf{1 0})\end{array}$ & 1 & 1 & 1 & 1 & I & $30(\mathbf{1 1})$ \\
\hline$-($ ito $) r$ & 1 & 1 & I & I & I & I & 2 & 1 & 1 & I & I & I & 3 \\
\hline$-(u) r$ & 1 & 1 & 1 & 1 & 1 & 1 & 1 & 1 & 1 & 1 & 1 & I & 1 \\
\hline$-(a) \check{s}$ & 1 & 2 & 1 & I & I & 5 & 1 & 1 & 1 & 1 & I & I & 8 \\
\hline$-(a) t$ & 1 & 1 & I & 1 & I & 2 & 8 & 1 & I & 1 & 1 & I & 10 \\
\hline$-(a n) t$ & 1 & I & 1 & I & 1 & 1 & $29(4)$ & 1 & 1 & 1 & 1 & I & $30(4)$ \\
\hline
\end{tabular}




\begin{tabular}{|c|c|c|c|c|c|c|c|c|c|c|c|c|c|}
\hline \multirow{2}{*}{$\begin{array}{l}\text { MOŠKO- } \\
\text { SPOLSKO } \\
\text { IZGLASJE }\end{array}$} & \multicolumn{13}{|c|}{ FEMINATIVNA PRIPONSKA OBRAZILA } \\
\hline & $-a$ & $-i c a$ & $-(a r) i c a$ & $-j a$ & -ulja & -inja & $-k a$ & $-(a r) k a$ & $-(e v) k a$ & $-(o v) k a$ & $-n a$ & $-e s a$ & SKUPAJ \\
\hline$-(a s) t$ & I & I & / & I & I & / & $3(\mathbf{1})$ & / & I & / & I & / & $3(\mathbf{1})$ \\
\hline$-(a v) t$ & / & / & / & / & / & / & $2(1)$ & I & / & / & / & / & $2(\mathbf{1})$ \\
\hline$-(e) t$ & 1 & / & / & / & / & 1 & 2 & 1 & 1 & I & 1 & 1 & 3 \\
\hline$-(e n) t$ & 1 & I & I & I & I & 2 & $22(2)$ & 1 & 1 & 1 & 1 & I & $24(2)$ \\
\hline$-(e v) t$ & I & I & I & 1 & I & 1 & $5(2)$ & 1 & 1 & 1 & I & I & $5(2)$ \\
\hline$-(i) t$ & 1 & 1 & 1 & 1 & 1 & 1 & 2 & 1 & 1 & 1 & 1 & 1 & 2 \\
\hline$-(o) t$ & I & I & I & I & I & 1 & 1 & 1 & I & 1 & I & I & 2 \\
\hline$-(i s) t$ & 1 & 1 & 1 & 1 & 1 & 3 & $129(\mathbf{2 4})$ & 1 & 1 & 1 & 1 & 1 & $132(\mathbf{2 4})$ \\
\hline$-\theta$ & $7(2)$ & $\begin{array}{c}42 \\
\text { (12) }\end{array}$ & 1 & $2(1)$ & 2 & $\begin{array}{c}88 \\
(\mathbf{3 4})\end{array}$ & $\begin{array}{l}109 \\
\text { (19) }\end{array}$ & $16(12)$ & 1 & 4 & 1 & $4(1)$ & $276(\mathbf{8 1})$ \\
\hline SKUPAJ & $14(2)$ & $\begin{array}{l}237 \\
(31)\end{array}$ & 1 & $4(1)$ & 2 & $\begin{array}{l}145 \\
\text { (37) }\end{array}$ & $590(\mathbf{1 0 3})$ & $26(15)$ & 3 & 4 & 6 & $4(\mathbf{1})$ & 1036 (190) \\
\hline
\end{tabular}


Analiza je pokazala, da so izglasja moškospolskih priponskih obrazil, ki se jim feminativna obrazila dodajajo, naslednja (izpostavljamo le novosti $\mathrm{v}$ primerjavi s $S S K J$ 1):

- K izglasju -(a)̌ se lahko dodajo -ica, ki nastopi pri vršilcu iz glagolskih podstav na -ati/-am, kar potrjujeta dva, v primerjavi s SSKJ 1 nova, feminativa (npr. potapljačica).

- Novo je moškospolsko izglasje na -(i)j, h kateremu dodamo obrazilo - $k a \mathrm{v}$ pomenski skupini nosilec (en primer: primarijka).

- Tudi po primerih iz SSKJ 2 sodeč lahko izglasju na -(ja)k dodajamo samo feminativno obrazilo -inja, in to znova v pomenski skupini nosilec, kadar se podstavni pridevnik konča na $-n$ (dva nova feminativa, npr. svobodnjakinja), ter pri sestavljenkah (en primer: soimenjakinja).

- Feminativno priponsko obrazilo -ica je še zmeraj edino, ki se dodaja izglasjem na -(ate)lj (trije novi primeri za vršilca dejanja iz glagolov na -ati/-em, kar je nekoliko več v primerjavi s SSKJ 1, npr. vlagateljica) in -(ite)lj (štirje novi primeri iz glagolov na -iti/-im, denimo kršiteljica).

- K izglasju na -(a)n kot dodajalno z novimi primeri nastopa priponsko obrazilo $-k a$ (po en primer pri nosilcu (rimokatoličanka) in opravkarju (krajanka), dva pri sestavljeni podstavi, npr. sokrajanka).

- Zelo pogosto gre za dodajanje feminativnih obrazil k izglasju -(a)r; kot taki nastopita naslednji obrazili: -ica $\mathrm{v}$ pomenski skupini opravkar (dva nova feminativa, npr. davkarica), -ka pa se pojavlja pri vršilcu (iz glagolov na -ati/-am šest novih primerov, npr. rolarka, -ariti/-arim dve novi tvorjenki, npr. krmarka) in opravkarju (sedem novih tvorjenk, npr. zeliščarka); nastopi tudi pri poimenovanju horoskopskega znamenja (en primer: vodnarka).

- K izglasju na -(e)r dodajamo obrazilo $-k a$ - pri vršilcu iz glagolov na -irati/-iram (štiri nove tvorjenke, npr. aranžerka) ali -ati/-am (en novi primer: blogerka) ter pri opravkarju (pet novih feminativov, denimo milijarderka). Primeri iz SSKJ 2 pa kažejo, da kot dodajalna lahko nastopa tudi -ica (trije primeri pri opravkarju, npr. pankerica). 
- Priponsko obrazilo - $k a$ kot dodajalno nastopa tudi pri izglasju na -(o)r, in to pri štirih novih primerih v pomenski skupini vršilec (npr. revizorka).

- V pomenski skupini vršilec pa nastopajo feminativi, tvorjeni z dodajanjem priponskih obrazil k moškospolskemu poimenovanju osebe z izglasjem na -(ato)r: taki sta feminativni obrazili -ica (ena nova tvorjenka: koordinatorica) in -ka (devet tvorjenk, npr. animatorka), pri čemer gre v vseh primerih za tvorbo iz glagolskih podstav na -irati/-iram. Zasledili smo tudi en primer tvorbe $\mathrm{v}$ pomenski skupini opravkar, in to pri priponskem obrazilu -ka (mediatorka).

- Novost je tudi moškospolsko priponsko obrazilo -(ito)r, ki se mu dodajata feminativni obrazili -ica, sicer le pri enem primeru (investitorica), in -ka pri dveh primerih (npr. korepetitorka).

- Tudi SSKJ 2 dokazuje, da k izglasjem na -(an)t, -(en)t in -(ev)t dodajamo le obrazilo $-k a$, in to pri prvih dveh v pomenski skupini vršilec (pri prvem štirje novi primeri na -irati/-iram, npr. migrantka, pri drugem dva nova primera, npr. producentka), k -(ev)t pa pri opravkarju (dva primera, denimo psihoterapevtka).

- Več primerov ponovno nastane $\mathrm{z}$ dodajanjem feminativnih obrazil $\mathrm{k}$ izglasju na -(is)t. Tako je sicer le obrazilo -ka (skupno 24 primerov tvorjenk, med temi $22 \mathrm{v}$ pomenski skupini opravkar (karieristka), po ena pa pri vršilcu iz glagolov na -irati/-iram, tj. lobistka, oz. -iti/-im: slovenistka).

- K izglasju tvorjenk na -(as)t pa nastopi le obrazilo - $k a$, kar potrjuje en primer v pomenski skupini opravkar (videastka).

V primerjavi s SSKJ 1 je novo moškospolsko izglasje na -(ito)r; k letemu se lahko dodajata feminativni obrazili -ica (en primer) in - $k a$ (dva primera). Drugih posebnosti ni: feminativno priponsko obrazilo $-k a$ prevladuje pri dodajanju $\mathrm{k}$ izglasjem na $-n,-r,-t,-i c a$ pri dodajanju $\mathrm{k}$ izglasjem moškospolskih samostalnikov na -lj, -inja pa na $-k$. Novi primeri to le potrjujejo. 


\section{Sinteza obrazilne produktivnosti - dodajanje $k$ izglasju podstave}

Spodnja preglednica prikazuje, katera feminativna priponska obrazila (in v kolikšni meri) se lahko dodajajo posameznim izglasjem podstav. Vključena je tvorba iz netvorjenk ter iz nekaterih zloženih in sestavljenih podstav. V oklepaju je s krepkim tiskom zapisano število novih primerov v primerjavi s SSKJ 1, sicer pa navajamo skupno število iz obeh izdaj.

Preglednica 57: Sinteza obrazilne produktivnosti-dodajalni način k izglasju podstave (SSKJ 2)

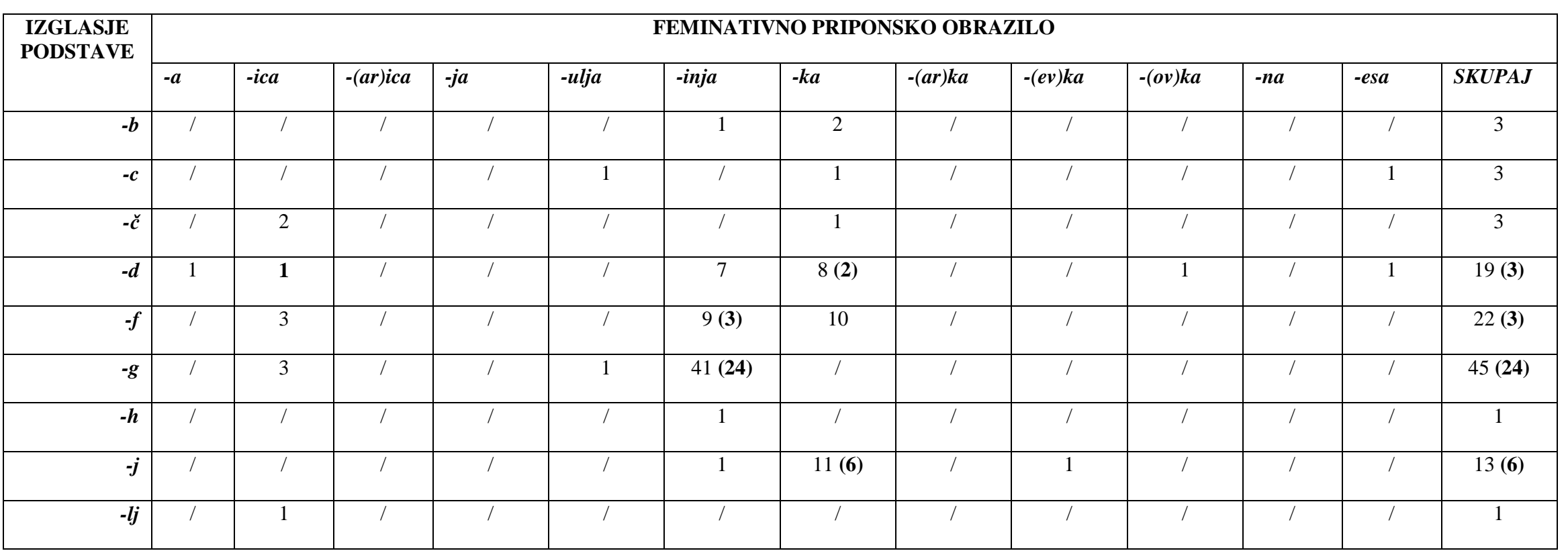




\begin{tabular}{|c|c|c|c|c|c|c|c|c|c|c|c|c|c|}
\hline \multirow{2}{*}{$\begin{array}{l}\text { IZGLASJE } \\
\text { PODSTAVE }\end{array}$} & \multicolumn{13}{|c|}{ FEMINATIVNO PRIPONSKO OBRAZILO } \\
\hline & $-a$ & $-i c a$ & $-(a r) i c a$ & $-j a$ & -ulja & -inja & $-k a$ & $-(a r) k a$ & $-(e v) k a$ & $-(o v) k a$ & $-n a$ & $-e s a$ & SKUPAJ \\
\hline$-n j$ & 1 & I & I & I & I & I & I & l & I & I & I & I & 1 \\
\hline$-k$ & I & 2 & 1 & I & I & $12(\mathbf{1})$ & 1 & $16(12)$ & l & 1 & I & I & $33(\mathbf{1 5})$ \\
\hline$-l$ & / & I & / & I & I & 1 & 2 & I & 1 & I & I & I & 2 \\
\hline$-m$ & I & 1 & 1 & 1 & 1 & 1 & 4 & I & 1 & I & 1 & I & 4 \\
\hline$-n$ & I & $6(3)$ & I & 1 & I & I & $21(5)$ & 1 & I & I & I & 1 & $29(\mathbf{1 0})$ \\
\hline$-p$ & 1 & 1 & 1 & 1 & 1 & 1 & 1 & 1 & 1 & I & I & 1 & 3 \\
\hline$-r$ & 2 & $16(6)$ & I & I & 1 & $3(1)$ & 19 (3) & I & I & 1 & I & I & 41 (10) \\
\hline$-S$ & 2 & 1 & 1 & 1 & 1 & 1 & I & 1 & 1 & 1 & 1 & I & $3(2)$ \\
\hline$-\check{s}$ & 1 & 2 & 1 & 1 & 1 & 1 & I & 1 & 1 & 1 & I & I & 2 \\
\hline$-t$ & I & 5 & 1 & 1 & 1 & $11(5)$ & $26(3)$ & I & I & 1 & 1 & 1 & $45(8)$ \\
\hline$-v$ & I & 1 & 1 & 1 & 1 & 1 & 1 & I & 1 & I & I & I & 1 \\
\hline$-z$ & I & I & I & 1 & 1 & 1 & 1 & 1 & I & I & I & I & 2 \\
\hline SKUPAJ & $7(2)$ & 42 (12) & 1 & $2(1)$ & 2 & 88 (34) & 109 (19) & $16(12)$ & 1 & 4 & I & $4(1)$ & $276(\mathbf{8 1})$ \\
\hline
\end{tabular}


Nekaj obravnavanih feminativnih priponskih obrazil se lahko dodaja tudi k izglasju podstave na (navajamo zgolj novosti v primerjavi s SSKJ 1):

- $\quad-\boldsymbol{d}$ (en primer z -ica iz netvorjene podstave, tj. frendica, ter dva primera s -ka, med njima eden iz zložene (presnojedka) in eden iz netvorjene podstave: nomadka);

- $\quad f$ (trije primeri z -inja: eden iz netvorjene, tj. škofinja, ter dva iz zložene podstave, npr. scenografinja);

- $-\boldsymbol{g}$ (24 konkretnih primerov z -inja - 22 iz zložene podstave, npr. pulmologinja, eden iz netvorjene podstave, tj. dramaturginja, ter eno poimenovanje horoskopskega znamenja: kozoroginja);

- $\quad-j$ (šest feminativov s -ka, zmeraj iz netvorjene podstave, npr. japijka);

- $\quad \boldsymbol{k}$ (en feminativ z -inja pri tvorbi iz sestavljene podstave, tj. podprvakinja, dve poimenovanji horoskopskih znamenj z -ica, npr. bikica, 12 feminativov z -(ar)ka, npr. komičarka);

- $\quad \boldsymbol{n}$ (pri sestavljenih podstavah dva feminativa z -ica (npr. sočlanica), tudi eno poimenovanje horoskopskega znamenja (ovnica), en feminativ z -ja iz netvorjene podstave (županja), pet primerov s $-k a$, zmeraj iz netvorjene podstave, npr. šamanka; tudi en primer z -esa: klovnesa);

- $\quad \boldsymbol{- r}$ (šest primerov z -ica, med njimi po trije iz netvorjene, npr. mentorica, in sestavljene podstave (npr. soavtorica), en primer z -inja iz zložene podstave geometrinja, trije feminativi $\mathrm{s}-k a$, in to eden iz zložene (supervizorka) ter dva iz netvorjene podstave, npr. vampirka);

- $\quad-s$ (iz netvorjene podstave dva feminativa z - $a$, npr. prfoksa);

- $\quad-\boldsymbol{t}$ (pet primerov z -inja, med njimi štirje primeri iz sestavljene ter eden iz zložene podstave, trije primeri s $-k a$, vsi iz netvorjenih podstav).

V primerjavi s SSKJ 1 smo zasledili 81 novih primerov, ko gre za dodajanje feminativnega priponskega obrazila k izglasju podstave. Najpogosteje kot taka nastopajo obrazila -inja (34 primerov ali $42 \%$ ), -ka (19 feminativov ali $23 \%$ ) ter -ica in -(ar)ka (po 12 primerov oz. $15 \%$ ). Opažamo, da se k izglasjem na $-f$ in - $g$ dodaja samo -inja, $\mathrm{k}-j$ pa zgolj $-k a$; pri izglasjih podstav na $-r$ pa se pojavljajo feminativna obrazila -ica, -inja in $-k a$. 


\subsection{Poimenovanja živali}

Ženskospolska poimenovanja živali smo zasledili le v obeh izdajah Slovarja slovenskega knjižnega jezika ter v Slovarju novejšega besedja slovenskega jezika. V SSKJ 1 jih je 91, v SSKJ 2 pa 93. Novost v primerjavi s prvo izdajo sta feminativa labradorka in risinja. Prva izdaja ponuja samo moškospolsko obliko labradorec, $\mathrm{k}$ risu pa kot feminativ nastopi le risa. V SNBSJ smo zasledili le primer perzijka.

\subsubsection{Prva izdaja Slovarja slovenskega knjižnega jezika}

V SSKJ 1 prevladujejo ženskospolska poimenovanja živali, nastala z dodajalnim načinom, takih feminativov je 60 (67 \%), medtem ko je tistih, nastalih z zamenjevalnim načinom, le 31 (33\%).

Grafikon 19: Ženskospolska poimenovanja živali v SSKJ 1 glede na način tvorbe

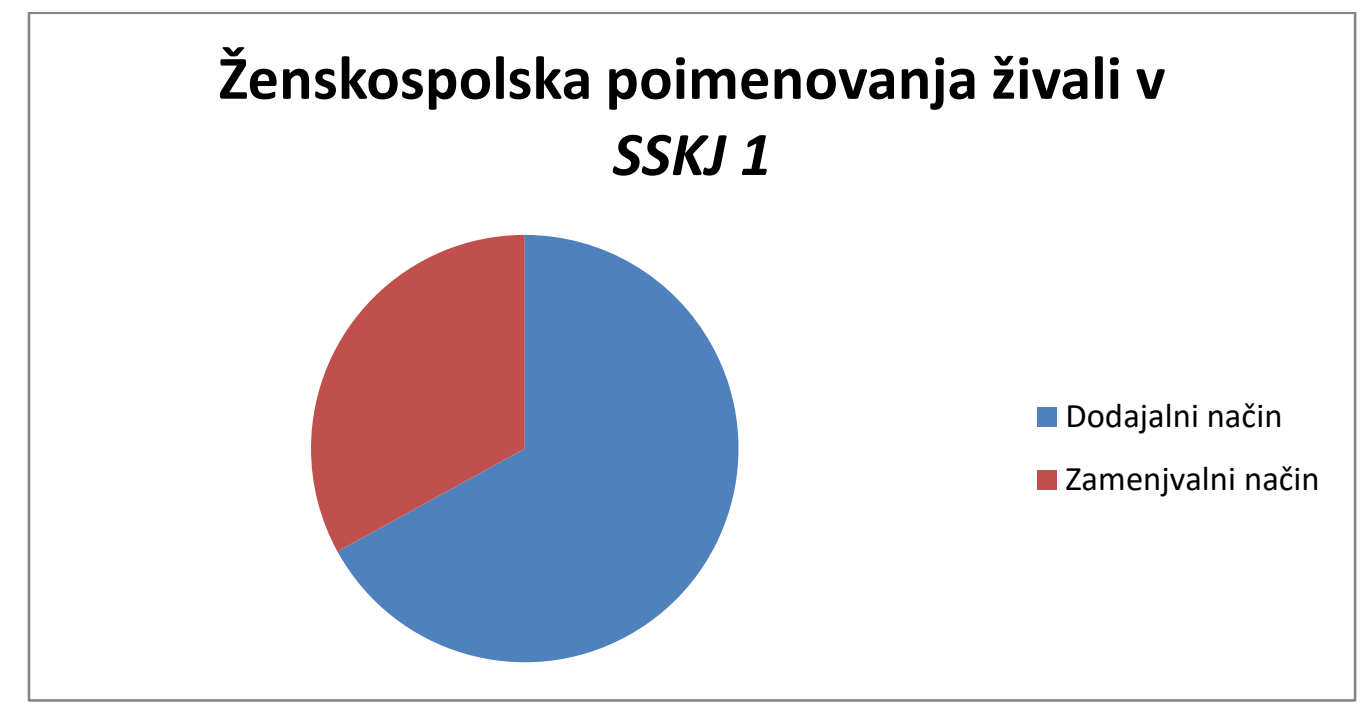

7.2.1.1 Feminativi, nastali $\mathrm{z}$ dodajanjem ženskospolskega obrazila tvorjenkam moškega spola

Z dodajanjem ženskospolskega obrazila moškospolskemu poimenovanju živali je nastalo 60 feminativov, od tega največ, to je 24 (39\%), s priponskim 
obrazilom -ica, nekoliko manj, 17 z obrazilom -ka (29,5\%), $8(13 \%)$ z -(ov)ka, štiri $(6,5 \%) \mathrm{z}-(e v) k a$, tri $(5 \%) \mathrm{z}$-inja in po dva $(3 \%) \mathrm{z}-a$ in $-u l j a$.

Grafikon 20: Dodajalna feminativna priponska obrazila za poimenovanja živali v SSKJ 1

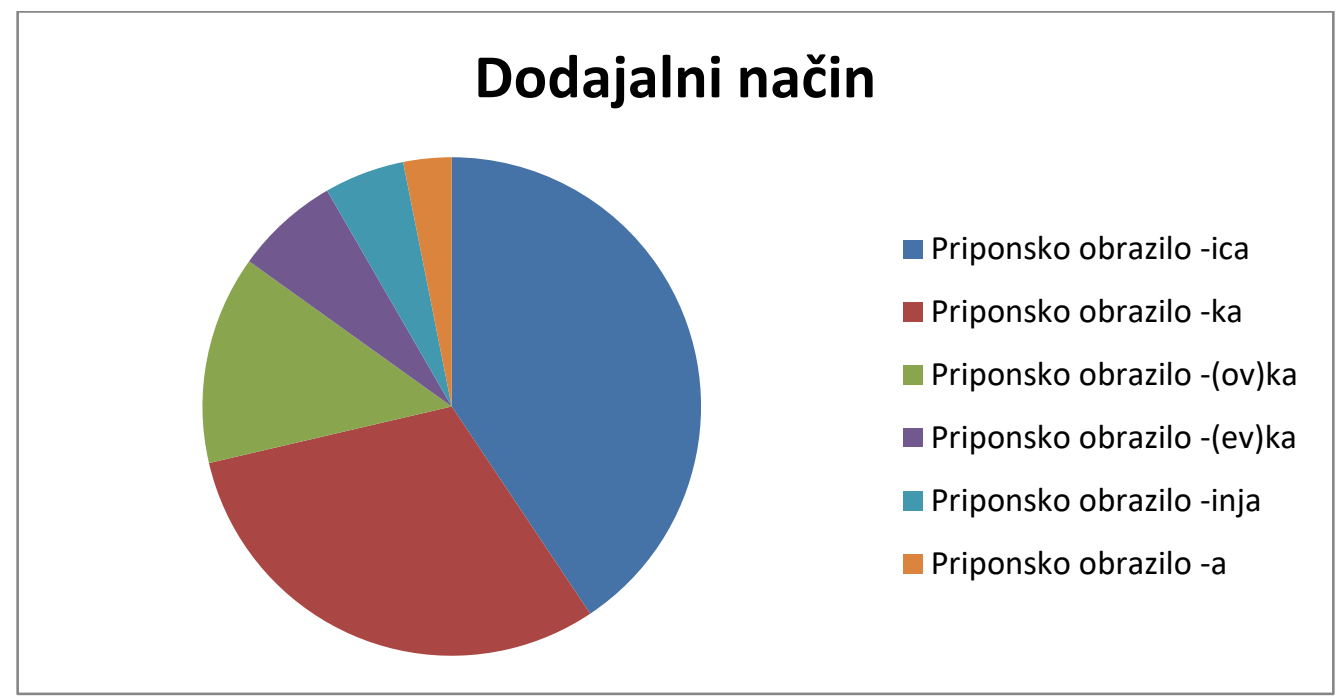

Spodnja preglednica prikazuje družljivost feminativnih priponskih obrazil z izglasji moškospolskih priponskih obrazil v pomenskih skupinah vršilec, nosilec, opravkar.

Preglednica 58: Dodajalna feminativna priponska obrazila pri tvorbi poimenovanj živali $v$ SSKJ 1

\begin{tabular}{|r|r|c|c|c|}
\hline \multirow{2}{*}{ OBRAZILO } & \multirow{2}{*}{ IZGLASJE } & \multicolumn{4}{|c|}{ PRIMERI TVORJENK } \\
\cline { 3 - 5 } & \multirow{2}{*}{ OBRAZILA } & $\begin{array}{l}\text { FEMINATIV } \\
\text { IZ VRŠILCA }\end{array}$ & $\begin{array}{c}\text { FEMINATIV } \\
\text { IZ NOSILCA }\end{array}$ & $\begin{array}{c}\text { FEMINATIV IZ } \\
\text { OPRAVKARJA }\end{array}$ \\
\hline$-\boldsymbol{i c a}$ & $-(a) r$ & roparica & $/$ & prepeličarica \\
\hline$-\boldsymbol{k} \boldsymbol{a} \boldsymbol{n}$ & $-(i) \check{c}$ & $/$ & mladička & $p$ sička \\
\cline { 2 - 5 } & $-(a) r$ & $/$ & $/$ & mrhovinarka \\
\hline$-(\boldsymbol{e v}) \boldsymbol{k} \boldsymbol{a} a$ & $-(e) c$ & $/$ & $/$ & jazbečevka \\
\hline
\end{tabular}

1. Priponsko obrazilo -ica lahko dodajamo k izglasju na -(a)r pri vršilcu iz glagolskih podstav na -ati/-am (roparica) in pri opravkarju (prepeličarica). V glavnem pa nastopa pri izglasjih netvorjenih podstav na $-b$ (golobica), $-d$ (labodica), -nj (jagnjica), -l (bivolica, orlica, oslica, sokolica, telica), -m (somica), -n (slonica), -r (voluharica), -s (psica), -t (hrtica), -v (pavica). Pri 
dodajanju priponskega obrazila $-i c a \mathrm{k}$ izglasjem na $-c,-h$ in na $-k$ pride do glasovne premene (kunčica; polšica; pajčica, volčica). Nekatere podstave netvorjenk so prevzete, npr. pri feminativih na -r panterica in tigrica, -nj tjulnjica, -d velblodica.

2. Obrazilo $-\boldsymbol{k a}$ se dodaja opravkarju na $-(\boldsymbol{a}) \boldsymbol{r}$ (mrhovinarka, ovčarka, prepeličarka, ptičarka) in nosilcu ter opravkarju na -(i)̌c (mladička; psička). Kot dodajalno nastopi tudi $\mathrm{k}$ izglasjem podstave na $-b$ (galebka), -̌̌ (ptička), -d (labodka, medvedka), - $n$ (fazanka, jelenka), prevzetim podstavam na $-d$ (leopardka), -l (̌́panjelka), -n (škorpijonka) in -r (terierka), tudi k zloženkam (srakoperka).

3. Obrazilo -(ov)ka nastopa kot dodajalno samo $\mathrm{k}$ netvorjenkam $\mathrm{z}$ različnimi izglasji: na -r bobrovka, na -d gadovka, na - $k$ rakovka, na $-m$ somovka, na $-s$ gamsovka in kosovka, na -t kitovka in na -z šimpanzovka.

4. Priponsko obrazilo -(ev)ka lahko dodajamo opravkarju na -(e)c, pri čemer pride do palatalizacije $\mathrm{v}-\check{c}$ in posledično do preglasa (jazbečevka, skobčevka), ali k netvorjenkam (škorčevka, vrabčevka).

5. Tudi obrazilo -inja se dodaja samo netvorjenkam z izglasjem netvorjene podstave na $-v$ (levinja, pavinja) in $-z$ (šimpanzinja).

6. Priponsko obrazilo - $\boldsymbol{a}$ se dodaja samo netvorjenim podstavam, in to le $\mathrm{v}$ dveh primerih: braka in risa.

7. Podobno velja za priponsko obrazilo -ulja, ki se doda le netvorjenkam z izglasjem na $-k$ (pajkulja, volkulja).

\section{Sinteza obrazilne produktivnosti}


Opažamo, da se feminativna priponska obrazila, kadar tvorijo Ženskospolska poimenovanja živali, $\mathrm{V}$ glavnem dodajajo netvorjenkam $\mathrm{Z}$ različnimi izglasji, le redko opravkarjem, in to vedno le z izglasjema na $-(\boldsymbol{a}) \boldsymbol{r}$ in -(i)̌̌ (k slednjemu tudi v pomenski skupini nosilec), vršilcu pa samo, če gre za večpomenke, ki lahko poimenujejo tudi osebe (npr. roparica). K -(a)r se tako dodajata le -ica in -ka; prva pri vršilcu dejanja iz glagolske podstave na -ati/-am ali k opravkarju z izglasjem na - $c$ ob glasovni premeni, druga pa le k opravkarju z izglasjem podstave na $-c$, znova ob glasovni premeni, ali $\mathrm{k}-n-$ vse navedeno je potrjeno s po enim primerom. K moškospolskemu izglasju na -(i)č pa se lahko doda le ženskospolsko obrazilo - $k a$, kar potrjujeta dva konkretna primera.

7.2.1.2 Feminativi, nastali $\mathrm{z}$ zamenjavo celotnega ali le izglasnega dela moškospolskega obrazila z ženskospolskim ob isti podstavi

$\mathrm{Z}$ zamenjavo moškospolskega priponskega obrazila s feminativnim je nastalo 31 tvorjenk. Kot zamenjevalna nastopajo feminativna priponska obrazila -ka z 20 primeri (63\%), -ica (9 primerov ali $30 \%$ ) in -ulja z dvema primeroma (6 $\%)$.

Grafikon 21: Zamenjevalna feminativna priponska obrazila za poimenovanja živali $v$ SSKJ 1

\section{Zamenjevalni način}

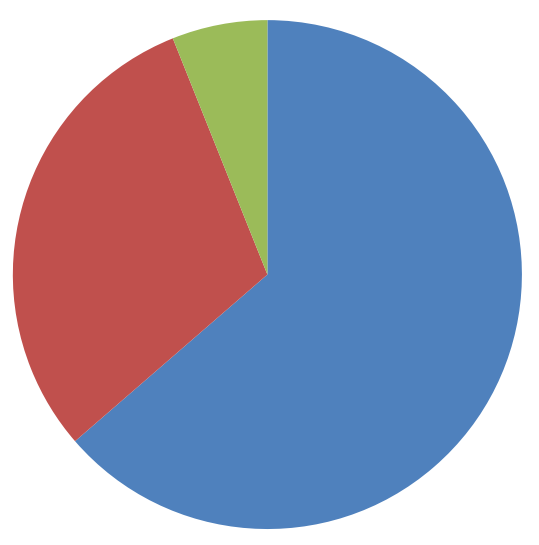

- Priponsko obrazilo -ka

- Priponsko obrazilo -ica

- Priponsko obrazilo -ulja 
Spodnja preglednica prikazuje, katera moškospolska priponska obrazila zamenjujejo feminativna priponska obrazila $\mathrm{v}$ pomenskih skupinah vršilec, nosilec, opravkar.

Preglednica 59: Zamenjava moškospolskega priponskega obrazila $z$ ženskospolskim pri tvorbi poimenovanj živali v SSKJ 1

\begin{tabular}{|c|c|c|c|c|c|}
\hline \multirow[t]{2}{*}{ OBRAZILO } & \multirow{2}{*}{$\begin{array}{l}\text { OBRAZILO } \\
\text { MOŠKEGA } \\
\text { SPOLA }\end{array}$} & \multirow{2}{*}{$\begin{array}{l}\text { IZGLASJE } \\
\text { PODSTAVE }\end{array}$} & \multicolumn{3}{|c|}{ PRIMERI TVORJENK } \\
\hline & & & $\begin{array}{l}\text { FEMINATIV } \\
\text { IZ VRŠILCA }\end{array}$ & $\begin{array}{l}\text { FEMINATIV } \\
\text { IZ NOSILCA }\end{array}$ & $\begin{array}{l}\text { FEMINATIV IZ } \\
\text { OPRAVKARJA }\end{array}$ \\
\hline \multirow[t]{6}{*}{$-i c a$} & \multirow[t]{5}{*}{$-e c$} & $-b$ & I & / & jazbica \\
\hline & & $-m$ & I & samica & I \\
\hline & & $-n$ & I & junica & I \\
\hline & & $-r$ & I & jarica & I \\
\hline & & $-v$ & l & jalovica & I \\
\hline & $-j a k$ & $-s$ & l & I & lisica \\
\hline \multirow[t]{9}{*}{$-k a$} & \multirow[t]{3}{*}{$-e c$} & $-m$ & I & siamka & I \\
\hline & & $-n$ & / & pitanka & / \\
\hline & & $-v$ & I & jalovka & I \\
\hline & -alec & $-v$ & prežvekovalka & / & / \\
\hline & -ilec & $-z$ & plazilka & I & I \\
\hline & -inec & $-t$ & / & kosmatinka & $/$ \\
\hline & -evec & $-\check{S}$ & 1 & 1 & ruševka \\
\hline & $-e k$ & $-c$ & / & / & backa \\
\hline & -ček & $-r$ & I & kanarka & I \\
\hline
\end{tabular}

1. Priponsko obrazilo -ica zamenjuje moškospolski obrazili:

- $\quad$ ec pri nosilcu z izglasjem podstave na $-m$ (samica), $-n$ (junica), $-r$ (jarica), $-v$ (jalovica), pri opravkarju ob izglasju podstave na -b (jazbica) ter pri netvorjenih podstavah, kadar je izglasje na -b (vrabica, žrebica) ali $-s$ (prasica);

- -jak pri opravkarju z izglasjem podstave na -s (lisica). 
2. Obrazilo $-\boldsymbol{k} \boldsymbol{a}$ lahko zamenja moškospolska priponska obrazila:

- $\quad$-ec za nosilca z izglasjem podstave na -m (samka, siamka), -n (pitanka, rezanka, rumenka), -v (jalovka, popadljivka, rjavka, ščinkavka, škodljivka, zajedavka); nastopi tudi pri netvorjenih podstavah (škrjanka, zajka);

- - -alec pri vršilcu iz glagolov na -ovati-ujem (prežvekovalka);

- -ilec pri vršilcu iz glagolov na -iti/-im (plazilka);

- - -inec ob nosilcu z izglasjem podstave na -t (kosmatinka);

- $\quad$-evec za opravkarja (ruševka) $;^{97}$

- $\quad$ ek pri opravkarju z izglasjem podstave na -c (backa) in pri netvorjenih podstavah (mačka);

- - -ček pri nosilcu z izglasjem podstave na -r (kanarka).

3. Priponsko obrazilo -ulja zamenja moškospolsko priponsko obrazilo -ec pri netvorjeni podstavi z izglasjem na $-b$ (vrabulja) ali - $v$ (slavulja).

\section{Sinteza obrazilne produktivnosti}

Opažamo, da pri tvorbi ženskospolskih poimenovanj živali kot zamenjevalna nastopajo tri feminativna obrazila: -ica, -ka in -ulja. Vsa tri lahko zamenjajo moškospolska obrazila (s sestavino) -ec; -ica pri nosilcu lastnosti in opravkarju z različnimi izglasji podstav, podobno $-k a$, le da slednja nastopi še pri vršilcu iz glagolskih podstav na -iti/-im in -ovati/-ujem, -ulja pa pri netvorjenih podstavah.

\subsubsection{Druga izdaja Slovarja slovenskega knjižnega jezika}

V drugi izdaji sta novi le ženskospolski poimenovanji risinja in labradorka; prva je nastala $\mathrm{z}$ dodajanjem feminativnega priponskega obrazila samostalniku moškega spola, druga pa z zamenjevalnim načinom. Priponsko obrazilo -inja se doda netvorjeni podstavi in opozori na variantnost obrazil

${ }^{97}$ Iz samostalnika ruševje (Snoj 2016: 657). 
(risinja - risa), obrazilo - $k a$ pa zamenjuje moškospolsko priponsko obrazilo -ec pri prevzeti besedi (labradorka).

\subsubsection{Slovar novejšega besedja slovenskega jezika}

$\mathrm{V}$ tem jezikovnem priročniku smo zasledili zgolj en primer ženskospolskega poimenovanja živali, to je perzijka, nastala $\mathrm{z}$ zamenjavo moškospolskega priponskega obrazila $-e c$ s feminativnim $-k a$ pri nosilcu $\mathrm{z}$ izglasjem podstave na $-j$.

\subsection{Primerjalni pregled}

\section{Poimenovanja oseb}

V primerjalni pregled smo vključili poimenovanja oseb in živali. Za raziskavo feminativne tvorbe $\mathrm{v}$ slovenščini smo uporabili tri različne vire: nekoliko starejši Slovar slovenskega knjižnega jezika (skupno 1939 poimenovanj oseb in 91 poimenovanj živali), vendar s posodobljeno, drugo izdajo (skupno 2229 poimenovanj oseb, 93 živali), ter novejša vira: iz leta 2009 Novejšo slovensko leksiko (243 tvorjenk) in iz leta 2013 Slovar novejšega besedja (163 poimenovanj oseb, eno poimenovanje živali). Izpisani feminativi so nastali bodisi $\mathrm{z}$ dodajalnim bodisi z zamenjevalnim obrazilom.

Preglednica 60: Primerjalni prikaz feminativov glede na način tvorbe

\begin{tabular}{|c|c|c|}
\hline VIR & DODAJALNO OBRAZILO & $\begin{array}{l}\text { ZAMENJEVALNO } \\
\text { OBRAZILO }\end{array}$ \\
\hline SSKJ 1 & $\begin{array}{c}846 \text { tvorjenk }(44 \%) \text { - osebe } \\
60 \text { tvorjenk }(67 \%) \text { - živali }\end{array}$ & $\begin{array}{c}1093 \text { tvorjenk }(56 \%) \text { - osebe } \\
31 \text { tvorjenk }(33 \%) \text { - živali }\end{array}$ \\
\hline SSKJ 2 & $\begin{array}{c}1036 \text { tvorjenk }(46,4 \%) \text { - osebe } \\
61 \text { tvorjenk }(68 \%) \text { - živali }\end{array}$ & $\begin{array}{c}1193 \text { tvorjenk }(53,6 \%) \text { - osebe } \\
32 \text { tvorjenk }(32 \%) \text { - živali }\end{array}$ \\
\hline$N S L$ & 167 tvorjenk (69\%) - osebe & 76 tvorjenk (31\%) - osebe \\
\hline SNBSJ & 107 tvorjenk (66\%) - osebe & $\begin{array}{c}56 \text { tvorjenk }(34 \%) \text { - osebe } \\
\text { ena tvorjenka - živali }\end{array}$ \\
\hline
\end{tabular}


Primerjalni prikaz števila tvorjenk za poimenovanja oseb, nastalih $\mathrm{z}$ dodajalnim oziroma z zamenjevalnim načinom, v vseh uporabljenih virih kaže, da feminativi iz NSL in SNBSJ večinoma nastajajo z dodajanjem obrazila; po NSL v $69 \%$, po SNBSJ pa $66 \%$. Gre za novotvorjenke oz. novejše enobesedne lekseme. Drugače je v SSKJ 1 in $S S K J$ 2, kjer večji odstotek (56 oz. 53,6 \%) nastane z zamenjevalnim načinom, res pa je, da je delež tovrstnih tvorjenk v novejši izdaji že za skoraj tri odstotke manjši. Nadalje ugotavljamo, da nekatera feminativna priponska obrazila nastopajo samo kot dodajalna (-na, -a, -esa, -(ov)ka, -(ev)ka) ali samo kot zamenjevalna (le-kinja).

Pri analizi vseh dodajalnih feminativnih obrazil smo bili pozorni na izglasja moškospolskih obrazil. Spodnja preglednica prikazuje, s katerimi izglasji se družijo feminativna priponska obrazila v vseh vključenih jezikovnih virih (pri tvorbi ženskospolskih poimenovanj oseb), pri čemer smo zajeli vse tri prve pomenske skupine izpeljank iz glagolske, pridevniške in samostalniške podstave.

Preglednica 61: Primerjalni pregled družljivosti feminativnih priponskih obrazil z izglasji moškospolskih samostalnikov po pomenskih skupinah

\begin{tabular}{|c|c|c|c|c|}
\hline \multirow[t]{2}{*}{ OBRAZILO } & \multirow{2}{*}{$\begin{array}{l}\text { IZGLASJE } \\
\text { OBRAZILA }\end{array}$} & \multicolumn{3}{|c|}{ VIR } \\
\hline & & SSKJ 1, SSKJ $2^{98}$ & NSL & SNBSJ \\
\hline \multirow[t]{5}{*}{$-a$} & $-(a) \check{c}$ & vršilec & / & / \\
\hline & $-(u) h$ & vršilec, nosilec & / & l \\
\hline & $-(u) k$ & nosilec & l & l \\
\hline & $-(e) l$ & vršilec & / & / \\
\hline & $-(a) n$ & opravkar & l & / \\
\hline$-c a$ & $-(a) r$ & / & opravkar & / \\
\hline \multirow[t]{5}{*}{$-i c a$} & $-(a) \check{c}$ & vršilec, opravkar & vršilec & vršilec \\
\hline & $-($ ate $) l j$ & vršilec & / & / \\
\hline & -(ite)lj & vršilec, opravkar & vršilec & vršilec \\
\hline & $-(j a) n$ & opravkar & l & I \\
\hline & $-(a) r$ & vršilec, opravkar & $\begin{array}{l}\text { vršilec, } \\
\text { opravkar }\end{array}$ & / \\
\hline
\end{tabular}

${ }^{98}$ Zapisane možnosti veljajo za obe izdaji; kadar gre za novost v SSKJ 2, smo to zapisali v oklepaju. 


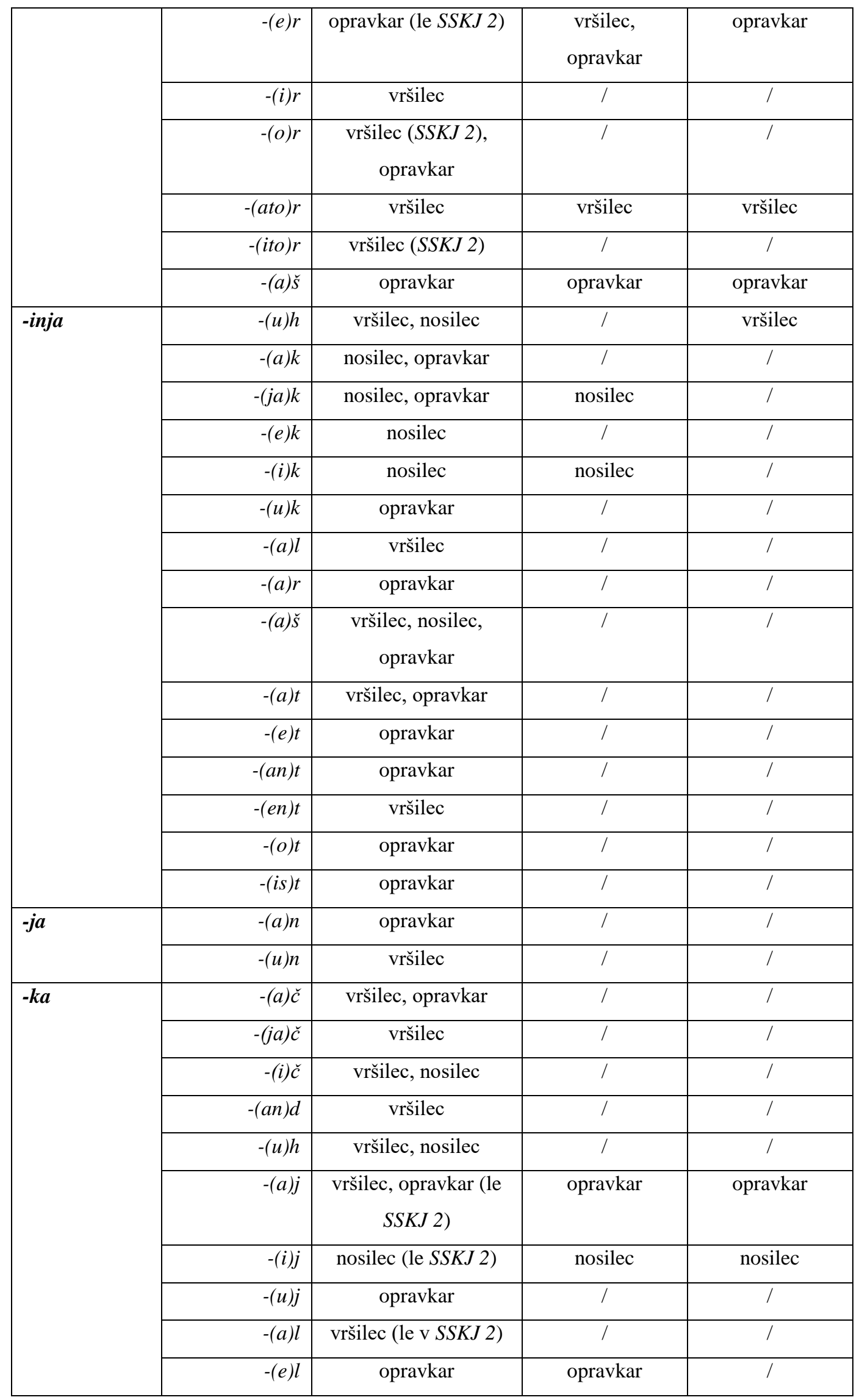




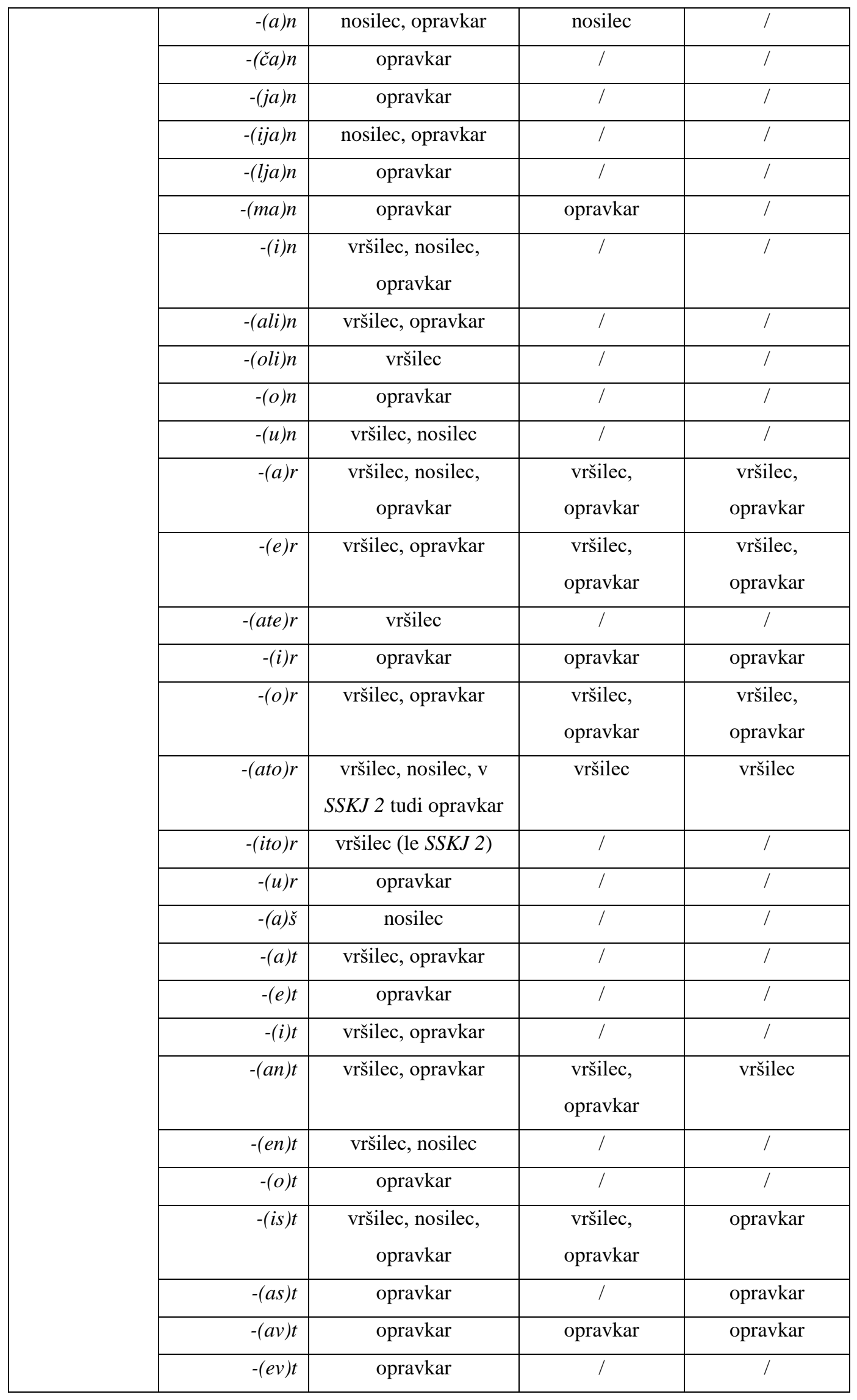




\begin{tabular}{|l|r|c|c|c|}
\hline \multirow{3}{*}{$-(\boldsymbol{a r}) \boldsymbol{k} \boldsymbol{a}$} & $-(i) k$ & $\begin{array}{c}\text { vršilec, nosilec, } \\
\text { opravkar }\end{array}$ & opravkar & $/$ \\
\cline { 2 - 5 } & $-(t i) k$ & opravkar (le SSKJ 2) & opravkar & $/$ \\
\cline { 2 - 5 } & $-(a t i) k$ & opravkar (le SSKJ 2) & $/$ & opravkar \\
\hline$-(\boldsymbol{e v}) \boldsymbol{k} \boldsymbol{a}$ & $-(i) \check{c}$ & vršilec, nosilec & $/$ & $/$ \\
\hline$-\boldsymbol{n} \boldsymbol{a}$ & $-(i) \check{c}$ & vršilec, opravkar & $/$ & $/$ \\
\hline
\end{tabular}

Največja raznolikost izglasij moškospolskih samostalnikov je razvidna iz gradiva SSKJ 1 in SSKJ 2, kar je glede na največje število zajetih primerov povsem pričakovano.

1. Tako se priponsko obrazilo $-a \mathrm{v}$ nobenem viru $\mathrm{z}$ nobenim izglasjem ne druži $\mathrm{v}$ vseh treh pomenskih skupinah. Večinoma je s primeri zastopano le v obeh izdajah SSKJ, dodaja pa se $\mathrm{k}$ izglasjem vršilca, redkeje nastopi v pomenskih skupinah nosilec in opravkar.

2. Priponsko obrazilo -(ar)ka se v pomenskih skupinah nosilec in opravkar druži z izglasjem obrazila na $-k$ v SSKJ 1, SSKJ 2, NSL in SNBSJ.

3. Priponsko obrazilo -ica se dodaja več različnim izglasjem, a kot kaže, je najpogosteje družljivo z izglasji na $-r$ v pomenskih skupinah vršilec in opravkar. Tudi iz primerjalnega pregleda je razvidno, da kot dodajalno obrazilo nikoli ne nastopi $\mathrm{v}$ pomenski skupini nosilec. Kot edino feminativno obrazilo se dodaja $\mathrm{k}$ izglasjem obrazila na $-l j$.

4. Tudi obrazilo -inja se dodaja različnim izglasjem moškospolskih samostalnikov, večinoma $\mathrm{v}$ pomenskih skupinah vršilec in opravkar, redkeje nastopi pri nosilcu. Za vse tri prve pomenske skupine izpeljank iz glagolske, pridevniške in samostalniške podstave, tj. za vršilca, nosilca in opravkarja, se pri dodajalnem obrazilu -inja pojavita izglasji na $-(a) k$ in $-(a) \check{s}$ glede na gradivo iz SSKJ 1 in SSKJ 2.

5. Priponsko obrazilo -ja kot dodajalno nastopi le pri primerih iz obeh izdaj SSKJ, a nikoli pri nosilcu.

6. Obrazilo - $k a$ nastopi kot dodajalno $\mathrm{k}$ več različnim izglasjem, a za vse tri pomenske skupine se pojavijo izglasja $-(i) n,-(a) r$ in $-(i s) t$, kar je $\mathrm{v}$ glavnem podprto s primeri iz obeh izdaj SSKJ, pogosto tudi iz drugih treh virov. 
7. Obrazilo $-(e v) k a$ nastopi kot dodajalno le pri izglasju na $-(i) \check{c}$ v pomenskih skupinah nosilec in vršilec. Tovrstne tvorjenke smo zasledili le v SSKJ, in to v obeh izdajah.

8. Obrazilo -na, po Toporišičevi Slovenski slovnici (2004) sicer -ična, se dodaja izglasju na $-(i) \check{c}$ pri vršilcu in opravkarju, primere pa ponujata le obe izdaji SSKJ.

$\mathrm{Ob}$ analiziranju feminativov smo bili pozorni tudi na izglasja moškospolskih poimenovanj oseb, s katerimi se feminativna priponska obrazila družijo. Spodnja preglednica vključuje podatke iz vseh štirih obravnavanih virov. ${ }^{99}$ Besede, ki se pojavijo v več virih, smo šteli le enkrat. Izpustili pa smo tvorjenke, pri katerih gre za dodajanje feminativnega obrazila k izglasju podstave in ne k izglasju obrazila.

99 Ker smo opazili, da so prav vsi primeri iz SSKJ 1 in SNBSJ vsebovani v SSKJ 2, smo k feminativom iz le-tega vira prišteli tistih 54 primerov, ki se pojavijo samo v NSL (navedenih na str. 213), in tako dobili skupno število. 
Preglednica 62: Sinteza obrazilne produktivnosti-dodajalni način (primerjalni prikaz)

\begin{tabular}{|c|c|c|c|c|c|c|c|c|c|c|c|c|c|c|}
\hline \multirow{2}{*}{$\begin{array}{l}\text { IZGLASJE } \\
\text { OBRAZILA }\end{array}$} & \multicolumn{14}{|c|}{ FEMINATIVNA PRIPONSKA OBRAZILA } \\
\hline & $-a$ & $-c a$ & $-i c a$ & $-(a r) i c a$ & $-j a$ & -ulja & -inja & $-k a$ & $-(a r) k a$ & $-(e v) k a$ & $-(o v) k a$ & $-n a$ & -esa & SKUPAJ \\
\hline$-(a) \check{c}$ & $\begin{array}{c}2 \\
(8 \%)\end{array}$ & 1 & $\begin{array}{c}19 \\
(52 \%)\end{array}$ & 1 & I & 1 & I & $\begin{array}{c}14 \\
(40 \%)\end{array}$ & I & I & I & 1 & I & 35 \\
\hline$-(j a) \check{c}$ & 1 & 1 & 1 & I & I & I & I & $\begin{array}{c}1 \\
(100 \%)\end{array}$ & I & 1 & I & 1 & 1 & 1 \\
\hline -(i) $\check{c}$ & I & 1 & I & I & I & 1 & I & $\begin{array}{c}5 \\
(39 \%)\end{array}$ & I & $\begin{array}{c}2 \\
(15 \%)\end{array}$ & 1 & $\begin{array}{c}6 \\
(46 \%)\end{array}$ & I & 13 \\
\hline$-(a n) d$ & 1 & I & I & 1 & I & 1 & I & $\begin{array}{c}2 \\
(100 \%)\end{array}$ & I & I & 1 & 1 & 1 & 2 \\
\hline$-(u) h$ & $\begin{array}{c}2 \\
(13 \%)\end{array}$ & 1 & I & I & 1 & 1 & $\begin{array}{c}8 \\
(53 \%)\end{array}$ & $\begin{array}{c}5 \\
(33 \%)\end{array}$ & I & 1 & 1 & 1 & I & 15 \\
\hline$-(a) j$ & I & 1 & 1 & 1 & 1 & 1 & 1 & $\begin{array}{c}4 \\
(100 \%)\end{array}$ & I & I & I & 1 & 1 & 4 \\
\hline$-(i) j$ & I & 1 & I & 1 & I & 1 & I & $\begin{array}{c}1 \\
(100 \%)\end{array}$ & I & I & 1 & 1 & 1 & 1 \\
\hline$-(u) j$ & I & I & I & I & 1 & 1 & I & $\begin{array}{c}1 \\
(100 \%)\end{array}$ & I & 1 & I & I & I & 1 \\
\hline$-(a) k$ & 1 & 1 & I & I & 1 & 1 & $\begin{array}{c}10 \\
(100 \%)\end{array}$ & I & I & I & 1 & 1 & I & 10 \\
\hline$-(j a) k$ & I & 1 & I & I & I & 1 & $\begin{array}{c}20 \\
(100 \%)\end{array}$ & 1 & I & I & I & 1 & 1 & 20 \\
\hline$-(e) k$ & I & 1 & I & I & I & 1 & $\begin{array}{c}1 \\
(100 \%)\end{array}$ & 1 & I & 1 & I & 1 & I & 1 \\
\hline$-(i) k$ & I & 1 & I & 1 & I & 1 & $\begin{array}{c}1 \\
(11,1 \%)\end{array}$ & 1 & $\begin{array}{c}8 \\
(88,9 \%) \\
\end{array}$ & I & 1 & 1 & 1 & 9 \\
\hline$-(t i) k$ & I & 1 & I & 1 & I & 1 & I & I & $\begin{array}{c}1 \\
(100 \%)\end{array}$ & I & I & 1 & 1 & 1 \\
\hline$-(a t i) k$ & I & 1 & I & I & 1 & 1 & I & 1 & $\begin{array}{c}1 \\
(100 \%)\end{array}$ & 1 & 1 & 1 & I & 1 \\
\hline$-(u) k$ & $\begin{array}{c}1 \\
(50 \%)\end{array}$ & 1 & I & 1 & 1 & 1 & $\begin{array}{c}1 \\
(50 \%)\end{array}$ & 1 & I & I & I & 1 & 1 & 2 \\
\hline$-($ ate $) l j$ & I & 1 & $\begin{array}{c}10 \\
(100 \%)\end{array}$ & 1 & I & 1 & I & 1 & I & I & I & 1 & 1 & 10 \\
\hline
\end{tabular}




\begin{tabular}{|c|c|c|c|c|c|c|c|c|c|c|c|c|c|c|}
\hline \multirow{2}{*}{$\begin{array}{l}\text { IZGLASJE } \\
\text { OBRAZILA }\end{array}$} & \multicolumn{14}{|c|}{ FEMINATIVNA PRIPONSKA OBRAZILA } \\
\hline & $-a$ & $-c a$ & $-i c a$ & -(ar)ica & $-j a$ & -ulja & -inja & $-k a$ & $-(a r) k a$ & $-(e v) k a$ & $-(o v) k a$ & $-n a$ & -esa & SKUPAJ \\
\hline -(ite)lj & I & I & $\begin{array}{c}40 \\
(100 \%)\end{array}$ & 1 & I & 1 & I & I & I & I & I & I & l & 40 \\
\hline$-(a) l$ & I & I & 1 & I & I & I & $\begin{array}{c}1 \\
(50 \%)\end{array}$ & $\begin{array}{c}1 \\
(50 \%)\end{array}$ & I & I & I & I & / & 2 \\
\hline$-(e) l$ & $\begin{array}{c}1 \\
(50 \%)\end{array}$ & I & I & I & I & I & l & $\begin{array}{c}1 \\
(50 \%)\end{array}$ & I & I & I & I & / & 2 \\
\hline$-(a) n$ & $\begin{array}{c}1 \\
(4 \%)\end{array}$ & I & l & I & $\begin{array}{c}1 \\
(4 \%)\end{array}$ & I & I & $\begin{array}{c}23 \\
(92 \%)\end{array}$ & I & I & I & I & / & 25 \\
\hline$-(\check{c} a) n$ & I & I & 1 & I & 1 & 1 & I & $\begin{array}{c}5 \\
(100 \%)\end{array}$ & I & 1 & 1 & I & I & 5 \\
\hline$-(j a) n$ & I & I & $\begin{array}{c}1 \\
(20 \%)\end{array}$ & I & I & 1 & I & $\begin{array}{c}4 \\
(80 \%)\end{array}$ & I & 1 & I & 1 & I & 5 \\
\hline$-(i j a) n$ & 1 & 1 & I & I & I & I & I & $\begin{array}{c}2 \\
(100 \%)\end{array}$ & I & 1 & 1 & 1 & I & 2 \\
\hline$-(l j a) n$ & I & I & 1 & I & I & I & I & $\begin{array}{c}4 \\
(100 \%)\end{array}$ & I & 1 & 1 & I & I & 4 \\
\hline$-(m a) n$ & 1 & 1 & 1 & I & I & 1 & I & $\begin{array}{c}3 \\
(100 \%)\end{array}$ & I & 1 & 1 & 1 & 1 & 3 \\
\hline$-(i) n$ & I & I & 1 & I & I & 1 & I & $\begin{array}{c}7 \\
(100 \%)\end{array}$ & I & I & 1 & 1 & 1 & 7 \\
\hline$-($ ali $) n$ & 1 & 1 & 1 & I & I & 1 & I & $\begin{array}{c}2 \\
(100 \%)\end{array}$ & I & 1 & 1 & 1 & I & 2 \\
\hline$-(o l i) n$ & 1 & I & I & I & 1 & I & 1 & $\begin{array}{c}1 \\
(100 \%)\end{array}$ & I & 1 & 1 & I & 1 & 1 \\
\hline$-(o) n$ & 1 & 1 & 1 & 1 & I & 1 & I & $\begin{array}{c}1 \\
(100 \%)\end{array}$ & I & 1 & 1 & I & 1 & 1 \\
\hline$-(u) n$ & I & 1 & I & 1 & $\begin{array}{c}1 \\
(33 \%)\end{array}$ & 1 & 1 & $\begin{array}{c}2 \\
(66 \%)\end{array}$ & I & 1 & 1 & 1 & 1 & 3 \\
\hline$-(a) r$ & 1 & $1(0,5 \%)$ & $\begin{array}{c}109 \\
(48 \%)\end{array}$ & I & I & I & $\begin{array}{c}1 \\
(0,5 \%)\end{array}$ & $\begin{array}{c}115 \\
(51 \%)\end{array}$ & I & I & I & I & I & 226 \\
\hline$-(e) r$ & 1 & 1 & $\begin{array}{c}4 \\
(9 \%)\end{array}$ & I & I & I & l & $\begin{array}{c}41 \\
(91 \%)\end{array}$ & I & 1 & 1 & I & 1 & 45 \\
\hline$-(a t e) r$ & 1 & 1 & I & I & 1 & 1 & I & $\begin{array}{c}2 \\
(100 \%)\end{array}$ & I & 1 & I & I & 1 & 2 \\
\hline$-(i) r$ & 1 & 1 & $\begin{array}{c}1 \\
(25 \%)\end{array}$ & I & I & 1 & 1 & $\begin{array}{c}3 \\
(75 \%)\end{array}$ & 1 & 1 & 1 & I & 1 & 4 \\
\hline
\end{tabular}




\begin{tabular}{|c|c|c|c|c|c|c|c|c|c|c|c|c|c|c|}
\hline \multirow{2}{*}{$\begin{array}{l}\text { IZGLASJE } \\
\text { OBRAZILA }\end{array}$} & \multicolumn{14}{|c|}{$\begin{array}{l}\text { FEMINATIVNA PRIPONSKA OBRAZILA } \\
\end{array}$} \\
\hline & $-a$ & $-c a$ & $-i c a$ & $-(a r) i c a$ & $-j a$ & -ulja & -inja & $-k a$ & $-(a r) k a$ & $-(e v) k a$ & $-(o v) k a$ & $-n a$ & -esa & SKUPAJ \\
\hline$-(o) r$ & 1 & I & $\begin{array}{c}10 \\
(55,5 \%) \\
\end{array}$ & I & I & I & I & $\begin{array}{c}8 \\
(44,5 \%) \\
\end{array}$ & 1 & I & 1 & 1 & I & 18 \\
\hline$-($ ato $) r$ & 1 & 1 & $\begin{array}{c}6 \\
(19 \%) \\
\end{array}$ & 1 & 1 & 1 & 1 & $\begin{array}{c}25 \\
(81 \%) \\
\end{array}$ & 1 & 1 & 1 & I & 1 & 31 \\
\hline -(ito)r & 1 & 1 & $\begin{array}{c}1 \\
(33 \%) \\
\end{array}$ & I & 1 & 1 & 1 & $\begin{array}{c}2 \\
(66 \%)\end{array}$ & 1 & 1 & 1 & I & I & 3 \\
\hline$-(u) r$ & 1 & I & I & I & I & I & I & $\begin{array}{c}1 \\
(100 \%) \\
\end{array}$ & I & I & I & I & I & 1 \\
\hline$\overline{-(a) \check{s}}$ & I & 1 & $\begin{array}{c}3 \\
(33 \%) \\
\end{array}$ & 1 & 1 & 1 & $\begin{array}{c}5 \\
(55 \%)\end{array}$ & $\begin{array}{c}1 \\
(11 \%)\end{array}$ & 1 & 1 & I & I & 1 & 9 \\
\hline$-(a) t$ & 1 & 1 & 1 & 1 & 1 & 1 & $\begin{array}{c}2 \\
(20 \%) \\
\end{array}$ & $\begin{array}{c}8 \\
(80 \%) \\
\end{array}$ & I & I & 1 & 1 & 1 & 10 \\
\hline$-(a n) t$ & 1 & I & I & I & 1 & 1 & $\begin{array}{c}1 \\
(3 \%)\end{array}$ & $\begin{array}{c}30 \\
(97 \%)\end{array}$ & 1 & I & I & I & I & 31 \\
\hline$-(a s) t$ & 1 & 1 & I & I & 1 & 1 & 1 & $\begin{array}{c}3 \\
(100 \%) \\
\end{array}$ & I & 1 & I & I & I & 3 \\
\hline$-(a v) t$ & 1 & 1 & I & 1 & 1 & 1 & I & $\begin{array}{c}2 \\
(100 \%)\end{array}$ & I & 1 & 1 & 1 & 1 & 2 \\
\hline$-(e) t$ & 1 & I & 1 & 1 & 1 & 1 & $\begin{array}{c}1 \\
(33 \%) \\
\end{array}$ & $\begin{array}{c}2 \\
(66 \%) \\
\end{array}$ & I & I & 1 & 1 & 1 & 3 \\
\hline$-(e n) t$ & 1 & 1 & 1 & I & 1 & I & $\begin{array}{c}2 \\
(8 \%)\end{array}$ & $\begin{array}{c}22 \\
(92 \%)\end{array}$ & 1 & 1 & 1 & 1 & 1 & 24 \\
\hline$-(e v) t$ & 1 & 1 & 1 & 1 & 1 & 1 & 1 & $\begin{array}{c}5 \\
(100 \%) \\
\end{array}$ & 1 & I & 1 & I & I & 5 \\
\hline$-(i) t$ & 1 & 1 & 1 & I & I & 1 & I & $\begin{array}{c}2 \\
(100 \%)\end{array}$ & I & I & I & I & 1 & 2 \\
\hline$-(i s) t$ & 1 & I & 1 & I & 1 & 1 & $\begin{array}{c}3 \\
(2 \%) \\
\end{array}$ & $\begin{array}{c}137 \\
(98 \%) \\
\end{array}$ & 1 & 1 & 1 & I & 1 & 140 \\
\hline$-(o) t$ & 1 & I & I & I & 1 & I & $\begin{array}{c}1 \\
(50 \%)\end{array}$ & $\begin{array}{c}1 \\
(50 \%)\end{array}$ & I & I & 1 & I & I & 2 \\
\hline$-\theta$ & $\begin{array}{c}7 \\
(2 \%) \\
\end{array}$ & I & $\begin{array}{c}43 \\
(14 \%) \\
\end{array}$ & $\begin{array}{c}1 \\
(0,3 \%)\end{array}$ & $\begin{array}{c}2 \\
(0,6 \%)\end{array}$ & $\begin{array}{c}2 \\
(0,6 \%)\end{array}$ & $\begin{array}{c}103 \\
(34 \%)\end{array}$ & $\begin{array}{c}114 \\
(38 \%)\end{array}$ & $\begin{array}{c}19 \\
(6 \%)\end{array}$ & $\begin{array}{c}1 \\
(0,3)\end{array}$ & $\begin{array}{c}5 \\
(1,5 \%)\end{array}$ & 1 & $\begin{array}{c}4 \\
(1,3 \%)\end{array}$ & 301 \\
\hline SKUPAJ & $\begin{array}{c}14 \\
(1,3 \%)\end{array}$ & $\begin{array}{c}1 \\
(0,1 \%)\end{array}$ & $\begin{array}{c}247 \\
(23 \%)\end{array}$ & $\begin{array}{c}1 \\
(0,1 \%)\end{array}$ & $\begin{array}{c}4 \\
(0,4 \%)\end{array}$ & $\begin{array}{c}2 \\
(0,2 \%)\end{array}$ & $\begin{array}{c}161 \\
(15 \%)\end{array}$ & $\begin{array}{c}613 \\
(56 \%)\end{array}$ & $\begin{array}{c}29 \\
(2,7 \%)\end{array}$ & $\begin{array}{c}3 \\
(0,3 \%)\end{array}$ & $\begin{array}{c}5 \\
(0,5 \%) \\
\end{array}$ & $\begin{array}{c}6 \\
(0,55 \%) \\
\end{array}$ & $\begin{array}{c}4 \\
(0,4 \%) \\
\end{array}$ & 1090 \\
\hline
\end{tabular}


Primerjalni pregled kaže, da sta priponski obrazili -ica in -ka s primeri dokaj enakovredno zastopani pri izglasjih obrazil na $-(V) \check{c}(-i c a$ : 19 primerov, $-k a$ :

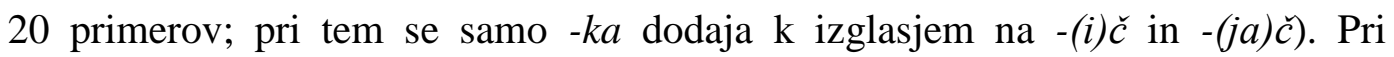
izglasjih obrazil na $-(V) k$ prevladuje tvorjenje feminativov $\mathrm{z}$-inja (33 tvorjenk), $\mathrm{k}$ izglasjem moškospolskih obrazil na -(ate)lj in -(ite)lj pa se dodaja samo -ica (50 primerov). K izglasjem obrazil na $-n$ prevladuje dodajanje feminativnega obrazila -ka (54 primerov, le eden $\mathrm{z}-i c a$ ). Kadar se moškospolska poimenovanja oseb končajo na izglasje (obrazila) -r, gre pri tvorbi feminativov pogosto za dodajanje ženskospolskih priponskih obrazil $-k a$ (197 primerov) in -ica (skupno 131 primerov); pri tem se k izglasjem na -(ate) $r$ in - $(u) r$ dodaja samo $-k a$. Če pa gre za izglasje na $-t$, prevladuje dodajanje obrazila $-k a$ (212 primerov, samo 10 tvorjenk $\mathrm{z}$-inja). Obrazilo $-k a$ torej prevladuje pri dodajanju k moškospolskim izglasjem obrazil na $-n,-r$ in $-t$, obrazilo -inja pri tovrstnih izglasjih na $-k$, -ica pa pri tistih na $-l j .{ }^{100}$

\section{Sinteza obrazilne produktivnosti - dodajanje k izglasju podstave}

Preglednica prikazuje, katera feminativna priponska obrazila (in $\mathrm{v}$ kolikšni meri) se lahko dodajajo posameznim izglasjem podstav. Vključena je tvorba iz netvorjenk ter iz nekaterih zloženih in sestavljenih podstav, in to iz vseh štirih obravnavanih jezikovnih virov.

\footnotetext{
${ }^{100}$ Pregled kompatibilnosti soglasniških fonemov (Unuk 2003: 42-43), ki temelji na primerjanju inherentnih distinktivnih lastnosti posameznega fonema $\mathrm{v}$ nizu $\mathrm{v}$ kombinaciji $\mathrm{z}$ inherentnimi distinktivnimi lastnostmi drugega $\mathrm{v}$ istem nizu, kaže, da se fonem $k$ (kot začetek obrazila $-k a$ ) druži s fonemi $c, \breve{c}, f, h, s, \breve{s}, t$, kar se le delno ujema z našimi ugotovitvami. Obrazilo -ka je med naštetimi najbolj družljivo samo $\mathrm{z}$ izglasji obrazil na $-t$. Nekateri drugi našteti fonemi bodo $\mathrm{s}$ feminativnim obrazilom - $k a$ kompatibilni (razen $h, s$ ), ko bo šlo za dodajanje $\mathrm{k}$ izglasjem podstav (v nadaljevanju, str. 288-289). Obrazila -ica, -ulja, -inja, -(ar)ka, -(ev)ka, -(ov)ka, -esa se zaradi začetnega samoglasnika lahko dodajajo k soglasniškim izglasjem (podstav ali obrazil) brez omejitev. Obrazili $-j a$ in $-n a$ sta zaradi začetnega zvočnika lahko kombinirani s preostalimi zvočniki $(m, l, n, r, j, v)$, kar se tudi zgolj deloma ujema z našo sintezo obrazilne produktivnosti, saj nastopita tudi ob nezvočnikih, denimo $-j a \mathrm{ob} t$ in $-n a$ ob $\check{c}$.
} 
Preglednica 63: Sinteza obrazilne produktivnosti-dodajalni način k izglasju podstave (primerjalni prikaz)

\begin{tabular}{|c|c|c|c|c|c|c|c|c|c|c|c|c|c|c|}
\hline \multirow{2}{*}{$\begin{array}{l}\text { IZGLASJE } \\
\text { PODSTAVE }\end{array}$} & \multicolumn{14}{|c|}{ FEMINATIVNO PRIPONSKO OBRAZILO } \\
\hline & $-a$ & $-c a$ & $-i c a$ & $-(a r) i c a$ & $-j a$ & -ulja & -inja & $-k a$ & $-(a r) k a$ & $-(e v) k a$ & $-(o v) k a$ & $-n a$ & $-e s a$ & SKUPAJ \\
\hline$-b$ & I & I & / & I & I & I & $\begin{array}{c}1 \\
(33 \%)\end{array}$ & $\begin{array}{c}2 \\
(66 \%)\end{array}$ & I & I & I & I & I & 3 \\
\hline$-c$ & / & I & / & I & I & $\begin{array}{c}1 \\
(33 \%) \\
\end{array}$ & I & $\begin{array}{c}1 \\
(33 \%) \\
\end{array}$ & I & I & I & l & $\begin{array}{c}1 \\
(33 \%) \\
\end{array}$ & 3 \\
\hline$-\check{c}$ & I & I & $\begin{array}{c}2 \\
(66 \%)\end{array}$ & I & I & 1 & I & $\begin{array}{c}1 \\
(33 \%) \\
\end{array}$ & I & I & I & I & 1 & 3 \\
\hline$-d$ & $\begin{array}{c}1 \\
(5 \%) \\
\end{array}$ & I & $\begin{array}{c}1 \\
(5 \%) \\
\end{array}$ & I & I & I & $\begin{array}{c}8 \\
(40 \%) \\
\end{array}$ & $\begin{array}{c}8 \\
(40 \%) \\
\end{array}$ & 1 & I & $\begin{array}{c}1 \\
(5 \%) \\
\end{array}$ & I & $\begin{array}{c}1 \\
(5 \%) \\
\end{array}$ & 20 \\
\hline$-f$ & 1 & I & $\begin{array}{c}3 \\
(2 \%) \\
\end{array}$ & I & I & I & $\begin{array}{c}11 \\
(46 \%) \\
\end{array}$ & $\begin{array}{c}10 \\
(42 \%) \\
\end{array}$ & I & I & 1 & I & I & 24 \\
\hline$-g$ & I & I & $\begin{array}{c}3 \\
(6 \%)\end{array}$ & I & 1 & $\begin{array}{c}1 \\
(2 \%)\end{array}$ & $\begin{array}{c}45 \\
(92 \%)\end{array}$ & I & I & I & I & I & I & 49 \\
\hline$-h$ & I & I & 1 & I & 1 & 1 & $\begin{array}{c}1 \\
(100 \%)\end{array}$ & I & 1 & I & I & I & I & 1 \\
\hline$-j$ & I & I & 1 & I & 1 & I & $\begin{array}{c}1 \\
(7 \%) \\
\end{array}$ & $\begin{array}{c}13 \\
(86 \%) \\
\end{array}$ & I & $\begin{array}{c}1 \\
(7 \%) \\
\end{array}$ & I & I & I & 15 \\
\hline$-l j$ & 1 & 1 & $\begin{array}{c}1 \\
(100 \%)\end{array}$ & I & I & I & 1 & I & I & 1 & I & 1 & I & 1 \\
\hline$-n j$ & $\begin{array}{c}1 \\
(100 \%)\end{array}$ & I & 1 & I & I & I & I & I & 1 & I & I & I & I & 1 \\
\hline$-k$ & 1 & I & $\begin{array}{c}2 \\
(5 \%) \\
\end{array}$ & $\begin{array}{c}1 \\
(2,5 \%) \\
\end{array}$ & 1 & I & $\begin{array}{c}16 \\
(39 \%) \\
\end{array}$ & $\begin{array}{c}1 \\
(2,5 \%) \\
\end{array}$ & $\begin{array}{c}19 \\
(46 \%) \\
\end{array}$ & 1 & $\begin{array}{c}2 \\
(5 \%) \\
\end{array}$ & I & I & 41 \\
\hline$-l$ & I & I & 1 & 1 & 1 & I & $\begin{array}{c}1 \\
(33 \%)\end{array}$ & $\begin{array}{c}2 \\
(66 \%) \\
\end{array}$ & 1 & I & 1 & I & I & 3 \\
\hline$-m$ & I & I & I & 1 & 1 & I & I & $\begin{array}{c}4 \\
(100 \%) \\
\end{array}$ & I & I & I & I & I & 4 \\
\hline$-n$ & 1 & 1 & $\begin{array}{c}6 \\
(21 \%) \\
\end{array}$ & 1 & $\begin{array}{c}1 \\
(3,5 \%) \\
\end{array}$ & I & 1 & $\begin{array}{c}21 \\
(72 \%) \\
\end{array}$ & 1 & I & I & I & $\begin{array}{c}1 \\
(3,5 \%) \\
\end{array}$ & 29 \\
\hline$-p$ & $\begin{array}{c}1 \\
(33 \%)\end{array}$ & 1 & $\begin{array}{c}1 \\
(33 \%)\end{array}$ & I & I & I & I & $\begin{array}{c}1 \\
(33 \%)\end{array}$ & 1 & I & I & I & 1 & 3 \\
\hline
\end{tabular}




\begin{tabular}{|c|c|c|c|c|c|c|c|c|c|c|c|c|c|c|}
\hline \multirow{2}{*}{$\begin{array}{c}\text { IZGLASJE } \\
\text { PODSTAVE }\end{array}$} & \multicolumn{14}{|c|}{ FEMINATIVNA PRIPONSKA OBRAZILA } \\
\hline & $-a$ & $-c a$ & $-i c a$ & $-(a r) i c a$ & $-j a$ & -ulja & -inja & $-k a$ & $-(a r) k a$ & $-(e v) k a$ & $-(o v) k a$ & $-n a$ & -esa & SKUPAJ \\
\hline$-r$ & $\begin{array}{c}2 \\
(4,5 \%)\end{array}$ & l & $\begin{array}{c}17 \\
(39 \%)\end{array}$ & l & l & / & $\begin{array}{c}4 \\
(9 \%)\end{array}$ & $\begin{array}{c}20 \\
(45,5 \%)\end{array}$ & l & l & $\begin{array}{c}1 \\
(2 \%)\end{array}$ & / & l & 44 \\
\hline$-s$ & $\begin{array}{c}2 \\
(50 \%)\end{array}$ & l & I & l & I & l & $\begin{array}{c}2 \\
(50 \%)\end{array}$ & l & I & l & I & / & I & 4 \\
\hline$-\check{s}$ & l & l & $\begin{array}{c}2 \\
(100 \%)\end{array}$ & l & l & / & I & l & I & l & l & I & I & 2 \\
\hline$-t$ & l & l & $\begin{array}{c}5 \\
(10 \%)\end{array}$ & l & $\begin{array}{c}1 \\
(2 \%)\end{array}$ & l & $\begin{array}{c}12 \\
(25 \%)\end{array}$ & $\begin{array}{c}28 \\
(58 \%)\end{array}$ & I & l & $\begin{array}{c}1 \\
(2 \%)\end{array}$ & l & $\begin{array}{c}1 \\
(2 \%)\end{array}$ & 48 \\
\hline$-v$ & I & I & I & I & I & I & I & $\begin{array}{c}1 \\
(100 \%)\end{array}$ & I & I & I & I & I & 1 \\
\hline$-z$ & I & I & I & I & I & I & $\begin{array}{c}1 \\
(50 \%)\end{array}$ & $\begin{array}{c}1 \\
(50 \%)\end{array}$ & 1 & I & I & I & I & 2 \\
\hline SKUPAJ & $\begin{array}{c}7 \\
(2 \%)\end{array}$ & I & $\begin{array}{c}43 \\
(14 \%)\end{array}$ & $\begin{array}{c}1 \\
(0,3 \%)\end{array}$ & $\begin{array}{c}2 \\
(0,6 \%)\end{array}$ & $\begin{array}{c}2 \\
(0,6 \%)\end{array}$ & $\begin{array}{c}103 \\
(34 \%)\end{array}$ & $\begin{array}{c}114 \\
(38 \%)\end{array}$ & $\begin{array}{c}19 \\
(6 \%)\end{array}$ & $\begin{array}{c}1 \\
(\mathbf{0 , 3})\end{array}$ & $\begin{array}{c}5 \\
(1,5 \%)\end{array}$ & I & $\begin{array}{c}4 \\
(1,3 \%)\end{array}$ & 301 \\
\hline
\end{tabular}


Opažamo naslednje: obrazili -(ar)ka in -(ar)ica se dodajata le izglasjem podstav na $-k$; feminativno obrazilo $-k a$ je najpogostejše ob izglasjih podstav na $-j$ (13 primerov ali $86 \%)$, - $n$ (21 feminativov ali $72 \%),-r$ (20 primerov ali 45,5\%), - $t$ (28 primerov ali $58 \%$ ), kot edino pa nastopi ob izglasju na $-v$, sicer z zgolj enim primerom; priponsko obrazilo -inja je najpogostejše ob moškospolskih izglasjih podstav na $-g$ (45 feminativov ali $92 \%)$ in $-k$ (16 primerov ali $39 \%)$ ter je edino, ki se pojavi ob izglasju na - $h$ (en primer). Priponsko obrazilo - $(e v) k a$ se pojavi le ob izglasju na $-j$, - eska le pri -c.

Spodnja preglednica pa prikazuje, katera moškospolska obrazila feminativna priponska obrazila zamenjujejo, pri čemer smo zajeli vse tri prve pomenske skupine izpeljank iz glagolske, pridevniške in samostalniške podstave.

Preglednica 64: Primerjalni prikaz zamenjave moškospolskih priponskih obrazil s feminativnimi po pomenskih skupinah

\begin{tabular}{|c|c|c|c|c|}
\hline \multirow[t]{2}{*}{ OBRAZILO } & \multirow{2}{*}{$\begin{array}{l}\text { OBRAZILO } \\
\text { MOŠKEGA } \\
\text { SPOLA }\end{array}$} & \multicolumn{3}{|c|}{ VIR } \\
\hline & & $\begin{array}{c}\text { SSKJ 1, } \\
\text { SSKJ } 2^{101}\end{array}$ & NSL & SNBSJ \\
\hline \multirow[t]{15}{*}{$-i c a$} & $-(d) e c$ & vršilec & 1 & 1 \\
\hline & $-(g) e c$ & nosilec & 1 & 1 \\
\hline & $-(h) e c$ & nosilec (le $S S K J$ 2) & nosilec & nosilec \\
\hline & $-(n j) e c$ & vršilec & 1 & 1 \\
\hline & $-(l) e c$ & nosilec & 1 & 1 \\
\hline & $-(m) e c$ & vršilec, nosilec & I & I \\
\hline & $-(n) e c$ & nosilec & I & 1 \\
\hline & $-(p) e c$ & nosilec & I & 1 \\
\hline & $-(r) e c$ & nosilec & 1 & 1 \\
\hline & $-(s) e c$ & $\begin{array}{c}\text { vršilec } \\
(S S K J \text { 2) }\end{array}$ & 1 & 1 \\
\hline & $-(t) e c$ & opravkar & I & 7 \\
\hline & $-(v) e c$ & vršilec, nosilec & 1 & I \\
\hline & $-(z) e c$ & vršilec & 1 & I \\
\hline & 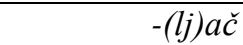 & vršilec & I & 1 \\
\hline & -(l)ek & nosilec & l & l \\
\hline
\end{tabular}

101 Zapisane možnosti veljajo za obe izdaji; kadar gre za novost v SSKJ 2, smo to zapisali v oklepaju. 


\begin{tabular}{|c|c|c|c|c|}
\hline & -(b)ček & nosilec & I & I \\
\hline & $-(j) \check{c} e k$ & nosilec & I & nosilec \\
\hline & $-(l) \check{c} e k$ & nosilec, opravkar & I & I \\
\hline & $-(n) \check{c} e k$ & 1 & nosilec & nosilec \\
\hline & $-(r)$ ček & / & nosilec & I \\
\hline & $-(n) i k$ & $\begin{array}{l}\text { vršilec, nosilec, } \\
\text { opravkar }\end{array}$ & nosilec & nosilec \\
\hline & $-(n j) i k$ & nosilec, opravkar & I & I \\
\hline & $-(b) n i k$ & vršilec & vršilec & vršilec \\
\hline & $-(c) n i k$ & opravkar & I & I \\
\hline & $-(\check{c}) n i k$ & vršilec & I & / \\
\hline & $-(\check{S} \check{c}) n i k$ & opravkar & I & / \\
\hline & $-(d) n i k$ & vršilec, nosilec & vršilec & I \\
\hline & $-(j) n i k$ & opravkar & I & I \\
\hline & $-(l j) n i k$ & vršilec & I & I \\
\hline & $-(l) n i k$ & opravkar (SSKJ 2) & opravkar & opravkar \\
\hline & $-(p) n i k$ & vršilec & I & I \\
\hline & $-(r) n i k$ & vršilec, opravkar & I & I \\
\hline & $-(s) n i k$ & vršilec (SSKJ 2) & I & I \\
\hline & $-(t) n i k$ & $\begin{array}{l}\text { vršilec (SSKJ 2), } \\
\text { nosilec, opravkar }\end{array}$ & nosilec & nosilec \\
\hline & $-(v) n i k$ & vršilec & vršilec & I \\
\hline & $-(z) n i k$ & vršilec & I & I \\
\hline & $-(\check{z}) n i k$ & vršilec & I & I \\
\hline & $-(r) \check{s} c ̌ i k$ & 1 & opravkar & opravkar \\
\hline & $-(\check{c})$ in & nosilec & I & I \\
\hline & $-(l) e \check{z}$ & nosilec & I & I \\
\hline & $-(n) e \check{z}$ & nosilec & nosilec & nosilec \\
\hline & $-(v) e \check{z}$ & opravkar & I & I \\
\hline$-j a$ & $-(t) i l e c$ & vršilec & I & I \\
\hline & -(z)ilec & vršilec & I & 1 \\
\hline -inja & $-(g) a$ & vršilec & 1 & I \\
\hline & $-(d) i \check{c}$ & vršilec & 1 & 1 \\
\hline & $-(k) a r$ & opravkar & I & I \\
\hline -kinja & $-(d) e c$ & vršilec & 1 & I \\
\hline & $-(m) i \check{c}$ & opravkar & I & I \\
\hline$-u l j a$ & $-(d) a \check{c}$ & vršilec & I & I \\
\hline
\end{tabular}




\begin{tabular}{|c|c|c|c|c|}
\hline & $-(k) a l o$ & vršilec & I & I \\
\hline & $-(n) a v s$ & nosilec & l & l \\
\hline & $-(d) u h$ & vršilec & I & I \\
\hline & $-(p) u h$ & nosilec & I & I \\
\hline$-k a$ & $-(b) e c$ & nosilec & I & I \\
\hline & $-(d) e c$ & vršilec, nosilec & I & I \\
\hline & $-(j) e c$ & nosilec, opravkar & opravkar & opravkar \\
\hline & $-(l j) e c$ & opravkar & / & I \\
\hline & $-(l) e c$ & nosilec, opravkar & / & I \\
\hline & $-(m) e c$ & vršilec, nosilec & I & I \\
\hline & $-(n) e c$ & $\begin{array}{c}\text { vršilec, nosilec, } \\
\text { opravkar }\end{array}$ & $\begin{array}{l}\text { nosilec, } \\
\text { opravkar }\end{array}$ & nosilec \\
\hline & $-(p) e c$ & $\begin{array}{l}\text { vršilec, nosilec, } \\
\text { opravkar }\end{array}$ & I & 1 \\
\hline & $-(r) e c$ & vršilec, nosilec & vršilec & vršilec \\
\hline & $-(s) e c$ & nosilec & vršilec & l \\
\hline & $-(t) e c$ & vršilec & I & l \\
\hline & $-(v) e c$ & $\begin{array}{c}\text { vršilec, nosilec, } \\
\text { opravkar }\end{array}$ & nosilec & nosilec \\
\hline & $-(b)$ alec & vršilec & / & I \\
\hline & $-(\check{c})$ alec & vršilec & / & I \\
\hline & $-(\check{S} \check{c})$ alec & vršilec & I & I \\
\hline & $-(d)$ alec & vršilec (SSKJ 2) & I & I \\
\hline & $-(g)$ alec & vršilec & / & I \\
\hline & $-(h)$ alec & vršilec & I & I \\
\hline & $-(j)$ alec & vršilec (SSKJ 2) & I & I \\
\hline & -(lj)alec & vršilec & l & l \\
\hline & $-(n j)$ alec & vršilec & I & / \\
\hline & $-(k)$ alec & vršilec & I & I \\
\hline & -(l)alec & vršilec & I & I \\
\hline & $-(m)$ alec & vršilec & I & I \\
\hline & $-(n)$ alec & vršilec & I & I \\
\hline & $-(p)$ alec & vršilec & I & 1 \\
\hline & $-(r)$ alec & vršilec & I & 1 \\
\hline & $-(s)$ alec & vršilec & I & I \\
\hline & $-(\check{S})$ alec & vršilec & I & vršilec \\
\hline & $-(t)$ alec & vršilec & I & 1 \\
\hline
\end{tabular}




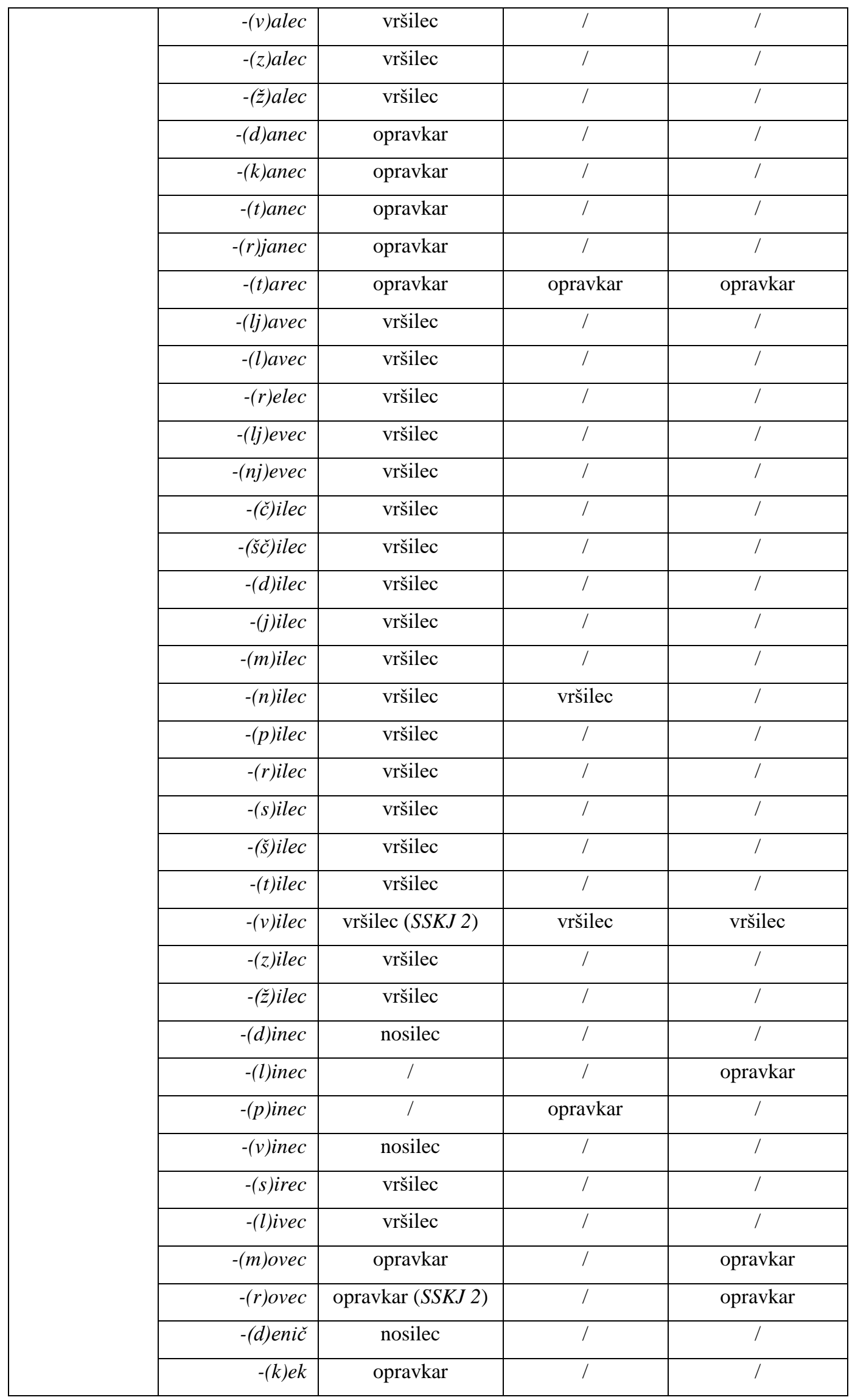




\begin{tabular}{|r|r|c|c|c|}
\hline \multirow{2}{*}{} & $-(n j) e k$ & vršilec & $/$ & $/$ \\
\cline { 2 - 5 } & $-(t) e k$ & nosilec & $/$ & $/$ \\
\cline { 2 - 5 } & $-(t) n i k$ & vršilec, opravkar & $/$ & $/$ \\
\cline { 2 - 5 } & $-(t) e \check{z}$ & nosilec & $/$ & $/$ \\
\hline
\end{tabular}

1. Priponsko obrazilo -ica zamenjuje različna moškospolska priponska obrazila, najpogosteje v pomenski skupini nosilec. Analiza kaže, da se za vse tri prve pomenske skupine izpeljank iz glagolske, pridevniške in samostalniške podstave pojavita obrazili $-(t) n i k$ in $-(n) i k$ pri tem feminativnem zamenjevalnem obrazilu, in to pri gradivu iz obeh izdaj SSKJ.

2. Obrazilo -ja lahko zamenja le moškospolsko obrazilo $-e c$ v pomenski skupini vršilec, konkretne primere pa ponujata le obe izdaji SSKJ.

3. Feminativno obrazilo -inja zamenjuje moškospolska priponska obrazila - $a$, -ar in -ič, in to vedno le pri vršilcu in opravkarju, upoštevajoč gradivo iz obeh SSKJ.

4. Priponsko obrazilo -kinja kot zamenjevalno potrjujejo le primeri iz obeh izdaj $S S K J$, in to zgolj pri vršilcu in opravkarju. Zamenjuje pa moškospolski priponski obrazili $-e c$ in $-i \check{c}$.

5. Tudi pojavnost zamenjevalnega priponskega obrazila -ulja je potrjena le s konkretnimi primeri iz obeh izdaj SSKJ, nastopi pa v pomenskih skupinah vršilec in nosilec, in to kot zamenjava moškospolskih obrazil -ač, $-u h$ in -avs.

6. Priponsko obrazilo $-k a$ lahko zamenja različna moškospolska priponska obrazila, večinoma pri vršilcu in opravkarju. Moškospolsko obrazilo -ec pa je edino, ki ga priponsko obrazilo - $k a$ zamenja v vseh treh pomenskih skupinah, in to le glede na gradivo iz SSKJ, če je podstavni soglasnik $-d,-l,-n,-p,-r$ ali $-v$.

Raziskali smo, katera so tista moškospolska priponska obrazila, ki jih feminativna obrazila lahko zamenjajo. Spodnja preglednica vključuje podatke iz vseh štirih obravnavanih virov. Besede, ki se pojavijo v več virih, smo šteli le enkrat. $^{102}$

${ }^{102}$ Tako smo k primerom $i z$ SSKJ 2 prišteli 29 novosti iz NSL (primeri so zapisani v opombi na str. 223; vsi feminativi iz SSKJ 1 in SNBSJ so namreč že vključeni v SSKJ 2). 
Preglednica 65: Sinteza obrazilne produktivnosti - zamenjevalni način (primerjalni prikaz)

\begin{tabular}{|c|c|c|c|c|c|c|c|c|}
\hline \multirow{2}{*}{$\begin{array}{l}\text { OBRAZILO } \\
\text { MOŠKEGA } \\
\text { SPOLA }\end{array}$} & \multicolumn{8}{|c|}{ FEMINATIVNA PRIPONSKA OBRAZILA } \\
\hline & -ica & $-(a r) i c a$ & $-j a$ & -ulja & -inja & -kinja & $-k a$ & SKUPAJ \\
\hline$-a$ & $1(20 \%)$ & $1(20 \%)$ & / & I & $3(60 \%)$ & / & / & 5 \\
\hline$-j a$ & l & / & l & / & l & $\begin{array}{c}6 \\
(100 \%)\end{array}$ & / & 6 \\
\hline$-e c$ & $\begin{array}{c}21 \\
(4,4 \%)\end{array}$ & / & / & / & / & $\begin{array}{c}1 \\
(0,2 \%)\end{array}$ & $\begin{array}{c}453 \\
(95 \%)\end{array}$ & 475 \\
\hline -alec & I & / & / & / & I & I & $\begin{array}{c}201 \\
(100 \%)\end{array}$ & 201 \\
\hline -elec & I & I & I & I & I & I & $1(100 \%)$ & 1 \\
\hline -ilec & I & I & $2(5 \%)$ & I & I & I & $37(95 \%)$ & 39 \\
\hline -anec & I & 1 & I & I & 1 & I & $4(100 \%)$ & 4 \\
\hline -janec & 1 & 1 & 1 & I & 1 & I & $1(100 \%)$ & 1 \\
\hline -enec & I & I & I & I & I & I & $1(100 \%)$ & 1 \\
\hline -inec & I & I & I & I & I & I & $2(100 \%)$ & 2 \\
\hline -arec & 1 & 1 & 1 & 1 & 1 & 1 & $2(100 \%)$ & 2 \\
\hline -irec & 1 & I & 1 & 1 & I & I & $1(100 \%)$ & 1 \\
\hline -avec & I & I & I & I & I & I & $15(100 \%)$ & 15 \\
\hline -evec & I & I & I & I & I & I & $2(100 \%)$ & 2 \\
\hline -ivec & I & I & I & I & I & I & $3(100 \%)$ & 3 \\
\hline -ovec & I & I & I & I & I & I & $7(100 \%)$ & 7 \\
\hline$-v e c$ & I & I & I & I & I & I & $3(100 \%)$ & 3 \\
\hline$-a \check{c}$ & $\begin{array}{c}1 \\
(33 \%)\end{array}$ & I & I & $\begin{array}{c}2 \\
(66 \%)\end{array}$ & I & I & I & 3 \\
\hline$-i \check{c}$ & 1 & 1 & I & I & $1(50 \%)$ & $1(50 \%)$ & I & 2 \\
\hline -enič & I & 1 & 1 & I & I & I & $1(100 \%)$ & 1 \\
\hline$-u h$ & 1 & I & I & $\begin{array}{c}2 \\
(100 \%)\end{array}$ & I & I & I & 2 \\
\hline$-e k$ & $\begin{array}{c}1 \\
(12,5 \%)\end{array}$ & 1 & I & I & I & I & $\begin{array}{c}7 \\
(87,5 \%)\end{array}$ & 8 \\
\hline$-\check{c} e k$ & $\begin{array}{c}4 \\
(100 \%)\end{array}$ & 1 & 1 & I & 1 & I & 1 & 4 \\
\hline$-i k$ & $\begin{array}{c}305 \\
(100 \%)\end{array}$ & 1 & 1 & I & I & I & I & 305 \\
\hline$-n i k$ & $\begin{array}{c}80 \\
(97 \%)\end{array}$ & I & I & I & I & I & $2(3 \%)$ & 82 \\
\hline$-i n$ & $\begin{array}{c}1 \\
(100 \%)\end{array}$ & I & I & I & I & I & I & 1 \\
\hline$-a r$ & I & I & I & I & $\begin{array}{c}1 \\
(100 \%)\end{array}$ & I & I & 1 \\
\hline -avs & 1 & I & 1 & $\begin{array}{c}1 \\
(100 \%)\end{array}$ & I & I & 1 & 1 \\
\hline
\end{tabular}




\begin{tabular}{|c|c|c|c|c|c|c|c|c|}
\hline \multirow{2}{*}{$\begin{array}{c}\text { OBRAZILO } \\
\text { MOŠKEGA } \\
\text { SPOLA }\end{array}$} & \multicolumn{8}{|c|}{ FEMINATIVNA PRIPONSKA OBRAZILA } \\
\hline & $-i c a$ & $-(a r) i c a$ & $-j a$ & - -ulja & -inja & $-k i n j a$ & $-k a$ & SKUPAJ \\
\hline$-e \check{z}$ & $\begin{array}{c}116 \\
(99 \%)\end{array}$ & l & l & I & l & I & $1(1 \%)$ & 117 \\
\hline SKUPAJ & $\begin{array}{c}\mathbf{5 3 0}^{103} \\
(41 \%)\end{array}$ & $\begin{array}{c}1 \\
(0,07 \%)\end{array}$ & $\begin{array}{c}2 \\
(0,1 \%) \\
\end{array}$ & $\begin{array}{c}5 \\
(0,4 \%)\end{array}$ & $\begin{array}{c}5 \\
(0,4 \%)\end{array}$ & $\begin{array}{c}8 \\
(0,6 \%) \\
\end{array}$ & $\begin{array}{c}744 \\
(57,5 \%) \\
\end{array}$ & 1295 \\
\hline
\end{tabular}

Opažamo, da pri vseh obrazilih $\mathrm{z}$ izglasno sestavino $-(e) c$ prevladuje zamenjava s priponskim obrazilom - $k a$ (skupno 733 primerov ali $97 \%$, z -ica pa samo 21 oz. $3 \%$ ). Drugače je pri moškospolskih obrazilih -ik in -nik, kjer prednjači zamenjava z -ica (385 tvorjenk ali 99,5\%, s - $k a$ le dve oz. 0,5\%), podobno velja pri moškospolskem -ež (z -ica 116 primerov, s -ka le eden). Feminativno obrazilo $-k a$ ima torej prednost, kadar gre za zamenjavo moškospolskega $-(K) e c,-i c a$ pa pri $-(n) i k$ in $-e \check{z}$.

Spodnja preglednica prikazuje, $\mathrm{h}$ katerim izglasjem (podstave ali obrazila) se feminativna priponska obrazila po zamenjavi moškospolskega obrazila dodajo. Vključena je tvorba iz netvorjenih, izpeljanih, zloženih in sestavljenih podstav, zajeli pa smo primere iz obeh izdaj SSKJ, Novejše slovenske leksike in SNBSJ.

Preglednica 66: Sinteza obrazilne produktivnosti - zamenjevalni način ob moškospolskih izglasjih (primerjalni prikaz)

\begin{tabular}{|c|c|c|c|c|c|c|c|c|}
\hline \multirow{2}{*}{$\begin{array}{c}\text { IZGLASJE } \\
\text { PODSTAVE }\end{array}$} & \multicolumn{8}{|c|}{ FEMINATIVNA PRIPONSKA OBRAZILA } \\
\hline & $-i c a$ & $-(a r) i c a$ & $-j a$ & -ulja & -inja & -kinja & $-k a$ & SKUPAJ \\
\hline$-b$ & $\begin{array}{c}1 \\
(33 \%)\end{array}$ & / & 7 & / & / & / & $\begin{array}{c}2 \\
(66 \%)\end{array}$ & 3 \\
\hline$\overline{-c}$ & $\begin{array}{c}4 \\
(80 \%)\end{array}$ & / & I & / & / & / & $\begin{array}{c}1 \\
(20 \%)\end{array}$ & 5 \\
\hline$-d$ & $\begin{array}{c}1 \\
(4 \%) \\
\end{array}$ & $\begin{array}{c}1 \\
(4 \%) \\
\end{array}$ & I & $\begin{array}{c}2 \\
(8 \%) \\
\end{array}$ & $\begin{array}{c}2 \\
(8 \%) \\
\end{array}$ & $\begin{array}{c}7 \\
(27 \%) \\
\end{array}$ & $\begin{array}{c}13 \\
(50 \%) \\
\end{array}$ & 26 \\
\hline$-g$ & $\begin{array}{c}4 \\
(66 \%)\end{array}$ & I & I & l & $\begin{array}{c}2 \\
(33 \%)\end{array}$ & I & I & 6 \\
\hline$-h$ & $\begin{array}{c}2 \\
(100 \%)\end{array}$ & / & I & $/$ & I & / & / & 2 \\
\hline$-j$ & l & / & 1 & 1 & 1 & 1 & $\begin{array}{c}11 \\
(100 \%)\end{array}$ & 11 \\
\hline$-l j$ & $\begin{array}{c}1 \\
(33 \%)\end{array}$ & I & I & I & I & I & $\begin{array}{c}2 \\
(66 \%)\end{array}$ & 3 \\
\hline$-n j$ & $\begin{array}{c}4 \\
(80 \%)\end{array}$ & I & 1 & I & I & I & $\begin{array}{c}1 \\
(20 \%)\end{array}$ & 5 \\
\hline
\end{tabular}

${ }^{103}$ Pri $-i k$ in $-e z ̌$ smo šteli primere, ki so lahko tvorjeni z obema obraziloma (torej smo nekaj feminativov šteli dvakrat). 


\begin{tabular}{|c|c|c|c|c|c|c|c|c|}
\hline \multirow{2}{*}{$\begin{array}{l}\text { IZGLASJE } \\
\text { PODSTAVE }\end{array}$} & \multicolumn{8}{|c|}{ FEMINATIVNA PRIPONSKA OBRAZILA } \\
\hline & -ica & $-(a r) i c a$ & $-j a$ & -ulja & -inja & -kinja & $-k a$ & SKUPAJ \\
\hline$-k$ & I & I & I & $\begin{array}{c}1 \\
(20 \%)\end{array}$ & $\begin{array}{c}1 \\
(20 \%)\end{array}$ & I & $\begin{array}{c}3 \\
(60 \%)\end{array}$ & 5 \\
\hline$-l$ & $\begin{array}{c}3 \\
(1 \%)\end{array}$ & / & $\begin{array}{c}2 \\
(0,7 \%) \\
\end{array}$ & 1 & 1 & / & $\begin{array}{c}279 \\
(98 \%)\end{array}$ & 284 \\
\hline$-m$ & $\begin{array}{c}2 \\
(18 \%)\end{array}$ & I & 1 & I & I & $\begin{array}{c}1 \\
(9 \%)\end{array}$ & $\begin{array}{c}8 \\
(72 \%)\end{array}$ & 11 \\
\hline$-n$ & $\begin{array}{c}424 \\
(66 \%)\end{array}$ & I & I & $\begin{array}{c}1 \\
(0,1 \%)\end{array}$ & I & I & $\begin{array}{c}215 \\
(34 \%)\end{array}$ & 640 \\
\hline$-p$ & $\begin{array}{c}1 \\
(14 \%)\end{array}$ & I & / & $\begin{array}{c}1 \\
(14 \%)\end{array}$ & I & I & $\begin{array}{c}5 \\
(71 \%)\end{array}$ & 7 \\
\hline$-r$ & $\begin{array}{c}2 \\
(9 \%)\end{array}$ & I & I & I & I & 1 & $\begin{array}{c}20 \\
(91 \%) \\
\end{array}$ & 22 \\
\hline$-s$ & $\begin{array}{c}1 \\
(4,5 \%)\end{array}$ & I & I & I & I & I & $\begin{array}{c}21 \\
(95,5 \%)\end{array}$ & 22 \\
\hline$-\check{s}$ & I & I & I & I & I & I & $\begin{array}{c}1 \\
(100 \%)\end{array}$ & 1 \\
\hline$-t$ & $\begin{array}{c}2 \\
(20 \%)\end{array}$ & I & I & I & I & I & $\begin{array}{c}8 \\
(80 \%)\end{array}$ & 10 \\
\hline$-v$ & $\begin{array}{c}4 \\
(2,5 \%)\end{array}$ & I & I & I & I & I & $\begin{array}{c}153 \\
(97,5 \%)\end{array}$ & 157 \\
\hline$-z$ & $\begin{array}{c}1 \\
(50 \%) \\
\end{array}$ & I & I & I & I & I & $\begin{array}{c}1 \\
(50 \%) \\
\end{array}$ & 2 \\
\hline SKUPAJ & $\begin{array}{c}457 \\
(37 \%)\end{array}$ & $\begin{array}{c}1 \\
(0,08 \%)\end{array}$ & $\begin{array}{c}2 \\
(0,16 \%)\end{array}$ & $\begin{array}{c}5 \\
(0,41 \%)\end{array}$ & $\begin{array}{c}5 \\
(0,41 \%)\end{array}$ & $\begin{array}{c}8 \\
(0,6 \%)\end{array}$ & $\begin{array}{c}744 \\
(61 \%)\end{array}$ & 1222 \\
\hline
\end{tabular}

Ugotavljamo, da se priponsko obrazilo -(ar)ica dodaja le k izglasju podstave na $-d$ (potrjuje zgolj en primer), feminativno priponsko obrazilo -ica najpogosteje nastopi ob izglasju podstave na $-n$ (424 primerov ali $66 \%$ ), priponsko obrazilo $-k a$ pa je najpogostejše ob $-l$ (279 primerov ali $98 \%),-r$ (20 feminativov ali $91 \%$ ), $-s$ (21 primerov ali 95,5\%), $-t$ (osem primerov ali $80 \%$ ) in $-v(153$ primerov ali $97,5 \%)$.

Primerjalni pregled dodajanja k izglasjem podstave bodisi po dodajalnem načinu tvorbe feminativov bodisi po zamenjevalnem nakazuje le delno ujemanje. Obrazila, ki se pri obeh načinih tvorbe dodajajo k podstavi, so -(ar)ica, -ica, -ja, -inja, -ulja in -ka. Opažamo naslednje:

- Priponsko obrazilo -(ar)ica se pri zamenjevalnem načinu tvorbe doda $\mathrm{k}$ izglasju podstave na $-d$, pri dodajalnem pa $\mathrm{k}$ izglasju na $-k$ (oboje sicer potrjuje po en konkretni primer).

- Obrazilo -ica se pri obeh načinih tvorbe dodaja k zelo različnim izglasjem podstav, skupna so le $-\check{c},-d,-g,-l j,-n,-p,-r,-s$ in $-t$ (samo pri 
zamenjevalnem možno tudi $\mathrm{k}-b,-h,-n j,-l,-m,-v$ in $-z$, zgolj pri dodajalnem načinu pa $\mathrm{k}-f,-k$ in $-\check{s}$.

- Feminativno obrazilo -ja pri dodajalnem načinu nastopi ob izglasju podstave na $-n$ ali $-t$ (za vsako po en primer), po zamenjavi dela moškospolskega obrazila pa se doda $\mathrm{k}-l$.

- Obrazilo -inja se pri obeh načinih tvorbe dodaja $\mathrm{k}$ izglasjem podstave na $-d,-g,-k$, samo pri dodajalnem načinu pa nastopi pri izglasjih podstav na $-b,-f,-h,-j,-l,-r,-s,-t$ in $-z$.

- Feminativno priponsko obrazilo -ulja je po zamenjavi moškospolskega obrazila dodajalno $\mathrm{k}$ izglasjem podstav na $-d,-k,-n$ in $-p$, pri dodajalnem načinu pa nastopi ob izglasjih podstav na $-c$ in $-g$.

- Obrazilo $-k a$ je pri obeh načinih tvorbe dodajalno $\mathrm{k}$ izglasjem na $-b,-\check{c},-d$, $-j,-k,-l,-m,-n,-p,-r,-t,-v$ in $-z$. Samo pri zamenjevalnem načinu nastopi pri izglasjih na $-l j,-n j,-s$ in $-\check{s}$, zgolj pri dodajalnem načinu pa pri izglasju na $-c$ in $-f .^{104}$

$\mathrm{Ne}$ moremo potrditi, da se pri dodajanju $\mathrm{k}$ netvorjenim ter nekaterim zloženim in sestavljenim podstavam ali po zamenjavi moškospolskega priponskega obrazila feminativna obrazila dodajajo k enakim izglasjem. To se zgodi le pri obrazilih -ica, -ja, -inja in -ka, ne velja pa za vsa izglasja podstav, ob katerih navedena obrazila nastopijo.

\section{Poimenovanja živali}

Ženskospolska poimenovanja živali ponujajo obe izdaji Slovarja slovenskega knjižnega jezika ter Slovar novejšega besedja slovenskega jezika. V SSKJ 1 jih je 91, v SSKJ 2 pa 93. Novost v primerjavi s prvo izdajo sta feminativa labradorka in risinja. V SNBSJ smo zasledili zgolj feminativ perzijka. Skupno smo torej analizirali 94 poimenovanj živali. Ugotavljamo, da je z dodajalnim

\footnotetext{
104 Glede na že omenjeni pregled kompatibilnosti soglasniških fonemov (Unuk 2003: 42-43) opažamo, da se obrazilo - $k a$ po zamenjavi moškospolskega obrazila dodaja tudi $\mathrm{k}$ izglasjem podstav na $s$ (česar pri dodajalnem načinu tvorbe nismo opazili), ne pa tudi $\mathrm{k} h$, obrazilo $-\mathrm{ja} \mathrm{z}$ zvočniško sestavino pa tudi k zvočniku $l$.
} 
načinom tvorjenih 61 tovrstnih feminativov (66 \%), medtem ko je tistih, nastalih z zamenjevalnim načinom, le 33 (34\%).

Z dodajanjem ženskospolskega obrazila moškospolskemu poimenovanju živali je skupno nastalo 61 feminativov, od tega največ, to je 24 (39\%), s priponskim obrazilom -ica, nekoliko manj, $17 \mathrm{z}$ obrazilom -ka (29\%), $8(13 \%) \mathrm{z}$ $-(o v) k a$, štiri $(6,5 \%) \mathrm{z}-(e v) k a$, štiri $(6,5 \%) \mathrm{z}-$ inja in po dva $(3 \%) \mathrm{z}-a$ in $-u l j a$. Ugotavljamo, da se feminativna priponska obrazila, ko tvorijo ženskospolska poimenovanja živali, v glavnem dodajajo netvorjenkam z različnimi izglasji, le redko opravkarjem, in to vedno le z izglasjem na $-(\boldsymbol{a}) \boldsymbol{r}$, vršilcu pa samo, če gre za večpomenke, ki lahko poimenujejo tudi osebe (npr. roparica). K -(a)r se tako dodajata le -ica in -ka (ki sta sicer ob tem izglasju pogosti tudi, kadar gre za poimenovanja oseb).

$\mathrm{Z}$ zamenjavo moškospolskega priponskega obrazila $\mathrm{s}$ feminativnim je nastalo 33 tvorjenk. Kot zamenjevalna nastopajo feminativna priponska obrazila -ka z 22 primeri (63\%), -ica (9 primerov ali $30 \%$ ) in -ulja $\mathrm{z}$ dvema primeroma (6 \%). Opažamo, da pri tvorbi ženskospolskih poimenovanj živali kot zamenjevalna nastopajo tri feminativna obrazila: -ica, $-k a$ in -ulja. Vsa tri lahko zamenjajo moškospolsko obrazilo -ec; -ica pri nosilcu lastnosti in opravkarju z različnimi izglasji podstav, podobno $-k a$, le da slednja nastopi še pri vršilcu iz glagolskih podstav na -iti/-im in -ovati/-ujem, -ulja pa pri vršilcu iz glagolov na -iti/-im. Obrazili -ica in - $k a$ zamenjujeta moškospolsko obrazilo -ec tudi pri tvorbi poimenovanj oseb, -ulja pa ne.

\section{VARIANTNOST FEMINATIVNIH PRIPONSKIH OBRAZIL}

Irena Stramljič Breznik v svoji doktorski disertaciji Prvostopenjske izpridevniške tvorjenke (1994) pri istopomenskih tvorjenkah za različna priponska obrazila ob isti podstavi uporablja poimenovanje vzporedna/tekmovalna/ konkurenčna obrazila (Stramljič Breznik 1994: 18). Kot tekmovalna/konkurentna obrazila jih imenuje tudi Slovenski pravopis (2001: 120), Toporišič pa V Enciklopediji slovenskega jezika (1992: 326) uporabi besedno zvezo tekmiško obrazilo in ga definira kot obrazilo, ki skuša spodriniti dotlej uveljavljeno ali pa si 
najti funkcijsko samostojnost nasproti njemu. V starejšem članku Stilna vrednost glasovnih, prozodijskih, (pravo)pisnih, morfemskih in naglasnih variant slovenskega knjižnega jezika (1973) pa avtor govori o variantah besedotvornih priponskih obrazil; ta termin bomo dosledno uporabljali tudi v pričujoči raziskavi. Pojav je sicer značilen tudi za druge slovanske jezike, npr. ukrajinščino, slovaščino, srbščino, makedonščino, opazimo pa ga že ob pregledu slovenskih slovnic in slovarjev skozi zgodovino.

Primerjava tovrstnih tvorjenk glede na kvalifikatorje v obeh izdajah SSKJ in SP kaže na njihovo slogovno zaznamovanost, Toporišič (1973: 241-247) pa opozarja, da je stilno zaznamovana lahko že podstava sama, medtem ko je priponsko obrazilo slogovno nevtralno. Stilna zaznamovanost takih izpeljank temelji na podlagi (vsaj potencialne) opozicijske izpeljanke ob isti podstavi s stilno nevtralnim priponskim obrazilom. Vsaj nekatera stilno zaznamovana priponska obrazila so družljiva le s pomensko ustreznimi podstavami, seveda pa se razna priponska obrazila iste kategorije ob isti podstavi uporabljajo večinoma za izražanje pomenskih razlik. ${ }^{105}$ Tudi po Slovenskem pravopisu (2001: 120) lahko imajo konkurenčna obrazila pomensko ali uporabnostno ločevalno vlogo, kar ponazarjajo zgledi v slovarju, izjemoma tudi slovnično-stilistične ali zvrstne oznake; ob pojmovani enakovrednosti obrazil dajemo prednost domačemu.

Pri analizi gradiva se je nabralo veliko število feminativov, kjer sta se ob isti podstavi pojavili dve ali več variantnih priponskih obrazil. Primerjava tovrstnih tvorjenk glede na kvalifikatorje v SSKJ 1 in SSKJ 2 ter v SP je pokazala njihovo slogovno zaznamovanost, večpomenskost in možno zamenljivost, korpusna analiza pa prikazuje njihovo pogostnost. V glavnem gre za variantna domača priponska obrazila, pri čemer smo ločili poimenovanja oseb od poimenovanj živali. Zbrano gradivo smo razdelili glede na to, ali variantni obrazili oz. obrazila nastopajo kot dodajalna, zamenjevalna ali oboje. Pregledali smo obe izdaji $S S K J$ in $S P$, upoštevali pa smo tudi primere iz SNBSJ in NSL.

${ }^{105}$ Toporišič v isti razpravi (1973: 246) omenja variantnost obrazil pri priimkovnih feminativih, izpeljanih s priponskimi obrazili za samostalnike, ki so zaznamovani pogovorno, v knjižnem jeziku pa tudi starinsko (npr. Turšička, Rogarica, Radmanca, Brnkovka, Volkulja, Matička, Boltela ipd.). Novodobni prizvok, ki pa se počasi izgublja, imajo feminativi na podlagi konvertiranega pridevnika, npr. (Zofka) Kvedrova (vendar imajo taka imena domačnostno pokrajinsko noto, ko so rabljena sama, npr. Kajžova, Poljančeva). 
Opazovali smo večpomenskost in slogovno zaznamovanost, pogostnost rabe pa smo preverili po korpusu Gigafida, po potrebi še po Novi besedi in Kresu. Zavedamo se, da raba $\mathrm{v}$ navedenih korpusih, ki vključujejo besedila do leta 2010/11, leta 2018 ne zadostuje več za preverjanje aktualne jezikovne prakse, zato smo v raziskavo vključili tudi poizvedbe iz spletnega iskalnika Google, ${ }^{106}$ pri čemer smo upoštevali le rezultate $\mathrm{v}$ slovenskem jeziku, dopustili pa smo samodejno izpuščanje vnosov, podobnih najdenim rezultatom. Pri predlogih ustreznejših variant smo sicer upoštevali tudi rezultate analize iz prejšnjega poglavja, a prednost smo dali možnosti, ki je pogostejša v rabi, saj, kot ugotavlja Irena Stramljič Breznik (2012: 103), staro izginja in novo nastaja.

\subsection{Dodajanje variantnih priponskih obrazil}

\subsubsection{Poimenovanja oseb}

Kot dodajalni se pojavijo pari variantnih priponskih obrazil ${ }^{107}-i c a$ in $-k a$, -inja in -ka, -ica in -inja, -ica in -(ov)ka, - $a$ in -inja, -(ar)ka in -inja, -ca in -ka, - $a$ in -ka, -inja in -(ov)ka, -ja in -inja za poimenovanja oseb; včasih se lahko ob isti podstavi in istem pomenu dodajo celo tri priponska obrazila: -ica/-ja/-ka, -ica/-inja/-ka, -inja/-ka/-esa, -lja/-ulja/-ka ter -ica/-ulja/-(ov)ka, prav tako pri ženskospolskih poimenovanjih oseb. Kadar gre za tvorbo feminativnih poimenovanj živali, pa kot variantni nastopijo naslednji pari: -ica in -ka, -ica in $-u l j a,-a$ in -inja, -ica in -inja, -inja in -(ov)ka, -ica in -(ov)ka. Zasledili pa smo celo skupino štirih variantnih priponskih obrazil, to so -ica, -lja, -ulja in -(ov)ka.

\subsubsection{Variantni priponski obrazili -ica/-ka}

anketarica $<$ anketarka

\footnotetext{
106 Do podatkov smo dostopali avgusta 2018; vključili smo jih pri parih z nizkim številom pojavitev v korpusih.

107 Pare vzporednih feminativnih priponskih obrazil navajamo glede na število primerov (od tistega $\mathrm{z}$ največ do tistega $\mathrm{z}$ najmanj konkretnimi primeri).
} 
Obe besedi nastopata zgolj v pomenu 'ženska, ki anketira; izpraševalka' brez kvalifikatorjev, ki bi nakazovali na slogovno zaznamovanost. Izraz anketarka zasledimo v SSKJ 2 in v SNBSJ, anketarico pa zgolj v SP kot ženskospolsko ustreznico k anketarju. Po korpusu Gigafida je razmerje naslednje: anketarka 21 konkordanc, anketarica 6 konkordanc. Sinteza obrazilne produktivnosti pa je pokazala, da se k izglasjem obrazil na -(a)r pogosteje dodaja feminativno obrazilo $-k a(51 \%$; za -ica $48 \%)$.

\section{avtorica > avtorka}

Avtorico in avtorko v pomenu 'ženska, ki ustvari umetniško ali znanstveno delo; ustvarjalka, tvorka' s podpomenom 'kdor kaj izdela, izumi, zlasti na tehničnem področju' je mogoče zaslediti v obeh izdajah $S S K J$, medtem ko $S P$ ponuja samo avtorico kot feminativ k avtorju. Tudi sicer iztočnica avtorka v obeh SSKJ nima polne pomenske razlage, pri čemer uporabnika slovarja v pomenskem delu usmeri $\mathrm{h}$ geslu avtorica. Korpusna analiza prav tako kaže, da je varianta avtorica pogostejša (33.853 konkordanc po Gigafidi) v primerjavi z avtorko (samo 25 konkordanc). Po sintezi obrazilne produktivnosti sodeč pa se k izglasjem podstav na $-r$ pogosteje dodaja feminativno obrazilo $-k a$ (20 primerov ali 45,5\%; za -ica 17 primerov ali $39 \%)$, ob izglasjih obrazila na $-(o) r$ pa je sicer pogostejše priponsko obrazilo -ica $(55,5 \%$; za - $k a 44,5 \%)$.

\section{bajtarica > bajtarka}

Izraza bajtarka in bajtarica pomenita 'lastnico zelo majhnega posestva', vendar lahko bajtarica poleg navedenega pomeni tudi 'bajtarjevo ženo', bajtarka pa 'bajtarjevo hčer'. Bajtarico zasledimo v obeh izdajah SSKJ in v SP, medtem ko bajtarka nastopi samo v obeh SSKJ. Pogostejšo rabo bajtarice potrjuje tudi korpus Gigafida, sicer zgolj s sedmimi konkordancami, a za drugo možnost zadetkov sploh ne ponuja. Zaradi skromnega števila pojavitev smo preverjali še po Novi besedi (bajtarica 5 konkordanc, bajtarka 1 konkordanca) in Kresu (bajtarica 3 konkordance, bajtarka 0 konkordanc), ki sta potrdila pogostejšo rabo bajtarice. Po sintezi obrazilne produktivnosti pa se k izglasjem na $-(a) r$ pogosteje dodaja priponsko obrazilo $-k a(51 \%)$. 


\section{blogerica $<$ blogerka}

Med jezikovnimi priročniki samo SSKJ 2 in NSL ponujata eno od obeh variant, in to blogerko v pomenu 'ženska, ki piše blog'. Drugo varianto, blogerico, smo zasledili le v Novejši slovenski leksiki. Razmerje po Gigafidi (blogerka 457 konkordanc; blogerica 14 konkordanc) dokaj prepričljivo kaže na pogostejšo rabo prve od obeh možnosti. To dokazuje tudi sinteza obrazilne produktivnosti, kjer pri dodajanju $\mathrm{k}$ izglasju obrazila na $-(e) r$ močno prevladuje priponsko obrazilo $-k a$ $(91 \%)$.

\section{ciganica $<$ ciganka}

Ciganka je po SSKJ 1 'pripadnica iz Indije priseljenega ljudstva, navadno brez stalnega bivališča', s kvalifikatorjem slabš. pa je označen podpomen 'ženska s ciganskim videzom ali lastnostmi'. Slovarsko geslo ciganica nas v pomenskem delu preusmeri k iztočnici ciganka, zaznamovano pa je s kvalifikatorjem nar. Podobno je v SSKJ 2, le da je ciganka označena kot 'Romkinja' s kvalifikatorjem nav. slabš., v podpomenu pa kot 'ženska temnejše polti in neurejenega videza' $s$ kvalifikatorjem slabš. Kot slabšalna je beseda ciganka zaznamovana tudi v $S P$ kot ženska oblika k iztočnici cigan ('zvit, malovreden človek'), medtem ko ciganice ta slovarski priročnik ne ponuja. Kot prebivalka pa Ciganka ('Rominja') po SP ni stilno zaznamovana. Tudi po korpusu Gigafida je varianta ciganka pogostejša (ciganka 1676 konkordanc, ciganica samo 22 konkordanc), to pa potrjuje tudi sinteza obrazilne produktivnosti. Ugotovili smo, da se k izglasjem podstave na $-n$ pogosteje dodaja priponsko obrazilo $-k a(72 \%)$; obrazilo $-k a$ je pogostejše tudi ob izglasjih moškospolskih obrazil na -(a)n (92\%).

\section{citrarica $<$ citrarka}

Oba izraza v pomenu 'ženska, ki igra na citre' najdemo v obeh $S S K J$ ter v $S P$. V SSKJ 1 in SSKJ 2 je pri obeh zabeležena polna razlaga pomena, obe različici sta brez stilnih kvalifikatorjev. Korpus se po številu konkordanc bolj nagiba k citrarki (citrarka 1092 konkordanc, citrarica 48 konkordanc), naša analiza iz prejšnjega 
poglavja pa dokazuje, da je obrazilo $-k a$ z $51 \%$ tisto, ki se pogosteje dodaja $\mathrm{k}$ izglasju moškospolskega obrazila na $-(a) r$.

\section{časnikarica < časnikarka}

Oba izraza je z istim pomenom ('poklicna sodelavka časopisa') mogoče najti v obeh izdajah $S S K J$ in $\mathrm{v} S P$. Vendar pa nas časnikarica $\mathrm{v}$ pomenskem delu slovarskega sestavka v obeh $S S K J$ z razlago preusmeri k časnikarki. Nobena od besed ni označena kot stilno zaznamovana. Korpus Gigafida pa izkazuje pogostejšo rabo časnikarke z 212 konkordancami (za časnikarico le štiri), hkrati pa je tudi naša analiza izkazala pogostejšo rabo obrazila $-k a$ ob izglasju na $-(a) r$ z $51 \%$.

\section{čebelarica $<$ čebelarka}

Čebelarka in čebelarica pomenita 'žensko, ki goji čebele', zastopani pa sta v SSKJ (v obeh izdajah) in v SP. Medtem ko sta v slednjem viru obe besedi enakovredni, pa je čebelarica v SSKJ 2 označena kot zastarela (po SSKJ 1 kot redka), pomenska razlaga pa preusmerja k čebelarki. K le-tej se nagiba tudi korpus Gigafida (čebelarka 149 konkordanc; čebelarica 0 konkordanc), sinteza obrazilne produktivnosti pa dokazuje, da se ob izglasju obrazila na $-(a) r$ pogosteje rabi obrazilo $-k a(51 \%)$.

\section{čuvarica $<\check{c u v v a r k a ~}$}

$\check{C}$ uvarka kot 'ženska, ki si prizadeva, da se kaj ohrani' je zabeležena v SSKJ 1 in 2 ter v $S P$, čuvarico pa z istim pomenom in s polno razlago beleži le $S S K J$ (v obeh izdajah). Nobena od besed ni slogovno zaznamovana. Korpus Gigafida pa daje prednost prvi od obeh variant (čuvarka 63 konkordanc, čuvarica 24 konkordanc). Sicer pa smo dokazali, da se k izglasjem na $-(a) r$ pogosteje dodaja feminativno priponsko obrazilo - $k a$ (51\% primerov).

\section{demonstratorica < demonstratorka}

V SSKJ 1 je demonstratorka še razložena kot 'ženska oblika od demonstrator', v SSKJ 2 pa je razlaga že samostojnejša ('ženska, ki kaj nazorno prikazuje' s 
podpomenom ob kvalifikatorju šol. 'študentka, ki pomaga profesorju pri administraciji ter obveščanju študentov in študentom s študijskimi nasveti'). Obe varianti kot enakovredni in brez kvalifikatorjev beleži SP, po korpusu Gigafida pa je pogostejša demonstratorka s 77 konkordancami (demonstratorico potrjuje le ena konkordanca). K izglasju obrazila na $-($ ato $) r$ se sicer pogosteje dodaja feminativno priponsko obrazilo $-k a(81 \%)$.

\section{diktatorica < diktatorka}

Po SSKJ 1 in 2 obe besedi pomenita 'oblastno, samovoljno žensko' (kvalifikator ekspr. imata le v SSKJ 2, v prvi izdaji pa sta slogovno nezaznamovani). Oba slovarska sestavka imata v SSKJ 2 še terminološko gnezdo in ob kvalifikatorju publ. kot modna diktatorka oz. modna diktatorica označujeta 'žensko, ki odločilno vpliva na spremembo mode'. Tudi $S P$ ponuja obe varianti, a prednost daje diktatorki $\mathrm{s}$ preusmeritvijo $\mathrm{k}$ nevtralnejši varianti, $\mathrm{tj}$. od diktatorice $\mathrm{k}$ diktatorki. Prednost slednji daje tudi Gigafida, saj jo potrjuje s 34 konkordancami, diktatorico pa le s šestimi. Sinteza obrazilne produktivnosti pa je pokazala, da k izglasju na -(ato)r pogosteje nastopa obrazilo $-k a$.

\section{dninarica $<$ dninarka}

Polno razlago pomena ('najeta kmetijska delavka, plačana na dan') zasledimo v obeh izdajah $S S K J$ le pri dninarici, medtem ko pomenska razlaga pri dninarki preusmeri $\mathrm{k}$ dninarici. Nobena od besed pa ni označena kot slogovno zaznamovana. Kot k nevtralnejši varianti od dninarke k dninarici usmerja tudi $S P$. Presenetljivo pa je po korpusu Gigafida pogostejša dninarka z 78 konkordancami, medtem ko jih dninarica ponudi le 24 (po Novi besedi dninarka 2 konkordanci, dninarica 6 konkordanc; po Kresu pa dninarka 35 konkordanc, dninarica 4 konkordance). Glede na analizo iz prejšnjega poglavja pa je ustreznejša varianta dninarka, saj se k izglasju na $-(a) r$ pogosteje, tj. z $51 \%$, dodaja feminativno obrazilo $-k a$.

dvorjanica $<$ dvorjanka 
Dvorjanka ob oznaki nekdaj po obeh izdajah SSKJ pomeni 'spremljevalka, družabnica ženskega člana vladarjeve družine', pri slovarski iztočnici dvorjanica pa je razlaga pomena le 'dvorjanka', a brez kvalifikatorja. Obe varianti navaja tudi SP: dvorjanko kot slogovno nezaznamovano, dvorjanico pa kot neobčevalno. Razmerje po korpusu Gigafida je naslednje: dvorjanka 128 konkordanc, dvorjanica samo tri konkordance. $\mathrm{V}$ prejšnjem poglavju pa smo ugotovili, da se $\mathrm{k}$ moškospolskemu izglasju na -(ja)n pogosteje dodaja priponsko obrazilo -ka (80 $\%$, vendar pri majhnem številu konkretnih primerov).

\section{ekspeditorica > ekspeditorka}

Ekspeditorica je po SSKJ 1 in 2 z oznako v stari Avstriji 'uradnica, ki samostojno opravlja službo na pošti'. Izraz ekspeditorka ponuja le SP, a tudi ta kot nevtralnejšo besedo navaja ekspeditorico. Vse to potrjuje Gigafida s sicer zgolj sedmimi konkordancami pri iskalnem pogoju ekspeditorica, zato pa za ekspeditorko sploh ne ponuja zadetkov. Dodatno preverjanje kaže naslednje: ekspeditorica 21 zadetkov, ekspeditorka 0 zadetkov po Novi besedi; ekspeditorica 1 zadetek, ekspeditorka 0 zadetkov po Kresu; ekspeditorka 13 zadetkov, ekspeditorica 48 zadetkov po Googlu. Sinteza obrazilne produktivnosti zanesljivih zaključkov ne ponuja: ob treh konkretnih primerih tvorbe z dodajalnim načinom k moškospolskemu -(ito)r gre pri dveh feminativih za tvorbo s $-k a$, pri enem pa z -ica.

\section{gostilničarica $<$ gostilničarka}

Gostilničarka po obeh izdajah SSKJ pomeni 'lastnico ali upravnico gostilne', medtem ko je gostilničarica označena s kvalifikatorjem zastar., s pomensko razlago pa preusmerja h gostilničarki. V SP pa je mogoče zaslediti le gostilničarko kot ženskospolsko ustreznico h gostilničarju. Korpus Gigafida prepričljivo govori v prid gostilničarki s 444 konkordancami, medtem ko za

gostilničarico ponudi zgolj eno konkordanco. Če upoštevamo še ugotovitve iz prejšnjega poglavja, je prav tako ustreznejša varianta gostilničarka.

gubernatorica $<$ gubernatorka 
SSKJ 1 in 2 vsebujeta samo prvo od obeh možnosti, pa še to $\mathrm{v}$ pomenu 'gubernatorjeva žena' in ne kot vzporedno poimenovanje k poklicu oz. dejavnosti moškega. Drugače je v $S P$, kjer sta obe varianti navedeni kot ženskospolski vzporednici h gubernatorju, in to brez posebnih pojasnil, da gre $\mathrm{v}$ katerem od primerov za zakonsko ženo. Po Gigafidi je razmerje sledeče: gubernatorka pet konkordanc, gubernatorica brez konkordanc. Vse najdene zadetke smo pregledali in ugotavljamo, da v prav vseh primerih gre za feminativ (in ne pomen 'žena'). Nova beseda ne ponudi konkordanc za nobeno od možnosti, Kres prinaša le eno potrditev za gubernatorko, po Googlu pa najdemo 15 pojavitev za gubernatorko in 17 za gubernatorico. Sinteza obrazilne produktivnosti pa kaže, da se k izglasju na -(ato)r pogosteje dodaja feminativno obrazilo - $k a(81 \%)$.

\section{harmonikarica $<$ harmonikarka}

V SSKJ 1 je mogoče zaslediti le varianto harmonikarica v pomenu ženska, ki igra (na) harmoniko, medtem ko SSKJ 2 ob že omenjeni ponudi tudi besedo harmonikarka ob istem pomenu. V SP pa najdemo samo harmonikarico kot feminativ k harmonikarju. Za razliko od jezikovnih priročnikov korpus Gigafida v ospredje postavlja harmonikarko s 309 konkordancami, čeprav je tudi harmonikarica močno zastopana z 259 zadetki. Zato smo preverili še po drugih korpusih: Nova beseda prinaša 6 zadetkov za harmonikarko in 7 za harmonikarico, Kres pa ponudi 18 zadetkov za harmonikarko in 26 za harmonikarico, kar potrjuje izenačenost obeh možnosti. Po sintezi obrazilne produktivnosti pa je ustreznejša možnost harmonikarka, saj se k izglasju obrazila na $-(a) r$ pogosteje dodaja priponsko obrazilo $-k a$, kadar gre za feminativno tvorbo.

\section{improvizatorica < improvizatorka}

Nobene od variant ni v SSKJ 1, se pa zato improvizatorka kot 'ženska, ki improvizira' pojavi v drugi izdaji slovarja. Samo improvizatorico pa beleži SP. Po korpusu Gigafida prednjači raba improvizatorke s 100 konkordancami, medtem ko improvizatorico potrjuje zgolj en zadetek. Podobne rezultate kaže tudi sinteza obrazilne produktivnosti: ob moškospolskem izglasju na -(ato)r kot dodajalno pogosteje nastopa feminativno obrazilo $-k a(81 \%)$. 


\section{investitorica > investitorka}

Tudi teh dveh možnosti SSKJ 1 ne beleži. Obe varianti sta prisotni v drugi izdaji v pomenu 'ženska ali država, ustanova, ki investira', a obe brez kvalifikatorjev. $S P$ kot feminativ $\mathrm{k}$ investitorju kot 'vlagalcu kapitala' ponuja le investitorico. Razmerje po korpusu Gigafida pa je zelo izenačeno: investitorka 228 konkordanc, investitorica 232 konkordanc (po Novi besedi investitorka 58 konkordanc, investitorica 84 konkordanc, po Kresu investitorka 11 konkordanc, investitorica 7 konkordanc, po Googlu investitorka 79 zadetkov, investitorica 90). Sinteza obrazilne produktivnosti pri odločanju, katera varianta je ustreznejša, ne pomaga: ob treh primerih dodajanja k moškospolskemu -(ito)r gre pri dveh feminativih za tvorbo s -ka, pri enem pa z -ica.

\section{ječarica $<$ ječarka}

Izraza ječarka in ječarica $\mathrm{v}$ obeh izdajah SSKJ ob oznaki nekdaj pomenita 'žensko, ki pazi na osebe, ki jim je odvzeta prostost, in jih oskrbuje'. V SP pa najdemo le drugo od obeh možnosti kot ženskospolsko obliko k ječarju, v prid ječarki pa govori tudi korpus Gigafida, saj jo potrjuje z 20 konkordancami, medtem ko za ječarico ne ponuja zadetkov. Tudi pričujoča analiza kot ustreznejšo možnost ponudi ječarko (k izglasju na $-(a) r$ nastopi $-k a$ pri $51 \%$ zbranih primerov, -ica pa pri $48 \%$ ).

\section{kanclerica $<$ kanclerka}

SSKJ 1 ne beleži nobene od navedenih besed, medtem ko SSKJ 2 ponuja le kanclerko ob oznaki v nekaterih državah in v pomenu 'ministrska predsednica'. Zato pa sta obe možnosti navedeni v SP kot ženskospolski vzporednici k iztočnici kancler, a nobena od variant ni slogovno zaznamovana. Razmerje po korpusu Gigafida pa je sledeče: kanclerka 3336 konkordanc, kanclerica ena konkordanca. Prevladovanje druge od obeh variant pa je izkazala tudi sinteza obrazilne produktivnosti: k izglasju obrazila na -(e)r pogosteje dodajamo priponsko obrazilo $-k a(91 \%)$. 


\section{ključarica $<$ ključarka}

Ključarka je v SSKJ 1 zaznamovana s kvalifikatorjem ekspr. redko in pomeni 'vratarico'. Ključarica pa nastopa v dveh pomenih: 1. nekdaj 'hišnica, oskrbnica'; 2. ekspr., redko 'vratarica'. Zapis v SSKJ 2 je enak, le brez oznake redko pri pomenu 'vratarica' pri slovarskih sestavkih za obe besedi. SP beleži le varianto ključarka, prednost le-tej pa daje tudi korpus Gigafida z enajstimi konkordancami (a za ključarico le nekoliko manj - osem konkordanc). Zaradi nizkega števila pojavitev smo izvedli dodatno preverjanje: ključarka 1 zadetek, ključarica 1 zadetek (Nova beseda); ključarka 1 zadetek, ključarica 5 zadetkov (Kres); ključarka 57 zadetkov, ključarica 43 zadetkov (Google). Če upoštevamo analizo iz prejšnjega poglavja, pa je ob izglasju obrazila na $-(a) r$ ustreznejša tvorba $\mathrm{s}$ priponskim obrazilom $-k a$.

\section{kočarica > kočarka}

Besedi kočarka in kočarica sta po obeh izdajah SSKJ zaznamovani kot starinski in pomenita 'bajtarico, kajžarico'. Po $S P$ pa sta obe varianti zaznamovani s kvalifikatorjem pokr., kot nevtralnejši možnosti pa sta navedeni bajtarica oz. bajtarka. Če sta obe možnosti po jezikovnih priročnikih zelo izenačeni, pa rezultati korpusne analize dajejo prednost kočarici s 36 konkordancami, medtem ko kočarko potrjuje le pet zadetkov. Sinteza obrazilne produktivnosti pa je pokazala pogostejše dodajanje obrazila $-k a \mathrm{k}$ izglasju na $-(a) r(51 \%$ konkretnih primerov).

\section{komentatorica $<$ komentatorka}

SSKJ 1 razlaga komentatorko samo kot 'žensko obliko od komentatorja', medtem ko je razlaga pomena v drugi izdaji že kompleksnejša: 1. 'ženska, ki piše, sestavlja komentarje; razlagalka'; 2. 'ženska, ki obširneje, s (svojimi) pojasnili in pripombami poroča o čem; poročevalka, novinarka'. Komentatorice ne beleži nobena od obeh izdaj, prav tako je ni mogoče zaslediti v SP (samo komentatorka ob moškospolskem komentatorju). Beleži jo le NSL, potrjuje pa jo tudi korpusna analiza ob 12 konkordancah. Še vedno pa je v rabi pogostejša komentatorka, potrjena s kar 749 zadetki po Gigafidi. Tvorba z obrazilom -ka, kadar gre za 
dodajanje $\mathrm{k}$ izglasju na -(ato)r, je pogostejša tudi glede na sintezo obrazilne produktivnosti $(81 \%)$.

\section{koordinatorica $<$ koordinatorka}

Nobene od navedenih variant ne ponuja $S S K J$ 1, zato pa obe najdemo v drugi izdaji ob pomenski razlagi 'ženska, ki kaj koordinira'. Obe varianti navajata tudi SNBSJ in NSL, medtem ko SP ob koordinatorju beleži le eno ženskospolsko vzporednico, in to koordinatorico, ob kateri kot nevtralnejšo besedo navede usklajevalko. Korpus Gigafida pa s pojavitvami govori v prid prvi od obeh možnosti (koordinatorka 2495 konkordanc, koordinatorica 1275 konkordanc). K izglasju na -(ato)r se pogosteje dodaja obrazilo -ka (81\%), kar kažejo primeri iz štirih jezikovnih virov.

\section{krčmarica $>$ krčmarka}

Krčmarica ima v SSKJ 1 polno razlago pomena 'lastnica ali upravnica krčme', krčmarka pa je zgolj 'krčmarica'. Podobno je v SSKJ 2, le da je tu krčmarica ob kvalifikatorju ekspr. tudi izraz za gostilničarko. Obe varianti navaja tudi $S P$, a pri krčmarki kot nevtralnejšo varianto izpostavi krčmarico. K slednji se nagibajo tudi rezultati korpusne analize (po Gigafidi za krčmarico 309 konkordanc, za krčmarko zgolj ena konkordanca), medtem ko sinteza obrazilne produktivnosti ob moškospolskem izglasju obrazila na -(a)r kaže na pogostejšo rabo obrazila -ka.

\section{krmarica $<$ krmarka}

V SSKJ 1 se pojavi samo krmarica kot 'ženska oblika od krmar', druga izdaja pa že navaja obe varianti: krmarko v pomenu 'ženska, ki krmari' in s terminološkim gnezdom ob kvalifikatorju šport. dvojec brez krmarke v pomenu 'tekmovalni čoln, v katerem sta le dve veslačici brez krmarke'; ob krmarici pa ponuja le razlago 'krmarka', a beseda lahko, poleg feminativa, v športnem žargonu pomeni tudi 'smučka, ki pri smučanju nosi težo in ki jo pri tem vleče naprej'. SP ponuja le varianto krmarka ob moškospolskem krmarju. Tudi po korpusu Gigafida je pogostejša raba krmarke (225 konkordanc, medtem ko za krmarico le 30). K 
moškospolskemu izglasju obrazila na $-(a) r$ pa se sicer pogosteje dodaja priponsko obrazilo $-k a$.

\section{lekarnarica $<$ lekarnarka}

Obe besedi, lekarnarka in lekarnarica, sta po SSKJ 1 večpomenki: lahko pomenita 'lekarnarjevo ženo', kot taki sta zaznamovani s kvalifikatorjem star., lahko pa pomenita 'farmacevtko', a dodatna oznaka kaže, da sta v tem pomenu redko rabljeni. V SSKJ 2 je drugače, saj je prvi pomen obeh besed 'farmacevtka' in ni zaznamovan z oznako redko. Drugi pomen je enak prvemu pomenu iz SSKJ 1. Obe varianti navaja tudi $S P$, a kot nevtralnejšo izpostavi lekarnarico. Slednji v prid govori tudi korpusna analiza, saj jo Gigafida potrjuje s 84 konkordancami, za lekarnarko jih ponudi nekoliko manj, tj. 69. Po Novi besedi prevladuje lekarnarka s 15 zadetki (za lekarnarico le 7), enako po Kresu (lekarnarka 19 zadetkov, lekarnarica pa 12). Kot dodajalno k izglasju moškospolskega obrazila na -(a)r pa je pogostejše feminativno obrazilo $-k a$.

\section{lončarica $<$ lončarka}

SSKJ 1 ponudi samo prvo od obeh variant v pomenu 'izdelovalka glinaste posode', medtem ko SSKJ 2 navaja obe, in to $\mathrm{z}$ že navedenim pomenom in brez kvalifikatorjev. SP beleži samo lončarko kot ženskospolsko vzporednico k lončarju, njeno pogostejšo rabo pa potrjuje tudi korpus Gigafida s 132 konkordancami, medtem ko za lončarico ponudi le štiri zadetke. Sinteza obrazilne produktivnosti pa ob konkretnih primerih kaže na pogostejšo rabo obrazila $-k a$ ob izglasju moškospolskega obrazila na $-(a) r$.

\section{lutkarica > lutkarka}

V obeh SSKJ je mogoče najti samo varianto lutkarica; prva izdaja jo razlaga kot 'žensko obliko od lutkarja', druga pa kot 'žensko, ki lutko premika in govori zanjo'. Obe varianti, in to kot enakovredni, navaja samo $S P$, po korpusu Gigafida pa je razmerje naslednje: lutkarka osem konkordanc, lutkarica 226 konkordanc. Po sintezi obrazilne produktivnosti pa je ustreznejša tvorba $\mathrm{z}$ obrazilom $-k a$ ob izglasju obrazila na $-(a) r$. 


\section{mazačica $<$ mazačka}

Mazačka je po SSKJ 1 označena s kvalifikatorjem nav. slabš. in pomeni 'ženska, ki nestrokovno opravlja kako delo, zlasti zdravljenje', slovarska iztočnica mazačica pa ob oznaki redko preusmerja k mazački. V SSKJ 2 je stanje podobno, le da je geslo mazačica brez oznake redko. V SP pa lahko najdemo samo mazačko, označeno kot slabšalno. Več konkordanc pri iskalnem pogoju mazačka izpiše tudi korpus (17 zadetkov), medtem ko za mazačico ne ponudi nobenega zadetka. Primeri iz štirih jezikovnih virov pa so pokazali, da se izglasju na - $(a) \check{c}$ nekoliko pogosteje dodaja feminativno obrazilo -ica (52\%, za -ka pa $40 \%)$.

\section{medičarica $<$ medičarka}

Medičarke SSKJ 1 in 2 ne beležita, zato pa zasledimo medičarico kot 'izdelovalko in prodajalko peciva, zlasti medenega'. Slovarski sestavek ima tudi terminološko gnezdo, po katerem je navadno $\mathrm{v}$ množini $\mathrm{v}$ zoologiji beseda rabljena za poimenovanje 'mravlje, ki dela v želodčku zalogo sladke tekočine za sušne dni'. Drugače je v $S P$, ki pa k moškospolskemu medičarju kot 'izdelovalcu medice in (medenega) peciva' navaja zgolj drugo od obeh variant, torej medičarko. K medičarki se bolj nagiba tudi korpus Gigafida, saj jo potrjuje z 32 konkordancami, medtem ko jih za medičarico ponudi le sedem. Pogostnost smo preverili tudi po Novi besedi (medičarka 4, medičarica 0 zadetkov), Kresu (medičarka 0, medičarica 2 pojavitvi) in Googlu (medičarka 76, medičarica 14 zadetkov). Sinteza obrazilne produktivnosti potrjuje, da je pogostejša tvorba z obrazilom $-k a$ ob izglasju obrazila na $-(a) r$.

mešetarica $<$ mešetarka

Mešetarka in mešetarica po SSKJ 1 pomenita 'ženska oblika od mešetar', pri čemer nobena od obeh besed ni zaznamovana s kvalifikatorjem. Pomenska razlaga v SSKJ 2 je kompleksnejša: 'posredovalka pri sklepanju kupčij, pogodb' pri slovarskem geslu mešetarka, pri mešetarici pa razlaga pomena preusmerja $\mathrm{k}$ mešetarki. Slednjo kot edino od obeh variant navaja tudi SP kot feminativ $\mathrm{k}$ mešetarju, kot prednostno pa jo potrjuje tudi korpus Gigafida, saj zanjo ponudi 81 
zadetkov, za mešetarico pa nobenega. Tudi sicer se k izglasju moškospolskega priponskega obrazila na $-(a) r$ pogosteje dodaja feminativno obrazilo $-k a$.

\section{organizatorica < organizatorka}

SSKJ 1 beleži obe navedeni varianti: za organizatorko ponuja polno pomensko razlago, in sicer 'ženska oblika od organizator', razlaga organizatorice pa preusmerja k organizatorki. Nobena od variant ni slogovno zaznamovana. Po SSKJ 2 pa je organizatorka 'ženska ali država, ustanova, ki kaj organizira', za organizatorico pa tudi ta izdaja slovarja ponuja zgolj nepolno pomensko razlago. Obe varianti sta navedeni tudi v SP, a za nevtralnejšo tudi tu velja organizatorka. Razmerje po korpusu Gigafida pa je sledeče: organizatorka 3394 konkordanc, organizatorica 1106 konkordanc. Tudi primeri iz štirih jezikovnih virov kažejo, da ob izglasju obrazila na -(ato)r pogosteje nastopi feminativno priponsko obrazilo -ka $(81 \%)$.

\section{pankerica > pankerka}

SSKJ 1 ne ponuja nobene od navedenih variant (tudi ne z drugačno pisno podobo, tj. punkerka in punkerica). Pankerico $\mathrm{v}$ pomenu 'pankerska glasbenica' $\mathrm{s}$ podpomenom 'ženska, ki se navdušuje za punk' beleži SSKJ 2, najdemo pa jo tudi v SNBSJ kot 'pripadnico subkulturne skupine, katere način življenja se kaže v izrazitem nepodrejanju veljavnim družbenim normam'. Zapis punkerica najdemo le v SNBSJ, a preusmerja $\mathrm{k}$ pankerici. Obe varianti, pankerko in pankerico, navajata SP in NSL. Glede na korpusno analizo pa je pogostejša varianta pankerica, ki jo potrjuje 49 konkordanc, pankerko pa le 24 zadetkov (po Novi besedi pankerica 4, pankerka 2 zadetka; po Kresu pankerica 12, pankerka 3 zadetki). Ob izglasju moškospolskega obrazila na -(e)r pa je sicer pogostejše priponsko obrazilo $-k a$ (91\% primerov iz štirih jezikovnih virov).

\section{partnerica > partnerka}

Partnerko in partnerico SSKJ 1 razlaga kot 'žensko obliko od partnerja', pri čemer nobena od obeh variant ni stilno zaznamovana. Po SSKJ 2 sta obe besedi večpomenki: 1. 'ženska, ki je z drugo osebo v ljubezenskem odnosu'; 2. 'ženska ali 
država, ustanova, ki s kom sodeluje, zlasti v gospodarstvu'; 3. 'soigralka'. Tudi v drugi izdaji slovarja ni nobena od besed označena s kvalifikatorjem. SP pa ponuja le varianto partnerica, ki je pogostejša $\mathrm{v}$ rabi tudi glede na korpusno analizo (partnerica 14.590 konkordanc, partnerka 8635 konkordanc). Sinteza obrazilne produktivnosti pa kaže, da se k moškospolskemu izglasju podstave na -r pogosteje dodaja feminativno obrazilo $-k a(45,5 \%$, za -ica nekaj manj, tj. $39 \%)$.

\section{pometačica > pometačka}

Pometačica po obeh izdajah SSKJ pomeni 'delavko, ki pometa', razlaga za pometačko pa je ob kvalifikatorju redko le 'pometačica, pometalka'. V SP zasledimo zgolj pometačico kot ženskospolsko obliko k pometaču, kot pogostejša varianta pa se kaže tudi v korpusnem gradivu; potrjuje jo namreč 23 konkordanc, pometačko pa samo dve. Priponsko obrazilo -ica pa je tudi sicer tisto, ki se najpogosteje (52\%) dodaja k izglasju obrazila na $-(a) \check{c}$.

\section{poštarica > poštarka}

Obe obliki po SSKJ 1 pomenita 'poštno delavko', le da je poštarica označena kot pogovorni izraz, beseda poštarka pa se uporablja redko. Enako je v drugi izdaji slovarja, le da je beseda poštarka brez oznake redko. Obe obliki navaja tudi $S P$, a kot nevtralnejšo izpostavi poštarico. Razmerje po korpusu Gigafida pa je naslednje: poštarka 119 konkordanc, poštarica 193 konkordanc, po Novi besedi poštarka 8 konkordanc, poštarica 45 konkordanc, po Kresu poštarka 19 konkordanc, poštarica 32 konkordanc. Sicer pa se k izglasju na -(a)r pogosteje dodaja priponsko obrazilo $-k a$, če upoštevamo analizo iz prejšnjega poglavja.

\section{priganjačica $<$ priganjačka}

SSKJ 1 in 2 ne beležita nobene od omenjenih variant (zasledimo samo moškospolsko obliko priganjač v treh pomenih: 'kdor priganja, goni živino'; slabš. 'kdor zahteva, poskuša doseči, da kdo hitreje dela' in redko 'kdor goni divjad pred stojišče lovca; gonjač'), zato pa najdemo obe v $S P$ kot feminativni obliki $\mathrm{k}$ priganjaču. Besedi pa (̌̌e) nista uveljavljeni v rabi, saj priganjačko potrjuje le ena konkordanca, za priganjačico pa Gigafida ne izpiše nobenega zadetka (po 
korpusu Nova beseda ni zadetkov za nobeno od možnosti, Kres potrjuje priganjačko z eno konkordanco, Google pa ponudi za priganjačko 10, za priganjačico pa šest zadetkov). Katera od besed se bo močneje usidrala, bo pokazal čas; sinteza obrazilne produktivnosti pa kaže, da je pri primerih iz štirih jezikovnih priročnikov ob izglasju moškospolskega obrazila na $-(a) \check{c}$ pogosteje dodano obrazilo -ica $(52 \%)$.

\section{promotorica $<$ promotorka}

Nobene od variant ni v SSKJ 1, druga izdaja pa ponuja zgolj promotorko, ki je večpomenka: 1. 'ženska, ki slovesno da, podeli doktorski naslov'; 2. 'ženska, ki širi poznavanje, ugled koga, česa v javnosti'; 3. knjiž. 'ženska, ki povzroča, pospešuje kako dogajanje ali delovanje'. Obe obliki navaja $S P$, nobena pa ni slogovno zaznamovana. Verjetno pa tudi večpomenskost promotorke pripomore $\mathrm{k}$ njeni pogostejši rabi, potrjuje jo namreč 324 konkordanc, medtem ko jih ob iskalnem pogoju promotorica korpus Gigafida ponudi le 13. Primeri iz štirih jezikovnih virov kažejo, da je 55,5 \% feminativov tvorjenih z -ica (deset primerov), 44,5\% pa s - $k a$ (osem primerov), kadar gre za dodajanje k izglasju obrazila na -(o)r.

\section{propagatorica $<$ propagatorka}

Propagatorka in propagatorica sta v SSKJ 1 razloženi kot 'ženska oblika od propagator', pri čemer nobena od variant ni stilno zaznamovana. V drugi izdaji slovarja sta obe besedi razloženi kot 'ženska, ki propagira', ponovno obe brez kvalifikatorja. Enaka je situacija v SP. Tudi po korpusni analizi sta obe varianti zelo izenačeni (propagatorka dve konkordanci, propagatorica tri konkordance po Gigafidi; propagatorka 1, propagatorica 0 po Novi besedi; propagatorka 0 , propagatorica 1 po Kresu; propagatorka 26, propagatorica 16 po Googlu); katera bo v rabi prevladala, se bo izkazalo šele sčasoma. Ob izglasju na -(ato)r pa se, sodeč po primerih iz različnih jezikovnih virov, pogosteje pojavlja feminativno obrazilo -ka (25 primerov ali $81 \%)$.

raperica $<$ raperka 
SSKJ v nobeni izdaji ne navaja teh dveh variant. K raperju kot 'rapovskemu glasbeniku', rabljenem v glasbenem žargonu, SP beleži zgolj raperico. Varianto raperka smo zasledili $\mathrm{v}$ diplomskem delu Katje Kustec Novotvorjenke za poimenovanje oseb. Razmerje po korpusu pa potrjuje pogostejšo rabo raperke (232 konkordanc; za raperico le 26 zadetkov). K izglasju na -(e)r se tudi sicer pogosteje dodaja feminativno obrazilo - $k a$ (41 primerov oz. $91 \%$, za -ica samo štirje primeri oz. $9 \%$ ), kot kažejo primeri iz obeh izdaj SSKJ, NSL in SNBSJ.

\section{roparica $<$ roparka}

Roparka v SSKJ 1 nastopa v pomenu 'ženska oblika od ropar', roparica pa lahko pomeni dvoje: samostojno ali kot prilastek je 'žival, ki lovi, pobija druge živali za hrano', redko pa nastopa v pomenu 'roparka'. Slovarski sestavek ima tudi terminološko gnezdo, saj slovarska iztočnica lahko nastopa tudi v besedni zvezi čebela roparica, tj. 'čebela, ki odnaša med iz tujih panjev'. V SSKJ 2 je pomenska razlaga roparke kompleksnejša ('ženska, ki ropa'), pri roparici pa ob pomenu 'roparka' ni več oznake redko. Tudi $S P$ k roparju navede obe ženskospolski varianti, le da kot nevtralnejšo izpostavi roparko. Pri korpusnih rezultatih je treba upoštevati večpomenskost prve od obeh variant: po Gigafidi roparica 797 konkordanc, roparka 176 konkordanc. Glede na sintezo obrazilne produktivnosti pa je ob izglasju na $-(a) r$ pogostejše priponsko obrazilo $-k a(52 \%)$.

\section{selektorica > selektorka}

V SSKJ 1 ni nobenega od navedenih feminativov (zgolj moškospolska oblika selektor), po drugi izdaji slovarja pa obe obliki pomenita 'ženska, ki izbira, odbira' s podpomenom (in kvalifikatorjem šport.) 'ženska, ki izbira, odbira najboljše igralke, tekmovalke za tekmovanje'. Obe varianti beleži tudi $S P$, nobena pa ni stilno zaznamovana. Korpusna analiza pa kaže na pogostejšo rabo prve od navedenih variant (Gigafida: selektorica 981 konkordanc, selektorka 363 konkordanc). K izglasju obrazila na $-(o) r$ pa se pogosteje dodaja feminativno obrazilo -ica $(55,5 \%$ ali deset primerov; z obrazilom - $k a$ nekoliko manj, osem primerov ali $44,5 \%)$. 


\section{senatorica $<$ senatorka}

SSKJ 1 beleži le senatorko kot 'žensko obliko k senatorju'. Po drugi izdaji je senatorka $\mathrm{v}$ nekaterih državah 'članica zgornjega doma parlamenta'. Za razliko od obeh SSKJ pa SP k senatorju ponuja le feminativ senatorica. Po korpusu Gigafida pa je prepričljivo v ospredju beseda senatorka s 1348 pojavitvami, medtem ko jih senatorico potrjuje le 70. Kadar gre za dodajanje k izglasju moškospolskega obrazila na -(o)r, se pogosteje rabi obrazilo -ica (deset primerov oz. 55,5\%, za $-k a 44,5 \%)$.

\section{sladoledarica $<$ sladoledarka}

V SSKJ 1 in 2 ne najdemo feminativa k sladoledarju, zato pa sta obe obliki popisani v $S P$, nobena pa ni stilno zaznamovana. Izraz sladoledarka smo zasledili tudi $\mathrm{v}$ že omenjenem diplomskem delu Katje Kustec. Izraza pa imata malo pojavitev tudi po Gigafidi: sladoledarka devet, sladoledarica pa le eno konkordanco (Nova beseda: sladoledarka 1, sladoledarica 0; Kres: sladoledarka 0, sladoledarica 0; Google: sladoledarka 67, sladoledarica: 15). Sinteza obrazilne produktivnosti kaže, da je pogostejše dodajanje obrazila -ka k izglasju na - $(a) r$.

\section{sleparica $<$ sleparka}

Sleparka po obeh izdajah SSKJ ob kvalifikatorju ekspr. pomeni 'ženska, ki goljufa, vara', medtem ko sleparica s pomensko razlago, sicer brez kvalifikatorja, preusmerja k sleparki. Podobno je v SP, kjer sta tudi zabeleženi obe varianti, a je k sleparici pripisana oznaka redko, za nevtralnejšo besedo pa velja sleparka. To potrjujeta tudi korpusna analiza (Gigafida: sleparka 91 konkordanc, sleparica 0 konkordanc) in sinteza obrazilne produktivnosti.

\section{slikarica $<$ slikarka}

Slikarka je, upoštevajoč pomensko razlago v obeh izdajah SSKJ, 'ženska, ki upodablja z barvami, navadno umetniško', medtem ko je slikarica z razlago 'slikarka' zaznamovana $\mathrm{s}$ kvalifikatorjem star. $S P$ kot podiztočnico $\mathrm{k}$ moškospolskemu slikarju navaja zgolj slikarko. K slednji se nagibajo tudi 
rezultati korpusne analize, saj jo potrjuje 9314 konkordanc, slikarico pa le 10 po Gigafidi. Tudi po sintezi obrazilne produktivnosti je ustreznejša možnost slikarka.

\section{spletkarica $<$ spletkarka}

Obe varianti sta po SSKJ 1 in 2 označeni s kvalifikatorjem nav. ekspr. in pomenita 'žensko, ki spletkari'. Samo spletkarka pa nastopa kot podiztočnica k spletkarju v $S P$. Druga od obeh variant prednjači tudi v korpusnem gradivu, saj jo potrjuje 91 pojavitev, medtem ko Gigafida za spletkarico izpiše le dve konkordanci. Da je ustreznejša varianta spletkarka, potrjuje tudi sinteza obrazilne produktivnosti, saj se v $51 \%$ primerov k izglasju obrazila na - $(a) r$ dodaja obrazilo $-k a$.

\section{šolarica $<$ šolarka}

SSKJ 1 in 2 razlagata šolarko kot 'učenko osnovne šole', šolarico pa označujeta s kvalifikatorjem star., pomenska razlaga zanjo je zgolj 'šolarka'. SP ob šolarju navaja kot feminativno podiztočnico le šolarko, da je ta varianta pogostejša tudi v rabi, potrjuje korpus Gigafida (šolarka 1441 konkordanc, šolarica le dve konkordanci). Če upoštevamo sintezo obrazilne produktivnosti, je ustreznejši izraz šolarka.

\section{tolmačica $<$ tolmačka}

Tolmačica je v SSKJ 1 razložena kot 'ženska oblika od tolmač', ob slovarskem geslu tolmačka pa pomenska razlaga daje prednost tolmačici. Drugače je v drugi izdaji slovarja, kjer ima samo tolmačka polno razlago pomena 'ženska, ki se (poklicno) ukvarja z neposrednim ustnim prevajanjem pogovorov', razlaga pri tolmačici pa je samo 'tolmačka'. V SP je kot ženskospolska vzporednica k tolmaču zabeležena samo tolmačka, kot pogostejšo od obeh variant pa jo potrjuje tudi korpus Gigafida, saj zanjo izpiše 129 pojavitev, za tolmačico pa 59. Preverjanje po Googlu pa kaže naslednje: tolmačka 122 zadetkov, tolmačica 97. Sinteza obrazilne produktivnosti pa kaže, da je priponsko obrazilo -ica tisto, ki se najpogosteje dodaja izglasju podstave na $-\check{c}$ (potrjeno sicer zgolj $\mathrm{z}$ dvema primeroma; s - $k a$ le eden). 
veslačica > veslačka

Obe izdaji SSKJ beležita samo veslačico: po starejši izdaji slovarja je to 'ženska oblika od veslač', po novejši pa 'ženska, ki vesla' s podpomenom 'športnica, ki se ukvarja z veslanjem'. Obe varianti kot podiztočnici k veslaču navaja $S P$, le da kot nevtralnejšo izpostavi veslačico. Slednja je pogostejša tudi glede na korpusno analizo, saj jo Gigafida potrdi z 228 konkordancami, medtem ko za veslačko ne ponuja nobenega zadetka. K moškospolskemu izglasju na - (a)č pa se najpogosteje dodaja feminativno priponsko obrazilo -ica (52\%).

\section{veslarica $<$ veslarka}

Veslarica $\mathrm{v}$ obeh izdajah SSKJ nastopa s pomensko razlago 'veslačica', veslarke pa ta jezikovni priročnik ne vsebuje. Obe varianti sta kot feminativa k veslarju popisani v $S P$, zaznamovani sta z oznako redko, kot primernejša pa je navedena beseda veslačica. Korpus Gigafida pa ne ponuja zadetkov za nobeno od navedenih variant (enako Nova beseda in Kres, po Googlu za veslarko 5 zadetkov, za veslarico pa 21). Pri izglasju obrazila na $-(a) r$ pa se po sintezi obrazilne produktivnosti pogosteje, to je v $51 \%$, pojavlja obrazilo $-k a$.

\section{vladarica > vladarka}

V SSKJ 1 je zabeležena le prva od obeh variant v pomenu 'ženska oblika od vladar'. V drugi izdaji vladarica pomeni 'žensko, ki vlada', novejša izdaja pa ponuja tudi varianto vladarka s pomensko razlago 'vladarica'. Tudi v SP je zabeležena le vladarica, slednja pa prevladuje še $\mathrm{v}$ rezultatih korpusne analize (vladarica 789 konkordanc, vladarka 164 konkordanc po Gigafidi). Po sintezi obrazilne produktivnosti pa bi bila ustreznejša varianta vladarka.

\section{vratarica $<$ vratarka}

Vratarica v SSKJ 1 in 2 pomeni 'ženska, ki poklicno nadzoruje vstopanje in izstopanje skozi vhodna vrata, daje informacije', vratarka pa ima dva pomena: v prvem pomeni 'vratarico', v drugem pa šport. 'igralko, ki brani vrata'. Obe varianti navaja tudi $S P$, le da prednost daje vratarici kot nevtralnejši besedi. Po korpusu Gigafida pa je pogostejša varianta vratarka (3297 konkordanc), kar je zagotovo 
pogojeno $\mathrm{z}$ večpomenskostjo. Za vratarico pa Gigafida ponudi bistveno manj pojavitev, le 52. Če pa upoštevamo sintezo obrazilne produktivnosti, ugotovimo, da se ob izglasju na -(a)r pogosteje pojavlja feminativno obrazilo $-k a$.

\section{vražarica > vražarka}

Vražarka in vražarica po obeh izdajah SSKJ pomenita 'ženska, ki na podlagi vraže, vraž a) zdravi, preprečuje bolezni; b) vedežuje', pri čemer nobena od variant ni slogovno zaznamovana. Obe varianti kot stilno nevtralni feminativni podiztočnici k vražarju popisuje tudi $S P$, korpus Gigafida pa se bolj nagiba k vražarici, ki jo sicer potrjuje s samo sedmimi konkordancami, a za vražarko ne ponuja nobene (Nova beseda za vražarico ponudi eno konkordanco, za vražarko nobene; Kres za nobeno od možnosti ne ponuja zadetkov, po Googlu pa je mogoče najti 29 zadetkov za vražarko in 28 za vražarico). Po sintezi obrazilne produktivnosti pa bi bila ustreznejša možnost vražarka.

\section{vrtnarica > vrtnarka}

SSKJ 1 vsebuje le vrtnarico, in to kot večpomenko: 1. 'ženska, ki se ukvarja z vrtnarstvom'; 2. 'ženska, ki ureja vrt, navadno večji'; 3. star., navadno v zvezi otroška vrtnarica 'vzgojiteljica v otroškem vrtcu'. Vrtnarico $\mathrm{v}$ istih pomenih ponuja SSKJ 2, v njej pa najdemo tudi vrtnarko v dveh pomenih: 'ženska, ki se ukvarja z vrtnarstvom' in 'ženska, ki ureja vrt, navadno večji'. Obe možnosti je mogoče najti tudi v $S P$, a kot nevtralnejša obvelja vrtnarica. Razmerje po korpusu Gigafida pa je skoraj izenačeno (vrtnarka 214, vrtnarica 239 pojavitev), zato smo izvedli dodatno preverjanje: po Novi besedi za vrtnarko 17, vrtnarico 38 pojavitev, po Kresu za vrtnarko 39, vrtnarico 44 zadetkov, po Googlu pa za vrtnarko 74, za vrtnarico pa 104 zadetki. Pri izglasju na -(a)r pa se po sintezi obrazilne produktivnosti pogosteje dodaja obrazilo $-k a$.

\section{zdraharica $>$ zdraharka}

V SSKJ 1 in 2 lahko zasledimo le zdraharico kot 'žensko, ki dela, povzroča zdrahe', beseda pa je zaznamovana s kvalifikatorjem ekspr. Obe, zdraharico in zdraharko, pa kot feminativni podiztočnici k zdraharju beleži $S P$, nobene od 
variant pa ne izpostavi kot nevtralnejše. Pojavitev po korpusu Gigafida je za obe možnosti malo: zdraharico potrjuje devet konkordanc, zdraharko pa le dve (Nova beseda in Kres ne ponudita pojavitev za nobeno). Sinteza obrazilne produktivnosti pa kaže, da prevladuje tvorba s priponskim obrazilom - $k a$, kadar gre za dodajanje k izglasju na $-(a) r$.

\section{zeliščarica $<$ zeliščarka}

Tudi ob tem paru SSKJ 1 navaja zgolj prvo od obeh variant, in to v pomenu 'ženska, ki nabira ali prodaja zdravilne rastline'. Druga izdaja pa ponudi obe varianti, in to v že navedenem pomenu in brez kvalifikatorjev. V SP je navedena le zeliščarica kot feminativ k zeliščarju, po korpusu Gigafida sodeč pa je v rabi pogostejša varianta zeliščarka (203 konkordance, za zeliščarico nekoliko manj, tj. 172 konkordanc). Zanimive izsledke dajejo Nova beseda, Kres in Google: po prvi sta varianti zelo izenačeni - zeliščarka 24 , zeliščarica 22 pojavitev, po Kresu je pogostejša zeliščarica z 29 konkordancami (za zeliščarko 17), Google pa izkazuje pogosto rabo zeliščarke (132 zadetkov, za zeliščarico pa 120). Primeri iz jezikovnih virov pa kažejo, da je k izglasju na - $(a) r$ pogostejše dodajanje obrazila $-k a$.

\section{zeljarica > zeljarka}

Obe varianti v obeh izdajah SSKJ pomenita 'žensko, ki prideluje ali prodaja zelje', nobena od besed pa ni slogovno zaznamovana. SP ponuja samo zeljarico kot ženskospolsko vzporednico k zeljarju, njeno pogostejšo rabo pa potrjuje tudi korpus Gigafida, ki ob iskalnem pogoju zeljarica ponudi 16 pojavitev, ob zeljarki pa le eno (Nova beseda: zeljarka 1, zeljarica 0 pojavitev; Kres: zeljarka 0, zeljarica 2 zadetka; Google: zeljarka 20 zadetkov, zeljarica 31). Upoštevajoč sintezo obrazilne produktivnosti pa bi bil ustreznejši izraz zeljarka.

\section{zgodovinarica $<$ zgodovinarka}

Zgodovinarka je po SSKJ (upoštevajoč obe izdaji) 'strokovnjakinja za zgodovino', pri slovarski iztočnici zgodovinarica pa je navedena pomenska razlaga 'zgodovinarka'. SP kot feminativno vzporednico k zgodovinarju navaja le 
zgodovinarko, le-ta pa je izrazito pogostejša tudi glede na korpusno analizo (zgodovinarka 2735 zadetkov, zgodovinarica le en zadetek). Feminativ zgodovinarka je ustreznejši tudi, če upoštevamo sintezo obrazilne produktivnosti.

\section{žeparica $<$ žeparka}

SSKJ 1 besedo žeparka razlaga kot 'žensko, ki krade zlasti denarnice iz žepov', za žeparico pa navede zgolj pomensko razlago redko 'žeparka'. Po SSKJ 2 pa je žeparica že označena kot zastarela. SP navaja le varianto žeparka, ki jo z več konkordancami potrjuje tudi korpus Gigafida (38 konkordanc, medtem ko za žeparico zgolj ena). Tudi po sintezi obrazilne produktivnosti se kot ustreznejša možnost kaže žeparka.

Spodnja preglednica ${ }^{108}$ prikazuje zastopanost variant $\mathrm{v}$ jezikovnih priročnikih - od obeh možnosti je zapisana tista, ki je zabeležena v več jezikovnih priročnikih ali ki nastopa v novejših jezikovnih virih (SSKJ 1, SP, NSL, SNBSJ, SSKJ 2). Glede na pomen smo dali prednost tisti vzporednici, ki je nosilka le enega pomena, upoštevali pa smo tudi preusmeritve jezikovnih priročnikov $\mathrm{k}$ ustreznejši varianti. Upoštevajoč kvalifikatorje smo kot ustreznejšo predlagali tisto možnost, ki je slogovno nezaznamovana; če sta zaznamovani obe, smo dali prednost tisti, ki ni označena kot zastarela ali redko rabljena. Pomembno je, katera od obeh variant je pogostejša v rabi; to smo preverjali po korpusu Gigafida, po potrebi še po Novi besedi, Kresu in spletnem iskalniku Google. Upoštevali smo tudi sintezo obrazilne produktivnosti - katero feminativno obrazilo se pogosteje dodaja k določenemu moškospolskemu izglasju (obrazila ali podstave). Nazadnje smo glede na vse napisano predlagali ustreznejšo možnost.

108 Če je zapisana zgolj ena od obeh variant, pomeni, da se nam zdi ustreznejša. Zapis obeh variant pomeni, da sta ustrezni obe. Pri razvrščanju smo upoštevali utemeljitve, zapisane v tem poglavju. 
Preglednica 67: Variantni priponski obrazili -ica in -ka

\begin{tabular}{|c|c|c|c|c|c|c|}
\hline Variante & $\begin{array}{l}\text { Prednostna varianta po } \\
\text { zastopanosti v jez. } \\
\text { priročnikih }(S S K J 1 \text {, } \\
S P, N S L, S S K J \text { 2) }\end{array}$ & $\begin{array}{l}\text { Prednostna varianta } \\
\text { glede na pomensko } \\
\text { obremenitev }\end{array}$ & $\begin{array}{l}\text { Prednostna varianta } \\
\text { glede na slogovno } \\
\text { (ne)zaznamovanost }\end{array}$ & \begin{tabular}{|l|} 
Prednostna \\
varianta po \\
pogostnosti \\
(korpusi, splet) \\
\end{tabular} & $\begin{array}{l}\text { Prednostna } \\
\text { varianta po } \\
\text { sintezi obrazilne } \\
\text { produktivnosti } \\
\end{array}$ & $\begin{array}{l}\text { Prednostna } \\
\text { varianta glede } \\
\text { na vse navedene } \\
\text { kriterije } \\
\end{array}$ \\
\hline anketarica : anketarka & anketarka & anketarica/anketarka & anketarica/anketarka & anketarka & anketarka & anketarka \\
\hline avtorica : avtorka & avtorica & avtorica & avtorica/avtorka & avtorica & avtorica & avtorica \\
\hline bajtarica : bajtarka & bajtarica & bajtarica/bajtarka & bajtarica/bajtarka & bajtarica & bajtarka & bajtarica \\
\hline blogerica : blogerka & blogerka & blogerica/blogerka & blogerica/blogerka & blogerka & blogerka & blogerka \\
\hline ciganica : ciganka & ciganka & ciganica/ciganka & ciganka & ciganka & ciganka & ciganka \\
\hline citrarica : citrarka & citrarica/citrarka & citrarica/citrarka & citrarica/citrarka & citrarka & citrarka & citrarka \\
\hline časnikarica : časnikarka & časnikarica/časnikarka & časnikarka & časnikarica/časnikarka & časnikarka & časnikarka & časnikarka \\
\hline čebelarica : čebelarka & čebelarica/čebelarka & čebelarka & čebelarka & čebelarka & čebelarka & čebelarka \\
\hline čuvarica : čuvarka & čuvarka & čuvarica/čuvarka & čuvarica/čuvarka & čuvarka & čuvarka & čuvarka \\
\hline $\begin{array}{l}\text { demonstratorica: } \\
\text { demonstratorka }\end{array}$ & demonstratorka & $\begin{array}{l}\text { demonstratorica/ } \\
\text { demonstratorka }\end{array}$ & $\begin{array}{l}\text { demonstratorica/ } \\
\text { demonstratorka } \\
\end{array}$ & demonstratorka & demonstratorka & demonstratorka \\
\hline diktatorica : diktatorka & diktatorica/diktatorka & diktatorica/diktatorka & diktatorka & diktatorka & diktatorka & diktatorka \\
\hline dninarica : dninarka & dninarica/dninarka & dninarica & dninarica/dninarka & dninarka & dninarka & dninarka \\
\hline dvorjanica : dvorjanka & dvorjanica/dvorjanka & dvorjanka & dvorjanka & dvorjanka & dvorjanka & dvorjanka \\
\hline $\begin{array}{l}\text { ekspeditorica: } \\
\text { ekspeditorka }\end{array}$ & ekspeditorica & ekspeditorica & ekspeditorica & ekspeditorica & $\begin{array}{l}\text { ekspeditorica/ } \\
\text { ekspeditorka }\end{array}$ & ekspeditorica \\
\hline $\begin{array}{l}\text { gostilničarica: } \\
\text { gostilničarka }\end{array}$ & gostilničarka & gostilničarka & gostilničarka & gostilničarka & gostilničarka & gostilničarka \\
\hline $\begin{array}{l}\text { gubernatorica: } \\
\text { gubernatorka }\end{array}$ & $\begin{array}{l}\text { gubernatorica/ } \\
\text { gubernatorka }\end{array}$ & $\begin{array}{l}\text { gubernatorica/ } \\
\text { gubernatorka }\end{array}$ & $\begin{array}{l}\text { gubernatorica/ } \\
\text { gubernatorka }\end{array}$ & gubernatorka & gubernatorka & gubernatorka \\
\hline $\begin{array}{l}\text { harmonikarica: } \\
\text { harmonikarka }\end{array}$ & harmonikarka & $\begin{array}{l}\text { harmonikarica/ } \\
\text { harmonikarka }\end{array}$ & $\begin{array}{l}\text { harmonikarica/ } \\
\text { harmonikarka }\end{array}$ & harmonikarka & harmonikarka & harmonikarka \\
\hline $\begin{array}{l}\text { improvizatorica : } \\
\text { improvizatorka }\end{array}$ & improvizatorka & $\begin{array}{l}\text { improvizatorica/ } \\
\text { improvizatorka }\end{array}$ & $\begin{array}{l}\text { improvizatorica/ } \\
\text { improvizatorka }\end{array}$ & improvizatorka & improvizatorka & improvizatorka \\
\hline $\begin{array}{l}\text { investitorica: } \\
\text { investitorka }\end{array}$ & investitorica & $\begin{array}{l}\text { investitorica/ } \\
\text { investitorka }\end{array}$ & \begin{tabular}{|l|} 
investitorica/ \\
investitorka
\end{tabular} & investitorica & investitorka & investitorica \\
\hline
\end{tabular}




\begin{tabular}{|c|c|c|c|c|c|c|}
\hline Variante & $\begin{array}{l}\text { Prednostna varianta po } \\
\text { zastopanosti v jez. } \\
\text { priročnikih }(S S K J \text { I, } \\
S P, N S L, S S K J \text { 2) }\end{array}$ & $\begin{array}{l}\text { Prednostna varianta } \\
\text { glede na pomensko } \\
\text { obremenitev }\end{array}$ & $\begin{array}{l}\text { Prednostna varianta } \\
\text { glede na slogovno } \\
\text { (ne)zaznamovanost }\end{array}$ & $\begin{array}{l}\text { Prednostna } \\
\text { varianta po } \\
\text { pogostnosti } \\
\text { (korpusi, splet) }\end{array}$ & $\begin{array}{l}\text { Prednostna } \\
\text { varianta po } \\
\text { sintezi obrazilne } \\
\text { produktivnosti }\end{array}$ & $\begin{array}{l}\text { Prednostna } \\
\text { varianta glede } \\
\text { na vse navedene } \\
\text { kriterije }\end{array}$ \\
\hline ječarica : ječarka & ječarka & ječarica/ječarka & ječarica/ječarka & ječarka & ječarka & ječarka \\
\hline $\begin{array}{l}\text { kanclerica : } \\
\text { kanclerka }\end{array}$ & kanclerka & kanclerica/kanclerka & kanclerica/kanclerka & kanclerka & kanclerka & kanclerka \\
\hline ključarica : ključarka & ključarka & ključarka & ključarica/ključarka & ključarka & ključarka & ključarka \\
\hline kočarica : kočarka & kočarica/kočarka & kočarica/kočarka & kočarica/kočarka & kočarica & kočarka & kočarica \\
\hline $\begin{array}{l}\text { komentatorica: } \\
\text { komentatorka }\end{array}$ & komentatorka & komentatorka & komentatorka & komentatorka & komentatorka & komentatorka \\
\hline $\begin{array}{l}\text { koordinatorica: } \\
\text { koordinatorka }\end{array}$ & $\begin{array}{l}\text { koordinatorica/ } \\
\text { koordinatorka }\end{array}$ & $\begin{array}{l}\text { koordinatorica/ } \\
\text { koordinatorka }\end{array}$ & $\begin{array}{l}\text { koordinatorica/ } \\
\text { koordinatorka }\end{array}$ & koordinatorka & koordinatorka & koordinatorka \\
\hline $\begin{array}{l}\text { krčmarica: } \\
\text { krčmarka }\end{array}$ & krčmarica/krčmarka & krčmarica & krčmarica & krčmarica & krčmarka & krčmarica \\
\hline krmarica : krmarka & krmarka & krmarka & krmarica/krmarka & krmarka & krmarka & krmarka \\
\hline lekarnarica : lekarnarka & lekarnarica/lekarnarka & $\begin{array}{l}\text { lekarnarica/ } \\
\text { lekarnarka }\end{array}$ & lekarnarica & $\begin{array}{l}\text { lekarnarica/ } \\
\text { lekarnarka }\end{array}$ & lekarnarka & lekarnarka \\
\hline lončarica : lončarka & lončarka & lončarica/lončarka & lončarica/lončarka & lončarka & lončarka & lončarka \\
\hline lutkarica : lutkarka & lutkarica & lutkarica/lutkarka & lutkarica/lutkarka & lutkarica & lutkarka & lutkarica \\
\hline mazačica : mazačka & mazačka & mazačica/mazačka & mazačka & mazačka & mazačica & mazačka \\
\hline medičarica : medičarka & medičarica/medičarka & medičarica/medičarka & medičarica/medičarka & medičarka & medičarka & medičarka \\
\hline mešetarica : mešetarka & mešetarka & mešetarka & mešetarica/mešetarka & mešetarka & mešetarka & mešetarka \\
\hline $\begin{array}{l}\text { organizatorica : } \\
\text { organizatorka }\end{array}$ & $\begin{array}{l}\text { organizatorica/ } \\
\text { organizatorka }\end{array}$ & organizatorka & organizatorka & organizatorka & organizatorka & organizatorka \\
\hline pankerica : pankerka & pankerica & pankerica/pankerka & pankerica/pankerka & pankerica & pankerka & pankerica \\
\hline partnerica : partnerka & partnerica & partnerica/partnerka & partnerica/partnerka & partnerica & partnerka & partnerica \\
\hline pometačica : pometačka & pometačica & pometačica & pometačica & pometačica & pometačica & pometačica \\
\hline poštarica : poštarka & poštarica/poštarka & poštarica/poštarka & poštarica & poštarica & poštarka & poštarica \\
\hline $\begin{array}{l}\text { priganjačica: } \\
\text { priganjačka }\end{array}$ & priganjačica/priganjačka & $\begin{array}{l}\text { priganjačica/ } \\
\text { priganjačka }\end{array}$ & $\begin{array}{l}\text { priganjačica/ } \\
\text { priganjačka }\end{array}$ & priganjačka & priganjačica & priganjačka \\
\hline $\begin{array}{l}\text { promotorica : } \\
\text { promotorka }\end{array}$ & promotorka & $\begin{array}{l}\text { promotorica/ } \\
\text { promotorka }\end{array}$ & $\begin{array}{l}\text { promotorica/ } \\
\text { promotorka }\end{array}$ & promotorka & promotorica & promotorka \\
\hline
\end{tabular}




\begin{tabular}{|c|c|c|c|c|c|c|}
\hline Variante & $\begin{array}{l}\text { Prednostna varianta po } \\
\text { zastopanosti v jez. } \\
\text { priročnikih }(S S K J 1 \text {, } \\
S P, N S L, S S K J 2)\end{array}$ & $\begin{array}{l}\text { Prednostna varianta } \\
\text { glede na pomensko } \\
\text { obremenitev }\end{array}$ & $\begin{array}{l}\text { Prednostna varianta } \\
\text { glede na slogovno } \\
\text { (ne)zaznamovanost }\end{array}$ & $\begin{array}{l}\text { Prednostna } \\
\text { varianta po } \\
\text { pogostnosti } \\
\text { (korpusi, splet) } \\
\end{array}$ & $\begin{array}{l}\text { Prednostna } \\
\text { varianta po } \\
\text { sintezi obrazilne } \\
\text { produktivnosti } \\
\end{array}$ & $\begin{array}{l}\text { Prednostna } \\
\text { varianta glede } \\
\text { na vse navedene } \\
\text { kriterije } \\
\end{array}$ \\
\hline $\begin{array}{l}\text { propagatorica : } \\
\text { propagatorka }\end{array}$ & $\begin{array}{l}\text { propagatorica/ } \\
\text { propagatorka }\end{array}$ & $\begin{array}{l}\text { propagatorica/ } \\
\text { propagatorka }\end{array}$ & $\begin{array}{l}\text { propagatorica/ } \\
\text { propagatorka }\end{array}$ & $\begin{array}{l}\text { propagatorica/ } \\
\text { propagatorka }\end{array}$ & propagatorka & propagatorka \\
\hline raperica : raperka & raperica & raperica/raperka & raperica/raperka & raperka & raperka & raperka \\
\hline roparica : roparka & roparica/roparka & roparka & roparka & roparica & roparka & roparka \\
\hline selektorica : selektorka & selektorica/selektorka & selektorica/selektorka & selektorica/selektorka & selektorica & selektorica & selektorica \\
\hline senatorica : senatorka & senatorica/senatorka & senatorica/senatorka & senatorica/senatorka & senatorka & senatorica & senatorica \\
\hline $\begin{array}{l}\text { sladoledarica : } \\
\text { sladoledarka }\end{array}$ & $\begin{array}{l}\text { sladoledarica/ } \\
\text { sladoledarka }\end{array}$ & $\begin{array}{l}\text { sladoledarica/ } \\
\text { sladoledarka }\end{array}$ & $\begin{array}{l}\text { sladoledarica/ } \\
\text { sladoledarka }\end{array}$ & sladoledarka & sladoledarka & sladoledarka \\
\hline sleparica : sleparka & sleparica/sleparka & sleparka & sleparka & sleparka & sleparka & sleparka \\
\hline slikarica : slikarka & slikarka & slikarka & slikarka & slikarka & slikarka & slikarka \\
\hline spletkarica : spletkarka & spletkarka & spletkarica/spletkarka & spletkarica/spletkarka & spletkarka & spletkarka & spletkarka \\
\hline šolarica : šolarka & šolarka & šolarka & šolarka & šolarka & šolarka & šolarka \\
\hline tolmačica : tolmačka & tolmačka & tolmačka & tolmačica/tolmačka & tolmačka & tolmačica & tolmačka \\
\hline veslačica : veslačka & veslačica & veslačica/veslačka & veslačica & veslačica & veslačica & veslačica \\
\hline veslarica : veslarka & veslarica & veslarica/veslarka & veslarica/veslarka & $\begin{array}{l}\text { veslarica/ } \\
\text { veslarka }\end{array}$ & veslarka & veslarica \\
\hline vladarica : vladarka & vladarica & vladarica & vladarica/vladarka & vladarica & vladarka & vladarica \\
\hline vratarica : vratarka & vratarica/vratarka & vratarica & vratarica & vratarka & vratarka & vratarka \\
\hline vražarica : vražarka & vražarica/vražarka & vražarica/vražarka & vražarica/vražarka & vražarica & vražarka & vražarica \\
\hline vrtnarica : vrtnarka & vrtnarica & vrtnarica/vrtnarka & vrtnarica & vrtnarica & vrtnarka & vrtnarica \\
\hline zdraharica : zdraharka & zdraharica & zdraharica/zdraharka & zdraharica/zdraharka & zdraharica & zdraharka & zdraharica \\
\hline zeliščarica : zeliščarka & zeliščarica & zeliščarica/zeliščarka & zeliščarica/zeliščarka & zeliščarka & zeliščarka & zeliščarka \\
\hline zeljarica : zeljarka & zeljarica & zeljarica/zeljarka & zeljarica/zeljarka & zeljarica & zeljarka & zeljarica \\
\hline $\begin{array}{l}\text { zgodovinarka : } \\
\text { zgodovinarica }\end{array}$ & zgodovinarka & zgodovinarka & $\begin{array}{l}\text { zgodovinarica/ } \\
\text { zgodovinarka }\end{array}$ & zgodovinarka & zgodovinarka & zgodovinarka \\
\hline žeparica : žeparka & žeparka & žeparka & žeparka & Žeparka & žeparka & žeparka \\
\hline
\end{tabular}


Analizirali smo 62 parov. Ugotavljamo, da se priponski obrazili -ica in -ka kot variantni dodajata izglasjem na:

- -(a)̌̌ (mazačica - mazačka, pometačica - pometačka, priganjačica priganjačka, veslačica - veslačka; -č tolmačica - tolmačka);

- $\quad$-n (ciganica - ciganka; -(ja)n dvorjanica-dvorjanka);

- -r (avtorica - avtorka, partnerica - partnerka; z izglasjem obrazila na -(a)r: anketarica - anketarka, bajtarica - bajtarka, citrarica - citrarka, časnikarica - časnikarka, čebelarica - čebelarka, čuvarica - čuvarka, dninarica - dninarka, gostilničarica - gostilničarka, harmonikarica harmonikarka, ječarica - ječarka, ključarica - ključarka, kočarica kočarka, krčmarica - krčmarka, krmarica - krmarka, lekarnarica lekarnarka, lončarica - lončarka, lutkarica - lutkarka, medičarica medičarka, mešetarica - mešetarka, poštarica - poštarka, roparica roparka, sladoledarica - sladoledarka, sleparica - sleparka, slikarica slikarka, spletkarica - spletkarka, šolarica - šolarka, veslarica veslarka, vladarica - vladarka, vratarica - vratarka, vražarica vražarka, vrtnarica - vrtnarka, zdraharica - zdraharka, zeliščarica zeliščarka, zeljarica - zeljarka, zgodovinarica - zgodovinarka, žeparica - žeparka; -(e)r: blogerica - blogerka, kanclerica - kanclerka, pankerica - pankerka, raperica - raperka; -(o)r: promotorica - promotorka, selektorica - selektorka, senatorica - senatorka; -(ato)r: demonstratorica - demonstratorka, diktatorica - diktatorka, gubernatorica gubernatorka, improvizatorica - improvizatorka, komentatorica komentatorka, koordinatorica - koordinatorka, organizatorica organizatorka, propagatorica - propagatorka; -(ito)r: ekspeditorica ekspeditorka, investitorica - investitorka.

8.1.1.2 Variantni priponski obrazili -inja/-ka

adutinja > adutka

SSKJ 1 in SP ne navajata nobene od zapisanih variant, pač pa obe najdemo v SSKJ $2 \mathrm{v}$ pomenu 'ženska, ki je zaradi svojih sposobnosti odločilna za uspeh skupine, 
skupnosti'. Besedi sta zabeleženi tudi v SNBSJ z enako pomensko razlago, a s pripisom, da gre zlasti za športnice. Obe beleži tudi NSL, korpus Gigafida pa z več pojavitvami daje prednost adutinji (71 konkordanc, za adtuko jih izpiše le 10). Priponski obrazili -inja in - $k a$ se sicer dodata netvorjenki z izglasjem na - $t$, vendar pa smo ugotovili, da k le-temu pogosteje dodajamo obrazilo - $k a$ (potrjeno z 28 primeri; z -inja le 12).

\section{advokatinja > advokatka}

Obe izdaji SSKJ beležita varianto advokatka, pri čemer je pomenska razlaga 'odvetnica'. Samo advokatko najdemo v SP, a je kot nevtralnejša beseda ponovno navedena odvetnica. Prvo od obeh variant, torej advokatinjo, pa zasledimo v SSKJ 2 (znova samo 'odvetnica'), NSL in SNBSJ. V slednjem je razložena kot 'ženska, ki poklicno daje pravno pomoč'. Razmerje po korpusu Gigafida pa je dokaj izenačeno: advokatko potrjuje 22 konkordanc, advokatinjo pa le dve več. Preverili smo še po Novi besedi (advokatka 2, advokatinja 7 konkordanc), Kresu (advokatka 2, advokatinja 2 konkordanci) in Googlu (advokatka 48, advokatinja 65 zadetkov). Kot smo že ugotovili pri prejšnjem primeru, je k izglasjem podstave na $-t$ pogostejše dodajanje feminativnega obrazila $-k a$.

\section{agentinja < agentka}

Agentka je po SSKJ 1 'ženska oblika od agent', pomenska razlaga pri agentinji pa je 'agentka' (tudi v drugi izdaji slovarja). Agentka pa je po SSKJ 2 prikazana kot večpomenka: 1. 'zastopnica podjetja pri sklepanju poslov, posrednica' s podpomenom 'samostojna posredovalka poslov'; 2. 'zaupna sodelavka državne obveščevalne službe'. SP navaja samo agentko kot feminativ k agentu, a tudi rezultati korpusne analize po Gigafidi govorijo v prid agentki, saj jo potrjujejo s 3130 konkordancami, medtem ko so za agentinjo samo štiri. Tudi sinteza obrazilne produktivnosti je pokazala, da se $\mathrm{k}$ izglasjem obrazila na -(en)t pogosteje dodaja feminativno obrazilo $-k a(92 \%)$.

arhitektinja < arhitektka 
SSKJ 1 in 2 vsebujeta samo prvo od obeh variant v pomenu 'strokovnjakinja za arhitekturo'. Enako je v SP, ki kot ženskospolsko vzporednico k arhitektu navaja samo arhitektko. Drugo možnost, arhitektinjo, pa najdemo samo v NSL, z malo pojavitvami (le $13 \mathrm{v}$ primerjavi z arhitektko, ki jo potrdi 2928 konkordanc) jo potrjuje tudi korpusna analiza. Ugotavljamo pa, da se $\mathrm{k}$ izglasjem podstav na $-t$ pogosteje dodaja priponsko obrazilo $-k a$.

\section{aristokratinja < aristokratka}

Aristokratko obe izdaji SSKJ razlagata kot 'pripadnico aristokracije, plemkinjo', pri aristokratinji pa je pomenska razlaga 'aristokratka'. Obe varianti zasledimo tudi v SP, a za nevtralnejšo velja aristokratka. Zanimivo pa je, da korpus Gigafida z večjim številom konkordanc daje prednost aristokratinji (159 pojavitev) pred aristokratko (98 pojavitev). Ženskospolsko obrazilo - $k a$ je tudi tisto, ki pogosteje nastopa ob moškospolskih izglasjih obrazil na $-(a) t$.

\section{atletinja > atletka}

Atletinja je po SSKJ 1 'športnica, ki goji atletiko' (po SSKJ 2 'športnica, ki se ukvarja z atletiko'), pomenska razlaga pri atletki pa preusmerja k atletinji. SP prav tako navaja obe varianti kot feminativa $\mathrm{k}$ atletu, a kot nevtralnejšo prikazuje atletinjo. Slednja je pogostejša tudi glede na rezultate korpusne analize, saj zanjo Gigafida ponuja kar 10.497 konkordanc, za atletko pa le 21. Kot smo že ugotovili, je po sintezi obrazilne produktivnosti pri tovrstni tvorbi pogostejša varianta $\mathrm{z}$ obrazilom $-k a$.

\section{bakhantinja < bakhantka}

Bakhantka je v SSKJ 1 in SSKJ 2 razložena kot pri starih Grkih 'udeleženka sprevoda na čast boga Bakha', bakhantinja pa pri starih Grkih 'bakhantka' s podpomenom knjiž. 'strastna, razuzdana ženska'. SP kot feminativno podiztočnico k bakhantu vsebuje le bakhantko, korpus Gigafida pa ponudi naslednje rezultate: bakhantka 304 konkordance, bakhantinja le tri. K izglasjem moškospolskega obrazila na -(an)t se, po sintezi obrazilne produktivnosti sodeč, pogosteje dodaja feminativno obrazilo $-k a(97 \%)$. 


\section{baptistinja < baptistka}

V obeh SSKJ je mogoče najti samo baptistinjo v pomenu 'pripadnica protestantske verske skupnosti, ki zahteva krst odraslih'. SP pa navaja obe varianti kot ženskospolski podiztočnici k baptistu, a kot nevtralnejšo izpostavi baptistko. Slednjo kot pogostejšo prikazuje tudi korpus Gigafida, saj zanjo ponudi deset pojavitev, za baptistinjo pa nobene. Ob izglasju na -(is)t pogosteje nastopa priponsko obrazilo $-k a$, kar potrjuje 137 primerov (98 \%) iz štirih jezikovnih virov.

\section{bibliografinja > bibliografka}

Oba SSKJ ponujata samo drugo od obeh možnosti; prva izdaja v pomenu 'ženska oblika od bibliograf', po drugi izdaji slovarja pa je bibliografka razložena kot 'ženska, ki sestavlja bibliografijo'. SP pa, nasprotno, navaja samo bibliografinjo kot feminativ k bibliografu. Rezultati korpusne analize so skromni: po Gigafidi za bibliografko le ena konkordanca, za bibliografinjo nobene (eno konkordanco pri iskalnem pogoju bibliografka ponuja tudi Kres, za bibliografinjo nobene; nobene od obeh variant ni mogoče najti po Novi besedi, medtem ko po Googlu zasedimo 18 zadetkov za bibliografko in 20 za bibliografinjo). Po sintezi obrazilne produktivnosti se $\mathrm{k}$ izglasjem podstav na $-f$ pogosteje dodaja feminativno priponsko obrazilo -inja (11 primerov, s -ka pa deset).

\section{bogatašinja > bogataška}

SSKJ 1 in SSKJ 2 navajata obe besedi: bogatašinjo v pomenu 'zelo bogata ženska', bogataško pa s pomensko razlago 'bogatašinja' in z oznako redko (s slednjo samo v prvi izdaji slovarja). Obe varianti je mogoče zaslediti tudi v $S P$, a je bogataška označena kot redka, bogatašinja pa je zabeležena kot nevtralnejša. Razmerje po korpusu je sledeče: bogataška (ob iskalnih pogojih samostalnik ženskega spola, ednina, živost) 0 konkordanc, bogatašinja ob enakih pogojih 758 konkordanc. K izglasju obrazila na -(a)̌s se sicer pogosteje dodaja priponsko obrazilo -inja (pet primerov oz. $55 \%$, medtem ko za $-k a$ le en primer oz. $11 \%$ ). 


\section{demokratinja < demokratka}

Obe izdaji SSKJ vsebujeta samo demokratko: starejša izdaja jo razloži kot 'žensko obliko od demokrata', v SSKJ 2 pa je prikazana kot večpomenka: 1. 'članica demokratske stranke'; 2. 'demokratična ženska'. Obe varianti najdemo v Slovenskem pravopisu kot feminativa k demokratu, a je kot nevtralnejša označena demokratinja. Korpus Gigafida pa govori v prid demokratki, ki jo potrdi s 404 pojavitvami, medtem ko jih za demokratinjo ponuja le 33. Po sintezi obrazilne produktivnosti se k izglasjem obrazil na -(a)t pogosteje dodaja priponsko obrazilo $-k a(80 \%)$.

\section{despotinja $<$ despotka}

Obe izdaji SSKJ navajata samo izraz despotka, le pomenska razlaga je različna. Prva izdaja jo razlaga kot 'žensko obliko od despota', druga pa kot v starem in srednjem veku 'vladarico z neomejeno oblastjo' s podpomenom ekspr. 'oblastna, samovoljna ženska'. Obe možnosti je mogoče najti v $S P$, kjer sta zabeleženi kot podiztočnici k despotu, kot nevtralnejša pa je prikazana despotinja. Po Gigafidi pa je njuna pojavnost skromna, a hkrati dokaj izenačena: despotko potrjujejo štiri konkordance, despotinjo pa šest (po Novi besedi despotka 1, despotinja 1 konkordanca, po Kresu despotka 0, despotinja 1 konkordanca, po Googlu despotka 33, despotinja 27 zadetkov). Sinteza obrazilne produktivnosti pa kaže, da se ob izglasjih podstav na $-t$ pogosteje (v $58 \%$ ) dodaja feminativno priponsko obrazilo $-k a$.

\section{ekspertinja < ekspertka}

SSKJ 1 ne ponuja nobene od navedenih variant, zato pa obe ponujata druga izdaja slovarja in SNBSJ (oba v pomenu 'strokovnjakinja, ki daje mnenja, nasvete o zadevah iz svoje stroke; izvedenka'), pri čemer nobena ni označena kot slogovno zaznamovana. V SP kot feminativ k ekspertu nastopi samo ekspertinja, a sta kot ustreznejši, nevtralnejši možnosti izpostavljeni izvedenka in strokovnjakinja. Po korpusu Gigafida pa je pogostejša ekspertka z 49 pojavitvami, medtem ko jih je za ekspertinjo le 16. Ob izglasjih podstav na - $t$ pa je sicer pogostejše priponsko obrazilo -ka 
estetinja < estetka

Estetka je po SSKJ 1 'ženska oblika od estet', po drugi izdaji slovarja pa 'ženska, ki ima razvit čut za lepoto in vse vrednoti s stališča lepega'. Z enako pomensko razlago nastopa estetinja, a le v drugi izdaji; najdemo jo tudi v SNBSJ in NSL. SP navaja obe varianti kot feminativa $\mathrm{k}$ estetu, a nobena ni slogovno zaznamovana. Po korpusu Gigafida pa je pogostejša estetka z 42 konkordancami, medtem ko jih estetinjo potrjuje 17. Če upoštevamo sintezo obrazilne produktivnosti, pa je ustreznejša možnost estetka.

\section{favoritinja > favoritka}

Obe možnosti sta navedeni v obeh izdajah SSKJ, in to kot večpomenki: 1. 'ženska, ki ima na tekmovanju največ možnosti za zmago'; 2. knjiž. 'ženska, ki uživa posebno naklonjenost, navadno kake visoke, vplivne osebe, ljubljenka'. Oba izraza kot feminativni podiztočnici k favoritu beleži tudi $S P$, a kot nevtralnejšo izpostavi favoritinjo. Le-ta je pogostejša tudi glede na rezultate korpusne analize, saj jo potrjuje 3875 konkordanc, za favoritko pa jih Gigafida izpiše 2469. Pri sintezi obrazilne produktivnosti pa smo ugotovili, da se $\mathrm{k}$ izglasjem moškospolskih poimenovanj oseb z izglasjem podstav na $-t$ sicer pogosteje dodaja obrazilo $-k a$.

\section{filozofinja $>$ filozofka}

Filozofka in filozofinja $\mathrm{v}$ obeh izdajah SSKJ nastopata $\mathrm{s}$ pomenom 'strokovnjakinja za filozofijo', pri čemer nobena varianta ni stilno zaznamovana. Je pa pri filozofki dodan še podpomen pog. 'slušateljica filozofske fakultete'. V SP je mogoče zaslediti le filozofinjo kot ženskospolsko vzporednico k filozofu. Razmerje po korpusu Gigafida pa je naslednje: filozofka 26 konkordanc, filozofinja 627 konkordanc. Sinteza obrazilne produktivnosti pa kaže, da je ob izglasjih podstav na $-f$ nekoliko pogostejše obrazilo -inja (46\%, s -ka pa $42 \%$ ).

fotografinja $>$ fotografka 
Obe besedi sta zastopani v SSKJ 1 in SSKJ 2, obe brez kvalifikatorja in v pomenu 'ženska, ki se (poklicno) ukvarja s fotografiranjem', ter v SP, prav tako brez stilne zaznamovanosti. Po korpusu je pogostejša fotografinja z 2592 pojavitvami, za fotografko pa jih je po Gigafidi le 60. Glede na sintezo obrazilne produktivnosti pa je ustreznejša varianta fotografinja, saj se $\mathrm{k}$ izglasjem podstav na $-f$ nekoliko pogosteje dodaja prav obrazilo -inja.

\section{geodetinja $<$ geodetka}

V obeh SSKJ najdemo samo geodetko: v starejši izdaji v pomenu 'ženska oblika od geodet', v novejši pa je prikazana kot večpomenka: 1. 'strokovnjakinja za geodezijo'; 2. astron. 'najkrajša pot, po kateri zlasti svetloba potuje med dvema točkama $\mathrm{v}$ ukrivljenem prostoru, prostoru-času'. Obe varianti kot stilno nezaznamovani najdemo v $S P$ kot feminativa h geodetu, izenačeni pa sta tudi po korpusu Gigafida, saj za vsako najdemo 12 pojavitev. Nova beseda ponudi za geodetko 2 zadetka, Kres 3, za geodetinjo pa ne Nova beseda ne Kres ne prinašata pojavitev (Google: geodetka 74, geodetinja 84 zadetkov). Analiza iz prejšnjega poglavja pa je pokazala, da se k izglasjem obrazil na $-(e) t$ nekoliko pogosteje dodaja feminativno obrazilo $-k a$.

\section{geografinja > geografka}

SSKJ 1 navaja samo geografko kot 'žensko obliko od geografa'; po drugi izdaji je razložena kot 'strokovnjakinja za geografijo', v enakem pomenu pa nastopi geografinja. Slednjo zasledimo tudi v SNBSJ in NSL, obe varianti pa navaja tudi $S P$, a nobena ni prikazana kot stilno zaznamovana, le kot nevtralnejša je navedena zemljepiska. V rezultatih korpusne analize pa po Gigafidi prevladuje geografinja s 87 pojavitvami (za geografko le štiri). Tudi sicer ob izglasjih podstav na $-f$ pogosteje nastopa obrazilo -inja (46\%).

\section{herojinja > herojka}

V SSKJ 1 najdemo samo herojinjo s pomensko razlago 'ženska oblika od heroj'; tudi $\mathrm{v}$ novejši izdaji slovarja najdemo samo prvo od navedenih variant, a v pomenu 'ženska, ki je storila izredno pogumno, junaško dejanje, junakinja'. Obe 
možnosti pa navaja $S P$, in to obe kot stilno nezaznamovani, pri obeh pa je kot nevtralnejša beseda pripisana junakinja. Po korpusu Gigafida je razmerje sledeče: herojinjo potrjuje 91 konkordanc, herojko pa 51. Po sintezi obrazilne produktivnosti se k izglasjem podstav na $-j$ pogosteje dodaja feminativno obrazilo $-k a$, kar potrjuje 13 primerov (z -inja le eden).

\section{homeopatinja > homeopatka}

Nobene od navedenih variant ne najdemo v starejši izdaji SSKJ. V SSKJ 2, SNBSJ in SP najdemo samo homeopatinjo v pomenu 'ženska, ki zdravi s homeopatijo' oz. kot feminativ k homeopatu. Obe možnosti najdemo v NSL, zato smo pojavnost obeh preverili tudi po korpusu Gigafida. Za homeopatinjo korpus izpiše 131 konkordanc, za homeopatko pa zgolj tri. K izglasjem podstav na $-t$ se sicer po sintezi obrazilne produktivnosti pogosteje dodaja feminativno priponsko obrazilo $-k a$.

\section{interpretinja < interpretka}

Interpretka je po SSKJ 1 razložena kot 'ženska oblika od interpret', pri slovarskem geslu interpretinja pa je pomenska razlaga 'interpretka'. Podobno je v drugi izdaji slovarja, le da je pomenska razlaga pri interpretki samostojnejša: 1. 'ženska, ki dela, povzroča, da se dojame, spozna pomen, vsebina česa; razlagalka, tolmačka'; 2. 'ženska, ki umetniško poustvarja a) dramske like, igralka; b) glasbeno delo, izvajalka'. SP navaja samo interpretko kot feminativ $\mathrm{k}$ interpretu, a $\mathrm{za}$ nevtralnejše besede predlaga razlagalko, tolmačko, igralko, izvajalko. Po korpusu Gigafida pa je razmerje sledeče: interpretka 222 konkordanc, interpretinja 109 konkordanc. Ob izglasjih podstav na $-t$ je po sintezi obrazilne produktivnosti pogostejše obrazilo $-k a$.

\section{kadetinja > kadetka}

SSKJ 1 ne ponuja nobene od navedenih variant. Druga izdaja in SNBSJ navajata samo kadetinjo $\mathrm{v}$ pomenu 'športnica $\mathrm{v}$ kategoriji med petnajstim in šestnajstim letom' (čeprav moškospolska oblika kadet lahko pomeni še 'gojenec šole za policiste', 'gojenec, ki se v vojaški šoli usposablja za častnika', v carski Rusiji, 
med državljansko vojno 'član buržoazne protirevolucionarne stranke'). Sta pa obe varianti zabeleženi v $S P$ kot feminativa h kadetu, pri čemer nobena ni stilno zaznamovana. Korpus Gigafida pa s 4236 konkordancami potrjuje pogostejšo rabo kadetinje (za kadetko le 69 konkordanc). Gre za dodajanje feminativnega obrazila k netvorjenki z izglasjem na $-t$; po sintezi obrazilne produktivnosti je pri tovrstni tvorbi pogostejše dodajalno obrazilo $-k a$.

\section{kandidatinja $<$ kandidatka}

Kandidatka je po SSKJ 1 razložena kot 'ženska oblika od kandidat', kandidatinja pa s pomensko razlago 'kandidatka'. Po drugi izdaji je kandidatka večpomenka: 1. 'ženska ali država, ustanova, ki si prizadeva, se poteguje za kaj' s podpomenom 'ženska ali država, ustanova, ki izpolnjuje pogoje za kaj'; 2. 'ženska, ki se prijavi k izpitu ali opravlja izpit'; pomenska razlaga pri geslu kandidatinja je enaka kot $\mathrm{v}$ prvi izdaji slovarja. Obe možnosti navaja tudi $S P$, pri čemer je kandidatinja označena kot redka, kandidatka pa kot nevtralnejša. Pogostejša je tudi po rezultatih Gigafide, saj jo potrjuje 44.631 konkordanc, kandidatinjo pa 250 . K izglasjem obrazila na $-(a) t$ se tudi sicer pogosteje dodaja priponsko obrazilo $-k a$, kar potrjuje osem primerov (80\%), medtem ko je tvorba z obrazilom -inja potrjena z zgolj dvema primeroma.

\section{koreografinja > koreografka}

SSKJ 1 in 2 razlagata koreografko kot 'žensko, ki se (poklicno) ukvarja s koreografijo', razlaga pri koreografinji pa je 'koreografka'. SP navaja samo koreografinjo kot feminativno podiztočnico h koreografu, ki pa je s 3039 pojavitvami pogostejša tudi glede na rezultate korpusne analize (za koreografko le 339). Tudi pričujoča analiza dokazuje, da je ob izglasjih podstav na $-f$ pogostejše priponsko obrazilo -inja z enim konkretnim primerom več kot - $k a$.

\section{kostumografinja < kostumografka}

Obe varianti navajata obe izdaji SSKJ: kostumografko v pomenu 'ženska, ki se (poklicno) ukvarja s kostumografijo', kostumografinjo pa s pomensko razlago 'kostumografka'. Tudi SP ponudi obe možnosti kot ženskospolski vzporednici h 
kostumografu, a nobena od njiju ne nastopi kot slogovno zaznamovana. Medtem ko je po korpusu Gigafida pogostejša kostumografka s 1216 pojavitvami (za kostumografinjo jih lahko najdemo 961), pa je po sintezi obrazilne produktivnosti nekoliko pogostejše dodajanje obrazila -inja $\mathrm{k}$ izglasjem podstav na $-f$.

\section{lenuhinja > lenuška}

Lenuška je v obeh izdajah SSKJ označena s kvalifikatorjem ekspr., pomeni pa 'leno žensko'. Lenuhinja nastopa $\mathrm{v}$ enakem pomenu, le da je označena kot slabšalna. SP kot feminativ k lenuhu navede samo lenuhinjo, le-ta pa je pogostejša tudi po korpusu Gigafida. Sicer je zanjo korpus ponudil le 14 pojavitev, za lenuško pa deset. Pri slednji opažamo, da gre pri nekaterih pojavitvah za pridevnik, zato smo uporabili napredno iskanje ob pogojih občno ime, samostalnik ženskega spola, živost, in dobili 0 konkordanc. Po analizi iz prejšnjega poglavja sodeč pa se k izglasju na $-(u) h$ pogosteje dodaja priponsko obrazilo -inja (osem primerov ali $53 \%$ ).

\section{magnatinja < magnatka}

V SSKJ 1 je mogoče zaslediti le obliko magnatka kot 'žensko obliko od magnata'. Le-ta je po SSKJ 2 razložena kot 'zelo bogata in vplivna ženska', označena pa je s kvalifikatorjem nav. ekspr. Za razliko od obeh $S S K J$ pa v $S P$ najdemo le obliko magnatinja kot feminativno podiztočnico k magnatu. Kot enakovredna domača vzporednica $\mathrm{k}$ prevzeti besedi pa je navedena mogočnica. Pojavitve v korpusu Gigafida so skromne: magnatko potrjuje sedem konkordanc, magnatinjo pa štiri. Preverili smo še po Novi besedi (magnatka 3, magnatinja 0 zadetkov), Kresu (magnatka 0, magnatinja 1 zadetek) in Googlu (magnatka 40, magnatinja 22 zadetkov). K izglasjem na -(a)t pogosteje dodajamo priponsko obrazilo $-k a$ (80 $\%)$, kar potrjuje naša analiza.

\section{nevropatinja $<$ nevropatka}

SSKJ 1 vsebuje le obliko nevropatka s pomensko razlago 'ženska oblika od nevropat'. V drugi izdaji slovarja je beseda označena s kvalifikatorjem med. in pomeni 'žensko, ki ima bolezen perifernega živčevja'. SP kot feminativ k 
nevropatu navaja samo nevropatinjo s kvalifikatorjem zdrav. Korpus Gigafida pa za nobeno od navedenih variant ne ponuja pojavitev (tudi ne Nova beseda in Kres; po Googlu pa za nevropatko 12, za nevropatinjo 11 zadetkov). Če upoštevamo sintezo obrazilne produktivnosti, je ustreznejša varianta nevropatka.

\section{nomadinja $<$ nomadka}

Nobena od obeh možnosti ni navedena v SSKJ 1, zato pa nomadko najdemo v drugi izdaji slovarja in v SNBSJ v pomenu 'pripadnica ljudstva, ki se seli iz kraja v kraj' s podpomenom 'ženska, ki pogosto potuje, se seli iz kraja v kraj'. Tudi $S P$ navaja samo to varianto kot feminativno podiztočnico $\mathrm{k}$ nomadu, obliko nomadinja pa najdemo v NSL. Korpusni rezultati kažejo, da je v rabi pogostejša oblika nomadka s 54 konkordancami, medtem ko jih Gigafida za nomadinjo izpiše le šest. Glede na sintezo obrazilne produktivnosti pa sta obrazili - $k a$ in -inja ob izglasjih podstav na - $d$ izenačeni; obe namreč potrjuje po osem primerov.

\section{patriotinja < patriotka}

Patriotka je po obeh SSKJ 'ženska, ki ljubi domovino; rodoljubka, domoljubka', patriotinja pa 'patriotka'. Nobena od variant ni slogovno zaznamovana. Obe možnosti beleži tudi $S P$, a kot nevtralnejši varianti pri obeh navaja rodoljubko in domoljubko. Po korpusu Gigafida pa prevladuje varianta patriotka s 34 konkordancami (za patriotinjo korpus ponuja le štiri zadetke). Po naši analizi sta ob izglasju moškospolskega obrazila na $-(o) t$ enakovredno zastopani obe obrazili; vsako je potrjeno samo s po enim primerom.

\section{potepuhinja > potepuška}

SSKJ 1 razlaga potepuško in potepuhinjo kot 'žensko obliko od potepuha', v drugi izdaji slovarja pa je pomenska razlaga pri obeh že natančnejša, tj. 'ženska, ki hodi iz kraja v kraj in je brez zaposlitve' s podpomenom ekspr. 'ženska, ki se (rada) potepa'. Tudi v SP najdemo obe varianti, le da je potepuška označena kot redka, potepuhinja pa kot nevtralnejša. Razmerje po korpusu pa je sledeče: potepuhinja 22 konkordanc, potepuška 0 konkordanc (iskalne pogoje smo pri slednji zaradi enake pridevniške oblike morali prilagoditi na občno ime, samostalnik ženskega 
spola, živost). K izglasju obrazila na $-(u) h$ kot dodajalno pogosteje nastopa feminativno obrazilo -inja (osem tvorjenk oz. $53 \%$ ).

psihopatinja < psihopatka

Psihopatka je v SSKJ 1 razložena kot 'ženska oblika od psihopat', psihopatinja pa kot 'psihopatka'. Nobena od variant ni označena kot stilno zaznamovana. Po SSKJ 2 je psihopatka nav. ekspr. 'značajsko, osebnostno neuravnovešena ženska', psihopatinja pa znova samo 'psihopatka'. Obe varianti kot slogovno nezaznamovani feminativni podiztočnici k psihopatu navaja tudi SP. Po korpusu Gigafida pa je pogostejša psihopatka s 53 pojavitvami (za psihopatinjo le 13). K izglasjem podstav na $-t$ se pogosteje dodaja ženskospolsko obrazilo $-k a$, če upoštevamo sintezo obrazilne produktivnosti.

\section{regentinja < regentka}

Regentka in regentinja $\mathrm{v}$ SSKJ 1 nastopata s pomensko razlago 'ženska oblika od regent', nobena varianta pa ni slogovno zaznamovana. V drugi izdaji slovarja je pomenska razlaga naslednja: v monarhističnih državah 'ženska, ki ima začasno funkcije, naloge vladarja, ki zaradi mladoletnosti, bolezni ne more vladati'. SP kot feminativ k regentu navaja samo regentinjo, a kot nevtralnejšo možnost ponudi neprevzeto namestnico. Po korpusu Gigafida pa je pogostejša regentka, ki jo potrjuje 44 pojavitev, medtem ko jih je za regentinjo 15 . Ugotovili smo, da kot dodajalno feminativno obrazilo $\mathrm{k}$ izglasju na -(en)t pogosteje nastopa priponsko obrazilo $-k a$ (22 primerov ali $92 \%)$.

\section{rivalinja $<$ rivalka}

V SSKJ 1 je mogoče najti le rivalinjo s kvalifikatorjem knjiž. in s pomensko razlago 'tekmica'. SSKJ 2 poleg navedenega ponudi tudi rivalko $\mathrm{v}$ enakem pomenu, a brez kvalifikatorja. V SP je kot feminativ od rivala zabeležena samo rivalka, ob njej pa je kot nevtralnejša možnost ponujena tekmica. Rivalka je s 105 konkordancami pogostejša po korpusu Gigafida; rivalinjo namreč potrjujeta le dve konkordanci. Glede na sintezo obrazilne produktivnosti ne moremo določiti ustreznejše variante, saj sta obrazili ob tem izglasju izenačeni. 


\section{scenografinja < scenografka}

SSKJ 1 vsebuje le scenografko $\mathrm{v}$ pomenu 'ženska, ki se (poklicno) ukvarja s scenografijo'. Druga izdaja slovarja ponudi tudi varianto scenografinja z enakim pomenom. V SP je zabeležena samo scenografka kot ženskospolska vzporednica k scenografu. Slednja pa prevladuje tudi v korpusnem gradivu, saj jo potrjuje 748 konkordanc, scenografinjo pa 344 po Gigafidi. Tudi pri tem primeru, ko gre za dodajanje k izglasju na - $f$, je po pričujoči analizi pogostejše obrazilo -inja.

\section{skavtinja > skavtka}

Skavtinja je po SSKJ 1 v nekaterih deželah 'članica mladinske organizacije, gibanja, ki si prizadeva oblikovati zdravo, iznajdljivo osebnost zlasti z življenjem v naravi', skavtka pa je zabeležena s pomensko razlago redko 'skavtinja'. Enako je v drugi izdaji slovarja, le da sta obe razlagi brez že navedenih kvalifikatorjev. Obe varianti navaja tudi $S P$, le da kot nevtralnejšo izpostavi skavtinjo. Le-ta je pogostejša tudi glede na rezultate korpusne analize, saj je potrjena s 749 konkordancami, skavtka pa le s 13 . K izglasjem podstav na -t pa se pogosteje dodaja obrazilo -ka, kot kaže sinteza obrazilne produktivnosti.

\section{stenografinja $<$ stenografka}

Stenografka je v obeh izdajah SSKJ razložena kot 'ženska, ki poklicno stenografira', stenografinja pa kot 'stenografka'. SP kot feminativno vzporednico k stenografu ponudi le stenografko, slednja pa z 42 konkordancami prevladuje tudi v korpusu Gigafida (za stenografinjo le dvanajst pojavitev). Sinteza obrazilne produktivnosti pa kaže, da se k izglasjem podstav na $-f$ nekoliko pogosteje dodaja feminativno obrazilo -inja.

\section{tragedinja > tragedka}

Obe varianti navaja že SSKJ 1: tragedinjo kot gled. 'igralko, ki igra glavne ženske vloge v tragedijah', tragedko pa kot gled. 'tragedinjo'. Enako je v drugi izdaji slovarja, SP pa ne ponuja nobene od navedenih možnosti. Rezultati korpusne analize dajejo prednost tragedinji z 42 pojavitvami, medtem ko za tragedko 
korpus ne najde nobene konkordance. Po analizi iz prejšnjega poglavja ne moremo določiti ustreznejše možnosti, saj sta obrazili $-k a$ in -inja ob izglasjih podstav na - $d$ izenačeni (vsako potrjuje po osem primerov).

\section{turistinja $<$ turistka}

SSKJ 1 razlaga turistko kot 'žensko obliko od turist', turistinjo pa kot 'turistko', označeno s kvalifikatorjem star. V SSKJ 2 je turistka 'ženska, ki potuje, začasno spremeni kraj bivanja zaradi oddiha, razvedrila', slovarski sestavek pri geslu turistinja pa je enak kot v prvi izdaji. $S P$ kot feminativno podiztočnico od turista vsebuje le turistko, le-ta pa s 1458 pojavitvami prevladuje po pogostnosti v korpusu Gigafida (za turistinjo korpus ponudi le en zadetek). K izglasjem na -(is)t se tudi sicer veliko pogosteje dodaja feminativno obrazilo - $k a$, kar potrjuje 137 primerov (98\%) iz štirih jezikovnih virov.

Tudi analizo te skupine parov smo glede na zastopanost $\mathrm{v}$ jezikovnih priročnikih, pomen, kvalifikatorje in korpuse prikazali v preglednici. 
Preglednica 68: Variantni priponski obrazili -inja in -ka

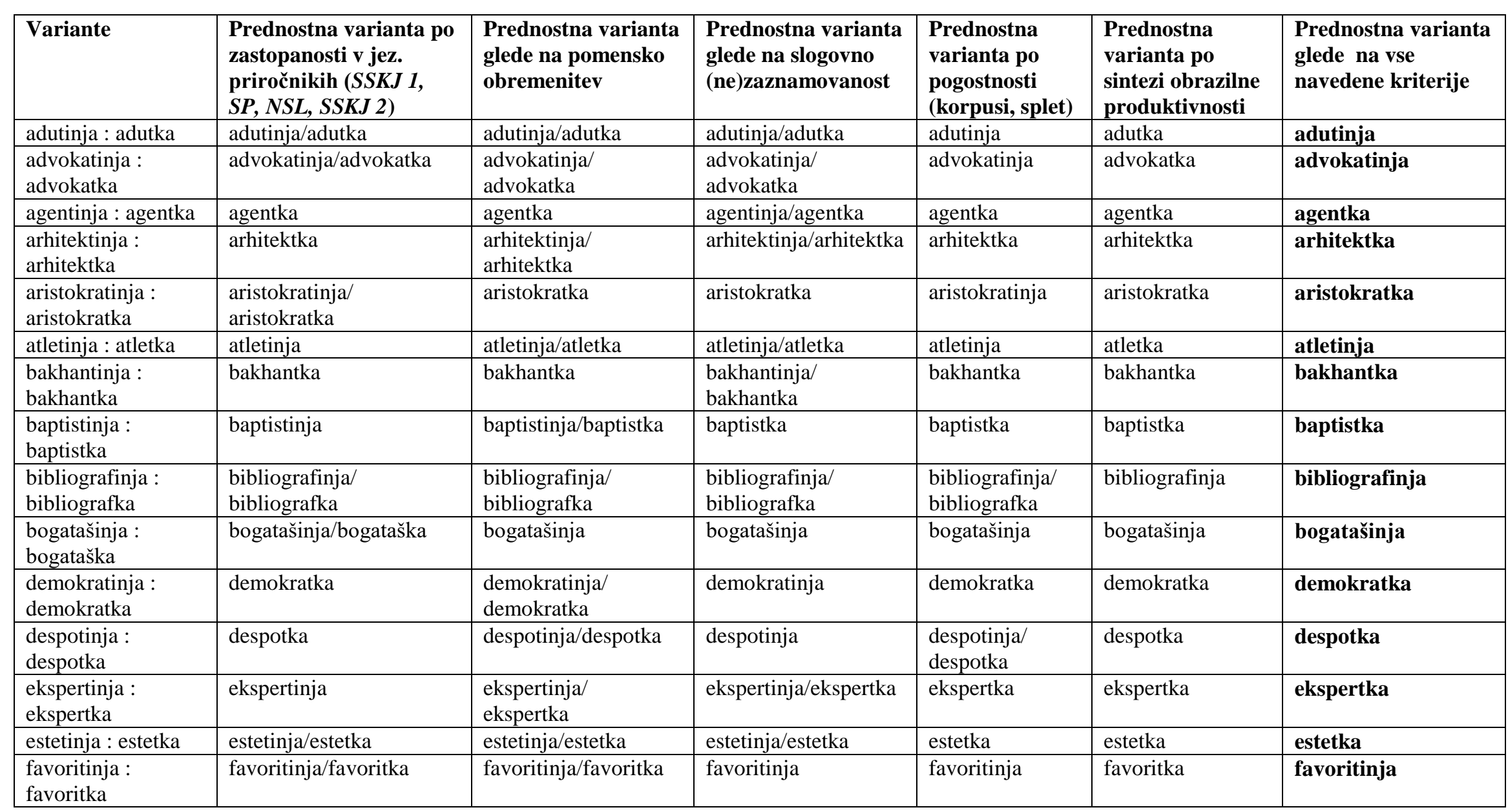




\begin{tabular}{|c|c|c|c|c|c|c|}
\hline Variante & $\begin{array}{l}\text { Prednostna varianta po } \\
\text { zastopanosti v jez. } \\
\text { priročnikih }(S S K J 1 \text {, } \\
S P, N S L, S S K J \text { 2) }\end{array}$ & $\begin{array}{l}\text { Prednostna varianta } \\
\text { glede na pomensko } \\
\text { obremenitev }\end{array}$ & $\begin{array}{l}\text { Prednostna varianta } \\
\text { glede na slogovno } \\
\text { (ne)zaznamovanost }\end{array}$ & $\begin{array}{l}\text { Prednostna } \\
\text { varianta po } \\
\text { pogostnosti } \\
\text { (korpusi, splet) }\end{array}$ & $\begin{array}{l}\text { Prednostna } \\
\text { varianta po } \\
\text { sintezi obrazilne } \\
\text { produktivnosti }\end{array}$ & $\begin{array}{l}\text { Prednostna varianta } \\
\text { glede na vse } \\
\text { navedene kriterije }\end{array}$ \\
\hline $\begin{array}{l}\text { filozofinja : } \\
\text { filozofka }\end{array}$ & filozofinja & filozofinja & filozofinja/filozofka & filozofinja & filozofinja & filozofinja \\
\hline $\begin{array}{l}\text { fotografinja : } \\
\text { fotografka }\end{array}$ & fotografinja/fotografka & $\begin{array}{l}\text { fotografinja/ } \\
\text { fotografka }\end{array}$ & $\begin{array}{l}\text { fotografinja/ } \\
\text { fotografka }\end{array}$ & fotografinja & fotografinja & fotografinja \\
\hline $\begin{array}{l}\text { geodetinja : } \\
\text { geodetka }\end{array}$ & geodetka & geodetinja/geodetka & geodetinja/geodetka & $\begin{array}{l}\text { geodetinja/ } \\
\text { geodetka }\end{array}$ & geodetka & geodetka \\
\hline $\begin{array}{l}\text { geografinja: } \\
\text { geografka }\end{array}$ & geografinja/geografka & $\begin{array}{l}\text { geografinja/ } \\
\text { geografka }\end{array}$ & $\begin{array}{l}\text { geografinja/ } \\
\text { geografka }\end{array}$ & geografinja & geografinja & geografinja \\
\hline herojinja : herojka & herojinja & herojinja/herojka & herojinja/herojka & herojinja & herojka & herojinja \\
\hline $\begin{array}{l}\text { homeopatinja: } \\
\text { homeopatka }\end{array}$ & homeopatinja & $\begin{array}{l}\text { homeopatinja/ } \\
\text { homeopatka }\end{array}$ & $\begin{array}{l}\text { homeopatinja/ } \\
\text { homeopatka }\end{array}$ & homeopatinja & homeopatka & homeopatinja \\
\hline $\begin{array}{l}\text { interpretinja: } \\
\text { interpretka }\end{array}$ & interpretka & interpretka & $\begin{array}{l}\text { interpretinja/ } \\
\text { interpretka }\end{array}$ & interpretka & interpretka & interpretka \\
\hline kadetinja : kadetka & kadetka & kadetinja/kadetka & kadetinja/kadetka & kadetinja & kadetka & kadetka \\
\hline $\begin{array}{l}\text { kandidatinja: } \\
\text { kandidatka }\end{array}$ & kandidatinja/kandidatka & kandidatka & kandidatka & kandidatka & kandidatka & kandidatka \\
\hline $\begin{array}{l}\text { koreografinja: } \\
\text { koreografka }\end{array}$ & koreografinja & koreografka & $\begin{array}{l}\text { koreografinja/ } \\
\text { koreografka }\end{array}$ & koreografinja & koreografinja & koreografinja \\
\hline $\begin{array}{l}\text { kostumografinja : } \\
\text { kostumografka }\end{array}$ & $\begin{array}{l}\text { kostumografinja/ } \\
\text { kostumografka }\end{array}$ & kostumografka & $\begin{array}{l}\text { kostumografinja/ } \\
\text { kostumografka }\end{array}$ & kostumografka & kostumografinja & kostumografka \\
\hline lenuhinja: lenuška & lenuhinja & lenuhinja/lenuška & lenuhinja/lenuška & lenuhinja & lenuhinja & lenuhinja \\
\hline $\begin{array}{l}\text { magnatinja: } \\
\text { magnatka }\end{array}$ & magnatinja/magnatka & $\begin{array}{l}\text { magnatinja/ } \\
\text { magnatka }\end{array}$ & $\begin{array}{l}\text { magnatinja/ } \\
\text { magnatka }\end{array}$ & magnatka & magnatka & magnatka \\
\hline $\begin{array}{l}\text { nevropatinja : } \\
\text { nevropatka }\end{array}$ & nevropatinja/nevropatka & $\begin{array}{l}\text { nevropatinja/ } \\
\text { nevropatka }\end{array}$ & $\begin{array}{l}\text { nevropatinja/ } \\
\text { nevropatka }\end{array}$ & $\begin{array}{l}\text { nevropatinja/ } \\
\text { nevropatka }\end{array}$ & nevropatka & nevropatinja \\
\hline $\begin{array}{l}\text { nomadinja : } \\
\text { nomadka }\end{array}$ & nomadka & nomadinja/nomadka & nomadinja/nomadka & nomadka & nomadka & nomadka \\
\hline $\begin{array}{l}\text { patriotinja : } \\
\text { patriotka }\end{array}$ & patriotinja/patriotka & patriotka & patriotinja/patriotka & patriotka & patriotinja & patriotka \\
\hline
\end{tabular}




\begin{tabular}{|c|c|c|c|c|c|c|}
\hline Variante & $\begin{array}{l}\text { Prednostna varianta po } \\
\text { zastopanosti v jez. } \\
\text { priročnikih }(S S K J 1, \\
S P, N S L, S S K J 2)\end{array}$ & $\begin{array}{l}\text { Prednostna varianta } \\
\text { glede na pomensko } \\
\text { obremenitev }\end{array}$ & $\begin{array}{l}\text { Prednostna varianta } \\
\text { glede na slogovno } \\
\text { (ne)zaznamovanost }\end{array}$ & $\begin{array}{l}\text { Prednostna } \\
\text { varianta po } \\
\text { pogostnosti } \\
\text { (korpusi, splet) }\end{array}$ & $\begin{array}{l}\text { Prednostna } \\
\text { varianta po } \\
\text { sintezi obrazilne } \\
\text { produktivnosti }\end{array}$ & $\begin{array}{l}\text { Prednostna varianta } \\
\text { glede na vse } \\
\text { navedene kriterije }\end{array}$ \\
\hline $\begin{array}{l}\text { potepuhinja : } \\
\text { potepuška }\end{array}$ & potepuhinja/potepuška & $\begin{array}{l}\text { potepuhinja/ } \\
\text { potepuška }\end{array}$ & potepuhinja & potepuhinja & potepuhinja & potepuhinja \\
\hline $\begin{array}{l}\text { psihopatinja: } \\
\text { psihopatka }\end{array}$ & psihopatinja/psihopatka & psihopatka & $\begin{array}{l}\text { psihopatinja/ } \\
\text { psihopatka }\end{array}$ & psihopatka & psihopatka & psihopatka \\
\hline $\begin{array}{l}\text { regentinja: } \\
\text { regentka }\end{array}$ & regentinja & regentinja/regentka & regentinja/regentka & regentka & regentka & regentinja \\
\hline rivalinja : rivalka & rivalinja/rivalka & rivalinja/rivalka & rivalinja/rivalka & rivalka & rivalinja/rivalka & rivalka \\
\hline $\begin{array}{l}\text { scenografinja: } \\
\text { scenografka }\end{array}$ & scenografka & $\begin{array}{l}\text { scenografinja/ } \\
\text { scenografka }\end{array}$ & $\begin{array}{l}\text { scenografinja/ } \\
\text { scenografka }\end{array}$ & scenografka & scenografinja & scenografka \\
\hline skavtinja : skavtka & skavtinja/skavtka & skavtinja & skavtinja & skavtinja & skavtka & skavtinja \\
\hline $\begin{array}{l}\text { stenografinja: } \\
\text { stenografka }\end{array}$ & stenografka & stenografka & $\begin{array}{l}\text { stenografinja/ } \\
\text { stenografka }\end{array}$ & stenografka & stenografinja & stenografka \\
\hline $\begin{array}{l}\text { tragedinja: } \\
\text { tragedka }\end{array}$ & tragedinja/tragedka & tragedinja & tragedinja/tragedka & tragedinja & $\begin{array}{l}\text { tragedinja/ } \\
\text { tragedka }\end{array}$ & tragedinja \\
\hline
\end{tabular}


Analizirali smo 40 parov. Ugotavljamo, da se priponski obrazili $-k a$ in -inja kot variantni dodajata $\mathrm{k}$ izglasjem (podstave ali obrazila) na:

- -d (nomadka - nomadinja; tragedka - tragedinja);

- -f (bibliografka - bibliografinja, geografka - geografinja, filozofka filozofinja, fotografka - fotografinja, koreografka - koreografinja, kostumografka - kostumografinja, scenografka - scenografinja, stenografka - stenografinja);

- -h (-uh: lenuška - lenuhinja, potepuška - potepuhinja);

- $\quad-j$ (herojka-herojinja);

- $\quad$-l (-al: rivalka - rivalinja);

- - -̌ (-ǎs: bogataška - bogatašinja);

- -t (izglasje podstave: advokatka - advokatinja, adutka - adutinja, atletka - atletinja, despotka - despotinja, estetka - estetinja, homeopatka homeopatinja, interpretka - interpretinja, kadetka - kadetinja, nevropatka - nevropatinja, psihopatka - psihopatinja, skavtka - skavtinja; -(a)t: aristokratka - aristokratinja, demokratka - demokratinja, kandidatka kandidatinja, magnatka - magnatinja; -(e)t: geodetka - geodetinja; -(i)t: favoritka - favoritinja; -(an)t: bakhantka - bakhantinja; -(en)t: agentka agentinja, regentka - regentinja; -(o)t: patriotka - patriotinja; -(is)t: baptistka - baptistinja, turistka - turistinja).

\subsubsection{Variantni priponski obrazili -ical-inja}

asica $>$ asinja

SSKJ 1, SSKJ 2 in SP ne navajajo nobene od teh dveh variant. Asico zasledimo v že omenjenem diplomskem delu Novotvorjenke za poimenovanje oseb, asinjo pa v Novejši slovenski leksiki. Rezultati korpusne analize pa kažejo na pogostejšo rabo asice, ki jo potrjujejo z 18 pojavitvami, medtem ko jih je za asinjo le osem. Gre za dodajanje feminativnih obrazil $\mathrm{k}$ netvorjenki $\mathrm{z}$ izglasjem podstave na $-s$, ob katerem sta obe obrazili izenačeni (vsako 50 \%).

\section{božica $<$ boginja}


Boginja je po obeh SSKJ večpomenka: 1. v mnogoboštvu 'žensko božansko bitje'; 2. zastar. 'zelo občudovana, oboževana ženska'; 3. star. 'ženska, ki prerokuje, vedežuje'. Beseda božica pa je po SSKJ 1 in 2 enakozvočnica: star., v mnogoboštvu 'žensko božansko bitje; boginja' in redko 'ubožica, revica'. V SP je kot ženskospolska oblika k bogu navedena le boginja, božica pa je navedena kot samostojna slovarska iztočnica, označena je s kvalifikatorjem star. in preusmerja k nevtralnejši varianti, tj. k boginji. Slednja je pogostejša tudi po korpusu Gigafida, potrjuje jo namreč 9515 pojavitev, božico pa le 329 (pri čemer korpus izpiše tudi lastnoimenske konkordance). Tudi $\mathrm{v}$ tem primeru gre za dodajanje priponskih obrazil -ica in -inja $\mathrm{k}$ netvorjenki z izglasjem podstave na $-g$. To je edini primer tovrstne tvorbe, zato težko rečemo, katero feminativno obrazilo bi bilo ustreznejše (sicer je ob izglasjih podstav na - $g$ mnogo pogostejše obrazilo -inja z $92 \%$ ).

\section{carica $>$ carinja}

Po SSKJ 1 in SSKJ 2 je carica 1. v nekaterih slovanskih državah, nekdaj 'vladarica'; 2. 'carjeva žena'. Carinja je označena s kvalifikatorjem zastar. s pomensko razlago 'carica'. Obe varianti kot feminativni podiztočnici k carju navaja tudi $S P$, vendar carinjo označuje kot zastarelo in daje prednost nevtralnejši carici. Slednja prednjači tudi v rezultatih korpusne analize s 1363 pojavitvami, medtem ko za carinjo Gigafida izpiše le eno konkordanco. Gre za dodajanje ženskospolskih obrazil $\mathrm{k}$ netvorjenki, tokrat $\mathrm{s}$ podstavo $\mathrm{z}$ izglasjem na $-r$; ob slednjem pogosteje nastopa feminativno obrazilo -ica (potrjeno s 17 primeri ali 39 $\%, \mathrm{z}$-inja le štirje feminativi).

\section{goljufica $<$ goljufinja}

Goljufica je po obeh izdajah SSKJ razložena kot 'ženska, ki goljufa', medtem ko goljufinja ni zabeležena $\mathrm{v}$ nobeni izdaji. Obe varianti navaja samo SP kot ženskospolski vzporednici h goljufu, pri čemer nobena od njiju ni slogovno zaznamovana. Po korpusu Gigafida pa je pogostejša varianta goljufinja z 51 konkordancami, medtem ko goljufico potrjujeta le dve pojavitvi. Glede na sintezo obrazilne produktivnosti je ob izglasjih podstave na $-f$ pogostejše obrazilo -inja, kar potrjuje 11 konkretnih primerov ali $46 \%$ (za -ica le trije). 


\section{grofica > grofinja}

Po SSKJ 1 beseda grofica nastopa kot večpomenka: 1. v nekaterih deželah 'plemkinja, za stopnjo nižja od kneginje'; 2. 'grofova žena'. V SSKJ 2 je enako, le da prvi pomen nima več prostorske oznake. Pomenska razlaga grofinje je po obeh izdajah 'grofova žena; grofica'. Obe varianti kot feminativa h grofu navaja tudi $S P$, vendar grofinjo označuje kot redko, grofico pa kot nevtralnejšo varianto. Kot pogostejšo pa jo prikaže tudi korpus Gigafida, saj zanjo ponudi 2795 pojavitev, medtem ko jih je za grofinjo le 16. Tudi v tem primeru gre za dodajanje feminativnih obrazil k izglasju podstave na $-f$, h kateremu pa pogosteje nastopa obrazilo -inja $(46 \%)$.

\section{opatica $<$ opatinja}

Beseda opatinja je po SSKJ 1 in 2 označena s kvalifikatorjem rel. in pomeni 'predstojnico večjega samostana, zlasti benediktinskega, cistercijanskega'. Pomenska razlaga pri slovarski iztočnici opatica je 'opatinja', prav tako označena z že omenjenim kvalifikatorjem. SP pa k opatu kot 'predstojniku večjega samostana' navaja samo eno ženskospolsko vzporednico, opatinjo, prednost slednji pa daje tudi Gigafida, saj jo potrjuje s 175 konkordancami, opatico pa z le enajstimi. Tokrat obrazili -ica in -inja nastopita kot dodajalni k izglasju podstave na $-t$; sinteza obrazilne produktivnosti pa je pokazala, da se $\mathrm{k}$ temu izglasju pogosteje dodaja feminativno obrazilo -inja (12 primerov ali $25 \%$; z -ica le pet primerov oz. $10 \%)$.

\section{pajdašica > pajdašinja}

SSKJ 1 kot 'žensko obliko od pajdaša' navaja samo pajdašico. SSKJ 2 slednjo označuje kot slabšalno in jo razlaga kot 'žensko, ki s kom sodeluje, zlasti pri nepoštenih dejanjih'. Varianto pajdašinja najdemo le v SP kot feminativ k pajdašu (oboje označeno kot slabšalno), zato v njem ni pajdašice. Po korpusu Gigafida pa je razmerje naslednje: pajdašica 42 konkordanc, pajdašinja 24 konkordanc. $\mathrm{Ob}$ moškospolskem izglasju podstave na $-\check{s}$ pa se, glede na sintezo obrazilne produktivnosti, pogosteje dodaja obrazilo -ica. 


\section{pešačica < pešakinja}

V obeh izdajah SSKJ zasledimo obe varianti. Pešakinja v obeh pomeni 'žensko, ki hodi peš', pomenska razlaga pri pešačici pa je samo 'pešakinja'; beseda je zaznamovana kot redka (SSKJ 2 zastar. 'peška'). SP navaja samo pešakinjo kot feminativ k pešaku, a označeno s kvalifikatorjem pešaj., kot nevtralnejšo varianto pa izpostavi peško. Po korpusu Gigafida je pogostejša pešakinja s 146 konkordancami, medtem ko za pešačico ne ponudi nobene pojavitve. K izglasju podstave na $-k$ pa po sintezi obrazilne produktivnosti kot dodajalno obrazilo pogosteje nastopa -inja (39\%).

\section{svatica $<$ svatinja}

Svatica je v obeh izdajah SSKJ označena s kvalifikatorjem star. in nastopa v pomenu 'družica'; svatinje prva izdaja slovarja ne navaja, jo pa zato najdemo v drugi izdaji kot 'žensko, ki se udeleži praznovanja ob poroki' in v SP kot edino podiztočnico k svatu. Pogostejša pa je tudi glede na izsledke Gigafide, saj jo potrjuje 22 konkordanc, svatico pa le tri. Gre za dodajanje k netvorjenki z izglasjem podstave na $-t$; če se oziramo na sintezo obrazilne produktivnosti, ugotovimo, da pri izglasjih na -t pogosteje nastopa priponsko obrazilo -inja.

\section{šefica $<$ šefinja}

Šefinja je po SSKJ 1 razložena kot 'ženska oblika od šef' (po drugi izdaji slovarja 'ženska, ki vodi delo kake delovne enote' s podpomenom 'ženska, ki vodi kako skupino s posebno nalogo'), šefica pa je označena kot žargonska beseda (po SSKJ 2 kot pogovorna), njena pomenska razlaga pa je 'šefinja'. Obe varianti najdemo tudi v SP kot ženskospolski podiztočnici k šefu, vendar je šefica označena s kvalifikatorjem žarg., šefinja pa je prikazana kot nevtralnejša. Glede na zapisano ne preseneča, da kot tako zaznamovana po korpusu Gigafida prevladuje šefica z 2937 konkordancami, a šefinja ne zaostaja veliko; potrjuje jo namreč 2697. Glede na to, da gre za dodajanje $\mathrm{k}$ izglasju podstave na $-f$, je $\mathrm{k}$ le-temu pogostejše dodajanje feminativnega obrazila -inja. 
Ponovno smo opazovali zastopanost obeh variant v jezikovnih priročnikih, njun pomen, kvalifikatorje, ki ju opredeljujejo, in pojavnost po korpusu. Spodnja preglednica prikazuje rezultate.

Preglednica 69: Variantni priponski obrazili -ica in -inja

\begin{tabular}{|c|c|c|c|c|c|c|}
\hline Variante & $\begin{array}{l}\text { Prednostna varianta po } \\
\text { zastopanosti v jez. } \\
\text { priročnikih (SSKJ 1, SP, } \\
N S L, S S K J \text { 2) }\end{array}$ & $\begin{array}{l}\text { Prednostna varianta } \\
\text { glede na pomensko } \\
\text { obremenitev }\end{array}$ & $\begin{array}{l}\text { Prednostna varianta } \\
\text { glede na slogovno } \\
\text { (ne)zaznamovanost }\end{array}$ & $\begin{array}{l}\text { Prednostna } \\
\text { varianta po } \\
\text { pogostnosti } \\
\text { (korpusi, splet) }\end{array}$ & $\begin{array}{l}\text { Prednostna } \\
\text { varianta po sintezi } \\
\text { obrazilne } \\
\text { produktivnosti }\end{array}$ & $\begin{array}{l}\text { Prednostna varianta } \\
\text { glede na vse } \\
\text { navedene kriterije }\end{array}$ \\
\hline asica : asinja & asica/asinja & asica/asinja & asica/asinja & asica & asinja/asica & asica \\
\hline $\begin{array}{l}\text { božica: } \\
\text { boginja }\end{array}$ & božica/boginja & boginja & boginja & boginja & božica/boginja & boginja \\
\hline $\begin{array}{l}\text { carica: } \\
\text { carinja }\end{array}$ & carica/carinja & carica & carica & carica & carica & carica \\
\hline $\begin{array}{l}\text { goljufica: } \\
\text { goljufinja }\end{array}$ & goljufica & goljufica/goljufinja & goljufica/goljufinja & goljufinja & goljufinja & goljufinja \\
\hline $\begin{array}{l}\text { grofica : } \\
\text { grofinja }\end{array}$ & grofica/grofinja & grofica & grofica & grofica & grofinja & grofica \\
\hline $\begin{array}{l}\text { opatica: } \\
\text { opatinja }\end{array}$ & opatinja & opatinja & opatica/opatinja & opatinja & opatinja & opatinja \\
\hline $\begin{array}{l}\text { pajdašica: } \\
\text { pajdašinja }\end{array}$ & pajdašica/pajdašinja & pajdašica/pajdašinja & pajdašica/pajdašinja & pajdašica & pajdašinja & pajdašica \\
\hline $\begin{array}{l}\text { pešačica : } \\
\text { pešakinja }\end{array}$ & pešakinja & pešakinja & pešakinja & pešakinja & pešakinja & pešakinja \\
\hline $\begin{array}{l}\text { svatica: } \\
\text { svatinja }\end{array}$ & svatica/svatinja & svatica/svatinja & svatinja & svatinja & svatinja & svatinja \\
\hline $\begin{array}{l}\text { šefica : } \\
\text { šefinja }\end{array}$ & šefica/šefinja & šefinja & šefinja & šefica & šefinja & šefinja \\
\hline
\end{tabular}


V analizo smo vključili 10 parov. Ugotavljamo, da se priponski obrazili -ica in -inja kot variantni dodajata $\mathrm{v}$ glavnem netvorjenkam (asica - asinja, božica - boginja, carica - carinja, goljufica - goljufinja, grofica - grofinja, opatica - opatinja, pajdašica - pajdašinja, pešačica - pešakinja, svatica svatinja, šefica - šefinja).

\subsubsection{Variantni priponski obrazili -ical-(ov)ka}

\section{mojstrica > mojstrovka}

Mojstrica v SSKJ 1 nastopa kot večpomenka: 'ženska oblika od mojster' ali kot star. 'mojstrova žena'. Pomenska razlaga pri slovarskem geslu mojstrovka pa ima oznako redko in preusmerja k mojstrici. V SSKJ 2 ima iztočnica mojstrica poleg že navedenih pomenov terminološko gnezdo: glasb. koncertna mojstrica 'vodja violinistov v orkestru'; rad. tonska mojstrica 'ženska, ki pri posnemanju zvoka skrbi, da je zvočni zapis odraz naravnega zvočnega dogajanja'; šah. mednarodna mojstrica 'naslov igralke, za stopnjo nižji od velemojstrice'. Mojstrovka pa v novejši izdaji slovarja ni zaznamovana kot redka varianta, ampak kot zastarela. $S P$ navaja samo izraz mojstrica kot ženskospolsko obliko $\mathrm{k}$ mojstru, po korpusu Gigafida pa je pogostejša varianta mojstrica, kar je zagotovo posledica večpomenskosti (3886 konkordanc; za mojstrovko 748). Po sintezi obrazilne produktivnosti se priponsko obrazilo -ica pogosto dodaja $\mathrm{k}$ izglasjem podstav na -r (17 primerov ali $39 \%)$, medtem ko -(ov)ka v tem položaju nastopi le enkrat.

\section{škratica $<$ škratovka}

Škratica in škratovka po obeh izdajah SSKJ pomenita v pravljicah 'zelo majhni deklici podobno bitje, navadno nagajivo'. Obe varianti kot feminativni podiztočnici k škratu navaja tudi $S P$, pri čemer nobena od besed ni slogovno zaznamovana. Rezultati korpusne analize pa govorijo v prid škratovki, ki jo potrjujejo s 40 pojavitvami, medtem ko jih Gigafida za škratico izpiše le 17. K izglasjem podstav na $-t$ se po sintezi obrazilne produktivnosti pogosteje dodaja obrazilo -ica (pet primerov ali $10 \%, \mathrm{z}-(\mathrm{ov}) \mathrm{ka}$ le eden). 
Preglednica 70: Variantni priponski obrazili -ica in -(ov)ka

\begin{tabular}{|l|l|l|l|l|l|l|}
\hline Variante & $\begin{array}{l}\text { Prednostna } \\
\text { varianta po } \\
\text { zastopanosti v } \\
\text { jez. priročnikih } \\
(\text { SSKJ 1, SP, } \\
\text { NSL, SSKJ 2) }\end{array}$ & $\begin{array}{l}\text { Prednostna } \\
\text { varianta } \\
\text { glede na } \\
\text { pomensko } \\
\text { obremenitev }\end{array}$ & $\begin{array}{l}\text { Prednostna } \\
\text { varianta glede na } \\
\text { slogovno } \\
\text { (ne)zaznamova- } \\
\text { nost }\end{array}$ & $\begin{array}{l}\text { Prednostna } \\
\text { varianta po } \\
\text { pogostnosti } \\
\text { (korpusi, } \\
\text { splet) }\end{array}$ & $\begin{array}{l}\text { Prednostna } \\
\text { varianta po } \\
\text { sintezi } \\
\text { obrazilne } \\
\text { produktivnosti }\end{array}$ & $\begin{array}{l}\text { Prednostna } \\
\text { varianta } \\
\text { glede } \\
\text { navedene } \\
\text { kriterije }\end{array}$ \\
\hline $\begin{array}{l}\text { mojstrica : } \\
\text { mojstrovka }\end{array}$ & mojstrica & $\begin{array}{l}\text { mojstrica/ } \\
\text { mojstrovka }\end{array}$ & mojstrica & mojstrica & mojstrica & mojstrica \\
\hline $\begin{array}{l}\text { škratica : } \\
\text { škratovka }\end{array}$ & $\begin{array}{l}\text { škratica/ } \\
\text { škratovka }\end{array}$ & $\begin{array}{l}\text { škratica/ } \\
\text { škratovka }\end{array}$ & $\begin{array}{l}\text { škratica/ } \\
\text { skratovka }\end{array}$ & škratovka & škratica & škratovka \\
\hline
\end{tabular}

Zasledili smo le dva para feminativov. Pri enem gre za dodajanje priponskih obrazil -ica in -(ov)ka $\mathrm{k}$ izglasju podstave na $-r$ (mojstrica mojstrovka), pri drugem pa za izglasje podstave na -t (škratica - škratovka).

\subsubsection{Variantni priponski obrazili -a/-inja}

soseda > sosedinja

Obe izdaji SSKJ vsebujeta obe varianti. Soseda je tako po obeh nosilka več pomenov: 1. 'ženska, ki živi, prebiva blizu koga' s podpomenom 'ženska, ki je najbližje koga v kaki smeri'; 2. publ. 'sosednja država'. Sosedinja pa je označena kot zastarela, njena pomenska razlaga je zgolj 'soseda'. SP pa kot feminativno podiztočnico k sosedu navaja le sosedo. Ta je pogostejša tudi glede na rezultate korpusne analize, saj jo potrjuje kar 120.909 pojavitev, medtem ko Gigafida za sosedinjo ponudi le tri konkordance. Sinteza obrazilne produktivnosti pa kaže, da se k izglasjem podstav na - $d$ pogosteje dodaja obrazilo -inja, kar potrjuje osem primerov oz. $40 \%$ ( $\mathrm{z}-a$ le eden).

\section{debeluha $<$ debeluhinja}

Obe besedi po obeh izdajah SSKJ pomenita 'zelo debelo žensko', označeni pa sta kot slabšalni. Najdemo tudi primer debeluša, prav tako zaznamovan kot ekspresiven in v enakem pomenu, le da pride do glasovne premene. V SP sta prav tako navedeni obe varianti, ponovno zaznamovani kot slabšalni, a je debeluha redka, kot splošna pomenska uvrstitev pa je izpostavljena debeluhinja. Korpus Gigafida ob splošnem iskanju za iskalni pogoj debeluha izpiše 2178 konkordanc, vendar opažamo, da večinoma pomenijo osebo moškega spola v različnih sklonih. 
Zato smo iskanje omejili (občno ime, samostalnik ženskega spola, ednina, živost) in takoj zmanjšali število na realnejših 80 konkordanc, a še vedno so le-te večinoma označevale osebe moškega spola. Za debeluhinjo pa korpus ob enakih iskalnih pogojih ponudi 34 konkordanc. K izglasju na $-(u) h$ se sicer najpogosteje dodaja feminativno obrazilo -inja (osem primerov ali $53 \%$, za - $a$ le dva primera ali $13 \%)$.

Preglednica 71: Variantni priponski obrazili -a in -inja

\begin{tabular}{|c|c|c|c|c|c|c|}
\hline Variante & $\begin{array}{l}\text { Prednostna } \\
\text { varianta po } \\
\text { zastopanosti v } \\
\text { jez. priročnikih } \\
(S S K J 1, S P \text {, } \\
N S L, S S K J \text { 2) } \\
\end{array}$ & $\begin{array}{l}\text { Prednostna } \\
\text { varianta } \\
\text { glede na } \\
\text { pomensko } \\
\text { obremenitev }\end{array}$ & $\begin{array}{l}\text { Prednostna } \\
\text { varianta glede na } \\
\text { slogovno } \\
\text { (ne)zaznamova- } \\
\text { nost }\end{array}$ & $\begin{array}{l}\text { Prednostna } \\
\text { varianta po } \\
\text { pogostnosti } \\
\text { (korpusi, } \\
\text { splet) }\end{array}$ & $\begin{array}{l}\text { Prednostna } \\
\text { varianta po } \\
\text { sintezi } \\
\text { obrazilne } \\
\text { produktivnosti }\end{array}$ & $\begin{array}{l}\text { Prednostna } \\
\text { varianta } \\
\text { glede na vse } \\
\text { navedene } \\
\text { kriterije }\end{array}$ \\
\hline $\begin{array}{l}\text { soseda: } \\
\text { sosedinja }\end{array}$ & soseda & soseda & soseda & soseda & sosedinja & soseda \\
\hline $\begin{array}{l}\text { debeluha: } \\
\text { debeluhinja }\end{array}$ & $\begin{array}{l}\text { debeluha/ } \\
\text { debeluhinja }\end{array}$ & $\begin{array}{l}\text { debeluha/ } \\
\text { debeluhinja }\end{array}$ & debeluhinja & $\begin{array}{l}\text { debeluha/ } \\
\text { debeluhinja }\end{array}$ & debeluhinja & debeluhinja \\
\hline
\end{tabular}

Analizirali smo dva para feminativov: pri prvem se variantni priponski obrazili - $a$ in -inja dodajata izglasju podstave na $-d$ (soseda - sosedinja), pri drugem pa izglasju nosilca na -h (-uh: debeluha-debeluhinja).

\subsubsection{Variantni priponski obrazili -inja/-(ar)ka}

\section{akademikinja > akademičarka}

Obe navedeni varianti najdemo v obeh izdajah SSKJ. Akademičarka v prvi izdaji slovarja nastopa $\mathrm{v}$ pomenu 'študentka, visokošolka', vendar raba izraza $\mathrm{v}$ navedenem pomenu peša. Akademikinja pa je zabeležena kot 'ženska oblika od akademik'. Drugače je v SSKJ 2, kjer je akademičarka večpomenka: 1. 'članica najvišje znanstvene in umetniške ustanove'; 2. star. 'študentka, visokošolka'. Akademikinja pa je razložena zgolj s prvim od že navedenih pomenov. SP kot ženskospolsko vzporednico k akademiku navaja zgolj akademikinjo, hkrati pa opozori na prepovedano rabo akademkinje. Korpus Gigafida potrjuje akademičarko s 40 pojavitvami, akademikinjo pa z 79. Zanimale so nas tudi konkordance za po $S P$ prepovedano varianto akademkinja: teh je enajst. Pri sintezi 
obrazilne produktivnosti smo opazili, da se k izglasjem obrazila na -(i)k pogosteje dodaja priponsko obrazilo -(ar)ka (skoraj $90 \%$, za -inja le $11 \%$ ).

\section{fanatikinja < fanatičarka}

Nobena od izdaj SSKJ ne navaja nobene od navedenih variant. Fanatikinjo kot feminativno iztočnico k fanatiku ('nestrpno zavzet, prenapet človek') najdemo v $S P$ in v NSL. V slednji je navedena tudi fanatičarka, zasledimo pa jo lahko še v diplomskem delu Novotvorjenke za poimenovanje oseb. Korpus Gigafida pa daje prednost fanatičarki (14 konkordanc; za fanatikinjo le dve). Preverili smo še po Novi besedi (ni zadetkov za nobeno varianto), Kresu (zgolj ena konkordanca za fanatičarko) in Googlu (58 za fanatičarko, 15 za fanatikinjo). Ob moškospolskih izglasjih podstave na $-k$ nastopi priponsko obrazilo -(ar)ka v $46 \%$ primerov (z -inja nekaj manj, tj. 39 \%), če upoštevamo sintezo obrazilne produktivnosti.

Preglednica 72: Variantni priponski obrazili -inja in -(ar)ka

\begin{tabular}{|l|l|l|l|l|l|l|}
\hline Variante & $\begin{array}{l}\text { Prednostna } \\
\text { varianta po } \\
\text { zastopanosti v } \\
\text { jez. priročnikih } \\
\text { (SSKJ 1, SP, } \\
\text { NSL, SSKJ 2) }\end{array}$ & $\begin{array}{l}\text { Prednostna } \\
\text { varianta } \\
\text { glede na } \\
\text { pomensko } \\
\text { obremenitev }\end{array}$ & $\begin{array}{l}\text { Prednostna } \\
\text { varianta glede na } \\
\text { slogovno } \\
\text { (ne)zaznamova- } \\
\text { nost }\end{array}$ & $\begin{array}{l}\text { Prednostna } \\
\text { varianta po } \\
\text { pogostnosti } \\
\text { (korpusi, } \\
\text { splet) }\end{array}$ & $\begin{array}{l}\begin{array}{l}\text { Prednostna } \\
\text { varianta po } \\
\text { sintezi } \\
\text { obrazilne } \\
\text { produktivnosti }\end{array} \\
\text { varianta glede } \\
\text { na vse } \\
\text { navedene } \\
\text { kriterije }\end{array}$ \\
\hline $\begin{array}{l}\text { akademikinja : } \\
\text { akademičarka }\end{array}$ & akademikinja & akademikinja & $\begin{array}{l}\text { akademikinja/ } \\
\text { akademičarka }\end{array}$ & akademikinja & akademičarka & akademikinja \\
\hline $\begin{array}{l}\text { fanatikinja : } \\
\text { fanatičarka }\end{array}$ & $\begin{array}{l}\text { fanatičarka/ } \\
\text { fanatikinja }\end{array}$ & $\begin{array}{l}\text { fanatičarka/ } \\
\text { fanatikinja }\end{array}$ & $\begin{array}{l}\text { fanatikinja/ } \\
\text { fanatičarka }\end{array}$ & fanatičarka & fanatičarka & fanatičarka \\
\hline
\end{tabular}

Zasledili smo le dva para feminativov. Pri obeh se ob dodajanju priponskega obrazila -(ar)ka izglasni $-k$ palatalizira $\mathrm{v}-\check{c}$; pri obrazilu -inja se to ne zgodi. V obeh primerih torej gre za dodajanje variantnih obrazil -(ar)ka in -inja $\mathrm{k}$ izglasju na -k (-(i)k: akademičarka-akademikinja; - $k$ : fanatičarka-fanatikinja).

Dodatno pozornost smo namenili ženskospolskemu priponskemu obrazilu -(ar)ka. Ada Vidovič Muha namreč v članku Prvine družbene prepoznavnosti ženske prek poimenovalne tipologije njenih dejavnosti, lastnosti (1997: 71) opozarja, da slovenščina nima oblik *fizičar, *matematičar ipd., zato moramo za vzporedno poimenovanje žensk uvesti obrazilo -(ar)ka. Preverjali smo, ali v korpusih najdemo oblike tipa fizičar, matematičar. Zbrali smo 30 primerov $\mathrm{z}$ obrazilom -(ar)ka: analitičarka, finomehaničarka, elektromehaničarka, keramičarka, mehaničarka, biomehaničarka, 
avtomehaničarka, fizičarka, matematičarka, kemičarka, kozmetičarka, higieničarka, blagajničarka, komičarka, optičarka, kiropraktičarka, kritičarka, dramatičarka, ekonometričarka, dietetičarka, genetičarka, botaničarka, biokemičarka, biofizičarka, hidravličarka, energetičarka, fotogrametričarka, informatičarka, statističarka, geofizičarka. Korpusna analiza je $\mathrm{z} \quad 0$ konkordancami po korpusu Gigafida pokazala, da za 11 primerov $(36,6 \%)$ ne obstaja moškospolska oblika tipa *fizičar. To so primeri *finomehaničar, *geofizičar, *kiropraktičar, *energetičar, *fotogrametričar, *biofizičar, *biokemičar, *genetičar, *ekonometričar, *avtomehaničar, *biomehaničar. Te besede se praviloma končujejo na izglasje $-k$. Petnajst primerov ima deset ali manj konkordanc po korpusu Gigafida: komičar (12), kritičar (8), fizičar (10), analitičar (8), statističar (10), dietetičar (3), hidravličar (2), higieničar (5), matematičar (7), informatičar (1), dramatičar (1), optičar (1), botaničar (1), mehaničar (1), elektromehaničar (1). Do sto konkordanc sta dosegli obliki blagajničar (87) in kozmetičar (82). Največ konkordanc, kar 442, smo zasledili pri obliki keramičar. Ob tej analizi lahko sklenemo, da sicer oblike tipa fizičar $\mathrm{v}$ slovenščini res niso pogoste ali jih po korpusih celo sploh ni zaslediti, obstajajo pa primeri, ki kažejo, da raba takih besed tudi ni popolnoma zanemarljiva (npr. keramičar).

\subsubsection{Variantni priponski obrazili -cal-ka}

\section{zobarca $<$ zobarka}

SSKJ 1 in SSKJ 2 ne navajata nobene od variant. V SP je ob moškospolskem zobarju kot knjižno pogovornem izrazu za zobozdravnika navedena le ena feminativna oblika, tj. zobarka, ki je prav tako zaznamovana s kvalifikatorjem knjiž. pog., kot nevtralnejša pa je navedena beseda zobozdravnica. Zato pa obe besedi, zobarko in zobarco, najdemo v NSL. Razmerje po korpusu Gigafida pa je naslednje: zobarka osem konkordanc (po Novi besedi ni zadetkov, po Kresu dve konkordanci, po Googlu 90 zadetkov), zobarca tri konkordance (po Novi besedi in Kresu ni zadetkov, po Googlu 58). K izglasju na $-(a) r$ se po sintezi obrazilne 
produktivnosti pogosteje dodaja feminativno obrazilo - $k a(51 \%$ oz. 115 primerov; za - ca zgolj eden).

Preglednica 73: Variantni priponski obrazili -ka in -ca

\begin{tabular}{|l|l|l|l|l|l|l|}
\hline Variante & $\begin{array}{l}\text { Prednostna } \\
\text { varianta po } \\
\text { zastopanosti v } \\
\text { jez. priročnikih } \\
(\text { SSKJ 1, SP, } \\
\text { NSL, SSKJ 2) }\end{array}$ & $\begin{array}{l}\text { Prednostna } \\
\text { varianta } \\
\text { glede na } \\
\text { pomensko } \\
\text { obremenitev }\end{array}$ & $\begin{array}{l}\text { Prednostna } \\
\text { varianta glede na } \\
\text { slogovno } \\
\text { (ne)zaznamova- } \\
\text { nost }\end{array}$ & $\begin{array}{l}\text { Prednostna } \\
\text { varianta po } \\
\text { pogostnosti } \\
\text { (korpusi, } \\
\text { splet) }\end{array}$ & $\begin{array}{l}\text { Prednostna } \\
\text { varianta po } \\
\text { sintezi } \\
\text { obrazilne } \\
\text { produktivnosti }\end{array}$ & $\begin{array}{l}\text { Prednostna } \\
\text { varianta } \\
\text { glede } \\
\text { navedene } \\
\text { kriterije }\end{array}$ \\
\hline $\begin{array}{l}\text { zobarca : } \\
\text { zobarka }\end{array}$ & zobarka & $\begin{array}{l}\text { zobarca/ } \\
\text { zobarka }\end{array}$ & $\begin{array}{l}\text { zobarca/ } \\
\text { zobarka }\end{array}$ & zobarka & zobarka & zobarka \\
\hline
\end{tabular}

Analizirali smo le en par. Gre za dodajanje obeh variantnih priponskih obrazil k izglasju opravkarja na -r (-(a)r: zobarka - zobarca).

\subsubsection{Variantni priponski obrazili $-a /-k a$}

\section{gostača $<$ gostačka}

Gostačka glede na obe izdaji SSKJ pomeni v kmečkem okolju, nekdaj 'ženska, ki stanuje v tuji, najeti hiši', gostača pa je označena kot redka varianta (v drugi izdaji slovarja kot zastarela); njena pomenska razlaga je 'gostačka'. SP navaja samo gostačko kot feminativ h gostaču, je pa gostača pogostejša po korpusu, saj jo potrjuje 156 pojavitev, gostačko pa le tri. Upoštevati je treba možnost izpisa moškospolske oblike pri gostači - dodatni iskalni pogoji (samostalnik, ednina, ženski spol, živost) vse zadetke izničijo. K izglasju na -(a)č se pogosteje dodaja priponsko obrazilo - $k a$ (14 primerov oz. $40 \%$ ); z - $a$ smo zasledili le dva primera $(8 \%)$.

Preglednica 74: Variantni priponski obrazili -a in -ka

\begin{tabular}{|l|l|l|l|l|l|l|}
\hline Variante & $\begin{array}{l}\text { Prednostna } \\
\text { varianta po } \\
\text { zastopanosti v } \\
\text { jez. priročnikih } \\
(S S K J \text { I, SP, } \\
\text { NSL, SSKJ 2) }\end{array}$ & $\begin{array}{l}\text { Prednostna } \\
\text { varianta } \\
\text { glede na } \\
\text { pomensko } \\
\text { obremenitev }\end{array}$ & $\begin{array}{l}\text { Prednostna } \\
\text { varianta glede na } \\
\text { slogovno } \\
\text { (ne)zaznamova- } \\
\text { nost }\end{array}$ & $\begin{array}{l}\text { Prednostna } \\
\text { varianta po } \\
\text { pogostnosti } \\
\text { (korpusi, } \\
\text { splet) }\end{array}$ & $\begin{array}{l}\text { Prednostna } \\
\text { varianta po } \\
\text { sintezi } \\
\text { obrazilne } \\
\text { produktivnosti }\end{array}$ & $\begin{array}{l}\text { Prednostna } \\
\text { varianta } \\
\text { glede } \\
\text { navedene } \\
\text { kriterije }\end{array}$ \\
\hline $\begin{array}{l}\text { gostača : } \\
\text { gostačka }\end{array}$ & gostačka & gostačka & gostačka & gostačka & gostačka & gostačka \\
\hline
\end{tabular}

Variantni feminativni priponski obrazili $-k a$ in $-a$ nastopata kot dodajalni k vršilcu na izglasje -č (-(a)̌c: gostačka - gostača). 


\subsubsection{Variantni priponski obrazili -inja/-(ov)ka}

\section{židinja > židovka}

SSKJ 1 židinjo razlaga kot 'pripadnico židovske vere' (druga izdaja: 'pripadnica judovske vere, judinja'), židovka pa je zaznamovana s kvalifikatorjem zastar., pomenska razlaga 'židinja' (po SSKJ 2 'judinja') pa daje prednost prvi od obeh navedenih variant. V SP lahko pri slovarski iztočnici žid ('pripadnik judovske vere') najdemo le eno feminativno podiztočnico, židinjo. Da je slednja pogostejša v rabi, potrjuje korpus Gigafida, ki zanjo izpiše 374 pojavitev, za židovko pa le osem. Tudi po sintezi obrazilne produktivnosti je ustreznejša varianta židinja, saj se ob izglasjih podstav na $-d$ pogosteje uporablja obrazilo -inja (osem primerov oz. $40 \%$, z -(ov)ka le eden).

Preglednica 75: Variantni priponski obrazili -inja in -(ov)ka

\begin{tabular}{|l|l|l|l|l|l|l|}
\hline Variante & $\begin{array}{l}\text { Prednostna } \\
\text { varianta po } \\
\text { zastopanosti v } \\
\text { jez. priročnikih } \\
(\text { SSKJ 1, SP, } \\
\text { NSL, SSKJ 2) }\end{array}$ & $\begin{array}{l}\text { Prednostna } \\
\text { varianta } \\
\text { glede na } \\
\text { pomensko } \\
\text { obremenitev }\end{array}$ & $\begin{array}{l}\text { Prednostna } \\
\text { varianta glede na } \\
\text { slogovno } \\
\text { (ne)zaznamova- } \\
\text { nost }\end{array}$ & $\begin{array}{l}\text { Prednostna } \\
\text { varianta po } \\
\text { pogostnosti } \\
\text { (korpusi, } \\
\text { splet) }\end{array}$ & $\begin{array}{l}\text { Prednostna } \\
\text { varianta po } \\
\text { sintezi } \\
\text { obrazilne } \\
\text { produktivnosti }\end{array}$ & $\begin{array}{l}\text { Prednostna } \\
\text { varianta } \\
\text { glede na vse } \\
\text { navedene } \\
\text { kriterije }\end{array}$ \\
\hline $\begin{array}{l}\text { židinja : } \\
\text { židovka }\end{array}$ & židinja & židinja & židinja & židinja & židinja & židinja \\
\hline
\end{tabular}

Zasledili smo le en par feminativov, kjer se obravnavani variantni priponski obrazili dodata netvorjenki z izglasjem podstave na $-d$.

\subsubsection{Variantni priponski obrazili -ja/-inja}

\section{gostja > gostinja}

Beseda gostja v SSKJ 1 nastopa v dveh pomenih: 'ženska oblika od gost' in redko 'gostačka'. V drugi izdaji slovarja so pomeni trije: 1. 'ženska, ki je kam povabljena ali pogoščena' s podpomenom 'ženska, ki pride kam na obisk'; 2. 'ženska, ki javno nastopi izven kraja stalnega udejstvovanja'; 3. 'gostačka'. Gostinja je po obeh izdajah SSKJ označena kot zastarela, njena pomenska razlaga je 'gostja'. SP k moškospolski iztočnici gost ponuja samo eno ženskospolsko vzporednico, gostjo. 
Ta je pogostejša tudi glede na korpusno analizo (za gostjo najdeni 15.702 konkordanci, za gostinjo zgolj tri). Glede na to, da priponsko obrazilo -ja samo enkrat nastopi kot dodajalno k izglasjem podstav na - $t$ (-inja pa dvanajstkrat), se glede na analizo iz prejšnjega poglavja zdi ustreznejša varianta gostinja.

Preglednica 76: Variantni priponski obrazili -ja in -inja

\begin{tabular}{|l|l|l|l|l|l|l|}
\hline Variante & $\begin{array}{l}\text { Prednostna } \\
\text { varianta po } \\
\text { zastopanosti v } \\
\text { jez. priročnikih } \\
(S S K J \text { 1, SP, } \\
\text { NSL, SSKJ 2) }\end{array}$ & $\begin{array}{l}\text { Prednostna } \\
\text { varianta } \\
\text { glede na } \\
\text { pomensko } \\
\text { obremenitev }\end{array}$ & $\begin{array}{l}\text { Prednostna } \\
\text { varianta glede na } \\
\text { slogovno } \\
\text { (ne)zaznamova- } \\
\text { nost }\end{array}$ & $\begin{array}{l}\text { Prednostna } \\
\text { varianta po } \\
\text { pogostnosti } \\
\text { (korpusi, } \\
\text { splet) }\end{array}$ & $\begin{array}{l}\text { Prednostna } \\
\text { varianta po } \\
\text { sintezi } \\
\text { obrazilne } \\
\text { produktivnosti }\end{array}$ & $\begin{array}{l}\text { Prednostna } \\
\text { varianta } \\
\text { glede } \\
\text { navedene } \\
\text { kriterije }\end{array}$ \\
\hline $\begin{array}{l}\text { gostja: } \\
\text { gostinja }\end{array}$ & gostja & gostja & gostja & gostja & gostinja & gostja \\
\hline
\end{tabular}

Pri edinem najdenem paru se priponski obrazili -ja in -inja dodajata vršilcu z izglasjem podstave na - $t$ (gostja - gostinja).

\subsubsection{Variantna priponska obrazila -ical-jal-ka}

\section{dekanica $<$ dekanja $>$ dekanka}

SSKJ 1 navaja samo dve varianti: dekanico v pomenu 'predstojnica fakultete' in dekanko s kvalifikatorjem agr. in pomenom 'zelo debela, okusna hruška'. V SSKJ 2 pa je dekanka že večpomenka in poleg 'hruške' pomeni tudi 'predstojnico fakultete'. Novejša izdaja pa beleži tudi varianto dekanja kot 'predstojnico fakultete'. Varianti dekanka in dekanja $\mathrm{v}$ tem pomenu pa navajata tudi NSL in SNBSJ. V SP nastopa samo dekanka kot ženskospolska ustreznica k dekanu, vendar jo najdemo tudi v samostojnem slovarskem sestavku v pomenu 'hruška'. Zanimivi so izsledki korpusne analize, ki kažejo naslednje: dekanko potrjuje 165 konkordanc, dekanico 377, dekanjo pa 483. Po sintezi obrazilne produktivnosti ob izglasju podstave na $-n$ prevladuje priponsko obrazilo $-k a$ (21 primerov), sledita -ica s šestimi primeri in -ja z enim.

\section{prodekanica $>$ prodekanja $=$ prodekanka}

V SSKJ 1 ni nobene od navedenih variant, najdemo samo moškospolsko slovarsko iztočnico prodekan s pomenom 'namestnik dekana'. Vse tri variante pa so že navedene v SSKJ 2 in v SNBSJ, vse brez kvalifikatorjev in v pomenu 'namestnica 
dekana ali dekanje'. V SP je kot ženskospolska podiztočnica k prodekanu navedena zgolj prodekanka, v NSL pa najdemo prodekanko in prodekanico. Korpusna analiza pa kaže, da je najpogostejša v rabi prodekanica, saj jo potrjuje 155 pojavitev, sledi prodekanja s 102 pojavitvama, najmanj jih korpus ponudi za prodekanko, tj. 44. Že pri prejšnjem primeru smo ugotovili, da se pri tovrstni tvorbi najpogosteje uporablja priponsko obrazilo $-k a$.

Preglednica 77: Variantna priponska obrazila -ica, -ja in -ka

\begin{tabular}{|l|l|l|l|l|l|l|}
\hline Variante & $\begin{array}{l}\text { Prednostna } \\
\text { varianta po } \\
\text { zastopanosti v } \\
\text { jez. priročnikih } \\
\text { (SSKJ 1, SP, } \\
\text { NSL, SSKJ 2) }\end{array}$ & $\begin{array}{l}\text { Prednostna } \\
\text { varianta } \\
\text { glede na } \\
\text { pomensko } \\
\text { obremenitev }\end{array}$ & $\begin{array}{l}\text { Prednostna } \\
\text { varianta glede na } \\
\text { slogovno } \\
\text { (ne)zaznamova- } \\
\text { nost }\end{array}$ & $\begin{array}{l}\text { Prednostna } \\
\text { varianta po } \\
\text { pogostnosti } \\
\text { (korpusi, } \\
\text { splet) }\end{array}$ & $\begin{array}{l}\text { Prednostna } \\
\text { varianta po } \\
\text { sintezi } \\
\text { obrazilne } \\
\text { produktivnosti }\end{array}$ & $\begin{array}{l}\text { Prednostna } \\
\text { varianta } \\
\text { glede na vse } \\
\text { navedene } \\
\text { kriterije }\end{array}$ \\
\hline $\begin{array}{l}\text { dekanica : } \\
\text { dekanja : } \\
\text { dekanka }\end{array}$ & $\begin{array}{l}\text { dekanica/ } \\
\text { dekanja/ } \\
\text { dekanka }\end{array}$ & $\begin{array}{l}\text { dekanica/ } \\
\text { dekanja }\end{array}$ & $\begin{array}{l}\text { dekanica/dekanja/ } \\
\text { dekanka }\end{array}$ & dekanja & dekanka & dekanja \\
\hline $\begin{array}{l}\text { prodekanica : } \\
\text { prodekanja : } \\
\text { prodekanka }\end{array}$ & prodekanka & $\begin{array}{l}\text { prodekanica/ } \\
\text { prodekanja/ } \\
\text { prodekanka }\end{array}$ & $\begin{array}{l}\text { prodekanica/ } \\
\text { prodekanja/ } \\
\text { prodekanka }\end{array}$ & prodekanica & prodekanka & prodekanica \\
\end{tabular}

Pri obeh skupinah feminativov gre za dodajanje treh variantnih obrazil izglasju podstave na - $n$ (dekanica - dekanja - dekanka in prodekanica prodekanja-prodekanka).

\subsubsection{Variantna priponska obrazila -ical-inja/-ka}

generalica $>$ generalinja $=$ generalka

$\mathrm{V} S S K J 1$ se pojavita samo generalka in generalica, a nobena ne nastopa kot feminativ h generalu. Generalka je večpomenka: 1. 'najpomembnejša in zadnja odrska vaja pred premiero'; 2. geogr. 'topografska karta v majhnem merilu, ant. specialka'; 3. zastar. 'generalova žena'. Generalica pa nastopa samo kot zastar. 'generalova žena'. V drugi izdaji slovarja je pri generalki kot tretji pomen (pri generalici kot prvi) zapisan 'nosilka najvišjega čina $\mathrm{v}$ kopenski vojski ali $\mathrm{v}$ letalstvu'. Obe varianti navaja tudi $S P$ kot podiztočnici h generalu, vendar sta obe označeni s kvalifikatorjem star. in pomenita zakonsko ženo. Sta pa zato obe navedeni $\mathrm{v} S N B S J$ in $N S L$ kot čin, generalinjo pa $\mathrm{v}$ tem pomenu zasledimo le $\mathrm{v}$ $N S L$. Njena redkost je razvidna tudi iz korpusne analize, saj jo potrjuje le ena 
konkordanca, medtem ko jih je po Gigafidi za generalko 5924 (kar je zagotovo posledica večpomenskosti), 72 pa za generalico. Sinteza obrazilne produktivnosti pri teh primerih ne more odločati zaradi enakomerne zastopanosti vseh treh obrazil ob izglasju podstave na $-l$.

Preglednica 78: Variantna priponska obrazila -ica, -inja in -ka

\begin{tabular}{|l|l|l|l|l|l|l|}
\hline Variante & $\begin{array}{l}\text { Prednostna } \\
\text { varianta po } \\
\text { zastopanosti v } \\
\text { jez. priročnikih } \\
\text { (SSKJ 1, SP, } \\
\text { NSL, SSKJ 2) }\end{array}$ & $\begin{array}{l}\text { Prednostna } \\
\text { varianta } \\
\text { glede na } \\
\text { pomensko } \\
\text { obremenitev }\end{array}$ & $\begin{array}{l}\text { Prednostna } \\
\text { varianta glede na } \\
\text { slogovno } \\
\text { (ne)zaznamova- } \\
\text { nost }\end{array}$ & $\begin{array}{l}\text { Prednostna } \\
\text { varianta po } \\
\text { pogostnosti } \\
\text { (korpusi, } \\
\text { splet) }\end{array}$ & $\begin{array}{l}\text { Prednostna } \\
\text { varianta po } \\
\text { sintezi } \\
\text { obrazilne } \\
\text { produktivnosti }\end{array}$ & $\begin{array}{l}\text { Prednostna } \\
\text { varianta } \\
\text { glede } \\
\text { navedene } \\
\text { kriterije }\end{array}$ \\
\hline $\begin{array}{l}\text { generalica : } \\
\text { generalinja : } \\
\text { generalka }\end{array}$ & $\begin{array}{l}\text { generalica/ } \\
\text { generalka }\end{array}$ & generalica & $\begin{array}{l}\text { generalica/ } \\
\text { generalka }\end{array}$ & generalka & $\begin{array}{l}\text { generalica/ } \\
\text { generalinja/ } \\
\text { generalka }\end{array}$ \\
\hline
\end{tabular}

Zasledili smo le eno skupino feminativov $\mathrm{z}$ variantnimi priponskimi obrazili -ica, -inja in -ka, pri čemer se slednja dodajajo izglasju podstave na -l.

\subsubsection{Variantna priponska obrazila -injal-kal-esa}

poetinja $=$ poetka $<$ poetesa

Poeteso obe izdaji SSKJ označujeta s kvalifikatorjem knjiž. v pomenu 'pesnica'. Z enakim kvalifikatorjem in pomenom nastopa poetka, le da je dodatno označena kot redka varianta (slednje le po prvi izdaji slovarja). Vse tri variante kot feminative k poetu navaja SP: poetinjo in poetko označuje s kvalifikatorjem neobč., poeteso pa z izobr.; pri vseh treh kot nevtralno izpostavi pesnico. Razmerje po korpusu Gigafida pa je naslednje: poetesa 70 konkordanc, poetinja 20 konkordanc, poetka sedem konkordanc. $\mathrm{K}$ izglasjem podstav na $-t$ pa se po analizi iz prejšnjega poglavja najpogosteje dodaja obrazilo $-k a$, in to ob 28 primerih ali $58 \%$ (-inja le pri dvanajstih, -esa pri enem). 
Preglednica 79: Variantna priponska obrazila -inja, -ka in -esa

\begin{tabular}{|l|l|l|l|l|l|l|}
\hline Variante & $\begin{array}{l}\text { Prednostna } \\
\text { varianta po } \\
\text { zastopanosti v } \\
\text { jez. priročnikih } \\
(\text { SSKJ 1, SP, } \\
\text { NSL, SSKJ 2) }\end{array}$ & $\begin{array}{l}\text { Prednostna } \\
\text { varianta glede } \\
\text { na pomensko } \\
\text { obremenitev }\end{array}$ & $\begin{array}{l}\text { Prednostna } \\
\text { varianta glede } \\
\text { na slogovno } \\
\text { (ne)zaznamova- } \\
\text { nost }\end{array}$ & $\begin{array}{l}\text { Prednostna } \\
\text { varianta po } \\
\text { pogostnosti } \\
\text { (korpusi, } \\
\text { splet) }\end{array}$ & $\begin{array}{l}\text { Prednostna } \\
\text { varianta po } \\
\text { sintezi } \\
\text { obrazilne } \\
\text { produktivnosti }\end{array}$ & $\begin{array}{l}\text { Prednostna } \\
\text { varianta } \\
\text { glede } \\
\text { navedene } \\
\text { kriterije }\end{array}$ \\
\hline $\begin{array}{l}\text { poetinja: } \\
\text { poetka : } \\
\text { poetesa }\end{array}$ & poetka/poetesa & $\begin{array}{l}\text { poetinja/ } \\
\text { poetka/ } \\
\text { poetesa }\end{array}$ & $\begin{array}{l}\text { poetinja/ } \\
\text { poetka/ } \\
\text { poetesa }\end{array}$ & poetesa & poetka & poetesa \\
\hline
\end{tabular}

Prevzeto feminativno priponsko obrazilo -esa ter domači -inja in -ka nastopijo kot varianta zgolj pri izglasju netvorjenke na $-t$.

\subsubsection{Variantna priponska obrazila -ljal-uljal-ka}

\section{bruclja = bruculja $<$ brucka}

Vse tri variante so po SSKJ 1 označene s kvalifikatorjem žarg., le da je pomenska razlaga pri brucki polna ('slušateljica prvega letnika na univerzi'), pri bruculji in bruclji pa samo 'brucka'; dodatno sta ti dve varianti zaznamovani kot slabšalni. V SSKJ 2 so pomenske razlage enake kot v prvi izdaji, le da so vse tri možnosti brez kvalifikatorja žarg. (ostaja pa slabš. pri že omenjenih). Vse tri možnosti so pri iztočnici bruc navedene tudi v SP, označene pa so s podobnimi kvalifikatorji kot $\mathrm{v}$ obeh SSKJ (vse tri s šol. žarg., bruclja in bruculja pa še s slabš.). Glede na povedano ne preseneča, da raba besede brucka prevladuje tudi po korpusu Gigafida (787 pojavitev), drugi dve sta zelo redki (za bruculjo tri pojavitve, za brucljo zgolj ena). Sinteza obrazilne produktivnosti pa najustreznejše rešitve ne ponuja, saj dodajanje $\mathrm{k}$ izglasju podstave $-c$ potrjuje po en primer $\mathrm{z}$-ulja, -esa in $-k a$.

Preglednica 80: Variantna priponska obrazila -lja, -ulja in -ka

\begin{tabular}{|l|l|l|l|l|l|l|}
\hline Variante & $\begin{array}{l}\text { Prednostna } \\
\text { varianta po } \\
\text { zastopanosti v } \\
\text { jez. priročnikih } \\
(S S K J \text { 1, SP, } \\
\text { NSL, SSKJ 2) }\end{array}$ & $\begin{array}{l}\text { Prednostna } \\
\text { varianta } \\
\text { glede na } \\
\text { pomensko } \\
\text { obremenitev }\end{array}$ & $\begin{array}{l}\text { Prednostna } \\
\text { varianta glede na } \\
\text { slogovno } \\
\text { (ne)zaznamova- } \\
\text { nost }\end{array}$ & $\begin{array}{l}\text { Prednostna } \\
\text { varianta po } \\
\text { pogostnosti } \\
\text { (korpusi, splet) }\end{array}$ & $\begin{array}{l}\text { Prednostna } \\
\text { varianta po } \\
\text { sintezi } \\
\text { obrazilne } \\
\text { produktivnosti }\end{array}$ & $\begin{array}{l}\text { Prednostna } \\
\text { varianta } \\
\text { glede na vse } \\
\text { navedene } \\
\text { kriterije }\end{array}$ \\
\hline $\begin{array}{l}\text { brucka : } \\
\text { bruculja : } \\
\text { bruclja }\end{array}$ & $\begin{array}{l}\text { brucka/ } \\
\text { bruculja/ } \\
\text { bruclja }\end{array}$ & brucka & brucka & brucka & brucka/ \\
bruculja & brucka \\
\hline
\end{tabular}


Gre za dodajanje variantnih priponskih obrazil -lja, -ulja in -ka netvorjenki z izglasjem na -c (bruclja-bruculja-brucka).

\subsubsection{Variantna priponska obrazila -ical-uljal-(ov)ka}

\section{vražica $=$ vragulja $<$ vragovka}

Beseda vražica v SSKJ 1 nastopa v treh pomenih: 1. 'ženska oblika od vrag'; 2. ekspr. 'zlobna, hudobna ženska'; 3. ekspr. 'mlada, živahna ženska'. Vragovka je 'ženska oblika od vrag' ali redko 'čarovnica', vragulja pa poleg tega dvojega pomeni še ekspr. 'zlobna, hudobna ženska'. V SSKJ 2 je pomen 'ženska oblika od vrag' pri vseh treh variantah zamenjan s pomensko razlago evfem. 'hudičevka', kvalifikator redko pri pomenski razlagi 'čarovnica' za vragovko in vraguljo pa je zamenjala oznaka zastar. V SP je pri iztočnici vrag navedena le podiztočnica vragovka, ki je označena s kvalifikatorjem olepš., kot splošna pomenska uvrstitev pa je navedena beseda hudičevka. Razmerje po korpusu Gigafida je naslednje: vragovka štiri konkordance, vražica dve konkordanci, vragulja pa je brez pojavitev. Izvedli smo dodatno preverjanje po Novi besedi (vragovka 4, vražica 3 in vragulja 0 zadetkov), Kresu (vragovka 1, vražica 2 in vragulja 0 pojavitev) in Googlu (vragovka 14, vražica 35 in vragulja 25 zadetkov). Tudi o tem primeru ne more odločati sinteza obrazilne produktivnosti.

Preglednica 81: Variantna priponska obrazila -ica, -ulja in -(ov)ka

\begin{tabular}{|c|c|c|c|c|c|c|}
\hline Variante & $\begin{array}{l}\text { Prednostna } \\
\text { varianta po } \\
\text { zastopanosti v } \\
\text { jez. priročnikih } \\
(S S K J 1, S P \text {, } \\
N S L, S S K J 2)\end{array}$ & $\begin{array}{l}\text { Prednostna } \\
\text { varianta } \\
\text { glede na } \\
\text { pomensko } \\
\text { obremenitev }\end{array}$ & $\begin{array}{l}\text { Prednostna } \\
\text { varianta glede } \\
\text { na slogovno } \\
\text { (ne)zaznamova- } \\
\text { nost }\end{array}$ & $\begin{array}{l}\text { Prednostna } \\
\text { varianta po } \\
\text { pogostnosti } \\
\text { (korpusi, } \\
\text { splet) }\end{array}$ & $\begin{array}{l}\text { Prednostna } \\
\text { varianta po } \\
\text { sintezi } \\
\text { obrazilne } \\
\text { produktivnosti }\end{array}$ & $\begin{array}{l}\text { Prednostna } \\
\text { varianta } \\
\text { glede na vse } \\
\text { navedene } \\
\text { kriterije }\end{array}$ \\
\hline $\begin{array}{l}\text { vražica: } \\
\text { vragulja: } \\
\text { vragovka }\end{array}$ & vragovka & $\begin{array}{l}\text { vražica/ } \\
\text { vragulja/ } \\
\text { vragovka }\end{array}$ & $\begin{array}{l}\text { vražica/ } \\
\text { vragulja/ } \\
\text { vragovka }\end{array}$ & vragovka & $\begin{array}{l}\text { vražica/ } \\
\text { vragulja/ } \\
\text { vragovka }\end{array}$ & vragovka \\
\hline
\end{tabular}

Navedena variantna priponska obrazila se dodajajo netvorjenki z izglasjem na - $g$. Pri dodajanju feminativnega priponskega obrazila -ica pride do glasovne premene izglasnega soglasnika $\mathrm{v}-\check{z}$, kar se pri drugih dveh dodajalnih priponskih obrazilih ne zgodi. 


\subsubsection{Poimenovanja živali}

\subsubsection{Variantni priponski obrazili -ical-ka}

\section{galebica $<$ galebka}

SSKJ 1 in 2 navajata samo galebko kot 'samico galeba'. SP pa kot feminativni podiztočnici h galebu ponuja obe možnosti, pri čemer nobena ni slogovno zaznamovana. Razmerje po korpusu Gigafida pa je sledeče: galebko potrjuje 86 pojavitev, galebico pa 17. Sinteza obrazilne produktivnosti pa kaže na enakovrednost obeh priponskih obrazil, saj dodajanje $\mathrm{k}$ izglasju podstave na $-b$ potrjuje po en primer za vsako, kadar gre za poimenovanja živali (pri poimenovanjih oseb pa se obrazilo -ica ob izglasju podstave na $-b$ sploh ne pojavi, medtem ko - $k a$ nastopi dvakrat).

\section{labodica $<$ labodka}

Labodka je po obeh izdajah SSKJ 'samica laboda', labodica pa je označena s kvalifikatorjem knjiž., njena pomenska razlaga preusmerja k labodki. Podobno je v SP, kjer sta prav tako navedeni obe varianti, a kot nevtralnejša je izpostavljena labodka. Njeno pogostejšo rabo potrjuje tudi Gigafida, saj zanjo izpiše 98 pojavitev, za labodico pa le 16 . V prejšnjem poglavju smo ugotovili, da nekoliko pogosteje ob izglasju podstave na - $d$ nastopa obrazilo - $k a$ (dva primera, z -ica le eden, če gre za poimenovanja živali; pri poimenovanjih oseb je razmerje naslednje: -ica 1 primer, $-k a$ osem primerov).

\section{prepeličarica < prepeličarka}

Polno razlago pomena ima po obeh SSKJ samo prepeličarka ('samica prepeličarja'), razlaga pri prepeličarici preusmerja k prvi navedeni varianti. $S P$ pa kot feminativ k prepeličarju navaja samo prepeličarko. Pojavitve po korpusu Gigafida so za obe iztočnici skromne (prepeličarko potrjuje ena konkordanca, prepeličarice pa nobena), zato smo dodatno preverili po Novi besedi in Kresu (po obeh za prepeličarko ena pojavitev, za prepeličarico nobene) ter Googlu (prepeličarka 33 zadetkov, prepeličarica 10). Ugotovili pa smo že, da se ob 
izglasju na $-(a) r$ pogosteje pojavlja feminativno obrazilo $-k a$ (51 \% pri poimenovanjih oseb).

Preglednica 82: Variantni priponski obrazili -ica in -ka pri poimenovanjih živali

\begin{tabular}{|l|l|l|l|l|l|l|}
\hline Variante & $\begin{array}{l}\text { Prednostna } \\
\text { varianta po } \\
\text { zastopanosti v } \\
\text { jez. priročnikih } \\
\text { (SSKJ 1, SP, } \\
\text { NSL, SSKJ 2) }\end{array}$ & $\begin{array}{l}\text { Prednostna } \\
\text { varianta } \\
\text { glede na } \\
\text { pomensko } \\
\text { obremenitev }\end{array}$ & $\begin{array}{l}\text { Prednostna } \\
\text { varianta glede na } \\
\text { slogovno } \\
\text { (ne)zaznamova- } \\
\text { nost }\end{array}$ & $\begin{array}{l}\text { Prednostna } \\
\text { varianta po } \\
\text { pogostnosti } \\
\text { (korpusi, } \\
\text { splet) }\end{array}$ & $\begin{array}{l}\text { Prednostna } \\
\text { varianta po } \\
\text { sintezi } \\
\text { obrazilne } \\
\text { produktivnosti }\end{array}$ & $\begin{array}{l}\text { Prednostna } \\
\text { varianta } \\
\text { glede } \text { na vse } \\
\text { navedene } \\
\text { kriterije }\end{array}$ \\
\hline $\begin{array}{l}\text { galebica : } \\
\text { galebka }\end{array}$ & galebka & $\begin{array}{l}\text { galebica/ } \\
\text { galebka }\end{array}$ & galebica/galebka & galebka & galebka & galebka \\
\hline $\begin{array}{l}\text { labodica : } \\
\text { labodka }\end{array}$ & $\begin{array}{l}\text { labodica/ } \\
\text { labodka }\end{array}$ & labodka & labodka & labodka & labodka & labodka \\
\hline $\begin{array}{l}\text { prepeličarica : } \\
\text { prepeličarka }\end{array}$ & prepeličarka & prepeličarka & $\begin{array}{l}\text { prepeličarica/ } \\
\text { prepeličarka }\end{array}$ & prepeličarka & prepeličarka & prepeličarka \\
\hline
\end{tabular}

Variantni priponski obrazili -ica in $-k a$ se, kadar tvorita ženskospolska poimenovanja živali, dodajata izglasjem podstave na -b (galebka-galebica), $-d$ $($ labodka-labodica) in -r (-(a)r: prepeličarka-prepeličarica).

\subsubsection{Variantni priponski obrazili -ical-ulja}

\section{volčica $<$ volkulja}

Volčica je po SSKJ (obe izdaji) večpomenka: 1. 'volkulja'; 2. 'volčja mladička'; 3. slabš. 'krvoločna, neusmiljena ali požrešna, pohlepna ženska'. Volkulja pa nastopa zgolj kot 'samica volka'. Samo slednjo navaja $S P$ kot feminativno podiztočnico k volku. Volčica je obravnavana v samostojnem slovarskem sestavku, označena je s kvalifikatorjema manjš. in ljubk., kot splošna pomenska uvrstitev pa je izpostavljena volkulja; poleg tega lahko, podobno kot v SSKJ, pomeni 'zelo okrutno, pohlepno žensko'. Korpus Gigafida pa s 788 konkordancami daje prednost volkulji; za volčico jih ponudi le devet. Pri analizi v prejšnjem poglavju pa smo ugotovili, da se obe obrazili redko dodajata $\mathrm{k}$ izglasju podstave na $-k$.

Preglednica 83: Variantni priponski obrazili -ica in -ulja pri poimenovanjih živali

\begin{tabular}{|c|c|c|c|c|c|c|}
\hline Variante & $\begin{array}{l}\text { Prednostna } \\
\text { varianta po } \\
\text { zastopanosti v } \\
\text { jez. priročnikih } \\
(S S K J 1, S P \text {, } \\
N S L, S S K J 2) \\
\end{array}$ & $\begin{array}{l}\text { Prednostna } \\
\text { varianta } \\
\text { glede na } \\
\text { pomensko } \\
\text { obremenitev }\end{array}$ & $\begin{array}{l}\text { Prednostna } \\
\text { varianta glede na } \\
\text { slogovno } \\
\text { (ne)zaznamova- } \\
\text { nost }\end{array}$ & $\begin{array}{l}\text { Prednostna } \\
\text { varianta po } \\
\text { pogostnosti } \\
\text { (korpusi, splet) }\end{array}$ & $\begin{array}{l}\text { Prednostna } \\
\text { varianta po } \\
\text { sintezi } \\
\text { obrazilne } \\
\text { produktivnosti }\end{array}$ & $\begin{array}{l}\text { Prednostna } \\
\text { varianta } \\
\text { glede na vse } \\
\text { navedene } \\
\text { kriterije }\end{array}$ \\
\hline $\begin{array}{l}\text { volčica: } \\
\text { volkulja }\end{array}$ & $\begin{array}{l}\text { volčica/ } \\
\text { volkulja }\end{array}$ & volkulja & volkulja & volkulja & volčica/volkulja & volkulja \\
\hline
\end{tabular}


Gre za dodajanje variantnih priponskih obrazil -ica in -ulja k netvorjenki $\mathrm{z}$ izglasjem na $-k$, pri čemer pride do glasovne premene izglasnega soglasnika $\mathrm{v}-\check{c}$, kadar kot dodajalno priponsko obrazilo nastopi -ica.

\subsubsection{Variantni priponski obrazili -al-inja}

risa $>$ risinja

Risa je po obeh izdajah SSKJ 'samica risa', medtem ko risinje prva izdaja ne navaja, $\mathrm{v}$ drugi pa nastopa $\mathrm{v}$ enakem pomenu kot risa. Nobena od variant ni zaznamovana s kvalifikatorjem. V SP najdemo zgolj riso kot ženskospolsko vzporednico k risu. Po korpusu Gigafida smo znova morali uporabiti napredno iskanje, saj je bilo mnogo zadetkov za iskalni pogoj risa nerelevantnih (skupno 11.923, a mnogo poimenovanj za žival moškega spola $\mathrm{v}$ različnih sklonih in številih). Tako je ob pogojih samostalnik ženskega spola v ednini, živost, korpus izpisal 1395 konkordanc za riso, 23 pa za risinjo. Dodajanje k izglasju podstave na $-s$ pa je pri obeh feminativnih obrazilih potrjeno s po enim primerom.

Preglednica 84: Variantni priponski obrazili -a in -inja pri poimenovanjih živali

\begin{tabular}{|l|l|l|l|l|l|l|}
\hline Variante & $\begin{array}{l}\text { Prednostna } \\
\text { varianta po } \\
\text { zastopanosti v } \\
\text { jez. priročnikih } \\
(\text { SSKJ 1, SP, } \\
\text { NSL, } S S K J)\end{array}$ & $\begin{array}{l}\text { Prednostna } \\
\text { varianta } \\
\text { glede na } \\
\text { pomensko } \\
\text { obremenitev }\end{array}$ & $\begin{array}{l}\text { Prednostna } \\
\text { varianta glede na } \\
\text { slogovno } \\
\text { (ne)zaznamova- } \\
\text { nost }\end{array}$ & $\begin{array}{l}\text { Prednostna } \\
\text { varianta po } \\
\text { pogostnosti } \\
\text { (korpusi, } \\
\text { splet) }\end{array}$ & $\begin{array}{l}\text { Prednostna } \\
\text { varianta po } \\
\text { sintezi } \\
\text { obrazilne } \\
\text { produktivnosti }\end{array}$ & $\begin{array}{l}\text { Prednostna } \\
\text { varianta } \\
\text { glede } \\
\text { navedene } \\
\text { kriterije }\end{array}$ \\
\hline $\begin{array}{l}\text { risa : } \\
\text { risinja }\end{array}$ & risa & risa/risinja & risa/risinja & risa & risa/risinja & risa \\
\hline
\end{tabular}

\subsubsection{Variantni priponski obrazili -ical-inja}

\section{pavica > pavinja}

V obeh SSKJ je pavica 'samica pava', pavinja pa je označena s kvalifikatorjema redko, knjiž. (po SSKJ 2 samo knjiž.) in ima pomensko razlago 'pavica'. Podobno je v SP: navedeni sta obe varianti, a za nevtralnejšo velja pavica. Slednji v prid govorijo tudi rezultati korpusne analize, saj jo potrdijo s 157 pojavitvami, medtem ko za pavinjo ponudijo le tri konkordance (po Gigafidi). Pri sintezi obrazilne produktivnosti (za poimenovanja živali) smo opazili, da se k izglasju podstave na - $v$ le nekoliko pogosteje dodaja -inja (dva primera, z -ica le eden). 
Preglednica 85: Variantni priponski obrazili -ica in -inja pri poimenovanjih živali

\begin{tabular}{|l|l|l|l|l|l|l|}
\hline Variante & $\begin{array}{l}\text { Prednostna } \\
\text { varianta po } \\
\text { zastopanosti v } \\
\text { jez. priročnikih } \\
\text { (SSKJ 1, SP, } \\
\text { NSL, SSKJ 2) }\end{array}$ & $\begin{array}{l}\text { Prednostna } \\
\text { varianta } \\
\text { glede na } \\
\text { pomensko } \\
\text { obremenitev }\end{array}$ & $\begin{array}{l}\text { Prednostna } \\
\text { varianta glede na } \\
\text { slogovno } \\
\text { (ne)zaznamova- } \\
\text { nost }\end{array}$ & $\begin{array}{l}\text { Prednostna } \\
\text { varianta po } \\
\text { pogostnosti } \\
\text { (korpusi, } \\
\text { splet) }\end{array}$ & $\begin{array}{l}\text { Prednostna } \\
\text { varianta po } \\
\text { sintezi } \\
\text { obrazilne } \\
\text { produktivnosti }\end{array}$ & $\begin{array}{l}\text { Prednostna } \\
\text { varianta } \\
\text { glede na vse } \\
\text { navedene } \\
\text { kriterije }\end{array}$ \\
\hline $\begin{array}{l}\text { pavica : } \\
\text { pavinja }\end{array}$ & pavica/pavinja & pavica & pavica & pavica & pavinja & pavica \\
\hline
\end{tabular}

Feminativni priponski obrazili -ica in -inja se kot variantni dodajata netvorjenki z izglasjem na $-v$ (pavica - pavinja).

\subsubsection{Variantni priponski obrazili -inja/-(ov)ka}

\section{šimpanzinja > šimpanzovka}

Obe možnosti v obeh izdajah $S S K J$ nastopita v pomenu 'samica šimpanza', nobena pa ni slogovno zaznamovana. SP kot ženskospolsko vzporednico k šimpanzu navaja le šimpanzovko, korpus Gigafida pa kaže drugače: več pojavitev ponuja pri iskalnem pogoju šimpanzinja, to je 56 (za šimpanzovko pa 25). Tvorbo ob izglasjih podstav na $-z$ potrjuje po en primer pri vsakem feminativnem priponskem obrazilu.

Preglednica 86: Variantni priponski obrazili -inja in -(ov)ka pri poimenovanjih živali

\begin{tabular}{|c|c|c|c|c|c|c|}
\hline Variante & $\begin{array}{l}\text { Prednostna } \\
\text { varianta po } \\
\text { zastopanosti v } \\
\text { jez. priročnikih } \\
(S S K J 1, S P \text {, } \\
N S L, S S K J \text { 2) } \\
\end{array}$ & $\begin{array}{l}\text { Prednostna } \\
\text { varianta } \\
\text { glede na } \\
\text { pomensko } \\
\text { obremenitev }\end{array}$ & $\begin{array}{l}\text { Prednostna } \\
\text { varianta glede na } \\
\text { slogovno } \\
\text { (ne)zaznamova- } \\
\text { nost }\end{array}$ & $\begin{array}{l}\text { Prednostna } \\
\text { varianta po } \\
\text { pogostnosti } \\
\text { (korpusi, } \\
\text { splet) }\end{array}$ & $\begin{array}{l}\text { Prednostna } \\
\text { varianta po } \\
\text { sintezi } \\
\text { obrazilne } \\
\text { produktivnosti }\end{array}$ & $\begin{array}{l}\text { Prednostna } \\
\text { varianta } \\
\text { glede na vse } \\
\text { navedene } \\
\text { kriterije }\end{array}$ \\
\hline $\begin{array}{l}\text { Šimpanzinja : } \\
\text { šimpanzovka }\end{array}$ & šimpanzovka & $\begin{array}{l}\text { šimpanzinja/ } \\
\text { šimpanzovka }\end{array}$ & $\begin{array}{l}\text { šimpanzinja/ } \\
\text { šimpanzovka }\end{array}$ & šimpanzinja & $\begin{array}{l}\text { šimpanzinja/ } \\
\text { šimpanzovka }\end{array}$ & šimpanzinja \\
\hline
\end{tabular}

Zasledili smo le en par, pri čemer ugotavljamo, da se variantni priponski obrazili -inja in -(ov)ka dodata izglasju na -z (šimpanzinja - šimpanzovka).

8.1.2.6 Variantni priponski obrazili -ical-(ov)ka

gadica $<$ gadovka 
SSKJ 1 in 2 navajata samo gadovko kot 'samico gada'. V SP pa najdemo obe varianti kot feminativni podiztočnici h gadu, nobena od njiju pa ni stilno zaznamovana. Korpus Gigafida se bolj nagiba h gadovki, čeprav so pojavitve skromne: za gadovko le pet konkordanc, za gadico nobene. Sinteza obrazilne produktivnosti pa ustreznejše možnosti ne ponudi, saj rabo obeh obrazil ob izglasju podstave na $-d$, kadar gre za poimenovanja živali, potrjuje po en konkretni primer (enako pri poimenovanjih oseb).

somica > somovka

Somica in somovka po obeh SSKJ pomenita 'samico soma', nobena pa ne nastopi kot slogovno zaznamovana varianta. Enako je v $S P$, kjer sta obe prikazani kot feminativa $\mathrm{k}$ somu. Korpus pa daje prednost somici, saj jo potrdi z osmimi konkordancami, medtem ko za somovko ne ponudi nobene. Glede na sintezo obrazilne produktivnosti pa ustreznejše možnosti ne moremo določiti, saj obe obrazili ob izglasju podstave na - $m$ potrdi po en konkretni primer.

Preglednica 87: Variantni priponski obrazili -ica in -(ov)ka pri poimenovanjih živali

\begin{tabular}{|l|l|l|l|l|l|l|}
\hline Variante & $\begin{array}{l}\text { Prednostna } \\
\text { varianta po } \\
\text { zastopanosti v } \\
\text { jez. priročnikih } \\
\text { (SSKJ 1, SP, } \\
\text { NSL, SSKJ 2) }\end{array}$ & $\begin{array}{l}\text { Prednostna } \\
\text { varianta } \\
\text { glede na } \\
\text { pomensko } \\
\text { obremenitev }\end{array}$ & $\begin{array}{l}\text { Prednostna } \\
\text { varianta glede na } \\
\text { slogovno } \\
\text { (ne)zaznamova- } \\
\text { nost }\end{array}$ & $\begin{array}{l}\text { Prednostna } \\
\text { varianta po } \\
\text { pogostnosti } \\
\text { (korpusi, } \\
\text { splet) }\end{array}$ & $\begin{array}{l}\text { Prednostna } \\
\text { varianta po } \\
\text { sintezi } \\
\text { obrazilne } \\
\text { produktivnosti }\end{array}$ & $\begin{array}{l}\text { Prednostna } \\
\text { varianta } \\
\text { glede na vse } \\
\text { navedene } \\
\text { kriterije }\end{array}$ \\
\hline $\begin{array}{l}\text { gadica: } \\
\text { gadovka }\end{array}$ & gadovka & $\begin{array}{l}\text { gadica/ } \\
\text { gadovka }\end{array}$ & $\begin{array}{l}\text { gadica/ } \\
\text { gadovka }\end{array}$ & gadovka & $\begin{array}{l}\text { gadica/ } \\
\text { gadovka }\end{array}$ & gadovka \\
\hline $\begin{array}{l}\text { somica : } \\
\text { somovka }\end{array}$ & $\begin{array}{l}\text { somica/ } \\
\text { somovka }\end{array}$ & $\begin{array}{l}\text { somica/ } \\
\text { somovka }\end{array}$ & $\begin{array}{l}\text { somica/ } \\
\text { somovka }\end{array}$ & somica \\
somica/ & somica \\
\hline
\end{tabular}

Zasledili smo le dva para in pri obeh se obravnavani variantni priponski obrazili dodajata netvorjenkam, in to $\mathrm{z}$ izglasjem podstave na - $d$ (gadica gadovka) in na - $m$ (somica - somovka).

\subsubsection{Variantna priponska obrazila -ical-lja/-uljal-(ov)ka}

pajčica $=$ pajklja $=$ pajkulja $<$ pajkovka

Pajčica, pajklja in pajkulja se pojavijo v obeh izdajah SSKJ; vse tri so označene kot ekspresivne in pomenijo 'samico pajka'. SP pa k slovarski iztočnici pajek 
ponudi le dve feminativni podiztočnici, pajkovko in pajkljo, pri čemer je slednja označena s kvalifikatorjem slabš. Rezultati korpusne analize pa so sledeči: pajčica šest konkordanc, pajkulja štiri konkordance, pajkovka 188 konkordanc, pajklja enajst konkordanc; vse po Gigafidi. Po analizi iz prejšnjega poglavja pa nobeno od navedenih feminativnih priponskih obrazil ne prevladuje pri dodajanju $\mathrm{k}$ izglasju podstave na $-k$.

Preglednica 88: Variantna priponska obrazila -ica, -lja, -ulja in -(ov)ka pri poimenovanjih živali

\begin{tabular}{|c|c|c|c|c|c|c|}
\hline Variante & $\begin{array}{l}\text { Prednostna } \\
\text { varianta po } \\
\text { zastopanosti v } \\
\text { jez. priročnikih } \\
(S S K J 1, S P \text {, } \\
N S L, S S K J 2)\end{array}$ & $\begin{array}{l}\text { Prednostna } \\
\text { varianta } \\
\text { glede na } \\
\text { pomensko } \\
\text { obremenitev }\end{array}$ & $\begin{array}{l}\text { Prednostna } \\
\text { varianta glede na } \\
\text { slogovno } \\
\text { (ne)zaznamova- } \\
\text { nost }\end{array}$ & $\begin{array}{l}\text { Prednostna } \\
\text { varianta po } \\
\text { pogostnosti } \\
\text { (korpusi, } \\
\text { splet) }\end{array}$ & $\begin{array}{l}\text { Prednostna } \\
\text { varianta po } \\
\text { sintezi } \\
\text { obrazilne } \\
\text { produktivnosti }\end{array}$ & $\begin{array}{l}\text { Prednostna } \\
\text { varianta } \\
\text { glede na vse } \\
\text { navedene } \\
\text { kriterije }\end{array}$ \\
\hline $\begin{array}{l}\text { pajčica: } \\
\text { pajklja : } \\
\text { pajkulja: } \\
\text { pajkovka }\end{array}$ & pajklja & $\begin{array}{l}\text { pajčica/ } \\
\text { pajklja/ } \\
\text { pajkulja/ } \\
\text { pajkovka }\end{array}$ & $\begin{array}{l}\text { pajčica/ } \\
\text { pajkulja/ } \\
\text { pajkovka/ }\end{array}$ & pajkovka & $\begin{array}{l}\text { pajčica/ } \\
\text { pajklja/pajkulja/ } \\
\text { pajkovka }\end{array}$ & pajkovka \\
\hline
\end{tabular}

\subsection{Zamenjava in dodajanje obrazila}

Opažamo, da je v nekaj primerih eno od variantnih priponskih obrazil dodajalno, drugo pa zamenjevalno. Taki pari obrazil so trije: -inja in -na ter -ka in $-(e v) k a$ za poimenovanja oseb, -ica in -(ev)ka pa za poimenovanja živali.

\subsubsection{Poimenovanja oseb}

\subsubsection{Variantni priponski obrazili -inja/-na}

dedinja > dedična

Dedična je po obeh SSKJ razložena kot 'dedinja', dedinja pa kot 'ženska, ki dobi dediščino'. SP navaja samo dedinjo kot feminativ $\mathrm{k}$ dediču, ta varianta pa je pogostejša tudi v korpusu Gigafida, saj jo potrjuje 3641 konkordanc, dedično pa le ena. Če se ozremo še na sintezo obrazilne produktivnosti, ugotovimo, da se priponsko obrazilo -na doda k izglasju obrazila na -(i)č pri šestih primerih (kar predstavlja $46 \%$ ). Obrazilo -inja pa zamenjuje moškospolsko obrazilo -ič samo pri enem primeru. 
Preglednica 89: Variantni priponski obrazili -inja in -na

\begin{tabular}{|l|l|l|l|l|l|l|}
\hline Variante & $\begin{array}{l}\text { Prednostna } \\
\text { varianta po } \\
\text { zastopanosti v } \\
\text { jez. priročnikih } \\
(\text { SSKJ 1, SP, } \\
\text { NSL, SSKJ 2) }\end{array}$ & $\begin{array}{l}\text { Prednostna } \\
\text { varianta } \\
\text { glede na } \\
\text { pomensko } \\
\text { obremenitev }\end{array}$ & $\begin{array}{l}\text { Prednostna } \\
\text { varianta glede } \\
\text { na slogovno } \\
\text { (ne)zaznamova- } \\
\text { nost }\end{array}$ & $\begin{array}{l}\text { Prednostna } \\
\text { varianta po } \\
\text { pogostnosti } \\
\text { (korpusi, } \\
\text { splet) }\end{array}$ & $\begin{array}{l}\text { Prednostna } \\
\text { varianta po } \\
\text { sintezi } \\
\text { obrazilne } \\
\text { produktivnosti }\end{array}$ & $\begin{array}{l}\text { Prednostna } \\
\text { varianta glede } \\
\text { na vse } \\
\text { navedene } \\
\text { kriterije }\end{array}$ \\
\hline $\begin{array}{l}\text { dedinja: } \\
\text { dedična }\end{array}$ & dedinja & dedinja & dedična/dedinja & dedinja & dedična & dedinja \\
\hline
\end{tabular}

Dedična je nastala $\mathrm{z}$ dodajanjem ženskospolskega obrazila $-n a \mathrm{k}$ moškospolskemu poimenovanju dedič, torej vršilcu dejanja na -ič, dedinja pa $\mathrm{z}$ zamenjavo moškospolskega priponskega obrazila -ič z obrazilom -inja.

\subsubsection{Variantni priponski obrazili -ka/-(ev)ka}

\section{zlodejka > zlodejevka}

Obe besedi navajata SSKJ 1 in 2: zlodejevka lahko pomeni slabš. 'zlobna, hudobna ženska', zlodejka pa nastopa $\mathrm{v}$ dveh pomenih in poleg navedenega pomeni še zastar. 'čarovnica'. Obe varianti navaja tudi SP: zlodejko kot feminativno obliko k zlodeju ('zloben, hudoben človek'), tvorjeno z dodajalnim načinom, zlodejevka pa je zabeležena kot podiztočnica k slovarskemu geslu zlodejevec ('zloben, hudoben človek'), torej ne nastane $\mathrm{z}$ dodajanjem, ampak z zamenjavo moškospolskega priponskega obrazila -ec s -ka. Pojavitve po korpusu Gigafida pa so skromne: zlodejko potrjujejo le tri konkordance, zlodejevke pa nobena. Preverili smo še po Novi besedi in Kresu, ki pa za nobeno možnost ne ponujata pojavitev. Sinteza obrazilne produktivnosti pa o boljši možnosti ne more odločati; če upoštevamo načelo ekonomičnosti in racionalnosti, je bolje uporabiti obrazilo - $k a$.

Preglednica 90: Variantni priponski obrazili -ka in -(ev)ka

\begin{tabular}{|l|l|l|l|l|l|l|}
\hline Variante & $\begin{array}{l}\text { Prednostna } \\
\text { varianta po } \\
\text { zastopanosti v } \\
\text { jez. priročnikih } \\
(\text { SSKJ 1, SP, } \\
\text { NSL, SSKJ 2) }\end{array}$ & $\begin{array}{l}\text { Prednostna } \\
\text { varianta } \\
\text { glede na } \\
\text { pomensko } \\
\text { obremenitev }\end{array}$ & $\begin{array}{l}\text { Prednostna } \\
\text { varianta glede na } \\
\text { slogovno } \\
\text { (ne)zaznamova- } \\
\text { nost }\end{array}$ & $\begin{array}{l}\text { Prednostna } \\
\text { varianta po } \\
\text { pogostnosti } \\
\text { (korpusi, } \\
\text { splet) }\end{array}$ & $\begin{array}{l}\text { Prednostna } \\
\text { varianta po } \\
\text { sintezi } \\
\text { obrazilne } \\
\text { produktivnosti }\end{array}$ & $\begin{array}{l}\text { Prednostna } \\
\text { varianta } \\
\text { glede na vse } \\
\text { navedene } \\
\text { kriterije }\end{array}$ \\
\hline $\begin{array}{l}\text { zlodejka: } \\
\text { zlodejevka }\end{array}$ & $\begin{array}{l}\text { zlodejka/ } \\
\text { zlodejevka }\end{array}$ & $\begin{array}{l}\text { zlodejka/ } \\
\text { zlodejevka }\end{array}$ & zlodejevka & zlodejka & zlodejka & zlodejka \\
\hline
\end{tabular}




\subsubsection{Poimenovanja živali}

\subsubsection{Variantni priponski obrazili -ical-(ev)ka}

\section{jazbica < jazbečevka}

Po obeh izdajah SSKJ je jazbečevka razložena kot 'samica jazbeca'. Jazbica v SSKJ nastopa s pomensko razlago 'jazbečevka'. SP navaja samo varianto jazbečevka kot feminativ k jazbecu, po korpusu pa sta obe možnosti dokaj izenačeni: za jazbečevko Gigafida ponudi pet konkordanc, za jazbico pa štiri. Izvedli smo dodatno preverjanje po Novi besedi (jazbečevka 2, jazbica 2 zadetka), Kresu (jazbečevka 1, jazbica 1 pojavitev) in Googlu (jazbečevka 30, jazbica 22 zadetkov), ki prav tako kaže na izenačenost obeh variant v rabi. Sinteza obrazilne produktivnosti kaže naslednje: priponsko obrazilo -ica lahko zamenjuje moškospolsko obrazilo -ec pri 21 primerih oz. 4,4\%. Obrazilo -(ev)ka pa, razen pri tem primeru, ne nastopi kot dodajalno $\mathrm{k}$ izglasju na $-c$.

Preglednica 91: Variantni priponski obrazili -ica in -(ev)ka pri poimenovanjih živali

\begin{tabular}{|c|c|c|c|c|c|c|}
\hline Variante & $\begin{array}{l}\text { Prednostna } \\
\text { varianta po } \\
\text { zastopanosti v } \\
\text { jez. priročnikih } \\
(S S K J 1, S P \text {, } \\
N S L, S S K J 2) \\
\end{array}$ & $\begin{array}{l}\text { Prednostna } \\
\text { varianta } \\
\text { glede na } \\
\text { pomensko } \\
\text { obremenitev }\end{array}$ & $\begin{array}{l}\text { Prednostna } \\
\text { varianta glede na } \\
\text { slogovno } \\
\text { (ne)zaznamova- } \\
\text { nost }\end{array}$ & $\begin{array}{l}\text { Prednostna } \\
\text { varianta po } \\
\text { pogostnosti } \\
\text { (korpusi, } \\
\text { splet) }\end{array}$ & $\begin{array}{l}\text { Prednostna } \\
\text { varianta po } \\
\text { sintezi } \\
\text { obrazilne } \\
\text { produktivnosti }\end{array}$ & $\begin{array}{l}\text { Prednostna } \\
\text { varianta } \\
\text { glede na vse } \\
\text { navedene } \\
\text { kriterije }\end{array}$ \\
\hline $\begin{array}{l}\text { jazbica: } \\
\text { jazbečevka }\end{array}$ & jazbečevka & jazbečevka & $\begin{array}{l}\text { jazbica/ } \\
\text { jazbečevka }\end{array}$ & jazbečevka & jazbica & jazbečevka \\
\hline
\end{tabular}

Jazbečevka je tvorjena $\mathrm{z}$ dodajanjem priponskega obrazila -(ev)ka samostalniku moškega spola, pri tem pa je prišlo do glasovne premene. Jazbica je tvorjena $\mathrm{z}$ zamenjevalnim načinom, ko feminativno priponsko obrazilo -ica zamenja moškospolsko obrazilo -ec.

\subsubsection{Variantna priponska obrazila -ica/-ulja/-(ev)ka}

\section{vrabica $=$ vrabulja $<$ vrabčevka}

Vrabčevka nastane $\mathrm{z}$ dodajanjem priponskega obrazila -(ev)ka samostalniku moškega spola, vrabica in vrabulja pa sta nastali z zamenjavo moškospolskega 
priponskega obrazila -ec $\mathrm{z}$ obrazilom -ica oz. -ulja. Vrabčevka in vrabulja sta $\mathrm{v}$ obeh izdajah SSKJ razloženi kot 'samica vrabca', vrabica pa je označena $\mathrm{s}$ kvalifikatorjem nar. v pomenu 'vrabčevka, vrabulja'. SP navaja samo varianti vrabčevka in vrabulja, a obe kot slogovno nezaznamovani. Razmerje po korpusu Gigafida pa je sledeče: vrabčevka 56 pojavitev, vrabica ena pojavitev, vrabulja dve pojavitvi. Glede na sintezo obrazilne produktivnosti ugotavljamo naslednje (za poimenovanja oseb): pri zamenjevalnih obrazilih -ulja in -ica bi dali prednost slednji, saj zamenja moškospolsko obrazilo -ec $\mathrm{v} 21$ primerih, -ulja pa pri nobenem. Obrazilo - $(e v) k a$ pa se sicer ne pojavlja pri izglasjih na $-(e) c$.

Preglednica 92: Variantna priponska obrazila -ica, -ulja in -(ev)ka pri poimenovanjih živali

\begin{tabular}{|c|c|c|c|c|c|c|}
\hline Variante & $\begin{array}{l}\text { Prednostna } \\
\text { varianta po } \\
\text { zastopanosti v } \\
\text { jez. priročnikih } \\
(S S K J 1, S P \text {, } \\
N S L, S S K J 2)\end{array}$ & $\begin{array}{l}\text { Prednostna } \\
\text { varianta } \\
\text { glede na } \\
\text { pomensko } \\
\text { obremenitev }\end{array}$ & $\begin{array}{l}\text { Prednostna } \\
\text { varianta glede } \\
\text { na slogovno } \\
\text { (ne)zaznamova- } \\
\text { nost }\end{array}$ & $\begin{array}{l}\text { Prednostna } \\
\text { varianta po } \\
\text { pogostnosti } \\
\text { (korpusi, } \\
\text { splet) }\end{array}$ & $\begin{array}{l}\text { Prednostna } \\
\text { varianta po } \\
\text { sintezi } \\
\text { obrazilne } \\
\text { produktivnosti }\end{array}$ & $\begin{array}{l}\text { Prednostna } \\
\text { varianta } \\
\text { glede na vse } \\
\text { navedene } \\
\text { kriterije }\end{array}$ \\
\hline $\begin{array}{l}\text { vrabica/ } \\
\text { vrabulja/ } \\
\text { vrabčevka }\end{array}$ & $\begin{array}{l}\text { vrabulja/ } \\
\text { vrabčevka }\end{array}$ & $\begin{array}{l}\text { vrabulja/ } \\
\text { vrabčevka }\end{array}$ & $\begin{array}{l}\text { vrabulja/ } \\
\text { vrabčevka }\end{array}$ & vrabčevka & vrabica & vrabčevka \\
\hline
\end{tabular}

\subsection{Zamenjevanje obrazila}

Nekatera variantna feminativna priponska obrazila lahko zamenjujejo moškospolsko priponsko obrazilo ob isti podstavi in istem pomenu. Taki pari obrazil so -ica in -inja, -ja in -ka, -ica in - $k a$ za poimenovanja oseb ter skupina priponskih obrazil -ica, -ulja in -(ev)ka za poimenovanja živali.

\subsubsection{Poimenovanja oseb}

\subsubsection{Variantni priponski obrazili -ical-inja}

\section{kolegica > koleginja}

Kolegica je po SSKJ 1 večpomenka: 1. 'ženska, ki ima s kom enak poklic ali je zaposlena v isti ustanovi'; 2. pog. 'tovarišica, prijateljica'. Koleginja pa v istem jezikovnem priročniku nastopa zaznamovana s kvalifikatorjem zastar. in zgolj s pomensko razlago 'kolegica, prijateljica'. Enako je v SSKJ 2 (le da je kolegica v 
drugem pomenu brez kvalifikatorja), SP pa ponuja samo izraz kolegica, pri katerem kot nevtralnejšo možnost navaja sodelavko, kot knj. pog. pa besedo označuje, kadar je mišljena 'tovarišica, prijateljica'. Kolegica je pogostejša tudi v rezultatih korpusne analize, saj jo potrdijo kar 23.704 konkordance, medtem ko za koleginjo korpus Gigafida ponudi le dve pojavitvi. Sicer pa moškospolsko obrazilo - $a$ zamenja ženskospolska -inja pri treh primerih (skupno $60 \%$ ), -ica pa le pri enem (20\%); po zamenjavi gre za dodajanje k izglasju podstave na -g, kjer je pogostejše obrazilo -ica s štirimi primeri (z -inja le dva).

Preglednica 93: Variantni priponski obrazili -ica in -inja

\begin{tabular}{|c|c|c|c|c|c|c|}
\hline Variante & $\begin{array}{l}\text { Prednostna } \\
\text { varianta po } \\
\text { zastopanosti v } \\
\text { jez. priročnikih } \\
(S S K J 1, S P, \\
N S L, S S K J 2)\end{array}$ & $\begin{array}{l}\text { Prednostna } \\
\text { varianta } \\
\text { glede na } \\
\text { pomensko } \\
\text { obremenitev }\end{array}$ & $\begin{array}{l}\text { Prednostna } \\
\text { varianta glede } \\
\text { na slogovno } \\
\text { (ne)zaznamova- } \\
\text { nost }\end{array}$ & $\begin{array}{l}\text { Prednostna } \\
\text { varianta po } \\
\text { pogostnosti } \\
\text { (korpusi, } \\
\text { splet) }\end{array}$ & $\begin{array}{l}\text { Prednostna } \\
\text { varianta po } \\
\text { sintezi } \\
\text { obrazilne } \\
\text { produktivnosti }\end{array}$ & $\begin{array}{l}\text { Prednostna } \\
\text { varianta glede } \\
\text { na vse } \\
\text { navedene } \\
\text { kriterije }\end{array}$ \\
\hline $\begin{array}{l}\text { kolegica : } \\
\text { koleginja }\end{array}$ & kolegica & kolegica & kolegica & kolegica & kolegica & kolegica \\
\hline
\end{tabular}

Obe zgoraj obravnavani feminativni variantni obrazili zamenjata moškospolsko priponsko obrazilo - $a$.

\subsubsection{Variantni priponski obrazili -ja/-ka}

pletilja $<$ pletilka

Pletilja je po obeh SSKJ 'ženska, ki se poklicno ukvarja s pletenjem oblačil', pletilka pa lahko pomeni dvoje: 1. 'podolgovat, tanjši, na enem koncu ošiljen predmet za pletenje'; 2. 'ženska, ki plete'. V SP sta navedeni obe možnosti kot feminativni podiztočnici k pletilcu, a nobena ni slogovno zaznamovana. Korpusni rezultati pa so sledeči: pletiljo potrjuje 235 konkordanc, pletilko pa 1153 konkordanc; slednje je zagotovo posledica večpomenskosti, kar je pokazal tudi natančnejši pregled dobljenih konkordanc. Moškospolsko obrazilo -ilec pa pogosteje zamenjuje feminativno obrazilo - $k a$ (95\%); po zamenjevalnem načinu gre za dodajanje ženskospolskega obrazila $\mathrm{k}$ izglasju podstave na $-l$, kjer pogosteje nastopi obrazilo -ka (279 primerov, z -ja le dva). 
Preglednica 94: Variantni priponski obrazili -ja in -ka

\begin{tabular}{|l|l|l|l|l|l|l|}
\hline Variante & $\begin{array}{l}\text { Prednostna } \\
\text { varianta po } \\
\text { zastopanosti v } \\
\text { jez. priročnikih } \\
(\text { SSKJ 1, SP, } \\
\text { NSL, SSKJ 2) }\end{array}$ & $\begin{array}{l}\text { Prednostna } \\
\text { varianta glede } \\
\text { na pomensko } \\
\text { obremenitev }\end{array}$ & $\begin{array}{l}\text { Prednostna } \\
\text { varianta glede } \\
\text { na slogovno } \\
\text { ne)zaznamova- } \\
\text { nost }\end{array}$ & $\begin{array}{l}\text { Prednostna } \\
\text { varianta po } \\
\text { pogostnosti } \\
\text { (korpusi, } \\
\text { splet) }\end{array}$ & $\begin{array}{l}\text { Prednostna } \\
\text { varianta po } \\
\text { sintezi } \\
\text { obrazilne } \\
\text { produktivnosti }\end{array}$ & $\begin{array}{l}\text { Prednostna } \\
\text { varianta } \\
\text { glede na vse } \\
\text { navedene } \\
\text { kriterije }\end{array}$ \\
\hline $\begin{array}{l}\text { pletilka : } \\
\text { pletilja }\end{array}$ & pletilka/pletilja & pletilja & pletilka/pletilja & pletilja & pletilka & pletilja \\
\hline
\end{tabular}

Obe variantni priponski obrazili zamenjujeta moškospolsko obrazilo -ec v pomenski skupini vršilec.

\subsubsection{Variantni priponski obrazili -ical-ka}

\section{jalovica $<$ jalovka}

Jalovka in jalovica sta nastali z zamenjavo moškospolskega priponskega obrazila -ec z ženskospolskim obrazilom -ka oz. -ica. Jalovka po obeh izdajah SSKJ pomeni 'jalovo samico' $\mathrm{s}$ podpomenom slabš. 'neplodna ženska', slovarski sestavek pa ima tudi terminološko gnezdo čeb. 'matica, ki zalega neoplojena jajčeca'. Jalovica pa je redko 'jalova samica; jalovka' s podpomenom nar. 'neplodna ženska'. SP ponuja le obliko jalovka kot feminativ k jalovcu, ta možnost pa je pogostejša tudi po Gigafidi, saj je potrjena z 49 konkordancami, za jalovico pa po korpusu najdemo le eno pojavitev. Tudi sinteza obrazilne produktivnosti govori $\mathrm{v}$ prid obliki jalovka: priponsko obrazilo $-k a$ namreč zamenjuje moškospolsko obrazilo -ec v $95 \%$ primerov, -ica le v 4,4\%; tudi sicer se $\mathrm{k}$ izglasju na $-v$ pogosteje dodaja obrazilo $-k a$, kar potrjuje 153 primerov (z -ica le štirje).

\section{krščenica $<\boldsymbol{k r s ̌ c ̌ e n k a}$}

Krščenka je po SSKJ 1 'ženska oblika od krščenec' (pri čemer ni zaznamovana z

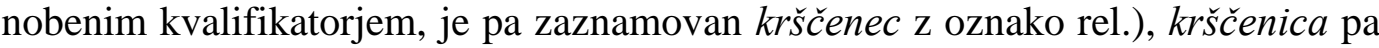
nastopa v dveh pomenih: star. 1. 'služabnica, dekla', 2. 'krščenka'. Po SSKJ 2 pa je krščenka označena s kvalifikatorjem rel. in pomeni 'ženska, ki je bila krščena ali se pripravlja na krst' s podpomenom 'krščena ženska v odnosu do svojega botra'. Slovarski sestavek pri geslu krščenica pa je enak tistemu iz prve izdaje slovarja. $S P$ vsebuje le krščenko ob krščencu; prednost tej varianti pa daje tudi Gigafida, ki 
krščenko potrjuje s 44 konkordancami, pri krščenici pa jih je zgolj sedem. Tudi v tem primeru lahko glede na sintezo obrazilne produktivnosti kot boljšo možnost predlagamo tisto, tvorjeno z obrazilom $-k a$, saj zamenjavo moškospolskega -ec potrjuje kar 453 primerov (95\%); k izglasju podstave na $-n$ pa se po zamenjavi moškospolskega obrazila pogosteje doda obrazilo -ica, kar potrjuje 424 primerov (s -ka 215).

\section{lovica $<$ lovka}

Lovka po obeh izdajah SSKJ pomeni 'žensko, ki se ukvarja z lovom'. Beseda pa je popisana kot enakozvočnica; lovka, navadno v množini, namreč lahko pomeni tudi 'gibljiv organ nekaterih nižje razvitih živali za lovljenje hrane, tipanje'. Izraz lovica je zaznamovan s kvalifikatorjem star., nastopa pa v pomenu 'ženska, ki se ukvarja z lovom'. V SP kot feminativ k lovcu najdemo le lovko, prednost pa ji daje tudi Gigafida, kar je najbrž pogojeno tudi z enakozvočnostjo (lovka 3868 konkordanc, lovica 30 konkordanc). Priponsko obrazilo -ka je tisto, ki pogosteje zamenjuje moškospolsko obrazilo $-e c$, in sicer v $95 \%$ primerov. Kot smo že ugotovili, se $\mathrm{k}$ izglasju podstave na $-v$ po zamenjavi moškospolskega obrazila mnogo pogosteje dodaja obrazilo $-k a(97,5 \%)$.

\section{slepica $<$ slepka}

Po obeh izdajah SSKJ je slepka knjiž. 'slepa ženska', beseda slepica pa nastopa v dveh pomenih (knjiž. 1. 'slepa ženska' s podpomenom 'ženska, ki česa ne opazi, dojame'; 2. 'preprosta svetilka'), slovarski sestavek pa ima tudi frazeološko (imeti slepice na očeh 'plašnice'; nar. notranjsko utrgati nekaj slepic 'telohov') in terminološko gnezdo (les. grča, prekrita s poznejšim večletnim prirastkom lesa; zool. majhna kača $\mathrm{z}$ valjastim gladkim telesom in kratkim repom, Typhlops vermicularis). Obe varianti zasledimo tudi $\mathrm{v} S P$, a je slepica označena kot neobčevalna, slepka pa kot nevtralnejša možnost. Drugačne ugotovitve ponuja korpus Gigafida, po katerem je pogostejša slepica (113 konkordanc, a večinoma neustreznih; za slepko samo 15 zadetkov). Tudi pri teh dveh variantah ima glede na sintezo obrazilne produktivnosti prednost tista, tvorjena $\mathrm{z}$ obrazilom -ka. Tudi 
ob izglasju podstave na - $p$ po zamenjavi moškospolskega obrazila je pogostejše obrazilo - $k a$ (pet primerov, z -ica le eden).

\section{starica $<$ starka}

Starka po SSKJ 1 pomeni 'staro žensko' s podpomenom star. 'ptičja samica', slovarski sestavek pa ima tudi frazeološko gnezdo (ekspr. starka zima se že poslavlja 'zima'; ekspr. prišla je starka s koso 'smrt'; zastar. moje starke ni doma 'žene'). Beseda starica pa je označena s kvalifikatorjem knjiž. in ima le razlago pomena 'starka'. SP navaja samo varianto starka, njeno pogostejšo rabo pa potrjuje tudi korpusna analiza (starka 5132 konkordanc, starica 18 konkordanc). Ponovno pa damo prednost varianti s $-k a$, saj tudi glede na sintezo obrazilne produktivnosti to obrazilo prevladuje (95 \%), kadar gre za zamenjavo moškospolskega -ec. $\mathrm{K}$ izglasjem podstav na $-r$ se po zamenjavi moškospolskega obrazila pogosteje dodaja obrazilo - $k a$ (20 primerov, le dva z -ica).

Preglednica 95: Variantni priponski obrazili -ica in -ka

\begin{tabular}{|l|l|l|l|l|l|l|}
\hline Variante & $\begin{array}{l}\text { Prednostna } \\
\text { varianta po } \\
\text { zastopanosti v } \\
\text { jez. priročnikih } \\
\text { (SSKJ 1, SP, } \\
\text { NSL, SSKJ 2) }\end{array}$ & $\begin{array}{l}\text { Prednostna } \\
\text { varianta } \\
\text { glede na } \\
\text { pomensko } \\
\text { obremenitev }\end{array}$ & $\begin{array}{l}\text { Prednostna } \\
\text { varianta glede na } \\
\text { slogovno } \\
\text { (ne)zaznamova- } \\
\text { nost }\end{array}$ & $\begin{array}{l}\text { Prednostna } \\
\text { varianta po } \\
\text { pogostnosti } \\
\text { (korpusi, } \\
\text { splet) }\end{array}$ & $\begin{array}{l}\text { Prednostna } \\
\text { varianta po } \\
\text { sintezi } \\
\text { obrazilne } \\
\text { produktivnosti }\end{array}$ & $\begin{array}{l}\text { Prednostna } \\
\text { varianta } \\
\text { glede na vse } \\
\text { navedene } \\
\text { kriterije }\end{array}$ \\
\hline $\begin{array}{l}\text { jalovica : } \\
\text { jalovka }\end{array}$ & jalovka & $\begin{array}{l}\text { jalovka/ } \\
\text { jalovica }\end{array}$ & jalovka & jalovka & jalovka & jalovka \\
\hline $\begin{array}{l}\text { krščenica : } \\
\text { krščenka }\end{array}$ & krščenka & krščenka & krščenka & krščenka & $\begin{array}{l}\text { krščenka/ } \\
\text { krščenica }\end{array}$ & krščenka \\
\hline $\begin{array}{l}\text { lovica : } \\
\text { lovka }\end{array}$ & lovka & lovica & lovka & lovka & slepka & slepka \\
\hline $\begin{array}{l}\text { slepica : } \\
\text { llepka }\end{array}$ & slepka/slepica & slepka & slepka & starka & starka & starka \\
\hline $\begin{array}{l}\text { starica }: \\
\text { starka }\end{array}$ & starka & starka & starka & & \\
\hline
\end{tabular}

Priponski obrazili -ica in $-k a$ kot variantni $\mathrm{v}$ vseh analiziranih primerih zamenjujeta obrazilo $-e c$, in to $\mathrm{v}$ štirih primerih pri nosilcu in enkrat pri vršilcu.

\subsection{Sklep}

Pri analizi feminativov iz različnih virov smo opazili veliko število tvorjenk, kjer sta se ob isti podstavi pojavili dve variantni obrazili, velikokrat tri in enkrat celo po štiri. Večinoma gre za domača priponska obrazila, prevzeto je le 
obrazilo -esa. Po pregledu obeh izdaj Slovarja slovenskega knjižnega jezika, Slovenskega pravopisa, Slovarja novejšega besedja slovenskega jezika in Novejše slovenske leksike smo ob izpisanih variantah opazovali večpomenskost in slogovno zaznamovanost, pogostnost rabe pa smo preverili po korpusu Gigafida, po potrebi, tj. ob nizkem ali izenačenem številu konkordanc, pa še po Novi besedi, Kresu in Googlu. Pri odločanju, katera od navedenih možnosti je primernejša, smo upoštevali tudi sintezo obrazilne produktivnosti. Glede na vse našteto smo predlagali ustreznejšo od variant.

Ugotavljamo, da variantna priponska obrazila večinoma nastopijo pri dodajalnem načinu tvorbe. Kot dodajalni se pojavijo pari variantnih priponskih obrazil -ica in - $\boldsymbol{k} \boldsymbol{a} \mathrm{k}$ izglasjem na $-(V) \check{c},-(V) n,-(V) r$; -ica in -inja $\mathrm{k}$ izglasjem na $-(V) \check{c}$ in $-(V) f$; -inja in - $\boldsymbol{k a}$ k izglasjem (podstave) na $-d,-(V) f,-(u) h,-(V) j,-(V) l$, $-(V) \check{s},-t ;-\boldsymbol{c a}$ in $-\boldsymbol{k} \boldsymbol{a} \mathrm{k}$ izglasju na $-(V) r ;-\boldsymbol{c} \boldsymbol{c} \boldsymbol{a}$ in -(ov)ka k izglasjem moškospolskih samostalnikov na $-(V) r$ in $-t ;-\boldsymbol{a}$ in -inja k izglasjem (podstave) na $-d$ in $-(u) h ;-\boldsymbol{a}$ in -ka $\mathrm{k}$ izglasju na $-(V) \check{c}$; -inja in -(ov)ka $\mathrm{k}$ izglasju podstave na $-d$; -ja in -inja $\mathrm{k}$ izglasju na $-t$; -inja in -(ar)ka $\mathrm{k}$ izglasju podstave na $-k$, vse našteto za poimenovanja oseb. Včasih se lahko ob enaki podstavi in pomenu dodajo celo tri priponska obrazila: -ica/-ja/-ka ob le dveh primerih $\mathrm{k}$ izglasju na $-(V) n$; -ica/-inja/-ka zgolj pri enem primeru $\mathrm{k}$ izglasju podstave na -l; -inja/-ka/-esa $\mathrm{k}$ izglasju na - $t$ pri samo enem konkretnem primeru; -lja/-ulja/-ka z enim primerom na izglasje podstave - $c$ ter -ica/-ulja/-(ov)ka, ki nastopijo ob izglasju podstave na - $g$, prav tako pri ženskospolskih poimenovanjih oseb.

Kadar gre za tvorbo feminativnih poimenovanj živali, pa kot variantni nastopijo naslednji pari: $-\boldsymbol{i c a}$ in $-\boldsymbol{k} \boldsymbol{a}$ ob izglasjih (podstav) na $-b,-d,-(V) r$; $-\boldsymbol{i c} \boldsymbol{a}$ in -ulja ob samo enem primeru z izglasjem na $-(V) k$; $-\boldsymbol{a}$ in -inja $\mathrm{k}$ izglasju podstave na $-s$; -ica in -inja kot dodajalni k izglasju podstave na $-v$; -inja in -(ov)ka $\mathrm{k}$ izglasju moškospolskih samostalnikov na -z; -ica in -(ov)ka k izglasju podstave na $-d$ in $-m$. Zasledili pa smo celo skupino štirih variantnih priponskih obrazil, to so -ica, -lja, -ulja in -(ov)ka ob izglasju podstave na $-k$.

Opažamo, da je v nekaj primerih eno od variantnih priponskih obrazil dodajalno, drugo pa zamenjevalno. Taki pari obrazil so trije: -inja in -na (-na se doda izglasju na $-k$; -inja pa zamenja moškospolsko priponsko obrazilo -ič) ter $-\boldsymbol{k a}$ 
in -(ev)ka (-ka se dodaja izglasju na $-j,-(e v) k a$ pa zamenjuje moškospolsko obrazilo $-e c)$ za poimenovanja oseb; -ica in $-(\boldsymbol{e v}) \boldsymbol{k} \boldsymbol{a}$ pa za poimenovanja živali $(-(e v) k a$ se dodaja k izglasju na $-c$, -ica pa zamenja priponsko obrazilo -ec).

Nekatera variantna feminativna priponska obrazila lahko zamenjujejo moškospolsko obrazilo ob enaki podstavi in pomenu. Taki pari obrazil so -ica in -inja, ki zamenjujeta priponsko obrazilo $-\boldsymbol{a},-j \boldsymbol{a}$ in $-\boldsymbol{k} \boldsymbol{a}$, ki zamenjata moškospolsko priponsko obrazilo -ec; -ica in -ka kot menjava priponskega obrazila -ec, vse za poimenovanja oseb, ter skupina feminativnih obrazil -ica, -ulja in -(ev)ka za poimenovanja živali, zamenjajo pa moškospolsko obrazilo -ec.

\section{OMEJENA TVORBA FEMINATIVOV}

Besedotvorne analize iz osemdesetih in devetdesetih let prejšnjega stoletja izpostavljajo moškospolska poimenovanja oseb, h katerim ni mogoče tvoriti ustreznega feminativa. Ugotavljali smo, ali v sodobnem knjižnem jeziku feminativi k izpostavljenim primerom že obstajajo oz. ali njihovo obliko lahko predvidimo. V ta namen smo uporabili obe izdaji SSKJ, spletni rastoči Slovar slovenskega knjižnega jezika (SSKJ 3), SNBSJ, SP, Pleteršnikov Slovensko-nemški slovar, ozrli pa smo se tudi po korpusih Gigafida, Kres in Nova beseda. Zavedamo se, da raba $\mathrm{v}$ navedenih korpusih, ki vključujejo besedila do leta 2010/11, leta 2018 ne zadostuje več za preverjanje aktualne jezikovne prakse, zato smo $\mathrm{v}$ raziskavo vključili tudi poizvedbe iz korpusa nestandardne slovenščine Janes in spletnega iskalnika Google.

$\mathrm{V}$ nadaljevanju smo opazovali, kateri feminativi se na novo pojavijo $\mathrm{v}$ SSKJ 2 v primerjavi s SSKJ 1, nato pa še v Sprotnem slovarju slovenskega jezika, SSKJ 3, v jezikovnih korpusih in na svetovnem spletu; pri tem smo v SSKJ 2 in 3 zaznali opuščanje t. i. navezovalne razlage z ženska oblika od, ki je kazala očitno odvisnost od moškospolskega poimenovanja (denimo raziskovalka po SSKJ 1 'ženska oblika od raziskovalec', po SSKJ 2 pa 'ženska, ki se (poklicno) ukvarja z raziskovanjem'); gre torej za od moškega neodvisno razlago pomena s ključnimi besedami uslužbenka, pripadnica, pristašinja, delavka, članica, strokovnjakinja, 
učenka. Pri primerih morebitne odsotnosti ženskospolskih vzporednic $\mathrm{k}$ moškospolskim poimenovanjem pa smo skušali pojasniti vzroke.

\subsection{Težavnejše vzporedne ženskospolske oblike}

O omejeni tvorbi feminativov se je spraševalo precej jezikoslovcev, med njimi tudi Jože Toporišič (1981: 79-94) in Marija Jež (1997: 103). Slednji so se zdele vprašljive ženskospolske vzporednice $\mathrm{k}$ besedam pešec, filharmonik, pisec, grafik, a feminativi po $S P \mathrm{k}$ navedenim primerom že obstajajo: peška, filharmoničarka, grafikinja (po obeh izdajah SSKJ sicer grafičarka). Preseneča odsotnost feminativa piska v vseh jezikovnih priročnikih, glede na to, da SSKJ 2 že ponuja feminative besedilopiska, romanopiska, strojepiska, jo pa zato najdemo v korpusnem gradivu Gigafide, potrjeno z 19 ustreznimi konkordancami.

Še posebej pa nas je k razmisleku spodbudil članek Jožeta Toporišiča (1981), po katerem tvorba feminativov v slovenščini vedno ni mogoča. Kot primer zadrege navaja samostalnika moškega spola kosec in jedec. S tega stališča, torej s stališča težav pri tvorbi feminativov, bi bilo treba pregledati vsa ustrezna moška priponska obrazila in še posamezne podstave, s katerimi so družljiva. Po pregledu ustreznih list v Slovenski slovnici (1976) so po Toporišiču ${ }^{109}$ ostali brez ustreznih ženskih parov z glagolsko podstavo vodja (možno je le voditeljica), sluga (možno služkinja), govorec, jezdec, hvalec, igrc, videc, jedec (imamo pa ob lovcu tudi lovko), brivec, čenčač (prim. čenča ž), bahač, količ, gonič (imamo pa vodiča in vodičko), smrduh (možno smrdela?), ovaduh (ovaduhinja?), dremavh (dremavhlja?), spovednik, učenik (imamo pa svečenik - svečenica), postrežček (žensko le postrežnica), godrnjavs (godrnjavslja?), klatež, gulež (guležka?). Pri tvorbah s pridevniško podstavo so brez ženskega para hromec, butec, svojec, hudič (hudičela?), mladič, slabič, ordinarij, bedak, četverček (vendar dvojček dvojčica), aristotelik (prim. alkoholičarka), dolgan (dolginka), grdun, debelko, rdečko (vendar naivko - naivka), grdavs (grdavslja?), enako grdavš, hudobněz (hudobnica), duhovitež. Pri tvorbah iz samostalniške podstave so brez najbližjega

$109 \mathrm{~V}$ oklepajih ob moškospolskih poimenovanjih bitij navajamo Toporišičeve predloge ženskospolskih vzporednic, njegove komentarje le-teh in morebitne pomisleke. 
para (ali sploh brez njega) zemljepisec (zemljepisarka?), grafik (grafičarka), bombaš (bombašica?), kočijaž (kočijažinja?), burkež, prismodež (ž. prismoda), klarisinja, uršulinka, grbec (grbavka), bradač (bradačka?). Seveda na ustrezni par ne moremo računati v primerih, kjer ga $\mathrm{v}$ resnici, $\mathrm{tj}$. predmetno ni, na primer klarisec ali kaj podobnega h klarisinja; ponekod se pri parih pojavijo tudi pomenske razlike (Toporišič 1981: 92-93).

Spodnja preglednica prikazuje tista moškospolska poimenovanja oseb, za katera Toporišič (1981) meni, da ostajajo brez vzporednega feminativa; v nekaterih primerih sicer predlaga ženskospolske vzporednice (drugi stolpec), nekaj feminativov pa že ponujajo novejši jezikovni priročniki oz. korpusi (tretji stolpec). ${ }^{110}$

Preglednica 96: Omejena tvorba feminativov

\begin{tabular}{|l|l|l|}
\hline $\begin{array}{l}\text { Moškospolsko } \\
\text { poimenovanje bitja }\end{array}$ & $\begin{array}{l}\text { Toporišičev predlog } \\
\text { feminativa (1981) }\end{array}$ & $\begin{array}{l}\text { Feminativ po novejših virih oz. } \\
\text { predlog pričujoče analize }\end{array}$ \\
\hline kosec & $/$ & kosica \\
\hline vodja & voditeljica & vodkinja \\
\hline sluga & služkinja & sluginja \\
\hline govorec & $/$ & govorka \\
\hline jezdec & $/$ & $\begin{array}{l}\text { družbenozgodovinsko pogojena } \\
\text { odsotnost }\end{array}$ \\
\hline hvalec & & $\begin{array}{l}\text { odsotnost moškospolskega } \\
\text { poimenovanja v sodobnem jeziku }\end{array}$ \\
\hline igrc & $/$ & $\begin{array}{l}\text { družbenozgodovinsko pogojena } \\
\text { odsotnost }\end{array}$ \\
\hline videc & $/$ & vidkinja \\
\hline jedec & & jedka \\
\hline
\end{tabular}

${ }^{110} \mathrm{~V}$ tretjem stolpcu so v ležečem tisku zapisana v priročnikih in korpusih potrjena ženskospolska poimenovanja, v pokončnem tisku pa naši predlogi oz. ugotovitve. O biološko pogojeni odsotnosti govorimo, kadar gre za navezanost na biološko tipične lastnosti ženskih oz. moških človeških bitij. Kadar moškospolske oblike ne najdemo v nobenem od novejših jezikovnih priročnikov ( $S P, S S K J$ 1, SSKJ 2, SSKJ 3, SNBSJ, Sprotni slovar slovenskega jezika), govorimo o odsotnosti uslovarjene moškospolske oblike $\mathrm{v}$ sodobnem jeziku. Ob družbenozgodovinsko pogojeni odsotnosti pa mislimo na zgodovinska dejstva, ki kažejo na odsotnost žensk v prenekaterih dejavnostih - gre za žensko netipične poklice. Utemeljitve so zapisane v nadaljevanju analize. 


\begin{tabular}{|c|c|c|}
\hline $\begin{array}{l}\text { Moškospolsko } \\
\text { poimenovanje bitja }\end{array}$ & $\begin{array}{l}\text { Toporišičev predlog } \\
\text { feminativa (1981) }\end{array}$ & $\begin{array}{l}\text { Feminativ po novejših virih oz. } \\
\text { predlog pričujoče analize }\end{array}$ \\
\hline brivec & I & brivka \\
\hline$\check{c} \bar{c} n \check{a} a \check{c}$ & čenča & čenčačka \\
\hline bahač & I & bahačka \\
\hline količ & I & $\begin{array}{l}\text { odsotnost moškospolskega } \\
\text { poimenovanja v sodobnem jeziku }\end{array}$ \\
\hline gonič & I & gonička \\
\hline smrduh & smrdela? & smrduha, smrdulja \\
\hline ovaduh & ovaduhinja? & ovaduhinja \\
\hline dremavh & dremavhlja? & dremavhlja \\
\hline spovednik & I & $\begin{array}{l}\text { družbenozgodovinsko pogojena } \\
\text { odsotnost }\end{array}$ \\
\hline učenik & I & učenica \\
\hline postrežček & postrežnica & $\begin{array}{l}\text { družbenozgodovinsko pogojena } \\
\text { odsotnost }\end{array}$ \\
\hline godrnjavs & godrnjavslja? & godrnjavslja \\
\hline gulež & guležka? & guležka \\
\hline klatež & I & klatežka/klatežinja \\
\hline hromec & I & hromka \\
\hline butec & I & butka \\
\hline svojec & I & svojka \\
\hline hudič & hudičela? & hudičevka \\
\hline mladič & l & mladička \\
\hline slabič & I & slabička \\
\hline ordinarij & l & ordinarijka \\
\hline bedak & / & bedakinja \\
\hline četverček & I & četverčica \\
\hline aristotelik & I & aristotelovka \\
\hline dolgan & I & dolganka \\
\hline grdun & I & grdunka \\
\hline
\end{tabular}




\begin{tabular}{|c|c|c|}
\hline $\begin{array}{l}\text { Moškospolsko } \\
\text { poimenovanje bitja }\end{array}$ & $\begin{array}{l}\text { Toporišičev predlog } \\
\text { feminativa (1981) }\end{array}$ & $\begin{array}{l}\text { Feminativ po novejših virih oz. } \\
\text { predlog pričujoče analize }\end{array}$ \\
\hline debelko & / & debelka \\
\hline rdečko & / & rdečka \\
\hline grdavs & grdavslja? & grdavsa \\
\hline grdavš & grdavšlja? & grdavša \\
\hline hudobnež & hudobnica & hudobnica \\
\hline duhovitež & / & duhovitnica \\
\hline zemljepisec & zemljepisarka? & zemljepiska \\
\hline grafik & grafičarka & grafikinja/grafičarka \\
\hline bombaš & bombašica? & bombašica, bombašinja \\
\hline kočijaž & kočijažinja? & kočijažinja \\
\hline burkež & / & burkežinja \\
\hline prismoděz & prismoda & prismoda \\
\hline grbec & grbavka & grbavka \\
\hline bradač & bradačka? & biološko pogojena odsotnost \\
\hline
\end{tabular}

\subsection{Utemeljitve predlaganih ženskospolskih vzporednic}

Po pregledu že navedenih jezikovnih priročnikov in korpusov ugotavljamo, da lahko izsledke $\mathrm{v}$ grobem strnemo $\mathrm{v}$ dva sklopa. $\mathrm{V}$ prvem predstavljamo ženskospolske vzporednice, ki jih je bodisi mogoče najti v jezikovnih priročnikih bodisi njihovo rabo izpričujejo korpusi. V drugem sklopu razmišljamo o ženskospolskih vzporednicah, ki jih v jezikovnih virih ni mogoče najti zaradi a) časovne zaznamovanosti moško- in ženskospolske oblike, b) pragmatične omejitve za ženskospolsko poimenovanje, c) odsotnosti moškospolskega poimenovanja, č) v jeziku že uveljavljenih poimenovanj, ki se nanašajo na oba spola, d) delovanja drug(ačn)ega para.

\subsubsection{Prvi sklop: obstoječe ženskospolske vzporednice}

Feminativi, ki jih zasledimo v jezikovnih priročnikih in v korpusih 
V prvo skupino smo uvrstili enaindvajset feminativov, ki jih je mogoče najti $\mathrm{v}$ vsaj enem od navedenih jezikovnih priročnikov in katerih rabo potrjuje vsaj eden od korpusov. Sem sodijo naslednji feminativi:

1. Kosica je v SSKJ 2 'ženska, ki kosi (travo)', potrjuje jo tudi korpus Gigafida z 233 konkordancami. Sicer niso vse relevantne, jih pa je dovolj, da potrdijo rabo navedenega leksema, denimo:

Vsi, ki ste redno sledili zapisom o mednarodni tekmi koscev in kosic v Sarntalu, ste lahko ugotovili, da pri nas deluje zadeva na prostovoljni ravni.

2. Sluginjo najdemo v obeh izdajah SSKJ (nekdaj 'ženska, ki v kaki ustanovi, podjetju opravlja pomožna dela') in v $S P$ (kot feminativno podiztočnico k slugi). V korpusu Gigafida je sicer ob iskalnem pogoju sluginja mogoče najti le tri konkordance, npr.:

Z mamo sta stanovala ob šoli pri njegov babici, ki je bila sluginja na takratni osnovni šoli železničarske kolonije.

3. Govorka je v rabi že dokaj ustaljena, kar dokazuje 138 konkordanc po korpusu Gigafida, zabeležena pa je tudi v jezikovnih priročnikih (SSKJ 2 in SNBSJ kot 1. 'ženska, ki govori, pripoveduje'; 2. 'ženska, ki zna spretno govoriti, pripovedovati' s podpomenom 'ženska, ki neposredno podaja $\mathrm{v}$ javnosti sestavek o kaki stvari', v SP kot feminativ h govorcu).

4. Že SSKJ 1 navaja besedo vidkinja kot 'žensko obliko od vidca', druga izdaja slovarja pa jo razlaga kot 'žensko, ki na osnovi kakih znakov vidi neznane, prihodnje stvari'. Kot ženskospolsko vzporednico k vidcu jo ponuja tudi $S P$, po Gigafidi pa zanjo najdemo 94 pojavitev.

5. Feminativ jedka že navaja $S P$ kot podiztočnico k jedcu, ne najdemo pa je v nobeni izdaji SSKJ (samo kot 'sredstvo za jedkanje'). Zato pa jo potrjuje korpus Gigafida z 61 pojavitvami ob iskalnih pogojih občno ime, samostalnik ženskega spola v ednini, živost (s tem smo izločili pridevniške konkordance), denimo: 
6. Brivka je po obeh izdajah SSKJ 'ženska, ki se poklicno ukvarja z britjem in striženjem las', kot ženskospolsko vzporednico k brivcu pa jo navaja tudi $S P$. Najdemo jo v Standardni klasifikaciji poklicev, korpus Gigafida pa sicer zanjo ponuja le štiri pojavitve, npr.:

Nato sem še enkrat zbral pogum in spretno brivko zaprosil še za masažo lasišča.

7. Bahačka je zabeležena v obeh izdajah $S S K J$ kot 'ženska, ki se (rada) baha', v $S P$ pa nastopi kot feminativ k bahaču. Ponujata jo korpus Gigafida s tremi konkordancami in Nova beseda $\mathrm{z}$ eno:

\section{Nočem, da me oceni kot razsipnico ali bahačko.}

8. Gonič je po obeh izdajah $S S K J$ večpomenka: 1. 'kdor goni, vodi živino: postal je gonič pri karavani'; 2. 'večji lovski pes, navadno lisast' s podpomenom lov. 'pes, ki ob zasledovanju divjadi laja'. V enakem pomenu nastopi v SP. Ženskospolske vzporednice ne ponuja noben slovarski priročnik, jo pa zato najdemo v korpusu Gigafida s tremi konkordancami, a vse nastopijo v drugem navedenem pomenu, denimo:

Nov dom tokrat potrebuje triletna Lili, rodovniška posavska gonička.

9. Jezikovni priročniki (obe izdaji $S S K J, S P$ ) kot feminativ k smrduhu ponujajo smrduho (po obeh SSKJ slabš. 'ženska, ki smrdi'), tudi smrduljo. Korpus Gigafida potrjuje obe: za smrduho (ob pogoju, da gre za samostalnik ženskega spola, ne moškospolsko poimenovanje $\mathrm{v}$ rodilniku, tožilniku ali $\mathrm{v}$ imenovalniku dvojine) ponudi 27 konkordanc, za smrduljo pa šest. Toporišičev predlog smrdela beleži le Pleteršnikov slovar, zato predpostavljamo, da ima kot arhaizem manjšo možnost rabe v sodobnem jeziku.

10. SSKJ 1 navaja ovaduhinjo kot 'žensko obliko od ovaduha' (v drugi izdaji je razložena kot 'ženska, ki sporoča nadrejenim o dejanjih kake osebe z namenom škodovati ji'), zabeležena je tudi v SP kot feminativ k ovaduhu. Potrdi jo tudi korpus Gigafida z 21 konkordancami.

11. SP navaja feminativ godrnjavslja h godrnjavsu, v obeh SSKJ pa v pomenu 'kdor (rad) godrnja' oz. 'ženska, ki (rada) godrnja' nastopata godrnjavec in godrnjavka. Godrnjavslja je sicer v korpusu Gigafida zabeležena le z eno 380 
konkordanco, a glede na zastopanost $\mathrm{v}$ jezikovnem priročniku lahko potrdimo Toporišičev predlog.

12. Feminativ klatežka v pomenu 'potepuhinja, pohajkovalka' ponovno navaja samo SP, najti pa ga je mogoče tudi v korpusu Gigafida, in to s petimi pojavitvami (tri konkordance korpus izpiše ob geslu klatežinja).

13. SSKJ 1 navaja hudičevko v pomenu 'ženska oblika od hudič', v drugi izdaji pa jo razlaga kot večpomenko: 1. rel. 'duhovno bitje ženskega spola, ki biva zunaj vidne narave in pooseblja zlo' s podpomenom star. 'čarovnica': 2. ekspr. 'zlobna, hudobna ženska' (z drugim pomenom nastopa tudi hudičela). Tudi v SP je hudičevka zabeležena kot ženskospolska podiztočnica k hudiču, korpus Gigafida pa jo potrjuje s kar 591 pojavitvami.

14. Kot 'ženska oblika od mladič(ek)' je v SSKJ 1 zabeležena mladička, v drugi izdaji pa je razložena kot 'žival ženskega spola v prvem obdobju življenja'. Kot feminativ k mladiču jo navaja tudi SP, korpus Gigafida pa njeno pojavnost (ob iskalnih pogojih občno ime, samostalnik ženskega spola, živost) potrdi s 1087 konkordancami.

15. Že SSKJ 1 navaja slabičko s pomensko razlago 'ženska oblika od slabič'; v SSKJ 2 nastopa ob kvalifikatorju nav. ekspr. in v pomenu 'neodločna, omahljiva ženska'. Tudi SP slabičko navaja kot ženskospolsko vzporednico k slabiču, korpus Gigafida pa jo beleži z desetimi pojavitvami, npr.:

Toda nobeden od teh razlogov ni tako velik, da bi upravičeval nenaden sestop, ki ji zato po mnenju praktično vseh političnih analitikov v ameriških medijih v prihodnosti zapira vrata na vidnejše položaje, saj se je bo vedno držala oznaka slabičke.

16. SSKJ 1 navaja bedakinjo $\mathrm{v}$ pomenu 'omejena, neumna ženska', označeno $\mathrm{s}$ kvalifikatorjem ekspr., redko (enako v SSKJ 2, le brez oznake redko). Kot feminativ k bedaku pa je bedakinja zabeležena tudi v SP. Po korpusu Gigafida pa zasledimo sedem pojavitev, denimo:

\footnotetext{
Medtem ko se jezim nase, kadar mi uide kakšen bedak, se bedakinjo pravzaprav še najbolj počutim sama.
} 
17. $S P$ kot feminativ k četverčku beleži četverčico, ne najdemo pa je v nobenem drugem jezikovnem priročniku. Korpus Gigafida ob geslu četverčica ponudi sedem pojavitev, npr.:

Seveda se ji sprva ni niti sanjalo, da nosi četverčice.

18. Rdečko je v obeh SSKJ 'žival rdečkasto rjave barve, navadno vol, konj'. V slovarjih pa je zabeležena tudi $r d e c ̌ k a$ kot 1 . 'rdečkasto rjava žival, navadno krava' s podpomenom 'rdeča mravlja'; 2. mn. 'nalezljiva bolezen z rdečkastimi izpuščaji na koži, ki se pojavlja zlasti pri otrocih'. V enakem pomenu obe besedi nastopata tudi v SP. Korpus Gigafida pa ob naprednem iskanju (občno ime, samostalnik ženskega spola v ednini, živost) izpiše 17 konkordanc.

19. Hudobnica v pomenu 'hudobna ženska' nastopa v obeh izdajah SSKJ, kot feminativ k hudobnežu pa jo beleži tudi SP. Korpus Gigafida zanjo ponudi 52 konkordanc.

20. Že SSKJ 1 vsebuje grafičarko v pomenu 'ženska oblika od grafik ali grafičar', v SSKJ 2 pa je grafičarka razložena kot 1. 'ženska, ki dela grafike'; 2. 'delavka v grafični, tiskarski industriji'. Kot feminativ h grafičarju jo ponuja tudi $S P$, korpus Gigafida pa njeno pogostnost potrdi s 143 konkordancami. SP pa ob moškospolskem grafiku ponuja feminativno podiztočnico grafikinja, za katero pa korpus ne beleži pojavitev.

21. Ženskospolsko obliko $\mathrm{k}$ duhovitežu ponuja samo $S P, \mathrm{tj}$. duhovitnica. $\mathrm{Ne}$ beležita je SSKJ (nobena izdaja) in korpus Gigafida, zato pa en primer rabe najdemo v korpusu Janes:

Publicistka, pesnica, prevajalka, duhovitnica, modrijanka Milic prejela prvo nagrado.

\section{Feminativi, ki jih zasledimo samo v jezikovnih priročnikih}

V drugo skupino smo uvrstili osem feminativov, ki jih najdemo samo $\mathrm{v}$ katerem od jezikovnih priročnikov:

1. SSKJ v obeh izdajah beleži samo samostalnik moškega spola čenčač v pomenu 'kdor (rad) čenča', kar je sicer presenetljivo, saj čenčanje stereotipno velja za tipično žensko dejavnost. Feminativ čenčačka najdemo v SP kot podiztočnico k 
čenčaču, korpusa Gigafida in Janes pa zanjo ne ponudita pojavitev. Toporišičev predlog čenča se ne zdi utemeljen, saj gre za klepetavo osebo nasploh, ne nujno žensko.

2. $S P$ je edini jezikovni priročnik, ki navaja feminativ k moškospolski obliki dremavh, tj. dremavhlja. Po korpusih Nova beseda, Kres, Janes in Gigafida pa zanjo ne najdemo pojavitev.

3. Guležka je tisti feminativ, ki ga ob moškospolskem guležu (šol. žarg. 'kdor se uči na pamet') navaja $S P$, ne najdemo pa je v nobenem drugem jezikovnem priročniku in ne $\mathrm{v}$ rezultatih korpusne analize.

4. Tudi hromko kot ženskospolsko podiztočnico h geslu hromec najdemo samo v $S P$, drugi jezikovni priročniki feminativa ne navajajo, prav tako ga ne zasledimo v korpusih Gigafida, Nova beseda, Janes in Kres.

5. Grdunko ponujata SSKJ 1 in SSKJ 2 v pomenu ekspr. 'malopridna, malovredna ženska', najdemo jo lahko tudi v $S P$ kot feminativno podiztočnico h grdunu. Po korpusih Gigafida, Nova beseda, Janes in Kres pa je ni mogoče zaslediti.

6. Zemljepisko kot feminativ k zemljepiscu lahko zasledimo le v $S P$, ne najdemo pa je v nobeni izdaji $S S K J$ in korpusih.

7. Samo SP navaja feminativ burkežinja ob moškospolskem burkežu (po obeh SSKJ 'kdor (rad) uganja burke' s podpomenom 'kdor poklicno zabava gledalce z burkami'). Za burkežinjo pa korpusa Gigafida in Janes ne ponujata pojavitev.

8. Ordinarijko kot feminativ k ordinariju navaja samo $S P$, korpusi pa zanjo ne ponujajo konkordanc.

\section{Feminativi, ki jih zasledimo samo v korpusih}

$\mathrm{V}$ tretjo skupino sodijo trije feminativi, ki jih ni $\mathrm{v}$ nobenem jezikovnem priročniku, njihovo rabo pa nakazujejo korpusi:

1. Feminativa k butcu ne ponuja noben jezikovni priročnik, zato pa najdemo dve pojavitvi v korpusu Janes in eno relevantno ${ }^{111}$ pojavitev v korpusu Gigafida za geslo butka:

Sem pač butka posebne vrste.

111 Pojavitev je sicer 21, vendar gre $\mathrm{v}$ preostalih primerih bodisi za lastno ime bodisi za moškospolsko obliko butko $\mathrm{v}$ različnih sklonih. 
2. Tudi k svojcu ne najdemo feminativa $\mathrm{v}$ jezikovnih priročnikih, zato pa za svojko v korpusu Gigafida zasledimo sedem konkordanc, v korpusu Janes šest in v Kresu dve:

V mrzlih poznojesenskih dneh smo imeli tudi delavnico - »izdelovanje iz gline«, ki jo je vodila Lučka Šičarov, ki je svojka ene izmed naših stanovalk.

3. Noben jezikovni priročnik ne ponuja feminativa k bombašu. Zato pa Gigafida ponudi sedem konkordanc za bombašico in dve za bombašinjo, Kres eno konkordanco za bombašinjo, Nova beseda pa štiri za bombašico, npr.:

Presenetljivo je, da so bile tovarišice pogosto kot bombašice in jurišnice še bolj korajžne kot fantje.

»Bombašinja« v zapor.

\subsubsection{Drugi sklop: odsotnost ženskospolskih vzporednic}

\section{Časovna zaznamovanost moško- in ženskospolskega poimenovanja}

Ugotavljamo, da so že nekatera moškospolska poimenovanja po jezikovnih priročnikih časovno zaznamovana, zato ne preseneča, da se tudi vzporedno ženskospolsko poimenovanje v sodobnem jeziku ni uveljavilo. Takšna sta dva primera:

1. Igrc po SSKJ 1 in SSKJ 2 pomeni 'godec, muzikant', označen pa je s kvalifikatorjem star. Verjetno so ženske v tej vlogi redko nastopale ali sploh ne, zato se poimenovanje zanje ni oblikovalo. Izraz najdemo že v Pleteršnikovem slovarju, kjer se avtor sklicuje na Megiserja, Miklošiča in tudi Trubarja.

2. Učenik je starinski izraz za učitelja (oba SSKJ, SP). Ženskospolsko vzporednico učenica $\mathrm{v}$ pomenu 'učiteljica' zasledimo v Pleteršnikovem slovarju, ne najdemo pa je v novejših jezikovnih priročnikih in korpusih.

\section{Odsotnost ženskospolskega poimenovanja}

Nekaj moškospolskih poimenovanj pa ostaja brez ustrezne ženskospolske vzporednice. Razlogi za to so različni: o biološko pogojeni odsotnosti govorimo, 
kadar gre za navezanost na biološko tipične lastnosti ženskih oz. moških človeških bitij. Kadar moškospolske oblike ne najdemo v nobenem od novejših jezikovnih priročnikov (SP, SSKJ 1, SSKJ 2, SNBSJ, Sprotni slovar slovenskega jezika), govorimo o odsotnosti moškospolske oblike $\mathrm{v}$ sodobnem jeziku. $\mathrm{Ob}$ družbenozgodovinsko pogojeni odsotnosti pa mislimo na zgodovinska dejstva, ki kažejo na odsotnost žensk v prenekaterih dejavnostih - gre za žensko netipične poklice. Brez ženskospolske vzporednice tako ostajajo:

1. Feminativa $\mathrm{k}$ moškospolskemu samostalniku jezdec ne navaja noben jezikovni priročnik, prav tako ženskospolske oblike ne beleži korpus Gigafida. Odsotnost ženskospolske vzporednice je najbrž družbenozgodovinsko pogojena, saj ženske v tej vlogi niso pogosto nastopale, ampak gre za tipično moško opravilo. Kljub temu pa preseneča v jeziku že uveljavljena jahačica, katere rabo ob tem, da jo najdemo v jezikovnih priročnikih, potrjujejo tudi korpusi. Iskanje možnosti jezdka po Googlu ni prineslo rezultatov, saj je šlo pri vseh primerih za pravopisne napake in ne poimenovanje ženske.

2. Spovednik je po obeh SSKJ 'duhovnik, ki spoveduje'; v tem primeru je odsotnost ženskospolske vzporednice družbenozgodovinsko pogojena, saj tega navadno ni opravljala (ne opravlja) ženska. Sta pa ženskospolski obliki duhovnica in župnica že zabeleženi v novejših jezikovnih priročnikih (župnica v SSKJ 2, duhovnica pa ob tem še v SP). Spovednica po vseh jezikovnih priročnikih za zdaj označuje le prostor.

3. Postrešček je po obeh SSKJ 'kdor se poklicno ukvarja s prenašanjem prtljage'. Tudi tu je odsotnost feminativa družbenozgodovinsko pogojena, saj je to opravilo še zmeraj bolj $\mathrm{v}$ domeni moških, najbrž tudi zaradi telesnih zmogljivosti. Toporišičev predlog postrežnica pomensko ni ustrezen, saj gre za feminativ k postrežniku, ki pomeni star. 1. 'služabnik, zlasti za osebno strežbo'; 2. '(bolniški) strežnik' (postrežnica pa 1. 'ženska, ki občasno pomaga pri gospodinjskih delih'; 2. star. 'služabnica, zlasti za osebno strežbo; strežnica'; 3. star. '(bolniška) strežnica'). 4. V jezikovnih priročnikih ( $S S K J$ 1, SSKJ 2, SP) se pojavi samo moškospolska oblika kočijaž 'voznik kočije'. Odsotnost ženskospolske vzporednice je zagotovo družbeno pogojena. Eno pojavitev ob geslu kočijažinja najdemo v korpusu Gigafida in eno v Novi besedi; po Kresu in Janesu ni zadetkov: 
Kočijažinja je nestrpno kobilo trdno potegnila za povodec in jo prisilila naravnost po ozki gozdni poti proti najbolj pravljičnemu gradu sveta.

5. Predvidevamo, da je odsotnost ženskospolske ustreznice pri bradaču biološko in sociološko pogojena - brada $\mathrm{v}$ pomenu 'dlakava rast na obrazu' namreč ni nekaj običajnega pri ženski.

\section{Odsotnost moško- in ženskospolskega poimenovanja}

Pri naslednjih dveh poimenovanjih pa $\mathrm{v}$ sodobnem jeziku niti moškospolska oblika ni uveljavljena oz. se rabi le redko:

1. Besede količ kot poimenovanja moške osebe v pomenu 'delavec, ki vtika kole v zemljo' ne navaja noben jezikovni priročnik (samo 'manjšalnica od kol' po obeh SSKJ), zato odsotnost ženskospolske vzporednice ne preseneča. Gre za delitev dela - kmečkih opravil - v ruralnem okolju, ki je temeljila na telesni zmogljivosti. 2. Beseda hvalec v pomenu 'kdor se (rad) hvali' je v SSKJ 1 zaznamovana $\mathrm{z}$ oznako redko, $S P$ pa je sploh ne beleži. Korpus Gigafida kaže, da se v glavnem rabi kot priimek Hvalec, iskanje po Googlu pa tudi ne kaže na rabo besede hvalka, saj vsi zadetki kažejo na pravopisno napako in ne feminativ. Zato niti ni nenavadno, da se ženskospolska vzporednica ni uveljavila, saj tudi obče poimenovanje moškega spola ni prav pogosto v vsakdanji rabi:

Verjetno najmočnejša je pesem Slava in večnost, saj v njej vzplamti popolni pesnik, ki je bodrilec, svetlometnik, predvsem pa podsmehovalec, zasmehovalec in nikakor hvalec.

\section{Poimenovanja, ki se nanašajo na oba spola}

Zanimive so tudi že ustaljene oblike, ki niso podvržene besedotvornemu algoritmu, temveč se pojavljajo »nesistemsko«, npr. tiste, ki jih oblikoslovno umeščamo v 2. moško sklanjatev (vodja, baraba, pavliha, prismoda ...), saj izkazujejo dvospolskost v obči in strokovni rabi. Peter Weiss ugotavlja (2014: 165), da je $\mathrm{v}$ jeziku pri mnogo uporabnikih še posebej izrazita spolska občutljivost, zaradi česar se veča potreba po tvorjenju in uporabljanju feminativov. Avtor vztraja, da mora zanje jezikoslovna stroka prispevati znanje, 
gradivo in načine z opisi postopkov, ki omogočajo tovrstno izražanje. V tej smeri s svojimi predlogi feminativov razmišlja tudi Janez Dular (2014: 16). Helena Dobrovoljc (b. 1., 2014) pa opozarja, da se za tista imena poklicev, kjer ženska oblika ni uveljavljena, navadno uporabijo moške oblike. Danes, ko je možnosti za ugotavljanje rabe precej več, se še v večji meri držimo načela, da ne normiramo oblik, ki se pojavljajo zaradi želje posameznika ali potrjujejo le v enem, dveh pisnih virih.

Zasledili smo dva tovrstna primera: vodja in prismoda.

1. Predlagamo varianto vodkinja - beleži jo le korpus Gigafida s sedmimi pojavitvami, denimo:

Vodkinja Mateja Černic je bila nagrajena za najboljšo izbiro programa.

Vendarle pa obe izdaji SSKJ že ponujata zloženke pevovodkinja, poslovodkinja, računovodkinja, ki vsebujejo sestavino vodkinja (kot ugotavlja že Weiss 2014: 167; Heleni Dobrovoljc (2014) pa se oblika vodkinja sicer sistemsko zdi upravičena, a malo rabljena.).

2. Prismodež je po SSKJ 1 in SSKJ 2 slabš. 'nespameten, neumen moški'. Ženskospolske oblike ne ponuja noben jezikovni priročnik (le v enakem pomenu prismojenka $\mathrm{k}$ prismojencu). Toporišičev predlog prismoda se nam glede na pomensko razlago slabš. 'nespameten, neumen človek' sicer ne zdi najboljši, saj gre za osebo nasploh. Možnosti prismodežka pa ni mogoče najti ne v korpusih in ne na svetovnem spletu.

\section{Feminativ se ni oblikoval/rabil, ker je začel delovati drug(ačen) par}

Pri nekaterih primerih neuveljavljenost ženskospolske vzporednice ne preseneča, saj se je v jezikovni rabi uveljavil drug(ačen) par, denimo:

1. Aristotelik je po obeh izdajah SSKJ filoz. 'pristaš filozofske smeri, ki temelji na osnovnih načelih Aristotelove filozofije'. Ženskospolske ustreznice ne navaja noben jezikovni priročnik. $\mathrm{V}$ enakem pomenu kot aristotelik nastopa $\mathrm{v} S P$ aristotelovec, h kateremu pa je zabeležen feminativ aristotelovka; za slednjo samo Gigafida ponudi eno konkordanco: 
»Ko ste goljufici Aristotelovka in Rižnarca videli, da ni več pomoči, prikrivati sleparstvo, hočete v vodo skočiti, najprej $v$ Savo, katera se jima je menda premrzla zdela, potem pa v Blejsko jezero, ki pa jima je morebiti pregloboko bilo. Zato ste si premislili.«

2. Dolgan je v obeh $S S K J$ starinski izraz za dolgina (po SP redko 'dolgin'). K dolginu po jezikovnih priročnikih že obstaja ženskospolska vzporednica dolginka, zato bi podobno predlagali za dolgana, torej feminativ dolganka - sicer je ne potrjuje noben jezikovni priročnik in tudi ne korpusi, a to niti ni presenetljivo, če upoštevamo časovno zaznamovanost moškospolskega poimenovanja.

3. Po obeh izdajah $S S K J$ in po $S P$ je debelko označen s kvalifikatorjem šalj. in razložen kot 'debel človek' (v enakem pomenu in ob enakem kvalifikatorju sicer nastopata še debelinko in debelinka). Predlagamo feminativ debelka, ki ga korpus Gigafida potrdi le $\mathrm{z}$ eno ${ }^{112}$ konkordanco:

Mogoče bi bilo preokrutno, da bi govorili o slovenski debelki, debeluški, debeluharici, pri kateri sta višina in salo edina atrakcija, ki pa se dobro prodaja.

4. Grdavs je po obeh $S S K J$ in $S P$ slabš. 'grd, neprikupen človek', noben jezikovni priročnik pa ne navaja ženskospolske oblike. K različici grdavš pa $S P$ ponuja feminativ grdavša, zato podobno predlagamo za feminativ $\mathrm{h}$ grdavsu, torej grdavsa. Slednjo je mogoče zaslediti tudi po korpusu Gigafida, in sicer z osmimi pojavitvami, in po korpusu Janes $\mathrm{z}$ eno.

5. Grbec v obeh izdajah SSKJ nastopa v pomenu 'grbavec'. Slednjemu ustreza feminativ grbavka, ki ga beleži tudi SP. Grbavka je po korpusu Gigafida potrjena z 20 konkordancami, po Kresu s petimi in Nova beseda s tremi.

\subsubsection{Sklep}

Analiza dokazuje, da k primerom, za katere po Toporišiču ni mogoče najti ženskospolske ustreznice (sicer je razprava iz leta 1981), v sodobnem knjižnem jeziku feminativi že obstajajo ali pa njihovo obliko lahko predvidimo. Veliko feminativov je ponudil že $S P$ (kjer je bil sicer prav Toporišič najbolj

\footnotetext{
112 Pojavitev ob iskalnem pogoju debelka je sicer 24, vendar gre v preostalih primerih bodisi za lastno ime bodisi za moškospolsko obliko debelko v različnih sklonih.
} 
tvoren): bahačka, bedakinja, brivka, govorka, grbavka, grdunka, hudičevka, hudobnica, mladička, ovaduhinja, prismojenka, rdečka, slabička, sluginja, smrduha, vidkinja (vsi navedeni primeri tudi v obeh izdajah SSKJ), aristotelovka, burkežinja, čenčačka, četverčica, dremavhlja, duhovitnica, godrnjavslja, grafikinja (v drugih priročnikih grafičarka), guležka, hromka, jedka, klatežka, ordinarijka, zemljepiska. S korpusno analizo smo potrdili, da je raba nekaterih med njimi (npr. govorka, mladička, vidkinja) že dokaj pogosta, drugi pa se v vsakdanji rabi šele uveljavljajo (z manj kot desetimi konkordancami sluginja, brivka, bahačka, svojka, četverčica). Šele v SSKJ 2 je mogoče najti feminativ kosica k moškospolskemu koscu, samo po korpusih Gigafida, Kres in Nova beseda pa zasledimo naslednje: bombašica in bombašinja, butka, debelka, gonička, grdavsa, svojka, vodkinja.

Ugotavljamo, da je odsotnost ženskospolske vzporednice k moškospolskemu poimenovanju družbenozgodovinsko pogojena pri naslednjih primerih: jezdec, igrc, kočijaž (čeprav po korpusu Gigafida že kočijažinja z eno konkordanco), spovednik, postrešček. Navadno teh poklicev oz. opravil niso opravljale ženske. Biološko pogojena je odsotnost feminativa k bradaču. Hkrati pa opažamo, da so nekatera moškospolska poimenovanja oseb, h katerim po Toporišiču ne obstaja ustrezni feminativ, v nekaterih jezikovnih priročnikih označena s kvalifikatorji redko (hvalec v SSKJ 1) ali star. (učenik po obeh izdajah SSKJ in po SP, a pri Pleteršniku tudi učenica $\mathrm{v}$ pomenu 'učiteljica'); količ $\mathrm{v}$ pomenu 'delavec, ki vtika kole v zemljo' pa je zabeležen samo v Pleteršnikovem slovarju. Ta poimenovanja so $\mathrm{v}$ sodobnem jeziku neuveljavljena (to je potrdila tudi korpusna analiza), zato morda niti ne preseneča odsotnost ustrezne ženskospolske vzporednice.

\subsection{Feminativi v SSKJ 2}

Analiza gradiva obeh izdaj slovarja kaže, da SSKJ 2 ponudi 290 feminativov, ki jih v SSKJ 1 ni. 103 (35\%) izpisani feminativi so nastali $\mathrm{z}$ zamenjevalnim načinom (bralec - bralka), pri katerem nekateri jezikoslovci, denimo Ada Vidovič Muha, vidijo očitno podrejanje tvorbe poimenovanj za 
ženske osebe poimenovanjem za moške. Preostalih 187 (65 \%) feminativov je tvorjenih z dodajalnim načinom (učitelj-učiteljica). Opažamo tudi pojavnost t. i. variantnih ali konkurenčnih obrazil (pri istopomenskih tvorjenkah ob isti podstavi nastopijo različna priponska obrazila): adutka/adutinja, dekanja/dekanka/dekanica, ekspertinja/ekspertka, investitorica/investitorka, koordinatorica/koordinatorka, selektorka/selektorica.

Ugotavljamo, da se 207 izpisanih feminativov na novo pojavi v SSKJ 2, medtem ko je v SSKJ 1 zabeleženo le moškospolsko poimenovanje. Taki so feminativi akterka, analitičarka, animatorka, anketarka, antropologinja, aranžerka, astrologinja, astronavtka, atašejka, balinarka, bančnica, basistka, bobnarka, cenilka, častnica, darkerica, davkarica, davkoplačevalka, dekanja, dekanka, deskarka, diabetičarka, dialektologinja, dietetičarka, domorodka, donatorka, dramatičarka, dramaturginja, ekologinja, ekspertinja, ekspertka, enologinja, epidemiologinja, estetinja, etnologinja, finančnica, folkloristka, frajerka, galeristka, genialka, geografinja, geometrinja, gospodarstvenica, gostinka, govorka, grafologinja, gurmanka, harmonikarka, homeopatinja, humoristka, imitatorka, improvizatorka, inovatorka, intervjuvanka, investitorica, investitorka, iskalka, karieristka, karikaturistka, kinologinja, kitaristka, klimatologinja, klovnesa, kmetovalka, knjigarka, komičarka, koncesionarka, kongresnica, konservativka, konzervatorka, koordinatorica, koordinatorka, koproducentka, korektorica, korepetitorka, kosica, krajanka, kriminalistka, krmarka, kronistka, kršilka, kršiteljica, lončarka, magistrica, mediatorka, menedžerka, mentorica, migrantka, mikrobiologinja, milijarderka, moderatorka, motoristka, muzikologinja, načrtovalka, navdušenka, navijačica, nečlanica, nomadka, nudistka, oboistka, očividka, odpadnica, odvisnica, onesnaževalka, opremljevalka, osmoljenka, osnovnošolka, ostrostrelka, parlamentarka, plenilka, piflarka, podložnica, podpisovalka, pogajalka, pohodnica, pokončnica, politologinja, porabnica, poročnica, poslovnica, posnemovalka, pospeřevalka, pošiljateljica, potapljačica, potrošnica, povzpetnica, požiralka, praktičarka, praktikantka, pravobranilka, pregledovalka, prfoksa, prijaviteljica, pripornica, pritožnica, producentka, projektantka, promotorka, protestnica, prvokategornica, psihoanalitičarka, psihoterapevtka, računalničarka, radijka, razgaljenka, 
rekreativka, rektorica, restavratorka, revizorka, saksofonistka, samohodka, scenografinja, seksologinja, selektorica, selektorka, siromakinja, slovenistka, snemalka, soavtorica, sočlanica, sodržavljanka, soimenjakinja, someščanka, sourednica, spodbujevalka, sprejemalka, stilistka, suhica, supervizorka, svatinja, svobodnjakinja, šamanka, šarmerka, škofinja, šolnica, teoretičarka, tožljivka, utemeljiteljica, vampirka, varnostnica, vegetarijanka, velemojstrica, vinogradnica, violistka, violončelistka, vlagateljica, vnašalka, vodnarka, vokalistka, vpisnica, vremenarka, vremenoslovka, vrtnarka, tehnologinja, televizijka, zahodnjakinja, zalezovalka, zapisovalka, zapustnica, zasledovalka, zaslužkarica, zasvojenka, zbirateljica, zdravilka, zeliščarka, žirantka, župnica.

Za 73 feminativov, ki se na novo pojavijo v SSKJ 2, pa v prvi izdaji ni mogoče zaslediti niti moškospolskega poimenovanja; torej se obe, žensko- in moškospolsko poimenovanje osebe pojavita šele v drugi izdaji. Sem sodijo feminativi abrahamovka, adutinja, adutka, akcentologinja, alternativka, andragoginja, anoreksičarka, bajsa, besedilopiska, bioenergetičarka, biseksualka, blogerka, bulimičarka, centristka, deloholičarka, didžejka, dizajnerka, dobrodelnica, donorka, estradnica, fizičarka, folklornica, frendica, gurujka, imenoslovka, japijka, kolumnistka, komunikologinja, krasoslovka, krupjejka, lobistka, marginalka, mirovnica, naglasoslovka, naravovarstvenica, narečjeslovka, negativka, nevrobiologinja, nominiranka, numerologinja, nutricionistka, obramboslovka, obrobnica, okoljevarstvenica, oskarjevka, pankerica, perfekcionistka, performerka, piarovka, podprvakinja, pozitivka, presnojedka, pulmologinja, refleksologinja, refleksoterapevtka, rejverka, rimokatoličanka, rolarka, rokerica, sokrajanka, someljejka, somentorica, sovoditeljica, tekstopiska, tetraplegičarka, tonematičarka, varstvoslovka, veganka, videoumetnica, videastka, vizažistka, zdraviteljica, žurerka.

Eno moškospolsko poimenovanje najdemo le v SP (abraham kot 'petdesetleten moški', v SSKJ 2 tudi abrahamka), eno pa (samo) v Pleteršnikovem slovarju (kratkolasec - v SSKJ 2 pa tudi kratkolaska).

Nekateri novi primeri ženskospolskih poimenovanj oseb kažejo na uveljavljanje žensk $\mathrm{v}$ poklicih in drugih dejavnostih, ki so jih sprva po tradicionalni delitvi na ženska in moška dela opravljali le moški, denimo 
bančnica, gospodarstvenica, računalničarka, vinogradnica. Med področja, kjer je bila zastopanost žensk nizka in ki so veljala za izrazito moško domeno, uvrščamo menedžment, znanost, gradbeništvo, politiko, policijo in vojsko (Krajnc 2013: 3842). Nova poimenovanja pa kažejo vse opaznejšo vlogo žensk prav na teh področjih: v menedžmentu (menedžerka), politiki (centristka, kongresnica, parlamentarka), policiji (kriminalistka) in vojski (častnica, poročnica). Ženske se uveljavljajo kot strokovnjakinje na različnih področjih (akcentologinja, imenoslovka, krasoslovka, pulmologinja, slovenistka), pogosto zavzemajo vodilne položaje $\mathrm{v}$ različnih institucijah (dekanka, rektorica). Jezik vse bolj izkazuje stalno prisotnost žensk v športu (balinarka, deskarka, potapljačica) in glasbi (bobnarka, didžejka, harmonikarka, kitaristka, oboistka, vokalistka), odseva njihove navade in način življenja (veganka, vegetarijanka, nomadka) ter kaže na njihovo aktivnost $\mathrm{v}$ aktualnem družbenem dogajanju (protestnica, potrošnica). Novost so tudi ženskospolska poimenovanja horoskopskih znamenj (vodnarka, bikica, rakica, strelka, škorpijonka, levinja).

\subsection{Feminativi v Sprotnem slovarju slovenskega jezika}

Sprotni slovar je zasnovan kot slovar informativne narave, ki zbira živo, v slovarjih še ne registrirano novejše besedje (vključuje tudi najnovejše, uveljavljajoče se pomene že registriranega besedja) in $\mathrm{v}$ temeljnih obrisih prikazuje njegove pomenske, slovnične in pragmatične lastnosti. Jedro geslovnika predstavlja še neuslovarjeno besedje, katerega rabo $\mathrm{v}$ zadnjih letih potrjuje korpusno gradivo, dopolnjeno s predlogi jezikovnih uporabnikov (spletni vir). ${ }^{113}$ Feminativi so tudi v Sprotnem slovarju slovenskega jezika samostojne slovarske iztočnice, pomenska razlaga pa je neodvisna od moškospolskega poimenovanja osebe. Slovar med 551 iztočnicami ponuja le šest feminativov, ${ }^{114}$ to so: mentoriranka $\mathrm{v}$ pomenu 'študentka, ki pod mentorjevim vodstvom piše zaključno študijsko delo' oz. 'ženska, ki jo kdo usmerja, vodi pri čem, ji predaja svoje izkušnje'; vlogerka kot 'ženska, ki objavlja videoposnetke o sebi, svoji dejavnosti,

${ }^{113}$ Domen Krvina: Sprotni slovar slovenskega jezika 2014-2017. Vir: www.fran.si, pridobljeno 3. 8. 2018.

${ }^{114}$ Do podatkov smo dostopali avgusta 2018. 
razmišljanju na spletnem mestu, kjer ima gledalec navadno možnost komentiranja'; antifeministka navadno ekspresivno 'ženska, ki se ne strinja z nazori feminizma, se bori proti njim'; hipsterka kot 'pripadnica urbane subkulture z izstopajočo mešanico starinskega in inovativnega sloga ter kritičnim, rahlo ciničnim odnosom do sveta'; hornistka 'ženska, ki igra (na) rog, navadno kot poklicna glasbenica'; sprehajalka 'ženska, ki vodi žival, navadno psa, na sprehod'. V slovarju so zabeležena tudi moškospolska poimenovanja hipster, mentoriranec, sprehajalec in vloger (ni pa antifeminista, hornista). Ob pregledu vseh slovarskih gesel smo zasledili še druga moškospolska poimenovanja oseb, vendar brez ustreznih ženskospolskih vzporednic: bolonjec, džihadist, fotolovec ('kdor načrtno išče in fotografira živali'), geek oz. gik (1. 'navdušenec, strokovnjak za določeno strokovno ali interesno področje, zlasti računalništvo', 1.1 kot pridevnik 'ki je v zvezi s takimi navdušenci, strokovnjaki'), hidrobiolog, izmenjevalec, kaps ('policist'), komunajzar, kreditodajalec, kronometrist (kolesar, ki tekmuje zlasti na kronometrih'), milenijec, optometrist, pešmerga ('kurdski vojak'), picajzel, prepotentnež, sledilec, soglasodajalec, težkokategornik, vejper ('kdor kadi elektronske cigarete'), vrvohodec, vulkanizer, žogobrcar. Ker pa gre za rastoči slovar, pričakujemo, da bodo v njem feminativi k izpostavljenim poimenovanjem kmalu zapisani.

Preverili smo stanje na svetovnem spletu: zanimalo nas je, ali se ženskospolske oblike $\mathrm{k}$ navedenim moškospolskim poimenovanjem oseb že pojavljajo v vsakdanji rabi. Tako smo na različnih spletnih portalih, v spletnih časopisih in forumih zasledili džihadistko, hidrobiologinjo, komunajzarico in komunajzarko, tudi komunajzerko, kreditodajalko, milenijko, optometristko, sledilko, soglasodajalko, vejperko, vrvohodko in vulkanizerko. ${ }^{115}$

\subsection{Feminativi v SSKJ 3}

Pregledali smo tudi spletni rastoči SSKJ 3 (spletni vir), ${ }^{116}$ nov temeljni informativno-normativni razlagalni slovar slovenskega knjižnega jezika. V njem

\footnotetext{
${ }^{115}$ Do podatkov smo dostopali s spletnim iskalnikom Google v avgustu 2018.

116 Slovar slovenskega knjižnega jezika 2016-2017. Vir: www.fran.si, pridobljeno 3. 8. 2018.
} 
so slovarski sestavki izdelani povsem na novo na podlagi analize sodobnega jezikovnega gradiva. Pri pregledu 611 iztočnic $^{117}$ smo zasledili zgolj tri feminative, ki jih $\mathrm{v}$ raziskavo vključenih virih nismo našli, to sta dve poimenovanji osebe alergologinja ('zdravnica specialistka za alergologijo') in pesimistka ('ženska, ki vse vidi slabo, slabše, kot je, in pričakuje najslabše tudi za prihodnost') ter eno poimenovanje živali rotvajlerka ('samica večjega, močnejšega psa črne barve s simetričnimi rdeče rjavimi lisami in kratko dlako').

Opažamo pa, da nekatera že $\mathrm{v}$ drugih virih zabeležena poimenovanja $\mathrm{v}$ SSKJ 3 nastopajo z drugačnimi, v glavnem natančnejšimi pomenskimi razlagami (17 primerov): abrahamovka 'ženska, ki praznuje petdeseti rojstni dan ali dopolni petdeset let' (po SSKJ 2 'ženska, ki je dopolnila petdeset let'); blogerka 'ženska, ki na spletnem mestu, namenjenem predstavljanju zlasti posameznikovih zanimanj, mnenj, objavlja besedila, slike, posnetke' (v SSKJ 2 'ženska, ki piše blog'); cvetličarka 'ženska, ki se poklicno ukvarja s prodajo, vzgojo okrasnih rastlin in njihovo uporabo v šopkih, okrasitvah' (v SSKJ 2 'ženska, ki goji cvetlice ali jih prodaja'); čistilka 1. 'ženska, ki se poklicno ukvarja s čiščenjem', 1.1 'ženska, ki čisti' (SSKJ 2: 'ženska, ki se poklicno ukvarja s čiščenjem'); čembalistka 'ženska, ki igra čembalo, navadno kot poklicna glasbenica' (po SSKJ 2 'ženska, ki igra čembalo'); faraonka 1. v starem Egiptu 'vladarica', 1.1 v starem Egiptu 'vladarjeva žena, sovladarica' (v SSKJ 2 'vladarica' oz. 'faraonova žena'); hišnica 'ženska, ki se poklicno ukvarja z manjšimi vzdrževalnimi deli, opravili in skrbi za urejenost stavbe in njene okolice' (v SSKJ 2 'ženska, ki opravlja manjša oskrbniška dela v večstanovanjski hiši' in 'hišnikova žena'); jezikoslovka 1. 'strokovnjakinja za jezikoslovje', 1.1 'študentka ali diplomantka jezikoslovja' (v SSKJ 2 samo 'strokovnjakinja za jezikoslovje'); kegljačica in kegljavka 'športnica, ki se ukvarja s kegljanjem' (SSKJ 2: 'igralka pri kegljanju'); kolednica 'ženska, ki hodi od hiše do hiše in vošči s petjem, igranjem obrednih pesmi, zlasti med 25 . decembrom in 6. januarjem' (SSKJ 2: 'ženska, ki koleduje'); mladoletnica 'ženska, ki ne dosega zakonsko določene starosti, navadno osemnajst let, in zato še nima polnih pravno določenih pravic ter dolžnosti' (po SSKJ 2 zgolj 'mladoletna ženska'); oboistka 'ženska, ki igra oboo, navadno kot poklicna glasbenica' (v SSKJ 2 samo 'ženska, ki

${ }^{117}$ Do podatkov smo dostopali avgusta 2018. 
igra oboo'); peška 'ženska, ki se premika brez prevoznega sredstva, s hojo, navadno v cestnem prometu' (po SSKJ 2 'ženska, ki hodi peš'); samohranilka 'ženska, ki v enostarševski družini preživlja, vzgaja otroka' (SSKJ 2: 'mati, ki mora sama skrbeti za otroka, otroke'); svakinja 'sestra (zakonskega) partnerja ali sorojenčeva (zakonska) partnerica' (SSKJ 2: 'bratova žena ali sestra zakonskega partnerja') in vampirka 'bajeslovno bitje ženskega spola, navadno z dolgima podočnikoma, ki ponoči vstaja iz groba in hodi pit kri živim bitjem, zlasti človeku' (SSKJ 2: 'mrtva ženska, ki vstaja ponoči iz groba in sesa ljudem kri'). Z enako pomensko razlago kot v SSKJ 2 pa nastopi judoistka ('športnica, ki se ukvarja z judom'). Nove, kompleksnejše pomenske razlage odsevajo smelo vstopanje žensk $\mathrm{v}$ slovenski jezikovni in družbeni prostor.

\subsection{Sklep}

Z vstopom žensk $\mathrm{v}$ celovit javni svet se je število ženskospolskih poimenovanj bitij izrazito povečalo. Seveda gre pri tem za poimenovalno zaporednost, pogojeno s prvotno vezanostjo dejavnosti ali položaja pretežno ali celo zgolj na moško osebo. Jezikovna resničnost vsekakor izkazuje družbeno resničnost. Tako opažamo, da se v novih jezikovnih priročnikih (že v $S P$, še bolj pa v SSKJ 2 in 3, SNBSJ in rastočem Sprotnem slovarju slovenskega jezika) in drugih virih, denimo $\mathrm{v}$ korpusih in na spletu, pojavljajo zmeraj nova ženskospolska poimenovanja bitij glede na starejše jezikovne vire in znanstvene razprave. Glede na podatke iz korpusov Gigafida, Nova beseda in Kres ter s svetovnega spleta so tovrstna nova poimenovanja $\mathrm{v}$ vsakdanji rabi že precej uveljavljena, nekatera med njimi pa $\mathrm{v}$ jezikovno rabo šele vstopajo. Ugotavljamo pa, da je odsotnost nekaterih ženskospolskih vzporednic družbenozgodovinsko in biološko pogojena; včasih pa se je uveljavil novi par, stari moškospolski del pa je izginil/izginja (npr. grbec ob grbavec - grbavka) ali pa ostaja osamljen (npr. jezdec ob jahač-jahačica). Glede na to, da je jezik živ organizem, menimo, da se bodo feminativi še naprej tvorili ob ustreznih moškospolskih novotvorjenkah ali novopomenkah, kjer je to mogoče, in se sčasoma v jeziku tudi ustalili. 


\section{TVORBA FEMINATIVOV IZ LASTNOIMENSKE PODSTAVE}

\subsection{Poimenovanja prebivalk}

Kot smo napovedali, so lahko feminativi v slovenščini, a tudi v drugih slovanskih jezikih, tvorjeni ne le iz občnoimenske, temveč tudi iz lastnoimenske podstave. Prvi primer tovrstne tvorbe so poimenovanja za prebivalke.

10.1.1 Poimenovanja prebivalk v drugih slovanskih jezikih

V ruščini Zemska (2006: 262-269) loči izobčno- in izlastnoimensko tvorbo feminativov. Tako posebej obravnava poimenovanja ženskih oseb glede na narodno pripadnost, kraj prebivanja ali rojstva (он коренной Москвич, она коренная Москвичка, Жаклин - франиуженка). Meni, da je v tej skupini semantična sestava samostalnikov moškega in ženskega spola enaka, to je Москвич 'prebivalec (ali domačin) Moskve' + 'moški'; Москвич $+\kappa a=$ 'prebivalec (ali domačin) Moskve' + 'ženska'. Tovrstna poimenovanja nastajajo z dodajalnim (Москвич - Москвич-ка) ali zamenjevalnim načinom (Естонец Естон-ка). Podobno velja za beloruščino in ukrajinščino.

Ženskospolska poimenovanja oseb so tudi v češčini lahko občnoimenska in lastnoimenska (Vesničanka, Pražanka). Poimenovanja prebivalk so tvorjena $\mathrm{z}$ dodajanjem ženskospolskega priponskega obrazila (denimo s -ka: Češka, Ruska, Srbka, Bulharka) ali z zamenjavo moškospolskega priponskega obrazila z Ženskospolskim (npr. -ec s -ka: Japonka, Slovinka, Němka) (Dokulil 1962: 47, 61). Opazimo, da pri dodajalnem načinu v nekaterih primerih prihaja do glasovne premene; podobno se zgodi v slovaščini ( $\check{C} e c h \rightarrow \check{C} e s ̌ k a)$. V poljščini pa so, po skromnih navedbah Pycie (2011: 100), tovrstna poimenovanja tvorjena s feminativnim obrazilom $-k a$ ob zamenjevalnem načinu (Amerykanin Amerykanka).

Poimenovanja prebivalk se v hrvaškem jeziku tvorijo iz poimenovanj za prebivalce, in to najpogosteje s priponskimi obrazili -ica (Hrvat - Hrvatica, 
Madžar - Madžarica), -inja (Čeh - Čehinja, Grk - Grkinja), -ka (Rumunj Rumunjka, Talijan - Talijanka), -kinja (Kelt - Keltkinja), pri čemer je najproduktivnejše ženskospolsko priponsko obrazilo -ka (Barić 1997: 314). V srbščini se poimenovanja prebivalk tvorijo s priponskimi obrazili $-\kappa a$ (Београђанин - Београђанка), -иња (Полјак - Полјакиња), -ища (Мађар Мађарица), -киња (Арапин - Арапкиња) (Ćorić 1982: 4). Pri tem so omenjena obrazila tudi konkurenčna/variantna (Мађарица, Мађарка, Мађаркиња) (Ćorić 1982: 110). V makedonščini so tovrstna poimenovanja lahko tvorjena $\mathrm{Z}$ zamenjevalnim (-ка z -ин: Бугарин - Бугарка, -ка z -ец: Македонец Македонка) in dodajalnim načinom (z -инка: Влаинка, Гркинка, Чехинка) (Koneski 2003: 65-67). Podobno velja v bolgarščini (zamenjava: Арменеu Арменка, Германеи - Германка, Африканеи - Африканка, Русин - Рускиня, Турчин - Туркиня, Немеи - Немкиня; dodajanje: Херияог - Херияогиня) (Radeva 1991: 153-154).

Zaključimo lahko, da vse obravnave feminativov v drugih slovanskih jezikih vključujejo tudi izlastnoimensko tvorbo, tj. poimenovanja za prebivalke, vendar precej skromno $\mathrm{v}$ primerjavi $\mathrm{z}$ izobčnoimenskimi tvorjenkami. To je razvidno iz majhnega števila konkretnih primerov, kjer niti niso navedena vsa možna feminativna priponska obrazila, produktivna pri tovrstni tvorbi, niti nista zajeta oba načina feminativne tvorbe.

10.1.2 Poimenovanja prebivalk v slovenščini

10.1.2.1 Poimenovanja prebivalk v slovenskih slovnicah skozi zgodovino

Prvič zasledimo ženskospolsko vzporednico $\mathrm{k}$ poimenovanju za prebivalca v Bohoričevi slovnici Zimske urice proste, a le z enim konkretnim primerom Lublančica k moškospolskemu Lublančiču, pri katerem obrazilo -ica zamenjuje moškospolsko priponsko obrazilo -ič. Z umestitvijo v drugo poglavje ga loči od preostalih feminativov, tvorjenih iz občnoimenske podstave. Za razliko od Bohoriča pa Zagajšek (1791: 221) tovrstnih poimenovanj ne loči od preostalih feminativov; obravnava jih kot izpeljane iz moškospolskih s priponskim 
obrazilom -anka (lublannzhanka, zellanka), pri čemer gre za dodajanje priponskega obrazila $-k a$ k izglasjem moškospolskih samostalnikov na $-(a) n$. Po Pohlinovi Kranjski gramatiki pa so tovrstna poimenovanja lahko tvorjena s priponskima obraziloma -ica (Krayniza) in -ka (Lublanzanka, Shtajerka), pri čemer ločuje tvorbo $\mathrm{z}$ dodajalnim (Lublanzan $\rightarrow$ Lublanzanka) in $\mathrm{z}$ zamenjevalnim načinom (Shtajerec $\rightarrow$ Shtajerka) (Pohlin 2003: 268).

Vodnik V svoji slovnici imena prebivalk loči od preostalih ženskospolskih poimenovanj oseb, vse skupaj pa obravnava znotraj istega poglavja Izobrazenje besed. »Domovinska imena«, kot jim pravi, se lahko tvorijo z naslednjimi feminativnimi priponskimi obrazili: -anka (Doblanka, Grajanka, Breshanka), ${ }^{118}$-ica (Krajnica, Gradišnica), -inja (Lahinja, Turkinja), -šca (Kamnišca), -ša (Koroša) $)^{119}$ (Vodnik 1811: 152). Tudi Dajnkova slovnica ponuja popis priponskih obrazil (Dajnko 1824: 48-72); ugotavljamo, da so poimenovanja prebivalk lahko tvorjena $\mathrm{z}$-inja (Turkinja), -ka (Čehka, Slovenka), -kinja (Slovenkinja, Čehkinja, Nemkinja, Koroškinja), -(ov)ka (Čehovka), pri čemer ni opaziti ločevanja med feminativi, tvorjenimi iz občnoimenske podstave, in tistimi iz lastnoimenske podstave. Ob variantnih obrazilih $-k a$ in -inja pa daje prednost drugemu. Podobno kot Dajnko tudi Metelko (1825: 66-68) ne loči feminativov, tvorjenih iz lastno- oz. občnoimenske podstave. Poimenovanja prebivalk so lahko tvorjena z zamenjevalnim načinom iz ustreznih moškospolskih vzporednic na -ec (s feminativnim priponskim obrazilom -ka: Gorenec - Gorenka, Dolenec Dolenka, Stajerec - Štajerka, Nemec - Nemka, Polanec - Polanka), z dodajalnim načinom iz vzporednih moškospolskih poimenovanj (prav tako s -ka: Gorjan Gornjaka, Ižan - Ižanka, Doblan - Doblanka oz. z -inja: Hrovatinja, Krajninja, Korošinja, Turkinja, Rusinja, Grkinja, Francozinja, Polakinja). Tudi Metelko opozori na variantni feminativni priponski obrazili - $k a$ in -inja, ki lahko zamenjata moškospolsko priponsko obrazilo -ec (Kranjka ali Krajninja).

Po Murščevi slovnici so poimenovanja prebivalk lahko tvorjena $\mathrm{z}$ zamenjevalnim načinom (namesto -ec nastopi -ka Nemec - Nemka, Slovenec Slovenka ali -ica: Krajnec - Krajnica, Korošec - Korošica) ali z dodajalnim

\footnotetext{
118 Tvorba s $-k a$ kot dodajalnim obrazilom k izglasju na $-(a) n$.

${ }^{119}$ Priponsko obrazilo - $a$ zamenja moškospolsko obrazilo -ec.
} 
načinom (z -ica Hrovat - Hrovatica ali z -inja Grk - Grkinja, Polak - Polakinja, Francoz - Francozinja, Rus - Rusinja), pri čemer primere tvorjenk iz lastno- in občnoimenske podstave obravnava kar skupaj (Muršec 1847: 71-72). Malavašič (1849: 93-112) pa $\mathrm{v}$ svoji slovnici $\mathrm{v}$ posebnem poglavju obravnava tvorbo lastnoimenskih poimenovanj, znotraj tega pa posebej t. i. Ljudstvine imena $s$ posebnim podpoglavjem Zlaga ženskih imen. Ženskospolska poimenovanja prebivalk so lahko tvorjena $\mathrm{s}$ feminativnimi priponskimi obrazili -ica (z zamenjavo vzporednega moškospolskega obrazila -ec Korošec - Korošica, Krajnec - Krajnica ali z dodajalnim načinom Hrovat - Hrovatica), -inja (z dodajalnim načinom Turk - Turkinja, Grek - Grekinja, Francoz - Francozinja, Rus - Rusinja), -ka (z zamenjevalnim načinom -ec $\rightarrow$-ka Gorenec - Gorenka, Ižanec - Ižanka, Slovenec - Slovenka ali z dodajanjem izglasju na -(a)n Litijan Litijanka). Potočnikova slovnica (1849: 5-9) ponuja popis priponskih obrazil, iz katerega je ob siceršnjem neločevanju tvorbe iz lastno- in občnoimenske podstave mogoče razbrati, da se poimenovanja prebivalk tvorijo samo s priponskim obrazilom -nja (Turknja). Zato pa Majarjeva slovnica feminativov, tvorjenih iz lastnoimenskih podstav, ne ponuja. Istega leta je izšla tudi Navratilova slovnica (1850: 40), po kateri so poimenovanja prebivalk obravnavana skupaj z izobčnoimenskimi feminativi, tvorjena pa so $\mathrm{Z}$ zamenjavo moškospolskega priponskega obrazila -ec s feminativnima -ka (Slovenec - Slovenka, Dalmatinec Dalmatinka, Ižanec - Ižanka) in -ica (Korošec - Korošica) oz. z dodajanjem priponskega obrazila $-k a$ moškospolskemu samostalniku z izglasjem na $-(a) n$ (Litijan-Litijanka).

Janežič loči poimenovanja, tvorjena iz lastnoimenske podstave, od preostalih tvorjenk. Poimenovanja prebivalk tako obravnava (poleg priimkovnih feminativov in poimenovanj pokrajin) v poglavju Zlaga ljudstvinih imen (Janežič 1854: 16-17). Tovrstna poimenovanja so lahko tvorjena $\mathrm{s}$ feminativnimi priponskimi obrazili z zamenjevalnim (priponsko obrazilo -ec je zamenjano z obrazilom -ka Gorenec - Gorenka oz. -ica Korošec - Korošica, Kranjec Kranjica) ali dodajalnim načinom (moškospolskemu samostalniku z izglasjem na -(a)n se doda priponsko obrazilo -ka, npr. Celovčan - Celovčanka, Egipčan Egipčanka, Gradčan - Gradčanka, Ljubljančan - Ljubljančanka). Po Miklošičevi 
primerjalni slovnici pa so poimenovanja prebivalk tvorjena s priponskimi obrazili -inja (Čehinja, Grkinja, Turkinja), -kinja (zamenjava moškospolskega priponskega obrazila -ec, npr. Nemkinja, Slovenkinja), -ka (prav tako zamenja moškospolsko obrazilo -ec, npr. Slovenka). Tudi Miklošič ne ločuje feminativov, tvorjenih iz lastno- oz. občnoimenske podstave (Miklošič 1875: 143-144, 266267, 295-297). V Šumanovi Slovenski slovnici po Miklošičevi primerjalni (1881: $232,241)$ pa so poimenovanja prebivalk tvorjena s priponskim obrazilom -inja kot dodajalnim (Grkinja) ter z zamenjevalnima -kinja (Slovenkinja) in -ka (Slovenka). V glavnem navaja Miklošičeve primere, ki jih ne loči od feminativov, tvorjenih iz občnoimenske podstave. Šuman nato v Slovenski slovnici za srednje šole (1884: 100-110) v popisu obrazil znova kot za feminativno tvorbo produktivna priponska obrazila navaja -ica, -inja, -ka, -(ov)ka in -ulja, pri čemer poimenovanja prebivalk, po primerih sodeč, tvorita le -ka (Slovenec - Slovenka) in -ica (Korošec - Korošica), obe pa zamenjujeta moškospolsko priponsko obrazilo -ec. Primeri, tvorjeni iz lastnoimenske podstave, niso ločeni od tistih, tvorjenih iz občnoimenske.

Slovnica Petra Končnika (1883) ne ponuja feminativov, tvorjenih iz lastnoimenske podstave. Zato pa Slovenska jezikovna vadnica za tesno združeni poduk v slovnici, pravopisju in spisju, ki sta jo pripravila Schreiner in Bezjak, navaja zgolj tri feminativna priponska obrazila, to so -ica, -inja in -ka, pri čemer je samo zadnje produktivno tudi pri tvorbi poimenovanj za prebivalke: Ljubljančan - Ljubljančanka, Mariborčan - Mariborčanka. Breznikove slovnice V primerjavi z že omenjenimi ne ponujajo ničesar novega. Prva iz leta 1916 popisuje največ feminativnih priponskih obrazil, ki tvorijo imena prebivalk, in tudi največ konkretnih primerov: -inja (Grkinja) in -ka (dodajalno k izglasju -(a)n v primerih Celjanka, Ljubljančanka ali k izglasju na - $r$ ob primeru Bolgarka in zamenjevalno za moškospolsko obrazilo -ec v primerih Slovenka, Nemka) (Breznik 1916: 175, 180). Izdaji iz 1924 in 1934 pa kot produktivno za tvorbo poimenovanj prebivalk navajata zgolj feminativno priponsko obrazilo $-k a$ ob samo dveh primerih: zamenjevalno pri primeru Slovenka in dodajalno pri konkretnem primeru Ljubljančanka (Breznik 1924: 169; 1934: 166). Leta 1956 so Slovensko slovnico izdali Anton Bajec, Rudolf Kolarič, Mirko Rupel in Jakob 
Šolar. Pregledali smo izdajo iz leta 1968, v njej pa je za našo raziskavo poimenovanj za prebivalke zanimivo le priponsko obrazilo $-k a$ ob primeru Slovenka, ko zamenjuje moškospolsko obrazilo -ec (Bajec idr. 1968: 152). V Bajčevem Besedotvorju slovenskega jezika lahko poimenovanja prebivalk tvori le priponsko obrazilo $-k a$. Kot dodajalno nastopa $\mathrm{k}$ izglasju moškospolskega samostalnika na $-(a) n$ (Norvežanka), kot zamenjevalno pa namesto moškospolskega priponskega obrazila -ec (Slovenka, Nemka).

Kot produktivna za poimenovanja prebivalk se $\mathrm{v}$ slovnicah slovenskega jezika pojavljajo feminativna priponska obrazila - a, -ica, -inja, -ka, -kinja, -nja, $-(o v) k a$ in $-\check{s} c a$, ki pa niso s primeri zabeležena v vseh pregledanih virih. Spodnja preglednica prikazuje zastopanost feminativnih priponskih obrazil pri tvorbi poimenovanj za prebivalke. Pri posameznih konkretnih primerih je v oklepaju dodan $\mathrm{D}$ za dodajalni način, $\mathrm{Z}$ za zamenjevalnega.

Preglednica 97: Zastopanost feminativnih priponskih obrazil pri tvorbi poimenovanj za prebivalke

\begin{tabular}{|c|c|c|c|c|c|c|c|c|}
\hline \multirow{2}{*}{$\begin{array}{l}\text { AVTORJI } \\
\text { SLOVNIC }\end{array}$} & \multicolumn{8}{|c|}{ FEMINATIVNA PRIPONSKA OBRAZILA } \\
\hline & $-a$ & $-i c a$ & $-\check{s c a}$ & $-n j a$ & $-i n j a$ & -kinja & $-k a$ & $-(o v) k a$ \\
\hline Bohorič & 1 & $\begin{array}{c}\text { Lambergarica } \\
\text { (D), Lublančica } \\
\text { (Z) }\end{array}$ & 1 & 1 & 7 & 1 & I & 7 \\
\hline Zagajšek & / & l & / & / & / & / & Zellanka $(D)$ & / \\
\hline Pohlin & 1 & Krayniza $(\mathrm{Z})$ & 1 & 1 & I & 1 & $\begin{array}{c}\text { Lublanzanka } \\
(D) \text {, Shtajerka } \\
\text { (Z) } \\
\end{array}$ & I \\
\hline Vodnik & $\begin{array}{c}\text { Koroša } \\
(Z)\end{array}$ & Krajnica $(Z)$ & Kamnišca (Z) & 1 & $\begin{array}{l}\text { Grkinja } \\
(D)\end{array}$ & 1 & Grajanka $(D)$ & I \\
\hline Dajnko & 1 & 7 & 1 & I & $\begin{array}{l}\text { Turkinja } \\
\text { (D) }\end{array}$ & $\begin{array}{l}\text { Slovenkinja } \\
(Z), \text { Čehkinja } \\
(D)\end{array}$ & $\begin{array}{c}\text { Slovenka }(Z), \\
\text { Cehka }(D)\end{array}$ & $\begin{array}{c}\text { Čehovka } \\
(D)\end{array}$ \\
\hline Metelko & I & I & 1 & 1 & $\begin{array}{c}\text { Hrovatinja } \\
(D), \\
\text { Korošinja } \\
(Z)\end{array}$ & 1 & $\begin{array}{l}\text { Gorenka }(Z), \\
\text { Gorjanka }(D)\end{array}$ & I \\
\hline Muršec & I & $\begin{array}{l}\text { Krajnica }(Z), \\
\text { Hrovatica }(D)\end{array}$ & 1 & 1 & $\begin{array}{l}\text { Grkinja } \\
\text { (D) }\end{array}$ & 1 & Nemka (Z) & 1 \\
\hline Malavašič & I & $\begin{array}{l}\text { Korošica }(Z), \\
\text { Hrovatica }(D)\end{array}$ & 1 & 7 & $\begin{array}{l}\text { Rusinja } \\
\text { (D) }\end{array}$ & 7 & $\begin{array}{c}\text { İ̌anka (Z), } \\
\text { Litijanka (D) }\end{array}$ & 7 \\
\hline Potočnik & $/$ & 7 & I & Turknja (D) & 7 & / & $/$ & 7 \\
\hline Majar & I & 1 & I & I & 1 & 1 & 1 & 1 \\
\hline Navratil & 1 & Korošica (Z) & I & I & 1 & 1 & $\begin{array}{c}\text { Dalmatinka }(Z), \\
\text { Litijanka }(D)\end{array}$ & 1 \\
\hline Janežič & 1 & Korošica (Z) & 1 & 1 & 1 & 1 & $\begin{array}{c}\text { Gorenka }(Z), \\
\text { Celovčanka }(D)\end{array}$ & 7 \\
\hline Miklošič & 7 & 1 & 7 & I & $\begin{array}{l}\text { Čehinja } \\
\text { (D) }\end{array}$ & Nemkinja (Z) & Slovenka $(Z)$ & 7 \\
\hline
\end{tabular}




\begin{tabular}{|c|c|c|c|c|c|c|c|c|}
\hline \multirow{2}{*}{$\begin{array}{l}\text { AVTORJI } \\
\text { SLOVNIC }\end{array}$} & \multicolumn{8}{|c|}{ FEMINATIVNA PRIPONSKA OBRAZILA } \\
\hline & $-a$ & $-i c a$ & $-\check{s c c a}$ & $-n j a$ & -inja & -kinja & $-k a$ & $-(o v) k a$ \\
\hline Šuman $^{120}$ & $/$ & / & / & I & $\begin{array}{c}\text { Grkinja } \\
\text { (D) }\end{array}$ & $\begin{array}{c}\text { Slovenkinja } \\
\text { (Z) }\end{array}$ & Slovenka $(Z)$ & I \\
\hline Šuman $^{121}$ & / & Korošica (Z) & $/$ & $/$ & / & / & Slovenka (Z) & 1 \\
\hline Končnik & 7 & 7 & 7 & 7 & 1 & I & 1 & I \\
\hline $\begin{array}{l}\text { Schreiner- } \\
\text { Bezjak }\end{array}$ & 1 & I & / & 7 & $/$ & 1 & $\begin{array}{l}\text { Mariborčanka } \\
\text { (D) }\end{array}$ & I \\
\hline Breznik & $/$ & $/$ & / & I & $\begin{array}{c}\text { Grkinja } \\
(D)\end{array}$ & 1 & $\begin{array}{c}\text { Celjanka }(D), \\
\text { Nemka }(Z)\end{array}$ & 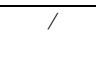 \\
\hline $\begin{array}{l}\text { Rupel, } \\
\text { Bajec, } \\
\text { Kolarič, } \\
\text { Šolar } \\
\end{array}$ & $/$ & $/$ & / & / & / & / & Slovenka & / \\
\hline Bajec & I & / & / & / & / & / & $\begin{array}{l}\text { Norvežanka } \\
\text { (D), Slovenka } \\
\text { (Z) }\end{array}$ & / \\
\hline
\end{tabular}

1. Feminativno priponsko obrazilo $-a$ se pojavi le $\mathrm{v}$ Vodnikovi slovnici kot zamenjava moškospolskega priponskega obrazila -ec ob izglasju podstave na $-\check{s}$ (Koroša).

2. Priponsko obrazilo -ica nastopa $\mathrm{v}$ osmih virih, in sicer kot zamenjevalno (le namesto moškospolskih obrazil -ec, npr. Korošica, ali -ič v primeru Lublančica) ali kot dodajalno k izglasjem na -(a)r (Lambergarica) ali na - $t$ (Hrovatica).

3. Obrazilo -inja smo kot produktivno za tvorbo poimenovanj prebivalk zasledili v osmih virih, $\mathrm{v}$ glavnem nastopa kot dodajalno $\mathrm{k}$ izglasjem podstav samostalnikov moškega spola na $-h$ (Čehinja), - $k$ (Grkinja), -s (Rusinja), -t (Hrovatinja), - $z$ (Francozinja), v enem primeru pa nastopi kot zamenjava moškospolskega priponskega obrazila -ec (Korošinja).

4. Priponsko obrazilo - $k a$ je pri tvorbi poimenovanj za prebivalke lahko dodajalno $\mathrm{k}$ izglasjem - $h$ (Čehka), $-(a) n$ (Zellanka) in -r (Bolgarka) ali zamenjevalno $\mathrm{k}$ priponskemu obrazilu -ec (Slovenka). Nastopa v vseh v analizo vključenih virih, razen pri Bohoriču, Majarju, Končniku in Potočniku.

5. Obrazilo -kinja je lahko dodajalno k izglasju podstave na $-h(\check{C}$ ehkinja) ali zamenjevalno k moškospolskemu obrazilu -ec (Slovenkinja). Zasledimo jo pri Dajnku, Miklošiču in Šumanu.

\footnotetext{
${ }^{120}$ Josip Šuman: Slovenska slovnica po Miklošičevi primerjalni (1881).

${ }^{121}$ Josip Šuman: Slovenska slovnica za srednje šole (1884).
} 
6. Feminativno obrazilo -nja se pojavi le v Potočnikovi slovnici kot dodajalno k izglasju podstave na $-k$ (Turknja).

7. Tudi priponsko obrazilo - $(o v) k a$ nastopa le $\mathrm{v}$ eni, tj. Dajnkovi slovnici kot dodajalno k izglasju podstave na - $h$ (Čehovka).

8. Obrazilo -šca nastopa le pri Vodniku kot zamenjava moškospolskega priponskega obrazila -čan (Kamnišca).

Zanimivo je opazovati variantna priponska obrazila, ki se kažejo skozi razvoj. Kot taka nastopajo dodajalna obrazila -inja, -kinja, -ka, -(ov)ka (Čehinja, Čehkinja, Čehka, Čehovka), -nja in -inja (Turknja, Turkinja), -inja in -ica (Hrovatinja, Hrovatica), kot zamenjevalna pa nastopajo -a, -ica, -inja; -kinja in -ka k priponskemu obrazilu -ec (Koroša, Korošica, Korošinja; Slovenkinja, Slovenka).

\subsubsection{Poimenovanja prebivalk v Slovenskem pravopisu}

Obravnava tega področja je v Slovenskem pravopisu (2001) zelo skopa, združena z občnoimenskimi poimenovanji; po njej izpeljanke za moške osebe ali živali načeloma imajo vzporednice za ženski spol. Tudi po tem jezikovnem viru jih tvorimo tako, da moškospolskemu poimenovanju dodamo ustrezno ženskospolsko priponsko obrazilo (učitelj - učiteljica, Novomeščan Novomeščanka, nemčur - nemčurka, knez - kneginja, prodekan - prodekanka, kustos - kustosinjalkustodinja) ali pa moškospolsko priponsko obrazilo zamenjamo z ženskospolskim (Slovenec - Slovenka, knjigovodja knjigovodkinja). Sicer pa so ženskospolska poimenovanja za prebivalke zbrana v slovarskem delu Slovenskega pravopisa kot podiztočnice pri zemljepisnih lastnih imenih. $\mathrm{Ob}$ iskalnem pogoju preb. smo našli 2501 iztočnico. Izločili smo poimenovanja, izpeljana iz enakih zemljepisnih lastnih imen (npr. Gabrje $\rightarrow$ Gabrčan $\rightarrow$ Gabrčanka, pri čemer je mišljeno Gabrje pri Novem mestu ali Gabrje pri Ajdovščini, poimenovanje za prebivalca oz. prebivalko pa je enako). Tako smo analizirali 2420 konkretnih primerov. Med temi jih je manj, to je 571 (ali $24 \%$ ), nastalo z zamenjavo moškospolskega obrazila, preostalih 1849 (76 \%) pa jih je 
bilo tvorjenih z dodajanjem ženskospolskega priponskega obrazila samostalniku moškega spola. Razmerje med obema načinoma tvorbe prikazuje spodnji grafikon.

Grafikon 22: Poimenovanja za prebivalke v SP (2001) glede na način tvorbe

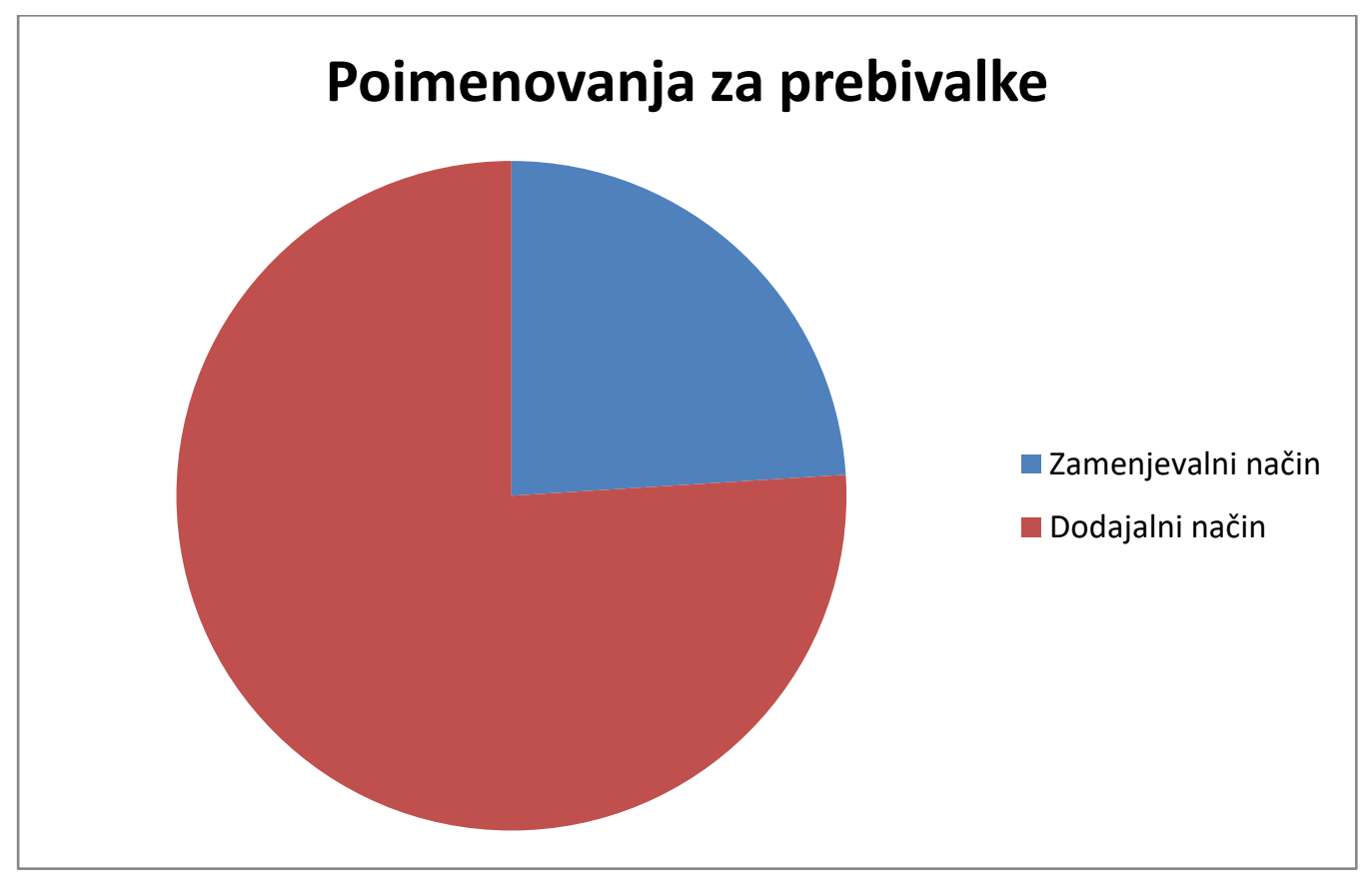

Najpogostejše ženskospolsko priponsko obrazilo je bilo obrazilo $-k a$, ki se je pojavilo skupno kar 2330-krat (96 \% vseh zbranih besed), sledi obrazilo -inja s skupno 65 pojavitvami (3\%), nato -ica z 20 (0,8 \%), feminativna priponska obrazila -ca, -kinja, -ijka, -anka in -(ev)ka pa so zastopana s po enim konkretnim primerom. Zastopanost navedenih feminativnih priponskih obrazil pri tvorbi poimenovanj za prebivalke v Slovenskem pravopisu prikazuje spodnji grafikon. 
Grafikon 23: Feminativna priponska obrazila pri poimenovanjih za prebivalke $v$ SP (2001)

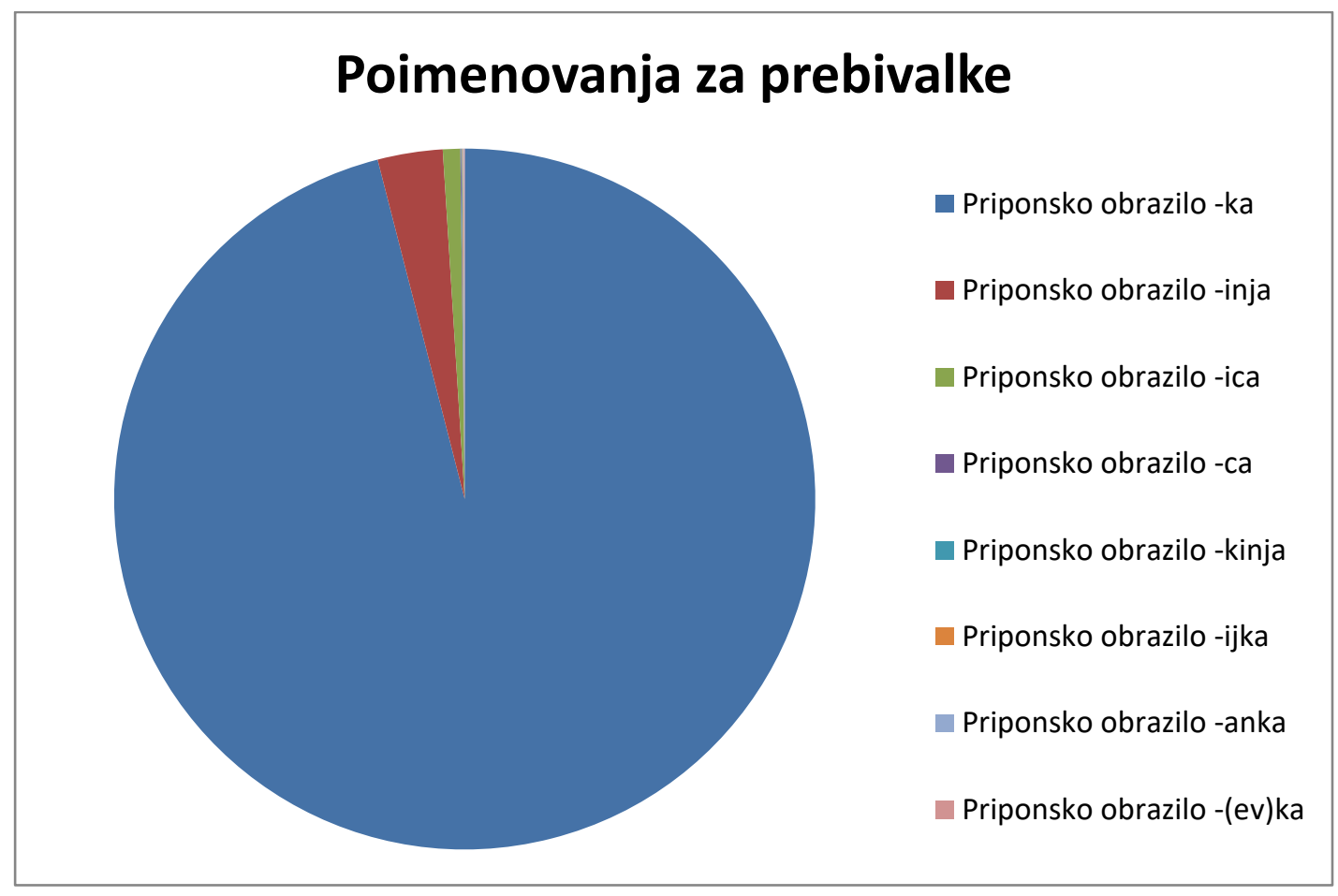

10.1.2.2.1 Poimenovanja, nastala $\mathrm{z}$ dodajanjem ženskospolskega obrazila $\mathrm{k}$ samostalnikom moškega spola

Večina, kar 76 \% oz. 1849 primerov, iz slovarskega dela Slovenskega pravopisa izpisanih poimenovanj $\mathrm{za}$ prebivalke, je nastala $\mathrm{z}$ dodajanjem ženskospolskega obrazila samostalnikom moškega spola. Največ primerov, 1766 $(95,5 \%)$, je nastalo z dodajanjem obrazila $-k a$. Drugo najpogostejše dodajalno feminativno priponsko obrazilo je bilo -inja s 65 primeri (3,5\%), tretje pa -ica s 15 primeri tvorjenk $(0,8 \%)$. Priponska obrazila -kinja, -ijka in -(ev)ka se pojavijo le po enkrat. 
Grafikon 24: Zastopanost feminativnih priponskih obrazil pri tvorbi poimenovanj za prebivalke $z$ dodajalnim načinom

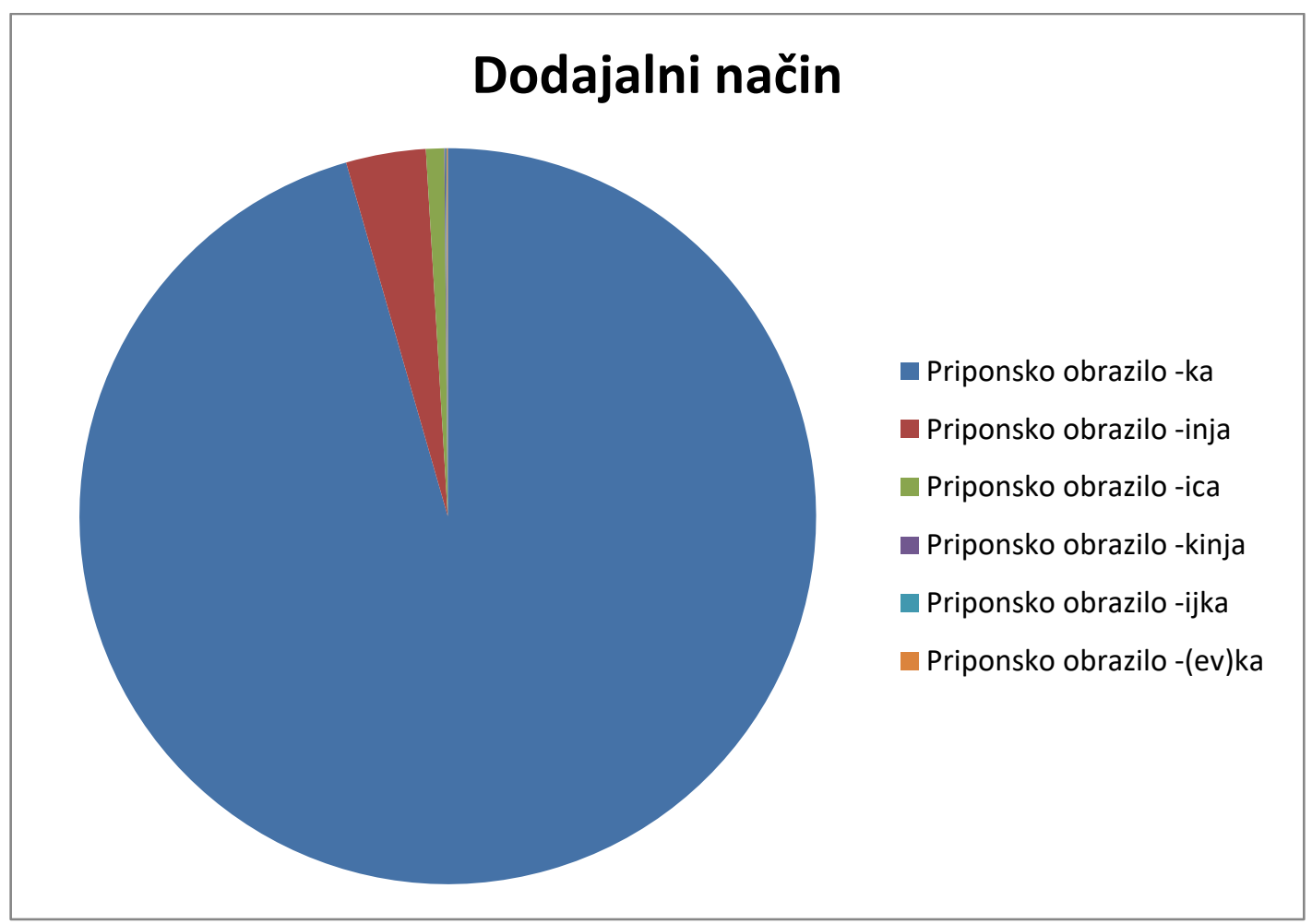

Spodnja preglednica prikazuje, katerim izglasjem (obrazil in podstav) moškospolskih samostalnikov se navedena feminativna priponska obrazila dodajajo, kadar tvorijo poimenovanja za prebivalke.

Preglednica 98: Poimenovanja za prebivalke, nastala $z$ dodajanjem ženskospolskega obrazila samostalnikom moškega spola

\begin{tabular}{|r|r|c|}
\hline DODAJALNO OBRAZILO & IZGLASJE & PRIMER POIMENOVANJA \\
\hline \multirow{3}{*}{$-\boldsymbol{i} \boldsymbol{c a}$} & $-(a) r$ & Bačarica \\
\cline { 2 - 3 } & $-t$ & Hrvatica \\
\hline \multirow{4}{*}{$-\boldsymbol{i n j a}$} & $-b$ & Švabinja \\
\cline { 2 - 3 } & $-\check{c}$ & Apačinja \\
\cline { 2 - 3 } & $-d$ & Judinja \\
\cline { 2 - 3 } & $-f$ & Volofinja \\
\cline { 2 - 3 } & $-g$ & Nibelunginja \\
\cline { 2 - 3 } & $-h$ & Čehinja \\
\cline { 2 - 3 } & $-k$ & Aztekinja \\
\cline { 2 - 3 } & $-(a) k$ & Poljakinja \\
\hline
\end{tabular}




\begin{tabular}{|c|c|c|}
\hline & $-m$ & Rominja \\
\hline & $-r$ & Burinja \\
\hline & $-s$ & Anglosasinja \\
\hline & $-\check{s}$ & Malgašinja \\
\hline & $-t$ & Baltinja \\
\hline & $-z$ & Aškenazinja \\
\hline & $-(o) z$ & Francozinja \\
\hline & $-(e) \check{z}$ & Angležinja \\
\hline -kinja & $-b$ & Srbkinja \\
\hline$-k a$ & $-b$ & Kašubka \\
\hline & $-\check{c}$ & Čička \\
\hline & $-d$ & Dravidka \\
\hline & $-j$ & Masajka \\
\hline & $-l$ & Mongolka \\
\hline & $-m$ & Eskimka \\
\hline & $-n$ & Hunka \\
\hline & $-(a) n$ & Afričanka \\
\hline & $-r$ & Madžarka \\
\hline & $-t$ & Obodritka \\
\hline$-i j k a$ & $-z$ & Kirgizijka \\
\hline$-(e v) k a$ & $-j$ & Majevka \\
\hline
\end{tabular}

1. Priponsko obrazilo -ica pri tvorbi poimenovanj za prebivalke dodajamo moškospolskim samostalnikom $\mathrm{z}$ izglasjem na $-r$ (vedno $-(a) r$ : Kočevarica, Dragarica, Pokljukarica, Šiškarica, Železnikarica) ali -t (samo primer Hrvatica).

2. Obrazilo -inja lahko dodajamo največ različnim izglasjem podstav

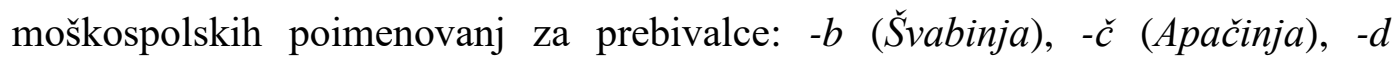
(Judinja, Kurdinja, Švedinja, Vendinja), $-f$ (Volofinja), - $g$ (Nibelunginja, Tuareginja, Vikinginja), -h (Čehinja, Kazahinja, Lahinja, Vlahinja), -k (Baskinja, Grkinja, Inkinja, Tadžikinja, tudi -(a)k: Poljakinja), -m (Rominja), -r (Burinja), -s (Prusinja, Rusinja, Sasinja), -š (Malgašinja), -t (Baltinja, Keltinja, Koptinja, Škotinja), -z (Aškenazinja, Čerkezinja; z -(o)z: Francozinja), -(e)ž (Angležinja).

3. Priponsko obrazilo -kinja je zastopano le z enim primerom, to je Srbkinja, pri čemer se ženskospolsko priponsko obrazilo doda moškospolskemu poimenovanju $\mathrm{z}$ izglasjem na $-b$. 
4. Obrazilo -ka se dodaja izglasjem podstav na -b (en primer: Kašubka), - ̌̌ (samo en primer - Čička), -d (Dravidka, Samojedka, Gepidka, Langobardka, Lombardka), -j (samo Masajka), -l (Mongolka, Vandalka), -m (le Eskimka), -n (Čečenka, Latinka, Tevtonka, Hunka, tudi z -(a)n: Afričanka), -r (Avarka, Berberka, Ilirka, Maorka, Ujgurka) in -t (Antka, Hotentotka, Obodritka, Sarmatka, Udmurtka).

5. Priponsko obrazilo -ijka se lahko doda samo izglasju na -z (Kirgizijka).

6. Obrazilo -(ev)ka je zastopano zgolj z enim konkretnim primerom, pri čemer se doda izglasju na -j (Majevka).

Ob primerjavi s tvorbo feminativov iz občnoimenske podstave smo zaznali nekaj podobnosti, pa tudi razlik. Priponsko obrazilo $-(e v) k a$ se dodaja izglasjem podstave na $-j$ tudi pri izobčnoimenski podstavi. Tudi priponsko obrazilo -ica ob tovrstni tvorbi nastopa kot dodajalno k izglasjem na - $(V) r$, ne pa k tistim na -t. Obrazilo -inja se lahko pri izlastnoimenski tvorbi feminativov dodaja različnim izglasjem (podstav); nekaj teh smo zasledili tudi pri izobčnoimenski tvorbi; enako velja za ženskospolsko obrazilo - $k a$.

10.1.2.2.2 Poimenovanja, nastala $\mathrm{z}$ zamenjavo celotnega ali le izglasnega dela moškospolskega obrazila z ženskospolskim ob isti podstavi

Manj je primerov, nastalih z zamenjevalnim načinom, samo 571. Večina jih je bila tvorjena s priponskim obrazilom $-k a$, to je $564(98,8 \%)$, samo pet primerov je nastalo z obrazilom -ica (ali 0,8 \%), priponski obrazili -ca in -anka pa se pojavita le pri enem primeru. 
Grafikon 25: Zastopanost feminativnih priponskih obrazil pri tvorbi poimenovanj za prebivalke z zamenjevalnim načinom

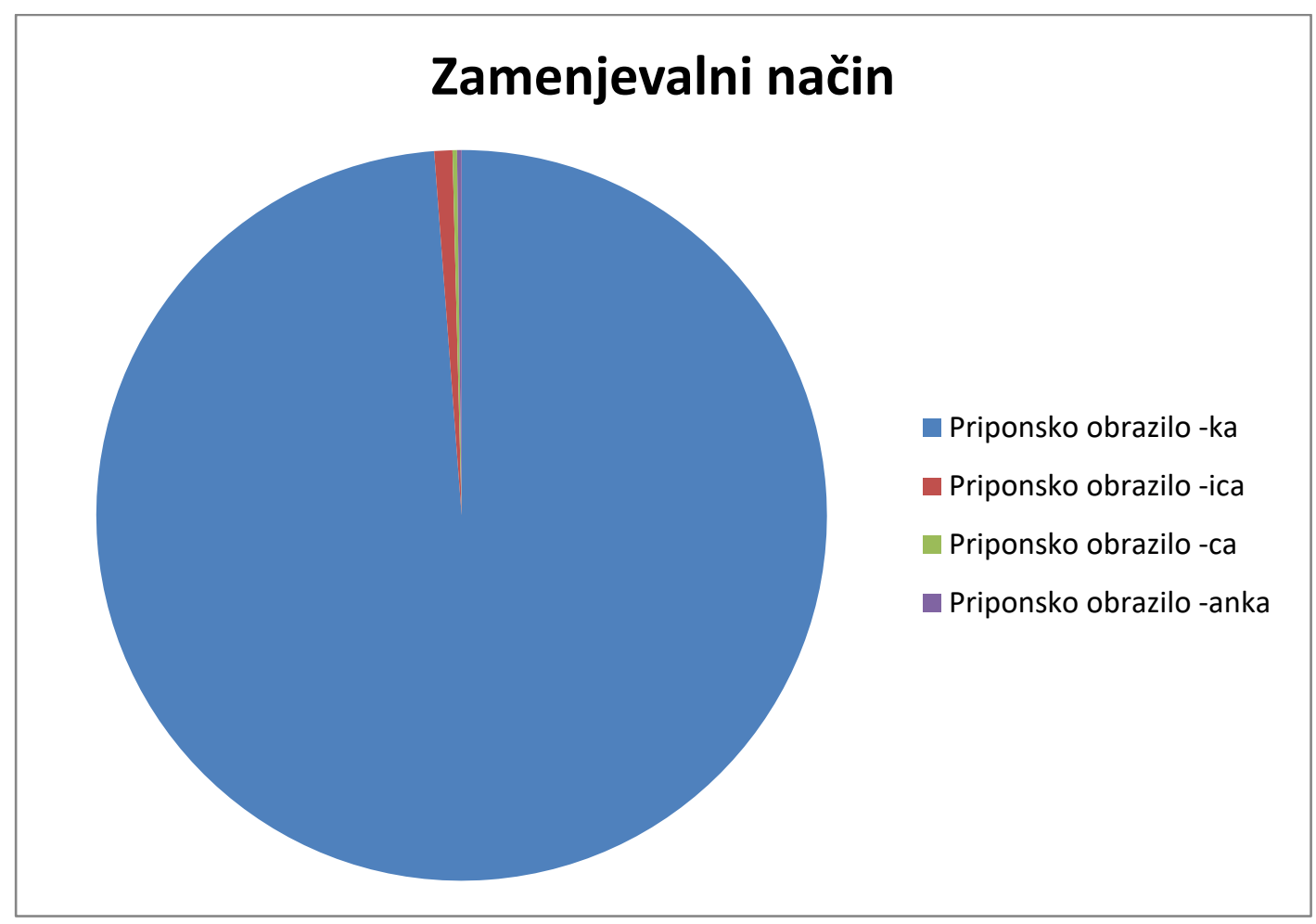

Spodnja preglednica prikazuje, katera moškospolska priponska obrazila se zamenjujejo z navedenimi feminativnimi priponskimi obrazili, kadar gre za poimenovanja prebivalk.

Preglednica 99: Poimenovanja za prebivalke, nastala z zamenjavo celotnega ali le izglasnega dela moškospolskega obrazila z ženskospolskim ob isti podstavi

\begin{tabular}{|c|c|c|c|}
\hline $\begin{array}{l}\text { ŽENSKOSPOLSKO } \\
\text { OBRAZILO }\end{array}$ & $\begin{array}{l}\text { OBRAZILO } \\
\text { MOŠKEGA SPOLA }\end{array}$ & $\begin{array}{l}\text { IZGLASJE } \\
\text { PODSTAVE }\end{array}$ & $\begin{array}{l}\text { PRIMER } \\
\text { POIMENOVANJA }\end{array}$ \\
\hline$-c a$ & $-e c$ & $-\check{s}$ & Črnovršca \\
\hline \multirow[t]{4}{*}{-ica } & \multirow[t]{3}{*}{$-e c$} & $-n j$ & Kranjica \\
\hline & & $-\check{s}$ & Korošica \\
\hline & & $-\check{z}$ & Vipolžica \\
\hline & $-i k$ & $-n$ & Močvirnica \\
\hline \multirow[t]{4}{*}{$-k a$} & \multirow[t]{3}{*}{$-c$} & $-l j$ & Dupeljka \\
\hline & & $-n$ & Komenka \\
\hline & & $-r$ & Nigrka \\
\hline & $-\check{c} a n$ & $-n j$ & Guštanjka \\
\hline
\end{tabular}




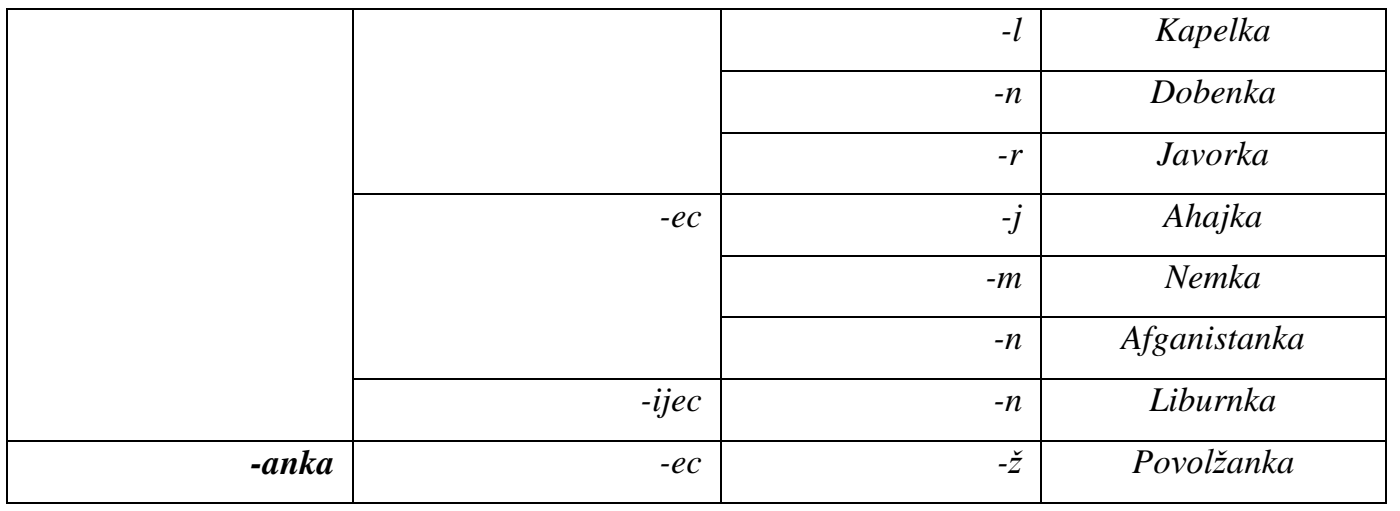

1. Priponsko obrazilo $-c a$ se pojavi le pri enem primeru, ko zamenja

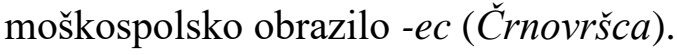

2. Feminativno priponsko obrazilo -ica zamenjuje moškospolski obrazili -ec (Črnovršica, Korošica, Kranjica, Vipolžica) in -ik (samo Močvirnica).

3. Priponsko obrazilo $-k a$ pa pri tvorbi poimenovanj za prebivalke lahko zamenjuje moškospolska obrazila -c (Biljenka, Bosenka, Brika, Dupeljka, Nigrka, Komenka, Skopeljka, Vatoveljka), -čan (Dobenka, Guštanjka, Javorka, Kapelka), -ec (Ahajka, Etiopijka, Hindujka, Kazahstanka, Nemka, Slovenka) in -ijec (Liburnka). Primeri moškospolskih poimenovanj $\mathrm{z}$ obrazilom -čan so lahko tvorjeni tudi s priponskim obrazilom $-e c$; tako obrazilo $-k a$ zamenja priponski obrazili -čan (Dobenčan, Guštanjčan, Javorčan, Kapelčan) ali -ec (Dobenec, Guštanjec, Javorec, Kapelec).

4. Obrazilo -anka nastopi le enkrat, in to kot zamenjava moškospolskega priponskega obrazila -ec pri primeru Povolžanka.

Tudi pri feminativih, ki so tvorjeni iz občnoimenske podstave, priponski obrazili -ica in - $k a$ zamenjujeta moškospolsko obrazilo -ec; samo obrazilo - $k a$ pa pogosto zamenjuje različna obrazila s sestavino $-e c$, tako da tudi zamenjava moškospolskega -ijec, kadar gre za poimenovanja prebivalk, ne preseneča. Tudi priponsko obrazilo -ica je edino, ki pri izobčnoimenski tvorbi feminativov zamenja moškospolsko obrazilo -ik, enako je pri izlastnoimenskih feminativih. Nikoli pri izobčnoimenski tvorbi pa ženskospolsko obrazilo $-k a$ ne zamenja moškospolskih $-c$ in -čan, kadar gre za poimenovanja oseb in živali, tvorjenih iz 
občnoimenskih podstav. Feminativni priponski obrazili -ca in -anka pa pri izobčnoimenskih feminativih ne nastopita.

\subsection{Priimkovni feminativi}

10.2.1 Priimkovni feminativi v drugih slovanskih jezikih

Pojav priimkovnih feminativov lahko zasledimo tudi v drugih slovanskih jezikih, čeprav v manjšem obsegu, saj se avtorji v monografijah, vključenih v našo raziskavo, v glavnem posvečajo izobčnoimenski tvorbi feminativov. Tako Stjepan Babić v monografiji Tvorba riječi u hrvatskom književnom jeziku ob predstavitvi priponskega obrazila -ka (Borkovićka, Brajdićka, Filipčićka ...) opozarja tudi na tvorbo priimkov ženskega spola v hrvaščini. Priponsko obrazilo -ka se najpogosteje doda izglasju na -ć, kot kažejo tudi navedeni primeri (Babić 1991: 256). Tvorbo ženskospolskih oblik priimkov v srbščini pa omenja Ivan Klajn (2003: 125) pri priponskem obrazilu -ka (primera, ki ju Klajn navaja, sta Spasićka in Popovićka). Iz navedenih primerov je razvidno, da se tudi v srbščini priponsko obrazilo $-k a$ pri tvorbi priimkovnih feminativov dodaja izglasju na $-\dot{c}$. Pri tem se Klajn sklicuje na Babića (1991: 257), ki pravi, da so tovrstne tvorjenke slogovno zaznamovane. V češčini (Mluvnice češtiny 1986: 306) pa je najbolj produktivno obrazilo za tvorbo priimkovnih feminativov priponsko obrazilo -ova (svojilna oblika: Horačkova, Novakova ...), pri čemer se moškospolskemu priimku odvzame morebitni končni samoglasnik (Dite - Ditova).

\subsubsection{Priimkovni feminativi skozi zgodovino}

Priimki sestavljajo skupaj z rojstnim oziroma krstnim imenom dvodelno osebno ime, ki ga uporabljamo za uradno identifikacijo. Priimek je postal zakonsko obvezen del uradnega poimenovanja moških in žensk ter se deduje 
navadno po očetu, redkeje po materi. ${ }^{122}$ Čeprav so priimki nastajali že v prvih stoletjih prejšnjega tisočletja (najprej $\mathrm{v}$ višjih družbenih plasteh), je njihova dednost in splošna obveznost zakonsko določena šele veliko pozneje, različno po raznih deželah, od 17. stoletja dalje. Na slovenskem ozemlju je bil zakon o obveznem priimku uveljavljen v zadnji tretjini 18. stoletja, v času vladanja Marije Terezije in Jožefa II. (Jakopin 1997: 25). Priimek je tako postal splošno veljavno pravno identifikacijsko sredstvo. Irena Orel (2001: 54) ugotavlja, da se priimkovni feminativi v uradovalnih besedilih pojavljajo nepretrgano od 16. do 19. stoletja, vendar opaža, da proti koncu 18. stoletja začnejo neenotno prevladovati moške oblike. Slednja trditev se ujema z navedbami Gorazda Makaroviča, da je bil pravno odgovoren v 18. stoletju predvsem moški, zato so tudi ženskam iz družine zapisovali priimek v moški obliki (Makarovič 2008: 24). V zapisih od 16. do 18. stoletja se priimki za ženske razlikujejo od priimkov moških, ker se jim dodajajo priponska obrazila -ikca, -ica, -ka, -klja, -(ov)ica, -(ov)ka/-(av)ka, -ska, -na, -ka, -ulja. Med njimi so najpogostejša -(ov)ka, -ka in -ical-ca (Torkar 2002: 72).

Tako že v Bohoričevi slovnici Zimske urice proste iz leta 1584 najdemo, sicer zgolj eno, navedbo ženske oblike priimka k moškemu priimku Lambergar Lambergarica (Bohorič 1987: 91-100). Toporišič (2001: 6) navaja, da je ženskospolske oblike priimkov mogoče najti tudi v Hipolitovi slovnici iz leta 1715 (Auerspergarska, Gallembergarska, Lambergarca, Raubarca, Tauffrarca, Gallembergarca, Blagojovka, Rospovka, Kušlanovka) in Japljevi iz leta 1807 (Auerspergarca, Lambergarca, Gallembergarca, Lihtenbergarca, Hohenwartarca, Raubarca, Švajgarca, Barbovka, Rajšpovka). Hipolitova slovnica s primeroma Gallembergarska - Gallembergarca potrjuje Torkarjevo (2002: 72) opažanje o dogajanju v zgodovini jezika, da so se pri istem priimku lahko za žensko obliko uporabljala različna priponska obrazila (po Torkarju npr. Novak - Novakovka, Novakinja, Novačica). Z zgledi ženskospolskih priimkov nadaljuje Valentin Vodnik (1811: 149) v slovnici Pismenost ali Gramatika za Perve šole iz leta 1811, kjer navede primera k priimkoma moškega spola: Hvala Hvaleška in Anže - Anžetla.

122 Že same ustreznice za besedo priimek v nekaterih jezikih kažejo, da je priimek povezan z družinsko skupnostjo, npr. angleško family name, francosko nom de famille, nemško Familienname (Jakopin 1997: 25). 
Fran Metelko v svoji slovnici Lehrgebaude der slavischen Sprache iz leta 1825 v poglavju Bildung der Eigennamen piše, da se priimku »moškega spola dajejo končaji -ka, -ca, -ica, -(ov)ka, -la, -ulja, da se tako označi njegova žena«, in izpostavi tvorjenje ženskih oblik priimkov (Jeklin - Jeklinka, Šalomon Šalomonka; Kolar - Kolarica, Praprotnik - Praprotnica, Razpotnik-Razpotnica) (Metelko 1825: 68). Naslednja slovnica, ki prinaša priimkovne feminative, je Murščeva Kratka slovenska slovnica za prvence iz leta 1847: Borovec - Borovka, Caf - Cafovka, Gomilšak - Gomilšakovka, Jaklin - Jaklinka, Macun - Macunka, Krajnic - Krajnička. Vidimo, da so priimki po Muršcu tvorjeni s priponskima obraziloma $-k a$ in $-(o v) k a$. Po Metelku povzete nekatere priimke navaja Fran Malavašič (1849: 108) v Slovenski slovnici za prve slovenske šole v mestih in na deželah iz leta 1849 (npr. Kolarica, Praprotnica).

Priimke obravnava tudi Anton Janežič v svoji Slovenski slovnici s kratkim pregledom slovenskega slovstva iz leta 1854: Jaklin - Jaklinka ali Jaklinova, Perko - Perkovka, Potočnik - Potočnikinja (Janežič 1854: 17). Opazimo lahko še eno potrditev Torkarjeve (2002: 72) ugotovitve, namreč da je od 2. polovice 19. stoletja, zlasti v meščanskem okolju, živi jezik izoblikoval za ločevanje priimkov žensk od priimkov moških svojilne pridevnike na -oval-eva (npr. pri Janežiču Jaklinova). Primer ženskospolskega priimka najdemo tudi $\mathrm{v}$ slovnici Josipa Šumana Slovenska slovnica po Miklošičevi primerjalni iz leta 1881: Pavlička. Primer je naveden pri obravnavi priponskega obrazila -ka, kadar gre za »ženski spol proti moškemu po izvoru, rodu, veri« (Šuman 1881: 245248). Kot zadnje omenimo delo Besedotvorje slovenskega jezika 1 (prvi zvezek je posvečen izpeljavi, 1950) Antona Bajca. Slednji kot možno za tvorbo ženskospolskih priimkov navaja zgolj priponsko obrazilo -ka, ki pri tej tvorbi »ustreza naslednjim moškim formantom«: -ač: Mihačka (»redno, najrajši ob priimkih«); -ič, »sicer često ob priimkih«: Pavlička; še ob drugih obrazilih, zlasti pri imenih in priimkih: Herodežka, Mahnečka, Slabečka (Bajec 1950: 94-95).

10.2.3 Priimkovni feminativi danes 
Silvo Torkar (2002: 71) ugotavlja, da se tipično slovenski priimki končujejo na -šek ali -nik. Prvotno so s tovrstnimi izrazi zaznamovali vzdevke ali hišna imena; slednja so bila v kmečkem okolju pogost vir pri nastajanju priimkov in so v rabi še danes. Ohranjajo se več rodov, včasih celo več stoletij. Viri za njihov nastanek so zelo podobni tistim za priimke.

V slovenski onomastiki ostaja tradicionalna pomenska delitev priimkov na štiri skupine:

1. iz rojstnih imen,

2. iz imen poklicev in dejavnosti,

3. iz krajevnih, ledinskih, pokrajinskih in etničnih imen,

4. iz vzdevkov (Torkar 2002: 73). ${ }^{123}$

Po Kebru (1999: 136-137) pa vir priimkov predstavljajo tudi živalske metafore. Priimke, ki so neposredno ali posredno nastali iz živalskih nazivov, uvršča v tri skupine: v prvi so priimki, ki so po obliki enaki živalskim nazivom (Jelen), v drugi so tako imenovani izpeljani priimki (Golobič), v tretji pa so priimki, ki so posredno povezani z živalskimi poimenovanji (Jazbinšek).

Besedno zvezo priimkovni feminativi uporabi Toporišič, ko pravi, da so slovenske gospodinje oziroma zakonske družice hišnih poglavarjev imele samosvoje priimkovne oblike, vzporednice moških priimkov (Toporišič 2001: 5). V Slovenski slovnici (2004: 161) Toporišič tvorbo ženskospolskih oblik priimkov omenja v poglavju Osnovni pojmi besedotvorja, podpoglavje Živost besedotvornih vrst in sredstev. Tako navaja priponski obrazili -ica in -ka, ko zaznamujeta ženski par moškemu (Smrekarica, Kežmanca, Pinterička, Tomšetka, Urekovka), opozarja pa, da se namesto tega, zlasti v meščanskih krogih, rabijo posamostaljene pridevniške besede $\mathrm{z}$ obraziloma -ova in -eva (Smrekarjeva, Pinteričeva, Tomšetova, Urekova). Kot pa med drugim ugotavlja Paula Zupanc v svojem članku v tematskem delu revije Dialogi (2009), se razmerje spola v jeziku odraža tudi pri oblikah priimkov, saj je običajna raba, s katero se ženska označuje kot lastnina (npr. »profesorica Tršarjeva«). S spolno ozaveščene perspektive zato

${ }^{123}$ Iz teh štirih virov so se oblikovali priimki tudi v drugih slovanskih jezikih (Jakopin 1997: 27). 
uporabljamo priimek brez dodajanja končnice, ki označuje svojino (npr. »profesorica Tršar«).

Danes se tovrstne ženske oblike priimkov uporabljajo le še v vaškem okolju, kjer zvenijo nevtralno, vendar na stilistično vrednost čedalje bolj vpliva mestno okolje, kjer se te oblike občutijo bolj ali manj kot slabšalne (Torkar 2002: 72). Tudi Toporišič (2001: 9) opozarja, da so se priimkovni feminativi iz knjižnega jezika izgubili in da so izpodrinjeni s posamostaljeno obliko svojilnega pridevnika (kar smo sicer opazili že pri Janežiču). Ostale pa so priimkovne ženske vzporednice moških priimkov na deželi kot nazivi za hišne gospodinje. Toporišič (1973: 244) to ponovno potrjuje, ko pravi, da so feminativi priimkov, izpeljani s priponskimi obrazili za samostalnike, zaznamovani pogovorno, v knjižnem jeziku tudi starinsko (Rogarica, Radmanca, Matička, Boltela ...).

\subsubsection{Priimkovni feminativi v Slovenskem pravopisu}

Po Slovenskem pravopisu (2001: § 994, 996) imajo izpeljanke za moške osebe ali živali vzporednice za ženski spol. Priimki so načeloma moškega spola: Prešeren, Detela, Potrata ... Kadar se nanašajo na ženske osebe, jih obravnavamo na tri načine:

1. Spremenijo spol in preidejo v 3. žensko sklanjatev (navadno le v zvezi $\mathrm{z}$ imenom), imena $\mathrm{s}$ končnico $-a$ pa tudi $\mathrm{v} 1$. žensko sklanjatev: Zofka Kveder - Zofke Kveder; Medana Bratina - Medane Bratina/Medane Bratine.

2. Kot priimek uporabljamo posamostaljeno obliko svojilnega pridevnika iz ustreznega lastnega imena, npr. pri priimku Kveder: Kvedrova, Kvedrove

3. Priimku dodamo samostalniško priponsko obrazilo ženskega spola oz. moškospolsko obrazilo zamenjamo z ženskospolskim (oboje je danes slengovsko, neknjižno ljudsko, pokrajinsko): Kocmur - Kocmurka; Ogorelec - Ogorelka; Radman - Radmanca; Visočnik - Visošca; Kovač Kovačica; Pozne - Poznela; Žibert-Žibertovka; Smole - Smoletovka. 
4. Če je priimek posamostaljena pridevniška beseda, se ustrezna oblika za žensko lahko dela z zamenjavo sklanjatvenega vzorca za spol: Matičetov Matičetova -e.

V slovarski del $S P$ je bilo uvrščenih 500 najpogostejših priimkov pri Slovencih, tem pa so bile pripisane tudi feminativne oblike. Jože Toporišič je moškim priimkom pripisal ženske, te pa sta presodila sourednik SP Janez Dular in redaktorica lastnoimenskega dela Alenka Gložančev. Taka poimenovanja so danes predvsem žargonska, v SP pa naj bi bila kot spomenik poimenovanjem slovenskih žena (Toporišič 2001: 5). Za raziskavo je bilo pregledanih 3248 iztočnic spletne verzije $S P . \mathrm{V}$ iskalnik smo vpisali kvalifikator oseb. $i$. in tako dobili izpis vseh osebnih imen. S seznama smo izpisali vseh 500 priimkovnih feminativov in jih analizirali. Zbranih in izpisanih je bilo torej 500 ženskospolskih oblik za priimke. Med temi jih je zgolj 38 (ali 8 \%) nastalo z zamenjavo moškospolskega obrazila, preostalih 462 (92 \%) pa z dodajanjem ženskospolskega obrazila priimku moškega spola.

Grafikon 26: Priimkovni feminativi v SP (2001) glede na način tvorbe

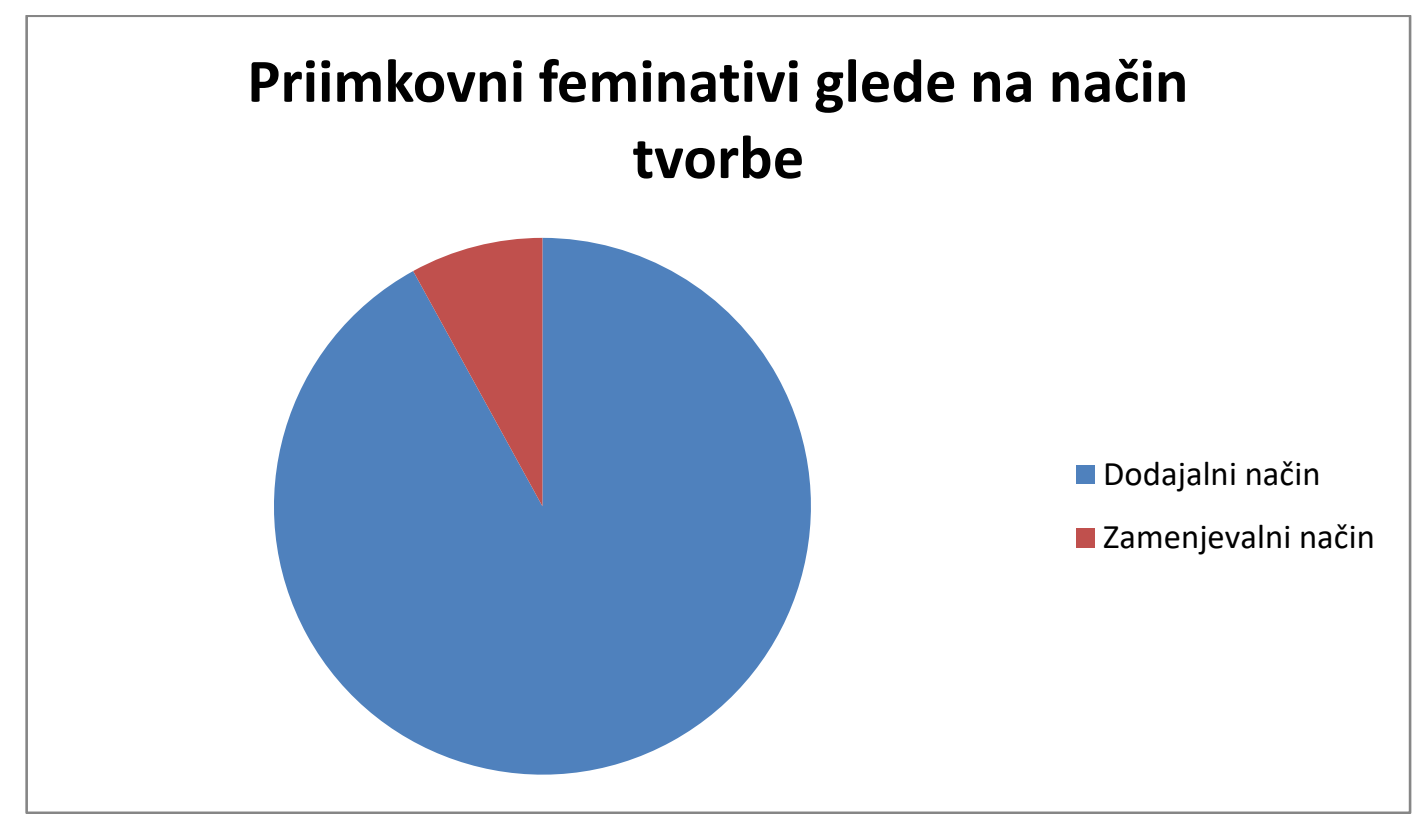

Najpogostejše ženskospolsko priponsko obrazilo je bilo obrazilo -(ov)ka, ki se je pojavilo 177-krat (35\% vseh zbranih besed), sledi obrazilo -ka s 153 
pojavitvami (31\%), nato -ica s $103(21 \%)$ in -(ev)ka s 66 (13\%) pojavitvami. Zasledili smo le en primer s priponskim obrazilom -inja.

Grafikon 27: Tvorba priimkovnih feminativov

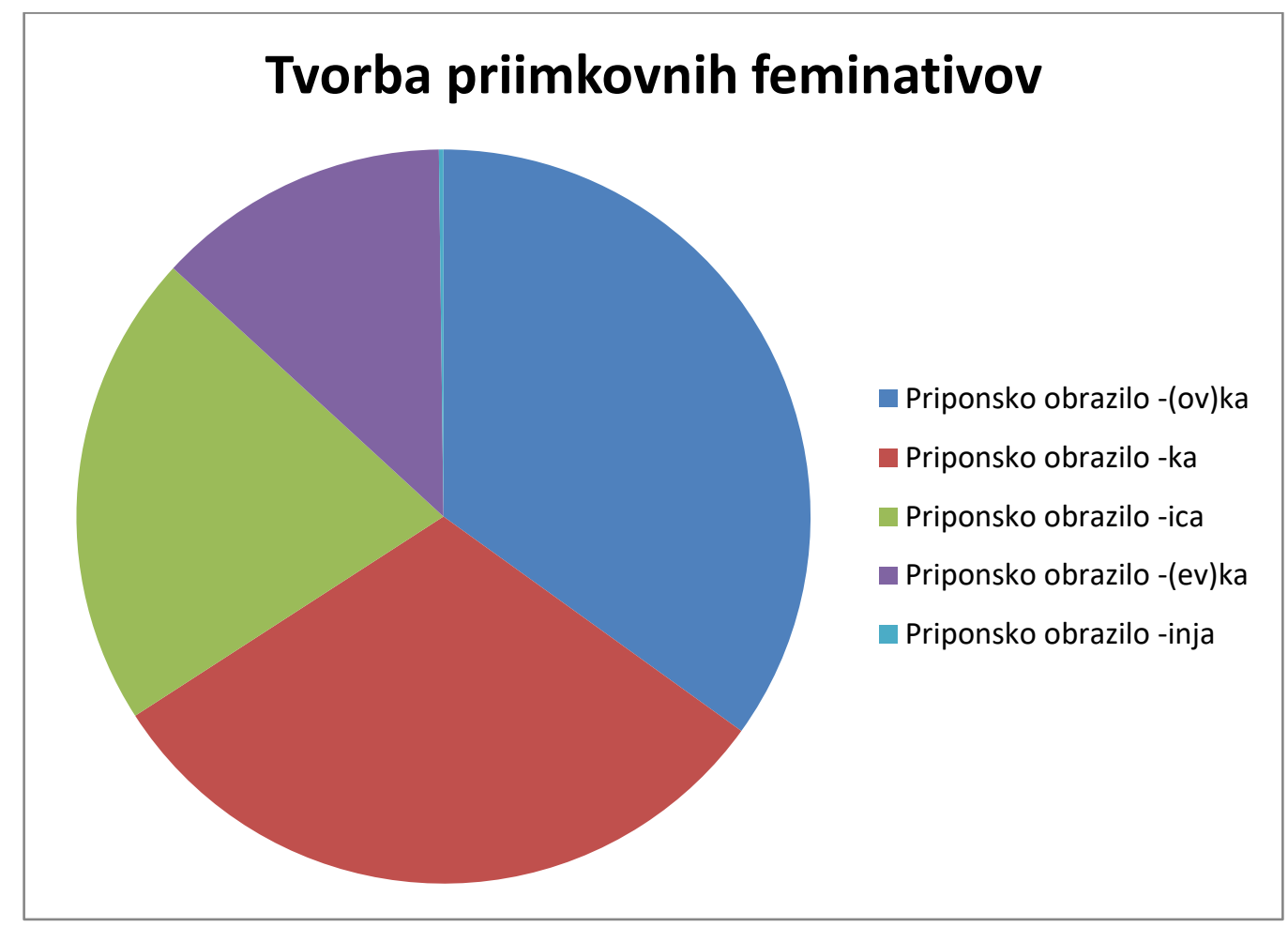

10.2.3.1.1 Priimki, nastali $\mathrm{z}$ dodajanjem ženskospolskega obrazila $\mathrm{k}$ priimkom moškega spola

Večina, kar $92 \%$, iz slovarskega dela $S P$ izpisanih ženskih oblik priimkov je nastala $\mathrm{z}$ dodajanjem ženskospolskega obrazila priimkom moškega spola. Največ primerov, 177 (38 \%), je nastalo z dodajanjem obrazila -(ov)ka. Ugotovili smo, da to obrazilo nastopa zgolj kot dodajalno; enako velja za priponsko obrazilo -(ev)ka, saj je vseh 66 izpisanih primerov (ali $14 \%$ ) nastalo z dodajanjem ženskospolskega priponskega obrazila priimku moškega spola. Obrazili -ica in - $k a$ lahko nastopata kot dodajalni ali zamenjevalni. Kot dodajalno priponsko obrazilo se -ica pojavi 73-krat (16\%), -ka pa 143-krat (31\%). Obrazilo -inja nastopi pri enem konkretnem primeru. 
Grafikon 28: Priimkovni feminativi, tvorjeni $z$ dodajanjem ženskospolskega obrazila

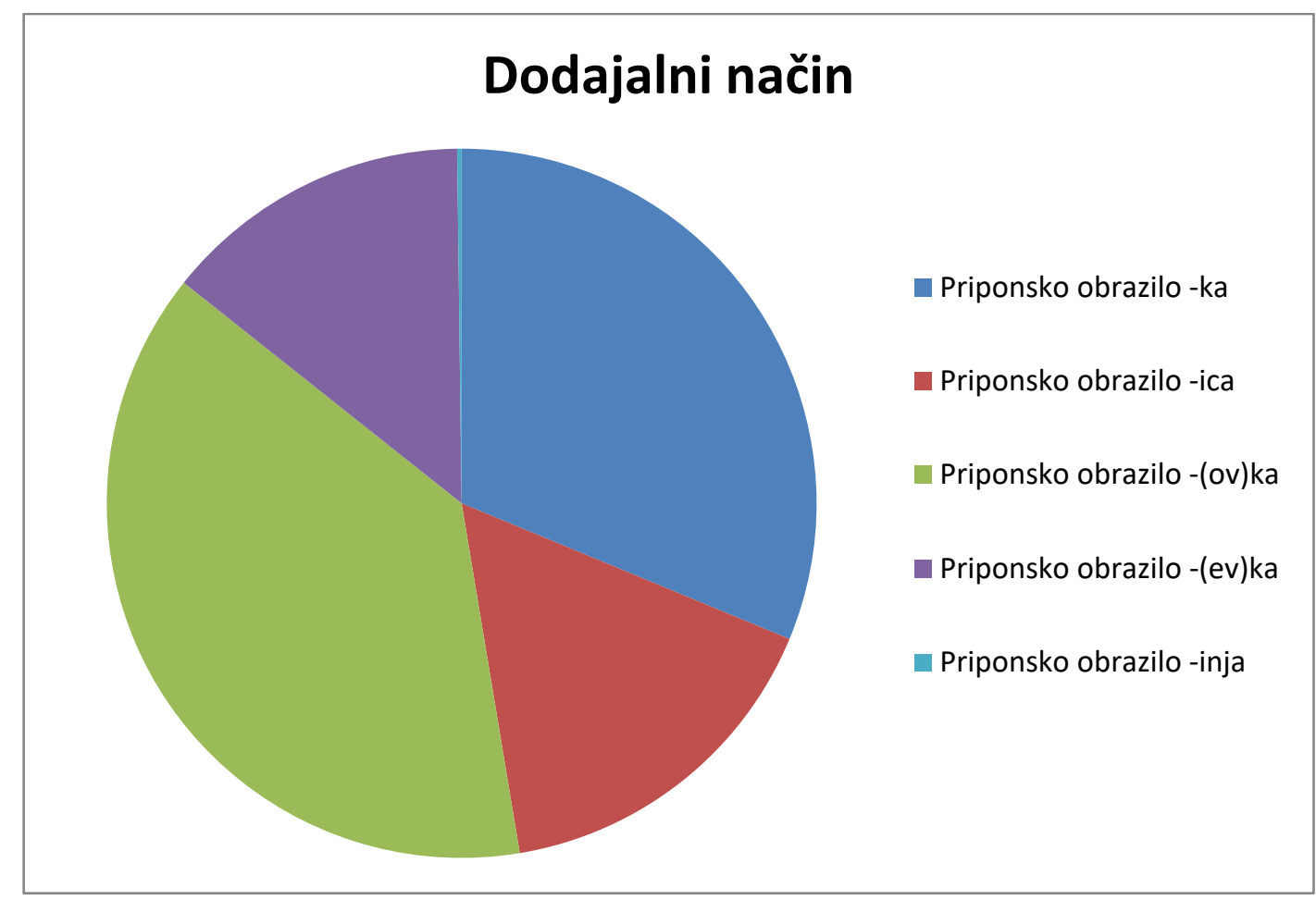

Spodnja preglednica prikazuje, katerim izglasjem (podstav ali obrazil) priimkov moškega spola se priponska obrazila -ica, -inja, -ka, -(ev)ka in -(ov)ka lahko dodajajo.

Preglednica 100: Priimkovni feminativi, nastali z dodajanjem ženskospolskega obrazila priimkom moškega spola

\begin{tabular}{|c|c|c|}
\hline DODAJALNO OBRAZILO & IZGLASJE & PRIMER PRIIMKA \\
\hline \multirow[t]{3}{*}{$-i c a$} & $-(a) n$ & Baumanica \\
\hline & $-(a) r$ & Vidmarica \\
\hline & $-(e) r$ & Majerica \\
\hline -inja & $-(j a) k$ & Hajdinjakinja \\
\hline \multirow[t]{7}{*}{$-k a$} & $-(i) \check{c}$ & Jerička \\
\hline & $-(a) d$ & Strnadka \\
\hline & $-(a) j$ & Bogatajka \\
\hline & $-(e) j$ & Sedejka \\
\hline & $-l$ & Peternelka \\
\hline & $-(a) n$ & Selanka \\
\hline & $-(a) r$ & Kolarka \\
\hline
\end{tabular}




\begin{tabular}{|c|c|c|}
\hline & $-\check{S}$ & Arnuška \\
\hline & $-(i) \check{S}$ & Smodiška \\
\hline & $-v$ & Žerjavka \\
\hline & $-\check{z}$ & Papežka \\
\hline \multirow[t]{5}{*}{$-(e v) k a$} & $-c /-\check{c}$ & Bajčevka \\
\hline & $-(a) j$ & Jerajevka \\
\hline & $-l j$ & Kokaljevka \\
\hline & $-\check{S}$ & Pirševka \\
\hline & $-\check{z}$ & Ambroževka \\
\hline \multirow[t]{13}{*}{$-(o v) k a$} & $-b$ & Golobovka \\
\hline & $-d$ & Šmidovka \\
\hline & $-f$ & Rudolfovka \\
\hline & $-g$ & Jugovka \\
\hline & $-h$ & Arhovka \\
\hline & $-k$ & Bernikovka \\
\hline & $-l$ & Grilovka \\
\hline & $-m$ & Grumovka \\
\hline & $-n$ & Kernovka \\
\hline & $-p$ & Gorjupovka \\
\hline & $-s$ & Flisovka \\
\hline & $-t$ & Bajtovka \\
\hline & $-z$ & Knezovka \\
\hline
\end{tabular}

1. Obrazilo -ica se dodaja $\mathrm{k}$ izglasjem na $-($ a)n (Baumanica, Pipanica, Rožmanica), -(a)r (Klinarica, Vidmarica) in -(e)r (Majerica).

2. Priponsko obrazilo -inja smo zasledili le v enem primeru z izglasjem na -(ja)k (Hajdinjak-Hajdinjakinja).

3. Obrazilo -ka se dodaja k izglasjem na -(i)č (Jerička, Savička), -(a)d (samo en primer - Strnadka), -j (-(a)j: Bogatajka, -(e)j: Sedejka), -l (Peternelka), -n (Prosenka, tudi z -(a)n: Selanka), -(a)r (Kolarka, Pintarka), -š (Arnuška, tudi z -(i)š: Smodiška), -v (Žerjavka), -ž (Papežka).

4. Priponsko obrazilo - (ev)ka se dodaja izglasjem na $-\check{c}$ iz $-c$ (Bajčevka, Gombočevka), -j (Plojevka, tudi k -(a)j Jerajevka), -lj (Kokaljevka, Koželjevka), -š (Pirševka), -ž (Ambroževka, Krapeževka). Pri teh izglasjih se pojavi priponsko obrazilo -(ev)ka in ne -(ov)ka zaradi preglasa. 
5. Obrazilo -(ov)ka dodajamo k izglasjem na -b (Golobovka, Jerebovka), $-d$ (Medvedovka, Šmidovka), -f (Rudolfovka, Škofovka), -g (Jugovka, Slugovka), - $h$ (Arhovka, Frelihovka), -k (Bernikovka, Gačnikovka), -l (Grilovka, Kobalovka), -m (Grmovka, Grumovka), -n (Banovka, Kernovka), -p (Gorjupovka), -s (Flisovka, Grosovka), -t (Bajtovka, Bergantovka), -z (Brglezovka, Knezovka).

Opažamo, da priponsko obrazilo -ica ob izobčnoimenski tvorbi nastopa kot dodajalno k izglasjem na $-(V) r$, zelo redko pa k tistim na $-n$. Obrazilo -inja se lahko tudi pri izlastnoimenski tvorbi feminativov dodaja $\mathrm{k}$ izglasju na $-k$. Priponsko obrazilo - $k a$ se, za razliko od lastnoimenskih, pri občnoimenskih feminativih zelo redko pojavlja kot dodajalno k izglasju na $-l$, redko nastopi tudi ob izglasju na -š. Pri različnih izglasjih se pojavi obrazilo -(ov)ka, ki pri izobčnoimenski tvorbi niti ni tako pogosto kot dodajalno; kjer pride do preglasa, pa nastopi priponsko obrazilo -(ev)ka.

10.2.3.1.2 Priimki, nastali $\mathrm{z}$ zamenjavo celotnega ali le izglasnega dela moškospolskega obrazila z ženskospolskim ob isti podstavi

Kot zamenjevalni obrazili se pri tvorbi ženskospolskih oblik priimkov iz priimkov moškega spola pojavita le priponski obrazili -ica (29 primerov ali $76 \%$ ) in $-k a$ (9 primerov ali $24 \%$ ). Ker je primerov priimkov, nastalih z zamenjavo moškospolskega obrazila, malo, bomo spodaj navedli vse najdene primere. 
Grafikon 29: Priimkovni feminativi, tvorjeni z zamenjavo moškospolskega priponskega obrazila z ženskospolskim

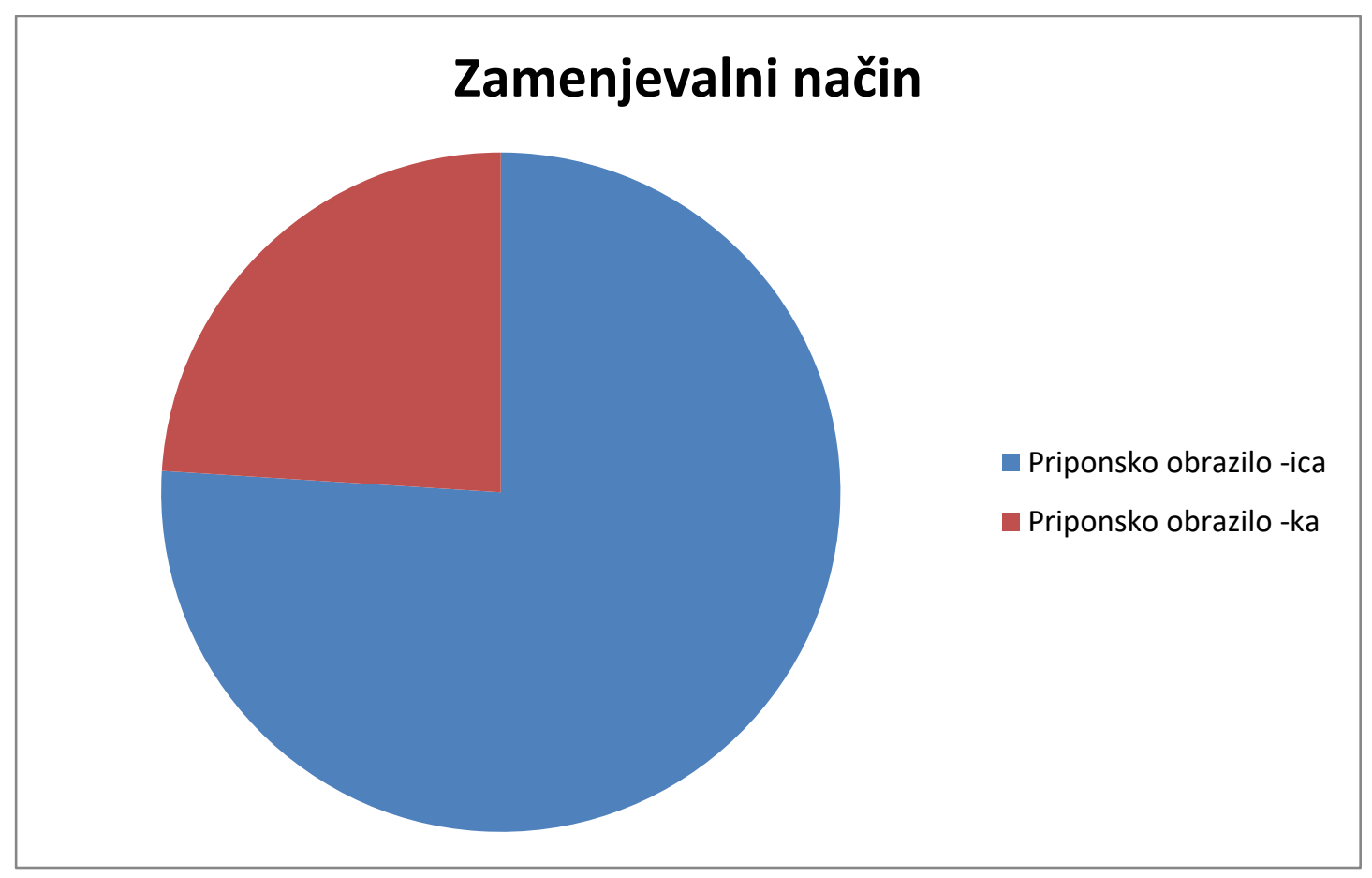

Spodnja preglednica prikazuje, katera moškospolska obrazila lahko feminativni obrazili -ica in - $k a$ zamenjujeta.

Preglednica 101: Priimkovni feminativi, nastali z zamenjavo celotnega ali le izglasnega dela moškospolskega obrazila z ženskospolskim ob isti podstavi

\begin{tabular}{|c|c|c|c|}
\hline $\begin{array}{l}\text { ŽENSKOSPOLSKO } \\
\text { OBRAZILO }\end{array}$ & $\begin{array}{l}\text { OBRAZILO } \\
\text { MOŠKEGA SPOLA }\end{array}$ & $\begin{array}{l}\text { IZGLASJE } \\
\text { PODSTAVE }\end{array}$ & PRIMER PRIIMKA \\
\hline \multirow[t]{2}{*}{$-i c a$} & $-e k$ & $-\check{S}$ & Hriberšica \\
\hline & $-i k$ & $-n$ & Klančnica \\
\hline \multirow[t]{4}{*}{$-k a$} & \multirow[t]{2}{*}{$-e c$} & $-n$ & Vogrinka \\
\hline & & $-v$ & Šinkovka \\
\hline & \multirow[t]{2}{*}{$-i c$} & $-l$ & Kastelka \\
\hline & & $-v$ & Sajovka \\
\hline
\end{tabular}

1. Obrazilo -ica zamenjuje moškospolski priponski obrazili -ek (Hriberšica, Zakrajšica) in -ik (Blatnica, Dornica, Gradišnica, Grobelnica, Hrastnica, Hribernica, Klančnica, Koritnica, Kotnica, Kržišnica, Jamnica, Ornica, Pečnica, Pečovnica, Podgornica, Podlesnica, Podobnica, Potočnica, Praprotnica, 
Rebernica, Repnica, Robnica, Stropnica, Tratnica, Vrhovnica, Založnica, Završnica).

2. Priponsko obrazilo -ka zamenjuje moškospolski obrazili -ec (Bukovka, Rijavka, Šinkovka, Vodopivka, Vogrinka, Vrhovka, Zadravka) in -ic (Kastelka, Sajovka).

Tudi pri izobčnoimenski tvorbi feminativov je pogosta zamenjava moškospolskega obrazila -ik $\mathrm{z}-i c a$, ne pa tudi $\mathrm{z}-e k$ (tu pogosteje kot zamenjevalno nastopa obrazilo $-k a$ ). Ženskospolsko priponsko obrazilo - $k a$ tudi pri izobčnoimenski tvorbi pogosto zamenjuje moškospolsko obrazilo $-e c$, nikoli pa ne zamenja obrazila -ic.

\subsubsection{Priimkovni feminativi po korpusu Gigafida}

Po korpusu Gigafida smo preverili ženskospolska priponska obrazila, ki so se pokazala kot produktivna za tvorbo ženskospolskih oblik priimkov v $S P$ : $-i c a,-i n j a,-k a,-(e v) k a$ in -(ov)ka. Delo je potekalo tako, da smo v iskalnik vpisali *ica, *inja, *ka, *evka oz. *ovka ob naslednjih dodatnih nastavitvah: samostalnik, lastno ime, ženski spol, živo.

\subsection{Priponsko obrazilo -ica}

Korpus je ob že navedenih iskalnih pogojih ponudil 356 konkordanc. Med temi smo zasledili 13 priimkovnih feminativov.

Preglednica 102: Priimkovni feminativi, tvorjeni s priponskim obrazilom -ica

\begin{tabular}{|c|c|c|}
\hline PRIIMEK & KONTEKST & VIR \\
\hline Brezigarica & $\begin{array}{l}\text { »/.../ Še dobro da ima brezigarico ki je znana po tem da še nobenemu } \\
\text { prijateljčku če le imata skupnega prijateljčka ni dokazala ničesar." }\end{array}$ & Splet, 2010 \\
\hline Cerarica & $\begin{array}{l}\text { »/.../ Pripombe so seveda letele na oblike družice Zajčevka, } \\
\text { Drobnička, Cerarica (za Zajec, Drobnič in Cerar), zapisane ob } \\
\text { priimkih v slovarskem delu. /.../« }\end{array}$ & Delo, 2002 \\
\hline Hribarica & $\begin{array}{l}\text { »/.../ Odločno Hribarico je temperamentno podala Mojca Korbar- } \\
\text { Hočevar, Sonja Pavčič pa spravljivo in razumevajočo županjo. /.../« }\end{array}$ & Dnevnik, 1996 \\
\hline Irglica & »/.../ A je Pečanka res moški ali Irglica laže? /.../« & Splet, 2010 \\
\hline
\end{tabular}




\begin{tabular}{|c|c|c|}
\hline PRIIMEK & KONTEKST & VIR \\
\hline Kresalica & $\begin{array}{l}\text { »LDS ne bo šla iz vlade, kako bo pa Kresalica hodila po nakupih v } \\
\text { Milano, če ne bo službenega avta in šoferja.« }\end{array}$ & Splet, 2010 \\
\hline Lužarica & $\begin{array}{l}» \text { Iz slovenske dramatike je odigrala Francko in Lužarico (Kralj na } \\
\text { Betajnovi) } / \ldots / \text {. . }\end{array}$ & Splet, 2010 \\
\hline Pečarica & $\begin{array}{l}\text { »/.../V dejanje je vtkanih več zgodb; zgodba Pečarjevega Lojza in } \\
\text { dekleta Ančke, ki jima stara Pečarica ne dovoli poroke, zgodbe ostalih } \\
\text { vaščanov, zgodba Amerikanca. /.../« }\end{array}$ & Revije, 2000 \\
\hline Rihterica & $\begin{array}{l}» \text { Rihterica bo konec svojega mandata dočakala v prenovljenem letnem } \\
\text { kinu Kinoteka. /.../« }\end{array}$ & $\begin{array}{l}\text { Mladina, } \\
2004\end{array}$ \\
\hline Rotarica & $\begin{array}{l}\text { »/.../ Komu rabijo Drnovškovka, Bajčevka, Rotarica, Frasovka in } \\
\text { zakaj ob Toporišiču ni tudi Toporišičke?« }\end{array}$ & Delo, 2001 \\
\hline Rutarica & $» / \ldots /$ Nataša Matjašec v vlogi zmedene matere Rutarice /.../« & Dnevnik, 2007 \\
\hline Smrekarica & $\begin{array}{l}\text { »/.../ Za J. Bavčar novi SP ni živ, je pa hkrati preveč liberalen; in ne } \\
\text { »grejo« ji ženski ljudski priimki tipa Kobalovka, Smrekarica /.../, } \\
\text { poleg tega pa se sprašuje, zakaj med takimi priimki ni navedena tudi } \\
\text { Toporišička. /.../« }\end{array}$ & Delo, 2002 \\
\hline Vidmarica & $\begin{array}{l}\text { »/.../ Najbolj zažigalna je bila tista, ki navaja ženske oblike priimkov; } \\
\text { SP jih zapiše kar po ljudsko (Zajčevka, Vidmarica), kar sicer žali } \\
\text { postsocialistični meščanski okus, zagotovo pa ni v nasprotju z živim } \\
\text { jezikom. /.../« }\end{array}$ & Delo, 2001 \\
\hline Zakrajšica & $\begin{array}{l}\text { »/.../ K gospodu Medvedu pride gospa Medvedovka, k Jakopiču } \\
\text { Jakopička, k Zajcu Zajčevka, k Štruklju Štrukljevka, k Zakrajšku } \\
\text { Zakrajšica, h Golobu Golobovka, k Trčku Trčkovka, k Božiču pa? } \\
\text { Kdo bi uganil? Božička.« }\end{array}$ & $\begin{array}{l}\text { Mladina, } \\
2001\end{array}$ \\
\hline
\end{tabular}

\subsection{Priponsko obrazilo -ca}

Ob pregledovanju korpusnega gradiva smo opazili pojav novega ženskospolskega priponskega obrazila - $c a$; obrazila, ki ga pri primerih, izpisanih iz SP, nismo zasledili. Ada Vidovič Muha v monografiji Slovensko skladenjsko besedotvorje obrazilo - ca šteje za varianto obrazila -ica, načeloma zunaj knjižne norme (Vidovič Muha 2011: 41). Varianta je nastala z redukcijo nenaglašenega ija. Korpus je ob zastavljenih iskalnih pogojih ponudil 439 konkordanc, med katerimi smo našli 17 priimkovnih feminativov. 
Preglednica 103: Priimkovni feminativi, tvorjeni s priponskim obrazilom -ca

\begin{tabular}{|c|c|c|}
\hline PRIMER & KONTEKST & VIR \\
\hline Brezigarca & $\begin{array}{l}\text { »jaz pa mislim da brezigarca nekaj ve o pahorju ali mučki v } \\
\text { vladi /.../« }\end{array}$ & Splet, 2010 \\
\hline Dremeljca & $\begin{array}{l}\text { »/.../ Ko še ni vedela, kako v resnici potekajo priprave na } \\
\text { Eurosong, verjamem, da se ji je vse skupaj zdelo za malo in da } \\
\text { so ji po glavi rojile misli, češ le kaj si zdaj ta Dremeljca ves čas } \\
\text { nekaj izmišljuje. } / . . . / \ll\end{array}$ & $\begin{array}{l}\text { Adria Media } \\
\text { (revija Lea), } \\
2008\end{array}$ \\
\hline Einsiedlerca & »Enako kot psihopatka Einsiedlerca. /.../« & Splet, 2010 \\
\hline Gotarca & »jest sem pa mislu, da ima gotarca licenco na vse himne« & Splet, 2010 \\
\hline Groharca & $\begin{array}{l}\text { »Groharca se je pa kr sama slikala. In pol pošle fotke na pop tv, } \\
\text { da jih objavjo. :D« }\end{array}$ & Splet, 2010 \\
\hline Hočevarca & $\begin{array}{l}\text { »K sreči je Hočevarca že naslednji trenutek pozabila name. } \\
/ \ldots / \ll\end{array}$ & Večer, 1999 \\
\hline Hribarca & $\begin{array}{l}\text { »/.../ Naša soseda Hribarca je imela v Gorici hčerko Zofijo. } \\
/ \ldots / \text {. }\end{array}$ & Delo, 2007 \\
\hline Malnarca & $\begin{array}{l}\text { »Malnarca je lušna mlada punca, prava blondinka } \mathrm{v} \text { vseh } \\
\text { pomenih besede blondinka .../.../« }\end{array}$ & Splet, 2010 \\
\hline Mulejca & »/.../ Pa ne govorim o Mulejci, Remarci in Groharci. /.../« & Splet, 2010 \\
\hline Osenarca & $\begin{array}{l}\text { »a kdo pa je tolko neumen, da bi dal toliko denarja za } \\
\text { kavbojke? Za tako vsoto dobiš res znamko. Ne pa od neke } \\
\text { Osenarce, ki jo vesoljni svet ne pozna.« }\end{array}$ & Splet, 2010 \\
\hline Pretnarca & $» / \ldots /$ Akhm, aja, nisem Pretnarca. Se pravi, igre. /.../« & $\begin{array}{l}\text { Revija } \\
\text { Joker, } 2006\end{array}$ \\
\hline Pušlarca & »Pušlarca je imela najboljšo pesem, žal se ni izteklo. /.../« & Splet, 2010 \\
\hline Remarca & »kok pa je ta remarca lušna ja valda če verjameš u palčke« & Splet, 2010 \\
\hline Rihterca & $\begin{array}{l}\text { »Združena glista predlaga, da njena Rihterca prevzame še } \\
\text { kmetijstvo. /.../« }\end{array}$ & $\begin{array}{l}\text { Mladina, } \\
2004\end{array}$ \\
\hline Šulerca & $\begin{array}{l}\text { »/.../ Šulerca ima prsi nenormalno visoko pripeti, kot balona } \\
\text { napolnjena s helijem. } / \ldots / \ll\end{array}$ & Splet, 2010 \\
\hline Vidmarca & $\begin{array}{l}\text { »/.../ Nekaj pa bodo tudi svetniki naredili, saj ima Vidmarca } \\
\text { velik vpliv na njih.« }\end{array}$ & $\begin{array}{l}\text { Dnevnik, } \\
1997\end{array}$ \\
\hline Žagarca & »Prava Slovenka je tale Žagarca. /.../« & Splet, 2010 \\
\hline
\end{tabular}

10.2.3.2.3 Priponsko obrazilo -inja 
Po korpusu smo sicer našli 51 konkordanc, vendar med njimi ni bilo nobenega priimkovnega feminativa.

\subsection{Priponsko obrazilo $-k a$}

Ob navedenih iskalnih pogojih je korpus Gigafida za priponsko obrazilo -ka ponudil 1278 konkordanc. Izpisali smo 31 primerov priimkov.

Preglednica 104: Priimkovni feminativi, tvorjeni s priponskim obrazilom -ka

\begin{tabular}{|c|c|c|}
\hline PRIIMEK & KONTEKST & VIR \\
\hline Bogatajka & $\begin{array}{l}\text { »/.../ Še posebej med urami zgodovine se nikakor ni mogla brzdati } \\
\text { in Bogatajka ji je že lep čas grozila z ukorom. /.../« }\end{array}$ & $\begin{array}{l}\text { Leposlovje, } \\
2008\end{array}$ \\
\hline Božička & $\begin{array}{l}\text { »/.../ K gospodu Medvedu pride gospa Medvedovka, k Jakopiču } \\
\text { Jakopička, k Zajcu Zajčevka, k Štruklju Štrukljevka, k Zakrajšku } \\
\text { Zakrajšica, h Golobu Golobovka, k Trčku Trčkovka, k Božiču pa? } \\
\text { Kdo bi uganil? Božička.« }\end{array}$ & $\begin{array}{l}\text { Mladina, } \\
2001\end{array}$ \\
\hline Cerarka & $\begin{array}{l}\text { »Mene pri Hribarju moti ker je med njegovimi gosti bilo dosti rdeče } \\
\text { golazni (Kučan, Denovšek, Cerarka, Kučkica..)« }\end{array}$ & Splet, 2010 \\
\hline Čepinka & »je pa že čepinka imela boljšo zabavo :)« & Splet, 2010 \\
\hline Drnačka & $\begin{array}{l}\text { »/.../ Tudi Drnačka je prišla na položaj urednice preko nekih poslov } \\
\text { ali ozsiljevanj s strani Požarja. /.../« }\end{array}$ & Splet, 2010 \\
\hline Drobnička & $\begin{array}{l}\text { »/.../ Pripombe so seveda letele na oblike družice Zajčevka, } \\
\text { Drobnička, Cerarica (za Zajec, Drobnič in Cerar), zapisane ob } \\
\text { priimkih v slovarskem delu. /.../« }\end{array}$ & Delo, 2002 \\
\hline Hozjanka & $\begin{array}{l}\text { »'Vse je tako, kot mora biti,' je mrmrala Hozjanka. Ko je spet } \\
\text { drobila s svojim tropom proti pokopališču na hribu. Tam je Hozjan } \\
\text { že dolgo počival. /.../« }\end{array}$ & $\begin{array}{l}\text { Kmečki glas, } \\
1998\end{array}$ \\
\hline Hribarka & $\begin{array}{l}\text { »KK, GG, Pahor in njihovi ritolizniki (npr. Ude, Koširka, Hribarka, } \\
576 \text { novinarjev, Ziher, Zalar, Anderlič, Školč, itd.) dnevno izgovorijo } \\
\text { besedo Janša večkrat kot vsi SLO duhovniki besedo očenaš, skupaj. } \\
\text { /.../« }\end{array}$ & Splet, 2010 \\
\hline Jakopička & $\begin{array}{l}\text { »/.../ K gospodu Medvedu pride gospa Medvedovka, k Jakopiču } \\
\text { Jakopička, k Zajcu Zajčevka, k Štruklju Štrukljevka, k Zakrajšku } \\
\text { Zakrajšica, h Golobu Golobovka, k Trčku Trčkovka, k Božiču pa? } \\
\text { Kdo bi uganil? Božička.« }\end{array}$ & $\begin{array}{l}\text { Mladina, } \\
2001\end{array}$ \\
\hline Jelušička & $\begin{array}{l}\text { »Jelušička je ena redkih slovenk, ki je tako samozavestna brez } \\
\text { podlage in tako smešna. } / . . . / \text { / }\end{array}$ & Splet, 2010 \\
\hline
\end{tabular}




\begin{tabular}{|c|c|c|}
\hline PRIIMEK & KONTEKST & VIR \\
\hline Jerajka & $\begin{array}{l}\text { »Potem gre pa Jerajka govorit o razlikah med učenci, ja taprava je, } \\
\text { ko bi le vedeli kaj se dogaja z njenim sinom v osnovni šoli .../.../« }\end{array}$ & Splet, 2010 \\
\hline Kalanka & $\begin{array}{l}\text { »V zdravniški zbornici je treba ukinit plače in honorarje. Delo naj bo } \\
\text { popolnoma volontersko. Takrat bodo pokvarjenci in zasluškarji in } \\
\text { spletkaroši, kot je Kalanka sami odstopili, kajti tu kjer so so samo } \\
\text { zaradi denarja in bonitet. /.../« }\end{array}$ & Splet, 2010 \\
\hline Kokotka & »'Vem, saj diši,' je rekla suho Kokotka in se namenila na vrh.« & $\begin{array}{l}\text { Kmečki glas, } \\
2009\end{array}$ \\
\hline Koširka & $\begin{array}{l}\text { »KK, GG, Pahor in njihovi ritolizniki (npr. Ude, Koširka, Hribarka, } \\
576 \text { novinarjev, Ziher, Zalar, Anderlič, Školč, itd.) dnevno izgovorijo } \\
\text { besedo Janša večkrat kot vsi SLO duhovniki besedo očenaš, skupaj. } \\
\text { /.../« }\end{array}$ & Splet, 2010 \\
\hline Kresalka & $\begin{array}{l}\text { »Senica in Kresalka naj kar odideta v tujino po možnosti takoj, } \\
\text { vendar samo v gatah - brez vsega kar sta nakradla!« }\end{array}$ & Splet, 2010 \\
\hline Kreslinka & $\begin{array}{l}\text { »HOČEMO NIKO KRESLIN V PLAYBOYU GOSPOD } \\
\text { OMERZEL. KRESLINKA JE NARAVNA, ČEPINKA JE } \\
\text { UMETNA ;)《 }\end{array}$ & Splet, 2010 \\
\hline Krivka & »In mati Krivka je tudi zardela, ker razumela ga je. /.../« & $\begin{array}{l}\text { Stvarna } \\
\text { besedila, } \\
2009\end{array}$ \\
\hline Kukovička & $\begin{array}{l}\text { »A Kukovička in Bačovnikova s oblačita pa pri Varteksu in obuvata } \\
\text { pri Borovu, frizirata se pa pod kosilnico? /.../« }\end{array}$ & Splet, 2010 \\
\hline Kuljajka & »/.../ Važno, da se je uturila kuljajka. A ona mu je pa všeč?« & Splet, 2010 \\
\hline Mihelička & $\begin{array}{l}\text { »Ljudje kot stara Mihelička, ta prototip vseh svetovnih udb, ki mu } \\
\text { ne more do živega nobena nadzorna komisija, so v urbanem okolju } \\
\text { še najmanjši problem; /.../« }\end{array}$ & Delo, 2007 \\
\hline Mušička & $\begin{array}{l}\text { »'Mušička, so ti že kaj zrasle?' je klical za menoj, ko sem se } \\
\text { vzpenjala po stopnicah. } / \ldots / \text { / }\end{array}$ & Večer, 1999 \\
\hline Pečanka & $» / \ldots /$ A je Pečanka res moški ali Irglica laže? /.../« & $\begin{array}{l}\text { Splet, 2009; } \\
\text { Dnevnik, } \\
\text { 1998, } 1999\end{array}$ \\
\hline Pintarička & $\begin{array}{l}\text { »Pintarička ni avtohtona štajerka ona je v MB prišla z drevesa in je } \\
\text { živ dokaz, da se je človek razvil iz rdeče opice.« }\end{array}$ & Splet, 2010 \\
\hline Simčička & $\begin{array}{l}\text { »/.../ Simčička in Potočnikova sta samo kradli in naredili } \\
\text { popolnoma nič.../.../« }\end{array}$ & Splet, 2010 \\
\hline Simšička & $\begin{array}{l}\text { »Da v sili hudič muhe žre, sta minuli teden dokazali Brezigarica in } \\
\text { Simšička. /.../« }\end{array}$ & $\begin{array}{l}\text { Mladina, } \\
2002\end{array}$ \\
\hline
\end{tabular}




\begin{tabular}{|c|c|c|}
\hline PRIIMEK & KONTEKST & VIR \\
\hline Tomažinka & $\begin{array}{l}\text { »/.../ A mi ni uspelo, saj me je Tomažinka preprosto odklopila in } \\
\text { prišla na drugo temo, čeprav je obče znano, da je prav seks najljubša } \\
\text { tema Kmetije slavnih.« }\end{array}$ & $\begin{array}{l}\text { Nedeljski } \\
\text { dnevnik, } \\
2009\end{array}$ \\
\hline Tomička & $\begin{array}{l}\text { »Ni mi všeč, da se je Tomička preveč, veliko preveč angažirala, ko } \\
\text { bi ob takih tepcih mirno lahko bila ves čas tiho.« }\end{array}$ & Splet, 2010 \\
\hline Tomšička & $\begin{array}{l}\text { »/.../ Dolga leta smo bili vajeni samo priimka Tomšič (-eva, } \\
\text { Tomšička).« }\end{array}$ & $\begin{array}{l}\text { Dnevnik, } \\
1997\end{array}$ \\
\hline Toporišička & $\begin{array}{l}\text { »/.../ Komu rabijo Drnovškovka, Bajčevka, Rotarica, Frasovka in } \\
\text { zakaj ob Toporišiču ni tudi Toporišičke?« }\end{array}$ & Delo, 2001 \\
\hline Vidmarka & $\begin{array}{l}\text { »/.../ In to } \mathrm{v} \text { demokratični Sloveniji ponovi še komunajzarka } \\
\text { Vidmarka, ki je za povrhu še članica društva Tigr.« }\end{array}$ & Splet, 2010 \\
\hline Žnidaršička & $\begin{array}{l}\text { »/.../ Kako pa rečemo, če nam je stopila na nogo na primer gospa } \\
\text { Žnidaršič? Žnidaršička me je potacala, vendar!« }\end{array}$ & Delo, 2001 \\
\hline
\end{tabular}

\subsection{Priponsko obrazilo - $(e v) k a$}

Po korpusu Gigafida je mogoče najti 14 konkordanc, med katerimi je bila zgolj ena ženskospolska oblika priimka Štrukljevka. Ta priimek je bil naveden v Mladini leta 2001. Druge oblike so bile najdene naključno ob iskanju konkordanc pri preostalih priponskih obrazilih.

Preglednica 105: Priimkovni feminativi, tvorjeni s priponskim obrazilom -(ev)ka

\begin{tabular}{|l|l|l|}
\hline PRIIMEK & KONTEKST & VIR \\
\hline Bajčevka & $\begin{array}{l}\text { »/.../ Komu rabijo Drnovškovka, Bajčevka, Rotarica, } \\
\text { Frasovka in zakaj ob Toporišiču ni tudi Toporišičke? « }\end{array}$ & Delo, 2001 \\
\hline Kranjčevka & »'Dajta mir,'ju je skušala pomiriti Kranjčevka. /.../« & Kmečki glas, \\
& $\begin{array}{l}\text { Jakopiču Jakopička, k Zajcu Zajčevka, k Štruklju } \\
\text { Štrukljevka, k Zakrajšku Zakrajšica, h Golobu Golobovka, k } \\
\text { Trčku Trčkovka, k Božiču pa? Kdo bi uganil? Božička.« }\end{array}$ & \\
\hline Zajčevka & $\begin{array}{l}\text { »/.../ K gospodu Medvedu pride gospa Medvedovka, k } \\
\text { Jakopiču Jakopička, k Zajcu Zajčevka, k Štruklju Štrukljevka, } \\
\mathrm{k} \text { Zakrajšku Zakrajšica, h Golobu Golobovka, k Trčku } \\
\text { Trčkovka, k Božiču pa? Kdo bi uganil? Božička.« }\end{array}$ & Mladina, 2001 \\
\hline
\end{tabular}


10.2.3.2.6 Priponsko obrazilo -(ov)ka

Korpus je ponudil 43 pojavitev. Nekaj priimkov je bilo najdenih med temi konkordancami, nekaj pa naključno pri iskanju za druga priponska obrazila.

Preglednica 106: Priimkovni feminativi, tvorjeni s priponskim obrazilom -(ov)ka

\begin{tabular}{|c|c|c|}
\hline PRIIMEK & KONTEKST & VIR \\
\hline Bajtovka & $\begin{array}{l}\text { »/.../ Nekoč sem dobila punčko iz cunj, ki mi jo je dala soseda } \\
\text { Bajtovka. } / . . . / \text { }\end{array}$ & $\begin{array}{l}\text { Gorenjski } \\
\text { glas, } 2007\end{array}$ \\
\hline Drnovškovka & $\begin{array}{l}\text { »/.../ Komu rabijo Drnovškovka, Bajčevka, Rotarica, Frasovka } \\
\text { in zakaj ob Toporišiču ni tudi Toporišičke?« }\end{array}$ & Delo, 2001 \\
\hline Frasovka & $\begin{array}{l}\text { »/.../ Komu rabijo Drnovškovka, Bajčevka, Rotarica, Frasovka } \\
\text { in zakaj ob Toporišiču ni tudi Toporišičke? « }\end{array}$ & Delo, 2001 \\
\hline Golobovka & $\begin{array}{l}\text { »/.../ K gospodu Medvedu pride gospa Medvedovka, k Jakopiču } \\
\text { Jakopička, k Zajcu Zajčevka, k Štruklju Štrukljevka, k } \\
\text { Zakrajšku Zakrajšica, h Golobu Golobovka, k Trčku Trčkovka, } \\
\text { k Božiču pa? Kdo bi uganil? Božička.« }\end{array}$ & $\begin{array}{l}\text { Mladina, } \\
2001\end{array}$ \\
\hline Grudnovka & »Tako se vede Grudnovka v komediji Za narodov blagor. /.../« & $\begin{array}{l}\text { Stvarna } \\
\text { besedila, } \\
\text { splet, } 2010\end{array}$ \\
\hline Kobalovka & $\begin{array}{l}\text { »/.../ Za J. Bavčar novi SP ni živ, je pa hkrati preveč liberalen; } \\
\text { in ne "grejo« ji ženski ljudski priimki tipa Kobalovka, } \\
\text { Smrekarica /.../, poleg tega pa se sprašuje, zakaj med takimi } \\
\text { priimki ni navedena tudi Toporišička. /.../« }\end{array}$ & Delo, 2002 \\
\hline Kresalovka & $\begin{array}{l}\text { »Pri vsej zadevi je dobro le to, da Kresalovka vedno bolj leze v } \\
\text { drek in da bo potopila LDS, ki na naslednjih volitvah sploh ne } \\
\text { bo prišla v parlament.« }\end{array}$ & Splet, 2010 \\
\hline Medvedovka & $\begin{array}{l}\text { »/.../ K gospodu Medvedu pride gospa Medvedovka, k } \\
\text { Jakopiču Jakopička, k Zajcu Zajčevka, k Štruklju Štrukljevka, k } \\
\text { Zakrajšku Zakrajšica, h Golobu Golobovka, k Trčku Trčkovka, } \\
\text { k Božiču pa? Kdo bi uganil? Božička.« }\end{array}$ & $\begin{array}{l}\text { Mladina, } \\
2001\end{array}$ \\
\hline Oražmovka & $\begin{array}{l}\text { »/.../ Medtem pa zapita koza Oražmovka ustanavlja komisijo o } \\
\text { brezplačnikih, dobro so se organizirali nimam kaj reč. /.../« }\end{array}$ & Splet, 2010 \\
\hline Trčkovka & $\begin{array}{l}\text { »/.../ K gospodu Medvedu pride gospa Medvedovka, k Jakopiču } \\
\text { Jakopička, k Zajcu Zajčevka, k Štruklju Štrukljevka, k } \\
\text { Zakrajšku Zakrajšica, h Golobu Golobovka, k Trčku Trčkovka, } \\
\text { k Božiču pa? Kdo bi uganil? Božička.« }\end{array}$ & $\begin{array}{l}\text { Mladina, } \\
2001\end{array}$ \\
\hline
\end{tabular}




\subsection{Sklep}

Skupno je bilo iz korpusa Gigafida zbranih 76 ženskospolskih priimkov. Posebej smo šteli tudi priimke, tvorjene z variantnimi obrazili (npr. Kresalka, Kresalica, Kresalovka). Tvorjeni so z obrazili:

-ica: Brezigarica, Cerarica, Hribarica, Irglica, Kresalica, Lužarica, Pečarica, Rihterica, Rotarica, Rutarica, Smrekarica, Vidmarica, Zakrajšica;

-ca: Brezigarca, Dremeljca, Einsiedlerca, Gotarca, Groharca, Hočevarca, Hribarca, Malnarca, Mulejca, Osenarca, Pretnarca, Pušlarca, Remarca, Rihterca, Šulerca, Vidmarca, Žagarca;

-inja: /

-ka: Bogatajka, Božička, Cerarka, Čepinka, Drnačka, Drobnička, Hozjanka, Hribarka, Jakopička, Jelušička, Jerajka, Kalanka, Kokotka, Koširka, Kresalka, Kreslinka, Krivka, Kukovička, Kuljajka, Mihelička, Mušička, Pečanka, Pintarička, Simčička, Simšička, Tomažinka, Tomička, Tomšička, Toporišička, Vidmarka, Žnidarička;

-(ev)ka: Bajčevka, Kranjčevka, Štrukljevka, Zajčevka;

-(ov)ka: Bajtovka, Drnovškovka, Frasovka, Golobovka, Grudnovka, Kobalovka, Kresalovka, Medvedovka, Oražmovka, Trčkovka.

Kljub manjšemu številu primerov lahko nakažemo nekaj zaključkov. Opazimo, da je večina priimkovnih feminativov nastala $\mathrm{z}$ dodajanjem ženskospolskega obrazila priimku moškega spola. Takih besed je 74 (97 \%): Cerarica, Hribarica, Irglica, Lužarica, Pečarica, Rotarica, Rutarica, Smrekarica, Vidmarica; Brezigarca, Dremeljca, Einsiedlerca, Gotarca, Groharca, Hočevarca, Malnarca, Mulejca, Osenarca, Pretnarca, Pušlarca, Remarca, Rihterca, Šulerca, Vidmarca, Žagarca; Bogatajka, Božička, Čepinka, Drobnička, Hozjanka, Hribarka, Jakopička, Kalanka, Kokotka, Koširka, Kreslinka, Mihelička, Pečanka, Pintarička, Simčička, Tomažinka, Tomšička, Toporišička, Vidmarka, Žnidarička; Bajčevka, Kranjčevka, Štrukljevka, Zajčevka; Bajtovka, Drnovškovka, Frasovka, Golobovka, Grudnovka, Kobalovka, Medvedovka, Trčkovka. 
Preglednica 107: Priimkovni feminativi, nastali z dodajanjem ženskospolskega obrazila $k$ priimkom moškega spola - primerjava med Slovenskim pravopisom in korpusom Gigafida

\begin{tabular}{|c|c|c|c|}
\hline $\begin{array}{l}\text { DODAJALNI } \\
\text { OBRAZILO }\end{array}$ & IZGLASJE & Slovenski pravopis & Korpus Gigafida \\
\hline \multirow[t]{3}{*}{$-c a$} & $-(e) j$ & I & Mulejca \\
\hline & $-(e) l j$ & $/$ & Dremeljca \\
\hline & $-(a) r$ & / & Osenarca \\
\hline \multirow[t]{3}{*}{$-i c a$} & $-l$ & / & Irglica \\
\hline & $-(a) n$ & Baumanica & / \\
\hline & $-(a) r$ & Vidmarica & Brezigarica \\
\hline -inja & $-(j a) k$ & Hajdinjakinja & / \\
\hline \multirow[t]{13}{*}{$-k a$} & $-(i) \check{c}$ & Jerička & Božička \\
\hline & $-(a) d$ & Strnadka & / \\
\hline & $-(a) j$ & Bogatajka & Jerajka \\
\hline & $-l$ & Peternelka & / \\
\hline & $-(a) l$ & / & Kresalka \\
\hline & $-(a) n$ & Selanka & / \\
\hline & $-(i) n$ & / & Čepinka \\
\hline & $-(a) r$ & Kolarka & I \\
\hline & $-(i) r$ & / & Koširka \\
\hline & $-\check{S}$ & Arnuška & / \\
\hline & $-t$ & / & Kokotka \\
\hline & $-v$ & Žerjavka & / \\
\hline & $-\check{z}$ & Papežka & I \\
\hline \multirow[t]{5}{*}{$-(e v) k a$} & $-c /-\check{c}$ & Bajčevka & Bajčevka \\
\hline & $-j$ & Jerajevka & / \\
\hline & $-l j$ & Kokaljevka & Štrukljevka \\
\hline & $-\check{S}$ & Pirševka & / \\
\hline & $-\check{z}$ & Ambroževka & / \\
\hline \multirow[t]{7}{*}{$-(o v) k a$} & $-b$ & Golobovka & Golobovka \\
\hline & $-d$ & Šmidovka & Medvedovka \\
\hline & $-f$ & Rudolfovka & / \\
\hline & $-g$ & Jugovka & / \\
\hline & $-h$ & Arhovka & Drnovškovka \\
\hline & $-k$ & Bernikovka & / \\
\hline & $-l$ & Grilovka & Kobalovka \\
\hline
\end{tabular}




\begin{tabular}{|r|r|c|c|}
\hline & $-m$ & Grumovka & Oražmovka \\
\cline { 2 - 4 } & $-n$ & Kernovka & Grudnovka \\
\cline { 2 - 4 } & $-p$ & Gorjupovka & Frasovka \\
\cline { 2 - 4 } & $-s$ & Flisovka & Bajtovka \\
\cline { 2 - 4 } & $-t$ & Bajtovka & $/$ \\
\hline
\end{tabular}

Kot najpogostejše dodajalno obrazilo pri primerih, najdenih v korpusu Gigafida, se je izkazalo priponsko obrazilo -ka (31 primerov od 74, to je $41 \%$ ). Dodaja se lahko izglasjem na -̌̌ (Božička, Drnačka, Drobnička, Jakopička, Jelušička, Kukovička, Mihelička, Mušička, Pintarička, Simčička, Simšička, Tomička, Tomšička, Toporišička, Žnidarička), -j (Bogatajka, Jerajka, Kuljajka), -l (Kresalka), -n (Čepinka, Hozjanka, Kalanka, Kreslinka, Pečanka, Tomažinka), -r (Hribarka, Koširka, Vidmarka), -t (Kokotka). Opazimo, da so vsa izglasja, ki se jim priponsko obrazilo $-k a$ dodaja, enaka tistim, ki smo jih zasledili pri analizi priimkovnih feminativov iz $S P$; novo je le izglasje na $-t$ s primerom Kokotka; v SP namreč najdemo primer Kokotovka, torej obrazilo -(ov)ka, dodano izglasju na -t. Kot varianta obrazila -ica se pojavi obrazilo - $c a$, ki ga pri primerih priimkov iz SP nismo zasledili. Iz korpusa Gigafida smo izpisali sedemnajst tvorjenk (22 \%), kar je drugo najpogostejše obrazilo med primeri iz korpusa. Obrazilo - ca se dodaja izglasjem na -j (Mulejca), -lj (Dremeljca), -r (Brezigarca, Einsiedlerca, Gotarca, Groharca, Hočevarca, Malnarca, Osenarca, Pretnarca, Pušlarca, Remarca, Rihterca, Šulerca, Vidmarca, Žagarca). Po pogostnosti obrazilu -ca sledi priponsko obrazilo -ica z dvanajstimi primeri (16\%). Priponsko obrazilo -ica se, glede na zbrano gradivo iz korpusa Gigafida, pri tvorbi priimkovnih feminativov lahko dodaja izglasjem na -l (Irglica, Kresalica), $-r$ (Brezigarica, Cerarica, Hribarica, Lužarica, Pečarica, Rihterica, Rotarica, Rutarica, Smrekarica, Vidmarica). Tudi tukaj opazimo pojav novega izglasja $-l$, ki ga pri primerih iz SP ni bilo mogoče zaslediti. Po številu pojavitev sledi obrazilo - $(o v) k a$ z desetimi primeri $(13 \%)$. Ugotovili smo, da se priponsko obrazilo - (ov)ka dodaja izglasjem na -b (Golobovka), -d (Medvedovka), -k (Drnovškovka, Trčkovka), -l (Kobalovka, Kresalovka), -m (Oražmovka), -n (Grudnovka), -s (Frasovka), -t (Bajtovka). Najmanj je bilo priimkov, nastalih $\mathrm{z}$ dodajalnim ženskospolskim obrazilom 
-(ev)ka (4 primeri, $5 \%$ ). Slednje se, sodeč po korpusnem gradivu, lahko dodaja izglasjem na -č (Bajčevka, Kranjčevka, Zajčevka) in -lj (Štrukljevka).

Grafikon 30: Zastopanost dodajalnih obrazil - primerjava med SP in Gigafido (v odstotkih)

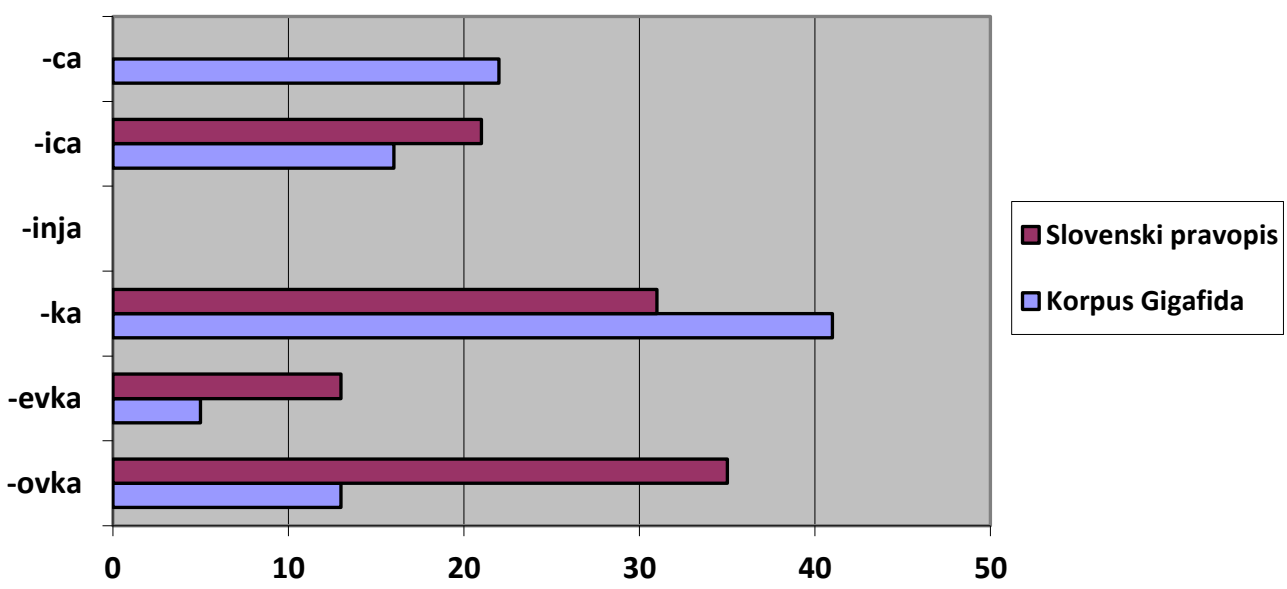

Opazimo, da je pri primerih priimkovnih feminativov iz $S P$ vodilno priponsko obrazilo -(ov)ka (35\%). Slednje je pri primerih iz korpusa Gigafida šele na 4. mestu (13\%). Pred njim so po pogostnosti obrazila -ka (41\%), -ca (22 $\%)$ in $-i c a(16 \%)$.

Preglednica 108: Priimkovni feminativi, nastali z zamenjavo celotnega ali le izglasnega dela moškospolskega obrazila z ženskospolskim ob isti podstavi primerjava med Slovenskim pravopisom in korpusom Gigafida

\begin{tabular}{|r|l|l|l|}
\hline $\begin{array}{l}\text { ŽENSKOSPOLSKA } \\
\text { OBRAZILA }\end{array}$ & $\begin{array}{l}\text { MOŠKOSPOLSKO } \\
\text { OBRAZILO }\end{array}$ & $\begin{array}{l}\text { Slovenski } \\
\text { pravopis }\end{array}$ & Korpus Gigafida \\
\hline \multirow{2}{*}{$-i c a$} & $-e k$ & Hriberšica & Zakrajšica \\
\cline { 2 - 4 } & $-i k$ & Klančnica & $/$ \\
\hline \multirow{2}{*}{$-k a$} & $-e c$ & Šinkovka & Krivka \\
\cline { 2 - 5 } & $-i c$ & Kastelka & $/$ \\
\hline
\end{tabular}

Zgolj dva priimka (3\%), najdena v korpusu Gigafida, sta nastala z zamenjavo moškospolskega priponskega obrazila z ženskospolskim: Krivka (-ec s priponskim obrazilom $-k a$ ob izglasju podstave na $-v$ ) in Zakrajšica (-ek $\mathrm{s}$ priponskim obrazilom -ica pri izglasju podstave na $-\check{s}$ ). 
Grafikon 31: Zastopanost zamenjevalnih obrazil - primerjava med SP in Gigafido (v odstotkih)

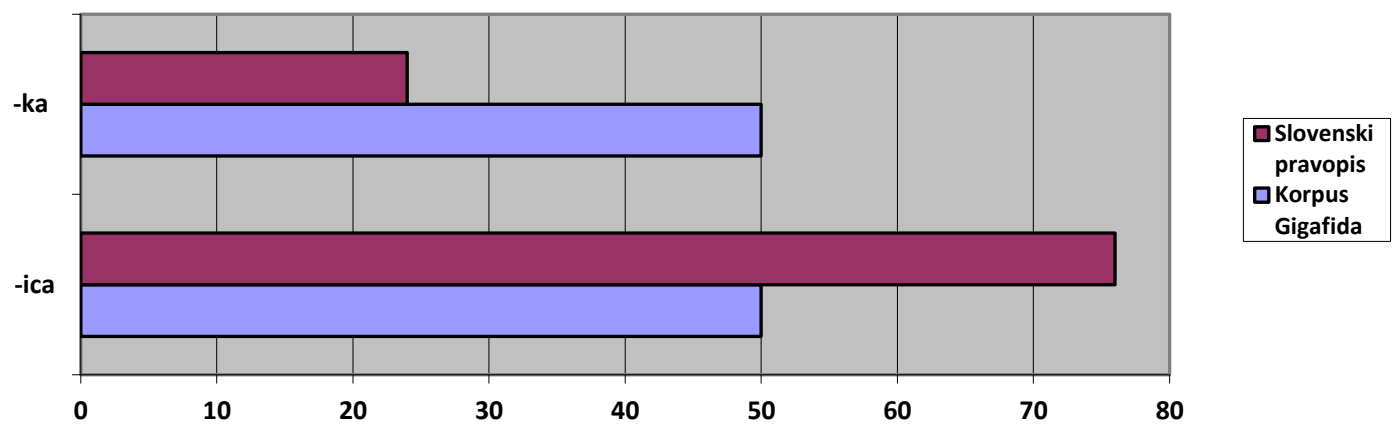

Kot je razvidno iz zgornjega grafikona, sta pri primerih iz korpusa Gigafida priponski obrazili -ica in -ka enakovredno zastopani, vendar moramo pri tem upoštevati, da gre zgolj za dva najdena primera, po enega za vsako obrazilo. Večje število priimkov bi najbrž nakazalo drugačen rezultat. Pri primerih priimkov iz $S P$ pa je po zastopanosti pogostejše obrazilo -ica (29 primerov; $76 \%$ ) pred priponskim obrazilom $-k a$ (9 primerov; $24 \%)$.

Opažamo dvoje: pojav novih izglasij, ki se jim ženskospolska obrazila dodajajo (v primerjavi s primeri priimkov iz $S P$; novi sta izglasji $-t$ pri obrazilu $-k a$ in $-l$ pri priponskem obrazilu $-i c a$ ), in pojav novega obrazila $-c a$, za katerega ugotavljamo, da je slabšalno.

Zanimalo nas je tudi, v katerih vrstah besedil se ženskospolske oblike priimkov $\mathrm{v}$ glavnem pojavljajo. Ugotavljamo, da vire lahko razdelimo $\mathrm{v}$ tri skupine:

1. Prvi zelo pogost vir je splet, zlasti spletni forumi na straneh 24 ur.com in siol.net. Tukaj se pojavljajo predvsem aktualna imena iz sveta zabave (Čepinka, Pintarička, Osenarca) in politike (Irglica, Simčička, Vidmarka). Gre za zapise uporabnikov forumov, zato so tudi nekatera imena zapisana $\mathrm{z}$ malo začetnico (čepinka) ali sploh napačno zapisana (Pintarička namesto Pinterička). Opažamo, da $\mathrm{v}$ glavnem gre za negativen odnos do žensk, o katerih uporabniki pišejo, kar je razvidno iz konteksta, dodanega $\mathrm{v}$ zgornjih preglednicah pri posameznem priimku.

2. Presenetljivo pogosta vira sta časnik Delo in časopis Mladina (pričakovali smo več revij s trači), ki sta z nekoliko ostrimi odzivi ob izidu SP v letu 2001 navajala 
priimkovne feminative in se ob tem spraševala, zakaj med 500 najpogostejšimi slovenskimi priimki ni priimka Toporišič in ženskospolske oblike Toporišička (Gigafida: Delo 2002). Tudi sama izbira ženskospolskih obrazil za tvorbo priimkovnih feminativov se omenjenima viroma zdi sporna.

3. Nekateri priimki se pojavijo tudi v leposlovju, zlasti v starejših literarnih delih, npr. Za narodov blagor (Grudnovka), Telečja pečenka (Krivka), Kralj na Betajnovi (Lužarica). Na to kaže tudi razprava Zinke Zorko (1993: 57), ki izpostavi priimkovne feminative v Prežihovi zbirki Samorastniki (Dihurka).

\section{NAGLAŠENOST FEMINATIVOV}

O naglasu tvorjenk so razmišljali Jože Toporišič (Slovenski knjižni jezik 2 in Slovenski jezik in sporočanje 2, oboje 1966, v vseh izdajah Slovenske slovnice, tudi v izdaji iz leta 2004, in v Slovenskem pravopisu, 2001), Ada Vidovič Muha v polemiki s Toporišičem $(1990,1991)$ in v Besedotvorju slovenskega jezika (1988, 2011) ter Irena Stramljič Breznik v učnem gradivu Besedotvorje (2006). Naglasna problematika tvorjenk je torej zelo zanimiva; kot ugotavlja Irena Stramljič Breznik (2006: 88), pa ni dokončno dognana, saj pogosto prihaja do razkoraka med teoretičnimi naglasnimi načeli in trenutnimi naglasnimi rešitvami $\mathrm{v}$ razpoložljivih slovarskih virih.

Vprašanje naglašenosti podstave oz. obrazila pri feminativih izpostavi Toporišič (2004: 183), ko navede feminativna priponska obrazila: -a/-á, -ica/-ica, -ja, -úlja, -inja/-inja, -ka, -ovka in -ična. S tem kot zmeraj naglašeni izpostavi obrazili -ulja in -ična. ${ }^{124}$ Kot samo nenaglašena Toporišič navaja feminativna obrazila -ja, -ka in -(ov)ka, naglašena ali nenaglašena pa so lahko -a, -ica in -inja. Opazovali smo še (ne)naglašenost priponskih obrazil -(ar)ka, -esa, -(ev)ka, -kinja, ki jih Toporišič sicer ne navaja med feminativnimi obrazili. Po SP (2001: 123) tvorjenke bodisi ohranjajo naglasne značilnosti svojih podstav bodisi imajo drugačne. Posebej smo proučili naglasne značilnosti feminativov, tvorjenih iz občnoimenske podstave, in tistih, ki so nastali iz lastnoimenske podstave.

${ }^{124}$ Pravzaprav gre za priponsko obrazilo -na, ki je po Toporišičevih primerih sodeč nenaglašeno (grofična, cesarična, kraljična, gospodična). 
Opazovali smo, ali ohranjajo naglasne značilnosti podstav (bráti - brálec - brálka) ali pa prihaja do sprememb (vôlk - volkúlja). Zanimalo nas je, katera feminativna priponska obrazila so naglašena, pri čemer smo bili pozorni na to, ali je bilo naglašeno moškospolsko obrazilo ali besedotvorna podstava.

\subsection{Feminativi, tvorjeni iz občnoimenske podstave}

Proučevane feminative smo zbrali po obeh izdajah Slovarja slovenskega knjižnega jezika.

\subsubsection{Nenaglašenost priponskega obrazila}

Preverili smo, ali so res priponska obrazila $-j a,-k a$ in $-(o v) k a$ zmeraj nenaglašena (tudi obrazilo -na, po Toporišiču sicer naglašeno -ična).

- Ugotavljamo, da priponsko obrazilo -ja ni naglašeno ne kot zamenjevalno (vezílja, pletílja) in ne kot dodajalno (gôstja, pestúnja, dekánja, župánja). Opažamo, da ni spremembe naglasa glede na poimenovanja oseb moškega spola.

- Obrazilo - $k a$ ni nikoli naglašeno, kar dokazuje spisek feminativov v poglavju o tvorbi feminativov iz občnoimenske podstave. Ugotavljamo, da pri zamenjevalnem načinu tvorbe feminativov tudi moškospolsko priponsko obrazilo, ki ga je obrazilo - $k a$ zamenjalo, ni bilo pri nobenem primeru naglašeno.

- Priponsko obrazilo - $(o v) k a$ nastopa le kot dodajalno, in to zmeraj kot nenaglašeno (mójstrovka, pékovka, škrátovka, vrágovka, žídovka za osebe ter bóbrovka, gádovka, gámsovka, kítovka, kósovka, rákovka, sómovka in šimpánzovka za živali).

- Po Toporišiču je ženskospolsko obrazilo -ična naglašeno, dejansko pa gre za dodajanje feminativnega priponskega obrazila -na samostalnikom moškega spola. Obrazilo -na je v vseh primerih nenaglašeno (bratíčna, cesarična, dedična, gospodična, grofična, kraljična, sestrična, strníčna). Drugače je z moškospolskim obrazilom -ič, ki je večinoma naglašeno, ni 
pa nujno (denimo dédič, gospódič). Tako ne moremo sklepati, da feminativ zmeraj ohrani naglas moškospolskega priponskega obrazila.

Po pregledu gradiva iz zgoraj navedenih virov smo opazili, da kot nenaglašena nastopajo tudi obrazila -(ev)ka, -kinja in -(ar)ka.

- Obrazilo -(ev)ka nastopa le kot dodajalno in vedno nenaglašeno: za osebe hudičevka in zlódejevka (naglašeno le moškospolsko priponsko obrazilo -ič; naglas na istem zlogu feminativ ohrani v obeh primerih), za živali pa jázbečevka, skóbčevka, škórčevka, vrábčevka (dodajanje $\mathrm{k}$ moškospolskemu obrazilu -ec, ki je $\mathrm{v}$ vseh navedenih primerih nenaglašeno).

- Brez naglasa je tudi sicer zgolj zamenjevalno priponsko obrazilo -kinja: pevovódkinja, poslovódkinja, računovódkinja, vídkinja, zborovódkinja, delovódkinja, knjigovódkinja in plémkinja. ${ }^{125} \mathrm{~V}$ vseh primerih je naglas ostal na istem zlogu kot pri poimenovanju osebe moškega spola.

- Obrazilo -(ar)ka je prav tako samo nenaglašeno (le poimenovanja oseb: akadémičarka, alkohóličarka, analitičarka, anoréksičarka, astmátičarka, bioenergétičarka, blagájničarka, botáničarka, bulímičarka, delohóličarka, diabétičarka, dietétičarka, dramátičarka, fizičarka, gráfičarka, higiéničarka, kémičarka, kerámičarka, kómičarka, kozmétičarka, krítičarka, matemátičarka, metódičarka, polítičarka, práktičarka, psíhoanalitičarka, razrédničarka, téhničarka, teorétičarka, tetraplégičarka, tonemátičarka). ${ }^{126}$ Obrazilo $-(a r) k a$ je v vseh primerih dodajalno $\mathrm{k}$ moškospolskemu priponskemu obrazilu $-i k$, ki pa nikoli ni naglašeno.

- Priponsko obrazilo - $a$ nastopa le kot dodajalno in je po Toporišiču lahko tudi naglašeno, vendar nismo zasledili nobenega takega primera (bájsa, bótra, debelúha, glavána, gostáča, lováča, prfôksa, prismúka, smrdúha, soséda, súžnja, trápa, zaletéla za osebe in bráka, rísa za živali).

\footnotetext{
${ }^{125}$ Besede s sestavino -vodkinja so enonaglasnice, ker gre za medponsko-priponske samostalniške zloženke z glagolsko sestavino v drugem delu.

${ }^{126}$ Feminativa bioenergetičarka in psihoanalitičarka sta kot podredni medponski zloženki, ki imata v podstavi dve samostalniški sestavini, seveda dvonaglasnici.
} 
11.1.2 Naglašenost feminativnega priponskega obrazila

Po Toporišiču je zgolj naglašeno samo priponsko obrazilo -ulja, ugotavljamo pa, da kot tako zmeraj nastopa tudi obrazilo -esa.

- Stalno naglašenost priponskega obrazila -ulja dokazujejo tudi primeri iz pričujoče raziskave: po zamenjevalnem načinu črnúlja, gobezdúlja, jezikúlja, skopúlja in smrdúlja za osebe (moškospolska obrazila -ač, -uh in -avs so naglašena) ter slavúlja in vrabúlja za živali (moškospolsko obrazilo -ec ni naglašeno), pri dodajalnem načinu pa pajkúlja, volkúlja za živali in vragúlja, brucúlja za osebe.

- Vedno naglašeno je tudi dodajalno priponsko obrazilo -esa: stevardésa, princésa, klovnésa in poetésa.

11.1.3 (Ne)naglašenost feminativnega priponskega obrazila

- Priponsko obrazilo -inja je nenaglašeno pri tvorbi $\mathrm{z}$ zamenjevalnim načinom (dédinja, pametnjákinja, slúginja, koléginja), kadar pa ga dodajamo samostalniku moškega spola, je lahko naglašeno (samo bogínja za osebe, levínja za živali) ali nenaglašeno (v vseh drugih primerih, denimo adútinja, astrológinja, divjákinja).

- Tudi obrazilo -ica je lahko naglašeno (kot zamenjevalno ob primerih dolžníca, glasníca, grabljíca, krvníca, lastníca, mučeníca, naročníca, oblastníca, obrtníca, oskrbníca, plačníca, plevíca, pomočníca, predíca, razsodníca, redníca, rejníca, sámoplačníca, skrbníca, sodníca, sòlastníca, sòmišljeníca, sòuredníca, sòvozníca, sòvrstníca, ${ }^{127}$ svečeníca, svetníca, tolažníca, tožníca, uredníca, vodníca, vozníca, vrstníca, založníca, zdravníca, zobozdravníca, za žival samo vrabíca; v vseh primerih gre za zamenjavo moškospolskih priponskih obrazil $-i k$ ali $-a \check{c}$, ki sta zmeraj

\footnotetext{
${ }^{127}$ Primeri solastnica, somišljenica, sourednica, sovoznica in sovrstnica sodijo med sestavljenke in so kot taki dvonaglasnice.
} 
naglašeni, razen pri vrabíca $\leftarrow$ vrábec, predica $\leftarrow$ prêdec ali predílec, plevica $\leftarrow$ plévec, kjer pa moškospolsko obrazilo -ec ni naglašeno) ali nenaglašeno (vsi preostali primeri, nastali ob zamenjavi moškospolskega priponskega obrazila $\mathrm{z}$ ženskospolskim, denimo bédnica, besédnica, čaróvnica ...). Tudi kot dodajalno je feminativno obrazilo -ica lahko naglašeno (samo primeri cesaríca, ciganíca, čebelaríca, ${ }^{128}$ čevljaríca, gospodaríca, grofica, kletaríca, ključaríca, kmetíca, kraljíca, krčmaríca, krmaríca, ovčaríca, pastiríca, sámovladaríca, ${ }^{129}$ sleparíca, slikaríca, tatíca, tovarišica, vladaríca, vražica, vrtnaríca za osebe in golobíca, oslíca, pavíca (a tudi pávica), polšíca, psíca, sloníca, somíca, telíca, volčíca, žrebíca za živali), v večini primerov pa je nenaglašeno (článica, dežníkarica, goljúfica ...).

Ugotavljamo naslednje:

- Med zbranimi feminativi prevladujejo enonaglasnice, nekaj je dvonaglasnic, med njimi sestavljenke (v glavnem s predpono so-, npr. sourednica, sovoznica ...) in zloženke (samoplačnica, bioenergetičarka $\ldots)$.

- Skupno smo analizirali 2229 feminativov iz obeh izdaj SSKJ, med njimi je takih, ki imajo naglašeno priponsko obrazilo, 86 oz. 3,86 \%. Med slednjimi je najpogosteje naglašeno feminativno obrazilo -ica (69 tvorjenk oz. $80,3 \%)$. Sledijo -ulja z enajstimi primeri (12,8\%), -esa s štirimi $(4,6$ $\%)$ in -inja $\mathrm{z}$ dvema primeroma $(2,3 \%)$.

\footnotetext{
${ }^{128}$ Opažamo, da ob moškospolskem izglasju -(a)r priponsko obrazilo - $k a$ ni nikoli naglašeno, -ica pa zelo pogosto (taki so naslednji pari: kletárka - kletaríca, ključárka - ključaríca, krčmárka krčmaríca, ovčárka - ovčaríca, slepárka - sleparíca, slikárka - slikaríca, vrtnárka - vrtnaríca). To velja le, kadar je moškospolsko obrazilo - ar naglašeno, ne pa, kadar je naglas na osnovi besede (npr. žêpar - žêparka-žêparica).

129 Samostalniška podredna medponska zloženka, zato dvonaglasnica; enako samoplačnica.
} 


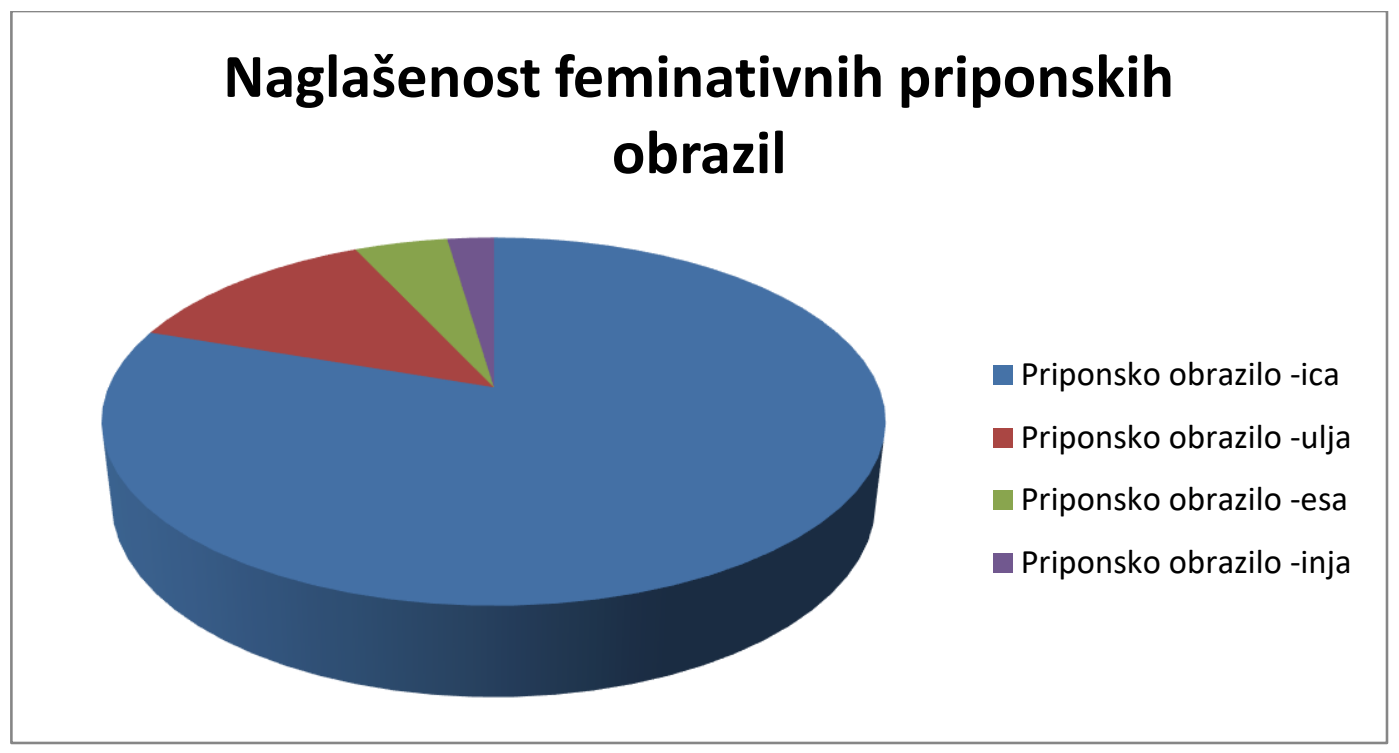

\subsection{Feminativi, tvorjeni iz lastnoimenske podstave}

V analizo smo vključili 500 priimkovnih feminativov in 2420 ženskospolskih poimenovanj za prebivalke, oboje zbrano po SP (2001).

\section{Priimkovni feminativi}

Ženskospolske oblike priimkov so lahko tvorjene s priponskimi obrazili -(ev)ka, -ica, -inja, -ka in -(ov)ka. Med njimi kot naglašeno feminativno obrazilo nastopa le -ica, in to pri treh primerih: Kovačíca, Pečaríca, Požaríca. V vseh treh primerih gre za dodajanje obrazila moškospolski obliki priimka, pri kateri je naglašeno priponsko obrazilo (-ač oz. -ar).

\section{Poimenovanja za prebivalke}

Tovrstna poimenovanja so lahko tvorjena s priponskimi obrazili -ca, -ica, -inja, -kinja, -ka, -ijka, -anka, -(ev)ka. Med njimi so enonaglasnice (Grúzijka, Čéhinja, Hočánka) in dvonaglasnice (Grénlándka, Morávskotopličanka).

Naglašeno je le priponsko obrazilo -ica, a le pri treh primerih (Hrvatíca z dodajalnim načinom tvorbe in Korošica, Kranjíca z zamenjavo moškospolskega priponskega obrazila -ec, ki pa ni bilo naglašeno). 
Opažamo dvoje: a) pri feminativih, tvorjenih iz lastnoimenske podstave, je naglašeno samo priponsko obrazilo -ica; b) naglašeno feminativno obrazilo -ica je zamenjalo moškospolsko obrazilo ali bilo k njemu dodano, pri čemer je bilo tudi priponsko obrazilo pri poimenovanju moškega spola naglašeno (-ač, -ar, -at, $-e c)$.

\section{SKLEP}

V jeziku se odraža stališče družbe do posameznega spola in s tem tudi do družbenih razlik med žensko in moškim. V Sloveniji se je začelo o tovrstnem zapostavljanju žensk ob moškem spolu kot nadspolu razmišljati šele v devetdesetih letih, drugod, denimo v Veliki Britaniji, Franciji in v nekaterih slovanskih državah, pa že prej. Problem bi v slovenščini lahko omilili z dosledno rabo feminativov.

I.

Feminativi se v slovenščini kot modifikacijske izpeljanke po Toporišiču tvorijo na dva načina: a) z dodajanjem ženskospolskega priponskega obrazila poimenovanju bitja moškega spola (učiteljica); b) z zamenjavo moškospolskega priponskega obrazila z ženskospolskim (bralka). Nekateri jezikoslovci, denimo Vidovič Muha, pri zamenjevalnem načinu vidijo očitno podrejanje tvorbe poimenovanj za ženske osebe poimenovanjem za moške, npr. pravnica, zdravnica, delavka - take tvorjenke bi bilo mogoče razumeti kot navadne izpeljanke iz glagola, pridevnika ali samostalnika $\mathrm{z}$ besedotvornim pomenom 'vršilka dejanja, nosilka lastnosti, povezave', kar pa bi povzročilo drugačnost obrazilnih razmerij. Zaradi ohranjanja enotne besedotvornopomenske kategorije, tvorjene $\mathrm{z}$ isto besedotvorno vrsto, smo sicer $\mathrm{v}$ pričujočem delu dosledno upoštevali Toporišičev model besedotvornih pomenov. Dejansko gre za poimenovalno (časovno) zaporednost, tj. tvorbo ženske oblike iz moške, kar 
dokazuje pregled eno-, dvo- ali večjezičnih slovarjev, slovenskih slovnic in drugih jezikovnih priročnikov skozi zgodovino, kjer so navedene številne moškospolske oblike brez ženskih vzporednic, kot jih poznamo danes. Poleg tega ugotavljamo, da tudi drugi slovanski jeziki obravnavajo dva načina tvorbe feminativov: dodajalnega, ki torej ni sporen, in zamenjevalnega - pri tem prav vse pregledane monografije, ki obravnavajo slovansko besedotvorje in znotraj tega ženskospolska poimenovanja bitij (Zemska, Lukašanec, Arhangelska, Mluvnice češtiny, Furdik in Sokolova, Pycia, Ćorić, Babič, Koneski, Radeva), izpostavljajo moškospolska obrazila, ki jih zamenjujejo ženskospolska. Res pa je, da na problem, podobno kot Vidovič Muha, opozarjajo tudi nekateri (sicer redki) drugi slovanski jezikoslovci, denimo Štebih Golub in Barić v hrvaščini. Že zgodovinski pregled kaže na prisotnost obeh načinov tvorbe - o prevladujočem v preteklosti ne bi mogli govoriti zaradi preskromne obravnave feminativov. V sodobnem slovenskem jeziku, kot smo videli, prevladuje tvorba $\mathrm{z}$ zamenjevalnim načinom (pri izobčnoimenski tvorbi), opažamo pa, da je $\mathrm{v}$ novejših jezikovnih virih vse pogostejši dodajalni način. Tvorbo $\mathrm{z}$ obema načinoma je izkazala tudi klasifikacija poklicev. Če nas torej zanima ženska kot družbeno bitje, govorimo o zakriti ali izraženi družbeni hierarhizaciji. Ugotavljamo, da se primeri, tvorjeni tako z zamenjevalnim kot dodajalnim načinom, pojavljajo pri obeh: pri zakriti hierarhizaciji gre za časovno poimenovalno zaporednost $\mathrm{z}$ izhodiščno vezanostjo dejavnosti pretežno/samo na moško osebo (denimo filozofinja, učiteljica, a tudi tkalka, svetovalka), pri izraženi pa poimenovanje ženske pomeni tudi zakonsko ženo (taki so primeri apotekarica, bajtarica, banica, bankirka, baronica, bobnarica, carica, cesarica, čevljarica, čevljarka, dacarka, davkarica, doktorica, doževka, faraonka, generalica, generalka, glavarica, glavarka, gozdarica, graščakinja, grofica, grofinja, gruntarica, guvernerka, hotelirka, kajžarica, kapetanica, kapitanka, kneginja, kovačica, kraljica, lekarnarica, lekarnarka, logarica, majorka, mař̌alica, maršalka, mesarica, mežnarica, ministrica, mlinarica, mojstrica, notarka, organistovka, pekovka, popinja, popovka, princesa, ribičevka, sodnikovka, šahinja, vikontesa, viničarka, žagarica, a tudi cerkovnica, črednica, hišnica, načelnica, polkovnica, prestolonaslednica, sodnica, stotnica, svetnica, vojvodinja). Opažamo, da so slednji večinoma sicer tvorjeni $\mathrm{z}$ 
dodajalnim načinom, vendar jih ne moremo obravnavati kot feminative, če upoštevamo pomen 'zakonska žena', saj ne gre za pomensko vzporednost moškospolski obliki. Enoznačnega odgovora ne ponudijo niti izlastnoimenska poimenovanja oseb (npr. Italijan - Italijanka, Bosanec - Bosanka), ki ne morejo odražati družbene hierarhizacije.

\section{II.}

Feminativi se sicer po Toporišiču lahko tvorijo z naslednjimi priponskimi obrazili: -a/-á, -ica/-íca, -ja, -ulja, -inja/-ínja, -ka, -ovka in -íčna. V novejših virih pa se pojavljajo še druga priponska obrazila, s katerimi tvorimo feminative. To velja za tvorbo iz občnoimenske in lastnoimenske podstave. Za raziskavo feminativne tvorbe $\mathrm{v}$ sodobnem slovenskem jeziku smo uporabili različne vire: nekoliko starejši Slovar slovenskega knjižnega jezika (skupno 1939 poimenovanj oseb in 91 poimenovanj živali), vendar s posodobljeno, drugo izdajo (skupno 2229 poimenovanj oseb, 93 živali), ter novejše vire: iz leta 2009 Novejšo slovensko leksiko (243 tvorjenk) in iz leta 2013 Slovar novejšega besedja (163 tvorjenk za poimenovanje oseb, ena za poimenovanje živali). Ugotavljamo, da kot feminativna priponska obrazila poleg zgoraj navedenih nastopajo tudi variante obrazil -ka (-(ar)ka, -(ev)ka) in -ica (-(ar)ica), pa tudi -esa. Toporišičevo obrazilo -ična smo zanemarili, saj pravzaprav gre za tvorbo $\mathrm{s}$ feminativnim priponskim obrazilom -na (grofična, cesarična, gospodična). Nekatera feminativna priponska obrazila nastopajo samo kot dodajalna (-a, -na, -(ev)ka, -(ov)ka, -esa), druga samo kot zamenjevalna (le -kinja).

Ločeno smo obravnavali ženskospolska poimenovanja oseb in nato posebej poimenovanja živali. Pri tem smo naprej raziskali, kateri način tvorjenja feminativov $\mathrm{v}$ slovenščini prevladuje, $\mathrm{z}$ dodajanjem feminativnega priponskega obrazila samostalniku moškega spola ali z zamenjavo moškospolskega obrazila z ženskospolskim. Primerjalni prikaz števila tvorjenk, nastalih $\mathrm{z}$ dodajalnim oziroma z zamenjevalnim načinom, kaže, da poimenovanja oseb iz NSL in SNBSJ večinoma nastajajo z dodajanjem obrazila; po NSL v $69 \%$ in po SNBSJ pa $66 \%$. Gre za novotvorjenke oz. novejše enobesedne lekseme. Drugače je v obeh izdajah 
Slovarja slovenskega knjižnega jezika, kjer večji odstotek (56 \% v prvi izdaji oz. $53,6 \% \mathrm{v}$ drugi) nastane $\mathrm{z}$ zamenjevalnim načinom. Pri poimenovanjih živali pa prevladuje tvorba z dodajalnim načinom v obeh izdajah SSKJ (67\% v prvi, $68 \%$ $\mathrm{v}$ drugi izdaji).

$\mathrm{Z}$ dodajalnim načinom je skupno nastalo 1090 feminativov poimenovanj oseb (47\%), med njimi jih je največ, tj. $621(56 \%)$ tvorjenih $\mathrm{z}$ obrazilom - $k a$. Sledita -ica (247 tvorjenk ali $23 \%$ ) in -inja (161 feminativov ali $15 \%$ ). Preostala obrazila so zastopana s po manj kot $3 \%$. Feminativna priponska obrazila smo, kadar tvorijo poimenovanja oseb, razvrstili glede na to, s katerimi tipičnimi soglasniškimi izglasji moškospolskih obrazil se družijo kot dodajalna feminativna obrazila. Dosedanje analize feminativnih priponskih obrazil (Stramljič Breznik 1992, 1994/95, Vidovič Muha 1997, Korošec 1998) izpostavljajo tipična obrazilna izglasja, ki se jim feminativna obrazila dodajajo. Tako je v ospredju dodajanje priponskega obrazila -ka tvorjenkam moškega spola na izglasja obrazil -č (brusačka), -d (doktorandka), -j (čuvajka), -n (dolganka), -r (arhivarka), -š (bogataška), -t (absolventka), -v (detektivka), priponski obrazili -a in -na se dodajata izglasjem na -č (gostača; dedična); -ica tistim s -č (beračica), -lj (braniteljica) in -r (bobnarica); -inja pa s $k$ (prerokinja), $g$ (drozginja), $h$ (varuhinja) v izglasju. Naša raziskava vse navedeno potrjuje, hkrati pa, upoštevajoč gradivo iz različnih jezikovnih priročnikov, opažamo naslednje: poleg že navedenih iz obstoječih raziskav se feminativno priponsko obrazilo $-k a$ lahko dodaja še izglasjem (podstav ali obrazil) na - $f$ (filozofka), -h (debeluška) in $-m$ (agronomka), njegove variante pa izglasjem na $-k$ (z -(ar)ka denimo kemičarka), -č (z -(ev)ka: ribičevka), -k in -r (-(ov)ka: pekovka, mojstrovka). Obrazilo - $a$ se dodaja tudi izglasjem (podstav in obrazil) na $-d$ (soseda), $-h$ (smrduha), -k (prismuka), -l (zaletela), -n (glavana), -nj (sužnja), -p (trapa), -r (botra), -na pa zgolj že omenjenemu izglasju obrazila na -č (grofična). Priponsko obrazilo -ica lahko kot dodajalno nastopa poleg že navedenih tudi k izglasjem podstav in obrazil na $-f$ (grofica), $-g$ (družica), $-k$ (bikica), -n (dekanica), $-\grave{s}$ (rokometašica) in -t (kmetica), njegova varianta -(ar)ica pa se dodaja le k izglasju podstave na $-k$ (matematikarica). Obrazilo -inja je pri tvorbi feminativov dodajalno še k izglasjem podstav ali obrazil na -d (logopedinja), - $f$ (šefinja), - $l$ 
(rivalinja), -r (bojarinja), -š (pristašinja) in -t (atletinja), obrazilo -ja pa k - $n$ (županja) in -t (gostja). Primerjalni pregled kaže, da sta priponski obrazili -ica in $-k a$ s primeri dokaj enakovredno zastopani pri izglasjih obrazil na -(V)̌̌ (-ica: 19 primerov, $-k a$ : 20 primerov; pri tem se samo $-k a$ dodaja $\mathrm{k}$ izglasjem na $-(i) \check{c}$ in $-(j a) c$ c). Pri izglasjih moškospolskih obrazil na $-(V) k$ prevladuje tvorjenje feminativov $\mathrm{z}$-inja (33 tvorjenk), $\mathrm{k}$ izglasjem na -(ate)lj in -(ite)lj pa se dodaja samo -ica (50 primerov). $\mathrm{K}$ izglasjem na $-(V) n$ prevladuje dodajanje feminativnega obrazila - $k a$ (54 primerov, le eden z -ica). Kadar se moškospolska poimenovanja oseb končajo na izglasje obrazila $-(V) r$, gre pri tvorbi feminativov pogosto za dodajanje ženskospolskih priponskih obrazil -ka (197 primerov) in -ica (skupno 131 primerov); pri tem se $\mathrm{k}$ izglasjem na -(ate)r in -(u)r dodaja samo -ka. Če pa gre za izglasje obrazil na $-t$, prevladuje dodajanje obrazila $-k a$ (212 primerov, samo deset tvorjenk $\mathrm{z}$-inja). Sklenemo lahko, da $-k a$ prevladuje pri dodajanju k moškospolskim izglasjem na $-n,-r$ in $-t$, obrazilo -inja pri izglasjih na $-k,-i c a$ pa pri izglasjih na $-l j$.

Z zamenjevalnim načinom je nastalo 1222 ženskospolskih poimenovanj oseb ali $53 \%$, med njimi pa prevladuje tvorba s feminativnim obrazilom -ka (744 primerov ali $61 \%$ ), sledita obrazili -ica s 457 primeri ali $38 \%$ in -inja z osmimi feminativi ali $0,6 \%$. Preostala obrazila so $\mathrm{v}$ manjšini. V okviru feminativne tvorbe smo želeli za vsa produktivna obrazila ugotoviti tudi, katera moškospolska obrazila zamenjujejo. Raziskave so do zdaj izpostavljale priponsko obrazilo -ica, ki zamenjuje -ik (bolnica), ter -ka, ki zamenjuje moškospolsko obrazilo -ec (vesoljka) z variantami. Po pregledu različnih jezikovnih virov ugotavljamo, da lahko -ica poleg že navedenega zamenja tudi moškospolska priponska obrazila -ač (grabljica), -ek (prišlica), -ček (ljubica), -ec (tekmica), -ež (dolgočasnica), -in (domačica) in -nik (coprnica), -ka pa ob omenjenem še (dele) obrazil -alec (oskrbovalka), -anec (mohamedanka), -janec (hitlerjanka), -arec (parlamentarka), -avec (ponavljavka), -elec (pogorelka), -enec (kaznjenka), -evec (grabljevka), -ež (srboritka), -ilec (kadilka), -inec (blondinka), -ivec (volivka), -nik (baletka), -ovec (svatovka) in -vec (pevka). Kot zamenjevalna nastopajo tudi obrazila -inja (zamenja moškospolska priponska obrazila -a koleginja, -ič dedinja in -ar pametnjakinja), -ja (pri moškospolskem -ilec: vezilja), -kinja (zamenjuje -ec 
vidkinja in -ič plemkinja) ter -ulja (zamenja obrazila -ač, -uh, -avs: gobezdulja, smrdulja, jezikulja, črnulja). Opažamo, da pri vseh obrazilih z izglasno sestavino -ec prevladuje zamenjava s priponskim obrazilom -ka (skupno 733 primerov, $\mathrm{z}$ -ica pa samo 21). Drugače je pri moškospolskih obrazilih -ik in -nik, kjer prednjači zamenjava z -ica (385 tvorjenk, s -ka le dve), podobno velja pri moškospolskem -ež ( $\mathrm{z}$-ica 116 primerov, s -ka le eden). Feminativno obrazilo - $k a$ ima torej prednost, kadar gre za zamenjavo moškospolskega $-(K) e c$, -ica pa pri $-(n) i k$ in $-e \check{z}$.

Ženskospolska poimenovanja živali smo zasledili v obeh izdajah $S S K J$ (91 v prvi, $93 \mathrm{v}$ drugi) ter v SNBSJ (en primer). Z dodajanjem ženskospolskega obrazila moškospolskemu poimenovanju živali je skupno nastalo 61 (66 \%) feminativov, od tega največ, to je 24 (39 \%) s priponskim obrazilom -ica, nekoliko manj, 17 z obrazilom -ka (29\%), $8(13 \%)$ z $-($ ov $) k a$, štiri $(6,5 \%)$ z $-(e v) k a$, štiri $(6,5 \%) \mathrm{z}$-inja in po dve $(3 \%) \mathrm{z}-a$ in -ulja. Ugotavljamo, da se feminativna priponska obrazila, ko tvorijo ženskospolska poimenovanja živali, v glavnem dodajajo netvorjenkam z različnimi izglasji, le redko opravkarjem, in to vedno le z izglasjem na $-(a) r$ (prepeličarica), vršilcu pa samo, če gre za večpomenke, ki lahko poimenujejo tudi osebe (npr. roparica). K - (a)r se tako dodajata le -ica in -ka (ki sta sicer ob tem izglasju pogosti tudi, kadar gre za poimenovanja oseb).

$\mathrm{Z}$ zamenjavo moškospolskega priponskega obrazila $\mathrm{s}$ feminativnim je nastalo skupno 33 (34 \%) poimenovanj živali. Kot zamenjevalna nastopajo feminativna priponska obrazila - $k a$ z 22 primeri (63\%), -ica (9 primerov ali 30 $\%)$ in -ulja z dvema primeroma (6\%). Opažamo, da pri tvorbi ženskospolskih poimenovanj živali kot zamenjevalna nastopajo tri feminativna obrazila: -ica, $-k a$ in -ulja. Vsa tri lahko zamenjajo moškospolsko obrazilo -ec; -ica pri nosilcu lastnosti in opravkarju $\mathrm{z}$ različnimi izglasji podstav (npr. jalovica, jazbica), podobno $-k a$, le da slednja nastopi še pri vršilcu iz glagolskih podstav na -iti/-im (plazilka) in -ovati/-ujem (prežvekovalka), -ulja pa pri netvorjenih podstavah. Obrazili -ica in -ka zamenjujeta moškospolsko obrazilo -ec tudi pri tvorbi poimenovanj oseb, -ulja pa ne. 


\section{III.}

Zanimivo je bilo opazovati obravnave feminativov $\mathrm{v}$ slovnicah slovenskega jezika skozi zgodovino. Ugotavljamo, da v le-teh kot najrodnejši, torej zastopani $\mathrm{v}$ prav vseh, tj. 21 obravnavanih jezikovnih virih, nastopata feminativni priponski obrazili -ica in - $k a, \mathrm{z} 18$ pojavitvami jima sledi feminativno priponsko obrazilo -inja. Kot najmanj produktivni sta se izkazali priponski obrazili - $a$ z zgolj dvema pojavitvama in -na (po Toporišiču sicer -ična) s štirimi. Ugotovili smo, da obrazilna razmerja vendarle niso zmeraj v popolnem nasprotju s tvorbo v sodobnem jeziku. Ženskospolsko obrazilo - $c a$ se tako skozi zgodovino dodaja k izglasju obrazila na -(a)r (npr. mlinarca), kar je sicer v skladu s tvorbo v sodobnem knjižnem jeziku; priponsko obrazilo -ca smo namreč zasledili le pri enem poimenovanju osebe, tvorjenem iz občnoimenske podstave, in to prav pri moškospolskem izglasju na -(a)r (zobarca). Priponsko obrazilo -ica zasledimo ob izglasju na -(a)r (npr. pisarica, a tu se pojavi tudi v sodobnem jeziku); res pa ob izglasjih na $-d$ ali $-k$, kadar gre za poimenovanje oseb, ne nastopa (le pri poimenovanjih živali, denimo velblodica, volčica - kot kažeta tudi primera račica in medvedica $\mathrm{v}$ slovenskih slovnicah $\mathrm{v}$ zgodovini jezika, torej gre tudi tukaj za ujemanje). Drugače je s priponskim obrazilom -inja, ki se ob izglasju na -(a)č v sodobnih jezikovnih virih, ko gre za tvorbo feminativov, res ne pojavi, ob izglasjih na $-r$ pa zelo redko (le en primer: bojarinja), zato pa ob navedenih izglasjih nastopi $\mathrm{v}$ različnih slovnicah $\mathrm{v}$ zgodovini (npr. beračinja, botrinja). Priponsko obrazilo -kinja $\mathrm{v}$ sodobnem jeziku ne nastopi kot dodajalno, temveč zgolj kot zamenjevalno (v slovnicah $\mathrm{v}$ zgodovini jezika pa se pojavi tudi pri dodajalnem načinu tvorbe feminativov ob izglasjih na $-h$ in $-l$ : Čehkinja, prijatelkinja). Obrazilo - $k a$ nastopi ob izglasju na $-h(\check{C} e h k a)$, kjer bi v sodobnem jeziku kot pogostejše pričakovali obrazilo -inja (to priponsko obrazilo ob izglasju na $-h$ namreč potrjuje nekaj več primerov kot $-k a$ ). Obrazila -ovca pa ob pregledu sodobnih jezikovnih virov nismo zasledili pri nobenem primeru ( $\mathrm{v}$ zgodovini: kovačovca). Feminativno priponsko obrazilo -(ov)ka pa nastopi ob izglasjih podstav na $-d,-k,-r$ in $-t$, kar se le delno ujema s tvorjenkami iz slovnic skozi zgodovino slovenskega jezika (samo Židovka, Čehovka, levovka). Podobno je z 
obrazilom -ulja, ki se v sodobnem slovenskem jeziku dodaja le k netvorjenkam z izglasji na $-c$ ali -g (torej drugače kot $\mathrm{v}$ pregledanih slovnicah, kjer nastopi ob -(a)č rogačulja in -k rakulja). Posebnost je tudi priponsko obrazilo -kinja kot zamenjevalno - zamenja moškospolsko obrazilo -ec, in to ob primerih, kjer bi v sodobnem knjižnem jeziku pričakovali ženskospolsko priponsko -ka oz. -ica (npr. Nemkinja). Sodobni jezikovni viri pa kažejo, da pri občnoimenski tvorbi feminativov priponsko obrazilo -ec večinoma zamenjujeta obrazili -ica $(4,4 \%)$ in -ka (95\%); -kinja nastopi le pri 0,2\% primerov.

\section{IV.}

Posebno poglavje je bilo namenjeno tvorbi feminativov iz lastnoimenske podstave: večinoma gre za tvorbo priimkovnih feminativov ali ženskospolskih poimenovanj za prebivalke. Slednja so zbrana v slovarskem delu SP; analizirali smo 2420 tovrstnih primerov. Med temi jih je manj, to je 571 (ali $24 \%$ ), nastalo z zamenjavo moškospolskega obrazila, preostalih 1849 (76 \%) pa jih je bilo tvorjenih $\mathrm{z}$ dodajanjem ženskospolskega priponskega obrazila samostalniku moškega spola. Najpogostejše ženskospolsko priponsko obrazilo je bilo obrazilo -ka, ki se je pojavilo skupno kar 2330-krat (96 \% vseh zbranih besed; npr. Masajka, Mongolka), sledi obrazilo -inja s skupno 65 pojavitvami (3\%; npr. Čehinja), nato -ica z 20 (0,8 \%; npr. Hrvatica), feminativna priponska obrazila -ca, -kinja, -ijka, -anka, -(ev)ka pa so zastopana s po enim konkretnim primerom (Črnovršca, Srbkinja, Kirgizijka, Povolžanka, Majevka). Ob primerjavi s tvorbo feminativov iz občnoimenske podstave smo zaznali nekaj podobnosti, pa tudi razlik. Priponsko obrazilo - $(e v) k a$ se dodaja izglasjem podstave na $-j$ tudi pri izobčnoimenski podstavi (npr. zlodejevka). Tudi priponsko obrazilo -ica ob tovrstni tvorbi nastopa kot dodajalno k izglasjem na $-(V) r$ (Bačarica; citrarica) in na -t (Hrvatica; opatica). Obrazilo -inja se lahko pri izlastnoimenski tvorbi feminativov dodaja različnim izglasjem (podstav); nekaj teh smo zasledili tudi pri izobčnoimenski tvorbi; enako velja za ženskospolsko obrazilo -ka. Tudi pri feminativih, ki so tvorjeni iz občnoimenske podstave, priponski obrazili -ica in -ka zamenjujeta moškospolsko obrazilo -ec; samo obrazilo $-k a$ pa pogosto 
zamenjuje tudi obrazila s sestavino $-e c$, tako da tudi zamenjava moškospolskega -ijec, kadar gre za poimenovanja prebivalk, ne preseneča (Liburnka). Priponsko obrazilo -ica je tudi pri izlastnoimenskih feminativih edino, ki zamenja moškospolsko obrazilo -ik (Močvirnica). Nikoli pri izobčnoimenski tvorbi pa ženskospolsko obrazilo $-k a$ ne zamenja moškospolskih $-c$ in -čan, kadar gre za poimenovanja oseb in živali, tvorjenih iz občnoimenskih podstav (pri izlastnoimenskih feminativih pa Dupeljka, Kapelka). Feminativni priponski obrazili -ca in -anka pa pri izobčnoimenskih feminativih ne nastopita.

Nato smo besedotvorno analizirali 500 ženskospolskih oblik priimkov, zabeleženih v SP. Ugotavljamo, da je zgolj 38 (ali 8 \%) priimkovnih feminativov nastalo z zamenjavo moškospolskega obrazila, preostalih 462 (92 \%) pa z dodajanjem ženskospolskega obrazila priimku moškega spola. Najpogostejše ženskospolsko priponsko obrazilo je bilo obrazilo -(ov)ka, ki se je pojavilo 177krat (35 \% vseh zbranih besed; npr. Golobovka), sledi obrazilo -ka s 153 pojavitvami (31\%; denimo Jerička), nato -ica s 103 (21\%; npr. Baumanica) in -(ev)ka s 66 (13 \%; npr. Bajčevka) pojavitvami. Priponsko obrazilo -ka z variantami zavzema $79 \%$ priimkovnih feminativov iz $S P$ in je tako najproduktivnejše. Zasledili smo le en primer s priponskim obrazilom -inja (Hajdinjakinja). Ob primerjavi $\mathrm{s}$ feminativi, tvorjenimi iz občnoimenske podstave, opazimo podobnosti in razlike. Priponsko obrazilo -ica tudi ob izobčnoimenski tvorbi nastopa kot dodajalno k izglasjem na $-(V) r$, zelo redko pa $\mathrm{k}$ tistim na -n (Vidmarica, Majerica, Baumanica; davkarica, darkerica, članica). Obrazilo -inja se lahko tudi pri izlastnoimenski tvorbi feminativov dodaja $\mathrm{k}$ izglasju na -k (Hajdinjakinja; odličnjakinja). Priponsko obrazilo -ka se, za razliko od lastnoimenskih, pri občnoimenskih feminativih zelo redko pojavlja kot dodajalno k izglasju na -l (Peternelka; modelka), redko nastopi tudi ob izglasju na -š (Arnuška; bogataška). Pri različnih izglasjih se pojavi obrazilo -(ov)ka, ki pri izobčnoimenski tvorbi niti ni tako pogosto; kjer pride do preglasa, pa nastopi priponsko obrazilo -(ev)ka (npr. Jerajevka). Tudi pri izobčnoimenski tvorbi feminativov je pogosta zamenjava moškospolskega obrazila -ik z -ica, ne pa tudi z -ek (Hriberšica; pri občnih poimenovanjih pogosteje kot zamenjevalno nastopa obrazilo - $k a$, npr. osebenjka). Ženskospolsko priponsko obrazilo - $k a$ tudi pri 
izobčnoimenski tvorbi pogosto zamenjuje moškospolsko obrazilo -ec, nikoli pa ne zamenja obrazila -ic (tukaj pa Sajovka). Navedena feminativna priponska obrazila so nam predstavljala izhodišče za korpusno analizo priimkovnih feminativov, vendar pa smo pri gradivu iz korpusa Gigafida zaznali novo obrazilo, to je priponsko obrazilo - ca kot varianta obrazila -ica, ki je bilo pri iz korpusa izpisanih primerih tudi drugo najpogostejše (17 primerov, $22 \%$; npr. Dremeljca), takoj za priponskim obrazilom - $k a$ z 31 primeri (41\%). Opažamo, da se ta razporeditev priponskih obrazil po pogostnosti ne ujema s tisto, ki se kaže pri primerih iz $S P$, ko je vodilno obrazilo -(ov)ka.

\section{V.}

Pričakovali smo, da bo doktorska disertacija ponudila rešitve pri t. i. variantnih feminativnih obrazilih. Pojav je značilen tudi za druge slovanske jezike, npr. ukrajinščino, slovaščino, srbščino, makedonščino, opazimo pa ga že ob pregledu slovnic in slovarjev skozi zgodovino (v Murkovem slovarju, v slovnicah Frana Metelka, Petra Dajnka, Josipa Šumana ...). Pri analizi gradiva se je nabralo veliko število feminativov, kjer sta se ob isti podstavi pojavili dve ali več variantnih priponskih obrazil. Primerjava tovrstnih tvorjenk glede na kvalifikatorje v obeh SSKJ in SP je pokazala njihovo slogovno zaznamovanost, večpomenskost in možnost zamenljivosti, korpusna analiza pa prikazuje njihovo pogostnost. Po pregledu obeh izdaj SSKJ, SP, SNBSJ in NSL smo ob izpisanih variantah opazovali večpomenskost in slogovno zaznamovanost, pogostnost rabe pa smo preverili po korpusu Gigafida, po potrebi, tj. ob nizkem ali izenačenem številu konkordanc, pa še po Novi besedi, Kresu in spletnem iskalniku Google. Upoštevali smo tudi sintezo obrazilne produktivnosti - katero ženskospolsko priponsko obrazilo se pogosteje druži z določenim moškospolskim izglasjem. Glede na vse našteto smo predlagali ustreznejšo od variant. Nadalje analiza v pričujoči disertaciji dokazuje, da k moškospolskim poimenovanjem bitij, za katera po Toporišiču ni mogoče najti ženskospolske ustreznice (sicer je razprava iz leta 1981), v sodobnem knjižnem jeziku feminativi že obstajajo ali pa njihovo obliko lahko predvidimo. Veliko feminativov je ponudil že SP iz leta 2001 (vidkinja, 
jedka, guležka, klatežka, hromka, ordinarijka, zemljepiska ...), torej dvajset let po Toporišičevi raziskavi; tolikšno število novih ženskospolskih poimenovanj ob porastu novotvorjenk v slovenščini niti ne more biti presenetljivo. S korpusno analizo smo dokazovali, da je raba nekaterih med njimi (npr. govorka, mladička) že dokaj pogosta, drugi feminativi pa si pot v vsakdanjo jezikovno rabo šele utirajo (npr. sluginja, vidkinja, brivka, bahačka, butka, svojka, četverčica ...). Ugotavljamo, da je odsotnost nekaterih ženskospolskih vzporednic družbenozgodovinsko (igrc, jezdec, spovednik), biološko in sociološko (bradač) pogojena; glede na to, da je jezik živ organizem, pričakujemo, da se bodo posamezni feminativi še naprej tvorili ob ustreznih moškospolskih novotvorjenkah ali novopomenkah, kjer je to le mogoče, in se sčasoma v jeziku tudi ustalili. Navsezadnje drži misel, navedena $\mathrm{v}$ začetku disertacije: Jezik ni univerzalen, niti nevtralen, in ni nedotakljiv.

\section{VIRI IN LITERATURA}

\section{VIRI}

1. eSSKJ: Slovar slovenskega knjižnega jezika 2016-2017, www.fran.si, dostop junij 2018.

2. Alenka GLOŽANČEV, Primož JAKOPIN, Maja MICHELIZZA, Lučka UR ̌̌IČ, Andreja ŽELE, 2009: Novejša slovenska leksika (v povezavi s spletnimi jezikovnimi viri). Ljubljana: Inštitut za slovenski jezik Frana Ramovša ZRC SAZU.

3. Korpus Fidaplus: http://www.fidaplus.net/, dostop 2012-2018.

4. Korpus Gigafida: http://www.gigafida.net/, dostop 2012-2018.

5. Korpus Janes: http://nl.ijs.si/janes/viri/avtomatsko-oznaceni-korpusi/ \#Janes, dostop 2018.

6. Korpus Nova beseda: http://bos.zrc-sazu.si/s_beseda.html, dostop 2012-2018. 
7. Domen KRVINA: Sprotni slovar slovenskega jezika 2014-2017. Vir: www.fran.si, dostop junij 2018.

8. Katja KUSTEC, 2009: Novotvorjenke za poimenovanje oseb v slovenskem jeziku. Diplomsko delo. Maribor: Filozofska fakulteta.

9. Slovar slovenskega knjižnega jezika, www.fran.si, dostop 2012-2018.

10. Slovar slovenskega knjižnega jezika, druga, dopolnjena in deloma prenovljena izdaja, www.fran.si, dostop 2012-2018.

11. Slovar novejšega besedja slovenskega jezika, www.fran.si, dostop 2012-2018.

12. Slovenski pravopis, www.fran.si, dostop 2012-2018.

13. Marko SNOJ, 2016: Slovenski etimološki slovar (3. izdaja). Ljubljana: Založba ZRC.

14. Statistični urad Republike Slovenije: http://www.stat.si/, dostop junij 2017.

15. Zavod RS za zaposlovanje. Vir: https://www.ess.gov.si/iskalci_zaposlitve/ prosta_delovna_mesta,dostop 18.5. 2012 in 5.7.2017.

\section{LITERATURA}

1. Kozma AHAČIČ, 2007: Zgodovina misli o jeziku in književnosti na Slovenskem: protestantizem. Ljubljana: Založba ZRC.

2. - -, Janez Novak, študentka slovenščine. Vir: https://www.delo.si/ novice/slovenija/janez-novak-studentka-slovenscine-54157.html.

Pridobljeno 27. 6. 2018.

3. Milica ANTIĆ GABER, Metka MENCIN, 1992: Ženske in politika. V: M. Cigale et al. (ur.). Ko odgrneš sedem tančic. Ljubljana: Društvo Iniciativa. $103-111$.

4. Milica ANTIĆ GABER, 1997: Ženske v slovenski politiki. V: A. Derganc (ur.). XXXIII. seminar slovenskega jezika, literature in kulture, 30. 6. - 19. 7. 1997. Ljubljana: Filozofska fakulteta, Oddelek za slovanske jezike in književnosti. 207-223. 
5. - -, 2004: Politične pravice in participacija žensk v politiki. V: V. Jelušič, D. Zagorac (ur.). Človekove pravice žensk. Ljubljana: Mirovni inštitut. 5788.

6. А. М. АРХАНГЕЛЬСЬКА, 2014: До проблеми словотвірної фемінізації в українській мові новітньої доби: традиція і сучасність. II. Мовознавство 2014/1. 58-70.

7. Stjepan BABIĆ, 1991: Tvorba riječi u hrvatskom književnom jeziku. Zagreb: Hrvatska akademija znanosti i umjetnosti.

8. - -, 2006: Hrvatski jezik, zakonodavstvo i ravnopravnost spolova. Jezik: časopis za kulturu hrvatskoga književnog jezika 53/3. 81-87.

9. Anton BAJEC, 1950: Besedotvorje slovenskega jezika. Ljubljana: SAZU.

10. Anton BAJEC, Rudolf KOLARIČ, Mirko RUPEL, Jakob S̆OLAR, 1956: Slovenska slovnica. Ljubljana: DZS.

11. Anton BAJEC, 1958: Pred novo izdajo SP. Jezik in slovstvo 3/4. 145-148.

12. Nikola BAJIĆ, 2012: Spolno (ne)občutljiva raba jezika v Srbiji in Sloveniji v teoriji in praksi. V: A. Bjelčević (ur.). Ideologije v slovenskem jeziku, literaturi in kulturi. Ljubljana: Znanstvena založba Filozofske fakultete. 124-128.

13. Eugenija BARIĆ, 1987: Mocijski parnjaci i njihova upotreba. V: Rasprave Instituta za hrvatski jezik i jezikoslovlje. Zagreb: Zavod za jezik IFF. 9-18.

14. - -, 1988: Tvorbeni status ženskog mocijskog parnjaka. Rasprave Instituta za hrvatski jezik i jezikoslovlje 14/1. 43-49.

15. Eugenija BARIĆ idr., 1997: Hrvatska gramatika. Zagreb: Školska knjiga.

16. Claudie BAUDINO, 2001: Politique de la langue et différence sexuelle. Paris: L'Harattan.

17. Marja BEŠTER, 1997: Raba poimenovanj za ženske osebe v uradovalnih besedilih. V: A. Derganc (ur.). XXXIII. seminar slovenskega jezika, literature in kulture, 30. 6. - 19. 7. 1997. Ljubljana: Filozofska fakulteta, Oddelek za slovanske jezike in književnosti. 9-24.

18. Gisela BOCK, 2004: Ženske v evropski zgodovini: od srednjega veka do danes. Maribor: Darima. 
19. Adam BOHORIČ, 1987: Arcticae horulae succisivae. Zimske urice proste. Maribor: Obzorja.

20. Ljudmila BOKAL, 2000: Leksikografska obravnava prvega slovenskega pravopisa (Fran Levec, 1899). Jezikoslovni zapiski 6. 15-26.

21. Silvija BOROVNIK, 1995: Pišejo ženske drugače? Ljubljana: Mihelač.

22. Anton BREZNIK, 1916: Slovenska slovnica za srednje šole. Celovec: Tiskarna Družbe sv. Mohorja.

23. - -, 1920: Slovenski pravopis. Ljubljana: Jugoslovanska knjigarna.

24. - -, 1924: Slovenska slovnica za srednje šole. Prevalje: Družba sv. Mohorja.

25. --, 1934: Slovenska slovnica za srednje šole. Celje: Družba sv. Mohorja.

26. Anton BREZNIK, Fran RAMOVŠ, 1935: Slovenski pravopis. Ljubljana: Znanstveno društvo.

27. Deborah CAMERON, 2002: Feminism and linguistic theory. New York: Pelgrave.

28. Matej CIGALE, 1860: Deutsch-slovenisches Wörterbuch. Ljubljana: J. Blasnik.

29. Nevenka ČERNIGOJ SADAR, Dorotea VERŠA, 2002: Zaposlovanje žensk. V: I. Svetlik et al. (ur.). Politika zaposlovanja. Ljubljana: Fakulteta za družbene vede. $398-430$.

30. Světla ČMEJRKOVA, 1995: Žena v jazyce. Slovo a slovesnost 1. 43-55.

31. Hana ĆOPIĆ, 2012: Žene i jezik. V: Neko je rekao feminizam? Kako je feminizam uticao na žene XXI. veka. Sarajevo: Sarajevski otvoreni centar.

32. Божо ЋОРИЋ, 1982: Моциони суфикси у српскохрватском језику. Београд: Филолошки факултет.

33. Peter DAJNKO, 1824: Lehrbuch der Windischen Sprache. Gradec.

34. Jurij DALMATIN, 1584: Biblia, tu ie, vse Svetu pismu, Stariga inu Noviga testamenta. Wittemberg: Hans Kraffts Erben.

35. John DeLAMATER, Janet SHIBLEY HYDE, 1998: Essentialism vs. social constructionism in the study of human sexuality. The Journal of Sex Research 35/1. 10-19. 
36. Mojca DOBNIKAR, 2009: Gibanje proti nasilju nad ženskami med feminizmom in socialnim delom. Dialogi 11-12/09. 98-110.

37. Helena DOBROVOLJC, b. 1.: Ženska poimenovanja poklicev. Vir: http://isjfr.zrcsazu.si/sl/svetovalnica/\%C5\%BEenska-poimenovanjapoklicev\#v. Pridobljeno 27. 3. 2018.

38. - -, 2014: Ženski spol in samostalnik »vodja«. Vir: http://isjfr.zrcsazu.si/sl/svetovalnica/ zenski-spol-in-samostalnik-vodja\#v. Pridobljeno 27. 3. 2018.

39. Helena DOBROVOLJC, Boris KERN: Pisanje moških in ženskih oblik in uporaba podčrtaja za izražanje »spolne nebinarnosti«. Vir: https://svetovalnica.zrc-sazu.si/topic/2247/pisanje-mo\%C5\%A1kih-in$\%$ C5\%BEenskih-oblik-in-uporaba-pod\%C4\%8Drtaja-zaizra\%C5\%BEanje-spolne-nebinarnosti. Pridobljeno julija 2018.

40. Miloš DOKULIL, 1962: Tvořeni slov v češtinĕ 1. Teorie odvozovani slov. Praga: Nakladatelstvi češkoslovenske akademie věd.

41. Rajna DRAGIĆEVIĆ, 2010: Verbalne asocijacije kroz srpski jezik $i$ kulturu. Beograd: Društvo za srpski jezik i književnost Srbije.

42. Janez DULAR, 2003a: Dopolnilo k odgovoru akademika Jožeta Toporišiča. Slavistična revija 51/2. 183-184.

43. - -, 2003b: Pravopisni kompromis ali kompromisni pravopis? Slavistična revija 51/2. 123-126.

44. - -, 2014: Vodja in vodjinja. Slovenski čas: časnik za družbo in kulturo (priloga tednika Družina) 48, 16.

45. Juraj FURDIK, 2004: Slovenska slovotvorba (teoria, opis, cvičenia). Prešov: Nauka.

46. Joža GLONAR, 1936: Slovar slovenskega jezika. Ljubljana: Umetniška propaganda.

47. Alenka GLOŽANČEV, 1997: Kratek pregled slovenskega pravopisja od konca devetnajstega stoletja do danes. Jezikoslovni zapiski 3. 85-104.

48. Tomislav GOLOB, 2009: Mihael Zagajšek: shivlenje ino dela: ob 270letnici rojstva. Šentjur: Občina. 
49. Maruša GORTNAR, Tanja SALECL, 2004: Pregled pravne ureditve v EU in Sloveniji na področju človekovih pravic žensk (ključne direktive in zakoni). V: Človekove pravice žensk. Ljubljana: Mirovni inštitut. 115-145.

50. Marta GROCHOWSKA, Agnieszka WIERZBICKA, 2015: Produktywne typy słowotwórcze nazw żeńskich we współczesnej polszczyźnie. Folia Linguistica 49. 45-55.

51. Ožbalt GUTSMAN, 1789: Deutsch-windisches Wörterbuch: mit einer Sammlung der verdeutschten windischen Stammwörter, und einiger vorzüglichern abstammenden Wörter. Celovec: Ignaz Aloys edlen von Kleinmayer.

52. Milena HAJNŠEK - HOLZ, 1997: Pleteršnikov Slovensko-nemški slovar kot vir za Slovar slovenskega knjižnega jezika. Jezikoslovni zapiski 3. $105-112$.

53. Уладзіслаў ГАРБАЦКИ, 2016: Гід па фэмінізаџылі беларускай мовы. Вільна.

54. Jasna HONZAK - JAHIĆ, 2003: Pohlinov in Metelkov opis slovenskega knjižnega jezika v luči časa njunega nastanka. Slavistična revija 51, posebna številka. 331-350.

55. Luce IRIGARAY, 1995: Jaz, ti, me, mi: za kulturo različnosti. Ljubljana: Znanstveno in publicistično središče.

56. Franc JAKOPIN, 1968: Slovnica ruskega knjižnega jezika. Ljubljana: DZS.

57. Franc JAKOPIN, 1997: Ženskost v slovanskih priimkih. V: A. Derganc (ur.). Zbornik predavanj/XXXIII. seminar slovenskega jezika, literature in kulture, 30. 6.-19. 7. 1997. Ljubljana: Filozofska fakulteta, Oddelek za slovanske jezike in književnosti. 25-32.

58. Vlasta JALUŠIČ, 1992: Dokler se ne vmešajo ženske ... Ljubljana: Krt.

59. - -, 2004: Prizadevanja za pravice žensk, njihovo uzakonitev in uresničevanje. V: V. Jalušič, D. Zagorac (ur.). Človekove pravice žensk. Ljubljana: Mirovni inštitut. 31-56.

60. Anton JANEŽIČ, 1850: Popolni ročni slovar slovenskega in nemškega jezika. Celovec: J. Sigmund. 
61.--, 1854: Slovenska slovnica s kratkim pregledom slovenskega slovstva ter z malim cirilskim in glagoliškim berilom za Slovence. Celovec.

62. Svitlana JERMOLENKO, 1999: Ukrainska mova. Opole: Uniwesytet Opolski.

63. Marija JEŽ, 1997a: Feminativi na Pohorju. Jezikoslovni zapiski 3. 113125.

64. --, 1997b: Iz novejšega besedotvorja. Slava: debatni list 10/2. 103-119.

65. - -, 1998: Iz teorije feminativov. V: I. Štrukelj (ur.). Jezik za danes in jutri. Ljubljana: Društvo za uporabno jezikoslovje Slovenije. 223-230.

66. Maca JOGAN, 2001: Seksizem v vsakdanjem življenju. Ljubljana: Fakulteta za družbene vede.

67. - -, 2013: Od gospe asistent do gospe doktor in gospe profesor. V: T. Logar (ur.). Prikrite oblike diskriminacije žensk $v$ znanosti. Univerza v Mariboru: Filozofska fakulteta. 9.

68. Aleksandra KANJUO MRČELA, 1992: Ali so »družinske kraljice« lahko tudi »šefice«? V: Marija Cigale et. al (ur.). Ko odgrneš sedem tančic. Ljubljana: Društvo Iniciativa. 77-87.

69. - -, 2007: Zaposlovanje in delo žensk v Sloveniji in Evropski uniji. V: B. Ferfila (ur.). Zbornik o Evropski uniji. Ljubljana: Fakulteta za družbene vede. 547-569.

70. Małgorzata KARWATOWSKA, Jolanta SZPYRA-KOZŁOWSKA, 2005: Lingwistyka ptci. Ona i on w języku polskim. Lublin.

71. Janez KEBER, 1999: Živalske metafore kot vir imen, vzdevkov in priimkov. Jezikoslovni zapiski 5. 135-149.

72. France KIDRIČ, 1929-1938: Zgodovina slovenskega slovstva: od začetkov do Zoisove smrti. Ljubljana: Slovenska matica.

73. Ivan KLAJN, 1996: Leksika. V: Milorad Radovanovič (ur.). Srpski jezik. Opole: Uniwesytet Opolski - Instytut Filologii Polskiej. 37-86.

74. - -, 2003: Tvorba reči u savremenom srpskom jeziku. Beograd: Institut za srpski jezik SANU.

75. Peter KONČNIK, 1883: Slovenska slovnica z naukom, kako se pišejo pisma in opravilni sestavki. Dunaj. 
76. Kiril KONESKI, 2003: Zboroobrazuvanjeto vo sovremeniot makedonski jazik. Skopje: Filološki fakultet Blaže Koneski.

77. Tomo KOROŠEC, 1989: O pripravljenosti slovenščine za sporazumevanje v vojaški enoti JLA. Teorija in praksa 26/3-4. 442-448.

78. - -, 1998: Slovenski vojaški jezik. Ljubljana: Fakulteta za družbene vede.

79. Simona KRANJC, Martina OŽBOT, 2013: Vloga spolno občutljivega jezika $v$ slovenščini, angleščini in italijanščini. V: Andreja Žele (ur.). Družbena funkcijskost jezika. Ljubljana: Znanstvena založba Filozofske fakultete. 233-239.

80. Bogusław KREJA, 1964: Słowotwórstwo nazw żeńskich we współczesnym języku polskim. Język Polski 44. 129-140.

81. Libuše KROUPOVA, 1980: Žena v zaměstnání a povolání. Slovo a slovesnost 3. 208-216.

82. Erika KRŽIŠNIK, 2008: Viri za kulturološko interpretacijo frazeoloških enot. Jezik in slovstvo 53/1. 33-47.

83. Zofia KUBISZYN-MĘDRALA, 2007: Ženskie nazwy tytułow i zawodow W słownikach wapołczesnego języka polskiego. LingVaria 1/3. 31-40.

84. Roman KUHAR, 2001: Favo ritke. V: Poročilo Skupine za spremljanje nestrpnosti. Ljubljana: Mirovni inštitut. 115-135.

85. Roman KUHAR: Marija Novak, študent slovenščine (odziv na članek K. Ahačiča "Janez Novak, študentka slovenščine"). Vir: http://www.ff.unilj.si/novice/Marija_Novak_student_slovenscine_odziv_na_clanek_K_Aha cica_Janez_Novak_studentka_slovenscine. Pridobljeno 27.6. 2018.

86. Blaž KUMERDEJ, 1787-1798: Dictionarium slavo-carniolicum (rokopis).

87. Olga KUNST GNAMUŠ, 1995: Razmerje med spolom kot potezo reference in spolom kot slovnično kategorijo. Jezik in slovstvo 40/7. 255262.

88. Ana KUZMANOVIĆ JOVANOVIĆ, 2013: Rodno osetljiv jezik u sektoru bezbednosti. Beograd: Beogradski centar za bezbednosnu politiku.

89. Vesna LESKOŠEK, 2000: Med nevtralnostjo in univerzalnostjo uporabe moškega slovničnega spola. Časopis za kritiko znanosti, domišljijo in novo antropologijo 28/200-201. 409-426. 
90. --, 2002: Zavrnjena tradicija. Ljubljana: Založba.

91.--, 2004: Žensko gibanje na Slovenskem in boj za pravice žensk. V: V. Jalušič, D. Zagorac (ur.). Človekove pravice žensk. Ljubljana: Mirovni inštitut. 89-113.

92. - -, 2009: Nujnost feminističnih refleksij naraščajočih globalnih enakosti. Dialogi 11-12/09. 111-121.

93. Fran LEVEC, 1889: Janežičev nemško-slovenski slovar; Deutschslovenisches Worterbuch von Anton Janežič. Ljubljanski zvon 9/11.

94. - -, 1899: Slovenski pravopis. Dunaj: Cesarska kraljeva zaloga šolskih knjig.

95. Nataša LOGAR BERGINC idr., 2012: Korpusi slovenskega jezika Gigafida, Kres, ccGigafida in ccKres: gradnja, vsebina, uporaba. Ljubljana: Trojina.

96. Matija MAJAR, 1848: Pravila kako izobraževati ilirsko narečje i u obče slavenski jezik. Ljubljana.

97. Fran MALAVAŠIČ, 1849: Slovenska slovnica za prve slovenske šole v mestih in na deželah. Ljubljana.

98. Gorazd MAKAROVIČ, 2008: Ko še nismo bili Slovenci in Slovenke. Ljubljana: Slovenska matica.

99. Andrzej MARKOWSKI, 1995: Zakres używania form żenskich nazw zawodów i funkcji w odniesieniu do kobiet - polityków. Czerwiec: Biuro Studiow i Ekspertyz.

100. Hieronim MEGISER, 1592: Dictionarium quatuor linguarum: videlicet, Germanicae, Latinae, Illyricae. Impressum Graecii Styriae: à Iohanne Fabro.

101. Majda MERŠE, 2008: Ženski pari moških poimenovanj v slovenskem knjižnem jeziku 16. stoletja. Slavia Centralis 1/2. 30-52.

102. - -, 2009: Slovenski knjižni jezik 16. stoletja. Razprave o oblikoslovju, besedotvorju, glasoslovju in pravopisu. Ljubljana: Založba ZRC. 
103. - -, 2013: Slovenski knjižni jezik 16. stoletja. Razprave o jezikovnem sistemu, besedju in prevodni problematiki. Ljubljana: Založba ZRC.

104. Polona MESEC, 2009: Feministična raba negativnosti. Dialogi 1112/09. 136-147.

105. Franc METELKO, 1825: Lehrgebäude der Slowenischen Sprache im Königreiche Illyrien und in den benachbarten Provinzen. Ljubljana.

106. Drago MEŽNAR, 2009: Enakost na delovnem mestu (primerjava med Slovenijo in Evropsko unijo). Podjetje in delo 35/3-4. 665-684.

107. Milica MIHAJLEVIĆ, Barbara ŠTEBIH GOLUB, 2010: Mocijska tvorba u hrvatskome i srpskome jeziku. V: B. Tošović (ur.). Die Unterschiede zwischen dem Bosnischen/Bosniakischen, Kroatischen und Serbischen I, Slawische Sprachkorelationen. Dunaj. 81-103.

108. Katja MIHURKO PONIŽ, 2005: Feministične literarnovedne raziskave - tukaj in zdaj. Jezik in slovstvo 50/3-4. 87-95.

109. Fran MIKLOŠIČ, 1875: Vergleichende Stammbildungslehre der slavischen Sprachen. Dunaj.

110. Mluvnice češtiny, 1986: Nazvy zdrobnele. (1) Fonetika. Fonologie. Morfonologie a morfemika. Tvoreni slov. Praga: Academia.

111. Toril MOI, 1999: Politika spola/teksta. Ljubljana: Literarnoumetniško društvo Literatura.

112. Anton MURKO, 1833: Slovénsko-Némshki in Némshko-Slovénski rózhni besédnik: kakor se slovénshina govorí na Shtájerskim, Koròshkim, Krájnskim in $v^{\prime}$ sahodnih stranih na Vógerskim. Slovénsko-Némshki dél. Gradec: Janes Lavre Greiner.

113. Jožef MURŠEC, 1847: Kratka slovenska slovnica za pervence. Gradec.

114. Ivan NAVRATIL, 1850: Kurze Sprachlehre mit einer möglichst vollständigen Rechtschreibung der slovenischen Sprache, nebst einem praktischen Anhange enthaltend. Ljubljana. 
115. Галина НЕЩИМЕНКО, 2003: Яэыковая экономия как импульс динамики номинационной системы. V: I. Ohnneiser (ur.). Słowotwórstvo/Nominacija. Opole: Uniwersytet Opolski.

116. Nomotehnične smernice. Vir: http://www.svz.gov.si/fileadmin/svz.gov.si/ pageuploads/Dokumenti/Nomotehnicne_smer.pdf. Pridobljeno: oktober 2013.

117. Irena OREL, 2001: Ženske oblike priimkov v uradovalnih besedilih do 19. stoletja. V: Jože Toporišič (ur.). Simpozij Slovenska lastnoimenskost: zbornik simpozija '99 v Pišecah. Novo mesto: Dolenjska založba. 41-54.

118. Martina OROŽEN, 1960: Dr. A. Bajec: Besedotvorje slovenskega jezika. Jezik in slovstvo 6/1. 25-28.

119. - - 1971: Pohlinovo jezikoslovno delo. Jezik in slovstvo 16/8. $250-254$

120. Katja PLEMENITAŠ, 2012: Sožitje med spoloma v luči manj vidnih oblik seksizma v slovenski družbi. V: M. Lamberger Khatib (ur.). Sožitje med kulturami: poti do medkulturnega dialoga II. Maribor: Pivec. $169-177$.

121. Maks PLETERŠNIK, 1893: Slovensko-nemški slovar. Ljubljana: Knezoškofijstvo.

122. Jože POGAČNIK, 1990: Strokovno vzorno slavistično delo. Jezik in slovstvo 35/7-8. 188-190.

123. Breda POGORELEC, 1984: Štiristo let Bohoričeve slovnice Arcticae horulae - Zimske urice 1586-1984. Jezik in slovstvo 29/6. 210 216.

124. Marko POHLIN, 1781: Tu malu besedishe treh jesikov. Ljubljana: Johann Friedrich Eger.

125. --, 2003: Kraynska grammatika. Ljubljana: Založba ZRC.

126. Poslovnik Državnega zbora z razlagami, 2011. Ljubljana: Državni zbor Republike Slovenije. 
127. Blaž POTOČNIK, 1849: Grammatik der slowenischen Sprache. Ljubljana.

128. Paulina PYCIA, 2011: Płeć a język (na materiale współczesnego języka polskiego i chorwackiego). Katowice: Wydawnictwo Uniwersytetu Śląskiego.

129. Vasilka RADEVA, 1991: Slovoobrazuvaneto $v$ b"lgarskija knjižoven ezik. Sofija: Universitetsko izdatelstvo Sv. Kliment Ohridski: Nauka i izkustvo.

130. Martin RIEGEL, Jean-Christophe PELLAT, Rene RIOUL, 1999: Grammaire methodique du français. Paris: Presse Universitaires de France.

131. Jakob RIGLER, 1967: Register v Dalmatinovi Bibliji. Jezik in slovstvo 12/4. 104-106.

132. Henrik SCHREINER, Janko BEZJAK, 1903-1905: Slovenska jezikovna vadnica za tesno združeni poduk v slovnici, pravopisu in spisju. Dunaj.

133. Mateja SEDMAK, Zorana MEDARIĆ, 2007: Med javnim in zasebnim: ženske na trgu dela. Koper: Univerza na Primorskem.

134. Slovenski pravopis, 1950. Ur. F. RAMOVŠ idr. Ljubljana: Državna založba Slovenije.

135. Slovenski pravopis, 1962. Ur. A. BAJEC idr. Ljubljana: Državna založba Slovenije.

136. Miloslava SOKOLOVA, 2007: Novy deklinačny system slovenskych substantiv. Prešov: Filozoficka fakulta Prešovskej univerzity v Prešove.

137. Susan SPEER, 2005: Gender talk: feminism, discourse and conversation analysis. London: Routledge.

138. Vladimir SRUK, 1995: Leksikon politike. Maribor: Obzorja.

139. Jože STABEJ, 1974: Vpliv in vrednost Pohlinovega Besedisha. Jezik in slovstvo 19/6-7. 249-255. 
140. $\quad--$, 1996: Nekaj ugotovitev ob popolnem izpisu Vodnikovega rokopisnega nemško-slovenskega slovarja. Jezik in slovstvo 11/1-2. 4244.

141. Marko STABEJ, 1997: Seksizem kot jezikovnopolitični problem. V: A. Derganc (ur.). Zbornik predavanj/XXXIII. seminar slovenskega jezika, literature in kulture, 30. 6.-19. 7. 1997. Ljubljana: Filozofska fakulteta, Oddelek za slovanske jezike in književnosti. 57-68.

142.,-- 2003: Ene in drugi: slovenščina in spola. Delo 45/31. 26.

143. Petra STANKOVSKA, 2009: Češka slovnica za bohemiste. Ljubljana: Znanstvena založba Filozofske fakultete.

144. Irena STRAMLJIČ BREZNIK, 1992: Izglagolske izpeljanke s pomenom vršilca dejanja. Slavistična revija 40/4. 411-427.

145. - - -, 1994: Prvostopenjske izpridevniške tvorjenke. Doktorska disertacija. Ljubljana.

146. - - 1994/95: Specializiranost obrazil za izpeljanke s pomenom vršilca dejanja, nosilca lastnosti ali stanja in opravkarja. Jezik in slovstvo 40. 285-291.

147. - - 1998: Dajnkovo besedotvorje med slovansko in slovensko besedotvorno tradicijo. V: Dajnkov zbornik. Maribor: Slavistično društvo.

148. - - - 1999a: Prispevki iz slovenskega besedoslovja. Maribor: Filozofska fakulteta.

149. - -, 1999b: Oblikovanje poimenovanj za besedne vrste v slovensko pisanih slovnicah med leti 1791-1854. Jezik in slovstvo 44/4. 103-110.

150. - -, 2004: Besednodružinski slovar slovenskega jezika. Poskusni zvezek za iztočnice na B. Maribor: Slavistično društvo.

151. $\quad--$, 2008: Besedotvorje predmetnopomenskih besed v Bohoričevi slovnici Zimske urice proste. Slavia Centralis 1/2. 67-76.

152. - -, 2010: Tvorjenke slovenskega jezika med slovarjem in besedilom. Maribor: Filozofska fakulteta.

153.,-- 2012: Neologizem in priložnostnica $\mathrm{z}$ vidika slovarja in korpusa. V: M. Jesenšek (ur.). Večno mladi Htinj: ob 80-letnici Janka 
Čara. Maribor: Mednarodna založba Oddelka za slovanske jezike in književnosti.

154. - -, 2013: Samostalniška tvorbena (a)tipika Pohlinovega Besedisha za imena oseb. V: Novi pogledi na filološko delo o. Marka Pohlina in njegov čas. Ljubljana: Filozofska fakulteta.

155. - - 2018: Ženske ne povedo nič pametnega: jezikovnokorpusna analiza stereotipa. Jezikoslovni zapiski 24/1. 27-43.

156. Nuša ŠČUKA, 2014: Jezik in spol: ženska poimenovanja v slovenščini. Jezikoslovni zapiski 20/2. 79-88.

157. Jakob ŠOLAR, 1951: Anton Bajec: Besedotvorje slovenskega jezika. Slavistična revija 4/1-2. 142-147.

158. Renata ŠRIBAR, 2010: Interne smernice za spolno občutljivo rabo jezika. Vir: www.arhiv.mvzt.gov.si/fileadmin/mvzt.gov.si/pageuploads/ pdf/znanost/Zenske_v_znanosti/interne_jezikovne_smernice_za_komisijo _ final.pdf. Pridobljeno: 10. 7. 2014.

159. - - 2013: Jezik kot razmerje ospoljene oblasti. V: M. Ule, R. Šribar, A. Umek Venturini (ur.). Ženske v znanosti, ženske za znanost. Ljubljana: Založba FDV. 148-161.

160. Barbara ŠTEBIH GOLUB, 2011: Imenice kojima se označuju osobe ženskoga spola u kajkavskome književnom jeziku. V: J. Sierociuk (ur.). Stowotwórstwo stowiańskie: system i tekst. Poznań 17-19. 05. 2011. $43-53$.

161. Saška ŠTUMBERGER: Transspolnost na »filofaksu«: Študentka Janez Novak, padli ste na izpitu pri profesorici Božo Repe! Vir: https://www.portalplus.si/2729/transspolnost-na-filofaksu/. Pridobljeno 27. 6. 2018.

162. Saška ŠTUMBERGER: Transspolnost $v$ slovenščini: Bomo nekoč pisali "povabili_e so ga_jo k sodelovanju"? Vir: https://www.portalplus.si/ mobile/2668/uvajanje-podcrtaja-za-izrazanje-spolne-nebinarnosti.

Pridobljeno julija 2018.

163. Josip ŠUMAN, 1881: Slovenska slovnica po Miklošičevi primerjalni. Ljubljana: Matica slovenska. 
164. - - 1884: Slovenska slovnica za srednje šole. Celovec: Družba sv. Mohorja.

165. Jože TOPORIŠIČ, 1966: Slovenski knjižni jezik 2. Maribor: Obzorja.

166. - - 1967: Sedemdeset let Antona Bajca. Jezik in slovstvo 12/1. 14.

167. --, 1972: Slovenski knjižni jezik 2. Maribor: Založba Obzorja.

168.,-- 1973: Stilna vrednost glasovnih, prozodijskih, (pravo)pisnih, morfemskih in naglasnih variant slovenskega knjižnega jezika. Slavistična revija 21/2. 217-263.

169. - -, 1975: Beseda o Brezniku. Jezik in slovstvo 20/4. 99-102.

170. - - - 1981: $\mathrm{K}$ teoriji spola $\mathrm{v}$ slovenskem (knjižnem) jeziku. Slavistična revija 29/1. 79-94.

171. - -, 1991: Breznik-Ramovšev Slovenski pravopis. Slavistična revija 39/1. 115-126.

172. - - 1992: Enciklopedija slovenskega jezika. Ljubljana: Cankarjeva založba.

173. - - 1996: Janežičeva Slovenska slovnica 1854. Slavistična revija 44/3. 307-316.

174. $\quad-\quad-$, 2001: Ženske oblike 500-ih najpogostejših priimkov v Sloveniji. V: J. Toporišič (ur.). Simpozij Slovenska lastnoimenskost: zbornik simpozija '99 v Pišecah. Novo mesto: Dolenjska založba. 5-20.

175. - -, 2004: Slovenska slovnica. Maribor: Založba Obzorja.

176. - -, 2006: Besedjeslovne razprave. Ljubljana: ZRC SAZU.

177. Silvo TORKAR, 2002: Priimki na Slovenskem. Jezikoslovni zapiski 2. 71-80.

178. Betka TRUNKELJ, 1991: Zgodovina besedotvorja $\mathrm{v}$ slovensko pisanih slovnicah. Slava 1.9-28.

179. Mirjana ULE, 2009: O vzpostavljanju feminističnega gibanja in Ženskih študij v Sloveniji. Dialogi 11-12/09. 69-81. 
180. $\quad--$, 2013: Prikrite oblike diskriminacije žensk v znanosti. V: T. Logar (ur.). Prikrite oblike diskriminacije žensk $v$ znanosti. Univerza v Mariboru: Filozofska fakulteta. 15.

181. Andreja UMEK VENTURINI, 2013: Ciljno usmerjene politike za ženske in znanost v Sloveniji in Evropi. V: M. Ule, R. Šribar, A. Umek Venturini (ur.). Ženske v znanosti, ženske za znanost. Ljubljana: Založba FDV. 15-24.

182. Drago UNUK, 2003: Zlog v slovenskem jeziku. Ljubljana: Rokus.

183. Boris URBANČIČ, 1964: Naš novi Pravopis. Jezik in slovstvo 9/45. $103-118$

184. Veliki slovar tujk, 2002. Ur. M. ZAVZES. Ljubljana: Cankarjeva založba.

185. Ada VIDOVIČ MUHA, 1988: Slovensko skladenjsko besedotvorje ob primerih zloženk. Ljubljana: Znanstveni inštitut Filozofske fakultete.

186. - - 1992: Besedotvorna tipologija »novoslovenskega« gradiva pri Miklošiču. V: J. Toporišič (ur.). Miklošičev zbornik: mednarodni simpozij, v Ljubljani od 26. do 28. junija 1991. 173-191.

187. - - , 1997: Prvine družbene prepoznavnosti ženske prek poimenovalne tipologije njenih dejavnosti, lastnosti. V: A. Derganc (ur.). Zbornik predavanj/XXXIII. seminar slovenskega jezika, literature in kulture, 30. 6.-19. 7. 1997. Ljubljana: Filozofska fakulteta, Oddelek za slovanske jezike in književnosti. 69-79.

188. - -, 1998: Slovnice slovenskega jezika. V: Enciklopedija Slovenije, zvezek 12. 79-81.

189. - -, 2003: Čas stiske jezikoslovnega nazora ali odgovor avtorju na vprašanja zasnove Slovarja Slovenskega pravopisa. Slavistična revija 51/2. 177-181.

190. - -, 2011: Slovensko skladenjsko besedotvorje. Ljubljana: Znanstvena založba Filozofske fakultete.

191. Valentin VODNIK, 1806-1817: Slovensek Besednjak/Slowenisches Wörterbuch.

192. - - 1811: Pismenost in Grammatika za perve šole. Ljubljana. 
193. Nastja VOJNOVIČ, 1995: O oblikovanju geslovnika za pravopisni slovar. Jezikoslovni zapiski 2. 241-249.

194. Ines VORŠIČ, 2013: Sistemska in nesistemska leksikalna tvorba $v$ novejšem besedju slovenskega jezika. Doktorska disertacija. Maribor: Filozofska fakulteta.

195. Helmut WEINBERGER, 2003: Hrvatski i srpski. V: I. Ohnneiser (ur.). Słowotwórstvo/Nominacija. Opole: Uniwersytet Opolski.

196. Peter WEISS, 2014: Vodkinja. Jezikoslovni zapiski 20/2. 163-167.

197. Anna WIERZBICKA, 1997: Understanding Cultures Through Their Key Words. Oxford: Oxford University Press.

198. Mihael ZAGAJŠEK, 1791: Slovennska grammatika oder Georg Sellenko's Wendische Sprachlehre. Celje.

199. Pavel ZDOVC, 1989: O besedotvornih variantah imen za prebivalce krajev na zamejskem Koroškem $\mathrm{v}$ zamejski koroški publicistiki. Slavistična revija 37/1-3. 159-169.

200. Jana ZEMLJARIČ MIKLAVČIČ, 1999: Slovenščina kot drugi/tuji jezik: zgodovina (od začetkov do 1850). Slavistična revija 47/2. 245-260.

201. E. A. ZEMSKA, 2006: Sovremennin russki jazik: Slovoobrazovanje. Moskva.

202. Zinka ZORKO, 1993: Dialektizmi v Prežihovi zbirki Samorastniki. Jezik in slovstvo 39/2-3. 55-64.

203. Alojzija ZUPAN SOSIČ, 2007: Spolni stereotipi in sodobni slovenski roman. Primerjalna književnost 30/1. 109-120.

204. Paula ZUPANC, 2009: Nesimetrije izraza spolov v slovenskem jeziku in v govorih. Dialogi 11-12/09. 123-135.

205. Joca ZURC, 2004: Spolna diferenciacija pri šolski športni vzgoji in prostočasni gibalni/športni aktivnosti učencev. Družboslovne razprave 20/46-47. 39-60.

206. Igor ŽAGAR, Mirjam MILHARČIČ HLADNIK, 1995: Temeljna izhodišča prizadevanj za odpravo seksistične rabe jezika. V: V. Kozmik, J. Jeram (ur.). Neseksistična raba jezika. Ljubljana: Vlada Republike Slovenije, Urad za žensko politiko. 7-18. 


\section{Življenjepis doktorandke}

Rodila sem se 22. avgusta 1986 v Mariboru. V letih 1993-2001 sem obiskovala Osnovno šolo Kungota v Zgornji Kungoti, v letih 2001-2005 pa Prvo gimnazijo Maribor, smer splošna gimnazija. Po uspešno opravljeni splošni maturi sem se v študijskem letu 2005/2006 vpisala na še takratno Pedagoško fakulteto Univerze v Mariboru in septembra 2010 uspešno zaključila univerzitetni študij slovenskega jezika s književnostjo in zgodovine na Filozofski fakulteti Univerze v Mariboru. Diplomirala sem s temama Leksikološka analiza oglasov v Slovenskem gospodarju pri slovenskem jeziku in književnosti pod mentorstvom red. prof. dr. Irene Stramljič Breznik ter Meljsko zbirno taborišče, kot so ga doživeli slovenski književniki pri zgodovini pod mentorstvom red. prof. dr. Jere Vodušek Starič. Dodiplomski študij sem zaključila s povprečno oceno opravljenih izpitov 9,01.

Izobraževanje sem nadaljevala na podiplomskem študiju na Filozofski fakulteti Univerze v Mariboru. V študijskem letu 2010/2011 sem se vpisala v 1. letnik doktorskega študijskega programa Slovenistične študije, smer Slovenski jezik - sinhronija.

Od 1. februarja do 30. novembra 2011 sem bila zaposlena kot pripravnica za slovenščino na Prvi gimnaziji Maribor. Od 1. septembra 2012 sem prav tam zaposlena kot profesorica slovenščine. Sem članica šolske maturitetne komisije, od leta 2012 sem vodja šolskega tekmovanja za Cankarjevo priznanje iz znanja slovenščine in stalna sodelavka na državni stopnji tega tekmovanja, v šolskem letu 2017/2018 pa sem bila organizatorka področnega tekmovanja. Sem tudi mentorica štirih raziskovalnih nalog in zbornika literarno nadarjenih dijakov. Sodelovala sem pri dveletnem projektu Zavoda za šolstvo, E-šolska torba, od septembra 2017 pa sem vključena v projekt Slovenščina na dlani v izvedbi Univerze v Mariboru.

Osrednje raziskovalno področje mojega znanstvenega dela je besedotvorje. Rezultate sem objavila $\mathrm{v}$ dveh izvirnih in enem preglednem znanstvenem članku, svoje ugotovitve pa sem predstavila tudi na petih mednarodnih konferencah in na Slavističnem kongresu. 
COBISS Kooperativni online bibliografski sistem in servisi COBISS

Tjaša Markežič

Osebna bibliografija za obdobje 2010-2018

\section{ČLANKI IN DRUGI SESTAVNI DELI}

\subsection{Izvirni znanstveni članek}

1. MARKEŽIČ, Tjaša. (Ne)omejenost tvorbe feminativov v slovenščini. Slavia Centralis, ISSN 1855-6302. [Tiskana izd.], 2018, letn. 11, št. 1, str. 61-78. [COBISS.SI-ID 94941441]

2. MARKEŽIČ, Tjaša. Raba priimkovnih feminativov nekoč in danes. Časopis za zgodovino in narodopisje, ISSN 0590-5966, 2013, letn. 84 = n. v. 49, zv. 4, str. 131-155, tabele, graf. prikazi. [COBISS.SI-ID 76772097]

\subsection{Pregledni znanstveni članek}

3. MARKEŽIČ, Tjaša. Distribucija priponskih obrazil -ica in -ka s poudarkom na feminativni tvorbi. Jezikoslovni zapiski: zbornik Inštituta za slovenski jezik Frana Ramovša, ISSN 0354-0448. [Tiskana izd.], 2012, 18, št. 1, str. 127-142, tabele. [COBISS.SI-ID 34585645]

\subsection{Objavljeni znanstveni prispevek na konferenci}

4. MARKEŽIČ, Tjaša. Feminativi v Slovarju slovenskega knjižnega jezika in Slovarju novejšega besedja slovenskega jezika. Philoslovenica: mednarodno znanstveno srečanje doktorskih študentov slovenistike in slavistike, ISSN 23859105, (Zbornik Študentske sekcije Slavističnega društva Slovenije, ISSN 23859148). [Tiskana izd.], 2014, str. 11-21. [COBISS.SI-ID 80797185]

5. MARKEŽIČ, Tjaša. Bolani na pljučah ali oglaševanje nekoč. V: KRAKARVOGEL, Boža (ur.). Slavistika v regijah - Maribor, (Zbornik Slavističnega društva Slovenije, ISSN 1408-3043, 22). Ljubljana: Zveza društev Slavistično društvo Slovenije. 2011, str. 241-243. [COBISS.SI-ID 18669320] 


\subsection{Objavljeni strokovni prispevek na konferenci}

6. LOGAR, Dagmar, SMOLE-KORPAR, Irena, KRALJ, Nataša, KANCLER, Aljoša, KOBALE, Mitja, ALATIČ, Andreja, MUNDA, Patricija, PETEK, Lilijana, MARKEŽIČ, Tjaša, LUTAR, Maja, MEKE-OŽINGER, Polona. E-Prva gimnazija Maribor. V: SAMBOLIĆ BEGANOVIĆ, Amela (ur.), ČUK, Andreja (ur.). Kaj nam prinaša e-Šolska torba: zbornik zaključne konference projekta eŠolska torba, Kranjska Gora, 27. -29. 5. 2015. 2. izd. Ljubljana: Zavod RS za šolstvo. 2015, str. 254-263. http://www.zrss.si/pdf/kaj-nam-prinasa-esolskatorba.pdf. [COBISS.SI-ID 2360444]

\subsection{Objavljeni povzetek znanstvenega prispevka na konferenci}

7. MARKEŽIČ, Tjaša. Z Ivanom Cankarjem na splošni maturi. V: ČEH STEGER, Jožica (ur.), ZEMLJAK JONTES, Melita (ur.). Cankarjev list v cvetu bele krizanteme: zbornik povzetkov, 2. mednarodna konferenca Slavistični znanstveni premisleki, Maribor, 30. - 31. 5. 2018. Maribor: Filozofska fakulteta, Oddelek za slovanske jezike in književnosti: Slavistično društvo. 2018, str. 30-31. [COBISS.SI-ID 94942721]

8. MARKEŽIČ, Tjaša. (Ne)omejenost tvorbe feminativov v slovenščini $=$ The (Un)limited Composition of Feminine (Noun, Adjective and Verb) Forms in Slovene. V: ZUPAN, Simon (ur.). Engendering difference: sexism, power and politics: book of abstracts = Spolno zaznamovana neenakost : seksizem, moč in politika: zbornik povzetkov: Maribor, 12-13 May 2017, 12. -13. maj 2017. Maribor: Faculty of Arts, University of Maribor: = Filozofska fakulteta, Univerza v Mariboru. [2017], str. 22. [COBISS.SI-ID 92178945]

9. MARKEŽIČ, Tjaša. Tvorba feminativov v slovanskih jezikih. V: REZONIČNIK, Lidija (ur.), ZAVAŠNIK, Nina (ur.). Slovanski jeziki v šolstvu, znanosti, literaturi in kulturi $=$ Slavic languages in education, science, literature and culture: zbornik povzetkov in program. 1. elektronska izd. Ljubljana: Zveza društev Slavistično društvo Slovenije, Študentska sekcija. 2017. http://641.gvs.arnes.si/Zbornik\%20povzetkov\%20in\%20program_LJ2017.p df. [COBISS.SI-ID94943489]

10. MARKEŽIČ, Tjaša. Manjšalnice feminativov v SSKJ in korpusu Gigafida = The Diminutives of Feminatives in the SSKJ and in the Gigafida Corpus. V: STRAMLJIČ BREZNIK, Irena (ur.). Manjšalnice v slovanskih jezikih: oblika in vloga = Umen'šitel'nye imena v slavjanskih jazykah: forma i rol' = Diminutives in slavic languages: form and role, 16. mednarodna znanstvena konferenca Komisije za besedotvorje pri Mednarodnem slavističnem komiteju. Maribor: Slavistično društvo. 2015, str. 42. [COBISS.SI-ID 1605065] 


\subsection{Samostojni znanstveni sestavek ali poglavje $v$ monografski publikaciji}

11. MARKEŽIČ, Tjaša. Manjšalnice feminativov v SSKJ in korpusu Gigafida. V: STRAMLJIČ BREZNIK, Irena (ur.). Manjšalnice v slovanskih jezikih: oblika in vloga = Deminutivy v slavjanskih jazykah: forma i rol' = Diminutives in Slavic languages: form and role, (Knjižna zbirka Zora, 113). Maribor: Mednarodna založba Oddelka za slovanske jezike in književnosti, Filozofska fakulteta. 2015, str. 468-478. [COBISS.SI-ID 22049544]

\subsection{Samostojni strokovni sestavek ali poglavje v monografski publikaciji}

12. MARKEŽIČ, Tjaša. Od prvih umetnikov do prvih znanstvenikov (izbirna tema). V: SAMBOLIĆ BEGANOVIĆ, Amela (ur.), ČUK, Andreja (ur.). Kaj nam prinaša e-Šolska torba. 2, Primeri obetavnih praks in evalvacija projekta. 1. izd. Ljubljana: Zavod RS za šolstvo. 2016, str. 97-98. http://www.zrss.si/pdf/kaj-namprinasa-esolska-torba-dobra-praksa.pdf. [COBISS.SI-ID 88213249]

13. MARKEŽIČ, Tjaša. Začetki gledališča. V: SAMBOLIĆ BEGANOVIĆ, Amela (ur.), ČUK, Andreja (ur.). Kaj nam prinaša e-Šolska torba. 2, Primeri obetavnih praks in evalvacija projekta. 1. izd. Ljubljana: Zavod RS za šolstvo. 2016, str. 99-101. http://www.zrss.si/pdf/kaj-nam-prinasa-esolska-torba-dobrapraksa.pdf. [COBISS.SI-ID 88213505]

14. MARKEŽIČ, Tjaša. Od magije do religije (izbirna tema). V: SAMBOLIĆ BEGANOVIĆ, Amela (ur.), ČUK, Andreja (ur.). Kaj nam prinaša e-Šolska torba. 2, Primeri obetavnih praks in evalvacija projekta. 1. izd. Ljubljana: Zavod RS za šolstvo. 2016, str. 102-103. http://www.zrss.si/pdf/kaj-nam-prinasa-esolska-torbadobra-praksa.pdf. [COBISS.SI-ID 88213761]

15. MARKEŽIČ, Tjaša. Grška religija. V: SAMBOLIĆ BEGANOVIĆ, Amela (ur.), ČUK, Andreja (ur.). Kaj nam prinaša e-Šolska torba. 2, Primeri obetavnih praks in evalvacija projekta. 1. izd. Ljubljana: Zavod RS za šolstvo. 2016, str.

104-106. http://www.zrss.si/pdf/kaj-nam-prinasa-esolska-torba-dobra-praksa.pdf. [COBISS.SI-ID 88214017] 


\section{MONOGRAFIJE IN DRUGA ZAKLJUČENA DELA}

\subsection{Diplomsko delo}

16. MARKEŽIČ, Tjaša. Leksikološka analiza oglasov v Slovenskem gospodarju: diplomsko delo. Maribor: [T. Markežič], 2010. 265 f., ilustr. http://dkum.unimb.si/Dokument.php?id=17538. [COBISS.SI-ID 17910536]

17. MARKEŽIČ, Tjaša. Meljsko zbirno taborišče, kot so ga doživeli slovenski književniki: diplomsko delo. Maribor: [T. Markežič], 2010. 103 f. http://dkum.unimb.si/Dokument.php?id=17011. [COBISS.SI-ID 17907720]

\section{SEKUNDARNO AVTORSTVO}

\section{Mentor - drugo}

18. SKUŠEK, Nika. Petdeset odtenkov slovenskih frazemov: kako z zlato sredino presekati govorniško sivino: raziskovalno področje: slovenski jezik. Maribor: Prva gimnazija, 2018. $57 \mathrm{f}$. http://zpm-mb.si/wp-

content/uploads/2018/07/SŠ_Slovenski_jezik_Petdeset_odtenkov_slovenskih_fraz emov.pdf. [COBISS.SI-ID 94947585]

19. REBERNIK, Žiga, MALOVRH, Eva. Poljubiti matildo ali Matildo: zakaj je zapis osebnih imen $v$ frazemih ahilova peta?: slovenski jezik: raziskovalna naloga. Maribor: Prva gimnazija Maribor, 2016. 52 f., ilustr. http://zpm-mb.si/wpcontent/uploads/2016/06/SŠ_Slovenski_jezik_Poljubiti_matildo_ali_Matildo.pdf. [COBISS.SI-ID 88214785]

nagrada: Nagrajena naloga

20. REBERNIK, Žiga, MALOVRH, Eva. Poljubiti matildo ali Matildo: zakaj je zapis osebnih imen $v$ frazemih ahilova peta?: slovenski jezik: raziskovalna naloga. Maribor: Prva gimnazija Maribor, 2016. 53 f., ilustr. [COBISS.SIID15347763] nagrada: Srebrno priznanje

21. LAVUGER, Pia, ŠTUMBERGER, Greta. Zmaj: rjoveča pošast ali veličastna žival?: zgodovina: raziskovalna naloga. Maribor: Prva gimnazija Maribor, 2015. 53 f., ilustr. http://zpm-mb.si/wpcontent/uploads/2015/06/SŠ_INTER_KNJ_UM_Zmaj_rjoveča_pošast_ali.pdf. [COBISS.SI-ID 88214529] nagrada: Bronasto priznanje 
22. ZAGORŠEK, Zala, NEDELJKO, Nejc, GODEC, Kim, LAVRENČIČ, Vito, ČERNOŠA, Iva, SEFAJ, Blendor, KRAŠEVEC, Manja, MARINIČ, Tina,

RICHTER PEČE, Nevenka (urednik). Veš, da sem to jaz: zbornik literarno nadarjenih dijakov Prve gimnazije Maribor. 1. izd. Maribor: Obzorja, 2013. ISBN 978-961-230-436-2. http://www.biblos.si/lib/book/9789612304362. [COBISS.SIID 75373825]

23. GOLUB, Tomaž. Inštruiram matematiko in te vabim na Halloween party: kaj lahko dijaki pričakujemo v oglasih. Maribor: Prva gimnazija Maribor, 2012. 55 f., ilustr. [COBISS.SI-ID 11678771]

24. GOLUB, Tomaž. Inštruiram matematiko in te vabim na halloween party: kaj lahko dijaki pričakujemo v oglasih: raziskovalno področje: slovenski jezik: raziskovalna naloga. Maribor: Prva gimnazija, 2012. 57 f., ilustr. [COBISS.SIID 74706689]

Izpis bibliografskih enot: vse bibliografske enote Izbrani format bibliografske enote: ISO 690

Razvrščanje bibliografskih enot: tipologija, leto - padajoče, naslov

Vir bibliografskih zapisov: Vzajemna baza podatkov COBISS.SI/COBIB.SI, 4. 10. 2018 


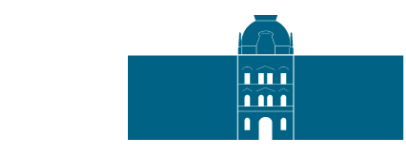

Univerza v Mariboru

Filozofska fakulteta

Koroška cesta 160

2000 Maribor, Slovenija

\section{IZJAVA DOKTORSKE KANDIDATKE}

Podpisana Tjaša Markežič, vpisna številka F0022929, izjavljam, da je doktorska disertacija z naslovom Feminativi v slovenskem jeziku

- rezultat lastnega raziskovalnega dela,

- da predložena disertacija $\mathrm{v}$ celoti ali $\mathrm{v}$ delih ni bila predložena za pridobitev kakršnekoli izobrazbe po študijskem programu druge fakultete ali univerze,

- da so rezultati korektno navedeni in

- da nisem kršil-a avtorskih pravic in intelektualne lastnine drugih.

Podpis doktorske kandidatke: 